ТРАДИЦИОННЫЕ И НОВАТОРСКИЕ ПУТИ ИЗУЧЕНИЯ социальной истории
России XII-XX веков

Сборник статей в честь

Елены Николаевны Швейковской 


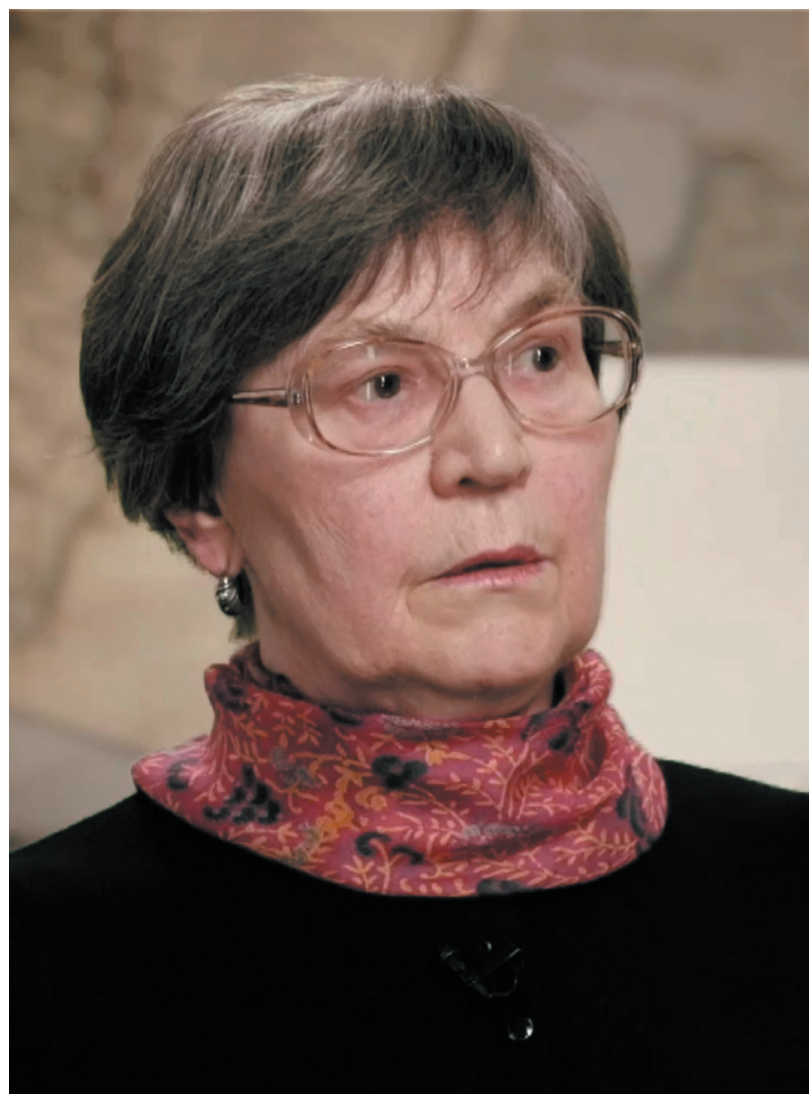

Е.Н. Швейковская 
РОССИЙСКАЯ АКАДЕМИЯ НАУК

ИНСТИТУТ СЛАВЯНОВЕДЕНИЯ

ИНСТИТУТ РОССИЙСКОЙ ИСТОРИИ

АРХЕОГРАФИЧЕСКАЯ КОМИССИЯ

\section{ТРАДИЦИОННЫЕ И НОВАТОРСКИЕ ПУТИ ИЗУЧЕНИЯ} социальной истории России XII-XX веков

Сборник статей в честь Елены Николаевны Швейковской 
УДК 93/94 [930]

ББК $63.3(2) 4$

$\mathrm{C} 23$

\section{Редколлегия:}

Д.Е. Гневашев (ГА РФ), А.В. Мельников (ИСл РАН),

Н.В. Соколова (ИСл РАН), Д.А. Хитров (МГУ),

И.Н. Шамина (ИРИ РАН)

\section{Рецензенты:}

доктор исторических наук Д.В. Лисейцев (ИРИ РАН), кандидат исторических наук Д.Г. Полонский (ИСл РАН), доктор исторических наук В.В. Тихонов (ИРИ РАН)

\section{С23 Традиционные и новаторские пути изучения социальной истории} России XII-XX веков. Сборник статей в честь Елены Николаевны Швейковской. М.: Новый хронограф, 2021. — 448 с., ил.

ISBN 978-5-94881-516-9

DOI 10.31168/94881-516-9

Сборник статей, приуроченный к юбилею доктора исторических наук Е.Н. Швейковской, объединяет работы по социальной истории, источниковедению, историографии. На основе впервые вводимых в научный оборот и переосмысления давно известных источников рассматриваются различные вопросы социальной истории служилого сословия, крестьянства, духовенства, приказной бюрократии, торговых людей, проблемы взаимоотношений верховной власти и общества в Московском государстве, юридические и социально-экономические аспекты деятельности восточнославянской крестьянской общины, функционирования государственных учреждений конца XVII-XVIII вв., ход и реализация на местах административных преобразований при Екатерине II и другие сюжеты. Ряд статей посвящен судьбам и научному наследию отечественных историков, терминологическим и источниковедческим исследованиям.

Для научных работников гуманитарных специальностей, студентов, всех интересующихся историей.

(C) Институт славяноведения РАН, Институт российской истории РАН, Археографическая комиссия РАН, 2021

(C) Коллектив авторов, текст, 2021

(C) Издательство «Новый Хронограф», 2021 


\section{К ЮБИЛЕЮ \\ ЕЛЕНЫ НИКОЛАЕВНЫ ШВЕЙКОВСКОЙ}

3 мая 2021 г. отмечает свой юбилей Елена Николаевна Швейковская один из крупнейших российских историков.

Знаток документов и архивов, тонкий источниковед, мудрый и терпеливый наставник, Елена Николаевна обладает огромным авторитетом в научном мире. По ее работам можно изучать этапы в развитии русской аграрной истории раннего Нового времени.

Ученица В.А. Александрова и С.О. Шмидта, наследница, через посредство М.Н. Тихомирова и С.В. Бахрушина, традиций школы В.О. Ключевского, она посвятила многие годы изучению истории северного крестьянства в переломную эпоху XVII-XVIII вв. Каждая из ее монографий отмечала определенный этап в развитии научных представлений об аграрной и социальной истории этой эпохи, отвечала глубоким потребностям в развитии науки. В 1970-х Е.Н. Швейковская одной из первых начала говорить о значении исследования демографических факторов аграрного развития, о роли двора и общины; в 1990-х, в эпоху резкой смены подходов в исторической науке, она поставила вопросы о влиянии природных факторов, аграрного пейзажа на имущественные отношения в деревне и на взаимодействие крестьянских миров с властями; в работе же 2012 г. рассматриваются «ценностные ориентации и мировидческие представления» обитателей северной деревни той эпохи.

Велика роль Елены Николаевны и в организации науки. Большинству специалистов она знакома как строгий и доброжелательный редактор - по журналу «История СССР», где она заведовала отделом феодализма с 1980 по 1991 г., по «Археографическому ежегоднику», по возрожденному благодаря ее усилиям «Ежегоднику по аграрной истории Восточной Европы». 
Вот уже несколько десятилетий Е.Н. Швейковская активно участвует в работе Симпозиума по аграрной истории Восточной Европы. Еще будучи аспирантом, она впервые выступила с сообщением на рижской сессии Симпозиума (1970 г.), а затем прошла путь до заместителя председателя и председателя Программного комитета. В течение двенадцати лет Елена Николаевна возглавляла Научный совет по аграрной истории РАН и руководила работой сессий Симпозиума. С 2019 г. она - Почетный председатель Программного комитета Симпозиума. Под ее руководством Симпозиум не только сумел преодолеть сложности, неизбежные в эпоху глубокой перестройки подходов к исследованию аграрной истории, но и получил новый импульс к развитию - расширилась проблематика сессий, пришло новое поколение участников.

Друзья, коллеги и ученики, участники этого сборника, от души поздравляют Елену Николаевну с юбилеем и желают ей крепкого здоровья, сил, новых интересных открытий и находок. 


\section{СПИСОК ПЕЧАТНЫХ ТРУДОВ Е.Н. ШВЕЙКОВСКОЙ}

\section{0}

Крестьянский двор как хозяйственная единица в Вологодском уезде в конце XVII в. // Тезисы докладов и сообщений XII сессии Межреспубликанского симпозиума по аграрной истории Восточной Европы (Рига-Сигулда, октябрь 1970 г.). М., 1970. [Ч. 1]. С. 136-137.

Личные имена вологодских крестьян по переписи 1717 г. // Личные имена в прошлом, настоящем, будущем: Проблемы антропонимики / Отв. ред. В.А. Никонов. М., 1970. С. 308-314.

Переписная книга 1717 г. как источник по истории крестьянской семьи в Вологодском уезде // Материалы по истории Европейского Севера СССР: Северный археографический сборник. Вологда, 1970. Вып. 1: Труды Вологодской научной конференции по историографии и источниковедению. Декабрь 1969 г. С. 170-181.

\section{1}

Антропонимия русского населения Вологодского уезда в начале XVIII века // Ономастика Поволжья-2: (Материалы II Поволжской конференции по ономастике) / Отв. ред.: Т.А. Исаева, В.А. Никонов. Горький, 1971. С. 35-39.

Переписные книги 1678 и 1717 гг. по Вологодскому уезду как ономастический источник // Этнография имен / Отв. ред.: В.А. Никонов, Г.Г. Стратанович. М., 1971. C. $104-110$.

\section{2}

Хозяйство крестьян Вологодского уезда в последней четверти XVII - первой четверти XVIII вв.: Автореф. дис. ... канд. ист. наук. М., 1971. 28 с.

\section{4}

Приходо-расходные книги мирских старост монастырской вотчины конца XVII в. как исторический источник // Тезисы докладов и сообщений XV сессии Межреспубликанского симпозиума по аграрной истории Восточной Европы, Вологда, 7-13 сентября 1974 г. М., 1974. Вып. 1. С. 46-49.

* Составитель - А.В. Мельников. Труды 1970-1981 гг. - под фамилией Е.Н. Бакланова, 1982 г. — Е.Н. Бакланова-Швейковская, с 1983 г. — Е.Н. Швейковская. 
Крестьянский двор и община на русском Севере: Конец XVII - начало XVIII в. / Отв. ред. В.А. Александров. М.: Наука, 1976. 221 с.

Рещ.: Колесников П.А. // История СССР. 1978. № 4. С. 175-178; Ellersieck H.E. // The American historical review. Washington. 1979. Vol. 84. № 4. P. 1099-1100; Goehrke C. // Jahrbücher für Geschichte Osteuropas. Neue Folge. 1980. Bd. 28. Hf. 1. S. 101-103; Zorn J. New soviet work on the Old-Russian peasantry// The Russian review. Stanford. 1980. Jul. Vol. 39. № 3. P. 339-347.

Приходо-расходные книги мирских старост монастырской вотчины конца XVII в. как исторический источник // Материалы XV сессии Симпозиума по проблемам аграрной истории СССР. Вологда, 1976. Вып. 1. С. 62-75.

\section{7}

К характеристике крестьянского двора как хозяйственной единицы в Вологодском уезде в конце XVII века// Ежегодник по аграрной истории Восточной Европы. 1970 г. / Отв. ред. В.Л. Янин. Рига, 1977. С. 86-94.

1980

Земельный оборот и правовые порядки черносошных крестьян XVII в. // Вклад северного крестьянства в развитие материальной и духовной культуры: Тезисы годичного собрания Проблемного объединения и Северного отделения Археографической комиссии, Вологда, 2-3 марта 1981 г. Вологда, 1980. С. 51-53.

Обычно-правовые нормы в земельно-распорядительных сделках крестьян XVII в. // Социально-политический и культурный облик деревни в его историческом развитии: XVIII сессия Симпозиума по изучению проблем аграрной истории, Воронеж, 25-29 сент. 1980 г.: Тезисы докладов и сообщений. М., 1980. [Ч. 2]. C. 263-265.

Рец. на кн.: Миненко Н.А. Русская крестьянская семья в Западной Сибири (XVIII перовой половины ХІХ в.). Новосибирск, 1979. 350 с.//Советская этнография. 1980. № 4. C. 179-181.

\section{1}

Поземельные права крестьян Поморья и Сибири в XVII в. // Сибирь в прошлом, настоящем и будущем: Тезисы докладов и сообщений Всесоюз. науч. конф. (1315 окт. 1981 г.). Новосибирск, 1981. Вып. 1: Сибирь в эпоху феодализма и капитализма. С. 29-31.

1982

Peu. на кн.: Очерки русской культуры XVII в. М., 1979. Ч. 1: Материальная культуpa. 350 с.; М., 1979. Ч. 2: Духовная культура. 344 с. // История СССР. 1982. № 2. С. 173-180 (в соавторстве с А.И. Клибановым).

1983

Peu. на кн.: Прокофьева Л.С. Крестьянская община в России во второй половине XVIII - первой половине XIX в.: (На материалах вотчин Шереметевых). Л., 1981. 215 с. // История СССР. 1983. № 1. С. 163-166. 


\section{4}

Крестьянская семья и сельская община как категории социальной структуры феодального общества (конец XV-XVII вв.) // Социально-демографические аспекты развития производительных сил деревни: XX сессия Всесоюзного симпозиума по изучению проблем аграрной истории. Таллин, 24-18 сентября 1984 года: Тезисы докладов и сообщений. М., 1984. С. 205-208.

Помещичьи крестьяне // История северного крестьянства. В 4 т. Архангельск, 1984. Т. 1: Крестьянство Европейского Севера в период феодализма / Отв. ред. П.А. Колесников. C. $175-187$.

\section{5}

Заклад земли как вид имущественного распоряжения у крестьян Севера России в XVII в. (по материалам Сольвычегодского уезда)// Феодализм в России: Юбилейные чтения, посвященные 80-летию со дня рождения академика Льва Владимировича Черепнина: Тезисы докладов и сообщений, Москва, 30 октября - 1 ноября 1985 г. М., 1985. С. 50-53.

Люди, хрестьяне, крестьяне // Знание - сила. 1985. № 7. С. 29-31; № 9. С. 17-20 (в соавторстве с В.Б. Кобриныл; лит. запись Р.Г. Подольного).

Нормы обычного права в земельно-распорядительных сделках крестьян русского Севера первой половины XVII века (По материалам Сольвычегодского уезда) // История СССР. 1985. № 2. С. 96-111.

\section{6}

Крестьянская семья и община как категории социальной структуры феодальной России: (Конец XV-XVII вв.) // Социально-демографические процессы в российской деревне (XVI - начало XX в.): (Материалы XX сессии Всесоюзного симпозиума по изучению проблем аграрной истории). Таллин, 1986. Вып. 1. С. 5-14.

Рец. на кн.: Власова И.В. Традиции крестьянского землепользования в Поморье и Западной. Сибири в XVII-XVIII вв. М., 1984. 203 с. // История СССР. 1986. № 6. С. 175-177.

\section{7}

Заклад земли у крестьян Севера в XVII в.//Феодализм в России: Сборник статей и воспоминаний, посвященный памяти академика Л.В. Черепнина/Отв. ред. В.Л. Янин. М., 1987. С. 149-156.

«Куда соха ходила...»// Встречи с историей: Научно-популярные очерки / Сост. И.Л. Андреев, вступ. ст. И.Д. Ковальченко. М., 1987. [Вып. 1]. С. 26-33.

Рец.: Захарова Л.Г., Карацуба И.В. // Вопросы истории. 1989. № 5. С. 162.

Рец.: Крестьянство России в контексте истории крестьянства Европы//История СССР. 1987. № 6. С. 156-168 (в соавторстве с А.П. Новосельиевым). К выходу в свет труда: История крестьянства в Европе: Эпоха феодализма. В 3 т. М., 19851986. T. 1-3.

\section{8}

Из истории финансово-налоговой системы в России XVII века // История СССР. 1988. № 5. С. 54-66. 
Сеньориальные элементы феодальной собственности на Севере России в XVII веке// Общее и особенное в развитии феодализма в России и Молдавии. Проблемы феодальной государственной собственности и государственной эксплуатации: (ранний и развитой феодализм): Чтения, посвященные памяти академика Л.В. Черепнина: Тезисы докладов и сообщений, Кишинев, 5-7 апреля 1988 г. М., 1988. [Ч. 2]. С. 241-245.

Рец.: Значительные итоги анализа писцовых книг с помощью ЭВМ// Вопросы истории. 1988. № 9. С. 155-157. Рец. на кн.: Милов Л.В., Булгаков М.Б., Гарскова И.М. Тенденции аграрного развития России первой половины XVII столетия: Историография, компьютер и методы исследования. М., 1986. 303 с.

\section{9}

Льгота как способ сельскохозяйственного пользования землей (Север, XVII в.) // Крестьяне и сельское хозяйство России в XIV-XVIII веках: Сборник научных трудов / Отв. ред. А.А. Преображенский. М., 1989. С. 62-84.

Воеводская администрация на Севере в XVII в.: связь с Центром и местным населением// Взаимосвязи города и деревни в их историческом развитии: XXII сессия Всесоюзного симпозиума по изучению проблем аграрной истории, Минск, 1114 октября 1989 г.: Тезисы докладов и сообщений. М., 1989. С. 214-216.

\section{0}

Писцовые книги и хозяйственная документация // Тезисы докладов и сообщений III Всероссийского совещания по вопросам изучения и издания писцовых книг и других историко-географических источников. Вологда, 1990. С. 51-55.

Социально-экономические, демографические и политические предпосылки крестьянской колонизации. Способы освоения земли // История крестьянства СССР с древнейших времен до Великой Октябрьской социалистической революции. В 5 т. М., 1990. Т. 2: Крестьянство в периоды раннего и развитого феодализма. C. $398-402$.

Внутренняя колонизация и ее значение для развития форм землевладения и землепользования // Там же. С. 402-405.

Приходо-расходные книги XVI-XVII в.: типология и классификация // Спорные вопросы отечественной истории XI-XVIII веков: Тезисы докладов и сообщений Первых чтений, посвященных памяти А.А. Зимина, Москва 13-18 мая 1990 г. / Отв. ред.: Ю.Н. Афанасьев, А.П. Новосельцев. М., 1990. [Ч. 2]. С. 299-302.

Рец. на кн.: Акты писцового дела (1644-1661). М.: Наука, 1977. 287 с.; Акты писцового дела 60-80-х годов XVII века М.: Наука, 1990. 475 с. // История СССР. 1990. № 6. C. 164-167.

Чл. и отв. секретарь редкол. тома: История крестьянства СССР с древнейших времен до Великой Октябрьской социалистической революции. В 5 т. М., 1990. Т. 2: Крестьянство в периоды раннего и развитого феодализма. 616 с.

\section{1}

Мир - универсальная общественно-социальная структура феодальной России (XV-XVII вв.)// Реализм исторического мышления. Проблемы отечественной 
истории периода феодализма: Чтения, посвященные памяти А.Л. Станиславского: Тезисы докладов и сообщений, Москва, 27 января - 1 февраля 1991 г. М., 1991. С. 260-261.

\section{2}

Земельные отношения черносошных крестьян в XVII веке // Крестьянское хозяйство: история и современность: Материалы к Всероссийской научной конференции, Вологда, октябрь 1992 [г.] / Отв. ред. М.А. Безнин. Вологда, 1992. Ч. 1. С. 20-30.

К характеристике мировосприятия черносошных крестьян (XVII век. Север) // История СССР. 1992. № 1. С. 75-86.

Общинная власть в системе феодально-административного управления России XVII в. // Проблемы отечественной истории и культуры периода феодализма: Чтения памяти В.Б. Кобрина: Тезисы докладов и сообщений, Москва, 26-29 января 1992 года. М., 1992. С. 198-200.

Приходо-расходные книги XVI-XVII в.: типология и классификации // Проблемы историографии и источниковедения истории Европейского Севера: Межвузовский сборник научных трудов, посвященный профессору Петру Андреевичу Колесникову / Редкол.: А.В. Камкин (отв. ред.) и др. Вологда, 1992. С. 37-52.

\section{3}

Государство и черносошные крестьяне России XVII в.: Автореф. дис. ... д-ра ист. наук. М., 1993. 50, [1] с., включ. обл.

Приходные и расходные книги XVI-XVII вв. в отечественной историографии 19301990-х гг. // Источниковедение XX столетия: Тезисы докладов и сообщений научной конференции, Москва, 28-30 января 1993 г. / Редкол.: В.А. Муравьев (отв. ред.) и др. М., 1993. С. 63-65.

Социальные представления черносошных крестьян XVII века: земля и власть // Система государственного феодализма в России: Сборник статей / Отв. ред. Л.В. Данилова. М., 1993. [Ч. 1]. С. 145-164.

Труд в представлениях крестьян России в XV-XVII вв. // Организация труда и трудовая этика: Древность. Средние века. Современность / Отв. ред.: В.Л. Мальков, Л.Т. Мильская. М., 1993. С. 225-240.

\section{4}

Государственная администрация и земские миры на Севере России: структура и взаимодействие (XVII век)// Сословия и государственная власть в России. XV - середина XIX вв.: Международная конференция - Чтения памяти акад. Л.В. Черепнина. Москва, 13-16 июня 1994 г.: Тез. докл.: [В 2 ч.]. М., 1994. Ч. 2. С. 196-206.

Меры государственного регулирования аграрного производства в России XVII в. // Формы сельскохозяйственного производства и государственное регулирование: XXIV сессия Симпозиума по аграрной истории Восточной Европы: Тезисы докладов и сообщений, Москва, 27-30 сентября 1994 г. М., 1994. С. 14-16.

Наследование и формирование ментальности в дореформенной России // Русская история: проблемы менталитета: Тезисы докладов научной конференции, Москва, 4-6 октября 1994 г. / Отв. ред. А.А. Горский. М., 1994. С. 23-26. 
Приходо-расходные книги четвертей и их значение для социально-экономической истории России XVII в. // Мир источниковедения: (Сборник в честь Сигурда Оттовича Шмидта). М.; Пенза, 1994. С. 84-88.

Чл. редкол:: Формы сельскохозяйственного производства и государственное регулирование: XXIV сессия Симпозиума по аграрной истории Восточной Европы. Тезисы докладов и сообщений, Москва, 27-30 сентября 1994 г. М., 1994. 206 с.

Аренда, земельная // Отечественная история: История России с древнейших времен до 1917 года: Энциклопедия. М., 1994. Т. 1: А-Д. С. 102 (в соавторстве с Т.Л. Моисеенко).

\section{5}

Меры государственного регулирования аграрного производства в России XVII в.// Формы сельскохозяйственного производства и государственное регулирование: XXIV сессия Симпозиума по аграрной истории Восточной Европы: [Материалы сессии, состоявшейся в Москве, 27-30 сентября 1994 г.] / Редкол.: Л.В. Милов (отв. ред.) и др. М., 1995. С. 45-53.

Русский север в XVI-XVII вв.: традиционализм как тип социально-экономического развития // Россия в X-XVIII вв.: проблемы истории и источниковедения: Тезисы докладов и сообщений Вторых чтений, посвященных памяти А.А. Зимина. Москва, 26-28 января 1995 г. / Редкол.: Ю.Н. Афанасьев (отв. ред.), С.М. Каштанов (зам. отв. ред.), А.Н. Сахаров (отв. ред.) и др. М., 1995. С. 667-672.

Тексты деловой письменности: норма и реализация // Актуальные проблемы археографии, источниковедения и историографии: Материалы к Всероссийской научной конференции, посвященной 50-летию Победы в Великой Отечественной войне / Гл. ред. М.А. Безнин. Вологда, 1995. С. 239-241.

Чл. редкол.: Формы сельскохозяйственного производства и государственное регулирование: XXIV сессия Симпозиума по аграрной истории Восточной Европы: [Материалы сессии, состоявшейся в Москве, 27-30 сентября 1994 г.] / Редкол.: Л.В. Милов (отв. ред.) и др. М., 1995. 295 с.

\section{6}

Государство и крестьяне России: Поморье, XVII в. // Вестник Российского гуманитарного научного фонда. 1996. № 3. С. 108-114.

К сотенной организации города на Севере России в XVII в. // Столичные и периферийные города Руси и России в средние века и раннее новое время (XI-XVIII вв.): Тезисы докладов научной конференции, (Москва, 3-5 декабря 1996 г.) / Редкол.: А.Л. Хорошкевич, А.В. Юрасов. М., 1996. С. 189-191.

«Методология истории» А.С. Лаппо-Данилевского и «Апология истории, или Ремесло историка» М. Блока: опыт источниковедческого сопоставления // Источниковедение и компаративный метод в гуманитарном знании: Тез. докладов и сообщений научной конференции, Москва, 29-31 января 1996 г. / Редкол: В.А. Муравьев (отв. ред.) и др. М., 1996. С. 380-385.

Природно-ландшафтные особенности и градация сельскохозяйственных угодий на Поморском Севере России в XVI-XVII вв.// Аграрные технологии в России IXXX вв.: XXV сессия Симпозиума по аграрной истории Восточной Европы: Тези- 
сы докладов и сообщений, Арзамас, 10-13 сентября 1996 г. / Редкол.: Л.В. Милов (отв. ред.) и др. М., 1996. С. 30-32.

Чл. редкол:: Аграрные технологии в России IX-XX вв.: XXV сессия Симпозиума по аграрной истории Восточной Европы: Тезисы докладов и сообщений, Арзамас, 10-13 сентября 1996 г. / Редкол.: Л.В. Милов (отв. ред.) и др. М., 1996. 188 с.

\section{7}

Государство и крестьяне России: Поморье в XVII веке. М.: Археографический центр, 1997. 285 с. (Исследования по русской истории; вып. 8).

Рец.: Покровский Н.Н. // Отечественная история. 1999. № 3. С. 194-196.

\section{8}

Крестьянское земельное владение как объект правосознания в середине XVIXVII вв.: (законодательство и реальность) // Представления о собственности в российском обществе XV-XVIII в.: Проблемы собственности в общественном сознании и правовой мысли феодальной эпохи. М., 1998. С. 51-86.

Проблемы расселения и земледельческого освоения Сибири в творчестве В.А. Александрова // Особенности российского земледелия и проблемы расселения IXXX вв.: XXVI сессия Симпозиума по аграрной истории Восточной Европы: Тезисы докладов и сообщений, Тамбов, 15-18 сентября 1998 г. М., 1998. С. 45-47.

Oтв. ред.: Представления о собственности в российском обществе XV-XVIII в.: Проблемы собственности в общественном сознании и правовой мысли феодальной эпохи. М., 1998. 194 с. (совместно с Н.А. Горской).

Чл. редкол.: Особенности российского земледелия и проблемы расселения IX-XX вв.: XXVI сессия Симпозиума по аграрной истории Восточной Европы: Тезисы докладов и сообщений, Тамбов, 15-18 сентября 1998 г. / Редкол.: Л.В. Милов (отв. ред.) и др. М., 1998. 216 с.

\section{9}

Нетрадиционная информация традиционных источников // Точное гуманитарное знание: традиции, проблемы, методы, результаты: Тезисы докладов и сообщений научной конференции, Москва, 4-6 февраля 1999 г. / Редкол.: В.А. Муравьев (отв. ред.) и др. М., 1999. С. 149-151.

Природно-ландшафтные особенности и градация сельскохозяйственных угодий на Поморском Севере России в XVI-XVII вв.// Аграрные технологии в России IXXX вв.: Материалы XXV сессии Симпозиума по аграрной истории Восточной Европы / Редкол.: Л.В. Милов (отв. ред.) и др. Арзамас, 1999. С. 81-88.

Прокопьевская трапеза: праздник и повседневность на Русском Севере в XVII веке // Одиссей: Человек в истории. 1999: Трапеза / Гл. ред. А.Я. Гуревич. М., 1999. С. $14-20$.

Русский Север в XVI-XVII вв.: традиционализм как тип социально-экономического развития // Россия в IX-XX веках: Проблемы истории, историографии и источниковедения: Сборник статей и тезисов Вторых чтений, посвященных памяти А.А. Зимина, Москва, 26-28 января 1995 г. / Сост.: С.М. Каштанов и др. М., 1999. C. $529-533$. 
Традиционализм как тип социально-экономического развития: Русский Север в XVIXVII вв. // Россия в Средние века и Новое время: Сборник статей к 70-летию чл.корр. РАН Л.В. Милова / Редкол.: В.А. Кучкин (отв. ред.) и др. М., 1999. С. 165-185.

Чл. редкол.: Аграрные технологии в России IX-XX вв.: Материалы XXV сессии Симпозиума по аграрной истории Восточной Европы / Редкол.: Л.В. Милов (отв. ред.) и др. Арзамас, 1999. 328 с.

Чл. редкол.: Массовые источники отечественной истории: Материалы X Всероссийской конференции «Писцовые книги и другие массовые источники XVI-XX вв.: Проблемы изучения и издания», посвященной 90-летию Александра Львовича Шапиро, Архангельск, 25-26 июня 1998 г. / Редкол.: А.А. Курпатов (гл. ред.) и др. Архангельск, 1999. 309 с.

\section{0}

Воеводский двор в северорусском городе XVII в. // Российское самодержавие и бюрократия: Сборник статей в честь Натальи Федоровны Демидовой. М.; Новосибирск, 2000. С.131-147.

Критерии зажиточности в российской деревне XVI-XVII вв. // Зажиточное крестьянство России в исторической ретроспективе (Землевладение, землепользование, производство, менталитет): XXVII сессия Симпозиума по аграрной истории Восточной Европы: Тезисы докладов и сообщений, Вологда, 12-16 сентября 2000 г. / Редкол.: Л.В. Милов (отв. ред.) и др. М., 2000. С. 22-24.

Проблемы расселения и землевладельческого освоения Сибири в творчестве В.А. Александрова // Особенности российского земледелия и проблемы расселения в России IX-XX вв.: Материалы XXVI сессии Симпозиума по аграрной истории Восточной Европы. Тамбов, 2000. С. 17-28.

Социум и государство России XVII в. в трудах В.А. Александрова // Историк во времени: Третьи Зиминские чтения. Доклады и сообщения научной конференции / Сост.: Е.А. Антонова и др. М., 2000. С. 186-187.

Чл. редкол.: Зажиточное крестьянство России в исторической ретроспективе (Землевладение, землепользование, производство, менталитет): XXVII сессия Симпозиума по аграрной истории Восточной Европы: Тезисы докладов и сообщений, Вологда, 12-16 сентября 2000 г. / Редкол.: Л.В. Милов (отв. ред.) и др. М., 2000. 265 с.

Чл. редкол.: Особенности российского земледелия и проблемы расселения в России IX-XX вв.: Материалы XXVI сессии Симпозиума по аграрной истории Восточной Европы. Тамбов, 2000. 362 с.

\section{1}

Воеводский двор в северорусском городе XVII века // Столичные и периферийные города Руси и России в Средние века и раннее Новое время (XI-XVIII вв.): Доклады Второй научной конференции, (Москва, 7-8 декабря 1999 г.) / Редкол.: Я.Е. Водарский (отв. ред.) и др. М., 2001. С. 228-236.

Критерии зажиточности в российской деревне XVI-XVII вв. // Зажиточное крестьянство России в исторической ретроспективе: Материалы XXVII сессии Симпозиума по аграрной истории Восточной Европы / Редкол.: Л.В. Милов (отв. ред.) и др. Вологда, 2001. С. 41-51. 
Труд и собственность. Крупная и мелкая земельная собственность, привилегированная и трудовая // Собственность в России: Средневековье и раннее новое время / Отв. ред. Н.А. Горская. М., 2001. С. 134-165.

Общинная собственность в русской деревне XIV-XVIII вв.// Там же. С.166-175 (в соавторстве с Н.А. Горской).

Рещ.: Комиссаренко А.И. // Российская история. 2003. № 4. С. 196-192.

Чл. редкол.: Зажиточное крестьянство России в исторической ретроспективе: Материалы XXVII сессии Симпозиума по аграрной истории Восточной Европы / Редкол.: Л.В. Милов (отв. ред.) и др. Вологда, 2001. 429 с.

\section{2}

Основные проблемы в исследованиях В.А. Александрова (к 80-летию со дня рождения) // Археографический ежегодник за 2001 год. М., 2002. С. 191-217.

Хроника заседания [Санкт-Петербургского филиала Института российской истории РАН и Археографической комиссии РАН к 80-летию К.Н. Тарновского] // Там же. С. 323-328 (в соавторстве с Б.Д.).

Земские расходы северных миров в XVII в.// Источниковедение и историография в мире гуманитарного знания: Доклады и тезисы XIV научной конференции, Москва, 18-19 апреля 2002 г. / Редкол.: В.А. Муравьев (отв. ред.) и др. М., 2002. С. 543-546.

Чл. редкол.: Землевладение и землепользование в России (социально-правовые аспекты): XXVIII сессия Симпозиума по аграрной истории Восточной Европы: Тезисы докладов и сообщений, Калуга, 24-28 сентября 2002 г. / Редкол.: Л.В. Милов (отв. ред.) и др. М., 2002. 196 с.

\section{3}

К сотенной организации города на Севере России в XVII веке // От Древней Руси к России нового времени: Сборник статей: К 70-летию Анны Леонидовны Хорошкевич / Сост. А.В. Юрасов; редкол.: В.Л. Янин (отв. ред.) и др. М., 2003. С. 234-242.

П.А. Колесников - археограф отечественной истории раннего Нового времени // Материалы XIII Всероссийского научно-практического совещания по вопросам изучения и издания писцовых книг и других историко-географических источников по истории России XVI-XIX вв., Вологда, 3-4 октября 2002 г.: Научные чтения, посвященные памяти Петра Андреевича Колесникова (к 95-летию со дня рождения). Вологда, 2003. С. 5-13.

Проблемы социально-экономической истории в работе Симпозиума по аграрной истории Восточной Европы (1958-2003 гг.)// Отечественная история. 2003. № 6. С. 158-173 (в соавторстве с С.А. Козловым).

Слуги на воеводском дворе в XVII в. // Сообщения Ростовского музея. Ростов, 2003. Вып. 13: Россия и проблемы европейской истории: Средневековье, Новое и Новейшее время: Сборник статей в честь члена-корреспондента Российской академии наук Сергея Михайловича Каштанова. С. 92-104.

Чл. редкол.: Материалы XIII Всероссийского научно-практического совещания по вопросам изучения и издания писцовых книг и других историко-географических источников по истории России XVI-XIX вв., Вологда, 3-4 октября 2002 г.: Научные 
чтения, посвященные памяти Петра Андреевича Колесникова (к 95-летию со дня рождения) / Редкол.: М.С. Черкасова (отв. ред.) и др. Вологда, 2003. 224 с.

Чл. редкол.: Землевладение и землепользование в России (социально-правовые аспекты): Материалы XXVIII сессии Симпозиума по аграрной истории Восточной Европы / Редкол.: Л.В. Милов (отв. ред.) и др. Калуга, 2003. 462 с.

\section{4}

Государство и крестьяне России XVI - начала XVIII в.: к характеру диалога // Народ и власть: исторические источники и методы исследования: Материалы XVI научной конференции, Москва, 30-31 января. 2004 г. / Редкол.: В.А. Муравьев (отв. ред.) и др. М., 2004. С. 43-64.

Хроника заседания [Тихомировских чтений 2002 года «Роль музеев в развитии отечественной археографии»]// Археографический ежегодник за 2002 год. М., 2004. C. 216-221.

Научные чтения памяти П.А. Колесникова // Там же. С. 465.

Компоненты инфраструктуры северной деревни XVII века// Динамика и темпы аграрного развития России: инфраструктура и рынок: XXIX сессия Симпозиума по аграрной истории Восточной Европы: Тезисы докладов и сообщений, Орел, 21-25 сентября 2004 г. М., 2004. С. 16-18.

Чл. редкол.: Динамика и темпы аграрного развития России: инфраструктура и рынок: XXIX сессия Симпозиума по аграрной истории Восточной Европы: Тезисы докладов и сообщений, Орел, 21-25 сентября 2004 г. / Редкол.: Л.В. Милов (отв. ред.) и др. М., 2004. 194 с.

\section{5}

М.М. Богословский - историк русского Севера // Археографический ежегодник за 2004 год. М., 2005. С. 180-191.

Заседание памяти Е.П. Маматовой // Там же. С. 542-545 (в соавторстве с Е.В. Пчеловылм).

M.М. Богословский и становление историографии Русского Севера // Образ науки в университетском образовании: Материалы XVII научной конференции, Москва, 27-29 января 2005 г. / Редкол.: В.А. Муравьев (отв. ред.) и др. М., 2005. С. 291294.

Представления власти о службе городовых воевод в России XVII в.// Восточная Европа в древности и средневековье: Проблемы источниковедения: XVII Чтения памяти члена-корреспондента АН СССР Владимира Терентьевича Пашуто, IV чтения памяти доктора исторических наук Александра Александрович Зимина, Москва, 19-22 апреля 2005 г.: Тезисы докладов. В 2 ч. / Редкол.: Е.А. Мельникова (отв. ред.) и др. М., 2005. Ч. 2. С. 357-360.

Назначения на воеводскую службу в северорусские города в XVII в. // Общество, государство, верховная власть в России в Средние века и раннее Новое время в контексте истории Европы и Азии (X-XVIII столетия): Международная конференция к 100-летию со дня рождения академика Л.В. Черепнина, Москва 30 ноября - 2 декабря 2005 г.: Тезисы докладов и сообщений. Препринт. М., 2005. C. 242-244. 
Прокопьевская трапеза: праздник и повседневность на русском Севере в XVII века // Глагол времени: Исследования и материалы, статьи и сообщения межрегиональной научной конференции «Прокопиевские чтения». Вологда, 2005. С. 205-213. Перепечатка из кн.: «Одиссей: Человек в истории». М., 1999.

Pец. на кн.: Стефанович П.С. Приход и приходское духовенство в России в XVIXVII веках. М., 2002. 352 с. // Отечественная история. 2005. № 3. С. 187-189.

\section{6}

Компоненты инфраструктуры северной деревни XVII в. // Динамика и темпы аграрного развития России: инфраструктура и рынок: Материалы XXIX сессии Симпозиума по аграрной истории Восточной Европы. Орел, 2006. С. 90-103.

Крестьянская семья XVI-XVIII вв.: понятие и демография // Проблемы источниковедения / Отв. ред. С.М. Каштанов. М., 2006. Вып. 1(12). С. 345-361.

Методические рекомендации В.О. Ключевского при изучении кадастровых источников// Вспомогательные исторические дисциплины: классическое наследие и новые направления: Материалы XVIII научной конференции. Москва, 26-28 января 2006 г. / Редкол.: В.А. Муравьев (отв. ред.) и др. М., 2006. С. 423-425.

Подьячие съезжих изб ведомства Устюжской четверти в первой половине XVII в. // Исследования по истории средневековой Руси. К 80-летию Юрия Георгиевича Алексеева / Редкол.: А.Ю. Дворниченко (отв. ред.) и др.; сост. С.В. Стрельников. М.; СПб., 2006. С. 156-168.

Семья XVI-XVIII вв.: определение и его наполнение // Вестник Российского гуманитарного научного фонда. 2006. № 1 (42). С. 34-44.

Peu. на кн.: Черкасова М.С. Крупная феодальная вотчина в России конца XVIXVII веков (по архиву Троице-Сергиевой лавры). М., 2004. 395 с. // Отечественная история. 2006. № 3. С. 188-191.

Чл. редкол.: Динамика и темпы аграрного развития России: инфраструктура и рынок: Материалы XXIX сессии Симпозиума по аграрной истории Восточной Европы / Редкол.: Л.В. Милов (отв. ред.) и др. Орел, 2006. 583 с.

Чл. редкол., зам отв. ред.: Неземледельческая деятельность крестьян и особенности российского социума: XXX сессия Симпозиума по аграрной истории Восточной Европы: Тезисы докладов и сообщений, Тула, 19-23 сентября 2006 г. / Редкол.: Л.В. Милов (отв. ред.) и др. М., 2006.

\section{7}

Наталья Александровна Горская: служение истории и людям// Археографический ежегодник за 2005 год. М., 2007. С. 336-359. 143 с.

\section{8}

К верификации ономастических сведений писцовых книг XVII в. (Сольвычегодский уезд) // Материалы XV Всероссийской конференции «Писцовые книги и другие массовые источники XVI-XX вв.»: К столетию со дня рождения П.А. Колесникова. М., 2008. С. 367-376.

Внутривидовое сравнение источников по истории России: акты имущественных сделок (к постановке вопроса)//Вспомогательные исторические дисциплины - 
источниковедение - методология истории в системе гуманитарного знания: Материалы XX Международной конференции, Москва 31 января - 2 февраля 2008 г. В 2 ч. / Редкол.: М.Ф. Румянцева (отв. ред.) и др. М., 2008. Ч. 2. С. 683-686.

Выборы и «выбор» в северорусском мире XVII в.//Право в средневековом мире. 2008: Сб. ст.: Памяти Ольги Игоревны Варьяш, создавшей проект «Право в средневековом мире», посвящается / Под ред. И.И. Варьяш, Г.А. Поповой. М., 2008. C. 249-274.

Рец. на кн.: Горская Н.А. Русская феодальная деревня в историографии ХХ века. М., 2006. 363 с. // Отечественная история. 2008. № 3. С. 183-184.

Отв. ред.: Актуальные проблемы аграрной истории Восточной Европы: историография; методы исследования и методология; опыт и перспективы: XXXI сессия Симпозиума по аграрной истории Восточной Европы: Тезисы докладов и сообщений, Вологда, 23-26 сентября 2008 г. / Редкол.: Е.Н. Швейковская (отв. ред.) и др. М., 2008. $184 \mathrm{c}$.

Чл. редкол.: Материалы XV Всероссийской конференции «Писцовые книги и другие массовые источники XVI-XX вв.»: К столетию со дня рождения П.А. Колесникова / Редкол.: М.Р. Рыженков (отв. ред.) и др. М., 2008. 379 с.

\section{9}

XXXI сессия Симпозиума по аграрной истории Восточной Европы «Актуальные проблемы аграрной истории Восточной Европы: историография; методы исследования и методология; опыт и перспективы» (Вологда, 23-26 сентября 2008 г.) // Вестник Российского гуманитарного научного фонда. 2009. № 1 (54). С. 183-188 (в coавторстве с М.А. Безниным).

К пятидесятилетию Симпозиума по аграрной истории Восточной Европы // Актуальные проблемы аграрной истории Восточной Европы: историография, методы исследования и методология, опыт и перспективы: Материалы XXXI сессии Симпозиума по аграрной истории Восточной Европы. В 2 кн. / Редкол.: Е.Н. Швейковская (отв. ред.) и др. Вологда, 2009. Кн. 1. С. 7-20.

Криминальная драма в Тотемском уезде первой трети XVII в. (к изучению демонологии) // Древняя Русь. Вопросы медиевистики. М., 2009. № 3 (37): Тезисы докладов участников V Международной научной конференции: «Комплексный подход в изучении Древней Руси». С. 127.

«На том крест целую...»: присяга при занятии должности в России XVII в. // Право в средневековом мире. 2009: Памяти Ольги Игоревны Варьяш, создавшей проект «Право в средневековом мире», посвящается / Под ред. И.И. Варьяш, Г.А. Поповой. М., 2009. C. 102-114.

О взаимодействии властных структур в первой половине XVII века // Верховная власть, элита и общество в России XIV — первой половины XIX века. Российская монархия в контексте европейских и азиатских монархий и империй: Вторая международная научная конференция, 2325 июня 2009 года: Тезисы докладов / Редкол.: А.К. Левыкин (отв. ред.), В.Д. Назаров (отв. ред.) и др. М., 2009. С. 190-192.

О методах установления населенности крестьянского двора XVI - первой половины XVII века в региональных исследованиях // Проблемы социальной и политической истории России: Сб. научных статей / Под общ. ред. Р.Г. Пихои. М., 2009. С. 62-69. 
Oтв. ред.: Актуальные проблемы аграрной истории Восточной Европы: историография, методы исследования и методология, опыт и перспективы: Материалы XXXI сессии Симпозиума по аграрной истории Восточной Европы. В 2 кн. Вологда, 2009. Кн. 1. 288 с.; Кн. 2. 279 с.

\section{0}

Источники XVI-XVIII вв. о крестьянской общине в историографии второй половины XX в.// Историография источниковедения и вспомогательных исторических дисциплин: Материалы XXII Международной научной конференции. Москва, 28-30 января 2010 г. / Редкол.: М.Ф. Румянцева (отв. ред.) и др. М., 2010. С. 34-46.

Источниковедческие аспекты в трудах В.А. Александрова 1960-1970 годов// Актуальные проблемы аграрной истории Восточной Европы X-XXI вв.: источники и методы исследования: XXXII сессия Симпозиума по аграрной истории Восточной Европы: Тезисы докладов и сообщений. М., 2010. С. 3-8.

Назначения на воеводскую службу в северорусские города в XVII в. // Сословия, институты и государственная власть в России: Средние века и раннее Новое время: Сборник статей памяти академика Л.В. Черепнина / Отв. ред.: В.Л. Янин, В.Д. Назаров. М., 2010. С. 740-751.

Судьи средневековой России: единство во множестве или множество без единства // Право в средневековом мире. 2010/Под. ред. Г.А. Поповой. М., 2010. C. 267-289.

Публ.: [Тексты заговоров, извлеченных из документов 1630-1632 гг., хранящихся в РГАДА: сыскного дела по поводу междоусобицы воевод Мангазеи Г.И. Кокорева и А.Ф. Палицына; следственного дела крестьянина Тимофея Кузмина Полоха, подозреваемого в ведовстве] // Русские заговоры из рукописных источников XVII первой половины XIX в. / Сост., подгот. текстов, статьи и коммент. А.Л. Топоркова. M., 2010. C. 313-323.

Отв. ред.: Актуальные проблемы аграрной истории Восточной Европы X-XXI вв.: источники и методы исследования: XXXII сессия Симпозиума по аграрной истории Восточной Европы: Тезисы докладов и сообщений, Рязань, 21-24 сентября 2010 г. / Редкол.: Е.Н. Швейковская (отв. ред.) и др. М., 2010. 187 с.

\section{1}

Проблемы социально-экономической истории в трудах В.Т. Пашуто // Древнейшие государства Восточной Европы. 2008 год: К 90-летию В.Т. Пашуто; Пашуто B.T. Русь. Прибалтика. Папство: Избранные статьи / Отв. ред. и сост. Е.А. Мельникова. М., 2011. С. 19-26.

Пространственный микромир деревни: Север, XVII в. // Историческая география: пространство человека vs человек в пространстве: Материалы XXIII Международной научной конференции, Москва, 27-29 января 2011 г. / Редкол.: М.Ф. Румянцева (отв. ред.) и др. М., 2011. С. 104-110.

Репрессивная роль общины - компенсационный механизм? // Русь, Россия: Средневековье и Новое время: Вторые чтения памяти академика РАН Л.В. Милова: Материалы к Международной научной конференции, Москва, 17-19 ноября 2011 г. М., 2011. C. 116-121. 
С.Ф. Платонов и изучение русского Севера // Памяти академика Сергея Федоровича Платонова: исследования и материалы / Отв. ред.: А.Ю. Дворниченко, С.О. Шмидт. СПб., 2011. С. 267-275.

Чл. редкол.: Русь, Россия: Средневековье и Новое время: Вторые чтения памяти академика РАН Л.В. Милова: Материалы к Международной научной конференции, Москва, 17-19 ноября 2011 г. М., 2011. 356 с.

\section{2}

Русский крестьянин в доме и мире: северная деревня конца XVI - начала XVIII века. М.: Индрик, 2012. 368 с.

Pец.: Новохатко О.В. Земля, крестьянин и воля: Русский Север XVII века (О новой монографии Е. Н. Швейковской) // Российская история. 2014. № 2. С. 60-76.

К пятидесятилетнему юбилею работы Симпозиума по проблемам аграрной истории Восточной Европы // Археографический ежегодник за 2007-2008 годы. М., 2012. C. 565-566.

Слово о Леониде Васильевиче Милове // Там же. С. 574-575.

Источниковедческие аспекты в трудах В.А. Александрова 1960-1970 гг. // Актуальные проблемы аграрной истории Восточной Европы X-XXI вв.: источники и методы исследования: Материалы XXXII сессии Симпозиума по аграрной истории Восточной Европы / Редкол.: Е.Н. Швейковская (отв. ред.) и др. Рязань, 2012. С. 7-20.

К реконструкции состава мирского архива XVII века на русском Севере // Русское средневековье: Сборник статей в честь профессора Юрия Георгиевича Алексеева. М., 2012. С. 199-212.

К стратификации частных актов XVI-XVII вв. // Проблемы дипломатики, кодикологии и актовой археографии: Материалы XXIV Международной научной конференции, Москва, 2-3 февраля 2012 г. М., 2012. С. 128-130.

К типологии форм общины в доимперской России (XV- первая четверть XVIII в.)// Типология и особенности аграрного развития России и Восточной Европы X-XXI вв.: XXXIII сессия Симпозиума по аграрной истории Восточной Европы: Тезисы докладов и сообщений, Брянск, 19-22 сентября 2012 г. / Редкол.: Е.Н. Швейковская (отв. ред.) и др. М., 2012. С. 15-17.

O формах общины в доимперской России (XV - первая четверть XVIII в.) // Ежегодник по аграрной истории Восточной Европы. 2012 год: Типология и особенности регионального аграрного развития России и Восточной Европы X-XXI вв. М.; Брянск, 2012. С. 79-90.

Рец. на кн.: Демидова Н.Ф. Служилая бюрократия в России XVII века (1625-1700): Биографический справочник. М., 2011. 718 с. // Вестник Российского гуманитарного научного фонда. 2012. № 3. С. 219-222.

Отв. ред.: Актуальные проблемы аграрной истории Восточной Европы X-XXI вв.: источники и методы исследования: Материалы XXXII сессии Симпозиума по аграрной истории Восточной Европы / Редкол.: Е.Н. Швейковская (отв. ред.) и др. Рязань, 2012. 406 с.

Oтв. ред.: Ежегодник по аграрной истории Восточной Европы. 2012 год: Типология и особенности регионального аграрного развития России и Восточной Европы X-XXI вв. / Редкол.: Е.Н. Швейковская (отв. ред.) и др. М.; Брянск, 2012. 661 с. 
Отв. ред.: Типология и особенности аграрного развития России и Восточной Европы X-XXI вв.: XXXIII сессия Симпозиума по аграрной истории Восточной Европы: Тезисы докладов и сообщений, Брянск, 19-22 сентября 2012 г. / Редкол.: Е.Н. Швейковская (отв. ред.) и др. М., 2012. 212 с.

\section{3}

Наталья Александровна Горская — вехи творческого пути // Образы аграрной России IX-XVIII вв.: Памяти Натальи Александровны Горской: сборник статей. М., 2013. C. 9-18.

Некоторые аспекты социально-экономической истории России конца XVI-XVIII вв. в литературе 1990-2000-х гг. // Историографические чтения памяти профессора Виктора Александровича Муравьева: Сборник статей. В 2 т. М., 2013. Т. 2. С. 101-141.

Поморский Север - традиционный регион местного сословного представительства. Вторая половина XVI - первая половина XVII вв. // Сословное представительство в России в контексте европейской истории: вторая половина XVI - середина XVII вв.: Международная научная конференция 7-10 октября 2013 г.: Тезисы докладов / Отв. ред.: А.В. Доронин, В.Д. Назаров. М., 2013. С. 196-200.

Самоуправление в России XVI-XVII вв.// Российская государственность: опыт 1150-летней истории: Материалы Международной научной конференции: (Москва, 4-5 декабря 2012 г.) / Редкол.: Ю.А. Петров (отв. ред.) и др. М., 2013. С. 130-142.

Публ.: Семейная драма в Тотемском уезде первой трети XVII в. (реплика к изучению демонологии) // Археографический ежегодник за 2009-2010 годы. М., 2013. С. 389-398.

Источниковедческий ракурс в работе Симпозиума по аграрной истории Восточной Европы X-XXI вв. (Рязань, 21-24 сентября 2010 г.) // Там же. С. 505-508.

Pеu. на кн.: Демидова Н.Ф. Служилая бюрократия в России XVII века (1625-1700): Биографический справочник. М., 2011. 718 с.// Российская история. 2013. № 1. C. 205-208.

Oтв. ред.: Образы аграрной России IX-XVIII вв.: Памяти Натальи Александровны Горской: сборник статей. М., 2013. 256 с.

XXXIII сессия Симпозиума по проблемам агарной истории Восточной Европы (Брянск, 19-22 сентября 2012 г.) // Вестник Российского гуманитарного научного фонда. 2013. № 1(70). С. 183-189 (в соавторстве С.И. Михальченко).

\section{4}

Акты имущественных сделок крестьян Русского Севера XVII в. // Археографический ежегодник за 2011 год. М., 2014. С. 383-390.

Oтв. ред.: Ежегодник по аграрной истории Восточной Европы. 2013 год: Земледельцы и землевладельцы российской деревни конца XV — конца XX веков: экономическое, социальное и культурное развитие. М., 2014. 258 с., илл.

\section{5}

XXXIV сессия Симпозиума по проблемам аграрной истории Восточной Европы «Фискальная политика и налогово-повинностные практики в аграрной истории России X-XXI вв.» (Самара, 22-26 сентября 2014 г.) // Вестник Российского гуманитарного научного фонда. 2015. № 1 (78). С. 204-212. 
Материалы государственного и вотчинного учета [писцовые книги и документы писцового делопроизводства; переписные книги; приходные и расходные книги]// Источниковедение: Учебное пособие / [И. Н. Данилевский и др.]; отв. ред. М. Ф. Румянцева. М., 2015. С. 185-193. Разд. 2: Источниковедение как метод исторического познания, часть 1: Корпус источников российской истории, гл. $1, \S 4$.

О некоторых источниковых вопросах писцового наказа 1681 г. // Русь, Россия: Средневековье и Новое время. М., 2015. Вып. 4: Четвертые чтения памяти академика РАН Л.В. Милова: Материалы к Международной научной конференции, Москва, 26 октября - 1 ноября 2015 г. С. 26-31.

Российское крестьянство XIV-XVIII веков в трудах академика Н.Н. Покровского // Ежегодник по аграрной истории Восточной Европы. 2014 год: Фискальная политика и налогово-повинностные практики в аграрной истории России X-XXI вв. М.; Самара, 2015. С. 165-175.

Отв. ред.: Ежегодник по аграрной истории Восточной Европы. 2014 год: Фискальная политика и налогово-повинностные практики в аграрной истории России X-XXI вв. М.; Самара, 2015. 511 с.

Чл. редкол.: Русь, Россия: Средневековье и Новое время. М., 2015. Вып. 4: Четвертые чтения памяти академика РАН Л.В. Милова: Материалы к Международной научной конференции, Москва, 26 октября - 1 ноября 2015 г. 676 с.

\section{6}

Александр Ильич Копанев (1915-1990): Служение истории // Петербургский исторический журнал: исследования по российской и всеобщей истории. 2016. № 2 (10). C. $139-154$.

О константных признаках демографического и земледельческого развития в России в средневековье и новое время // Аграрное освоение и демографические процессы в России X-XXI вв.: XXXV сессия Симпозиума по аграрной истории Восточной Европы: Тезисы докладов и сообщений, Уфа, 20-23 сентября 2016 г. М., 2016. С. 3-5.

Судебно-следственные материалы XVI-XVIII вв. в творчестве академика Н.Н. Покровского: Источниковедческий аспект // Археографические и источниковедческие аспекты в изучении истории России: Сборник научных трудов [к 85-летию со дня рождения Н.Н. Покровского] / Отв. ред. А.Х. Элерт. Новосибирск, 2016 (Археография и источниковедение Сибири; вып. 34). С. 25-34.

Отв. ред.: Ежегодник по аграрной истории Восточной Европы. 2016 год.: Аграрное освоение и демографические процессы в России X-XXI вв. М.; Уфа, 2016. 523 с.

Oтв. ред.: Аграрное освоение и демографические процессы в России X-XXI вв.: XXXV сессия Симпозиума по аграрной истории Восточной Европы: Тезисы докладов и сообщений, Уфа, 20-23 сентября 2016 г. М., 2016. 256 с.

\section{7}

О сословном представительстве на Поморском севере России во второй половине XVI - первой половине XVII в.// Представительные институты в России в контексте европейской истории: XV - середина XVII в. / Отв. ред. В.Д. Назаров. М., 2017. C. 150-162. 
Чл. редкол.: Русь, Россия: Средневековье и Новое время. М., 2017. Вып. 5: Пятые чтения памяти академика РАН Л.В. Милова: Материалы к международной научной конференции Москва, 9-10 ноября 2017 г. 669 с. (Труды исторического факультета МГУ: Вып. 104. Сер. ІІ. Исторические исследования: 57).

\section{8}

За помещиком «во крестьянех не живал»: к действию пятилетнего срока сыска беглых крестьян в первой трети XVII века // Веков неспешный ход: проблемы социальноэкономической и политической истории России: Сборник статей к 70-летию профессора Валерия Николаевича Никулина / Отв. ред. И. Н. Данилевский. Калининград, 2018. С. 56-70.

Мирские выборы в системе земского самоуправления на севере России в XVIXVII вв. // «Вертоград многоцветный»: Сборник к 80-летию Бориса Николаевича Флори / Редкол.: А.А. Турилов (отв. ред.) и др. М., 2018. С. 441-452.

Проблемы аграрной и социальной истории России в трудах Симпозиума по аграрной истории Восточной Европы: к 60-летию деятельности // Ежегодник по аграрной истории Восточной Европы. 2018 год: Итоги и перспективы исследования аграрной истории России Х-XXI вв. М.; Брянск, 2018. С. 7-18.

Oтв. ред.: Ежегодник по аграрной истории Восточной Европы. 2017 год: Формы землевладения и системы землепользования, сельское управление и самоуправление в аграрной истории России X-XXI вв. М.; Брянск, 2108. 264 с.

Oтв. ред.: Ежегодник по аграрной истории Восточной Европы. 2018 год: Итоги и перспективы исследования аграрной истории России X-XXI вв. М.; Брянск, 2018. 291 c.

\section{9}

Еще раз о поземельных актах крестьян Русского Севера в XVII в. // Русь, Россия: Средневековье и Новое время. М., 2019. Вып. 6: Шестые чтения памяти академика РАН Л.В. Милова: Материалы к Международной научной конференции. Москва, 21-22 ноября 2019 г. С. 348-351.

Материалы государственного и вотчинного учета [писцовые книги и документы писцового делопроизводства; переписные книги; приходные и расходные книги] // Источниковедение: учебное пособие / [Д.А. Добровольский, И.Н. Данилевский, Р. Б. Казаков и др.]; отв. ред. М.Ф. Румянцева. 2-е изд., испр. М., 2019. С. 185-193. Разд. 2: Источниковедение как метод исторического познания, часть 1: Корпус источников российской истории, гл. $1, \S 4$.

Некоторые размышления по поводу шестидесятилетия Симпозиума по аграрной истории Восточной Европы // Российская история. 2019. № 1. С. 119-126.

Чл. редкол.: Русь, Россия: Средневековье и Новое время. М., 2019. Вып. 6: Шестые чтения памяти академика РАН Л.В. Милова: Материалы к Международной научной конференции, Москва, 21-22 ноября 2019 г. 732 с. (Труды исторического факультета МГУ: Вып. 163. Сер. ІІ. Исторические исследования: 102). 
Владимир Терентьевич Пашуто: Штрихи к портрету // Древнейшие государства Восточной Европы. 2019-2020 годы: Дипломатические практики античности и средневековья / Отв. ред. тома Б. Е. Рашковский. М., 2020. С. 10-18.

Роль сервитутов в землевладении и землепользовании российской деревни XVIпервой четверти XVIII вв.: к постановке вопроса // Ежегодник по аграрной истории Восточной Европы. 2019 год: Проблемы аграрного развития России XIV-XX вв. / Секция по проблемам аграрной истории Научного совета РАН. М.; Воронеж, 2020. C. 25-31.

Роль сервитутов в землевладении и землепользовании российской деревни XVI - первой четверти XVIII в.: к постановке вопроса // Социальный мир деревни X-XXI вв.: Земельные собственники / землевладельцы и земледельцы: XXXVII сессия Симпозиума по аграрной истории Восточной Европы: Тезисы докладов и сообщений, Воронеж, 22-25 сентября 2020 г. М., 2020. С. 15-18.

Чл. редкол.: Социальный мир деревни X-XXI вв.: Земельные собственники/землевладельцы и земледельцы: XXXVII сессия Симпозиума по аграрной истории Восточной Европы: Тезисы докладов и сообщений, Воронеж, 22-25 сентября 2020 г. / Редкол.: А.А. Горский (отв. ред.), В.В. Кондрашин (отв. ред.) и др. М., 2020. $278 \mathrm{c}$.

\section{1}

Статьи о межах в Правде Русской // Dísablót: Сборник статей коллег и учеников к юбилею Елены Александровны Мельниковой. М., 2021. С. 249-260. 


\title{
Д.Е. Гневашев
}

\section{ВОЛОГОДСКОЕ ПОМЕСТЬЕ МалютЫ СкУрАтовА}

\begin{abstract}
Аннотация В статье проанализированы немногочисленные ретроспективные данные, которые содержатся в финансовых документах Вологодской архиерейской кафедры первой половины XVII в., указывающие на наличие поместья в Вологодском уезде одного из самых известных опричников Малюты Скуратова.

Ключевые слова: опричнина, поместная система, Малюта Скуратов, Вологодский уезд, приходо-расходные и окладные книги.

Summary The article analyzes the few retrospective data contained in the financial documents of the Vologda episcopal diocese of the first half of the 17th century, indicating the presence of an estate of one of the most famous guardsmen Malyuta Skuratov in the Vologda district (uezd).

Keywords: oprichnina, estate system, Malyuta Skuratov, Vologda district, income and expense books and budget books.
\end{abstract}

В историографии опричнины частной и публичной сторонам жизни наиболее известного опричника Малюты Скуратова было уделено объяснимо заметное внимание. Казалось бы, после многочисленных трудов по истории опричнины классиков дореволюционной поры, исследователей советского и уже нашего времени ${ }^{1}$ новое слово и об опричнине, и о самом Малюте

1 Назовем авторов фундаментальных трудов по истории опричнины и примыкающим темам С.Б. Веселовского, А.А. Зимина, В.Б. Кобрина, В.И. Корецкого, Н.Е. Носова, П.А. Садикова, Р.Г. Скрынникова, опиравшихся на уже накопленную в предшествующее время фактографию опричнины и версии ее концептуального осмысления в работах Н.М. Карамзина, В.О. Ключевского, С.Ф. Платонова, Л.М. Сухотина и других ученых. Особо отметим исследования В.А. Аракчеева, В.И. Буганова, А.А. Булычева, К.Ю. Ерусалимского, В.А. Колобкова, И.В. Курукина, С.П. Мордовиной и А.Л. Станиславского, В.Д. Назарова, А.П. Павлова, Ю.Д. Рыкова, Я.Г. Солодкина, А.Л. Хорошкевич, А.И. Филюшкина, Б.Н. Флори, И.Я. Фроянова, С.О. Шмидта, А.Л. Юрганова, возвышающиеся на фоне многих других разнокалиберных исторических и околоисторических сочинений об опричном времени. 
Скуратове добавить сложно. Однако интерес к природе и причинам установления опричного режима, руководителям и рядовым членам опричного корпуса, практикам и символизму проявлений опричнины не иссякает. Биографические исследования, в ходе которых открываются новые факты семейной истории и служебного пути опричных деятелей и их жертв, позволяют с большей подробностью, а иногда и вовсе по-иному, рассматривать отдельные моменты в жизни России XVI в., в особенности пришедшиеся на тяжелые годы второй половины царствования Ивана Грозного.

Несколько поколений историков занимались поиском и осмыслением фактов генеалогии рода Бельских и служебной биографии самого яркого его представителя Малюты Скуратова. Впрочем, вновь обратиться к его персоне заставляют недавние работы Д.М. Володихина, Н.В. Башнина и А.Л. Корзинина, которые специально сосредоточились на его биографии и предложили иные трактовки накопленных данных ${ }^{2}$ В них в концентрированном виде изложены известные авторам сведения о Малюте Скуратове и его предках и потомках, служебном пути до и во время опричнины, движимом и недвижимом имуществе, упокоении его праха и установлении поминальной памяти Малюты и его родни.

В заголовок данной статьи вынесен локальный сюжет, которым определяется лишь один аспект биографии Малюты Скуратова, а именно землевладельческий. Необходимо на время отринуть какие бы то ни было моральные оценки личности Малюты и последствий его дел и sine ira et studio взглянуть на него как на одного из многих русских землевладельцев XVI в. Задача эта актуальна хотя бы потому, что по наблюдениям В.Б. Кобрина, авторитетного специалиста по истории опричного двора и его служилых, сведений о землевладении опричника М. Скуратова сохранилось мало ${ }^{3}$ Вообще, землевладение тех или иных лиц и институтов зачастую является единственным ключом к некоторым туманным, плохо обеспеченным источниками, а потому до сих пор дискуссионным сюжетам истории России доромановской поры. Вот и сейчас через реконструкцию землевладения одной из центральных

2 Бамнин Н.В., Корзинин А.Л. Новые данные к биографии опричника Малюты Скуратова // Российская история. 2017. № 2. С. 172-188; Из работ Д.М. Володихина укажем на эту, как на одну из самых насыщенных безапелляционными, далекими от научной доказательности утверждениями и фривольными домыслами: Володихин Д.М. Заметки о семействе Г.Л. Скуратова-Бельского // Археографический ежегодник за 2007-2008 годы. М., 2012. С. 113-125; Эта статья впоследствии почти дословно включена в первую главу другой работы того же автора: Володихин Д.М. Малюта Скуратов. М., 2012.

3 Кобрин В.Б. Состав Опричного двора Ивана Грозного // Кобрин В.Б. Опричнина. Генеалогия. Антропонимика. М., 2008. С. 25; Сам В.Б. Кобрин привел единственный известный ему факт: М. Скуратов отдал в приданое за дочерью в род князей Шуйских свою переславскую вотчину (сельцо Семеновское, 660 четвертей земли). 
фигур в опричнине можно попытаться узнать что-либо новое о функционировании и этапах развития самого «опричного проекта», и в особенности о малоизученной вологодской странице его истории.

Но мы еще более сузим поставленную задачу. Несмотря на выявленные к настоящему времени факты наличия малютинских поместий и вотчин в нескольких уездах страны, далее будем рассматривать его владения только в Вологодском уезде. Такое сознательное сужение исследовательского поля даст необходимую подробность и максимальное внимание к деталям картины землевладения Малюты Скуратова, так как источников для ее воссоздания у историка крайне мало, а те, которые имеются, носят подчас специфический характер и вызывают к жизни весьма экстравагантные авторские суждения.

Так, в статье Н.В. Башнина и А.Л. Корзинина «Новые данные к биографии опричника Малюты Скуратова» агрегировано большинство общеизвестных немногочисленных фактов о землевладении М. Скуратова в Вологодском уезде. Для связности дальнейшего изложения повторим их ниже в увязке с их интерпретацией названными соавторами.

Н.В. Башнин и А.Л. Корзинин, отмечая отрывочность сохранившихся сведений, констатируют наличие у Малюты Скуратова в разное время предположительных и убедительно подтверждаемых источниками земельных владений в Переславском, Перемышльском, Новгородском, Вяземском уездах. Этот ряд замыкает Вологодский уезд, в котором располагалось, по характеристике соавторов, «значительное владение» Скуратова ${ }^{4}$. Помогла установить и географически локализовать это владение, по их словам, некая «архивная находка», чем, видимо, отчасти и обусловлено название их статьи ${ }^{5}$.

${ }^{4}$ Башнин Н.В., Корзинин А.Л. Новые данные... С. 185-186.

5 К слову, к моменту опубликования Н.В. Башниным и А.Л. Корзининым своей статьи (2017 г.) с «новооткрытыми» данными о вологодском поместье Малюты Скуратова сведения об этом владении находились в научном обиходе уже свыше 150 лет. Еще в 1865 г. знаток вологодских церковных древностей Н.И. Суворов обратил внимание (правда, в кратком примечании) на почерпнутый им из окладных книг церковной дани Вологодского архиерейского дома факт наличия в уезде скуратовского поместья. Эти сведения окладных книг были впоследствии подтверждены В.Н. Сторожевым, опубликовавшим в 1906 г. единственный обнаруженный на сей день официальный документ светского происхождения, свидетельствующий о владениях М. Скуратова в Вологодском уезде. Данный документ был переиздан А.В. Антоновым в 2002 г. (Суворов Н.[И.] Несколько статистических и топографических сведений о Вологодской епархии от начала XVII столетия до настоящего времени // Вологодские епархиальные ведомости. 1865. № 21. Прибавления. С. 814. Прим. 38; Материалы для истории делопроизводства Поместного приказа по Вологодскому уезду в XVII веке, собранные В.Н. Сторожевым. СПб., 1906. Вып. 1. С. 361-364; Акты служилых землевладельцев XV - начала XVII века / Сост. А.В. Антонов. М., 2002. T. III. № 266. С. 217-218 (без указания на публикацию В.Н. Сторожева)). 
Из дальнейшего повествования становится понятным, что данная «архивная находка» - это окладные книги церковной дани Вологодской епархии за 1628/29 г., а принадлежит она М.С. Черкасовой, которая еще в 2010 г. сделала доклад с привлечением информации этого источника на XXXII сессии Симпозиума по аграрной истории Восточной Европы. В своей статье, опубликованной по итогам работы Симпозиума, М.С. Черкасова привела данные из упомянутых окладных книг о поместье М. Скуратова, которое, по ее мнению, состояло из «12 приходов, расположенных преимущественно в районе Сухонского правобережья в волостях Авнега, Шилегда, по р. Нозме, Черный Шингарь, Шуя, Паршенга, а северной своей оконечностью заходя на левобережье Сухоны по р. Наремке (Наремская слободка)» ${ }^{6}$. (В более ранней своей работе М.С. Черкасова писала только о восьми церковных приходах, входивших в поместье М. Скуратова. ${ }^{7}$ ) Впоследствии этот источник опубликовал Н.В. Башнин ${ }^{8}$. Сведения М.С. Черкасовой о 12 приходах, якобы составивших поместье М. Скуратова, были повторены Н.В. Башниным в вводном комментарии к этой публикации, а расположение поместья расплывчато указано им на приложенной карте9.

В разбираемой статье Н.В. Башнина и А.Л. Корзинина вновь повторен тезис о 12 приходах, входивших в поместье М. Скуратова, храмы этих приходов перечислены, территория их расположения приблизительно локализована в 40-70 км к востоку от г. Вологды. Из этих 12 приходов Авнежской и Шилегодской волостей соавторам удалось точно локализовать 11. Локализованные приходские центры нанесены на карту под названием «Поместье Малюты Скуратова в Вологодском уезде по окладной книге $1628 / 29$ г.» ${ }^{10}$. Чтобы оценить населенность скуратовского поместья, соавторы привлекли информацию окладных книг церковной дани Вологодской епархии на 1647/48 г., в которых зафиксированы наиболее ранние массовые сведения о количестве селений и дворов прихожан, окормлявшихся

6 Черкасова М.С. Архиерейские окладные книги как источник по землевладению и народонаселению в XVII в. // Актуальные проблемы аграрной истории Восточной Европы X-XXI вв.: источники и методы исследования. Материалы XXXII сессии Симпозиума по аграрной истории Восточной Европы. Рязань, 2012. С. 140.

7 Черкасова М.С. К изучению церковно-административных и территориальных структур на Русском Севере в XVI - начале XVIII в. // Государство и общество в России XV начала XX века. Сборник статей памяти Николая Евгеньевича Носова. СПб., 2007. С. 218.

8 Приходо-расходные денежные книги Вологодского архиерейского дома святой Софии и окладные книги церквей Вологодской епархии. XVII - начало XVIII в. / Сост. Н.В. Башнин. М.; СПб., 2016. [далее - ПРиОК] С. 471-504.

9 ПРиОК. С. 17; Иллюстрация 9. Карта, лист 8.

${ }^{10}$ Башнин Н.В., Корзинин А.Л. Новые данные... С. 187. 
священником того или иного прихода ${ }^{11}$. Так, по подсчетам Н.В. Башнина и А.Л. Корзинина, в поместье Скуратова должно было находиться не менее 136 селений с 776 дворами ${ }^{12}$.

Далее утверждается, что после смерти Малюты Скуратова начался раздел его поместья. Среди тех, кто получил жеребьи поместья, перечислены П.Ф. и И.Ф. Басмановы, вдова князя А.В. Голицына Мария, еще какое-то лицо или лица, по именам не названные ${ }^{13}$.

Статья снабжена картой, на которой визуализированы умозаключения соавторов. На карте сплошной заливкой, отграниченной двумя видами пунктиров от остальной территории Вологодского и смежных уездов, отмечена впечатляющая по площади территория поместья М. Скуратова. По ориентировочным измерениям, проведенным с помощью инструментария сайта «Публичная кадастровая карта» ${ }^{14}$, площадь скуратовского поместья, судя по карте Н.В. Башнина и А.Л. Корзинина, должна была составить свыше 1800 км² (для сравнения: площадь г. Москвы в пределах кольцевой автодороги составляет менее 900 км², площадь Княжества Лихтенштейн $\left.160 \mathrm{\kappa м}^{2}\right)$.

\footnotetext{
${ }^{11}$ ПРиОК. С. 527-529.

12 «По данным окладной книги 1647/48 г. на территории бывшего поместья Малюты Скуратова была 1 слободка, 16 селец, 114 деревень (одна пустая), 5 починков, 10 помещичьих дворов, 766 крестьянских дворов (4 пустых). Зная, что пик земледельческого освоения Вологодского уезда приходится на середину XVI в., можно утверждать, что к моменту получения поместья Малютой Скуратовым этот комплекс был не менее значительным» (Башнин Н.В., Корзинин А.Л. Новые данные... С. 186-187). Приведенный Н.В. Башниным и А.Л. Корзининым подсчет селений, якобы входивших в поместье Малюты, следует признать некорректным, поскольку при подсчете не учтены селения самого крупного из авнежских и шилегодских приходов - Никольского Старосельского. В окладных книгах 1647/48 г. по нему показано только количество дворов (247), данных о количестве селений в источнике нет. Кроме Старосельского в Авнежской и Шилегодской волостях было еще 14 приходов; по ним есть данные как по числу селений, так и по числу дворов. Совокупно к этим приходам тянуло 172 селения с 669 дворами. Вычислив среднее количество дворов, приходившихся на одно селение в 14 приходах $(669 / 172 \approx 3,89$ двора на селение), находим, что из расчетов Н.В. Башнина и А.Л. Корзинина выпало приблизительно 64 селения, тянувших к церкви Николая чудотворца в Старом селе $(247 / 3,89 \approx 64)$. Всего, таким образом, поместье Скуратова должно было бы включать, в соответствии с логикой примененного соавторами подсчета, около 200 селений.

${ }^{13}$ Соавторы приводят ссылку на источник (отдельную выпись от 26.07.1610 г. на поместье братьев Мишевских), упоминая только имя его составителя, отдельщика В.А. Холопова (Н.В. Башнин и А.Л. Корзинин почему-то называют его Хлоповым), но не указывая лиц, получивших землю из бывшего скуратовского поместья, что, на наш взгляд, представляется гораздо более важным в контексте разбираемого ими вопроса о землевладении М. Скуратова.

${ }^{14}$ www.pkk5.ru; Точность измерений определяется масштабом и доступными ориентирами, имеющимися на карте Башнина - Корзинина.
} 
В финале своих рассуждений соавторы констатируют, что «Малютинское поместье Скуратова» упоминается еще раз в архиерейских приходо-расходных книгах 1627/28 г., в иных же источниках церковного происхождения (окладных и приходо-расходных книгах) за 1630-1690 гг. упоминаний поместья Малюты больше не встречается ${ }^{15}$.

Суммируем выводы Н.В. Башнина и А.Л. Корзинина. По их мнению, в уезде Вологды, взятой в опричный удел царя Ивана Грозного, был испомещен ряд опричников, в числе которых находился Малюта Скуратов. О его вологодском поместье свидетельствуют три источника: отдельная выпись 1610 г., архиерейские приходо-расходные книги 1627/28 г. и окладные книги церковной дани 1628/29 г. Последний источник для соавторов наиболее информативен: в нем перечислены 12 приходов, селения которых ранее состояли в поместье М. Скуратова. 11 приходов располагались в двух смежных волостях - Авнежской и Шилегодской, один приход - в Заозерской половине уезда. Судя по приложенной карте, поместье представляло собой сплошной земельный массив огромной площади, раскинувшийся преимущественно на правом и частично на левом берегах p. Сухоны. Восточной границей поместье смыкалось с территориями Галичского и Тотемского уездов. На севере, заходя на территорию Заозерской половины Вологодского уезда, поместье граничило с ее присухонскими волостями, на юге - с вологодской волостью Лежский волок, а на западе - с землями Авнежской волости (западная часть волости Авнеги в «малютинское поместье» не включена). В единый земельный массив поместья вклинивалась вотчина ростовских архиереев, обозначенная на карте как «Шейбухта» ${ }^{16}$. После смерти Скуратова его поместье было разделено; среди лиц, получивших земли поместья, поименно названы братья Петр и Иван Федоровичи Басмановы и княгиня Мария Голицына. В учетно-финансовой документации Вологодского архиерейского дома 1630-1690 гг. сведений о поместье Малюты соавторам больше не встретилось.

Проведя собственное исследование вопроса о вологодском поместье Малюты Скуратова, находим, что в подавляющем большинстве вышеизложенные утверждения Н.В. Башнина и А.Л. Корзинина или неполны, или неточны, или вовсе не соответствуют действительности.

Проанализируем построения Н.В. Башнина и А.Л. Корзинина. В их основу и предпринятую географическую реконструкцию поместья М. Ску-

\footnotetext{
${ }^{15}$ Баинин Н.В., Корзинин А.Л. Новые данные... С. 188; Также: ПРиОК. С. 17.

${ }^{16}$ Вотчина ростовских архиереев в XVI - XVII вв. состояла из трех смежных, но все же самостоятельных отдельных волостей - Шейбухты, Кочкова и Козланги.
} 
ратова, по сути, положен единственный источник ${ }^{17}$ - окладные книги церковной дани 1628/29 г., в которых под соответствующей рубрикой «Малютинское поместье Скуратова» (вариант: «Малюты Скуратова»), действительно, перечислено несколько приходов Авнежской и Шилегодской волостей. Но сразу возникает вопрос: можно ли на информации источника церковного происхождения, созданного через 56 лет после смерти упоминаемого в нем исторического деятеля, реконструировать реалии его светской жизни более чем полувековой давности? Если ответ положительный и источник допущен исследователем к дальнейшему рассмотрению и использованию в качестве доказательства, то неминуемо должны возникнуть другие, не менее важные, вопросы. При каких условиях (ограничениях) можно использовать источник таким образом? Существуют ли подобные источники, созданные до или после данного источника, содержащие значимые для целей исследования сведения? Есть ли иные источники церковного и/или светского происхождения, которые подтверждают (дополняют, опровергают) сведения выбранного источника? Также важно понять, оригинален ли привлеченный текст или он базируется на ином тексте (текстах)? Если да, то что это за текст (тексты), и возможно ли восстановление протографа? Наконец, в каких целях и кем был создан источник, как он использовался и подвергался ли при этом исправлениям и редактуре? Послужил ли он сам основой для других письменных памятников?

Все эти базовые источниковедческие вопросы, обычно предшествующие и сопровождающие любую историческую штудию, в рассуждениях Н.В. Башнина и А.Л. Корзинина не были даже поставлены. Между тем, они должны были бы звучать предельно отчетливо, в особенности в данном конкретном исследовании, учитывая происхождение, назначение и столь позднее время создания единственного привлекаемого значимого документа, к тому же на фоне обнаруженного соавторами явного дефицита иных источников, налагающего на пишущих высокую ответственность публикуемых выводов.

Но так ли уж узка источниковая база, как это явствует из статьи Н.В. Башнина и А.Л. Корзинина? К счастью, нет. Окладные книги церковной дани Вологодской епархии сохранились также и за другие годы. Н.В. Башнин выявил 12 окладных книг XVII-XVIII вв., из которых под его эгидой опубликовано четыре: за 1628/29, 1647/48, 1677/78, 1702 гг. Среди

\footnotetext{
${ }^{17}$ На основе остальных двух привлекаемых источников (отдельной выписи 1610 г. и единственного упоминания поместья в приходо-расходных книгах 1627/28 г.) соавторам не удалось бы написать столь грандиозную картину вологодских владений знаменитого опричника.
} 
выявленных, но неопубликованных, он называет наиболее ранние книги за $1616 / 17,1626^{18}, 1638^{19}$ гг. $^{20}$ То же самое можно сказать и об архиерейских приходо-расходных книгах, которые, несомненно, должны были бы в пандан к окладным привлекаться соавторами к исследованию для взаимной проверки информации обеих групп источников. Их Н.В. Башниным выявлено 86, в том числе 33 книги за 1585, 1600, 1612/13-1650 гг. ${ }^{21}$

И в этой связи возникает еще один очевидный вопрос - почему к исследованию привлечены из нескольких сохранившихся окладных книг (и хорошо известных одному из соавторов) только книги за 1628/29 г.? Почему именно за этот год? Весьма странно, что не привлечены наиболее ранние из выявленных или, вообще, все такого рода источники, раз уж в одном из них были обнаружены поистине уникальные данные о Малюте Скуратове и его вологодском поместье. Подобный вопрос уместно задать и по поводу приходо-расходных книг.

Вызывают сомнения некоторые исследовательские приемы, примененные Н.В. Башниным и А.Л. Корзининым. Обнаружив противоречивые данные источников (в окладных книгах 1628/29 г., по мнению соавторов, в поместье Скуратова насчитывается 12 погостов, а приходо-расходные книги 1627/28 г. к поместью определенно относят только один из них), соавторы посчитали возможным пройти мимо этого вопиющего факта, никак его не прокомментировав и произвольно выбрав основным только один из источников. Пытаясь охарактеризовать освоенность (количество селений) и населенность (количество дворов и их жителей) малютинско-

\footnotetext{
${ }^{18}$ В действительности - 1624/25 г.

${ }^{19}$ В действительности - 1638/39 г.

${ }^{20}$ ПРиОК. С. 8.

${ }^{21}$ ПРиОК. С. 9-10; Безусловно, нас более всего должны были бы заинтересовать две наиболее ранние книги. Но, увы, эти источники не относятся к Вологодскому архиерейскому дому. Так, приходо-расходные книги «1585 г. (черновые записи)» (по Н.В. Башнину) в действительности являются подлинными расходными книгами старца Вологодского Спасо-Печенгского (?) монастыря Власия на покупку ржи, «что в Шуйском горотке покупал», за 20.12.1585 -29.05.1586 г. (Государственный архив Вологодской области [далее - ГАВО]. Ф. 883. Оп. 1. Д. 1). Приходо-расходные книги «1600 г. (отрывки)» (по Н.В. Башнину) в действительности являются подлинными приходными книгами старца Вологодского Спасо-Печенгского монастыря Зосимы с датированными записями за 19.08.1596, 5.08-20.09.1599, 2.01-3.03.1600 г., сохранившимися в полном объеме (Там же. Д. 3). В связи с этим автоматически снимается недоумение В.И. Иванова, И.А. Устиновой и И.Н. Шаминой, почему в публикацию хозяйственных документов Вологодского архиерейского дома Н.В. Башниным так и не были включены его наиболее древние приходо-расходные книги (Иванов В.И. Рецензия на книгу: Приходо-расходные денежные книги Вологодского архиерейского дома... // Вестник Вологодского государственного университета. 2018. № 2. С. 93; Устинова И.А., Шамина И.Н. История Вологодского архиерейского дома: новые источники // Российская история. 2019. № 4. С. 224).
} 
го поместья, соавторы пишут о пике освоения Вологодского уезда в середине XVI в., ссылаясь на работу П.А. Колесникова, (который, к слову, ни о каких «пиках» ни в середине XVI в., ни когда бы то ни было еще, вообще, не упоминал ${ }^{22}$ ). Тем самым они подводят читателя к мысли, что степень освоенности уезда и, следовательно, волостей, которые поглотило поместье Малюты, была одинаковой и в середине XVII в., и в середине XVI в. Взяв за основу этот неочевидный тезис, Н.В. Башнин и А.Л. Корзинин механически переносят специфические данные церковного учета о величине приходов середины XVII в. на столетие (!) назад, на то время, когда даже самой территории уезда (и епархии тоже!) еще не сложилось в привычных границах XVII в. Но правомерны ли такие исторические проекции, как будто не было ни поветрия 1570-х гг, ни годуновского голода, ни опустошительных походов казаков, польско-литовских отрядов и русских «воров» во времена Смуты, ни частых зяблых лет и государственного «финансового террора», гнавших податное население с обжитых территорий, ни кратковременных и географически неравномерных периодов восстановительного роста народного хозяйства за счет крестьянского труда и колонизаторской инициативы сменявших друг друга владельцев этих земель?

Трудно согласиться с некоторыми следующими констатациями соавторов рассматриваемой статьи. Если в описываемом районе Авнежской и Шилегодской волостей помимо поместья Малюты Скуратова они отыскивают еще поместье опричника И.А. Бутурлина ${ }^{23}$, то, спрашивается, где же оно располагалось конкретно и какие земли включало? И если у думного дворянина Скуратова было настолько огромное поместье, то какого же размера оно должно было быть у опричного боярина Ивана Андреевича Бутурлина? Кроме того, где-то рядом надо было найти сравнимое (по крайней мере, не меньшее) количество населенной земли и для кравчего Федора Алексеевича Басманова. (Последний указан соавторами в числе вологодских помещиков-опричников.) Однако с Ф.А. Басмановым вышла полная неразбериха. Н.В. Башнин и А.Л. Корзинин пишут: «В 1588 г. в деловой братьев П.Ф. и И.Ф. Басмановых упоминается в Вологодском уезде село Никольское, бывшее ранее в составе “Малютинского поместья"» ${ }^{24}$. Но в деловой грамоте нет ни единого намека на то, что село принадлежало Малюте

\footnotetext{
22 Даем ту же ссылку, что и Н.В. Башнин и А.Л. Корзинин: Колесников П.А. Северная деревня в XV - первой половине XIX века. К вопросу об эволюции аграрных отношений в Русском государстве. [Вологда,] 1976. С. 84.

${ }^{23}$ Башнин Н.В., Корзинин А.Л. Новые данные... С. 188.

${ }^{24}$ Там же.
} 
Скуратову $^{25}$. Кроме того, Ф.А. Басманов, чьи земли в 1588 г. делила его бывшая жена между сыновьями, окончил жизнь около 1570 г. (казнен или умер в ссылке, доподлинно неизвестно). Тогда каким образом опальный и, вероятно, уже умерший в 1570 г. Ф.А. Басманов мог получить село Никольское из поместья Скуратова, погибшего в 1573 г.? Не объясняется.

Серьезные вопросы возникают и к представленной карте. Непостижимым образом в поместье Малюты Скуратова «растворились» вотчины Троице-Авнежского монастыря в Авнежской и Александро-Коровиной пустыни в Шилегодской волостях, полученные этими монастырями еще в доопричные годы. Нет достоверных данных, что вотчины этих духовных корпораций были конфискованы в опричнину и пущены в поместную раздачу. Территория поместья Малюты, как она представлена Н.В. Башниным и А.Л. Корзининым на карте, «перекинулась» через р. Сухону в Заозерскую половину уезда не только в районе Наремской слободки, но и ниже Шуйского городка, захватив селения на левобережье Сухоны вплоть до слободки Мотыри. Эти земли, действительно, административно тянули в XVII в. к Шилегодской волости, но их жители приходили молиться (вернее сказать, приплывали по реке) к Иоанно-Предтеченскому храму на Векшенге в Тотемском уезде, который, даже по версии Н.В. Башнина и А.Л. Корзинина, к малютинскому поместью отношения не имел. Все это говорит о том, что нельзя механически переносить церковные структуры организации пространства (сеть приходов / погостов) на формальные территориальные образования, порожденные конкретными обстоятельствами истории местных социумов (волостных миров и землевладельцев всех типов) и организаторской деятельностью властей различных уровней.

Можно было бы и далее указывать на ошибки и несоответствия, имеющиеся в статье Н.В. Башнина и А.Л. Корзинина, но и уже отмеченные говорят о том, что работа проведена ими неопрятно. Неоправданное сужение соавторами источниковой базы и легковерное отношение к произвольно отобранным источникам, некорректные ни методологически, ни арифметически подсчеты, хронологические несуразицы и весьма вольные трактовки информации источников и научной литературы повлекли за собой набор легковесных, противоречащих другу другу утверждений, не имеющих ничего общего с историческими реалиями. При этом авторские утверждения преподносятся без малейшей тени сомнений. К сожалению, эти заблуждения под видом твердо доказанных фактов из профессиональной узкопро-

${ }^{25}$ Акты юридические, или Собрание форм старинного делопроизводства. СПб., 1838. № 266. С. 278; Назаров В.Д. Из истории аграрной политики царизма в XVI веке // Советские архивы. 1968. № 3. С. 114. 
фильной литературы уже мигрировали в литературу научно-популярную ${ }^{26}$ и сайты в интернете ${ }^{27}$, где получили доступ к максимально широкой читательской аудитории.

Попробуем разобраться, что же было или, скорее, могло быть в реальности, поскольку источников для окончательных суждений, действительно, мало, они отрывочны, а между временем создания этих источников и ретроспективно отраженными в них событиями пролегает значительный временной промежуток. Но одно можно сказать вполне точно - вологодское поместье Малюты Скуратова не было столь гигантским, каким преподносят его Н.В. Башнин и А.Л. Корзинин. А каким же оно было?

Для начала необходимо установить, когда имя Малюты Скуратова проникло в архиерейские окладные книги. Как уже отмечено, к настоящему времени за первую половину XVII в. окладные книги известны только за 1616/17, 1624/25, 1628/29, 1638/39 и 1647/48 гг., хотя еще первооткрыватель этого вида источников Н.И. Суворов держал в руках 14 (!) вологодских окладных книг этого периода ${ }^{28}$. Обратимся к этим пяти сохранившимся книгам во времени назад. В книгах 1647/48 г. имени Малюты нет $^{29}$. Но вот в книгах $1638 / 39,1628 / 29$ и 1624/25 гг. рубрика «Малютинское поместье Скуратова» (в вариациях) имеется. В наиболее ранних книгах 1616/17 г., сохранившихся без начала и конца (при этом текст памятника, перечисляющий приходы Авнежской и Шилегодской волостей, исправен), имени Малюты также не встречается. Для сравнения соберем сведения окладных книг по всем приходам Авнежской и Шилегодской волостей в таблицу. Кроме того, добавим в нее крайне важные сведения из несохранившихся или пока не разысканных окладных книг 1621 г., сообщенные Н.И. Суворовым. В таблицу также включим описания этих погостов, выбранные из писцовых материалов 1610-1620-х гг.

Общими для всех окладных книг являются только храмоименования и порядок перечисления приходов, лишь однажды перебиваемый включением в церковный оклад Воскресенского погоста на р. Великой, стоявшего в вотчине Спасо-Прилуцкого монастыря (книги 1624/25 и 1628/29 гг.). Привязка приходов к волостям уезда по писцовому описанию наибольшее соответствие находит в окладных книгах 1616/17 г. (за исключением Наремского прихода). Нетрудно заметить, что все окладные книги

${ }^{26}$ Черкасова М.С. Северная Русь: история сурового края XIII-XVII вв. М., 2017. С. 79-80.

${ }^{27}$ Сайт «Правящая элита Русского государства в правление Ивана Грозного» (https:// russian-court.spbu.ru/component/fabrik/details/1/2372.html?Itemid=108).

${ }^{28}$ Суворов Н.[И.] Несколько статистических... С. 597.

${ }^{29}$ ПРиОК. С. 505-550. 


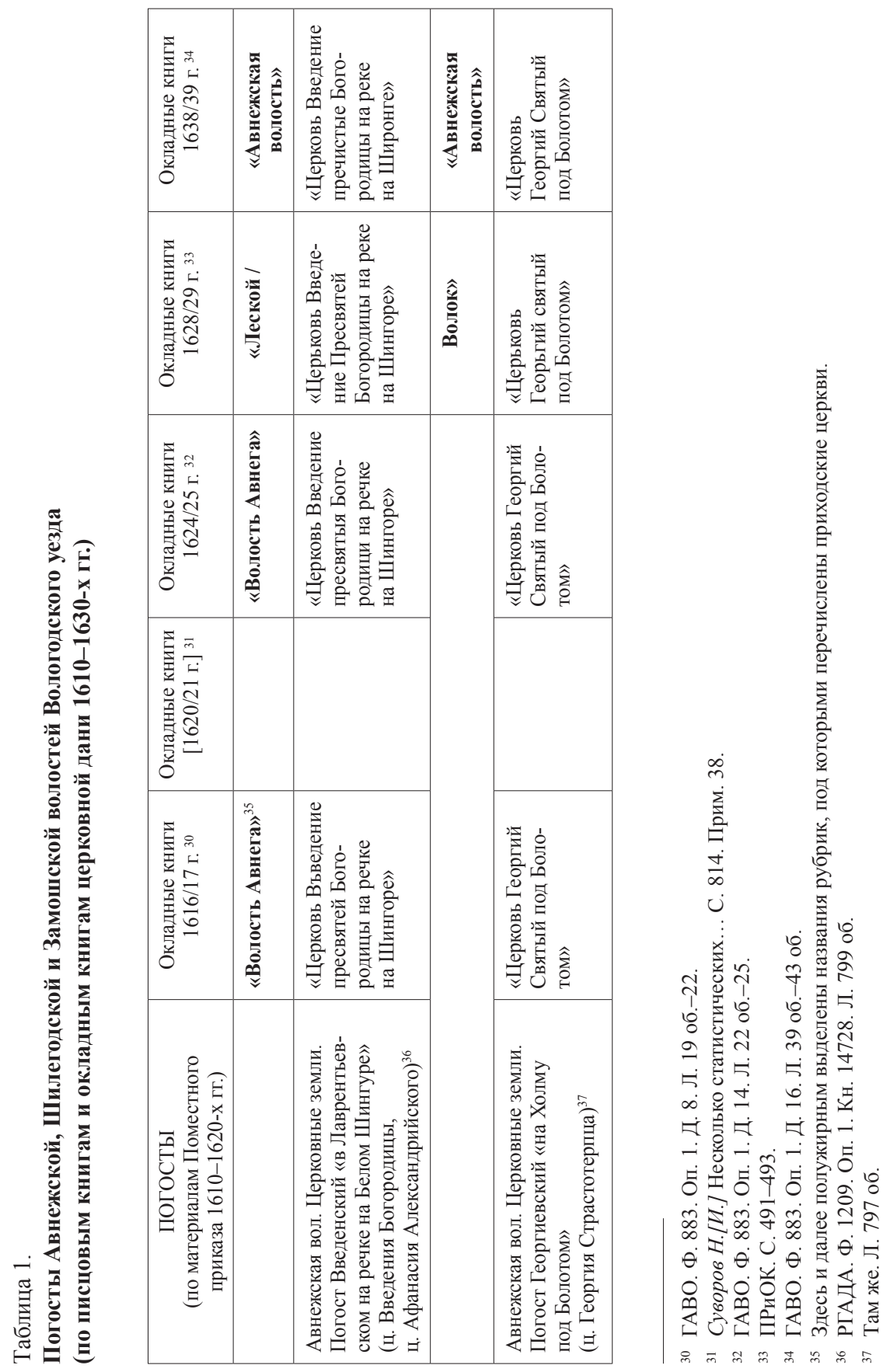




\begin{tabular}{|c|c|c|c|c|c|c|c|c|}
\hline 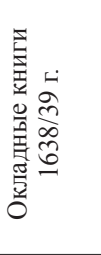 & 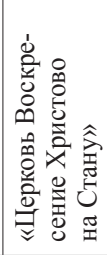 & & & 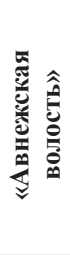 & 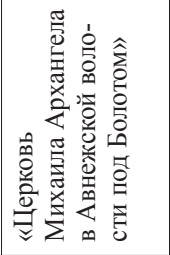 & & 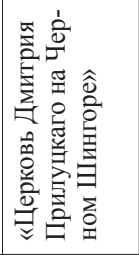 & $\begin{array}{l}\dot{6} \\
\dot{0} \\
\infty \\
\dot{\sigma} \\
\dot{0}\end{array}$ \\
\hline 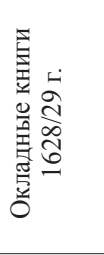 & 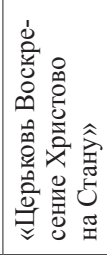 & 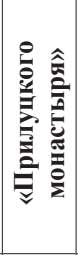 & 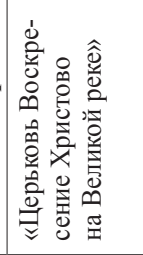 & & 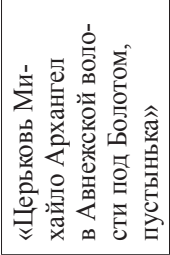 & 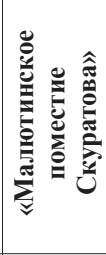 & 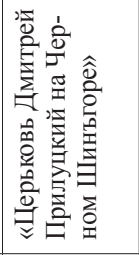 & 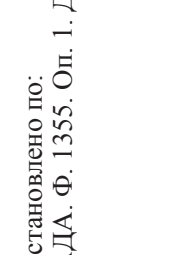 \\
\hline 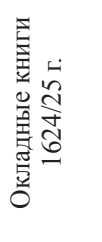 & 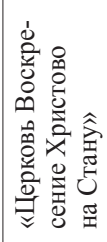 & 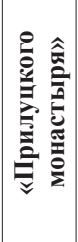 & 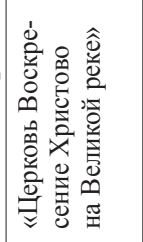 & & 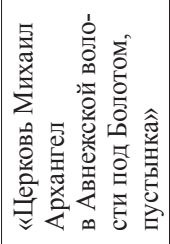 & 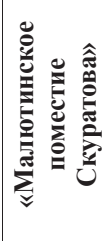 & 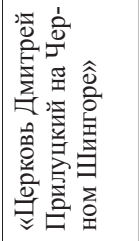 & 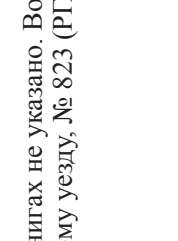 \\
\hline 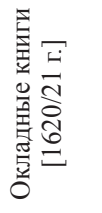 & & & & & & & 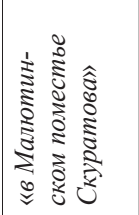 & 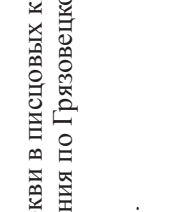 \\
\hline 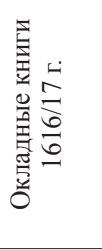 & 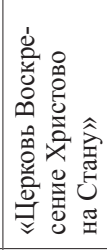 & & & & 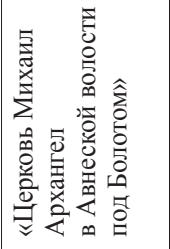 & & 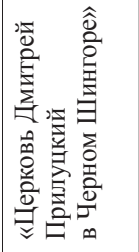 & 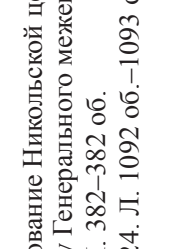 \\
\hline 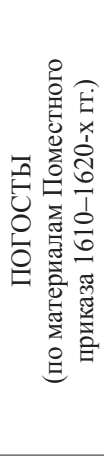 & 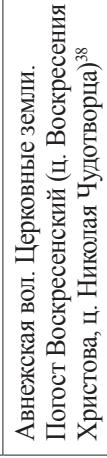 & & 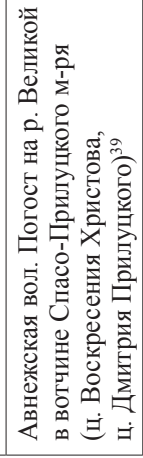 & & 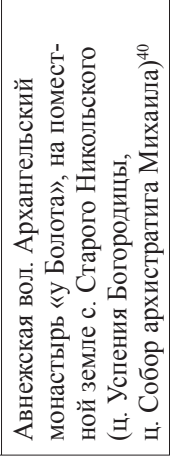 & & 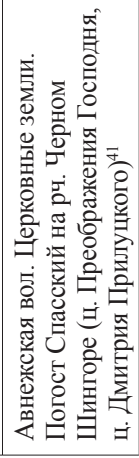 & 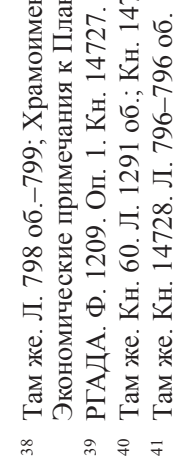 \\
\hline
\end{tabular}




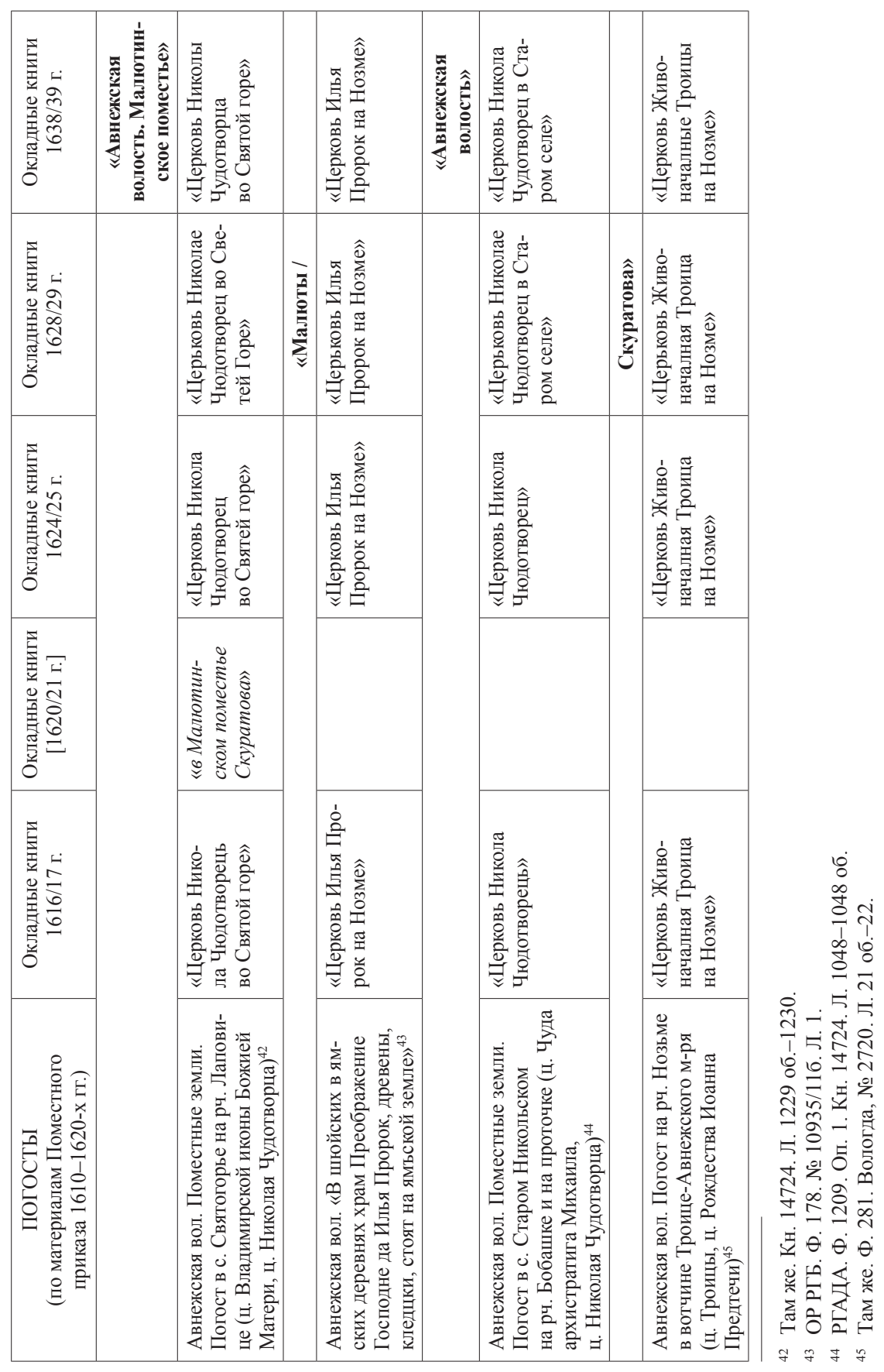




\begin{tabular}{|c|c|c|c|c|c|c|c|c|c|}
\hline 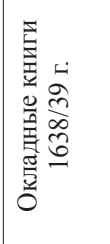 & 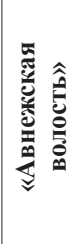 & 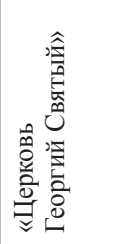 & & 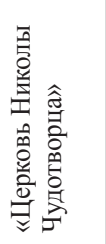 & 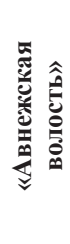 & 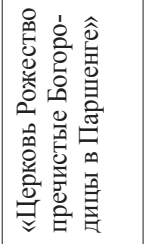 & & 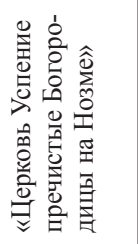 & \\
\hline 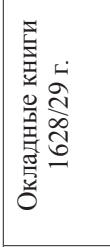 & 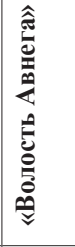 & 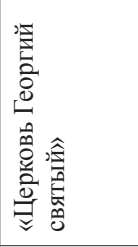 & 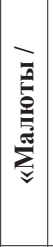 & 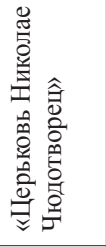 & & 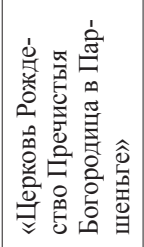 & 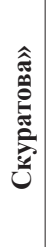 & 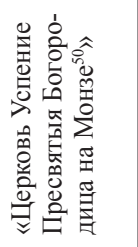 & \\
\hline 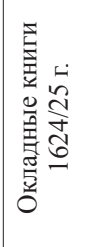 & 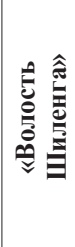 & 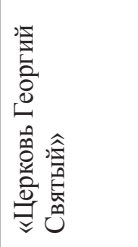 & & 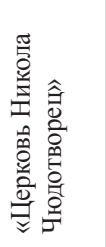 & & 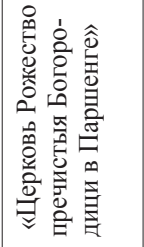 & & 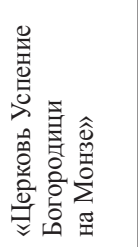 & \\
\hline 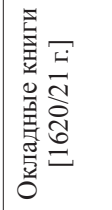 & & & & & & & & & ๙ิ \\
\hline 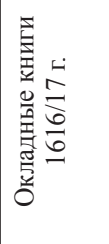 & 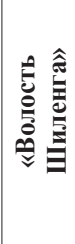 & 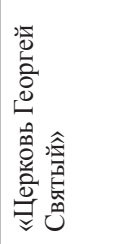 & & 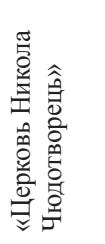 & & 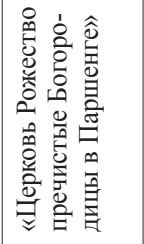 & & 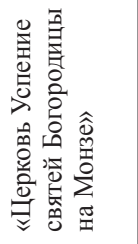 & 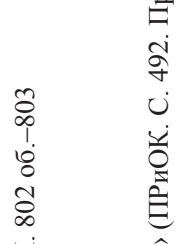 \\
\hline 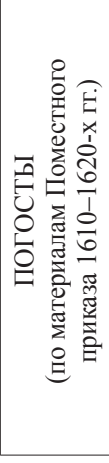 & & 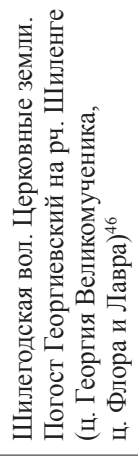 & & 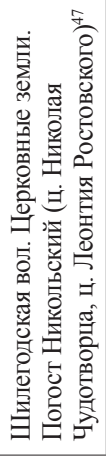 & & 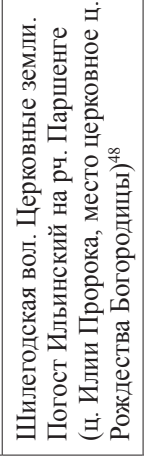 & & 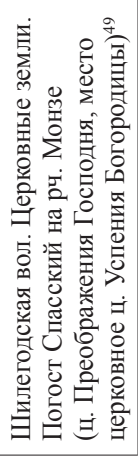 & 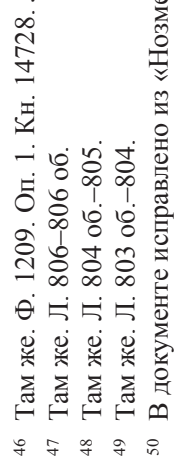 \\
\hline
\end{tabular}




\begin{tabular}{|c|c|c|c|c|c|}
\hline 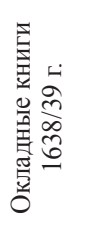 & 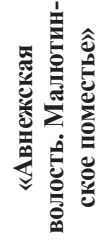 & 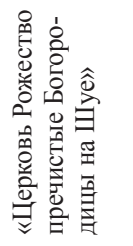 & 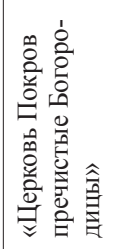 & 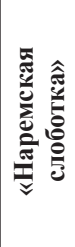 & 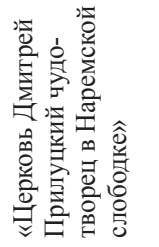 \\
\hline 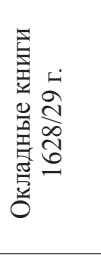 & & 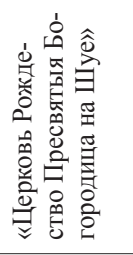 & 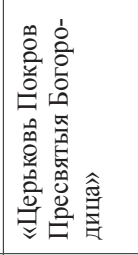 & & 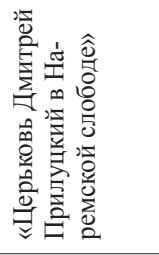 \\
\hline 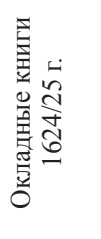 & & 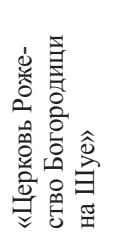 & 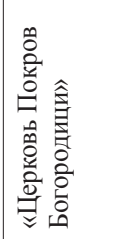 & & 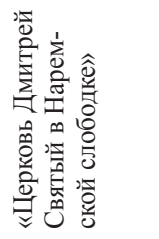 \\
\hline 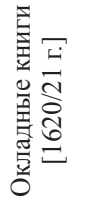 & & & & & \\
\hline 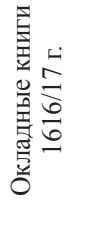 & & 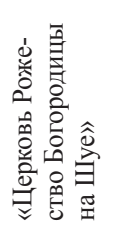 & 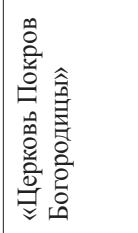 & & 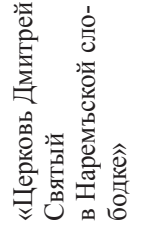 \\
\hline 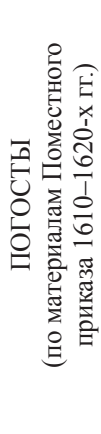 & & 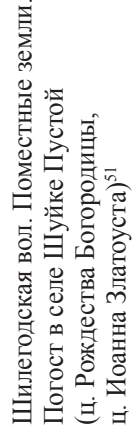 & 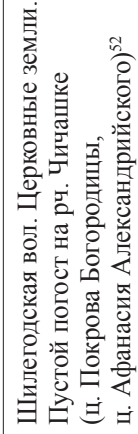 & & 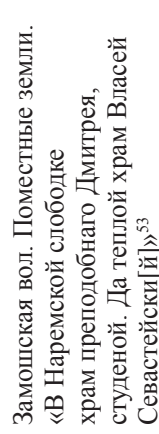 \\
\hline
\end{tabular}

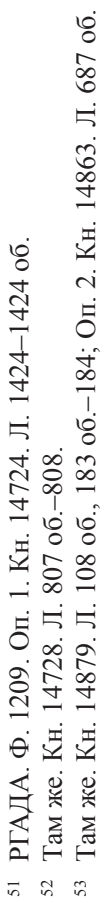


заметно различаются по набору и расположению рубрик, внутри которых записаны приходы. В книге 1616/17 г. — всего две рубрики, в книгах $1624 / 25$ и 1628/29 гг. их уже четыре, причем они разнятся между собой, в книге 1638/39 г. — только три рубрики, но при этом появляется новая, неизвестная трем ранним книгам («Наремская слоботка»). Впервые поместье Малюты упомянуто в книгах 1624/25 г., при этом под рубрикой «Малютинское поместие Скуратова» перечислены пять храмов только Авнежской волости; все остальные храмы записаны под самостоятельными рубриками. Уже один этот факт ограничивает поместье Малюты лишь пятью погостами, а не двенадцатью, как у М.С. Черкасовой, Н.В. Башнина и А.Л. Корзинина.

К сожалению, в распоряжении исследователей нет текстов окладных книг за 1617/18-1623/24 гг., при помощи которых можно было бы уточнить время появления в них имени Малюты. Однако есть важное, хотя и довольно позднее и нечеткое, свидетельство Н.И. Суворова, которым в данном случае пренебрегать нельзя: «О церквах под №№ 136 и 137 в окладной книге 1621 года помечено, что они находились “в Малютинском поместье Скуратова”, т. е. в поместье Малюты Скуратова, известного опричника царя Ивана IV» ${ }^{54}$. Неясно, правда, для какого фискального года - 1620/21 или 1621/22 - была изготовлена эта книга, но из общих соображений считаем ее книгой за 1620/21 г. Следует подчеркнуть и то, что если бы в распоряжении внимательнейшего исследователя Н.И. Суворова были книги за 1618/19 и 1619/20 гг. и в них было бы упоминание малютинского поместья, то он, скорее всего, сослался бы на самую раннюю книгу, в которой бы ему повстречалось имя Скуратова. По крайней мере, на окладную книгу 1618 г. (очевидно, 1617/18), которую Н.И. Суворов активно цитирует в своей работе, он не ссылается как на источник, упоминающий Скуратова. Можно заключить, что Н.И. Суворов не был знаком с окладными книгами за 1618/19 и 1619/20 гг, а если и был знаком, то не нашел в них упоминания малютинского поместья. Итак, твердо установлено, что имя Малюты Скуратова в окладных книгах возникает не ранее 1616/17 г. и не позднее 1624/25 г., а если принять свидетельство Н.И. Суворова, то младшую дату мы с оговорками вправе сдвинуть к 1620/21 г.

Окладные книги составлялись в архиерейских казенных приказах ежегодно. Очевидно, при составлении книги на следующий год за основу

${ }^{54}$ Суворов Н.[И.] Несколько статистических... С. 814. Прим. 38; в перечне Н.И. Суворова под №№ 136 и 137 значатся церкви Дмитрия Прилуцкого на Черном Шингоре и Николая чудотворца во Святой горе, обе в Авнежской волости. 
бралась книга, используемая в завершающемся году. Поэтому зачастую ошибки, описки, исправления, уточнения, дополнения, содержащиеся в книге, с которой готовилась копия на следующий год, в том или ином объеме попадали в новую книгу. К сожалению, пока нет возможности сравнить тексты книг за соседние годы, что позволило бы надежно доказать справедливость этого наблюдения. Впрочем, анализ текстов имеющихся книг дает серьезные основания считать именно так. Даже из приведенных примеров видно, как с течением времени накапливались, наслаивались друг на друга при очередном копировании погрешности и текстуальные вставки, иногда приводящие к невообразимой путанице ${ }^{55}$. Церкви одной волости оказывались записанными в другую. Например, авнежские Введенский, Воскресенский и Георгиевский приходы в книгах 1628/29 г. попали в рубрику «Ле[ж]ской волок», а ряд шилегодских приходов был записан в волость Авнегу (см. табл. 1). Впрочем, архиерейские дьяки, замечая подобные несоответствия, пытались их исправлять ${ }^{56}$. Но эти исправления и уточнения вносились казенными дьяками без всякой системы, и, вероятно, только ради своего удобства пользования книгой, поскольку они не влияли на главную задачу ведения книги - бухгалтерскую. К сожалению, Н.В. Башнин и А.Л. Корзинин, вольно или невольно, выбрали для своего исследования из трех окладных книг, упоминающих вологодское поместье Малюты Скуратова, текстуально самую испорченную, откуда и возникла ошибка с 12 приходами в его поместье ${ }^{57}$. Учитывая приведенные доводы, в дальнейших рассуждениях целесообразно опираться на наиболее ранний текст окладных книг (1624/25 г.), перечисляющий в поместье М. Скуратова только пять храмов Авнежской волости, а тексты более поздних окладных книг считать вторичными, испорченными многократными переписываниями, и исключить их из рассмотрения.

\footnotetext{
${ }^{55}$ Некритическое использование топонимии этого вида источников способно привести к абсурдным выводам. Так, слепое доверие источникам сподвигло Н.В. Башнина наделить один из приходов из «поместья М. Скуратова» (Покровский Шилегодский) поистине квантовыми свойствами и способностью находиться одновременно в трех волостях. В указателе к опубликованным им документам одна из церквей поименована так: «Покрова в Авнеге в Шилегодской вол[ости] на Лежском Волоке» (!) (ПРиОК. С. 782).

${ }^{56}$ См. примеры таких исправлений в книгах 1628/29 г. (ПРиОК. С. 475. Прим. 44, 49; С. 479 . Прим. 111 ; С. 480 . Прим. 115 ; С. 481 . Прим. 137 и т. д.).

${ }^{57}$ Строго говоря, даже этот испорченный текст перечисляет только девять малютинских приходов. Георгиевский Шиленгский приход записан под уточняющей (и тем самым исключающей данный приход из числа скуратовских), но при этом неверной (!) подрубрикой «Волость Авнега», а Покровский Шиленгский и Наремский приходы записаны в книге, вообще, вне рубрик. Поэтому принадлежность этих трех храмов к поместью Малюты Скуратова даже в этом случае неочевидна (см. табл. 1; также: ПРиОК. С. 492-493).
} 
Безусловно, добытая из окладных книг информация о поместье Малюты подлежит проверке и уточнению сведениями из архиерейских приходо-расходных книг. Для такого уточнения понадобятся только приходные разделы этих книг, в которых учитывались поступления церковной дани и венечных пошлин. Типовая формула записи в них о приеме в архиерейскую казну той или иной суммы включала в себя дату события, сведения об адресате (архиерейская казна) и адресанте платежа (название храма по его главному престолу и его географическое расположение, имя священника, вносившего деньги), а также вид и величину принятых пошлин. Важно установить, каким образом в приходных книгах, синхронных окладным, фиксировалось географическое расположение тех пяти храмов, которые окладные книги 1624/25 г. отнесли к поместью Малюты Скуратова. Сведем эти данные в таблицу, в которую также включим имена священников этих храмов. Это в некоторой степени поможет уточнить хронологию происходивших событий. Имена священников, чьи храмы были записаны в книгах с пометкой «Малютинского поместья Скуратова» (или аналогичными), выделим полужирным шрифтом (см. табл. 2).

Приведенные сведения приходных книг рисуют любопытную картину. Во-первых, в книгах за разные годы малютинскими названо различное количество храмов, от одного до трех, при этом в их число никогда не попадают Троицкий и Дмитриевский приходы. (Здесь же отметим, что в исследованных нами приходных книгах малютинским более не назван ни один храм во всем Вологодском уезде, кроме тех, что отмечены в таблице 2.) Во-вторых, в приходных книгах 1612/13-1620/21 гг. малютинские храмы не упомянуты, и, что важно, впервые имя Малюты фиксируют только приходные книги за 1621/22 г. В книгах предыдущего 1620/21 г. таких сведений нет. Данный факт как будто бы подтверждает свидетельство Н.И. Суворова о том, что в окладных книгах сведения о малютинских храмах возникают не позднее 1621 г., но совершенно с ним расходится по их набору. Напомним, согласно Н.И. Суворову, окладные книги 1621 г. называют малютинскими Дмитриевский Черношингорский и Никольский Святогорский приходы, а приходные книги 1621/22 г. - только Ильинский Нозьменский приход. В приходных книгах 1623/24 г. к малютинскому Ильинскому добавляются оба никольских прихода: Святогорский и Старосельский. В книгах следующих лет число малютинских приходов вновь сокращается: до двух в 1626/27 г., и до одного в 1627/28 г. Но теперь этот единственный малютинский приход уже не Ильинский (как в 1621/22 г.), а Никольский Святогорский.

Обнаружить какую-либо систему в именовании того или иного храма малютинским, анализируя только окладные и приходные книги, к сожалению, 


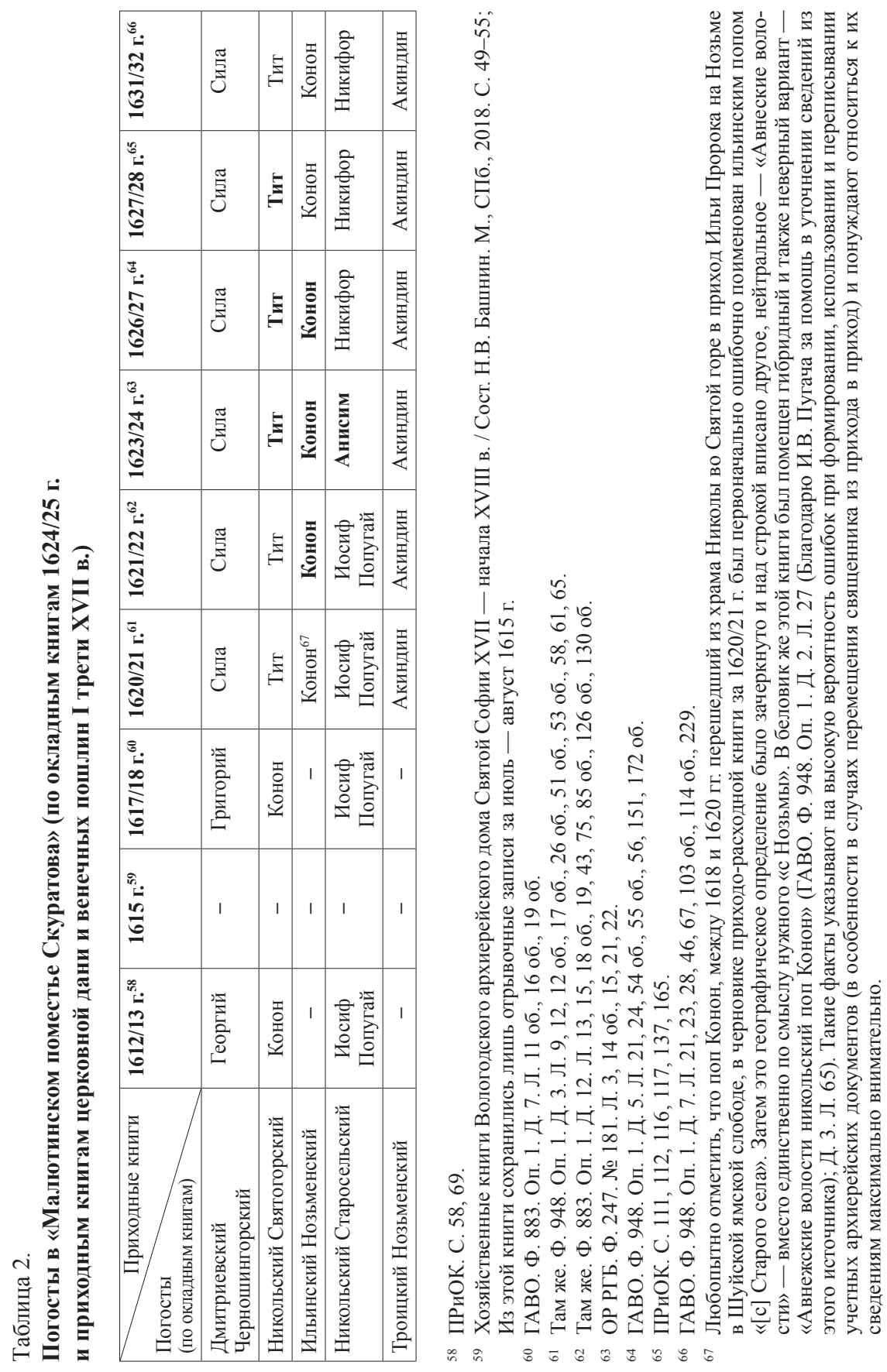


пока невозможно. Скорее всего, прояснить это поможет детальное изучение системы документооборота внутри архиерейского Казенного приказа и между приказом и отдельными священниками. Увы, мы досконально не знаем даже того, как происходила такая, на первый взгляд, рутинная элементарная операция как ежегодный платеж священником церковной дани и пошлин в архиерейскую казну. Применительно к характеризуемым сюжетам важно понять, в каких документах отражалась эта операция ${ }^{68}$, и, главное, как курсировала из документа в документ (и/или от человека в документ) та или иная информация, в частности, ссылки на малютинское поместье ${ }^{69}$. Из сохранившихся источников трудно определить, была ли в этом хоть какая-то система, или же участники событий действовали каждый раз ситуативно и в зависимости от своих субъективных качеств и конкретных обстоятельств.

Необходимо отметить и тот факт, что до раздачи Авнежской волости в поместья опричникам она была преимущественно черносошной. Небольшие вотчинки Троице-Авнежского монастыря и светских владельцев не могли коренным образом влиять на социально-экономическое и административное устройство волости. Сеть церковных приходов Авнеги, сложившаяся в XIVXV вв., была непригодной, точнее говоря, практически не нужной для организации поместной системы в волости. Церковное и возникшее со второй половины 1560-х гг. поместное деление волости существовали параллельно, не конкурируя, не дополняя и не мешая друг другу. Границы церковных приходов были проницаемы для прихожан, оказавшихся в географически смежных поместьях за разными владельцами. Совершенно типична ситуация, когда крестьяне разных поместий стекались к одному приходу. И, наоборот, в более-менее крупных поместьях могло действовать два, а то и три церковных прихода. Кроме того, при разверстке волости и наделении помещиков

\footnotetext{
${ }^{68}$ Было бы желательно установить взаимосвязи между окладными и приходными книгами (в том числе между их беловиками и черновиками), а также платежными отписями, выдаваемыми священнику в приеме денежных сумм в казну, венечными знаменами, заказными памятями, жалованными льготными архиерейскими грамотами и иными документами, выстраивавшими взаимоотношения церковных приходов и архиерейского Казенного приказа.

${ }^{69} \mathrm{~B}$ сущности, для точной идентификации конкретного прихода в финансовых документах архиерейской казны дьяку достаточно было зафиксировать только имя священника, название и расположение храма (к примеру, «никольский поп Тит из Святые горы»). Набор этих трех параметров надежно отделял данный храм от массы остальных, делая запись о событии (в нашем случае, платеже пошлин) уникальной. Упоминание того, что данный храм еще и «Малютинского поместья Скуратова», было избыточным для целей его идентификации. Поэтому можно полагать, что казенные дьяки могли пренебрегать этой факультативной информацией и не писать всякий раз в приходные книги и, вероятно, в платежные отписи «полный титул» храма, имевшийся в окладных книгах. Наблюдаемая нестабильность числа малютинских храмов в приходных книгах 1620-х гг. как будто подтверждает это предположение.
} 
землей дьяки Поместной избы не оперировали понятием «приход» (в значении группы селений, тянувших к такому-то храму), хотя бы уже потому, что у них не было такого рода учетной информации. Известные писцовые описания середины XVI в., отмечая храмы в селениях, построены на иных сметно-учетных принципах. В этом отношении описывать масштабы структур светского землевладения в количестве церковных округов (приходов / погостов) некорректно.

Хотя опричнина в политическом смысле была шагом назад, возрождала архаические образцы государственного устройства и управления удельного времени, она лишь в незначительной степени отменяла или видоизменяла сложившиеся практики государевой службы и материального обеспечения этой службы. Приказный аппарат в вопросах наделения помещиков (неважно, откуда они, из Опричнины или из Земщины) государевой землей действовал по всем законам бюрократической жизни, сообразуясь и с устоявшимися обычаями в деловом обороте своих учреждений, и со здравым смыслом. Понятие денежного и поместного оклада, нормы наполнения поместного оклада реальными земельными дачами, чинопроизводство в соответствии с личными и родовыми заслугами претендента на поместье уже прочно вошли в повседневный обиход Разряда и Поместного приказа. Не стоит забывать и об институте местничества, влиявшем на служебные назначения и, как следствие, на материальную основу службы членов Государева двора. Посему, каким бы фаворитом царя ни был Малюта Скуратов, разного рода государственные и общественные регуляторы не позволили бы ему ни получить, ни владеть поместьем, которое занимало почти две крупных волости и своей величиной выбивалось из установленной лестницы окладов и общих представлений о соразмерности служилого чина и вознаграждения. Размеры вологодских поместий опричников вполне соответствовали общепринятым (и в приказном аппарате, и в среде служилых людей) нормативам того времени $^{70}$. Поместья отделялись членам опричного Государева двора в самом очевидном, практическом, смысле - для обеспечения службы государевых дворян по месту новой ставки царя в Вологде. Не в награду, не в поощрение, но только для материального поддержания служебной годности опричников. Такие же испомещения опричников производились и в других регионах, в которые на более-менее продолжительное время перемещался царь и его двор (Александрова слобода, Старица, Великий Новгород).

Из проведенного исследования становится ясно, что источники церковного происхождения (окладные и приходные книги) дают противоречи-

${ }^{70}$ Назаров В.Д. Из истории аграрной политики... С. 107. 
вые сведения о количестве и номенклатуре храмов, которые некогда могли стоять в поместье М. Скуратова: от одного в приходных книгах 1621/22 и 1627/28 гг. ${ }^{71}$ до пяти в окладных книгах 1624/25 г. Выбрать какой-то один или комбинацию источников невозможно. Обратное значило бы только одно - пойти по неверному пути, который неминуемо приведет к конструированию заведомо искаженной реальности прошлого. В опоре только на церковные источники продвинуться вперед нельзя, а, значит, необходимо привлечение дополнительных документов. В отдельной работе нами будут изложены результаты дальнейшего исследования, построенного на изучении всей совокупности доступных источников - актов, памятников церковного и светского приказного делопроизводства.

В заключение попытаемся ответить на вопрос, которому во многом и обязан своим появлением этот текст: зачем было внесено имя Малюты Скуратова в окладные книги церковной дани Вологодского архиерейского дома спустя полвека после его гибели под стенами Пайды 1 января 1573 г.? Конечно, твердо доказуемого ответа получить, увы, нельзя, но высказать некоторые предположительные суждения источники позволяют.

При поиске ответа на этот вопрос многое дают установленные факты хронологии. Напомним, имя Скуратова появляется в окладных книгах в промежутке 1616/17-1624/25 гг. (с учетом сведений Н.И. Суворова в промежутке 1620/21-1624/25 гг.). Присмотримся к событиям этих лет и в стране, и отдельно в Вологде.

По условиям Деулинского перемирия с Польшей был освобожден из плена и 14 июня 1619 г. прибыл в Москву отец нового царя Михаила Романова митрополит Ростовский и Ярославский Филарет. Спустя десять дней митрополит Филарет был наречен и поставлен в патриархи Московские и всея Руси. На церемонии присутствовали вологодский архиепископ Макарий и игумен вологодского Спасо-Прилуцкого монастыря Кирилл ${ }^{72}$. Архиепископ Макарий находился в Москве уже с февраля 1619 г. $^{73} 22$ июля 1619 г. он был переведен с вологодской на новгородскую кафедру в сане митрополита $^{74}$. Вологодская кафедра вдовствовала недолго. 6 февраля 1620 г. на нее возвели архиепископа Корнилия. Подробной биографии этого архиерея пока не написано, приходится довольствоваться краткими сведениями

\footnotetext{
${ }^{71}$ Причем, приходы разные (!).

72 Дополнения к Актам историческим, собранные и изданные Археографическою комиссиею. СПб., 1846. Т. ІІ. № 76. С. 209, 215 и др.

${ }^{73}$ ГАВО. Ф. 883. Оп. 1. Д. 10.

${ }^{74}$ Списки иерархов и настоятелей монастырей Российския церкви / Сост. П.[М.] Строев. СПб., 1877. Стб. 36.
} 
о нем в справочной литературе. Но, кажется, довологодский период жизни архиепископа Корнилия служит ключом к поставленному вопросу об имени Малюты Скуратова в окладных книгах.

Значительную информацию о вологодском архиепископе Корнилии дает поминальная запись его рода, обнаруженная в синодике вологодского Корнильево-Комельского монастыря. Среди 70 имен, записанных в синодике, первые четыре таковы: архиепископ Феоктист, архиепископ Корнилий, епископ Антоний, преподобный Герасим ${ }^{75}$. С высокой степенью вероятности, под Феоктистом надо понимать архиепископа Тверского и Кашинского Феоктиста (1603-1609 гг), под Корнилием - самого архиепископа Вологодского и Великопермского Корнилия (1620-1625 гг), под Антонием - епископа Вологодского и Великопермского Антония (1585-1588 гг.). Преподобного Герасима можно было бы отождествить с местночтимым святым Герасимом Вологодским, но к моменту смерти архиепископа Корнилия в 1625 г. преподобный Герасим еще не был прославлен в лике святых. Единственной подходящей фигурой для отождествления преподобного Герасима из поминальной записи в корнильевском синодике выступает другой Герасим - Болдинский. Даже беглое знакомство с фактами биографий этих четырех церковных деятелей, приведенных в справочнике П.М. Строева, указывает на самую тесную их связь. Вологодский епископ Антоний был учеником преподобного Герасима Болдинского и третьим игуменом основанного Герасимом Болдина монастыря в Дорогобужском уезде. Феоктист до хиротонисания во архиепископа Тверского и Кашинского также был настоятелем этого монастыря в 1602-1603 гг. Остается предположить, что и вологодский архиепископ Корнилий тоже был связан с Болдиным монастырем. Знатоку вологодской церковной истории Н.И. Суворову прежнее место службы Корнилия было неизвестно ${ }^{76}$. Впоследствии П.М. Строев отметил, что до поставления на вологодскую епархию Корнилий был архимандритом Богородицкого Свияжского монастыря (1613-1620 гг.) $)^{77}$. Других сведений о его служении до 1613 г. в литературе не обнаруживается. Впрочем, в перечне П.М. Строева среди настоятелей Болдина Дорогобужского монастыря встречается имя некоего игумена Корнилия, упоминаемого между 1603 и 1604 гг. Скорее всего, соименные болдинский игумен (1603-1604), свияжский архимандрит (1613-1620) и вологодский архиепископ (1620-1625) -

\footnotetext{
${ }^{75}$ Вологодский государственный историко-архитектурный и художественный музейзаповедник. Отдел письменных источников [далее - ВГИАХМЗ]. № ВОКМ-2008. Л. 20-21.

${ }^{76}$ Исторические сведения об иерархах древне-Пермской и Вологодской епархии / Сост. Н.[И.] Суворов. Вологда, б/г [1868]. С. 55.

${ }^{77}$ Списки иерархов и настоятелей... Стб. 291, 731.
} 
одно и то же лицо ${ }^{78}$. Таким образом, становятся прозрачными мотивы включения основателя и двух настоятелей Болдина Дорогобужского монастыря в поминальную запись вологодского архиепископа Корнилия.

В том же корнильевском синодике мы встречаем еще одно примечательное поминание - «Род игумена Кирила Болдинца». Перечислим первые четыре имени из этой поминальной записи: преподобный игумен Герасим, игумен Кирилл, епископ Антоний и архиепископ Феоктист ${ }^{79}$. Три персоны из этого ряда, за исключением Кирилла, уже знакомы нам из вышеприведенной поминальной записи архиепископа Корнилия. Среди вологодских церковных деятелей XVI - первой четверти XVII в. находим двух, носивших имя Кирилл. Один из них был настоятелем Корнильево-Комельского монастыря; он управлял обителью между 1587 и 1589 гг. ${ }^{80}$ Однако он не может быть отождествлен с игуменом Кириллом Болдинцем, поскольку скончался, по-видимому, раньше, чем поминаемые в его роду иерархи заняли свои кафедры. Подходящей фигурой для отождествления с игуменом Кириллом Болдинцем является спасо-прилуцкий игумен Кирилл, занимавший свой пост в 1613-1623 гг. ${ }^{81}$ Как было отмечено выше, именно этот игумен Кирилл с вологодским архиепископом Макарием присутствовал на поставлении патриарха Филарета. То, что в поминании игумена Кирилла Болдинца отсутствует имя архиепископа Корнилия, по всей видимости, объясняется тем, что первый скончался на два года раньше второго.

Нетрудно заметить, что со времени занятия вологодской кафедры епископом Антонием до 20-х гг. XVII в. с церковными институциями Вологодской земли самым тесным образом были связаны постриженики Троицкого Болдина Дорогобужского монастыря. О возвышении этого монастыря и упрочении позиций его руководителей в общерусской церковной номенклатуре начиная с 1580-х гг, а также весьма правдоподобной трактовке этого возвышения благодаря поддержке монастыря семейством Годуновых, повествуется в обстоятельной статье А.С. Усачева ${ }^{82}$.

Безусловно, смена первого лица вологодской церковной иерархии в июле 1619 г. — феврале 1620 г., привела к серьезным кадровым изменениям внутри архиерейского двора. Значимые для нашей темы изменения

${ }^{78}$ Там же. Стб. 291, 443, 597, 731.

${ }^{79}$ ВГИАХМЗ. № ВОКМ-2008. Л. 195 об.

${ }^{80}$ Списки иерархов и настоятелей... Стб. 750.

${ }^{81}$ Там же. Стб. 738; Игумен Кирилл был поставлен в Спасо-Прилуцкий монастырь 6 мая 1613 г. из игуменов Никольского Антониева Бежецкого монастыря (ГАВО. Ф. 1260. Оп. 1. Д. 15. Л. 5).

${ }^{82}$ Усачев А.С. Вологодский епископ Антоний и Русская Церковь в период борьбы за власть при дворе в середине 1580-х гг. // Российская история. 2018. № 6. С. 136-146. 
мы можем проследить с точностью до месяца. После своего назначения на вологодскую кафедру архиепископ Корнилий продолжительное время (почти весь 1620 г. $^{83}$ ) оставался в Москве, очевидно, будучи задействован в ряде сменявших друг друга соборных совещаний ${ }^{84}$. Управление вверенной ему епархией происходило дистанционно, посредством отсылки указных грамот из Москвы в Вологду ${ }^{85}$. В Вологде текущими делами епархии заведовали двое приказных архиепископа: князь Григорий Федорович Дябринский и Борис Исакович Патрикеев. Они служили еще при дворе прежнего архиерея, и остались на службе новопоставленного. Но вот главные администраторы Казенного архиерейского приказа сменились полностью. Казенные дьяки Юрий Карпов и Никифор Ананьин последний раз упоминаются на вологодской службе в феврале 1618 - феврале 1619 г. Затем мы их находим в числе дворовых слуг новгородских митрополитов (очевидно, они уехали в Новгород в свите новгородского (бывшего вологодского) архиерея Макария) $)^{86}$. В мае 1620 г. казенным дьяком вологодского архиерея служил уже некий Иван Задонский ${ }^{87}$.

Более интересна ситуация с главой архиерейского Казенного приказа (казначеем), которым и направлялась вся финансовая политика архиерейского дома. При архиепископе Макарии в должности казначея мы встречаем старца Иону (21 февраля 1618 г.). Но уже в июле 1620 г. казначеем показан старец Вассиан ${ }^{88}$. Источники позволяют идентифицировать их обоих. Казначеем архиепископа Макария, по всей видимости, стал вологодский сын боярский Иван Евстигнеевич (Малечкин сын) Гневашев, принявший монашеский постриг под именем Ионы. В середине 1610-х гг. он активно работал дозорщиком земель Вологодского уезда ${ }^{89}$. Этот опыт, разумеется, пригодился ему на должности архиерейского казначея. Старца Вассиана

${ }^{83}$ Архиепископ Корнилий в указной грамоте от 3 декабря 1620 г. велел своим приказным отпустить из Вологды в Москву девять архиерейских детей боярских, «не мешкая», для охраны архиерея на пути из Москвы в Вологду, так как царь и патриарх «хочет с Москвы властей отпустить с Николина дни» (ГАВО. Ф. 1260. Оп. 1. Д. 57. Л. 10).

${ }^{84}$ Подробнее см.: Черепнин Л.В. Земские соборы Русского государства в XVI-XVII вв. M., 2015. C. 229-239.

${ }^{85}$ Подборка таких грамот за осень-зиму 1620 г. сохранилась (ГАВО. Ф. 1260. Оп. 1. Д. 57).

${ }^{86}$ ГАВО. Ф. 883. Оп. 1. Д. 7. Л. 29; Д. 10. Л. 1; Греков Б.Д. Новгородский дом Святой Софии (опыт изучения организации и внутренних отношений крупной церковной вотчины) // Греков Б.Д. Избранные труды. М., 1960. Т. 4. С. 50-51, 79, 327; Зерцалов А.Н. О «неправдах и непригожих речах» новгородского митрополита Киприана (1627-1633 гг.) // Чтения в Императорском обществе истории и древностей российских при Московском университете. М., 1896. Кн. 1 (176). С. 24.

${ }^{87}$ ГАВО. Ф. 883. Оп. 1. Д. 11. Л. 1 об.

${ }^{88}$ Там же. Д. 7. Л. 29; Д. 11. Л. 4.

${ }^{89}$ Писцовые книги Русского Севера / Сост. Н.П. Воскобойникова и др. М., 2001. С. 40-46. 
можно с уверенностью отождествить со старцем Вассианом Болдинским, получившим свое прозвище по месту пострига, безусловно, в Болдине Дорогобужском монастыре. Вассиан Болдинский прямо назван архиерейским казначеем в синодике Спасо-Прилуцкого монастыря ${ }^{90}$. Поминания рода Вассиана Болдинского внесены также в синодики нижегородского Вознесенского Печерского ${ }^{91}$, Благовещенского Киржачского ${ }^{92}$ и КорнильевоКомельского ${ }^{93}$ монастырей. Набор включенных в родовое поминание имен во всех четырех синодиках однозначно позволяет связать их с одним и тем же человеком. Вклады Вассиана Болдинского в нижегородский и владимирский монастыри, вероятно, сделаны им в то время, когда его будущий патрон (архиепископ Корнилий) возглавлял Богородицкий Свияжский монастырь в соседней Казанской епархии.

Очевидно, свияжского архимандрита (будущего вологодского архиерея) Корнилия и старца Вассиана Болдинского сплачивало не только общее происхождение из болдинской обители, но и какая-то совместная деятельность в 1600-1610-е гг. Вот почему старец Вассиан, будучи доверенным лицом Корнилия, стал во главе важнейшего финансового органа епархии, архиерейского Казенного приказа, в то время как его патрон вынужденно оставался в столице.

Любопытна дальнейшая карьера и старца Ионы Гневашева. Из архиерейских казначеев он был перемещен на схожий по роду деятельности пост келаря в вологодский Спасо-Прилуцкий монастырь, под начало к уже упоминавшемуся прилуцкому игумену Кириллу Болдинцу. Еще в июне 1619 г. прилуцким келарем упоминается старец Варфоломей, а уже 8 августа того же года известен новый келарь Иона Гневашев ${ }^{94}$. Вероятно, в эти летние месяцы 1619 г. пост архиерейского казначея получил и Вассиан Болдинский, почти за полгода до официальной хиротонии Корнилия.

Как следует из сказанного, значительные посты в местном церковном мире в 1580-1620-х гг. занимали выходцы из Болдина Дорогобужского монастыря (Антоний, Корнилий, Кирилл, Вассиан). Здесь же стоит упомянуть

\footnotetext{
${ }^{90}$ ВГИАХМЗ. № ВОКМ-2013. Л. 172.

${ }^{91}$ Синодик Нижегородского Вознесенского Печерского монастыря 1595 года. Синодик архимандрита Трифона. Нижний Новгород, 2010. С. 527.

${ }^{22}$ Нижегородская государственная областная универсальная научная библиотека им. В.И. Ленина. Ф. 1. Оп. 2. № 37. Л. 54 об.

${ }^{93}$ ВГИАХМЗ. № ВОКМ-2008. Л. 286 об.

${ }^{94}$ ГАВО. Ф. 1260. Оп. 2. Д. 328. Л. 6, 8, 9; В деловой грамоте на поместье между своими сыновьями от 22 января 1621 г. он был послухом и наименован как «великий старец Иона Гневашев» (РГИА. Ф. 1343. Оп. 19. Д. 2245. Л. 11).
} 
черного священника Гурия и старца Левкия, постриженников Болдина монастыря, давших в 1621 г. вклады в Кириллов-Белозерский монастырь ${ }^{95}$.

Появление в Вологодском уезде небольшой группы лиц, связанных с Болдиным монастырем, можно объяснить лишь одним. По Деулинскому перемирию 1618 г. Дорогобуж с уездом (в том числе и Болдин монастырь) отходил Польше. Очевидно, местные светские и церковные элиты, ориентированные на Москву, были вынуждены покинуть утраченные земли и устраивать свою судьбу на новых местах внутри России. Позиции болдинских выходцев были сильны в Вологодском уезде со времени епископа Антония, и, возможно, кандидатура на вологодскую кафедру свияжского архимандрита Корнилия рассматривалась властями с учетом этого исторически сложившегося положения.

А.С. Усачев справедливо указывает на тесные связи некоторых видных землевладельцев Вяземского и сопредельных уездов с Болдиным монастырем, установившиеся еще при самом преподобном Герасиме. Среди лиц, благоволивших обители, были Дмитрий Иванович и Борис Федорович Годуновы. Последний был женат на дочери нашего героя, Марье Григорьевне Малютиной Скуратовой Бельской. Несомненно, что и вяземский помещик Малюта Скуратов был «своим» человеком в Болдине монастыре в доопричные и особенно опричные годы и тоже каким-либо образом оказывал монастырю свое покровительство. Очень вероятно, что и архиепископ Корнилий, и старец Вассиан Болдинский были лично знакомы с Малютой Скуратовым. Примерная хронология жизни этих лиц позволяет сделать такое допущение. Вот, вероятно, почему имени Малюты Скуратова не могло оказаться в бухгалтерской документации Вологодского архиерейского дома при архиепископе Макарии. Для Макария Скуратов, можно предположить, был рядовым историческим деятелем минувшего времени, а для болдинских выходцев Корнилия и Вассиана - соседом, покровителем, вкладчиком, другом, может быть, даже родственником или свойственником, в общем, человеком из прошлой, но не ушедшей из памяти безвозвратно совместной жизни в опричной Вязьме. Имя Малюты Скуратова могло попасть в окладные книги только с санкции архиерея и/или его главных доверенных лиц (приказного, казначея), самодеятельность рядовых архиерейских служилых в таком деле вряд ли была бы возможна. Таким необычным образом, в виде факультативных добавлений в стандартные описательные формулы окладных книг, память о вологодском помещике Малюте Скуратове поддержива-

\footnotetext{
${ }^{95}$ Приходные и расходные денежные книги Кирилло-Белозерского монастыря. 16011637 гг. / Сост. 3.В. Дмитриева. М.; СПб., 2010. 196, 216; В январе 1622 г. вклад (100 рублей) в монастырь дал и новый вологодский архиепископ Корнилий (Там же. С. 216).
} 
лась в годы правления архиепископа Корнилия. Как бы то ни было, любые объяснения этому факту навсегда останутся в ранге более или менее убедительных предположений.

\section{Литература}

Башнин Н.В., Корзинин А.Л. Новые данные к биографии опричника Малюты Скуратова // Российская история. 2017. № 2. С. 172-188.

Володихин Д.М. Заметки о семействе Г.Л. Скуратова-Бельского // Археографический ежегодник за 2007 - 2008 годы. М., 2012. С. 113-125.

Володихин Д.М. Малюта Скуратов. М., 2012.

Греков Б.Д. Новгородский дом Святой Софии (опыт изучения организации и внутренних отношений крупной церковной вотчины) // Греков Б.Д. Избранные труды. М., 1960. Т. 4.

Зериалов А.Н. О «неправдах и непригожих речах» новгородского митрополита Киприана (1627-1633 гг.) // Чтения в Императорском обществе истории и древностей российских при Московском университете. М., 1896. Кн. 1 (176). С. I-IV, 1-28.

Иванов В.И. Рецензия на книгу: Приходо-расходные денежные книги Вологодского архиерейского дома... // Вестник Вологодского государственного университета. 2018. № 2. C. 93-94.

Кобрин В.Б. Состав Опричного двора Ивана Грозного // Кобрин В.Б. Опричнина. Генеалогия. Антропонимика. М., 2008. С. 13-98.

Колесников П.А. Северная деревня в XV — первой половине XIX века. К вопросу об эволюции аграрных отношений в Русском государстве. [Вологда,] 1976.

Назаров В.Д. Из истории аграрной политики царизма в XVI веке // Советские архивы. 1968. № 3. С. 106-114.

Суворов Н.[И.] Несколько статистических и топографических сведений о Вологодской епархии от начала XVII столетия до настоящего времени // Вологодские епархиальные ведомости. 1865. № 21. Прибавления. С. 813-833.

Усачев А.С. Вологодский епископ Антоний и Русская Церковь в период борьбы за власть при дворе в середине 1580-х гг. // Российская история. 2018. № 6. C. 136-146.

Устинова И.А., Шамина И.Н. История Вологодского архиерейского дома: новые источники // Российская история. 2019. № 4. С. 223-231.

Черепнин Л.В. Земские соборы Русского государства в XVI-XVII вв. М., 2015.

Черкасова M.C. Архиерейские окладные книги как источник по землевладению и народонаселению в XVII в. // Актуальные проблемы аграрной истории Восточной Европы X-XXI вв.: источники и методы исследования. Материалы XXXII сессии Симпозиума по аграрной истории Восточной Европы. Рязань, 2012. С. 133-147.

Черкасова М.С. К изучению церковно-административных и территориальных структур на Русском Севере в XVI - начале XVIII в. // Государство и общество в России XV - начала XX века. Сборник статей памяти Николая Евгеньевича Носова. СПб., 2007. С. 206-223.

Черкасова М.С. Северная Русь: история сурового края XIII-XVII вв. М., 2017. 


\title{
А.А. Горский
}

\section{«ВОЛХВЫ» И «ЖРЕЦЫ» В ДРЕВНЕРУССКОЙ КНИжнОСТИ}

\begin{abstract}
Аннотация В статье рассматривается вопрос, применялся ли термин волхвы к языческим жрецам. Делается вывод, что древнерусские книжники различали понятия волхв и жрец.

Ключевые слова: волхвы, жрецы, древнерусские источники.
\end{abstract}

Summary The article is devoted to the problem of relation of volkhvy (magi) and zhretsy (pagan priests). The author came to conclusion that Old Russian writers differed these terms.

Keywords: magi, pagan priests, Old Russian sources.

Согласно устоявшемуся мнению, языческие жрецы восточных славян назывались «волхвами» ${ }^{1}$. Данная точка зрения исходит из того несомненного факта, что волхвы - единственный термин, которым в древнерусских источниках именуются жители Руси, обладающие неким, доступным не каждому, дохристианским религиозным знанием. В последнее время, однако, высказываются сомнения относительно отождествления волхвов с жрецами ${ }^{2}$. Основанием служит то, что известия о волхвах X-XIII вв. рисуют их как гадателей, прорицателей, (лже)чародеев, но не связывают с культом какого-либо языческого бога ${ }^{3}$ : когда речь идет о поклонении богам, в ка-

${ }^{1}$ См.: Рыбаков Б.А. Язычество Древней Руси. М., 1987. Гл. 7: Жреческое сословие Древней Руси; Петрухин В.Я. Волхвы // Древняя Русь в средневековом мире: энциклопедия. М., 2014. С. 151 (волхвы - «маги, языческие жрецы, чародеи, звездочеты и предсказатели»); Петрухин В.Я. Язычество // Древняя Русь в средневековом мире... С. 914 («Скудны известия о жрецах (именуемых волхвами)»).

${ }^{2}$ Карпов А.В. Язычество, христианство, двоеверие: религиозная жизнь Древней Руси в IX-XI веках. СПб., 2008. С. 49-53, 118-120; Введенский А.М. Древнерусские волхвы и волхование в домонгольский период // Восточная Европа в Древности и Средневековье. М., 2020. Вып. 32: Сравнительные исследования социокультурных практик. С. 33-37.

3 «Сказание о построении града Ярославля», где говорится о волхве, служившем богу Волосу, не может быть принято во внимание, так как записано во второй половине XVIII века. 
честве действующих лиц упоминаются князь, воевода-посадник, «люди», «старцы», «боляре», но никогда - волхвы ${ }^{4}$. Тем не менее положение, согласно которому термин «волхвы» обозначал языческих жрецов, продолжает сохраняться в историографии 5 .

В связи с вопросом, тождественны или нет волхвы восточнославянским языческим жрецам, до сих пор не обращалось внимания, что собственно слово жьрьиьь встречается в древнерусских памятниках (и почти так же часто, как вълхвъ ${ }^{6}$ ). Применялось оно не к «своим» (восточнославянским) язычникам, а при описании сюжетов из библейской истории, т. е. в основе переводных 7 . При этом существуют памятники, где встречаются оба термина — и «жрецы», и «волхвы», что дает возможность определить, обозначали они в представлениях того времени одну и ту же категорию или разные.

В Повести временных лет (где содержится большинство упоминаний о деяниях волхвов на Руси X-XI вв.), под 986 г., в «Речи Философа» упоминается «Илии жрець» (персонаж 1-й Книги Царств [1Цар. 1-4]) - священнослужитель, причем не языческого бога, а единого Бога Израилева ${ }^{8}$.

В Ефремовской Кормчей волхвы упоминаются в правилах Лаодикийского собора: «36. Яко не подобаеть священикомъ или клирикомъ вълъхвомь и пагоубникомь быти или навыкающемъ или звђздочьтьцьмъ или творити глаголемая съхранения яже соуть оузница душь ихъ носящиимъ же отъвръщи повельниемь оть церкве», а жрец в главе «Епифания Кипрского о ересях»: «16. Садоукеи съказаеми правьдьници иже от рода оубо бъша самарииска въкоупь жьрьца Садоука именьмь». Жьрьць передает содержащееся

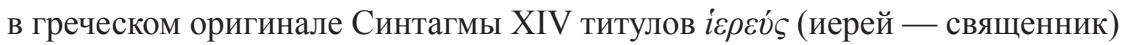

${ }^{4}$ ПСРЛ. М., 1997. Т. 1. Стб. 54 (под 945 г.), 79 (под 980 г.), 82-83 (под 983 г.).

5 Из работ недавнего времени, авторы которых не сомневаются в тождестве волхвов и жрецов, см.: Климов Е.В. К вопросу о социальном и политическом статусе жреческого сословия Древней Руси // Вестник Челябинского государственного университета. 2008. № 34; Козлов М.Н. Служители языческого культа в религиозной и политической жизни восточных славян (IX-XI века). М., 2020.

${ }^{6}$ См.: Словарь древнерусского языка (XI-XIV вв.). М., 1989. Т. 2. С. 164-165 (вълхвъ, 181 зафиксированный составителями случай в рукописях, датируемых не позднее начала XV в.); М., 1990. Т. 3. С. 275-276 (жьрьць, 131 случай).

7 Тем не менее полагать, что это старославянский термин, нехарактерный для древнерусского языка (и соответственно отечественных реалий), нет оснований, так как исходный глагол жрети/жьрти («приносить в жертву», «совершать жертвоприношение» - Там же. Т. 3. C. 269-270, 275) употребляется в отношении восточных славян/Руси до крещения: Новгородская первая летопись старшего и младшего изводов. М.; Л., 1950. С. 103: «куда же древле погани жряху бъсомъ...»; С. 104: «бяху же поганъ, жруще озером и кладязем и рощениемъ»; ПСРЛ. Т. 1. Стб. 79 (под 980 г.): «и жряху бъсомъ»; «и жряху ему (идолу Перуна. - А.Г.) людье нооугородьстии».

${ }^{8}$ ПСРЛ. Т. 1. Стб. 97. 
и относится к служителю ветхозаветного Бога, а словом вълъхви переведе-

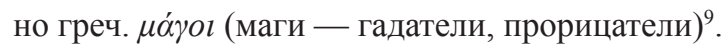

В сочинениях Кирилла Туровского о волхвах говорится дважды. 1) В послании к печерскому игумену Василию: «Да се есть подобно время оного благоразумного свђтника, еже не искати чаров, ни волхвов, но вђрою глаголати: Благо мнђ, яко смирил мя еси, да научюся оправданием твоим» ${ }^{10}$; 2) В Слове о «расслабленном» исцеленный Христом отвечает на вопрос, кто его спас: «Нъсть вълхв, ни чародъй, ни есть ходатай, ни ангел, нъ сам господь Бог Израилев, понеже не осяза мене руками, ни приложи былия к врьдом удов моих» ${ }^{11}$. Речь идет в обоих случаях о людях, наделенных способностями совершать чудеса. Термин «жрец» у Кирилла прилагается к иудейским священникам (в евангельских сюжетах) ${ }^{12}$. Таким образом, эти понятия не пересекаются.

Встречаются оба термина и в Толковой Палее. Волхвами там называются египетские маги, противившиеся Моисею: «Вольсви же егюпьтьстии тако створи жезлы своя, и быша змиеве. Того ради попусти Богъ волъхвомъ егюпьтьскымъ свои жезлы в змие претворяти, да не ркуть къ фараону, яко волхв есть Моиси» ${ }^{13}$. О жрецах говорится в речи Левия «О жречестве» из апокрифического «Завета двенадцати патриархов». Сначала жрецами там именуются служители Бога Израилева, затем делается предсказание, что «въ седмую же седмицу придуть жерци, кумиромъ служаще, вражедници, златолюбци, презориви и безаконьници, прокудници, скоту сквернители». ${ }^{14}$ Следовательно, жрецы - священнослужители (в том числе языческих богов), волхвы же с культом богов напрямую не связаны.

Особенно примечательно «Слово о волхвах» из сборника «Златая цепь», поскольку в нем оба термина встречаются в одном контексте. Автор, начав со слов «волхвов же, чада моя, блюдитеся», далее пересказывает сюжет из 4-й Книги Царств о болезни израильского царя Охозии. Согласно библейскому тексту, Охозия отправил послов в филистимлянский город Аккарон, чтобы узнать у местного божества Ваала, суждено ли ему остать-

9 Бенешевич В.Н. Древнеславянская Кормчая XIV титулов без толкований. СПб., 1906. T. 1. C. $274,651$.

${ }^{10}$ Еремин И.Н. Литературное наследие Кирилла Туровского // Труды отдела древнерусской литературы Института русской литературы АН СССР (Пушкинский Дом) (далее ТОДРЛ). М.; Л., 1956. Т. 12. С. 350.

${ }^{11}$ Еремин И.Н. Литературное наследие Кирилла Туровского // ТОДРЛ. М.; Л., 1958. Т. 15. C. $334-335$.

${ }_{12}$ Там же. С. 337; Еремин И.Н. Литературное наследие Кирилла Туровского // ТОДРЛ. М.; Л., 1957. Т. 13. С. 411, 414, 418, 421, 426.

${ }^{13}$ Палея толковая. М., 2002. С. 314-315.

${ }^{14}$ Там же. С. 277. 
ся в живых, но этой миссии воспрепятствовал пророк Илья: «И посла слы и рече к нимъ: Идъте взыщете у Вала, да негли поможеть ми Акаронъ, да негли живъ боудоу от бользни сеи. Идоша въпрашатъ его его радьма. И аггель Господень рекъ Ильи Фезвитяниноу...» (далее пространное изложение действий Ильи $)^{15}$. Через какую категорию людей предполагалось получить пророчество Ваала, не говорится. Составитель же «Златой цепи» излагает ход событий следующим образом: «И посла к Валови болвану и къ жерцемь его, рка: буду ли живъ ци ли оумру. О глубино, о зло есть оставити Божию помощь. Ти впрашали вълъхвовъ, иже в бъса вьрують. И стрђте слы Охозиевы Илья, и рече имъ: ИдЂте ко цесару своему и рцђте ему, понеже оставивъ Бога и законъ Его, и послалъ еси къ бъсомъ въпрашатъ о животь и смерти. Да си ти рци глаголю от Бога оусты своими, оумреши нынь преже времени, понеже Бога оставивъ, къ бъсомъ послаль еси, тако ти бываеть смерть» ${ }^{16}$. И далее идет комментарий: «Сынове мои, ходивше преже времени к волхвомъ, да не отметници Божии явистеся. Святии бо апостоли и святи отци прокляли волхвования, тако же прокляли и на 7-и сборъ, и от причастья отлучили, и иже к нимъ приходили, и держати имъ вьлено опитемья, како бы имъ избыти грђха то тяжкаго» ${ }^{17}$. Представление автора о людях, имеющих отношение к Ваалу, явно связано с его знакомством с сюжетом, в котором Илья посрамляет служителей идола, из 3-й Книги Царств. Но в бытовавшем на Руси ее переводе эти лица определяются не как «жрецы» или «волхвы», а как «пророци Валовы» ${ }^{18}$. Автору «Слова» нужно было ввести в действие волхвов, так как его задачей являлось осуждение современников, обращающихся к волхвам в случае болезни. Проще всего было вместо «пророков» говорить о «волхвах», тем более что речь шла как раз о прорицании. Но, очевидно, термин «волхвы» не подходил для обозначения служителей культа бога, нельзя было сказать - «к Валови болвану и къ вълъхвамъ его», и пришлось использовать два определения: когда речь шла о культе Ваала-болвана (статуи — кумира) — «жрецы его» ${ }^{19}$, когда о предсказании - «волхвы, верующие в беса».

Таким образом, древнерусским книжникам не было свойственно отождествление «жрецов» и «волхвов»: первым термином обозначали служите-

15 ОР РГБ. Ф. 304/І. Собр. Троице-Сергиевой лавры. № 278 (Троицкий Хронограф). Л. 248-249.

16 Златая цепь: Тексты, исследования, комментарии. М., 2002. С. 26-27.

${ }_{17}$ Там же. С. 27.

${ }^{18}$ ОР РГБ. Ф. 304/I. Собр. Троице-Сергиевой лавры. № 278. Л. 243-244.

${ }^{19} \mathrm{~B}$ помещенном в «Златой цепи» «Слове некоего христолюбца и ревнителя по правой вере» упоминается эпизод из 3-й Книги Царств с посрамлением Ильей жрецов Ваала, и там они определяются как «ерея и жерца идольскыя» (Златая цепь. С. 47-48). 
лей богов (как языческих, так и ветхозаветного единого Бога), вторым гадателей-прорицателей ${ }^{20}$. Соответственно, хотя связь древнерусских волхвов с языческими представлениями несомненна, оснований отождествлять эту категорию с восточнославянским жречеством имеющиеся источники не дают.

\section{Литература}

Бенешевич В.Н. Древнеславянская Кормчая XIV титулов без толкований. СПб., 1906. T. 1 .

Введенский A.M. Древнерусские волхвы и волхование в домонгольский период // Восточная Европа в Древности и Средневековье. М., 2020. Вып. 32: Сравнительные исследования социокультурных практик. С. 33-37.

Древняя Русь в средневековом мире: энциклопедия. М., 2014.

Еремин И.Н. Литературное наследие Кирилла Туровского // Труды Отдела древнерусской литературы. М.; Л., 1956. Т. 12. С. 340-361; М.; Л., 1957. Т. 13. С. $102-$ 117; М.; Л., 1958. Т. 15. С. 331-348.

Златая цепь: Тексты, исследования, комментарии. М., 2002.

Карпов А.В. Язычество, христианство, двоеверие: религиозная жизнь Древней Руси в IX-XI веках. СПб., 2008.

Климов E.B. К вопросу о социальном и политическом статусе жреческого сословия Древней Руси // Вестник Челябинского государственного университета. 2008. № 34. С. 5-13.

Козлов М.Н. Служители языческого культа в религиозной и политической жизни восточных славян (IX-XI века). М., 2020.

Новгородская первая летопись старшего и младшего изводов. М.; Л., 1950.

Палея толковая. М., 2002.

ПСРЛ. М., 1997. Т. 1.

Рыбаков Б.А. Язычество Древней Руси. М., 1987.

Словарь древнерусского языка (XI-XIV вв.). М., 1989. Т. 2; М., 1990. Т. 3.

Старославянский словарь (по рукописям Х-XI веков). М., 1994.

${ }^{20} \mathrm{O}$ различии этих терминов свидетельствует и тот факт, что в переводных памятниках они служили для перевода разных слов: «жрец»- преимущественно ієрєи́ৎ (священник), «волхв» - $а \dot{\alpha} \gamma о \varsigma$ (маг) (Словарь древнерусского языка. Т. 2. С. 164-165; Т. 3. С. 275-276; Старославянский словарь (по рукописям Х-XI веков). М., 1994. С. 118, 121). 


\title{
Л.И. Грацианская
}

\section{ТВОРЧЕСКАЯ ЛАБОРАТОРИЯ СТРАБОНА}

\begin{abstract}
Аннотация В статье подводятся итоги многолетней работы автора над текстологическим исследованием характера компилятивной деятельности Страбона в «Географии» и обосновывается вывод о творческом характере компилятивной деятельности географа.

Ключевые слова: Страбон, «География», механическая компиляция, творческая компиляция, источник, воззрения, характер, авторское начало, система, план.
\end{abstract}

Summary The article summarizes the results of the author's many years of work on a textual study of the nature of the compilation activity of Strabo in «Geography» and substantiates the conclusion about the creative nature of the compilation activity of the geographer.

Keywords: Strabo, «Geography», mechanical compilation, creative compilation, source, views, character, author's principle, system, plan.

Творческая лаборатория Страбона - феномен, мало кем из ученого мира признаваемый. Соответственно он почти не исследован и, как мне представляется, доныне исследуется мало. Надо сказать, что до последней трети XIX в. господствовала идущая от Средневековья достаточно высокая оценка сочинения Страбона с точки зрения творческой оригинальности, но с этого времени она сменилась резко отрицательной оценкой творческой самостоятельности его труда. Причем эта оценка, утвердившись сначала в немецкой, а вслед за этим во французской и англоязычной историографии, была воспринята и историографией отечественной. Попытка Х. Бутцера привлечь внимание к оригинальным научным заслугам географа ${ }^{1}$ успеха не имела.

1 Butzer H. Über Strabo's Geographica, insbesonders über Plan und Ausfürung des Werkes zu seinen Vorgängern. Frankfurt-a-M., 1887. S. 5-8. Cp.: Sollima F. Le fonti di Strabone nella geografia della Sicilia. Messina, 1897. P. 45. 
$\mathrm{O}$ «механистичности» Страбоновой компиляции говорили с тех пор многие ${ }^{2}$. Наиболее отчетливо эту точку зрения выразил М.И. Ростовцев в «Скифии и Боспоре»: «В контаминации своих источников он (Страбон. - Л.Г.) не проявил ни особого таланта, ни особого желания скрыть швы» ${ }^{3}$. Вторая точка зрения на характер географии состоит в том, что Страбон сюжетно и идейно целиком зависит от своих источников, но стилистически обрабатывает компилируемое ${ }^{4}$.

Особняком стоит фундаментальный труд В. Али, вышедший посмертно, где комментируются отдельные пассажи «Географии» и их источники В этом исследовании чувствуются попытки представить творческую составляющую работы географа, но поскольку «География» не рассматривается Али специально как литературное единство, то и четко выраженной мысли о творческой оригинальности и целостности произведения Страбона там нет.

Появившиеся в конце 80 -гг. XX в. содержательные работы перуджийской группы исследователей «Географии» также этого вопроса практически не касаются, хотя не только останавливаются на толковании отдельных фрагментов «Географии», но и прослеживают ряд текстологических и идейных закономерностей по всему тексту ${ }^{6}$.

В 2000 г. вышла монография (на базе доктората) Д. Дуэк, где сделана попытка включить творчество Страбона и его фигуру как ученого и литератора в широкий эллинско-римский культурный контекст. Но лишь в последней, шестой, главе этой работы речь частично идет о творческих особенностях самой «Географии»7. В вышедшем через 11 лет переиздании этой монографии шестая глава осталась без изменений ${ }^{8}$.

2 Историография вопроса приведена в: Honigmann E. Strabon 3 // Pauly's Real encyclopädie der Classischen Altertumswissenschaft. Stuttgart. 1931. Hbd. 7. Sp. 102-103; более позднюю см.: Грацианская Л.И. «География» Страбона. Проблемы источниковедения // Древнейшие государства на территории СССР. 1986. М., 1988. С. 155-175; Strabone. Saggio di bibliografia 1469-1978 a cura di A.M. Biraschi, P. Maribelli, G.D. Massaro, M.A. Pagnotta. Perugia, 1981.

3 Ростовцев М.И. Скифия и Боспор: Критическое обозрение памятников литературных и археологических. Л., 1925. С. 41.

4 Wolski J. Les études sur texte de Strabon. Charisteria Sinko quinquaginta abhinc annos amplissimis in philosophia honoribus ornato ab amicis collegis discipulis. Varsaviae; Wratisclaviae, 1951. S. 292-293.

5 Aly W. Strabon von Amaseia. Untersuchungen über Text, Aufbau und Quellen der Geographica. Bonn, 1957.

${ }^{6}$ Strabone. Contributi allo studio della personalità e dell'opera. Perugia. Universitetà delgi studi, 1986. Vol. II.

7 Dueck D. Strabo of Amasia. A Greek Man of Letters in Augustan Rome. Abingdon, Oxom, 2000.

8 Dueck D. Strabo of Amasia. A Greek Man of Letters in Augustan Rome. L.; N. Y., 2011. P. $145-187$. 
В 2005 г. группой страбоноведов из разных стран выпущен сборник «Strabo's Cultural Geography. The Making of Kolossourgia», где освещаются различные аспекты труда географа от его гомеровских и поэтических штудий до философских рефлексий и от конкретных представлений о той или иной стране до его общеэтнологических воззрений ${ }^{2}$. Но и там о творческом начале в «Географии» ничего не сказано.

Представляется необходимым отметить также деятельность еще двух исследователей-страбоноведов, работающих на рубеже XX и XXI вв. Это, в первую очередь, И. Энгельс, написавший содержательный труд «Augusteische Oekumenegeographie und Universalhistorie im werk Strabon's von Amaseia», где затрагиваются вопросы биографии Страбона и влияния его философских и политических взглядов на подачу материала в «Географии», а также высказывается ряд предположений о составе «Исторических записок», рассматривается широкое полотно предшественников Страбона и дается ряд исследований по конкретике страбоновых описаний людей и местностей. Творческая составляющая работы географа в этой монографии также опущена ${ }^{10}$.

Отмечу деятельность К. Кларк, выпустившей в 1997 г. содержательную статью с полемическим названием «In Search of the Author of Strabo's "Geography"», а спустя два года монографию «Between Geography and History. Hellenistic Contributions of the Roman World» ${ }^{11}$. Исследовательница вплотную подошла к определению творческого начала в «Географии», но полноценного развития этой идее не дала.

В начале 70-х гг. XX в. Сектор истории древнейших государств на территории СССР Института истории СССР АН СССР под руководством В.Т. Пашуто начал работу над «Сводом древнейших иностранных источников по истории народов СССР». Мне достался Страбон. Выбрав все тексты, которые относились к территории тогдашнего СССР, и попытавшись их комментировать, я довольно быстро поняла, что вряд ли смогу это сделать, не впадая в локальный утилитаризм, если не уясню себе, что же представляет собой данное сочинение в целом, во имя чего оно написано, каковы философские, политические, географические, исторические и естественно-научные воззрения его автора, какими источниками и, глав-

9 Strabo's Cultural Geography. The Making of a Kolossurgia / Ed. by D. Dueck, H. Lindsay, S. Pothecary. Cambridge, 2005.

${ }^{10}$ Engels $J$. Augusteische Oikumenegeographie und Universalhistorie im Werk Strabons von Amaseia. Stuttgart, 1999 (Geographica Historica. Bd 12).

${ }^{11}$ Clarke K.J. In Search of the Author of Strabo's Geography // Journal of Roman Studies. 1997. № 87. P. 92-110; Clarke K. J. Between Geography and History. Hellenistic Contributions of the Roman World. Oxford, 1999. 
ное, как он пользовался, сколь риторичен был его подход к изложению материала и многое другое. Найти ответы на все эти вопросы в предшествующей и современной для того времени литературе я не могла, поскольку посвящена она была в основном источникам Страбона. В ней разными авторами уверенно приписывались разные куски из Страбона разным античным источникам. Часто одно и то же место «Географии» отдавалось нескольким источникам, в то время как для самого Страбона места в его сочинении практически не оставалось. Очень популярна была среди исследователей теория «основного источника» (Hauptquelle), когда большие отрывки из сочинений Страбона приписывались одному автору ${ }^{12}$.

Исследование текста Страбона по всем этим параметрам заняло более 10 лет. В результате в ежегоднике «Древнейшие государства на территории СССР» была издана монография ““География” Страбона. Проблемы источниковедения» ${ }^{13}$. Монография и лежащая в основе ее кандидатская диссертация стали первыми опытами исследования всего текста Страбона с вышеуказанных позиций, как в отечественной, так и в зарубежной историографии. К сожалению, работа была написана и опубликована только на русском языке, что помешало зарубежным исследователям воспользоваться ее результатами.

В процессе исследования памятника с вышеуказанных позиций для меня стала очевидна большая творческая работа Страбона над «Географией», в значительной степени определяющая возможности использования этого сочинения как исторического источника. Страбон подчеркивает преемственность и однородность жанров своего исторического и географического сочинений, определяя их как ن் работает как историк, но в «Географии» четко дает понять, что география для него - не просто фон исторических событий, как это было у Полибия, но равноправный компонент историко-географического знания и исследования ${ }^{15}$.

Дошедший до нас труд Страбона предназначен для наставления и развития будущего государственного деятеля проримского толка ${ }^{16}$. Впрочем, он, с точки зрения его автора, интересен и небесполезен и более широкому

${ }^{12}$ Примеры и ссылки см.: Гращианская Л.И. «География» Страбона... С. 34-46.

${ }^{13}$ Там же. С. 6-175.

${ }^{14}$ Strab., I, 1, 23; XI, 9, 3; XVII, 1, 36 etc.

${ }^{15}$ Грацианская Л.И. Роль и назначение географии в системе геополитических и политических представлений Страбона // Восточная Европа в древности и Средневековье: Миграция, расселение, война как факторы политогенеза: XXIV чтения памяти члена-корреспондента АН СССР Владимира Терентьевича Пашуто. М., 2012. С. 70-73.

${ }^{16}$ Strab., I, 1, 16; 21-23 et al. 
кругу читателей ${ }^{17}$. Таким образом, сочинение Страбона носит дидактический характер, что влечет за собой определенные закономерности в выборе фактического материала для изложения и специфические формы его подачи. Страбон декларирует необходимость излагать только то, что может быть полезным и нужным предполагаемому адресату. Он останавливается на способах научения, например, на необходимости занимательности и разного рода литературных приемов, служащих этой цели ${ }^{18}$ и, в частности, на роли мифологического или полумифологического для лучшего восприятия при научении, поскольку мифы сладки, всем известны и способствуют скорейшему восприятию изложенного ${ }^{19}$.

«География» написана компилятивным методом, что является вполне закономерным для времени и обстоятельств ее создания. Вопрос лишь в характере этой компиляции. Компилятивный метод присущ античной литературе, как греческой, так еще в большей степени и римской, на разных этапах ее развития с очень древних времен. Компиляция, равно как и сюжетный плагиат, ни греками, ни римлянами никогда не оценивалась отрицательно. Наоборот, литературные каноны предписывали ему брать сюжеты из общеизвестного запаса: мифологии и генеалогии. Подобно тому, как на надгробных плитах писались имена отца, а то и деда умершего, так и литературное произведение должно было иметь своих предшественников в мифах или литературе. Причем ограничение это касалось не только содержания (сюжета, действия, в какой-то степени, идей), но и формы, которые взаимно обуславливались. Эта предопределенность темы происходила не только из стремления автора (пересказчика, компилятора) сделать более достоверным свое детище - иель, но и обуславливалась известной фатальностью античного мышления - предпосылка, нашедшей яркое отражение еще в творчестве Гомера, а также заинтересованностью автора (и читателя) не в конечном пункте развития сюжета, не в том, «что будет дальше», а в процессе. Античной литературе архаического и классического (а отчасти и эллинистического) времени не свойственен интерес к концу произведения, который вовсе не является кульминацией: важно действо. Писатель-беллетрист (поэт, драматург) сообщает сведения с точки зрения их познавательности давно и в достаточной мере известные: знают Ахилл и Медея, что должно с ними случиться, знает об этом и античный читатель. Интерес же его сосредоточен на промежуточных событиях, на искусстве

${ }^{17}$ Strab., I, 1, 13; 17; 20-22; II, 5, 1; 17 et al.

${ }^{18}$ Грацианская Л.И. «География» Страбона... С. 96-98 и др.

${ }^{19}$ Strab., I, 2, 8-9; 19; VII, 7, 10; X, 3, 23; XV, 3, 18; XVII, 3, 3 et al; Грацианская Л.И. «География» Страбона... С. 78-79, 135, 146-152. 
описания: априорное знание исхода позволяет целиком сосредоточиться на психологической глубине и языковых и образных красотах всего произведения.

Сообщение литературным произведением чего-то нового с познавательной точки зрения стало его функцией значительно позже по двум линиям: литературы сочиненной, авантюрной - беллетристики, что впоследствии развивается и окончательно определяется как роман (в какой-то мере поздняя драма-комедия), и литературы научной, т. е. историко-географической и естественнонаучной. Роднит же эти линии еще долго элемент грядущей новизны содержания.

С этими линиями связано сюжетное и авторское начало в античной литературе, которое доселе проявлялось лишь в форме (языке, стиле, отчасти и композиции), да в относительной свободе выбора сюжета. Но если в романе или поздней драме развитие авторского начала ведет к сокращению компилятивного элемента и сюжетного плагиата, то в литературе научной, где целью изложения является истина бывшего (научная достоверность рассказываемого), роль этих элементов неуклонно растет. Здесь дело в различии цели создания двух родов литературы: первая предназначена для услаждения, вторая - для познания, познания любым способом, в частности, услаждением.

Страбон считает, что целью научного (историко-географического) сочинения должна быть истина, однако в отличие, скажем, от Полибия, Диодора Сицилийского или Лукиана, допускает в него элементы мифического, говорит о возможности излагать нечто историческое в мифологической форме для легкости усвоения и восприятия. Научение любым способом и услаждением также - такова исходная позиция автора «Географии» и его цель ${ }^{20}$.

Труд Страбона, относясь по материалу своему и манере изложения к литературе научной, целями написания (воспитание) сближается с литературой художественной: потому-то и трудно отнести его просто к жанру землеописания или географо-исторического трактата, коль скоро в произведении этом имеются элементы и комментария, и грамматического произведения, и фольклора, и новеллы, - словом всего, что могло положительно воздействовать на начинающего государственного деятеля рубежа нашей эры (но - увы! - не воздействовало) и что счастливо дает современному источниковеду материал не только глобально-исторический, но и разный другой, в том числе бытовой. Эта неканоничность, неоднородность жанра и выделяет «Географию» как исключительное явление литературы. Исто-

${ }^{20}$ Strab., I, 2, 8-9; Грацианская Л.И. «География» Страбона... С. 148-153. 
рик получает из нее самые разнообразные сведения от известий о «войнах, засухах, морах, потопах» до пикантных анекдотов о женщинах и содержателе притона ${ }^{21}$.

Дискуссионным является и порядок написания Страбоном его грандиозного труда. Молчаливое допущение большей частью исследователей строго последовательного составления «Географии», по-видимому, является принятием того, что должно быть доказано, за отправную точку доказательной системы $^{22}$. Мне этот порядок представляется несколько иным: из большого количества набросков, заметок, конспектов прочитанного, фиксаций услышанного и увиденного, записей собственных соображений Страбон собирает свой труд. Собирает по заранее продуманному и, может быть, даже письменно намеченному и зафиксированному плану: общетеоретические части, описание Европы в определенной последовательности областей, аналогичным способом скомпонованное описание Азии, потом - Африки. Однако это вовсе не предполагает, что европейские части появились в окончательном виде до азиатских и африканских. Скорее всего, продумав и зафиксировав план всего сочинения ${ }^{23}$, географ далее работал над отдельными его частями не обязательно в той последовательности, в какой они представлены в окончательном варианте (аналогичным образом, по-видимому, работал Эфор ${ }^{24}$ ). К этой идее когда-то близко подошел Ф.Г. Мищенко, рассматривая состояние книг VIII-IX вв. в рукописной традиции ${ }^{25}$. Относительно книг I-II (так называемые prolegomena) это предположение переходит в уверенность ${ }^{26}$. Структурное построение отдельных частей «Географии», описывающих выделенные Страбоном как единое целое районы, удачно проследил в свое время М.И. Ростовцев: 1. перипл, 2. исторические справки, 3. общее описание страны с историческими справками ${ }^{27}$. Добавлю, что место морского перипла может занимать речной перипл, периегеса или описание по карте 28 . Кроме того, периплу-периегесе крупных или легко выделяемых по формально-картографическому принципу районов

\footnotetext{
${ }^{21}$ Грацианская Л.И. «География» Страбона... С. 94.

${ }^{22}$ Там же. С. 39-43.

${ }^{23}$ Strab., III, 1, 1; cp.: XVII, 1, 36.

${ }^{24}$ Подробнее см.: Грацианская Л.И. «География» Страбона... С. 68-74.

${ }^{25}$ Мищенко Ф.Г. Древняя рукопись «Географии» Страбона, открытая в 1875 г. в аббатстве Гроттаферрата базилианским монахом Джузеппе Коццою // Университетские известия (Киев). 1876. № 5. С. 358-371.

${ }^{26}$ Подробнее см.: Грацианская Л.И. «География» Страбона... С. 39-44.

${ }_{27}^{27}$ Ростовцев М.И. Страбон как источник для истории Боспора // Сборник статей в честь проф. В.П. Бузескула: Издан по поводу тридцатилетия его преподавательской деятельности. Харьков, 1914. С. 368.

${ }^{28}$ Подробнее см.: Грацианская Л.И. «География» Страбона... С. 96-98.
} 
(Иберия, Италия, Сицилия, вся ойкумена и др.) всегда предшествует общая математико-образная характеристика формы, а также основных особенностей ландшафта, иногда климата или восприятия региона (ойкумена хламида, Иберия - шкура быка и др. $)^{29}$.

Творческий характер компиляции Страбона и личностные моменты прослеживаются на материале лексики (терминология, предложные употребления, синонимика), синтаксиса и стилистики этого произведения. Проявляется он и в системе ссылок на использованные источники, равно как и в понятийном аппарате автора ${ }^{30}$.

Система ссылок на источники разработана Страбоном достаточно четко. Например, на 55 тойбнеровских страниц III книги встречается 99 ссылок на конкретные и неконкретные источники, а также 24 ссылки на свой текст, причем иногда вторичное упоминание встречается достаточно далеко от первичного. В 40 случаях индивидуальный подход автора к информации проявляется в модальности («пожалуй», «видимо», «кажется», «должно быть», и т. д.). Таким образом, каждые 10 строк текста являют в той или иной степени следы активной работы компилятора над источником. Нельзя также сбрасывать со счета тот факт, что после такой переработки сведения приобретали ощутимую печать страбоновских воззрений ${ }^{31}$.

Самый предмет изложения и полемические принципы построения «Географии» предполагают сообщение по каждому поводу более одного однотипного факта. При механической компиляции естественны были бы и лексические повторения, однако они практически отсутствуют за теми редкими исключениями, когда исполняют стилистическую функцию, т. е. сделаны заведомо. Число случаев предумышленного подбора синонимики для выражения аналогичных явлений говорит о пристальном внимании географа к стилистической стороне текста.

Из анализа текста «Географии» с достаточной очевидностью следует, что все, что дается Страбоном «от себя», ему и принадлежит по праву ли аутентичности, образования, разработки источников, опроса свидетелей и т. д., т. е. прошло через память и относится к реальному багажу знаний,

${ }^{29}$ Подробнее см.: Там же. С. 97.

${ }^{30}$ Грациинская Л.И. Место политической истории Боспора в «Географии» Страбона. // Древнейшие государства на территории СССР. Ежегодник. 1975. М., 1976. С. 6-20; Грацианская Л.И. Социально-политическая терминология в «Географии» Страбона (ки́рıь) // Восточная Европа в древности и Средневековье. М., 1978. С. 84-92; Грацианская Л.И. Особенности компилятивного метода Страбона (определение истинного-ложного) // Методика изучения древнейших источников по истории народов СССР. М., 1978. С. 76-91; Грацианская Л.И. Оí лєрі у Страбона // Проблема античной истории и культуры. Ереван, 1979. Т. 1. С. 433-440; Грачианская Л.И. «География» Страбона... С. 93-126.

${ }^{31}$ Грачианская Л.И. «География» Страбона... С. 107-109. 
а не переписано некритически непосредственно с источника. Ему же принадлежит активная роль отбора и компоновки материала, а также его стилистической и терминологической обработки согласно представлениям рубежа нашей эры. Географ же - создатель достаточно жесткой и логически обоснованной композиции своего сочинения.

Следует добавить также, что Страбон часто строит свое изложение, основываясь на принципах школьных риторик ${ }^{32}$. Создавая «Географию», он использует как книжные источники, так и внекнижные. Исследование разветвленной иерархии этого использования необходимо не только для определения методов работы географа с источниками, но и для оценки достоверности с исторической точки зрения приводимой информации. Эта работа проводилась мной много лет и частично опубликована в монографии, а частично в вышедших после монографии статьях.

Анализ терминологии (терминов и «терминологизирующих» слов) географа плодотворен, но по причине размытости границ между первыми и вторыми, а также принимая во внимание некоторую условность терминологии в литературном произведении, часто не позволяет использовать его результаты однозначно. И все же тотальная выборка исследуемого термина из текста (обязательно с сопутствующим контекстом) позволяет определить его понимание и использование географом ${ }^{33}$.

При исследовании творческого метода Страбона, как мне кажется, следует особое внимание уделить так называемым повторам, которые не есть результат недоработанности текста, но намеренный композиционный прием. Из анализа их можно сделать вывод об активном владении географом значительной частью материала, как книжного, так и внекнижного, а также о характере использования этого материала, часто указывающем на цель и причину написания конкретного места «Географии» ${ }^{34}$.

Я умышленно не говорю здесь о литературных стереотипах, используемых Страбоном, поскольку это отдельная большая тема. Отмечу только, что выявление такого рода стереотипов необходимо при источниковедческом использо-

\footnotetext{
32 Подробнее см.: Там же. С. 106-109; Грацианская Л.И. Страбон и риторика // Восточная Европа в древности и Средневековье. Проблемы источниковедения. Чтения памяти В.Т. Пашуто. М., 1990. С. 39-40.

${ }^{33}$ Грацианская Л.И. «География» Страбона... С. 113-126; Грацианская Л.И. Некоторые замечания об ойкосе терминологическом и ойкосе текстологическом // Боспор Киммерийский и варварский мир в период античности и Средневековья. Ойкос. VII боспорские чтения. Керчь, 2006. С. 85-88; Грацианская Л.И. О соотнесенности различных смысловых компонентов термина «полис» в диахронии // XIII Боспорские чтения. Боспор Киммерийский и варварский мир в период античности и Средневековья. Проблемы урбанизации. Керчь, 2012. С. 116-118.

${ }^{34}$ Грацианская Л.И. «География» Страбона... С. 39-43, 133-136 и др.
} 
вании текста «Географии». Опускаю я и обширный, собранный мною материал о роли ассоциаций параллелей и доказательств у Страбона, что также очень важно для источниковедческого анализа «Географии», поскольку определяет в значительной степени историческую достоверность, переданного в них.

\section{Литература}

Грацианская Л.И. Место политической истории Боспора в «Географии» Страбона // Древнейшие государства на территории СССР. Ежегодник. 1975. М., 1976. C. 6-20.

Грацианская Л.И. Социально-политическая терминология в «Географии» Страбона (кúpıо૬) // Восточная Европа в древности и Средневековье. М., 1978. С. 84-92.

Грациианская Л.И. Особенности компилятивного метода Страбона (определение истинного-ложного) // Методика изучения древнейших источников по истории народов СССР. М., 1978. С. 76-91.

Грачиианская Л.И. Oí лєрі́ у Страбона // Проблема античной истории и культуры. Ереван, 1979. Т. 1. С. 433-440.

Грацииаская Л.И. «География» Страбона. Проблемы источниковедения // Древнейшие государства на территории СССР 1986. М., 1988. С. 6-175.

Грачианская Л.И. Страбон и риторика // Восточная Европа в древности и Средневековье. Проблемы источниковедения. Чтения памяти В. Т. Пашуто. М., 1990. C. 39-40.

Грацианская Л.И. Некоторые замечания об ойкосе терминологическом и ойкосе текстологическом // Боспор Киммерийский и варварский мир в период античности и Средневековья. Ойкос. VII боспорские чтения. Керчь, 2006. С. 85-88.

Грациианская Л.И. Роль и назначение географии в системе геополитических и политических представлений Страбона // Восточная Европа в древности и Средневековье: Миграция, расселение, война как факторы политогенеза: XXIV чтения памяти члена-корреспондента АН СССР Владимира Терентьевича Пашуто. М., 2012. C. 70-73.

Грацианская Л.И. О соотнесенности различных смысловых компонентов термина «полис» в диахронии // XIII Боспорские чтения. Боспор Киммерийский и варварский мир в период античности и Средневековья. Проблемы урбанизации. Керчь, 2012. С. 116-118.

Мищеенко Ф.Г. Древняя рукопись «Географии» Страбона, открытая в 1875 г. в аббатстве Гроттаферрата базилианским монахом Джузеппе Коццою // Университетские известия (Киев). 1876. № 5. С. 358-371.

Ростовцев М.И. Скифия и Боспор: Критическое обозрение памятников литературных и археологических. Л., 1925.

Ростовиев М.И. Страбон как источник для истории Боспора // Сборник статей в честь проф. В.П. Бузескула: Издан по поводу тридцатилетия его преподавательской деятельности. Харьков, 1914. С. 366-380. 
Aly W. Strabon von Amaseia. Untersuchungen über Text, Aufbau und Quellen der Geographica. Bonn, 1957.

Butzer H. Über Strabo's Geographica, insbesonders über Plan und Ausfürung des Werkes zu seinen Vorgängern. Frankfurt-a-M., 1887.

Clarke K.J. In Search of the Author of Strabo's Geography // Journal of Roman Studies (London). 1997. № 87. P. 92-110.

Clarke K.J. Between Geography and History. Hellenistic Contributions of the Roman World. Oxford, 1999.

Dueck D. Strabo of Amasia. A Greek Man of Letters in Augustan Rome, Abingdon, 2000.

Dueck D. Strabo of Amasia. A Greek Man of Letters in Augustan Rome. L.; N. Y., 2011.

Engels $J$. Augusteische Oikumenegeographie und Universalhistorie im Werk Strabons von Amaseia. Stuttgart, 1999 (Geographica Historica. Bd 12).

Honigmann E. Strabon 3 // Pauly's Real encyclopädie der Classischen Altertumswissenschaft. Stuttgart. 1931. Hbd. 7. Sp. 76-155.

Strabo's Cultural Geography. The Making of a Kolossurgia / Ed. by D. Dueck, H. Lindsay, S. Pothecary. Cambridge, 2005.

Sollima F. Le fonti di Strabone nella geografia della Sicilia. Messina, 1897.

Strabone. Saggio di bibliografia 1469-1978 a cura di A.M. Biraschi, P. Maribelli, G.D. Massaro, M.A. Pagnotta. Perugia, 1981.

Strabone. Contributi allo studio della personalità e dell'opera. Perugia. Universitetà delgi studi, 1986. Vol. II.

Wolski J. Les études sur texte de Strabon. Charisteria Sinko quinquaginta abhinc annos amplissimis in philosophia honoribus ornato ab amicis collegis discipulis. Varsaviae; Wratisclaviae, 1951. P. 382-394. 


\section{3.В. Дмитриева}

\section{ЦЕНЫ НА ЗЕРНО ПО ВКЛАДНОЙ КНИГЕ КИРИЛЛО-БЕЛОЗЕРСКОГО МОНАСТЫРЯ (I570-I6IO-E ГГ.)}

Аннотация В статье показана возможность изучения цен одного из основных продуктов потребления населения России раннего Нового времени - хлеба (ржи, овса, ячменя и пшеницы) - по материалам монастырских вкладных книг XVI-XVII вв. Вкладные книги велись, как правило, во всех монастырях, независимо от числа насельников, времени возникновения и средств существования обителей. Вклады, как правило, оценивались, что позволяет использование их записей для изучения истории цен, в том числе на зерно. Исследование проведено на основе записей вкладной книги Кирилло-Белозерского монастыря 1559/60-1620-е гг. (Архив СПбИИ РАН. Кол. 115. Д. 1074). Выявленные данные сопоставимы с ценами на зерно, опубликованные по приходо-расходным книгам монастырей Русского Севера, и отражают движение «хлебных» цен в регионе на протяжении кризиса последней трети XVI в., великого голода и Смуты начала XVII в.

Ключевые слова: Кирилло-Белозерский монастырь, вкладные книги, «хлебные» вклады, Русский Север, кризисы конца XVI - начала XVII в.

Summary The article describes the feasibility of the study of prices fixed for bread (rye, oat, barley and wheat), one of the basic products consumed by Russia's population in the early Modern Time according to materials containing in monastery vkladnye knigi of the XVI-XVII centuries. As a rule, all monasteries used to keep account books irrespective of how large the monastery brethren were, the time of monastery foundation and means of support they had. As a rule, contributions to monastries were priced, and it makes it possible to use such contribution records for a study of price history including grain prices. The study is based on the records containing in the account book of Kirillo-Belozersky Monastery for the period between 1559/60-1620s. (Archive of St.Petersburg History Institute, Russian Academy of Sciences. Coll. 115. T. 1074). The found price data are 
comparable with grain prices published on the basis of account books of the Russian North monasteries and feature «bread» price changes in the region over the period of the crisis in the final third of the XVI century, Great Famine and the Time of Trouble at the turn of the XVII century.

Keywords: Kirillo-Belozersky Monastery, vkladnye knigi, «bread» gifts, Russian North, crises at the turn of the XVII century.

Движение цен на продукты потребления (рожь, овес, пшеницу, ячмень, соль, мясо, рыбу и проч.), предметы быта, скот и всей совокупности товаров является важнейшей составляющей в изучении торговли, экономического положения и благосостояния населения любого общества. Однако в российской историографии изучение цен можно отнести к малоизученной или дискуссионной проблеме, особенно это касается истории России XVII в.

Более 50 лет назад вышла в свет известная монография А.Г. Манькова «Цены и их движение в Русском государстве XVI века» ${ }^{1}$. Автор на основе данных монастырских хозяйственных книг, прежде всего приходо-расходных, составил перечни товаров с указанием их цены за 100 лет, а также предложил провести анализ цен отдельных товаров, «прибегнув к помощи простейшего приема исчисления группового индекса как простой средней арифметической индивидуальных индексов нашей совокупности»². Последние подверглись критике со стороны В.М. Панеяха, который предложил изучение цен региональных рынков при критическом отношении к источниковой базе ${ }^{3}$. Новации с индексами цен не получили развития в историографии, но книга Манькова стала настольной для всех историков, занимающихся экономической историей XVI в. В последующие десятилетия никто из российских историков-аграрников не смог повторить подвиг этого исследователя и подготовить обобщающую работу по истории цен в России XVII в. ${ }^{4}$ Среди причин можно назвать значительное увеличение

1 Маньков А.Г. Цены и их движение в Русском государстве XVI века. М., 1951.

2 Там же. С. 12.

3 Панеях В.М. Рец. на кн.: А.Г. Маньков. Цены и их движение в Русском государстве XVI века// Вопросы истории. 1952. № 12. С. 141, 142.

4 Вышедший в 1999 г. труд американского ученого Р. Хелли (Hellie R. The economy and material culture of Russia, 1600-1725. Chicago; London, 1999) не решил вопроса о движении цен в России XVII в. (автор не раскрыл метод работы с массовыми источниками, возможности сопоставления их данных и построения единого графика колебания цен на тот или иной товар для всей России). Критику построений Р. Хелли, например, см.: Крайковский A.B. Цена на соль в России в 1630-1650 гг. // Источник. Историк. История: Сборник научных работ. СПб., 2001. Вып. 1. С. 73-99; Дмитриева 3.В., Крайковский А.В. Цены на рыбу и рыбопродукты в начале XVII в. (по приходо-расходным книгам Кирилло-Белозерского монастыря) // Торговля, купечество и таможенное дело в России в XVI-XIX вв.: Сборник материалов Второй международной научной конференции. Курск, 2009. С. 50-59. 
объема цифрового материала и отсутствие единой методики его обработки. Вместе с тем необходимо отметить, что за последние 10 лет появились исследования, где приведен и проанализирован значительный материал отдельных комплексов массовых источников и выявлены региональные цены ${ }^{5}$.

В настоящей статье показана возможность изучения цен одного из основных продуктов потребления населения России раннего Нового времени - хлеба (ржи, овса, ячменя и пшеницы) - по материалам монастырских вкладных книг XVI-XVII вв. Этот вид монастырской документации получил широкое распространение после Стоглавого собора 1551 г. ${ }^{6}$ Вкладные книги велись, как правило, во всех монастырях, не зависимо от числа насельников, времени возникновения и средств существования обителейㄱ. Вклады, как правило, оценивались, что позволяет использование их записей для изучения истории цен, в том числе на зерно.

5 Лисейцев Д.В. Торговые люди Московской Руси в эпоху Смуты начала XVII в. // Topговля, купечество и таможенное дело в России XVI-XVII вв.: Сборник материалов Третьей международной научной конференции (г. Коломна, 24-26 сентября 2013 г.). Коломна, 2015. Т. 1. С. 28, 29; Дмитриева 3.В. «Хлебный бюджет» Кирилло-Белозерского монастыря в начале XVII в. // Монастыри и архиерейские дворы в документах XVI-XVIII веков. СПб., 2015. C. 9-39 (Труды Санкт-Петербургского института истории РАН. Вып. 1(17)); Башнин Н.B., Поляков И.А. Разработка базы данных о ценах в России XVII в. (по материалам приходо-расходных книг Вологодского архиерейского дома) // Русь, Россия: Средневековье и Новое время. М., 2017. Вып. 5: Пятые чтения памяти академика РАН Л.В. Милова. С. 278-293; Башнин Н.В. Приходо-расходные книги Вологодского архиерейского дома XVII в. как источник по истории цен в России // Торговля, купечество и таможенное дело в России XVI-XIX вв.: Сборник материалов Четвертой международной научной конференции (Нижний Новгород, 28-30 сентября 2017 г.). Нижний Новгород, 2018. С. 144-147; Франиузова Е.Б. К вопросу о движении хлебных цен в России в первой четверти XVII в. (цены на зерно по оценкам приказчиков холмогорской службы Соловецкого монастыря)// Торговля, купечество и таможенное дело в России XVI-XIX вв... С. 136-143; Башнин Н.В., Поляков И.А. Цены на рынках Вологды и Тихвина в XVII в. (по материалам монастырских и архиерейских приходо-расходных книг) // Новгородика - 2018. Повседневная жизнь новгородцев: история и современность: Материалы VI международной научной конференции 26-27 сентября 2018. В 2 т. Великий Новгород, 2018. Т. 2. С. 193-201; Хозяйственные книги Вологодского архиерейского дома Святой Софии XVII - начала XVIII в. / Сост. Н.В. Башнин. М.; СПб., 2018. Приложение. С. 589-750 (в 41 таблицу сведены данные о 1464 видах товаров, приобретенных Вологодским архиерейским домом в 1612-1703 гг. на Вологодском рынке). Здесь же (c. 583-587) дан историографический обзор изучения ценообразования в России X-XVII вв.

${ }^{6}$ В главе 75 Стоглавого собора («Ответ о вотчинах и о куплях, которые боголюбцы давали святым церквам на память своим душам и по своих родителех в вечной поминок») предписывалось «ставити» по вкладчикам «кормы», «на их памяти пети собором панахиды самем пастырем, и обедни служити, и братию кормити по монастырскому чину... их имена... в сенаники написати и поминати их всегда по церковному чину» (Российское законодательство X-XX вв.: Законодательство периода образования и укрепления Русского централизованного государства / Отв. ред. А.Д. Горский. М., 1985. Т. 2. С. 352).

7 О вкладных книгах русских монастырей см.: Кузьмин А.В., Стрельников С.В. Вкладные книги // Православная энциклопедия. М., 2004. Т. 8. С. 613-617. 
Покажем это на примере самой ранней вкладной книги Кирилло-Белозерского монастыря: Архив СПбИИ РАН. Кол. 115. Д. 1074 (1559/60-1620-е гг.) (далее - ВКА) $^{8}$. Во вкладных книгах фиксировали пожертвования в монастырь «людей разных чинов», от российских государей до нищих. «Даяния» предполагали молитвы монашествующих «о здравии» и «на помин души»9. Вкладывали деньги и имущество также при пострижении в монастырь. Представители княжеских и боярских родов чаще всего передавали в Кириллов монастырь земельные угодья, иконы с дорогими окладами и пеленами, серебряную церковную утварь, одежду, а дети боярские, посадские люди, крестьяне - скот, иконы, предметы быта и самое разнообразное имущество ${ }^{10}$. Важно отметить, что денежные и «хлебные» вклады делали все категории населения.

Денежная оценка вкладов проводилась с учетом рыночной цены товара на момент фиксации вклада и позволяет рассматривать вкладные книги как источник для изучения цен в России, в частности на зерно (рожь, овес, пшеницу и ячмень). Прямое свидетельство об этом содержит запись 5 февраля 1602 г. вклада крестьянина из села Илгощи Бежецкого Верха Емельяна (Омельяна) Борисова, который дал 20 четвертей ячменя, 30 четвертей овса за 25 руб., «а в те поры купили ячмень четь по 30 алтын без гривны, а овса четь по полтине» ${ }^{11}$.

Следует также отметить, что формуляр записей в ВКА не был унифицирован. Царские и княжеские вклады не оценивались и записывались «как великие». Так, например, не указана цена значительного хлебного вклада кн. Старицких: Ефросиния с сыном Владимиром с 1552 по 1559 гг. вложила

8 Дмитриева 3.В. Вкладная книга Кирилло-Белозерского монастыря (1559/1560-1620-е гг.) [Электронный ресурс]// История. Электронный научно-образовательный журнал. 2017. Т. 8. Вып. 5(59) (URL: https://history.jes.su/s207987840001876-2-1 (дата обращения: 11.04.2021)). Текст вкладной книги до 1560 г. по другой редакции опубликован: Алексеев А.И. Первая редакция вкладной книги Кирилло-Белозерского монастыря (1560-е гг.) // Вестник церковной истории. 2010. № 3/4(19/20). С. 25-65. Вкладные книги, последовательно составленные в XVII в., хранятся в Кирилло-Белозерском собрании Отдела рукописей Российской национальной библиотеки: ОР РНБ. Кир.-Бел. № 78/1317 (1610-е-1640-е гг.); Кир.-Бел. № 87/1325 (1650-1670-е гг.). Обзор вкладных книг из собрания ОР РНБ дан: Алексеев А.И. «Сих же память пребывает во веки»: (Мемориальный аспект в культуре русского православия) // Материалы научной конференции 29-30 ноября 1997 г. СПб., 1997. С. 69-80.

9 О поминальной практике в Кирилло-Белозерском монастыре см.: Никольский Н.К. Кирилло-Белозерский монастырь и его устройство до второй четверти XVII века (1397-1625). Т. 1. Вып. 2: О средствах содержания монастыря. СПб., 1910. С. 140-215; Шаблова Т.И. Кормовое поминание в Успенском Кирилло-Белозерском монастыре в XIV-XVII веках. СПб., 2012. C. 3-94.

${ }^{10}$ Никольский Н.К. Кирилло-Белозерский монастырь и его устройство... Т. 1. Вып. 2. C. $140-227$.

${ }^{11}$ ВКА. Л. 405 об., 406. 
в Кириллов монастырь более 7 тыс. четвертей зерна ${ }^{12}$. Также не оценивались «малые» вклады, включенные в раннюю редакцию вкладных книг (записи до 1560 г.). Приведем типичный формуляр: «Терентей Веньяминов дал пол-30 рублев да 100 четвертей ржы... Денисей с Углы дал 100 четвертей ржы да 5 рублев денег» ${ }^{13}$. Часто «хлебные» вклады могли записываться суммарно с другими дачами. Так, в 101 (1592/93) г. крестьянин Романовой Слободки (вотчина Кириллова монастыря) дал вкладом «мерина», ржи, овса, пшеницы и ячменя, всего «на 7 рублев на четыре гривны» ${ }^{14}$. В таких случаях фиксируется только факт передачи зерна в монастырские житницы.

Сведения о цене хлеба изъяты из формуляра, в котором присутствуют дата, размер хлебного пожалования в четвертях и его денежной оценке: «Слуга монастырьской Тихон Карцов... 125-го году дал 5 чети ржы, четь по 2 рубли, да 5 чети ячмени, четь по рублю, да 8 чети овса, четь по 20 алтын» ${ }^{15}$. Как видим, в данном случае дата вклада (1616/17 г.) внесена в текст ВКА. Датировка могла быть указана в предшествующей записи или отмечена на верхнем поле рукописи: «Того же (117, сентябрь. - 3. Д.) году Волока Словинскаго хрестьянин Зиновей Филипьев сын Булганин 2 рубля денег да 6 чети овса, цена 20 алтын» ${ }^{16}$.

По тексту ВКА нами выявлено 63 записи о цене ржи, овса и ячменя за 1574/75-1619/20 гг. (см. табл.; № 1-63). Сведенные в таблицу данные отражают движение «хлебных» цен на протяжении кризиса последней трети XVI в., великого голода и Смуты начала XVII в. В эти годы зерно вкладывали дети боярские, священники, монастырские слуги крестьяне кирилловских сел и белозерских езовых дворцовых волостей. Как видно из таблицы, в 1570-х гг. четверть ржи оценивалась в 20-40 ден ${ }^{17}$. При этом в течение 1574-1578 гг. в ряде записей цена не поднималась выше 24 ден. (табл.; № 1, 2, 4-6); увеличение началось с начала 1580-х гг. (60-90 ден.), в 1590-е гг. (1593-1600/01) вновь снизилась до 32-40 ден. Заметное исключение составил вклад крестьянина «из Гор» (вероятно, из деревни вблизи Воскресенского Горицкого монастыря) 120 ден. за четверть (точная

${ }^{12}$ Алексеев А.И. Первая редакция вкладной книги Кирилло-Белозерского монастыря... С. 29.

${ }^{13}$ ВКА. Л. 199 об., 200 об.

${ }^{14}$ Там же. 370 об.

${ }^{15}$ Там же. Л. 422 об.

${ }^{16}$ Там же. Л. 483 об. Дата отмечена также на верхнем поле в правом углу -117.

${ }^{17}$ B XVI в. в России бытовала четырехпудовая четверть как официальная мера сыпучих тел (Камениева Е.И., Устюгов Н.В. Русская метрология. 2-е изд. М., 1975. С. 105). ВКА не указывает размер четверти в пудах; в 126 (1617/18) г. при фиксации вклада сына боярского Федора Лескова указано, что он вложил «30 чети овса в белозерскую меру», которая, вероятно, была больше монастырской четверти (цена овса «в белозерскую меру» в 1,7 раз превысила цену четверти вкладного овса, учтенного в 1615/16 г.) (табл.; № 60, 62). 
дата не указана, зафиксирован после пострижения в Кириллов монастырь в 1593/94 г.) (табл.; № 21).

Представленные данные сопоставимы с ценами на рожь А.Г. Манькова: с 1573 до 1581 г. из 26 показателей в 21 случае цена ржи колебалась, как и в ВКА, от 20 до 40 ден., а в 11 из них была менее 30 ден.; в 1580-х гг. цена резко повысилась, причем заметны значительные ее колебания, в 1586-1588 гг. от 45 до 120 ден.; в 1590-х гг. вновь началось понижение, но сохранялось ценовое колебание по регионам ${ }^{18}$. Стабилизацию хлебных цен в 1590-х г. по данным приходо-расходных книг Спасо-Прилуцкого монастыря отметила и Е.Б. Французова (монастырь перепродавал вологодские товары в Холмогорах). По ее подсчетам, цена ржи, проданной монастырем на холмогорском рынке в 1599 г,, составила 47-53 ден., овса — 32 ден.; в 1600 г. рожь продали по 46 ден $^{19}$.

Великий голод внес значительные коррективы в цены на зерно: четверть ржи в марте 1603 г. (вклад крестьянина из дворцовой Усть-Угольской волости) была оценена в 1 руб. (200 ден.) (табл.; № 33). Однако в 1606/07 г. она понизилась до 48 ден. (табл.; № 37). В последующие годы на цену четверти ржи прямое влияние оказала конкретная ситуация в регионе: до начала польско-литовского и «казачья» разорения Русского Севера цена четверти ржи снизилась до 36 ден. - 54 ден. (табл.; № 39-42); пошла вверх в 1611-1618 гг. и составляла чаще всего 100, 120 ден. (табл.; № 47-49, 51, 55, 59, 60, 63); повысилась до 200 ден. (1 рубля) в 1614/15 г. (табл.; № 57) и 400 ден. (2 рубля) в 1616/17 г. (табл.; № 61).

Цена четверти овса, как правило, была в 2-2,5 раза ниже ржи (см. табл.). Ячменя вкладывали значительно меньше, цены на него были близки к ценам на овес. Единичны случаи передачи в монастырь пшеницы, причем объемы были незначительные и могли записываться суммарно с рожью. Так, при пострижении в 1603 г. крестьянин дворцовой Усть-Угольской волости Савин Вахрамеев, по прозвищу Вьялица, передал в монастырь 10 четвертей ржи, 10 четвертей овса, 20 четвертей овса, 2 чети пшеницы, 2 коровы, 2 чети солоду ячного, 2 лошади; хлебный вклад был оценен: «ржы и пшенице четь по рублю, а ячмени, солоду яшнему и овса четь по полтине» ${ }^{20}$.

Представленная тенденция в целом отражает цены на хлебном рынке Русского Севера в 1610-е гг. Так, кирилловские власти в августе 1602 г. и весной 1603 г. продавали рожь на Вологде; цена одной четверти составляла 20 алтын (120 ден. $)^{21}$.

\footnotetext{
${ }^{18}$ Маньков А.Г. Цены и их движение... Табл. 1. С. 107-111.

${ }^{19}$ Франиузова Е.Б. К вопросу о движении хлебных цен... С. 141.

${ }^{20}$ ВКА. Л. 467.

${ }^{21}$ Дмитриева 3.В. «Хлебный бюджет» Кирилло-Белозерского монастыря... С. 13, 14.
} 


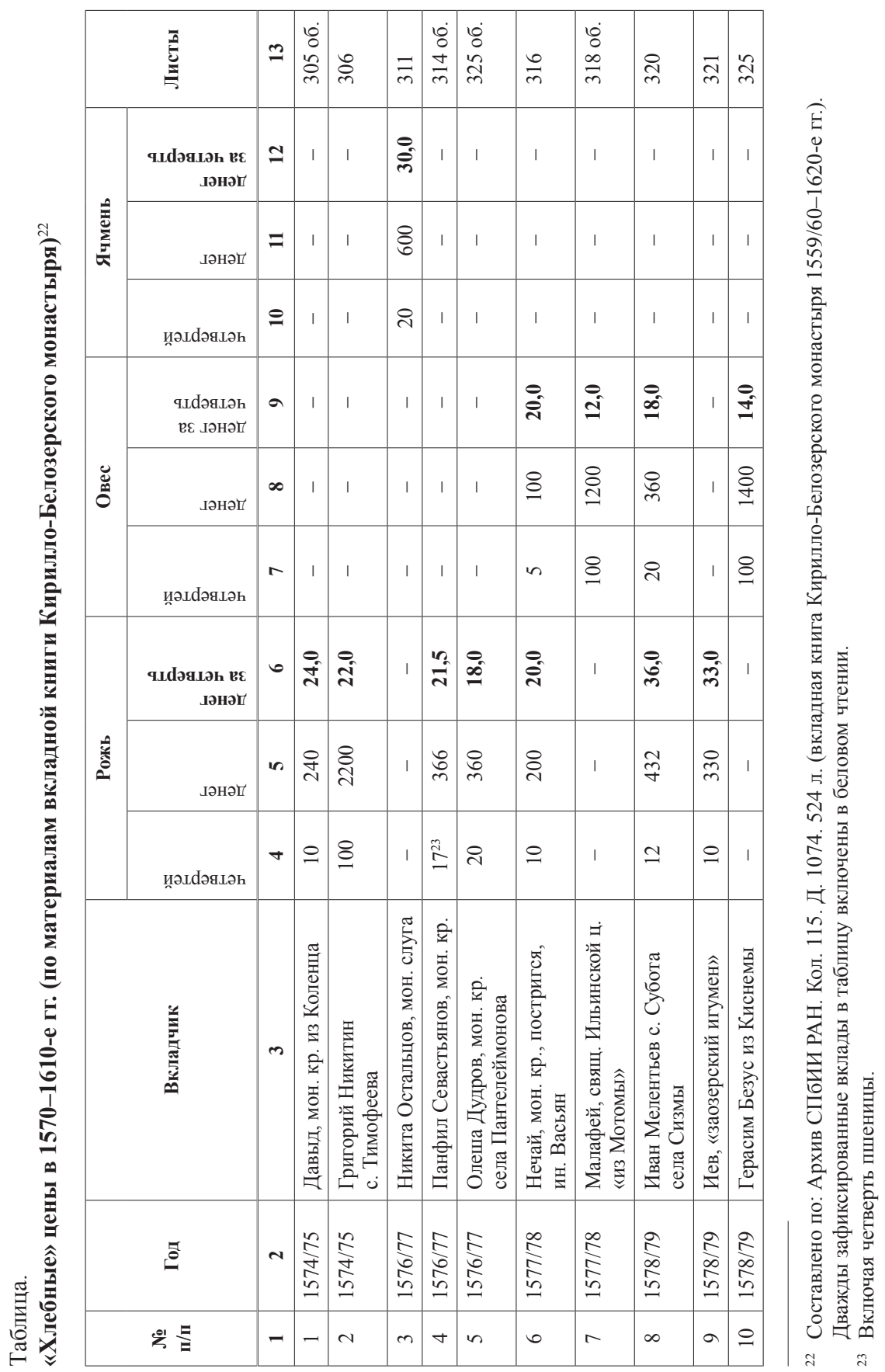




\begin{tabular}{|c|c|c|c|c|c|c|c|c|c|c|c|c|c|}
\hline 2 & 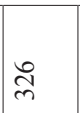 & $\widehat{\widetilde{n}}$ & $\begin{array}{l}\dot{8} \\
\dot{m}\end{array}$ & $\stackrel{\circ}{\sigma}$ & $\stackrel{\mathscr{\gamma}}{\mathscr{\gamma}}$ & $\vec{q}$ & $\tilde{F}$ & 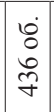 & $\begin{array}{l}\dot{0} \\
\vdots \\
\dot{\gamma} \\
\dot{\gamma}\end{array}$ & $\begin{array}{l}\dot{8} \\
8 \\
f \\
f\end{array}$ & f & $\begin{array}{l}\dot{8} \\
\text { ஜn } \\
\dot{f}\end{array}$ & 过 \\
\hline$\simeq$ & 1 & 1 & 1 & 1 & 1 & 1 & 是 & 1 & $\hat{\dot{d}}$ & 1 & 1 & 1 & 1 \\
\hline$=$ & 1 & 1 & 1 & 1 & 1 & 1 & 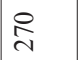 & 1 & $\stackrel{8}{8}$ & 1 & 1 & 1 & 1 \\
\hline$\Theta$ & 1 & 1 & 1 & 1 & 1 & 1 & in & 1 & $\mathscr{f}$ & 1 & 1 & 1 & 1 \\
\hline$a$ & 1 & 1 & 1 & 1 & हि & हि & $\stackrel{\ominus}{\circ}$ & 1 & 1 & 1 & 1 & $\stackrel{10}{=}$ & تิ \\
\hline$\infty$ & 1 & 1 & 1 & 1 & 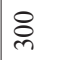 & হু & $\stackrel{\infty}{\infty}$ & 1 & 1 & 1 & 1 & 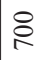 & 곡 \\
\hline r & 1 & 1 & 1 & 1 & 으 & $\bar{m}$ & $\stackrel{0}{-}$ & 1 & 1 & 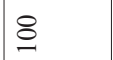 & 1 & of & $\simeq$ \\
\hline 6 & $\ddot{8}$ & 悹 & ల & $\overbrace{\infty}^{2}$ & $\hat{8}$ & है & ڤิ) & ڤे & 1 & 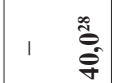 & @ิ & $\stackrel{\theta}{\dot{q}}$ & 1 \\
\hline in & ஓ & $\underset{\infty}{\stackrel{\infty}{-}}$ & 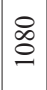 & 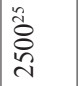 & \&్ర & 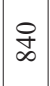 & i & 导 & 1 & | $1 \begin{array}{l}\tilde{d} \\
\infty \\
0 \\
n\end{array} \mid$ & 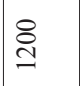 & \& & 1 \\
\hline r & $ㅇ$ & in & m & 总 & 은 & \pm & \begin{tabular}{l}
$\stackrel{n}{2}$ \\
\multirow{r}{*}{}
\end{tabular} & $\stackrel{0}{ }$ & 1 & 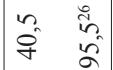 & 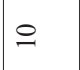 & $\cong$ & 1 \\
\hline$m$ & 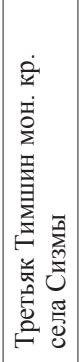 & 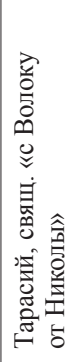 & 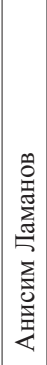 & 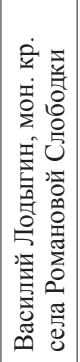 & 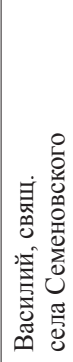 & 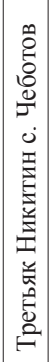 & 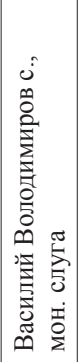 & 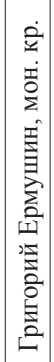 & 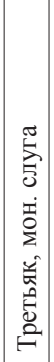 & 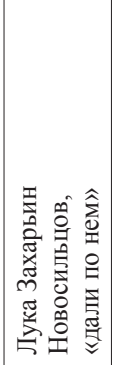 & 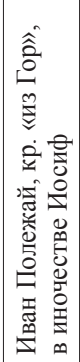 & 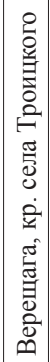 & 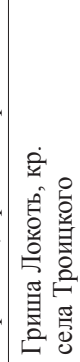 \\
\hline$N$ & $\begin{array}{l}\frac{a}{\infty} \\
\frac{1}{n} \\
\frac{n}{n}\end{array}$ & $\begin{array}{l}\infty \\
\frac{\infty}{2} \\
i n\end{array}$ & $\begin{array}{l}\infty \\
\frac{\infty}{2} \\
\stackrel{\hat{n}}{a}\end{array}$ & $\begin{array}{l}\infty \\
\infty \\
\infty \\
\varrho \\
\sim\end{array}$ & $\begin{array}{l}\infty \\
\infty \\
\infty \\
\infty \\
n \\
n\end{array}$ & 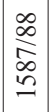 & 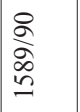 & 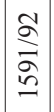 & $\begin{array}{l}\hat{\hat{\lambda}} \\
\hat{\jmath} \\
\end{array}$ & 竞 & 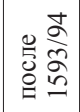 & $\begin{array}{l}2 \\
2 \\
2 \\
2 \\
2\end{array}$ & 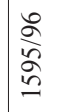 \\
\hline- & $=$ & $\simeq$ & $\underline{\simeq}$ & \pm & $\cong$ & $\stackrel{0}{0}$ & $=$ & $\stackrel{\infty}{\sim}$ & 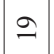 & ণ & $\vec{\sim}$ & $\approx$ & $\approx$ \\
\hline
\end{tabular}

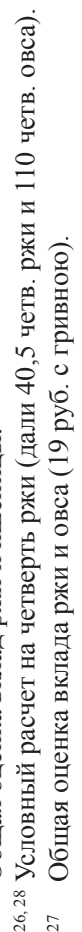




\begin{tabular}{|c|c|c|c|c|c|c|c|c|c|c|c|c|c|}
\hline$=$ & $\begin{array}{l}\dot{0} \\
8 \\
0 \\
j\end{array}$ & 手 & 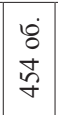 & $\begin{array}{l}\dot{0} \\
\vdots \\
\vdots \\
b\end{array}$ & 宍 & $\begin{array}{l}\dot{0} \\
\vdots \\
\sigma \\
\sigma\end{array}$ & $\begin{array}{l}0 \\
0 \\
0 \\
\delta \\
+\end{array}$ & 志 & 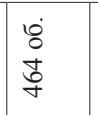 & $\bar{b}$ & $\begin{array}{l}0 \\
0 \\
0 \\
\vdots \\
+\end{array}$ & $\stackrel{\mathscr{f}}{\mathscr{f}}$ & $\stackrel{\vartheta}{\vec{\gamma}}$ \\
\hline$\simeq$ & 1 & If & if & ' & ثิ & If & 1 & 1 & 宓 & 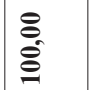 & $\stackrel{\Theta}{\hat{\theta}}$ & 1 & $\vec{f}$ \\
\hline$=$ & 1 & $\stackrel{\overbrace{}}{\simeq}$ & $\tilde{\check{n}}$ & 1 & ৪্ল & $\stackrel{\mathscr{\otimes}}{\stackrel{\circ}{\leftrightarrows}}$ & 1 & 1 & ః్లి & $\stackrel{8}{\circ}$ & $\&$ & 1 & ఫิ \\
\hline$\Theta$ & 1 & in & $\pi$ & 1 & $\cong$ & if & 1 & 1 & $\stackrel{\sim}{~}$ & 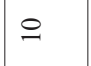 & 0 & 1 & 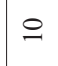 \\
\hline$\sigma$ & 1 & $\stackrel{\text { जิ }}{\text {. }}$ & i & 1 & 1 & $\hat{\Xi}$ & 1 & 1 & ثิ & 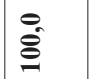 & 1 & 1 & 1 \\
\hline$\infty$ & 1 & \&̊ & 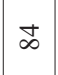 & 1 & 1 & $\stackrel{\mathscr{\circ}}{\stackrel{\circ}{9}}$ & 1 & 1 & ఫ్ల & ¿্ণ & 1 & 1 & 1 \\
\hline$r$ & 1 & 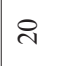 & $r$ & 1 & 1 & 8 & 1 & 1 & \& & i & 1 & 1 & 1 \\
\hline 6 & $\stackrel{8}{\bar{f}}$ & స్ల & 1 & if & 1 & id & है & $\stackrel{i}{i}$ & 1 & ثิ & 1 & 竎 & 1 \\
\hline in & \& & $\stackrel{8}{ }$ & 1 & 辛 & 1 & 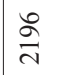 & 8 & in & 1 & ¿্ণి & 1 & 名 & 1 \\
\hline$\sigma$ & $\cong$ & in & 1 & 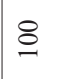 & 1 & $\overrightarrow{6}$ & $\stackrel{\circ}{\circ}$ & $\infty$ & 1 & 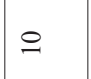 & 1 & 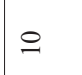 & 1 \\
\hline$m$ & 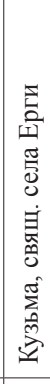 & 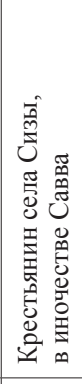 & 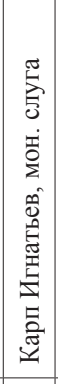 & 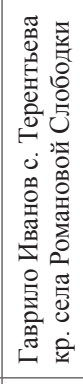 & 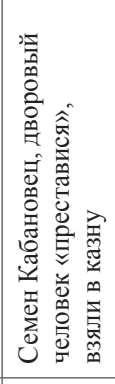 & 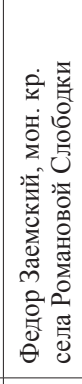 & 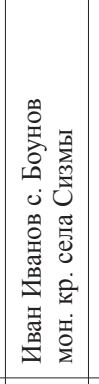 & 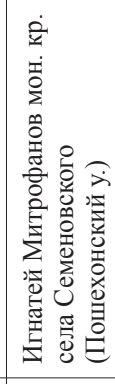 & 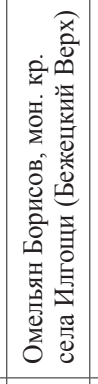 & 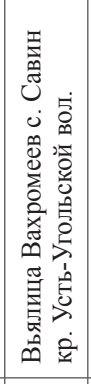 & 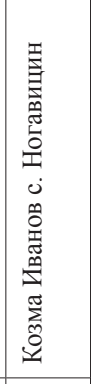 & 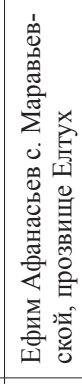 & 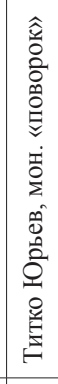 \\
\hline N & 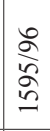 & \begin{tabular}{l}
\multirow{2}{2}{} \\
\multirow{2}{2}{} \\
2 \\
2
\end{tabular} & $\begin{array}{c}\infty \\
\vdots \\
\vdots \\
\vdots \\
\\
\end{array}$ & 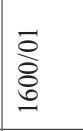 & $\begin{array}{l}\overline{0} \\
\text { పे } \\
\text { - }\end{array}$ & 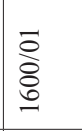 & 帘 & 帘 & 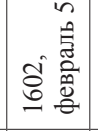 & 客 & 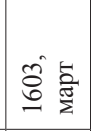 & : & 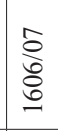 \\
\hline- & I & 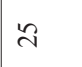 & $i$ & $\bar{\lambda}$ & $\stackrel{\infty}{\infty}$ & ते & $\stackrel{\text { }}{ }$ & $\vec{m}$ & $\approx$ & 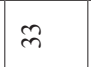 & $\stackrel{ \pm}{m}$ & $\approx$ & i \\
\hline
\end{tabular}




\begin{tabular}{|c|c|c|c|c|c|c|c|c|c|c|c|c|c|c|}
\hline$\cong$ & 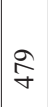 & $\begin{array}{l}\dot{0} \\
0 \\
\infty \\
\infty \\
+\end{array}$ & $\begin{array}{l}\infty \\
+\infty \\
+\end{array}$ & $\begin{array}{l}\stackrel{0}{0} \\
\dot{0} \\
\infty \\
+\end{array}$ & 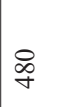 & $\begin{array}{l}\infty \\
\stackrel{\infty}{+}\end{array}$ & $\begin{array}{l}\dot{8} \\
\dot{0} \\
2 \\
\dot{\sigma}\end{array}$ & 衣 & $\begin{array}{l}\dot{0} \\
\circ \\
\stackrel{\sigma}{\sigma}\end{array}$ & $\begin{array}{l}0 \\
0 \\
0 \\
\delta \\
\tilde{n}\end{array}$ & ¿ & D্ & $\begin{array}{l}0 \\
0 \\
0 \\
i \\
i n\end{array}$ & $\begin{array}{l}0 \\
8 \\
0 \\
i n \\
i n\end{array}$ \\
\hline$\simeq$ & 1 & 1 & 1 & 1 & $\stackrel{0}{\stackrel{\infty}{+}}$ & 1 & 1 & $\stackrel{\theta}{\hat{\theta}}$ & 1 & $\stackrel{8}{8}$ & $\stackrel{8}{8}$ & 1 & 1 & $\stackrel{8}{8}$ \\
\hline$=$ & 1 & 1 & 1 & 1 & $\underset{\infty}{\infty}$ & 1 & 1 & ষ্ల & 1 & 웜 & ৪্ & 1 & 1 & 8 \\
\hline$\varrho$ & 1 & 1 & 1 & 1 & $\beth$ & 1 & 1 & in & 1 & 우 & $n$ & 1 & 1 & $\stackrel{0}{ }$ \\
\hline$a$ & 1 & ิㅗㅇ & $\stackrel{\circ}{\Omega}$ & 1 & ิㅗㅇ & 1 & 1 & 1 & 1 & 1 & $\stackrel{\ominus}{\dot{q}}$ & 1 & $\stackrel{\theta}{\dot{q}}$ & $\ddot{\theta}_{\dot{q}}$ \\
\hline$\infty$ & 1 & 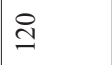 & $\stackrel{i}{i}$ & 1 & \& & 1 & 1 & 1 & 1 & 1 & \& & 1 & \& & $\underset{8}{8}$ \\
\hline$r$ & 1 & 0 & ిల & 1 & 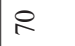 & 1 & 1 & 1 & 1 & 1 & $m$ & 1 & 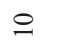 & P \\
\hline$b$ & 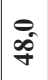 & 1 & $\begin{array}{l}\theta \\
\text { हे }\end{array}$ & $\hat{n}^{2}$ & in & in & $\stackrel{8}{8}$ & 1 & $\stackrel{\ominus}{\otimes}$ & I & $\stackrel{\ominus}{\hat{\theta}}$ & 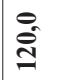 & $\stackrel{\ddot{\theta}}{\stackrel{\theta}{0}}$ & $\stackrel{8}{\infty}$ \\
\hline$n$ & 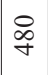 & 1 & 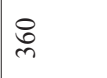 & $\underset{0}{8}$ & ర్రి & $\underset{\infty}{\mathbb{D}}$ & శ్ & 1 & \& & 1 & § & $\begin{array}{l}\text { तิ } \\
\text { ปे }\end{array}$ & $\stackrel{8}{\varrho}$ & \&్ర \\
\hline$\nabla$ & 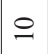 & 1 & 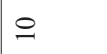 & ిల & ిల్ల & 0 & $\begin{array}{l}n \\
n\end{array}$ & 1 & $n$ & 1 & 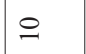 & $\vec{\sim}$ & $=$ & $\stackrel{\lambda}{ }$ \\
\hline$m$ & 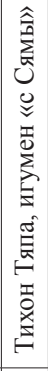 & 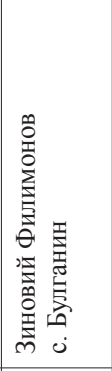 & 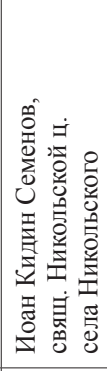 & 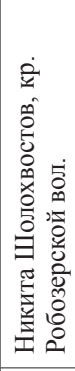 & 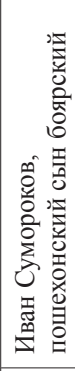 & 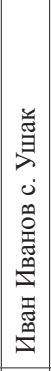 & 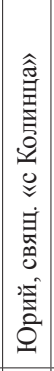 & 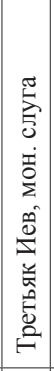 & 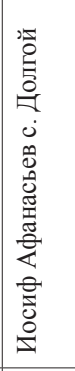 & 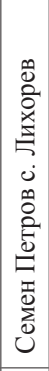 & 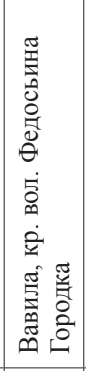 & 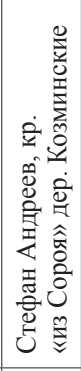 & 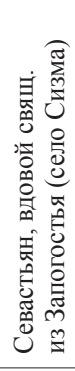 & 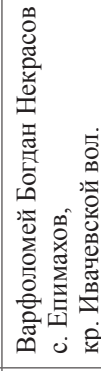 \\
\hline$N$ & $\begin{array}{l}\hat{0} \\
0 \\
0 \\
0 \\
0\end{array}$ & 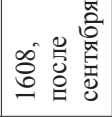 & $\begin{array}{l}\stackrel{0}{0} \\
\infty \\
0 \\
0\end{array}$ & $\begin{array}{l}\stackrel{0}{a} \\
\stackrel{0}{0}\end{array}$ & $\frac{0}{6}$ & $\begin{array}{l}0 \\
\stackrel{0}{0}\end{array}$ & $\begin{array}{l}\cong \\
\Xi \\
\Xi \\
-\end{array}$ & $\stackrel{\simeq}{\Xi}$ & 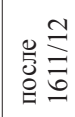 & 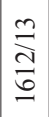 & 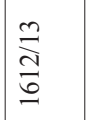 & 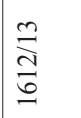 & $\frac{n}{\stackrel{n}{\sigma}}$ & 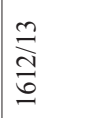 \\
\hline- & $\hat{m}$ & $\underset{m}{\infty}$ & શે & P & $\bar{\nabla}$ & F & $\mathscr{F}$ & 寸 & fo & fo & ซ & $\stackrel{\infty}{+}$ & g) & in \\
\hline
\end{tabular}




\begin{tabular}{|c|c|c|c|c|c|c|c|c|c|c|c|c|c|}
\hline 9 & $\begin{array}{l}0 \\
0 \\
0 \\
0 \\
i n\end{array}$ & is & $\begin{array}{l}\dot{0} \\
0 \\
0 \\
0 \\
i n\end{array}$ & $\begin{array}{l}\dot{0} \\
\dot{0} \\
\dot{n}\end{array}$ & $\begin{array}{l}8 \\
0 \\
\text { in } \\
\text { in }\end{array}$ & $\frac{0}{n}$ & $\mid \begin{array}{l}0 \\
0 \\
1 \\
i n\end{array}$ & $\begin{array}{l}\dot{8} \\
\stackrel{2}{a} \\
\text { in }\end{array}$ & $\begin{array}{l}0 \\
0 \\
0 \\
\text { in }\end{array}$ & $\begin{array}{l}\dot{8} \\
0 \\
0 \\
\text { ñ }\end{array}$ & 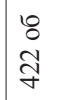 & $\mid \begin{array}{l}0 \\
0 \\
0 \\
n \\
n\end{array}$ & $\underset{\sim}{\stackrel{ \pm}{~}}$ \\
\hline$\simeq$ & î & ڤิ) & 1 & है & 1 & $\stackrel{\vec{S}}{\vec{S}}$ & 1 & ثీ & 1 & 1 & ثิ & 1 & ळิ \\
\hline$=$ & : & 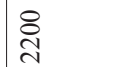 & 1 & ঐ্ণ & 1 & ঙ্ণి & 1 & \& & 1 & 1 & $\underset{\Xi}{\stackrel{0}{0}}$ & 1 & $\stackrel{8}{0}$ \\
\hline$\varrho$ & 0 & $=$ & 1 & 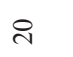 & 1 & $r$ & 1 & 6 & 1 & 1 & in & 1 & $\sim$ \\
\hline$a$ & 1 & 1 & 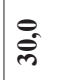 & $\stackrel{\theta}{\hat{q}}$ & $\underset{\text { of }}{\stackrel{0}{+}}$ & ڤิ & I & 1 & 1 & ळิ & Оิ & $\underset{\dot{f}}{\stackrel{8}{2}}$ & î \\
\hline$\infty$ & 1 & 1 & \&ু & $\stackrel{\infty}{\infty}$ & \& & in & 1 & 1 & 1 & $\underset{0}{8}$ & $\AA$ & $\begin{array}{l}\text { ô } \\
\text { ơ }\end{array}$ & in \\
\hline$r$ & I & 1 & 尺 & $\stackrel{\sim}{~}$ & 年 & in & 1 & 1 & 1 & ¿ & $\infty$ & 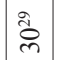 & 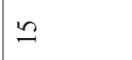 \\
\hline b & $\stackrel{\Theta}{\Theta}$ & 1 & : & 1 & $\stackrel{\theta}{\hat{\theta}}$ & 1 & ̊ิ & 1 & @ิ & 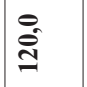 & ڤิ & 1 & $\stackrel{\ominus}{\stackrel{\theta}{\Xi}}$ \\
\hline in & $\begin{array}{l}8 \\
\text { g } \\
y\end{array}$ & 1 & 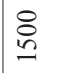 & 1 & 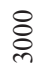 & 1 & $\underset{\infty}{\infty}$ & 1 & 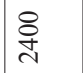 & \&్ర & ષ્ণ & 1 & \&్ల \\
\hline$\nabla$ & $\mathscr{f}$ & 1 & $\ddot{n}$ & 1 & in & 1 & $\nabla$ & 1 & ¿ & in & in & 1 & $m$ \\
\hline$m$ & 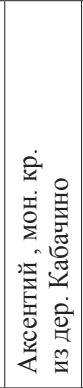 & 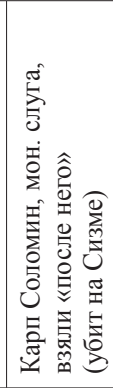 & 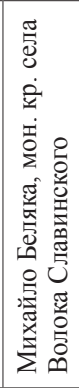 & 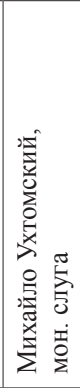 & 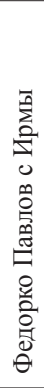 & 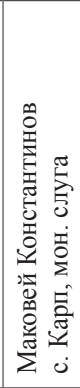 & 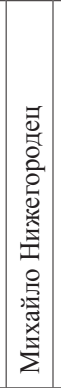 & 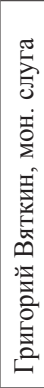 & 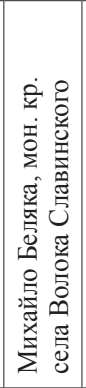 & 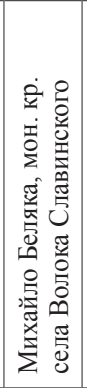 & 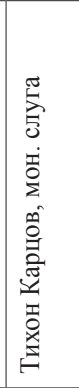 & 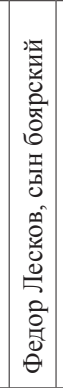 & 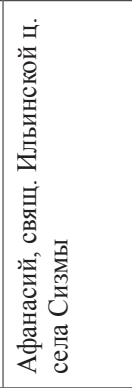 \\
\hline$N$ & 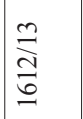 & $\frac{n}{\sigma}$ & $\underset{\frac{m}{\sigma}}{\frac{\Delta}{\sigma}}$ & $\frac{\Delta}{\frac{0}{\sigma}}$ & $\stackrel{t}{\underline{\sigma}}$ & $\frac{n}{\frac{1}{\sigma}}$ & $\begin{array}{c}\frac{n}{2} \\
\frac{\sigma}{\sigma} \\
-1\end{array}$ & $\frac{n}{\frac{2}{6}}$ & $\frac{i n}{\frac{i}{7}}$ & $\frac{0}{\frac{1}{2}}$ & $\frac{5}{6}$ & 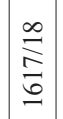 & 莺站 京 \\
\hline- & $\vec{n}$ & กี & $\tilde{n}$ & $\stackrel{*}{n}$ & in & in & in & in & in & 8 & $\bar{\sigma}$ & $\sigma$ & 3 \\
\hline
\end{tabular}


Соловецкие старцы, приказчики холмогорской службы, в годы великого голода на промыслы посылали рожь, оценивая ее по 92-300 ден., а с 1604 г. до начала 1612 г. - чаще всего по 40-50 ден. (рыночная цена ржи в Холмогоpax в 1604/05 г. составила 42 ден., в 1609/10 г. - 36 ден.) (налицо значительное снижение цены хлеба) ${ }^{30}$. Резкое повышение цен на хлеб в Холмогорах, а также по оценке соловецких приказчиков, началось с 1611/12 г. и, как пишет Е.Б. Французова, «было обусловлено опустошением сельскохозяйственных угодий, ставших театром военных действий в ходе гражданской войны, сокращением запашки, нарушением межрегиональных экономических связей» ${ }^{31}$.

Как видим, приведенные данные о движении «хлебных» цен по материалам вкладной книги Кирилло-Белозерского монастыря 1559/60-1620-х гг. дают основание сделать несколько выводов. Вкладные книги, наряду с монастырской хозяйственной документацией, могут быть использованы для изучения региональных рынков и движения цен на продукты и товары. Записи вкладных книг еще раз демонстрируют стабильность аграрного развития Русского Севера: постепенный выход из кризиса последней трети XVI в.; ликвидацию последствий великого голода к началу Смуты; нарушение экономического развития под воздействием внешнеполитических факторов.

\section{Литература}

Алексеев А.И. Первая редакция вкладной книги Кирилло-Белозерского монастыря (1560-е гг.) // Вестник церковной истории. 2010. № 3/4(19/20). С. 17-117.

Алексеев А.И. «Сих же память пребывает во веки»: (Мемориальный аспект в культуре русского православия)// Материалы научной конференции 29-30 ноября 1997 г. СПб., 1997. С. 69-80.

Башнин Н.В. Приходо-расходные книги Вологодского архиерейского дома XVII в. как источник по истории цен в России // Торговля, купечество и таможенное дело в России XVI-XIX вв.: Сборник материалов Четвертой международной научной конференции (Нижний Новгород, 28-30 сентября 2017 г.). Нижний Новгород, 2018. C. 144-147.

Башнин Н.В., Поляков И.А. Разработка базы данных о ценах в России XVII в. (по материалам приходо-расходных книг Вологодского архиерейского дома)// Русь, Россия: Средневековье и Новое время. М., 2017. Вып. 5: Пятые чтения памяти академика РАН Л.В. Милова. С. 278-293.

Дмитриева 3.В. Вкладная книга Кирилло-Белозерского монастыря (1559/15601620-е гг.) [Электронный ресурс]// История. Электронный научно-образовательный журнал. 2017. Т. 8. Вып. 5(59) (URL: https:/history.jes.su/s207987840001876-2-1 (дата обращения: 11.04.2021)).

\footnotetext{
30 Франиузова Е.Б. К вопросу о движении хлебных цен... С. 138, табл. 1; 140, табл. 2.

${ }^{31}$ Там же. С. 138, табл. 1, 142.
} 
Дмитриева 3.В. «Хлебный бюджет» Кирилло-Белозерского монастыря в начале XVII в.// Монастыри и архиерейские дворы в документах XVI-XVIII веков. СПб., 2015. С. 9-39 (Труды Санкт-Петербургского института истории РАН. Вып. 1(17)).

Дмитриева 3.B., Крайковский А.В. Цены на рыбу и рыбопродукты в начале XVII в. (по приходо-расходным книгам Кирилло-Белозерского монастыря) // Торговля, купечество и таможенное дело в России в XVI-XIX вв.: Сборник материалов Второй международной научной конференции. Курск, 2009. С. 50-59.

Каменцева Е.И., Устюгов Н.В. Русская метрология. 2-е изд. М., 1975.

Крайковский А.В. Цена на соль в России в 1630-1650 гг. // Источник. Историк. История: Сборник научных работ. СПб., 2001. Вып. 1. С. 73-99.

Кузьмин А.В., Стрельников С.В. Вкладные книги// Православная энциклопедия. М., 2004. T. 8. С. 613-617.

Лисейщев Д.В. Торговые люди Московской Руси в эпоху Смуты начала XVII в. // Торговля, купечество и таможенное дело в России XVI-XVII вв.: Сборник материалов Третьей международной научной конференции (г. Коломна, 24-26 сентября 2013 г.). Коломна, 2015. Т. 1. С. 28-35.

Маньков А.Г. Цены и их движение в Русском государстве XVI века. М., 1951.

Никольский Н.К. Кирилло-Белозерский монастырь и его устройство до второй четверти XVII века (1397-1625). СПб., 1910. Т. 1. Вып. 2: О средствах содержания монастыря.

Панеях В.M. Рец. на кн.: А.Г. Маньков. Цены и их движение в Русском государстве XVI века// Вопросы истории. 1952. № 12. С. 141-146.

Французова Е.Б. К вопросу о движении хлебных цен в России в первой четверти XVII в. (цены на зерно по оценкам приказчиков холмогорской службы Соловецкого монастыря)// Торговля, купечество и таможенное дело в России XVIXIX вв.: Сборник материалов Четвертой международной научной конференции (Нижний Новгород, 28-30 сентября 2017 г.). Нижний Новгород, 2018. С. 136-143. Шаблова Т.И. Кормовое поминание в Успенском Кирилло-Белозерском монастыре в XIV-XVII веках. СПб., 2012.

Hellie R. The economy and material culture of Russia, 1600-1725. Chicago; L., 1999. 


\title{
Г.А. Иванова
}

\section{ПОДЬЯЧИЕ, ВОЗГЛАВЛЯВШИЕ ПИСЦОВЫЕ КОМИССИИ XVII В.}

\begin{abstract}
Аннотация На протяжении XVII в. состав представителей служилой бюрократии, проводивших описания земель и переписи населения на общегосударственном уровне, не оставался неизменным. Первое валовое письмо отличается участием большого количества дьяков, а также подьячих, имеющих высокий чин (большой срок службы). К концу века ощутимо увеличивается количество сотрудников Поместного приказа, связанных с этими работами профессионально.

Ключевые слова: приказная бюрократия, дьяки, подьячие, приказы, приказные избы, Поместный приказ, писцовые работы, переписи, сошное письмо.

Summary The membership among the representatives of the service class bureaucracy, who carried on the description of the land allotments and general census of the population during the 17 th century, wasn't invariable. The first General Cadaster is notable for the participation in it of the significant number of high rank clerks and scriveners with considerable service experience. By the end of the century, we can observe the increase of the Landownership Department staff who, were connected with similar activity on professional basis exclusively.

Keywords: Government and minor officials, clerks, scriveners, departments, local state institutions, Landownership Department, cadasters, census, The General Land Description.
\end{abstract}

Среди разнообразных работ, требовавших присутствия большого количества подьячих вне Москвы (посольств, работы в полковых шатрах, розысков), на первом месте находится проведение писцовых (в том числе межевых и переписных) работ.

Как известно, писцовая комиссия состояла из группы подьячих, во главе которых находились дворянин (иногда достаточно высокого ранга) и представитель служилой бюрократии (подьячий или дьяк). Эти лица назначались царским указом и несли персональную ответственность за проводимую работу. 
Работа писцовых комиссий, особенно когда речь шла об описании земель, являлась достаточно сложной. Лица, проводившие ее, должны были уметь определять площадь земельного участка, знать сошное письмо, уметь пользоваться приправочными книгами и свести впоследствии черновые записи в писцовые или переписные книги - поэтому требования, предъявляемые к ним, были очень высокими. Попробуем определить, из кого же конкретно формировалось руководство писцовых комиссий на протяжении XVII в.

Для изучения были взяты только руководители общегосударственных работ - Первого валового письма (1628-1630 гг.), переписей 1640-х и 1670-х гг. и Второго валового письма (1685-1686 гг.), — поскольку лишь они достоверно указаны в наказах писцам (рядовые члены комиссии там, к сожалению, не упомянуты). Источниками для выявления этих лиц послужили справочники «Каталог писцовых книг Русского государства» ${ }^{1}$, «Сошное письмо» С.Б. Веселовского ${ }^{2}$ и неизданные материалы М.Ю. Зенченко, представляющие собой описание материалов Поместного приказа ${ }^{3}$. Всего удалось обнаружить 408 представителей служилой бюрократии, принимавших участие в этих общегосударственных мероприятиях, после чего по справочнику Н.Ф. Демидовой «Служилая бюрократия в России XVII века (1625-1700)» ${ }^{4}$ я попыталась установить их послужной список. Это получилось сделать для 295 человек, 114 подьячих остались неатрибутированными, так как далеко не по всем учреждениям и не за все годы сохранились их списки, на которых, собственно, и базируется справочник. Но можно с уверенностью сказать, что в число неатрибутированных не попали дьяки и подьячие Поместного приказа, так как данные и по тем, и по другим сохранились ${ }^{5}$.

Разумеется, 100\% подьячих, участвовавших в писцовых комиссиях, выявить не удалось. Тем не менее, учитывая довольно большое количество вы-

1 Писцовые книги Русского Севера / Отв. сост. Н.П. Воскобойникова. М., 2001; Писцовые книги Новгородской земли / Отв. сост. М.Ю. Зенченко. М., 2004; Писцовые книги Восточного Замосковья / Отв. сост. М.Ю. Зенченко. М., 2007; Писцовые книги Верхнего Заволжья / Отв. сост. М.Ю. Зенченко. М., 2010; Писцовые книги юго-западного порубежья / Отв. сост. М.Ю. Зенченко. М., 2013; Писцовые книги Рязанской и Нижегородской земли / Отв. сост. М.Ю. Зенченко, Г.А. Иванова. М., 2018.

2 Веселовский С.Б. Сошное письмо. М., 1917. Т. 2: Приложения.

3 РГАДА. Ф. 1209. ОП. 1.

4 Демидова Н.Ф. Служилая бюрократия в России XVII века (1625-1700): Биографический справочник. М., 2011. Вся информация, касающаяся службы подьячих взята оттуда. Поскольку данный справочник составлен по алфавиту фамилий, ссылки на страницы этого издания далее опускаются.

5 Информация по дьякам содержится в боярских книгах и боярских списках (РГАДА. Ф. 210. Оп. 1, 2 (Боярские списки)), списки подьячих Поместного приказа см.: Там же. Оп. 9 (Столбцы Московского стола). Стб. 881. Л. 584-617; Стб. 594. Л. 205-208; Ф. 1209. Оп. 4. Кн. 4885. Л. 122-136; Кн. 5094. Л. 50-71. 
явленных (408) и то, что 3/4 из них атрибутированы, можно предположить, что отмеченные нами тенденции можно экстраполировать на весь корпус лиц, принимавших участие в работах во главе писцовых комиссий.

Традиционно считается, что основу писцовых комиссий составляли подьячие Поместного приказа, а в некоторых случаях к ним подключались подьячие местных учреждений. Попытаемся определить, насколько это представление соответствует действительности и сохранялась ли ситуация одинаковой на протяжении XVII в.

Штаты Поместного приказа во время Первого валового письма и во время переписи 1640-х гг. составляли около 100 человек, т. е. никак не могли обеспечить все писцовые комиссии своими подьячими - это привело бы к остановке работы самого приказа. Во время Первого валового письма сотрудников приказа насчитывалось даже меньше, чем писцовых комиссий (минимум 121 комиссия при 101 подьячем Поместного приказа $\left.{ }^{6}\right)$. Становится очевидным, что писцов и переписчиков брали и из других учреждений.

Рассмотрим для начала общий состав глав писцовых комиссий по месту их постоянной службы.

Таблица 1.

Главы писцовых комиссий по месту их постоянной службы

\begin{tabular}{|l|c|c|c|c|c|}
\hline & $\begin{array}{c}\text { Первое } \\
\text { валовое } \\
\text { письмо }\end{array}$ & $\begin{array}{c}\text { Перепись } \\
\mathbf{1 6 4 5} \text { г. }\end{array}$ & $\begin{array}{c}\text { Перепись } \\
\mathbf{1 6 7 7 - 7 8} \text { гг. }\end{array}$ & $\begin{array}{c}\text { Второе } \\
\text { валовое } \\
\text { письмо }\end{array}$ & Всего \\
\hline Дьяки & 11 & - & 1 & - & 12 \\
\hline Поместный приказ & 31 & 19 & 25 & 67 & 142 \\
\hline Центральные приказы & 41 & 22 & 35 & 20 & 118 \\
\hline Местные учреждения & 4 & 3 & 12 & 3 & 22 \\
\hline Не атрибутированы & 34 & 26 & 24 & 30 & 114 \\
\hline Всего & 121 & 70 & 96 & 121 & 408 \\
\hline
\end{tabular}

Из таблицы видим, что среди глав писцовых комиссий во время Первого валового письма подьячие Поместного приказа составляли 25,6\% от общего числа; в переписях 1645-1646 и 1677-1678 гг. — по 26\% и только во время Второго валового письма картина радикально изменилась: во главе более чем половины комиссий (55\%) стояли сотрудники Поместного приказа.

Ко времени Второго валового письма штаты Поместного приказа увеличились до 458 человек. По численности служащих это самое крупное централь-

6 РГАДА. Ф. 210. Оп. 9. Стб. 881. Л. 584-617. 
ное учреждение государства. Всего во Втором валовом письме участвовали 202 подьячих Поместного приказа. Кроме 67 глав писцовых комиссий еще 135 человек участвовали в описании в качестве рядовых сотрудников. Среди них было довольно большое количество неверстанных и прослуживших всего 2-3 года ${ }^{7}$.

Кто же принимал участие в писцовых работах кроме подьячих Поместного приказа?

Из табл. 1 видно, что как минимум 30\% подьячих являлись служащими разнообразных центральных учреждений. Всего в разных работах принимали участие сотрудники 38 приказов, не считая Поместного. Чаще всего в данных мероприятиях были задействованы подьячие Разряда: в Первом валовом письме - Первой Богданов ${ }^{8}$ и Аким Ларионов ${ }^{9}$, в переписи 1645 г. - Осип Гневышев ${ }^{10}$, в переписи 1678 г. - Семен Исаков ${ }^{11}$, Роман Прокшин ${ }^{12}$, Иван Ралин ${ }^{13}$, Иван Саблин ${ }^{14}$, Василий Текутьев ${ }^{15}$; во Втором валовом письме - Семен Сычев ${ }^{16}$ и Логин Урусков ${ }^{17}$. Всего из Разряда во всех комиссиях участвовали 10 человек. Кстати, и максимальное количество подьячих от одного приказа одновременно участвующих в писцовых работах - 5 человек - также зафиксировано именно в Разряде, а также в Новой четверти ${ }^{18}$.

Кроме Разряда во всех работах участвовали подьячие еще трех приказов Московского судного (в Первом валовом письме и переписи 1645 г. - по $3^{19}$,

\footnotetext{
7 РГАДА. Ф. 1209. ОП. 4. Кн. 5094. Л. 50-71.

8 Описывал Мценск, Одоев, Чернь (Там же. Кн. 15935, 8980, 525).

9 Описывал Ярославль (Писцовые книги Верхнего Заволжья. С. 334).

${ }^{10}$ Переписывал Шацк и Касимов (Писцовые книги Рязанской и Нижегородской земли. C. $446-447,457-458)$.

${ }^{11}$ Переписывал Новосиль (РГАДА. Ф. 1209. Оп. 1. Кн. 8984).

12 Переписывал Болхов (Там же. Кн. 10046).

${ }^{13}$ Переписывал Ливны (Там же. Кн. 14258).

${ }^{14}$ Переписывал Вологодский уезд (Писцовые книги Русского Севера. С. 115-122).

${ }^{15}$ Переписывал Тулу (РГАДА. Ф. 1209. Оп. 1. Кн. 14239).

${ }^{16}$ Описывал Великие Луки (Там же. Кн. 279. Л. 192-218).

${ }^{17}$ Описывал Луховский уезд (Там же. Кн. 1153).

${ }^{18}$ Во время Первого валового письма - Иван Павлов в Зубцове (Веселовский С.Б. Указ. соч. С. 596), Андрей Иевлев на Вятке (Писцовые книги Русского Севера. С. 171-172), Леонтий (Лев) Лазарев во Владимире (Писцовые книги Восточного Замосковья. С. 23-24), Федор Протопопов в Торопце (Веселовский С.Б. Указ. соч. С. 634) и Макар Чукарин (Писцовые книги Русского Севера. С. 337).

${ }^{19}$ Анисим Ильин (РГАДА. Ф. 1209. Оп. 1. Кн. 686), Григорий Никифоров (Там же. Кн. 408. Л. 560-637), Богдан Фадеев (Веселовский С.Б. Указ. соч. С. 633). Данила Калинин (Писцовые книги Восточного Замосковья. С. 393, 395.), Никита Семенов (Там же. С. 188, 203, 317, 320), Семен Парфеньев (Писцовые книги юго-западного порубежья. С. 122-123, 143, 208-209).
} 
в переписи 1677-1678 гг. и Втором валовом письме - по $1^{20}$ ), Разбойного (соответственно $-2^{21}, 1^{22}, 2^{23}, 1^{24}$ ) и Ямского (соответственно $-4^{25}, 1^{26}$, $\left.3^{27}, 1^{28}\right)$. Сотрудники остальных приказов были задействованы в двух-трех работах. Количество участвующих в каждой работе обычно составляло один-два, реже три подьячих.

Единожды принимали участие в работе писцовых комиссий служащие следующих приказов. В Первом валовом письме - Костромской четверти $^{29}$, Приказа Сыскных дел Ю.Я. Сулешева ${ }^{30}$, Приказа Сыскных дел А.В. Измайлова ${ }^{31}$. В переписи 1645-1646 гг. - Сибирского ${ }^{32}$. В переписи 1677-1678 гг. - Каменных дел ${ }^{33}$, Монастырского ${ }^{34}$, Новгородской четверти $^{35}$, Померной избы ${ }^{36}$, Сытного двора ${ }^{37}$, Хлебного приказа ${ }^{38}$. Во Втором валовом письме - Приказа Сбора стрелецкого хлеба ${ }^{39}$, Казенного ${ }^{40}$, Княжества Смоленского ${ }^{41}$, Малороссийского ${ }^{42}$, Печатного ${ }^{43}$.

Даже по уже упомянутым приказам видно, насколько разнообразные учреждения принимали участие в писцовых работах — от территориальных

\footnotetext{
${ }^{20}$ Максим Устинов (Веселовский С.Б. Указ. соч. С. 602). Иван Булгаков (РГАДА. Ф. 1209. Оп. 1. Кн. 378).

${ }^{21}$ Федор Витовтов (Писцовые книги Восточного Замосковья. С. 173), Григорий Гаврилов (Веселовский С.Б. Указ. соч. С. 621).

${ }^{22}$ Андрей Фрязинов (РГАДА. Ф. 1209. Оп. 1. Кн. 10980).

${ }^{23}$ Михаил Шаров (Писцовые книги юго-западного порубежья. С. $\left.321,322.\right)$ и Семен Самойлов (РГАДА. Ф. 1209. Оп. 1. Кн. 7044).

${ }^{24}$ Василий Бокарев (Писцовые книги Восточного Замосковья. С. 393, 398-400).

${ }^{25}$ Иван Гаврилов (Писцовые книги юго-западного порубежья. С. 63, 119-121), Петр Максимов (Там же. С. 371-373.), Иван Кокушкин (Писцовые книги Русского Севера. С. 162, 193.), Наум Петров (РГАДА. Ф. 1209. Оп. 1. Кн. 256. Л. 17-20, Кн. 265. Л. 50-60).

${ }^{26}$ Алексей Юрьев (Писцовые книги Рязанской и Нижегородской земли. С. 64-67, 70).

${ }^{27}$ Никита Воробьев (Веселовский С.Б. Указ. соч. С. 596, 601, 629), Аввакум Григорьев (Там же. С. 587), Федор Прокофьев (Ф. 1209. Оп. 1. Кн. 339, 340, 520).

${ }^{28}$ Корнило Смирной (РГАДА. Ф. 1209. Оп. 1. Кн. 279. Л. 525-528).

${ }^{29}$ Никита Власьев (Там же. Кн. 265. Л. 329-379).

${ }^{30}$ Роман Прокофьев (Писцовые книги Восточного Замосковья. С. 208, 210-215, 224).

${ }^{31}$ Никон Федоров (Писцовые книги Верхнего Заволжья. С. 338-343).

${ }^{32}$ Александр Титов (Веселовский С.Б. Указ. соч. С. 634).

${ }^{33}$ Кузьма Конюхов (Писцовые книги Восточного Замосковья. С. 188, 203, 205, 321-322, 396-397).

${ }^{34}$ Семен Напалков (Писцовые книги Рязанской и Нижегородской земли. С. 451, 467-468).

35 Петр Ахматов (Писцовые книги Восточного Замосковья. С. 402-404).

${ }^{36}$ Аника Прасолов (Писцовые книги Рязанской и Нижегородской земли. С. 67-68).

${ }^{37}$ Борис Башмаков (Там же. С. 72-74).

${ }_{38}^{38}$ Василий Крюков (Писцовые книги Русского Севера. С. 299, 313-318).

${ }^{39}$ Шарапов Иван (РГАДА. Ф. 1209. Оп. 1. Кн. 279. Л. 211-222).

${ }^{40}$ Василий Лобанов (Там же. Кн. 954. Л. 1-189).

${ }^{41}$ Федор Каргопольцев (Там же. Кн. 5074. Л. 177-188).

42 Семен Щеголев (Писцовые книги Новгородской земли. С. 189, 386, 394, 482-483).

${ }^{43}$ Федор Кондратов (РГАДА. Ф. 1209. Оп. 1. Кн. 281. Л. 123-133).
} 
до финансовых, розыскных, судебных и узкоспециальных (типа Конюшенного или Ямского).

Особенно интересно выглядит в этом контексте участие подьячих региональных приказов.

Таблица 2.

Участие в переписях подьячих региональных приказов

\begin{tabular}{|l|c|c|c|c|}
\hline \multicolumn{1}{|c|}{$\begin{array}{c}\text { Региональные } \\
\text { приказы }\end{array}$} & $\begin{array}{c}\text { Первое валовое } \\
\text { письмо }\end{array}$ & $\begin{array}{c}\text { Перепись } \\
\mathbf{1 6 4 5} \text { г. }\end{array}$ & $\begin{array}{c}\text { Перепись } \\
\mathbf{1 6 7 7 - 7 8} \text { гг. }\end{array}$ & $\begin{array}{c}\text { Второе валовое } \\
\text { письмо }\end{array}$ \\
\hline Галицкая четверть & $1^{*}$ & 1 & 1 & - \\
\hline Казанский дворец & 2 & 2 & $1+2$ & - \\
\hline Костромская четверть & 1 & - & - & - \\
\hline $\begin{array}{l}\text { Малороссийский } \\
\text { приказ }\end{array}$ & - & - & - & - \\
\hline Новгородская четверть & - & - & 2 & - \\
\hline $\begin{array}{l}\text { Приказ княжества } \\
\text { Смоленского }\end{array}$ & - & - & - & 1 \\
\hline Сибирский приказ & - & 1 & - & $4(1+3)$ \\
\hline Устюжская четверть & $1+2$ & 2 & - & \\
\hline Всего & $7(2+5)$ & $6(2+4)$ & $6(3+3)$ & -1 \\
\hline
\end{tabular}

* Курсивом указаны подьячие, описывавшие территории, подведомственные соответствующему приказу.

Как мы видим, только 8 подьячих из 23 работали в «своих уездах». Остальные выезжали на территории, никак не связанные с деятельностью их приказов: подьячие Казанского дворца описывали Устьянские волости, Бежецкий Верх, Вязьму и Лебедянь; Устюжской четверти - Тулу и Дедилов; Малороссийского приказа - Шелонскую пятину; Костромской четверти - Старицу и Торжок и т. д. Причем, когда подьячий Костромской четверти описывал ямские слободы в Старице, Торжке и Ржеве Владимировой $^{44}$, в самой Костроме работала комиссия, возглавляемая подьячим из Устюжской четверти ${ }^{45}$. Можно сказать, что учреждения, организовывавшие писцовые работы, практически не соотносили специализацию подьячих, работавших с определенной территорией и их назначения. Либо же можно предположить, что эта специализация была столь невелика, что ее при назначениях просто не принимали в расчет.

${ }^{44}$ РГАДА. Ф. 1209. ОП. 1. Кн. 265. Л. 329-379.

${ }^{45}$ Там же. Кн. 1113; Кн. 265. Л. 273-303 об. 
Рассмотрим участие в писцовых работах сотрудников местных учреждений. По данным табл. 1 можно сделать вывод, что оно было незначительным - 22 человека на протяжении всего XVII в. На самом деле, именно в эту категорию, скорее всего, попадали те 114 подьячих, биографии которых не удалось найти в справочнике Н.Ф. Демидовой, так как именно приказные избы имеют весьма существенные лакуны в списках своих сотрудников.

Те же подьячие приказных изб, которых нам удалось атрибутировать, работали в своем уезде или в непосредственной близости от него. Последних случаев было очень мало. Например, подьячий Тульской приказной избы Трофим Анцифоров описывал Землянск в 1686 г. ${ }^{46}$, Сильвестр Булгаков из Кромской приказной избы в 1691 г. доописывал Ливны ${ }^{47}$. В обоих случаях города, в которых они служили, расположены достаточно близко от тех уездов, где они работали. Известен единственный случай, когда подьячего приказной избы использовали для описания совершенно другого региона - проведение переписи крестьян дворцовых земель в Вяземском уезде подьячим Ярославской приказной избы Яковом Незамаевым в 16751678 гг. ${ }^{48}$ Но следует отметить, что после этой работы Незамаев перешел служить в Приказ Большого дворца ${ }^{49}$, поэтому вполне возможно, что проведение переписи именно на дворцовых землях связано с его последующим назначением и является явным исключением из правил.

Таким образом, можно сделать вывод, что в писцовых комиссиях принимали участие как подьячие местных учреждений, так и центральных, с решающей долей служащих Поместного приказа. Причем эта доля резко возросла в 80-х гг. XVII в. - до этого времени сотрудники Поместного приказа составляли чуть больше четверти руководителей писцовых комиссий, хотя и это значительно превышало долю остальных учреждений.

Попробуем приблизительно оценить профессиональный уровень подьячих, руководивших писцовыми комиссиями. Можно ориентироваться либо на их чин (дьяк, подьячий с приписью, старый подьячий и т. п.), либо на их стаж. К сожалению, даже эти данные далеко не всегда можно получить из списков подьячих. В некоторых случаях приходиться ориентироваться на размер оклада, который служит примерным эквивалентом времени службы, учитывая, разумеется, то, что в разных приказах величина оклада имела свои градации.

\footnotetext{
${ }^{46}$ Писцовые книги юго-западного порубежья. С. 431.

${ }^{47}$ Там же. С. 498-500.

${ }^{48}$ Веселовский С.Б. Указ. соч. С. 587.

${ }^{49}$ Демидова Н.Ф. Указ. соч.
} 
Таблица 3.

Профессиональный уровень подьячих, руководивших писцовыми комиссиями

\begin{tabular}{|l|c|c|c|c|}
\hline & $\begin{array}{c}\text { Первое валовое } \\
\text { письмо }\end{array}$ & $\begin{array}{c}\text { Перепись } \\
\mathbf{1 6 4 5} \text { г. }\end{array}$ & $\begin{array}{c}\text { Перепись } \\
\mathbf{1 6 7 7} \text { г. }\end{array}$ & $\begin{array}{c}\text { Второе валовое } \\
\text { письмо }\end{array}$ \\
\hline Дьяки & 11 & - & 1 & - \\
\hline $\begin{array}{l}\text { Получившие дьячество } \\
\text { сразу после участия } \\
\text { в комиссии }\end{array}$ & 7 & - & - & - \\
\hline Подьячие с приписью & - & - & - & 1 \\
\hline Подьячие со справой & - & - & 1 & 66 \\
\hline $\begin{array}{l}\text { Срок службы 10 лет } \\
\text { и больше }\end{array}$ & {$[52]$} & 33 & 39 & 10 \\
\hline Срок службы 5-9 лет & - & {$[7]$} & 21 & 9 \\
\hline $\begin{array}{l}\text { Срок службы менее } \\
\text { 5 лет }\end{array}$ & - & 4 & 4 & 22 \\
\hline Не определены & 47 & 29 & 30 & 6 \\
\hline Всего & 21 & 3 & 6 & \\
\hline
\end{tabular}

Во время Первого валового письма дьяки составляли $10 \%$ от общего числа, а если посчитать получивших дьячество сразу после проведения описания, то и вовсе 15\%. В описании участвовали 4 подьячих с приписью, а остальные руководители писцовых комиссий, судя по их окладам (от 15 рублей и выше ${ }^{50}$ ) явно служили уже более 10 лет.

Во время обеих переписей и Второго валового письма чиновный ранг участников резко понизился - в переписях практически не участвовали дьяки (единственный дьяк - Андрей Покрышкин - вынужденно заканчивал перепись на Устюге после умершего А. Ерофеева ${ }^{51}$ ). Известно лишь об одном подьячем с приписью, зато появились подьячие, срок службы которых составлял менее 5 лет (это или прямо указано, или соответствует таковому сроку, судя по их окладу).

Вероятно, это можно объяснить несколькими причинами. Первое валовое письмо было для правительства более важным мероприятием, чем последующие работы (необходимо было привести в порядок налоговую базу после Смуты). Переписи требовали меньших знаний, чем описания, а во Втором валовом письме занято гораздо больше подьячих Поместного

${ }^{50}$ Годовой оклад у начинающего подьячего мог составлять 1 руб. и даже 50 коп. Причем, чтобы дослужиться даже до такого оклада, приходилось несколько лет сидеть не верстанными.

${ }^{51}$ Писцовые книги Русского Севера. С. 345. 
приказа (т. е. специалистов). Качество приправочных книг на протяжении XVII в. совершенствовалось, в связи с этим лицам, проводившим переписи и Второе валовое письмо, было проще работать.

B целом мы видим, что на протяжении XVII в. состав представителей служилой бюрократии, работавших во главе писцовых комиссий, не оставался неизменным. На первое место к концу века вышла специализация: работы гораздо чаще стали осуществлять профессионалы из штата Поместного приказа, которых к концу XVII в. было подготовлено достаточно, и пропала нужда привлекать кадры, зачастую в высоком чине, но с меньшими знаниями и опытом работы по «сошному письму».

\section{Литература}

Веселовский С.Б. Сошное письмо. М., 1917. Т. 2: Приложения.

Демидова Н.Ф. Служилая бюрократия в России XVII века (1625-1700): Биографический справочник. М., 2011.

Демидова Н.Ф. Служилая бюрократия в России XVII века и ее роль в формировании абсолютизма. М., 1987.

Писцовые книги Русского Севера / Отв. сост. Н.П. Воскобойникова. М., 2001. Писцовые книги Новгородской земли / Отв. сост. М.Ю. Зенченко. М., 2004.

Писцовые книги Восточного Замосковья / Отв. сост. М.Ю. Зенченко. М., 2007. Писцовые книги Верхнего Заволжья / Отв. сост. М.Ю. Зенченко. М., 2010.

Писцовые книги юго-западного порубежья / Отв. сост. М.Ю. Зенченко. М., 2013.

Писцовые книги Рязанской и Нижегородской земли/Отв. сост. М.Ю. Зенченко, Г.А. Иванова. М., 2018. 


\section{А.В. Ковальчук}

\section{КОМИССИЯ О КОММЕРЦИИ И ДИСКУССИЯ О КРЕСТЬЯНСКОЙ ТОРГОВЛЕ I765 Г.}

Аннотация Статья посвящена обмену мнениями по вопросу о крестьянской торговле. Он состоялся в 1765 г. в недавно созданной Комиссии о коммерции. Обсуждение, которое протекало в узком кругу немногочисленных членов Комиссии, инициировала Екатерина II. Все члены комиссии приняли в нем живое участие. Характер довольно горячо проходившей дискуссии и выдвинутые ее участниками аргументы указывают на неподдельный интерес современников из достаточно близких к императрице лиц к обсуждаемой тематике. Несмотря на то что участникам прений так и не удалось сблизить позиции относительно допустимости участия крестьян в торговле, особенно владельческих, или фактической легализации осуществляемых ими торговых операций, представленная аргументация имеет несомненный интерес для понимания глобального процесса вызревания в крестьянской толще предпосылок к предпринимательству во всех нюансах.

Ключевые слова: Екатерина II, земледелие, физиократы, крестьянство, мещанство, сословия, помещики, торговля, конкуренция, гильдейская реформа, капитал.

Summary The article is devoted to the exchange of views on the issue of peasant trade. It was held in 1765 in the newly created Commission on Commerce. The discussion, which took place in a narrow circle of the few members of the Commission, was initiated by Catherine II. All the members of the commission took a lively part in it. The nature of the rather heated discussion and the arguments put forward by its participants indicate the genuine interest of contemporaries from people close enough to the empress in the topic under discussion. Despite the fact that the participants of the debate did not manage to bring their positions closer together regarding the permissibility of the participation of peasants in trade, especially ownerowned ones, or the actual legalization of trade operations carried out by them, the presented argument is of undoubted interest for understanding 
the global process of maturing the prerequisites for entrepreneurship in all nuances in the peasant thicket.

Keywords: Catherine II, agriculture, physiocrats, peasantry, philistinism, estates, landowners, trade, competition, guild reform, capital.

Говорить об исключительной роли крестьянства в дореформенной России, стране преимущественно аграрной на протяжении большей части своей истории, нет особой необходимости. От внутреннего состояния сословия во многом зависело благополучие всего общества. Ибо крестьяне - главные производители или «делатели», как признавали представители бюрократической элиты второй половины XVIII в., принадлежавшие к другому социальному лагерю (им еще будет «предоставлено слово» ниже). Они же основные плательщики податей. Наконец, воины-ратники, поскольку регулярные рекрутские наборы для армии периодически производились в основном из крестьянской среды.

Нелишне напомнить и об одном из постулатов большинства распространенных и наиболее популярных во времена правления Екатерины II экономических теорий физиократов, разделяемых императрицей: «Земледелие есть первый и главный труд, к которому людей поощрять должно» ${ }^{1}$. Эти слова принадлежали самой императрице и включены ею в ХІІІ главу общего Наказа Уложенной комиссии².

Екатерина II последовательно отстаивала принадлежность каждому сословию определенных и строго разграниченных прав и обязанностей. Крестьянство не являлось исключением. Впоследствии указанная позиция наиболее полно и последовательно закрепилась в принципах, положенных в основу гильдейской реформы 1775-1785 гг. Но прежде, чем утвердиться в законоположениях, им надлежало пройти многократные обсуждения в узком кругу ближайших советников императрицы. Образование в 1763 г. Комиссии о коммерции в составе небольшой группы лиц существенно не изменило ситуацию и не расширило рамки обсуждения отдельных вопросов до более широких масштабов. На момент создания Комиссия состояла из бывшего генерал-прокурора Сената Я. П. Шаховского, И. И. Неплюева (выбыл из нее в 1764 г., а на его место назначен Н. Е. Муравьев), Э. Миниха и статс-секретаря Екатерины II Г. Н. Теплова. В помощь к ним определены Т. Клингштет (в том же 1764 г. включен в основной состав), М. Пушкин и М. Одар.

1 ПСЗ-І. Т. 18. № 12949 (п. 295-296).

2 См.: Ковальчук А. В. Экономическая политика правительства Екатерины II во второй половине XVIII в.: Идеи и практика. М.; СПб., 2017. С. 228-232. 
Немалый перечень стоявших перед Комиссией о коммерции задач сразу по нескольким направлениям, поначалу контурно и бегло очерченных самой Екатериной II, включал совершенствование внутренней и внешней торговли, улучшение транспортной инфраструктуры внутри страны путем ремонта и строительства новых мостов, улучшения не только больших, но и местных путей сообщения, строительство собственного внешнеторгового флота для ослабления зависимости от иностранных купеческих компаний, облегчение кредитования российских купцов посредством образования коммерческих банков, пересмотр «тягостного» купечеству таможенного тарифа, унификацию находившихся в обращении медных монет, увеличение отдачи от беломорских рыбных промыслов и др. Но в этом перечне отсутствовал вопрос о крестьянской торговле.

На первый взгляд, вопрос малозначительный. Но в глазах современников крестьянский торг зачастую вырастал до масштабов одной из самых острых и ключевых экономических проблем страны, от решения которой во многом зависело ее дальнейшее развитие. Кроме того, некоторые из лиц, прямо или косвенно причастных к выработке правительственного курса, обратили внимание на противоречие между декларированными в начале 1760-х гг. либеральными ценностями, в первую очередь заявлениями верховной власти о приверженности принципам экономической свободы, и стремлением определенной части властной бюрократии начать новое наступление на торговых крестьян с целью искоренения их промысла. И потому состоявшееся в правительственных верхах живейшее обсуждение этого вопроса заслуживает самого пристального внимания. Инициатива его тщательной проработки принадлежала императрице. Поводом к началу разбирательств послужила челобитная не названных в документах купцов, поданная на высочайшее имя в мае 1765 г. Она отложилась в фонде Комиссии о коммерции в виде отдельного дела 3 .

О содержании прошения «анонимных» купцов не трудно догадаться даже несмотря на отсутствие самого текста. Судить о нем можно на основании других, косвенных источников. И сделать вывод о поданной жалобе купцов на крестьян за массовое участие в торговых операциях, не подобающее их реальному общественному статусу, нарушавшее сложившийся порядок и общественное разделение труда. Именно такой основной мотив звучал в протоколе состоявшихся 4 июня слушаний по этому делу. Их проводила Комиссия о коммерции, которой Екатерина II поручила вести необходимые разбирательства. С самого начала слушаний большинство членов Комиссии определило свое довольно негативное отношение к торговым промыслам крестьян. Вырази-

3 РГАДА. Ф. 10. Оп. 3. Д. 68. Л. 272. 
тели мнения этого большинства подкрепили его рядом дополнительных аргументов. Во-первых, крестьяне, прежде всего владельческие, вступали в заведомо недобросовестную конкуренцию с купцами, будучи свободными от всех обязанностей («тягостей») последних и к тому же пользовались защитой («протекцией») своих помещиков. Во-вторых, они оставляли самые значимые для государства земледельческие работы - «фундамент общего богатства» - ради более легких и совершенно «ненужных», с точки зрения общественной пользы, занятий, которые еще и способствовали «повреждению порядка в торговых промыслах»; вдобавок, занимаясь мелочной торговлей в городах, крестьяне отнимали пропитание у бедных солдатских и мещанских жен. В-третьих, разрушали привычный деревенский уклад, надолго оставляя жен и детей без «призрения». К тому же пополняя число городских жителей, особенно в Петербурге и Москве, они способствовали заметному удорожанию съестных припасов, в том числе и посредством увеличения рядов разного рода перекупщиков продовольствия. Участники слушаний, высказываясь по этому поводу, представили выразительную и пеструю картину многоликой крестьянской торговой «экспансии». Она осуществлялась «не только под именем купцов» и силами бесчисленных лавочных сидельцев, умножавших «излишнее число лавок в рядах, но также и на рынках, и по улицам в лавочках, в прилавках, в погребах, в шалашах и на ларях». Кроме них действовали целые сообщества перекупщиков, скупавших как российские товары и «харчевыя припасы», так и «привозимую из-за границ водою к питомству градских жителей потребную провизию». Обе группы товаров попадали «в руки другим перекупщикам и еще же из прибыли разнощикам продавать по улицам, кои все сыскивают способы питать роскошных и излишне лакомых» ${ }^{4}$.

В итоге общий вывод сводился к безоговорочному запрещению торговли в любых ее формах не только применительно к крестьянам, но и разночинцам. Также не допускалось их использование в качестве купеческих приказчиков или лавочных сидельцев. Однако, чтобы полностью не перекрывать тем и другим доступ к торговым операциям, предполагалось сохранить за ними право записываться в купечество при наличии «достаточного» капитала на основании действующего, хотя и не слишком четкого на тот момент, законодательства. Таким образом фактически выражалась идея, законодательно воплотившаяся значительно позднее, во время гильдейской реформы 1775 г. Тем самым, что весьма примечательно и заслуживает отдельного внимания, данная идея наверняка родилась не спонтанно и, вероятно, принадлежала

\footnotetext{
4 Там же. Л. 274 об.-275.
} 
не одной конкретной личности. Она вынашивалась постепенно и выносилась на обсуждение неоднократно, как и в данном конкретном случае.

Любопытен последний, четвертый пункт, протокола. Несколько в завуалированной форме в нем зафиксировано наличие проблемы крестьянского малоземелья и ее дальнейшего обострения, поскольку материалы ревизского учета последних лет зафиксировали рост численности крестьянского населения. Членам комиссии, вынужденным считаться с данным фактом, волей-неволей пришлось поставить вопрос о последующей занятости малоземельных поселян. По существу же им ничего не оставалось, как примириться с фактом широкого распространения неземледельческих крестьянских отхожих промыслов как с существующей реальностью, не имеющей альтернативы. Хотя сами промыслы признавались менее полезными для общества по сравнению с земледельческими работами. К числу вполне приемлемых и допустимых отнесены наемные работы на фабриках, предназначенные для промышленной переработки природных сырьевых ресурсов («произращений») в конечный готовый товар. Сюда же отнесены работы на «рудокопных и минеральных заводах», занятия извозом, включая транспортировку продукции фабрик и заводов, а также «при каменных, деревянных и при многих других мелочных у партикулярных людей, а наипаче в казенных разных же работах». Казенные работы, принимавшие при Екатерине II все больший размах, выделены особо. Они явно рассматривались в качестве основного канала перераспределения «избыточных» трудовых ресурсов из-за возникшей проблемы безземельного крестьянства. Вместе с тем Комиссия не хотела брать на себя ответственность за выявление «пристойных» способов «к снабжению таких в Российской империи недостаточных землями и угодьями крестьянских селений» ${ }^{5}$ и потому она обратилась к императрице с просьбой переложить на Сенат столь непростую миссию.

Требование о запрещении крестьянской торговли казалось большинству членов Комиссии о коммерции очевидным и бесспорным. Возможно, еще и по причине крайне невысокого общественно-юридического статуса крестьян, особенно владельческих, фактически лишавшего их права выступать в качестве самостоятельных хозяйственных субъектов. Правда, открыто никто на этот счет не высказывался. Но данное обстоятельство подразумевалось как само собой разумеющееся и сквозило в тех рассуждениях, в которых право на торговлю оставлялось только за купечеством.

Некоторые члены Комиссии заранее подготовили свои соображения насчет вреда крестьянской торговли. Они собирались приобщить их к итогово-

5 РГАДА. Ф. 10. Оп. 3. Д. 68. Л. 276-276 об. 
му протоколу, пребывая в уверенности о наличии общего согласия по этому вопросу среди всех членов Комиссии. Об этом, в частности, прямодушно написал Я. Шаховской спустя несколько дней после состоявшегося 4 июня 1765 г. собрания. Когда же выяснилась явная преждевременность подобного умозаключения, Шаховской заявил о присоединении своего «голоса» к схожим мнениям генерал-поручика и сенатора Николая Муравьева и статского советника Тимофея Клингштета.

Решительным противником этой группы оказался статс-секретарь императрицы Григорий Теплов. В протоколе его должность не указана, а лишь отмечен чин действительного статского советника. Кроме того, против заголовка его «Мнения о крестьянском торге» в левом верхнем углу листа присутствует помета «секретно». На каком основании суждениям Г. Теплова придана завеса секретности, до конца не ясно даже после ознакомления с содержанием его пространной записки.

После краткого, но емкого изложения существа аргументов своих оппонентов, Теплов приступил к их опровержению. Начал немного издалека, стараясь сначала показать неубедительность приводимой ими ссылки на некие иностранные «благоучрежденные государства», в которых крестьяне якобы оттеснены от неподобающей их статусу торговли. Торговля - удел исключительно купечества, самим же крестьянам пристало оставаться при одном земледелии. Подобное утверждение Теплов счел неверным. В таких государствах крестьяне наравне с купцами имеют возможность приобщаться к искусству коммерции, а переняв его, в равной мере вливаться в ряды «особливого благовоспитанного рода людей», к которому все члены общества относятся с почтением и доверием. Поэтому и следует в первую очередь перенимать иностранный опыт по формированию такого слоя людей. И не имеет значения, кем и в какой мере он будет представлен - купцами или же торгующими крестьянами.

Такое вступление понадобилось Теплову для перехода к характеристике российской специфики. Она в его представлении настолько отличалась от реалий других европейских стран, что ссылки на их опыт, касавшийся существования жестких границ между правами крестьянства и купечества на торговлю, казались ему совершено необоснованными и некорректными. В первую очередь из-за свойств и облика самих российских купцов. И здесь Теплов не останавливается перед жесткими определениями, отпуская немало нелестных выражений в их адрес. По его словам, под именем российских купцов, действительно «упражняющихся» в коммерции, скрывается много людей, давно не соответствующих своему званию и утративших всякую связь с торговлей. Согласно имеющимся у него сведениям, сокращалась даже номинальная 
численность купцов: «их пятью тысячами в одной Москве меньше же прежнего в государстве оказалося; то же самое и в других городах находится» ${ }^{6}$.

Для получения полного представления Теплов предлагал произвести перепись купечества, чтобы выяснить, «сколько именно купцов достойных и средних, и сколько в работах подлейших, в бурлачестве, пьянстве и крайнем невежестве пребывающих найдется». Он не сомневался в крайней малочисленности того «корпус[а] российского купечества, достойного сего имени», который, по его мнению, в действительности «самой малой в государстве» ${ }^{7}$ по причине отсутствия в нем «благовоспитанных» купцов. Таковых имелась лишь «самая малая доля». Остальные же - «хуже самого крестьянства, а яко не пахатные и никакому помещику не подобострастные, упражняются только в бурлачестве, пьянстве, вероломстве и никакого торгу не имеют, а промышляют в отдаленных городах всякими службами или и копанием земли, а иногда попадаются и на разбоях». Не говоря уже о взаимном недоверии и вражде даже между вполне состоятельными купцами, которые «по худому своему воспитанию целыми городами в нестроении между собою живут и друг друга разоряют так, как то и ныне всемилостивейшая наша государыня по человеколюбию своему милосердием, а не строгостию целой город Орел от последнего падения охранить соизволила» ${ }^{8}$.

В целом довольно неприглядную картину усугубляло поведение российских купцов за границей. Они по незнанию и неумению привозили туда товары без должной «спекуляции», действуя при этом разрозненно и подрывая общий «кредит». Последнее утверждение Теплов высказывал не голословно, а ссылался на реляцию российского резидента в Константинополе А.М. Обрескова от 26 февраля 1765 г. на имя императрицы (документ оказался приобщенным к делу о «крестьянском торге»). В донесении Обресков отозвался о «надмерном невежестве и неразуменении подданных ваших», осуществлявших причерноморскую торговлю, но не оставил без внимания и непростые условия, в каких им приходилось осуществлять торговлю, в том числе и трудности с получением займов. В частности, российские купцы не располагали возможностями для получения кредитов на приемлемых условиях, сопоставимых с банковскими ставками внутри страны: они не могли найти заимодавцев, соглашавшихся предоставить займы менее $15 \%$ даже под залог привезенных товаров ${ }^{9}$.

Из данной Г. Тепловым характеристики российскому купечеству логично вытекал вывод о невозможности выполнения им своей основной миссии

\footnotetext{
6 РГАДА. Ф. 10. Оп. 3. Д. 68. Л. 280.

7 Там же. Л. 280 об.

8 Там же. Л. 282-282 об.

9 Там же. Л. 293 об.
} 
без участия крестьянства. Более того, упоминаемые объективные данные об увеличении почти втрое торговых оборотов за прошедший после Петра I период Теплов объяснял прежде всего участием в торговле крестьян. Он утверждал, «что сами купцы, будучи недостаточны капиталами, не могли никогда пробыть без помочи крестьянскаго торгу и всегда в торговом соединении во внутренних городах с богатыми крестьянами сообщалися» ${ }^{10}$. К тому же предпринимавшиеся правительством в прошлом неоднократные попытки прикрыть крестьянскую торговлю результата не имели. Так, Соборное уложение 1649 г. (гл. 19 «О посадских людях», п. 5, 9, 15, 16, 17) предусматривало полный запрет крестьянского торга и уничтожение не только крестьянских лавок, но и самого «торгового промысла». Теплов приводил ссылки и на законодательство первой половины XVIII в. (причем далеко не точные, а иногда и на несуществующие указы; во всяком случае, упоминаемые им указы Петра I за 1723 г. и не датированный указ Анны Иоанновны найти в Полном собрании законов не удалось).

Поэтому общий вывод Теплова о непрекращавшихся со стороны правительства попытках притеснения, а тем более искоренения крестьянской торговли нуждается в некоторых пояснениях. Да, действительно, с формально-правовой точки зрения норма 19-й главы Соборного уложения являлась действующей, сохраняющей юридическую силу и в XVIII в. В случае необходимости она легко могла быть использована против крестьян, что иногда и происходило на практике. Но все дело в том, что острие этой нормы, как и последующих петровских указов, было направлено в большинстве случаев не против участия самих крестьян в торговле, а на уточнение фактического рода их занятий с целью определения размеров налогообложения, соответствующего реальному статусу. Фискальная составляющая являлась явно доминирующей. Она просматривалась еще в боярском приговоре от 1 января 1699 г. Согласно ему, «которые люди государевы и патриарши, и монастырские, и помещиковы крестьяне похотят жить для торговых своих промыслов на Москве: и им велено по купечеству записываться в слободы, где кто похочет, и всякие его государевы подати платить и службы служить, также из слободы в слободу не закладываться» ${ }^{11}$.

Такую же направленность имел и указ Петра І от 24 ноября 1699 г. «О записке в посады разночинцов и крестьян, занимающихся в городах торгом и промыслами» $^{12}$. Он предписывал крестьянам, желавшим заниматься торговлей, записываться в посады, считая такую запись обязательным условием для

\footnotetext{
${ }^{10}$ Там же. Л. 285 об.

${ }^{11}$ ПСЗ-І. Т. 3. № 1666.

12 Там же. № 1723.
} 
торговой деятельности. Однако при возобладании в экономической линии правительства фритредерского начала появился сенатский указ от 1 октября 1711 г. «О свободной торговле всякого чина людям, с платежом надлежащих пошлин» ${ }^{13}$. Он безоговорочно дозволял «всякого чина людям» вести любую легализованную торговлю, подразумевавшую выплаты установленных податей. Указ от 4 февраля 1714 г. произвел некоторую коррекцию этого законоположения. Он касался патриарших, архиерейских, монастырских, помещичьих и вотчинных крестьян, «которые на Москве торгуют всякими товары в лавках», обязав их платить сверх крестьянских податей еще и «десятую деньгу» со своих торговых оборотов. В противном случае занятия торговыми промыслами крестьянам категорически запрещались ${ }^{14}$.

13 апреля 1722 г. Петр I подписал указ, не вошедший в Полное собрание законов (о его содержании известно из указа Елизаветы Петровны от 19 августа $\left.1745 \Gamma^{15}\right)$. В соответствии с ним всех крестьян, имевших в городах и городских слободах «домы, лавки и заводы», велено записывать в посад и оставить за ними право на торговлю. Напротив, те кто продолжал жить в деревнях, такого права лишались. От непосредственной торговли они отстранялись. Им дозволялось лишь передавать для продажи свои товары посадским людям. При Анне Иоанновне, 15 марта 1732 г., последовал указ, запрещавший крестьянам торговать «при портах портовыми товарами». Для обоснования запрета оказалось достаточным сослаться на упоминавшуюся норму Соборного уложения ${ }^{16}$.

Названный выше указ Елизаветы Петровны от 19 августа 1745 г., пожалуй, впервые попытался смягчить или даже частично обойти законодательную норму Соборного уложения относительно категоричного запрета крестьянского торга. Он разрешил крестьянам мелочную торговлю вдоль больших дорог, но в отдалении от городов, причем не только сугубо деревенскими изделиями, но и городскими, приобретаемыми мелким оптом в городах и на ярмарках. 1 июля 1751 г. Сенат своим указом скорее в виде исключения позволил оброчным крестьянам нижегородской Благовещенской слободы осуществлять торговлю ${ }^{17}$. В принятом 1 декабря 1755 г. Таможенном уставе (гл. II) акцентировалось внимание на недопущении крестьян к торговле с иностранцами при морских портах. Ей надлежало поставить крепкий заслон, в равной мере, как и торговле иностранцам между собой на российской территории. Такая торгов-

\footnotetext{
${ }^{13}$ ПСЗ-І. Т. 4. № 2433.

14 Там же. Т. 5. № 2770.

${ }^{15}$ Там же. Т. 12. № 9201.

16 Там же. Т. 8. № 5987.

${ }^{17}$ Там же. Т. 3. № 9866.
} 
ля выделена особо, с точки зрения наносимого ей вреда и «помешательства» русским торговым людям. О каких-либо дополнительных мерах против иной торговой деятельности крестьян Таможенный устав не упоминал. Напротив, в нем ставилась задача по защите крестьянской торговли «хлебом и другими съестными и прочими припасами» от любого «помешательства и притеснения». Надо полагать, Устав имел в виду продукты сугубо земледельческого происхождения. Кроме того, подтверждалась сила указа от 19 августа 1745 г., разрешавшего крестьянам торговать возле больших дорог ${ }^{18}$.

Других сколь-нибудь значимых законодательных актов, призванных регулировать крестьянскую торговлю, до начала развернувшейся в Комиссии о коммерции дискуссии не появлялось. Правда, Теплов упоминал указ Елизаветы Петровны от 20 ноября 1760 г. о запрещении розничного торга ${ }^{19}$, называя его весьма строгим и, по его мнению, распространяющимся также и на крестьянский торг («из котораго понимать надобно и торг крестьянской во всем государстве запрещенным, что сумневаться уже было не должно о прекращении онаго» $\left.{ }^{20}\right)$. Однако в действительности указ преследовал вполне конкретную цель пресечения розничной торговли иностранцев в Петербурге в занимаемых ими домах: «Некоторые иностранные купцы, да и других званий люди, не быв здешние подданные, а еще меньше мещане, пользуются, однако ж, мещанскими преимуществами, и не нося никаких гражданских тягостей и не содержа лавок, сделали оныя из своих домов, и всякие товары продают в розницы к предосуждению здешнего мещанства».

Таким образом, едва ли Теплов имел основания говорить о жестком противодействии правительства крестьянской торговле в прошлом. Оно старалось не пресекать торговые устремления крестьян, а исключить прежде всего неконтролируемые торговые операции, не поддающиеся податному учету. Однако вывод Теплова о сложившемся определенном симбиозе купечества и богатой крестьянской верхушки, взаимном переплетении капиталов представителей того и другого социального слоя, а потому тесно связанных между собой и нуждавшихся друг в друге, выглядит достаточно убедительно. К тому же он подкреплял его отнюдь не голословными доказательствами. По всей видимости, справедливо подмечена им и еще одна характерная особенность: жалобы на крестьян и упреки в недобросовестной конкуренции поступали со стороны купцов преимущественно из столичных или портовых городов, являвшихся в недавнем прошлом такими же крестьянами. Записавшись в купечество, они тут же стремились извлечь материальную выгоду из своего нового статуса,

\footnotetext{
${ }^{18}$ Там же. Т. 14. № 10468. Гл. Х, п. 3, 4.

${ }^{19}$ Там же. Т. 15. № 11145.

${ }^{20}$ РГАДА. Ф. 10. Оп. 3. Д. 68. Л. 285.
} 
руководствуясь корыстными интересами и не думая о государственной пользе. Теплов недвусмысленно связывает их побуждения со стремлением занять монопольное положение («жалобы же на крестьянской торг от таковых только купцов исстари были и ныне приносятся, которые, живучи в столичных и ближайших к порту городах, о государственной пользе нимало не думают, но каждый о своем персональном прибытке и якобы о своей собственной у целого народа монополии. Доказывается тем, что самые те купцы, когда производили торг, бывши еще во крестьянех под именем какого-либо купца, не почитали торг вредным купечеству» ${ }^{21}$ ). И всячески предостерегал от этого. Ибо «здрава политика учит, что государству весьма полезнее, когда капитал разделен во многи руки, ибо тогда весь оный в обращении коммерческом, как, напротиву того, денежной купец или от жадности, или от неумения, или, что чаще случается, видеть бы у себя для запасу много мешков в доме, насилу некоторую часть капитала пущает в обращение, но и то не по спекуляции, из которой он отваги не имеет, прочее же все или мертво лежит, или на то употребляет, чтоб малокапитальному все пути пресечь торг свой распространять. И сим образом по городам сильные купцы маломожных в порабощение приводят, что можно доказать живыми многими примерами» 22.

Еще один штрих к непривлекательному в целом портрету российского купечества в глазах Теплова понадобился ему для обоснования вывода о полной бессмысленности запрета крестьянской торговли. Такой вывод проистекал из его убежденности в неспособности купцов самим, без привлечения крестьян, осуществлять все торговые операции: «Купцы одни не в состоянии у крестьян будут по деревням и малым городам выкупить лен, пеньку и прочие продукты, ибо теперь отправляют сие крестьяне купечествующие и сами тем с купцами торгуют, от чего коммерция знатной упадок, как скоро сей торг прекратится, почувствует, а в сборах таможенных урон воспоследует» ${ }^{23}$. Во-первых, из-за малочисленности купеческого корпуса применительно к огромному пространству империи. Во-вторых, из-за явных недостатков в его качественном составе («наполнять пропорцию числа потребного государству купечествующих людей тем наипаче, что достигать онаго не глупостию, пьянством и обманами, но разумом, честностью и доброю верою необходимо надобно» $\left.{ }^{24}\right)$. В-третьих, такого запрета можно добиться только при помощи исключительно репрессивных мер («строжайших экзекуций»), и к тому же на непродолжительное время. Однако последствия столь опрометчивого шага

\footnotetext{
${ }^{21}$ РГАДА. Ф. 10. ОП. 3. Д. 68. Л. 286.

${ }^{22}$ Там же. Л. 286-286 об.

${ }^{23}$ Там же. Л. 290 об.-291.

${ }^{24}$ Там же. Л. 288.
} 
не заставят себя ждать: торговля ощутит нехватку выбывшей из обращения немалой части капитала; жившие торговлей вполне состоятельные крестьяне окажутся не у дел и, возможно, предпочтут уход в сопредельные государства; помещики, владельцы малоземельных крестьян, «которые, однако ж, от промыслов своих весьма больше помещикам доходу приносят, нежели крестьяне, изобилующие землями», неминуемо почувствуют сокращение своих доходов; в свою очередь, пострадают и купцы, «которые отдают свое имя торгующим крестьянам», получая от этого немалый доход и рискуя вдобавок остаться без части торговых приказчиков и лавочных сидельцев; наконец, неминуемо «между купцами и крестьянами, торговавшими, и между прикащиками и сидельцами их произойдут жалобы и процессы», и сложится крайне нездоровая обстановка: «Доносители во всех городах, а паче в отдаленных, для жадности получат половину товару за донос в награждение, заведут клеветы и ябеды, а приказные люди тем воспользуются» ${ }^{25}$.

Очерченная Тепловым в достаточно резких тонах не слишком радужная перспектива возможных последствий от введения полного запрета крестьянской торговли выглядела вполне реалистично. Она опиралась на знание существующего положения вещей и конкретных фактов. И потому в ней незаметно присутствие нарочитого сгущения красок.

Однако доводы Теплова показались неубедительными Н. Муравьеву и вице-президенту Комиссии о коммерции Т. Клингштету, его наиболее решительно настроенным оппонентам в этом органе. Они представили сразу две недатированные записки (скорее всего, обе написаны по горячим следам заслушанного в начале июня 1765 г. «мнения» Теплова) в ответ на его соображения. В первой они попытались опровергнуть всю аргументацию Теплова, а во второй - сформулировать собственное видение проблемы «крестьянского торга».

В их понимании, не имелось никаких оснований для того, чтобы превозносить деловые и морально-нравственные качества крестьян. Те успешно подвизались в торговле лишь благодаря использованию преимуществ собственного положения: вдвое более низкому размеру подушной подати и втрое - общей имущественно-податной нагрузки, с учетом налагаемых на купцов различных повинностей (сюда включались чрезвычайные «поборы», такие как рекрутские, поставка лошадей и несение обременительных городских купеческих служб). Увеличение численности купеческого корпуса, в том числе и за счет крестьян, представлялось мерой излишней. Вместо этого предлагалось сосредоточить усилия на распространении земледелия и увеличении производства

\footnotetext{
${ }^{25}$ Там же. Л. 290.
} 
земледельческих продуктов. С их реализацией на внешнем и внутреннем рынках в состоянии справиться имевшееся российское купечество, даже с учетом присущих ему недостатков, «ибо коммерцию не число торгующих распространяет, но размножение земных произращений. Довольно 20-ти тысяч человек, чтоб торговать в год на 20 миллионов. Разделяя весь торг, не больше тысячи рублей обойдется на человека» ${ }^{26}$. По их убеждению, ничем, впрочем, не подкрепленному, единственным источником пополнения российского купечества должно стать посадское население общей численностью 200 тыс. человек по последней ревизии, вполне способное выдвинуть из своей среды потребное количество торговых людей, отвечающих самым высоким требованиям. Вследствие чего удастся предотвратить сокращение крестьян-«делателей», по выражению авторов записки, т. е. основных производителей-земледельцев, в чем усматривалась одна из главных задач Комиссии о коммерции.

Другая спорная проблема, которую вычленили Муравьев и Клингштет после ознакомления с «мнением» Теплова, сводилась к оценке конкуренции между купечеством и крестьянством в сфере торговли. Если Теплов считал конкуренцию благом и необходимым стимулом, подстегивающим развитие коммерции, то его оппоненты не допускали и мысли о соперничестве такого рода. Они снова исходили из незаконности производимых крестьянами торговых операций, подрывавших купеческий «торг», которые вдобавок якобы не сопровождались последующим вкладыванием капитала в торговлю («крестьяня, обогатившиеся коммерцию, не принесли в торг своих капиталов»). А потому задавались чисто риторическим вопросом: «И так сходно ли с правосудием сей неправедно отнятой у купцов нажиток почитать доказательством, что и впредь надлежит крестьянам дозволить продолжить их беззаконныя злоупотребления?» ${ }^{27}$.

Третья проблема, по мнению Муравьева и Клингштета, сводилась не к постоянному закреплению за крестьянами их нынешнего социального статуса, а к созданию правового механизма, позволяющего им подниматься на более высокие социальные ступени, в частности, записываться в купечество. При этом во внимание принимался опыт «многих европейских областей», в которых «дозволено крестьянам и всякому вольно и в честном звании рожденному человеку вступать в купеческой корпус, но он прежде должен показать аттестат о своем учении и о капитале, сколько приносит в торг» ${ }^{28}$. По существу, речь шла о принципах, позднее положенных в основу гильдейской реформы 1775 г. Однако оставалась одна существенная неясность, касавшаяся владельческих

\footnotetext{
${ }^{26}$ РГАДА. Ф. 10. Оп. 3. Д. 68. Л. 299.

${ }^{27}$ Там же. Л. 300.

${ }^{28}$ Там же. Л. 301 об.
} 
крестьян. Ее, разумеется, не могли обойти стороной оппоненты Теплова, но они ограничились лишь постановкой вопроса: «Для упреждения излишнего умножения числа купцов сверх надлежащей пропорции и дабы не дозволено было крестьянину своевольно отставать от своего помещика и записываться в посад, надобно сделать добрые учреждения, тем паче, что кажется и нынешних купцов довольно для произвождения внутреннего государственного торгу вместо того что число земледельцов и работников, которых работа действительно распространяет коммерцию, никогда не может быть довольно размножено» ${ }^{29}$.

Наконец, в заключительной части записки Муравьева и Клингштета сгруппированы частные возражения. Среди них обращает внимание предусмотренная ответственность помещиков за незаконную торговлю собственных крестьян. Она примечательна во многом из-за употребления весьма выразительной лексики: «Что некоторые помещики получают больше прибыли от торгующих крестьян, нежели от земледельцов, сие не удивительно, ибо крестьяня имеют в торге преимущество против купечества, а особливо, когда помещик вместо трудолюбивых земледельцов имеет пронырливых торгашей» ${ }^{30}$. Причем авторы признавали наличие проблемы крестьянского малоземелья, но не спешили считаться с ней и делать какие-либо послабления («хотя б была и правда, что поместьи их малоземельны и пропитать крестьян не могут, ибо человек бедной еще не в праве беззаконным образом искать себе пропитания»).

В обобщенном виде собственное видение проблемы Муравьев и Клингштет изложили в упоминавшемся «Мнении о крестьянском торге», в котором сформулированы несколько принципиальных положений, оказавшихся несколько шире рамок обсуждаемой темы.

Прежде всего они обратили внимание на необходимость расширения сферы производства земледельческих продуктов, но никак не обмена. Данное положение они облекли в довольно емкую формулу: «Надлежит стараться, чтобы было сколько возможно больше делателей, а сколько возможно меньше торгашей» ${ }^{31}$. При этом призывали с осторожностью использовать механизм ценообразования, который далеко не всегда может рассматриваться в качестве универсального регулятора. В их понимании установление высоких цен, в первую очередь во внешней торговле, лишь тогда оправданно и полезно, когда оно продиктовано повышенным спросом со стороны иностранных купцов на определенные виды продуктов, предлагавшихся рынку в изобилии. Напротив, искусственное завышение цен, вследствие

\footnotetext{
${ }^{29}$ Там же. Л. 303 об.-304.

${ }^{30}$ Там же. Л. 302-302 об.

${ }^{31}$ Там же. Л. 306 об.
} 
ограниченного предложения на рынке, рассматривалось, безусловно, вредным. Иными словами, узко монетаристский подход уступал пониманию необходимости преимущественного развития сферы производства.

Отсюда и стремление ограничить расширение торгового сословия: «Ежели дать крестьянам беспредельную свободу вступать в мещанские и купеческие промыслы, сие неприметно весьма убавит число земледельцов» ${ }^{32}$. В то же время смешение разных «чинов» казалось совершенно недопустимым, ибо невозможно совмещать торговые промыслы с крестьянским трудом, а «не пахатной крестьянин кажется нам такой же член общества, каковы суть безграмотной священник, не служащей и не служившей дворянин и не торгующий купец» ${ }^{33}$.

В итоге Муравьев и Клингштет выступили за тщательное сословное разграничение прав и обязанностей, исключавшее переплетение и совмещение функций. При этом они предлагали предоставить право беспрепятственного перехода в мещанство тем крестьянам, которые избрали торговый промысел единственным занятием и порвали с земледелием. Однако конкретных мер в отношении владельческих крестьян они так и не предусмотрели.

Рассуждения Муравьева и Клингштета совершенно не убедили Теплова. Последний заявил в поданной 6 июня короткой записке о приверженности прежней собственной позиции, назвав возражение оппонентов «основанным на принципиях весьма сумнительных, из которых и следствия выведенные вид один возражения справедливого имеют» ${ }^{34}$, не пожелав повторно возвращаться к существу спора.

Мнение Теплова в целом поддержал гр. Э. Миних. Он не стал углубляться во все детали дискуссии. Для него решающим аргументом продолжал оставаться капитал, привносимый в коммерцию крестьянами. Именно благодаря их финансовым вливаниям, полагал Миних, российская коммерция сумела удвоить свои обороты, начиная с Петра I. И был готов закрывать глаза на все связанные с данным обстоятельством издержки. Вместе с тем он считал целесообразным и даже необходимым учесть, как интересы купцов и мещан, с одной стороны, так и крестьян, с другой, обозначив «неподвижныя границы каждому званию так, чтоб одни не несли тягостей к единственной прибыли других». С этой целью Миних предлагал «учредить пределы, в которых они должны пребывать, и назначить пункты ко исполнению всем тем крестьянам, которые захотят вмешаться в торг» ${ }^{35}$.

\footnotetext{
${ }^{32}$ РГАДА. Ф. 10. Оп. 3. Д. 68. Л. 307.

${ }^{33}$ Там же. Л. 307 об.

34 Там же. Л. 314.

${ }^{35}$ Там же. Л. 313.
} 
Итак, в ходе непродолжительной дискуссии выявились различия в подходах к рассмотренной проблеме, но так и не удалось найти единого способа ее решения. Часть членов Комиссии о коммерции высказалась за ужесточение мер в отношении торговли крестьян вплоть до ее полного запрета (Я. Шаховской, Н. Муравьев, Т. Клингштет). Свою точку зрения они пытались подкрепить ссылками на российское законодательство, начиная с Соборного уложения, но не всегда привлекали его в полном объеме и производили отбор целиком беспристрастно (в равной мере сказанное относится и к выразителю иной точки зрения Г. Теплову, стремившемуся подчеркнуть запретительный характер принимавшихся в прошлом указов). Неоднократно предпринимавшиеся правительством попытки вывести крестьянскую торговлю из тени, максимально включив ее в сферу податного учета, вольно или невольно замалчивались. При этом одна из сторон в своем стремлении накрепко привязать частновладельческих крестьян к земле и полностью лишить хозяйственной свободы, вернув в обращение соответствующие статьи Соборного уложения, старалась подчеркнуть полную незаконность любых попыток официального признания крестьянского торга.

Выразители другой точки зрения, в первую очередь Г. Теплов, и во многом согласный с ним Э. Миних, напротив, доказывали безуспешность любых действовавших в прошлом запретов. Они противились связывать крестьянам руки при выборе занятий и закрывать доступ к неземледельческим промыслам. Во многом ими двигало желание узаконить уже фактически сложившийся порядок в областях, где укоренилась оброчная система на фоне хронического крестьянского малоземелья. В то же время нельзя недооценивать и другие побудительные мотивы. С деятельными крестьянами, поднаторевшими в торговых (и не только) операциях, связывались надежды на оживление российской коммерции. Во многом по причине неизбежного усиления конкуренции и пробуждения частной инициативы. В гораздо меньшей степени подобные надежды возлагались на купечество, удостоенное самых нелестных эпитетов за необразованность и множество возложенных на него человеческих пороков. Отсюда проистекало и нежелание жесткой фиксации сословных перегородок.

\section{Литература}

Ковальчук А. В. Экономическая политика правительства Екатерины II во второй половине XVIII в.: Идеи и практика. М.; СПб., 2017. 


\title{
Н.В. Козлова
}

\section{ВЕНЦЕНОСНЫЕ ОСОБЫ В РОЛИ ДУШЕПРИКАЗЧИКОВ И ГАРАНТОВ НАСЛЕДСТВЕННЫХ ПРАВ ЗНАТИ В ПЕТРОВСКОЕ ВРЕМЯ}

\begin{abstract}
Аннотация $\mathrm{B}$ статье на примере духовных завещаний некоторых представителей петровской чиновной элиты рассмотрена существовавшая в их среде практика апелляции к монарху как к высшему арбитру при решении вопросов наследования родового и семейного имущества и как гаранту точного исполнения своей воли. Другим стимулом для обращений к венценосным особам было желание обеспечить своим сыновьям монаршее покровительство. Существование такой практики отражало признание верхами общества патримониальных черт власти российских монарх Ключевые слова: власть, общество, знать, петровское время, земельные владения, наследование имущества, душеприказчики, покровительство.

Summary On the example of the wills of some representatives of the Peter's official elite, the author considers the practice of addressing the monarch as the supreme arbiter in deciding the inheritance of ancestral and family property and as a guarantor of the exact execution of their will. Another incentive was the desire to provide their sons with royal protection. The existence of such a practice reflected the recognition of the patrimonial features of the power of the Russian monarchs by the upper classes of society of the imperial era. Keywords: power, society, nobility, Peter's time, land holdings, property inheritance, executors, patronage.
\end{abstract}

В петровское время усилилась роль законодательных установлений в качестве инструмента воздействия государственной власти на все сферы жизни общества. Одной из наиболее значимых социальных областей являлись имущественные отношения, а важнейшим средством их регулирования выступал институт наследования. Для дворян основной ценностью была земельная недвижимость и «крещеная собственность», наличие которых 
отражало их социальное положение и материальное состояние. Институт наследования являлся не только важнейшим средством регулирования имущественных отношений в рамках семьи и рода, но и через законодательные установления использовался государственной властью для развития социальных процессов в нужном для нее русле. Наиболее яркий тому пример - Указ о единонаследии 1714 г. Вводимое им ограничение прав дворян в наследовании недвижимости по замыслу законодателя должно было прекратить дробление земельных владений и стимулировать заинтересованность дворян, не наследовавших населенные земли, в государственной службе как основном источнике их существования.

В историографии институт наследования и имущественные отношения в семье долгое время изучались главным образом в юридически-правовом аспекте ${ }^{1}$. Практика же реализации закрепленного в законодательных нормax XVIII в. порядка наследования движимого и недвижимого имущества среди различных социальных групп, преимущественно в купеческой среде, только начинает разрабатываться в историографии ${ }^{2}$. В новейшей литературе семейные тактики наследования и брачных союзов, а также связанная с ними мобильность земельных владений применительно к некоторым знатным родам XVII в. стали предметом изучения О.Е. Кошелевой ${ }^{3}$.

1 Савельев А. Юридические отношения между супругами по законам и обычаям великорусского народа. Н. Новгород, 1881; Владимирский-Буданов М.Ф. Обзор истории русского права. 3-е изд. Киев; СПб., 1900; Якушкин В.Н. Очерки по истории русской поземельной политики в XVIII и XIX вв. М., 1890. Вып. 1: XVIII в.; Латкин В.Н. Учебник истории русского права периода империи (XVII-XIX вв.). 2-е изд. СПб., 1909; Сергеевич В.И. Лекции и исследования по древней истории русского права. 3-е изд. СПб., 1903; Индова Е.И. К вопросу о дворянской собственности в России в поздний феодальный период // Дворянство и крепостной строй в России XVI-XVIII вв.: Сборник статей, посвященный памяти Алексея Андреевича Новосельского. М., 1975. С. 277-281; Киприянова Н.В. К вопросу о дворянском землевладении в законодательстве XVIII века // Вестник Московского университета. Сер. 8. История. 1983. № 1. С. 57-69; Цатурова М.К. Русское семейное право XVI-XVIII вв. М., 1991; Новиикая T.E. Правовое регулирование имущественных отношений в России во второй половине XVIII века. М., 2005.

2 Козлова Н.В. Из истории семейно-имущественных отношений в среде привилегированного купечества в начале XVIII века // Экономика, управление, демография городов Европейской России XV-XVIII веков. История, историография, источники и методы исторического исследования: Материалы научной конференции, Тверь, 18-21 февраля 1999 г. Тверь, 1999. С. 56-63; Козлова H.B. Семейно-имущественные отношения в среде московского купечества XVIII века (к постановке проблемы) // Столичные и периферийные города Руси и России в средние века и раннее новое время (XI-XVIII вв.): Доклады Второй научной конференции (Москва, 7-8 декабря 1999 г.). М., 2001. С. 148-159; Козлова Н.В. Имущественное право и положение женщины в купеческой семье Москвы XVIII в. // Столичные и периферийные города Руси и России в средние века и раннее новое время XI-XVIII вв. Проблемы культуры и культурного наследия: Доклады Третьей научной конференции (Муром, 17-20 мая 2000 г.). М., 2003. С. 259-275.

3 Кошелева O.E. Родственные связи в высших кругах знати XVII столетия и землевладение // Cahiers du Monde russe. 2016. Vol. 57. № 2/3. P. 545-570. 
До указа 1714 г. наследственное право учитывало происхождение оставшегося после смерти владельца имущества. Так, указ 1684 г. «по примеру купленных вотчин» ввел различия между тяглыми и купленными дворами. Если из тяглых дворов бездетные вдовы наследовали четвертую часть, то купленные дворы полностью доставались вдовам умершего владельца ${ }^{4}$. Указ о единонаследии, не делая различий между источниками обретения недвижимости (земельных владений, дворов, лавок, промысловых и промышленных заведений), закрепил принцип ее неделимости, став причиной многочисленных судебных разбирательств между членами семьи и родственниками из-за наследуемого имущества. Ситуация усугублялась, когда в тексте духовного завещания одна из спорящих сторон находила положения, противоречащие законодательным нормам. В таком случае одни в доказательство своих прав апеллировали к закону, другие - к воле завещателя. Да и законодательные нормы были не безупречны, нередко допускали возможность разного толкования и не могли предусмотреть многообразие жизненных ситуаций и коллизий. На практике при решении спорных дел судебные структуры апеллировали не только к нормам указа 1714 г., но и к «новоуказным статьям» и Соборному уложению 1649 г. Согласно именному указу Петра I от 16 апреля 1714 г., в случае возникновения спорных дел, их следовало решать по Уложению5.

Дворяне не были пассивными, когда ущемлялись их интересы, особенно в той сфере, которая составляла основу их благополучия ${ }^{6}$ Обращение к семейно-правовым документам позволяет выявить те средства и ухищрения, к которым прибегали землевладельцы ${ }^{7}$, чтобы, не нарушая явно, все же обойти нормы, установленные законом ${ }^{8}$. Так, запрет на включение в состав приданого недвижимого имения, направленный на предотвращение дробления земельной собственности дворян, преодолевался передачей части

${ }^{4}$ ПСЗ-I. Т. 2. № 1081.

5 РГАДА. Ф. 248. ОП. 13. Кн. 691. Л. 19.

${ }^{6}$ О скрытном сопротивлении дворян Указу о единонаследии 1714 г. см.: Lee A. Farrow. Peter the Great's Law of Single Inheritance: State Imperatives and Noble Resistance // Russian Review. Vol. 55. № 3 (Jul., 1996). P. 430-447.

7 Факты прямого нарушения наследственных норм Указа о единонаследии в купеческой среде не известны. Купцы и до выхода указа о единонаследии в основной своей массе предпочитали не дробить недвижимое имущество, заключающееся в промысловых и промышленных заведениях. Поэтому указ 1714 г. не вызвал недовольства среди купцов. В записках, предложениях и доношениях, с которыми обращались купцы в различные государственные учреждения (например, в Комиссию о коммерции) в период действия принципа неделимости недвижимого имущества, вопрос об отмене этого положения ни разу не поднимался.

8 В общем плане о применении дворянами разных способов обхода запрета на раздел недвижимых имений говорится и в указе 17 марта 1731 г., отменившем принцип неделимости вотчин (ПСЗ-I. Т. 8. № 5717). 
недвижимости незамужним дочерям и сестрам «в поминовение души». Причем регистрация духовных завещаний, содержащих подобные распоряжения, не вызывала никаких возражений со стороны соответствующих структур. Другая практика, уже в обход норм законодательства (п. 12 Указа о единонаследии), состояла в фиктивной продаже части полученного наследства своему брату или другому родственнику ${ }^{9}$.

Представители знати, порой, действовали иначе. Они напрямую апеллировали к монарху как к высшему арбитру при решении внутрисемейных проблем: вопросов наследования, обеспечения будущности детей, ссор и разногласий между супругами. Рассмотрение примеров подобных обращений к монарху, адресуемых в духовных завещаниях знати, высвечивает отдельные нюансы в характере отношений социальной и политической элиты общества и венценосных особ.

Боярин князь Б. И. Прозоровский в отсутствии прямых наследников в своем завещании, написанном во время «болезни тяжкие... на смертной постеле» 19 марта 1718 г., передал в полное распоряжение царицы Екатерины Алексеевны все свое движимое и недвижимое имущество. Вручая свою «любезную супругу» княгиню Ирину «под покров ее величества», князь просил «всемилостивейшую государыню царицу» не оставить ее своей заботой, передать деньги, вырученные от продажи части деревень, «для поминовения души» родственникам и молил, «дабы грешная... душа [его] незабвенна была в поминовении по обычаю христианскому» ${ }^{10}$.

В условиях действия Указа о единонаследии, дополненного указом 1716 г., при бездетном браке муж своим завещанием мог выделять жене только четвертую часть всего своего имущества, а остальное имение вправе был передать ближнему наследнику из своей фамилии ${ }^{11}$. Род князей Прозоровских был весьма разветвленным, и не было опасности пресечения их фамилии за отсутствием сыновей у кого-то из ее представителей. У трех из четырех двоюродных братьев князя Бориса Ивановича, Андрея, Никиты и Владимира (сыновей князя Петра Семеновича Меньшого) были наследники по мужской линии ${ }^{12}$. С учетом данного обстоятельства родная племянни-

9 Многочисленные примеры различных манипуляций дворян с наследственной недвижимостью в обход Указа о единонаследии привел В.П. Киселев (Киселев В.П. Взаимоотношения власти и общества в свете эволюции института наследования в первой половине XVIII века. Дипломная работа, защищенная на кафедре отечественной истории до XIX в. исторического факультета МГУ имени М.В. Ломоносова. Студента V курса д/о. Научный руководитель д.и.н., профессор Н.В. Козлова. М., 2009 (рукопись). С. 36-54).

${ }^{10}$ РГАДА. Ф. 1451. Оп. 1. Д. 7. Л. 320-320 об.

${ }^{11}$ ПСЗ-І. Т. 5. № 2789, п. ІХ; № 3013.

${ }^{12}$ Родословная князей Прозоровских // Прозоровский A.A. Записки генерал-фельдмаршала князя Александра Александровича Прозоровского, 1756-1776. М., 2004. С. 690-702. 
ца завещателя, дочь его старшего брата князя Петра Ивановича Прозоровского, княгиня Анастасия Петровна Голицына не могла быть его законной наследницей, как об этом, порой, упоминается в литературе. Указ о единонаследии предусматривал такую возможность, но только как крайний случай при отсутствии лиц мужского пола «для возобновления фамилеи» и с непременным условием обретения мужем наследницы и его потомства новой фамилии (п. 7). Очевидно, что ситуация с наследством князя Б.И. Прозоровского под такой случай не подходила. К тому же Анастасия Петровна как раз в это время сильно скомпрометировала себя причастностью к делу царевича Алексея и подверглась опале ${ }^{13}$.

Ровно через месяц после смерти Б.И. Прозоровского ${ }^{14}$ Петр I собственноручно наложил на духовное завещание князя краткую резолюцию: «Учинить по сему завещанию», и, уточняя свою волю, сделал пояснение: «А понеже по смерти жены ево просил, дабы мы употребили в волю свою и поминали душу ево и ее, того для в том случае определяем оныя деревни в гошпиталь» ${ }^{15}$. Строго говоря, покойный в завещании обращался не к Петру I, а к царице Екатерине Алексеевне, вверяя «в волю ея величества, моей всемилостивейшей государыне» свою жену и все имение. Царица в такой интерпретации становилась не простой душеприказчицей, выполнявшей волю завещателя, а государыней, диктующей свою волю. Однако в итоге, как и следовало, не царица, а Петр I выразил «волю свою», указав после смерти жены князя Прозоровского и ради поминовения их душ, принадлежавшие им деревни употребить на содержание раненых. Примечательна высказанная царем мотивация его решения: «ибо сия добродетель по святому писму и натуре выше всех». Она соответствовала понятию «доброго чина милостыни»,

${ }^{13}$ Княгиня А.П. Голицына входила в состав ближайшего окружения Петра I и царицы Екатерины Алексеевны, участвовала во всех забавах царя, в том числе и в деятельности «всепьянейшего собора» в качестве «княгини-игуменьи». Накануне дня подписания Б.И. Прозоровским своего завещания княгиня была признана виновной по делу царевича Алексея, и 28 марта 1718 г. публично бита батогами. Ко двору ее возвратили в 1722 г., а в 1724 г., в связи с коронацией Екатерины Алексеевны, она первой получила титул статс-дамы (См.: Русский биографический словарь. В 25 т. / Изд. под наблюдением А. А. Половцова. М., 1896-1918. Т. 7. С. 208).

${ }^{14}$ Князь Борис Иванович Прозоровский скончался 6 апреля 1718 г.

${ }^{15}$ РГАДА. Ф. 1451. Оп. 1. Д. 7. Л. 320 об. См. также: Воскресенский Н.А. Петр Великий как законодатель. Исследование законодательного процесса в России в эпоху реформ первой четверти XVIII века. М., 2017. С. 353; Законодательные акты Петра I. Редакции и проекты законов, замети, доклады, доношения, челобитья и иностранные источники. Сборник документов. В 3 т. / Сост. Н.А. Воскресенский. Т. 2: Акты об общественных классах; Т. 3: Акты о промышленности и торговле / Отв. ред. Е.В. Анисимов; предисл. и подгот. текста Д.О. Серов; археограф. предисл. А.А. Богданов. М., 2020. № 15; Intinera petri: Биохроника Петра Великого день за днем. 06.05.1718, вт. П. в СПб. (URL: https://spb.hse.ru/humart/history/peter/ biochronic/228259731 (дата обращения - 15.01.2021)). 
активно в это время внедряемого в общественное сознание с помощью многочисленных указов о запрете ручной милостыни, отныне определяемой как «неправой» и «суетной» ${ }^{16}$.

Через три дня, 9 мая, повеление Петра I уже в виде указа было объявлено кабинет-секретарем А. Макаровым, о чем на последней странице текста завещания князя Прозоровского секретарем Сената сделана соответствующая запись ${ }^{17}$. Здесь же, в Книге записей именных указов Петра I, содержится текст «письма», в котором Петр I дает конкретные указания относительно наследства князя Б.И. Прозоровского ${ }^{18}$. Сославшись на просьбу князя «призрить оставшую по нем ево супругу княгиню Ирину» и не забыть его душу «поминовением по обычаю христианскому», а также подчеркнув, что все свое имение князь распорядился по кончине жены отдать «в волю нашу» и «в нашу диспозицыю», царь пишет: «И хотя его царское величество указал учинить по тому ево завещанию, и о том изволил на том ево завещательном писме собственною своею подписать рукою, однако ж мы из недвижимаго ево имения по тому ево завещанию себе ничего не требуем, но заблагоразсудили всем ево, князь Борисовом, недвижимым имением владеть жене ево по ее смерть». Такое распоряжение соответствовало норме Указа о единонаследии 1714 г., но противоречило указу 1716 г. о четвертой доле наследства бездетной вдовы. На это, видимо, и рассчитывал князь Прозоровский, взывая в завещании к царской воле, а не к силе закона. По смерти же княгини Ирины, согласно воле государя, следовало все «недвижимое имение отдать на поминовение души ево в Троицкой Александров монастырь ${ }^{19}$, в шпиталь». В этом распоряжении в соответствии с ранее вынесенной резолюцией соединялся благочестивый долг с гражданской пользой. Далее следовали конкретные указания, касающиеся просьбы княгини Ирины о выделении из деревень мужа 40 дворов и употреблении денег от их продажи на поминовение души князя. Деньги «по настоящей цене», что за дворы «посторонние купцы давать будут», было решено выдать княгине из того монастыря, но сами дворы оставить вместе с прочим

${ }^{16}$ Указы 1718 и последующих годов под угрозой штрафа (от 5 до 10 руб.) запрещали подавать милостыню и повелевали задерживать бродячих нищих. Отныне законным проявлением нищелюбия могла быть передача денег в богадельни, госпитали и другие подобные заведения. В Духовном регламенте 1721 г. со ссылкой на священные тексты и благоразумие православного люда подробно излагалась суть «доброго чина милостыни». Подробнее см.: Козлова Н.В. Люди дряхлые, больные, убогие в Москве XVIII века. М., 2010. С. 38-41.

17 «Сей великого государя указ объявил кабинет-секретарь Алексей Макаров маия 9 д. 1718. Записать в книгу».

${ }^{18}$ РГАДА. Ф. 1451. Оп. 1. Д. 7. Л. 321-322.

${ }^{19}$ Видимо, речь идет об Успенском монастыре в Александровой слободе и его Троицком соборе, построенном еще в XVI в. 
недвижимым имением. Эта записка заканчивается заверением, что «для вящей силы и свидетельства впредь сие наше писмо мы нашею печатью утвердить повелели. В Санкт Питербурху маия дня 1718 году».

Письмо не имеет точной даты, подписи и печати; отсутствует и помета об их наличии на подлинном тексте. Это обстоятельство, а также стилистически чуждая отсылка к резолюции царя на завещании Прозоровского позволяют думать, что перед нами до конца не выправленный секретарем черновой вариант «письма» Петра I, которое он так и не подписал. К тому же в полном объеме и именно в таком виде эти распоряжения реализованы не были. Княгиня И.М. Прозоровская умерла 10 января 1719 г., т. е. через семь месяцев после начертания Петром I резолюции на завещании ее мужа. В течение этого срока она продолжала владеть всем его имением, но не могла свободно им распоряжаться. После ее кончины Петр I указом в Военную коллегию от 11 июля 1719 г. передал рузскую и можайскую вотчины Прозоровского в Санкт-Петербургский госпиталь ${ }^{20}$. Другие земли в Можайском уезде в 1723 г. стали вотчиной Екатерины I, а позднее оказались во владении разных лиц ${ }^{21}$. В итоге венценосные особы в соответствии с желанием князя Б.И. Прозоровского распорядились его наследством по своей воле.

Ирина Михайловна Прозоровская, урожденная Римская-Корсакова, за три дня до кончины, находясь в «тяжкие болезни», также написала завещание 22 В нем она, обращаясь по примеру покойного мужа к царице Екатерине Алексеевне, просила ее быть своей душеприказчицей, распорядиться о поминовении ее души «по обычаю христианскому» и быть гарантом исполнения имущественных определений. Они касались как родственников покойного мужа (его братьев, сестер и двоюродных племянников), так и своего племянника Якова Васильева сына Корсакова, передаваемого под «материнскую милость» государыне царице. Ему оставлялось собственное приданое княгини, недвижимость («вотчин четвертой жеребей»), полученная ею после первого мужа стольника и полковника И.К. Нечаева, а также

${ }^{20} \mathrm{~B}$ ходе Северной войны вопрос об организации стационарных военных госпиталей стоял очень остро. В 1707 г. в Москве возник первый в России постоянный госпиталь. Как выяснено в новейших исследованиях, к 1710 г. в Санкт-Петербурге уже действовали военные госпитали для армии и флота, а в 1715 г. указом Петра I было принято решение о создании на Выборгской стороне единого комплекса Генеральных госпиталей. Правда, по разным причинам его строительство затянулось, и к концу второго десятилетия XVIII в. вопрос о военных госпиталях и подготовки медицинских кадров оставался исключительно актуальным (См.: Милашева Н.В., Самойлов В.О. Первые военные госпитали Санкт-Петербурга // Вестник Российской Военно-медицинской академии. 2020. № 3(71). С. 258-266).

${ }^{21}$ URL: http://wp.wiki-wiki.ru/wp/index.php/Поречье_(Можайский район).

22 Дворяне Москвы: свадебные акты и духовные завещания петровского времени / Сост., очерки и коммент. Н.В. Козловой и А.Ю. Прокофьевой. М., 2015. № 165. С. 246-248. 
загородный двор в Петербурге и московский двор на Пречистенке, перешедший по просроченной закладной Андрея Городецкого к покойному мужу завещательницы. За другой «двор на Знаменке», также заложенный покойному князю А.Ф. Тверитоновым, племяннику по закладной полагалось взыскать выданные под залог дома 1 тыс. руб.

В завещании не упомянуты доли наследства, которые после смерти второго мужа князя Луки Федоровича Долгорукова (умер в 1710 г.) и третьего мужа князя Прозоровского должна была получить Ирина Михайловна. Их, видимо, она имеет в виду под определением «протчее оставшее все движимое, так и недвижимое» имение. Его употребление она оставляет на «высокомудрое разсуждение» царицы. Родственники князя Б.И. Прозоровского, его родной брат Петр Иванович, двоюродный брат Андрей Петрович и сестра боярыня Марфа Ивановна Салтыкова, согласно завещанию, получали по 2 тыс. руб.; сестра инокиня княжна Александра - 1 тыс. руб.; сыновья двоюродного брата Никиты Петровича князья Александр, Владимир и Петр, помимо денежной дачи в 2 тыс. руб. каждому, награждались двором в Санкт-Петербурге. Еще один двор, московский, с каменными палатами, где жила сама завещательница, княгиня Прозоровская распорядилась продать за 2 тыс. руб. родственникам умершего мужа, а деньги употребить на выкуп пленных. То, что двор следовало продать родственникам князя Прозоровского, указывает на его принадлежность покойному, и, вероятнее всего, после смерти Ирины Михайловны двор подлежал возвращению в княжеский род. Согласно Переписи московских дворов 1716 г., князю Б.И. Прозоровскому принадлежали два двора в приходе церкви Сошествия Святого Духа у Пречистенских ворот. Об одном из них, скорее всего, и идет речь в завещании вдовы князя Прозоровского. Старший брат покойного князь Петр Иванович в соседнем приходе церкви Успения Богородицы, что в Остожье, владел загородным двором ${ }^{23}$.

Обращение к царице имело важный смысл для обеспечения воли завещательницы в полном объеме, особенно в части имущественных интересов племянника, которые влиятельный и многочисленный род князей Прозоровских мог оспорить. На эту мысль наводят и заключительные строки духовной с мольбой к государыне царице и великой княгине Екатерине Алексеевне принять племянника «в свою материнскую милость» и показать ему «всякое милосердие». Такая просьба была не лишней, принимая во внимание отсутствие прямых наследников. Особенно сомнительными в правовом

${ }^{23}$ Перепись московских дворов 1716 г. // Переписи московских дворов XVIII столетия. M., 1896. C. 39, 41, 42. 
отношении были распоряжения княгини относительно санкт-петербургского и московских дворов. Они переходили к трем разным наследникам: родственникам князя Б.И. Прозоровского и отдельно двоюродным племянникам, а также к племяннику завещательницы Якову Васильеву сыну Корсакову.

Княгиня Прозоровская опасалась не случайно. Реализация ее распоряжений относительно наследства Я.В. Корсакова встретила трудности, которые его мать, вдова стольника Василия Михайлова сына Римского-Корсакова ${ }^{24}$ Евфимия Федоровна, пыталась решить в Санкт-Петербурге при поддержке государыни Екатерины Алексеевны. Как следует из синодальных документов $^{25}$, для этого в феврале 1719 г., т. е. через месяц после кончины княгини Ирины Михайловны, собираясь в северную столицу, она привезла в дом к священнику московской церкви Воскресения Христова за Пречистенскими воротами Дмитрию Христофорову, бывшему ее духовным отцом, четыре сундука с серебряною посудою «на соблюдение». Евдокия Федоровна жила в доме у своей золовки Прасковьи Михайловны (сестры В.М. Римского-Корсакова и княгини И.М. Прозоровской), которая была в это время больна и не могла присмотреть за имуществом. Запертые и запечатанные печатью Евфимии сундуки были поставлены в церковь, а в мае того же года, т. е. почти через три месяца, Прасковья Михайловна, оправившись от болезни, как и было заранее оговорено, сама приехала к священнику и взяла от него все имущество «в совершенной сохранности». Когда в 1720 г. Евфимии Федоровне вновь понадобилось ехать в Санкт-Петербург, она также оставила сундуки с имуществом, а также баул с 3 тыс. руб. под присмотром Прасковьи Михайловны «в доме Городецкого», где она в это время жила. Это был тот самый двор на Пречистенке, что княгиня Прозоровская завещала своему (и своей сестры Прасковьи Михайловны) племяннику Я.В. Корсакову.

Далее события развивались по криминальному сюжету. Его подробности излагаются в челобитной Корсаковой, поданной в Канцелярию ведомства лейб-гвардии Преображенского полка капитана князя Г.А. Урусова. В мае

${ }^{24}$ В.М. Римский-Корсаков, стольник царицы Прасковьи Федоровны, родился около 1650 г., умер не позднее 1718 г., так как известны две крепостные записи сговорных его вдовы Афимьи (Евфимии) Федоровны 1718 и 1723 гг. на дочерей Авдотью и Анну, в которых А.Ф. Римская-Корсакова упомянута как вдова (См.: Вершинин А.А. Материалы к составлению родословной росписи дворян Римских-Корсаковых // Культура и быт русского дворянства в провинции XVIII в. Проект Германского исторического института в Москве (URL: http://adelwiki.dhi-moskau.de/index.php (дата обращения - 15.01.2021)).

${ }^{25}$ Описание документов и дел, хранящихся в архиве Святейшего Правительствующего Синода (далее - ОДиДС). СПб., 1879. Т. 2. Ч. 1. Стб. 225-228. 
того же года в отсутствии Евфимии Федоровны в дом Городецкого приехал некий Иван Грузинец, не объявляя никакого указа, «сослал» Прасковью Михайловну Римскую-Корсакову со двора и, сорвав печати и сбив замки, «выбрал» из сундуков пожитки и их роспись, а из баула деньги. Однако, судя по названию дела, присланного для расследования по указу царицы Екатерины Алексеевны в июле 1721 г. из Петербурга к московскому вице-губернатору И.Л. Воейкову ${ }^{26}$, именно вдова Евфимия Федоровна и ее золовка Прасковья Михайловна Римские-Корсаковы обвинялись в вывозе из дома супругов князей Прозоровских их пожитков. Такое развитие событий свидетельствует о том, что наследственные права племянника княгини И.М. Прозоровской были оспорены как в отношении движимого, так и недвижимого имущества, принадлежавшего не лично княгине, а ее почившему супругу. Нам не известны все обстоятельства и результаты расследования этого дела. Но очевидно, что отдельные пункты духовной княгини Ирины Михайловны не соответствовали духу завещания ее супруга и входили в противоречие с наследственными интересами рода Прозоровских, а потому вызвали их протестные действия.

Помимо монарха и его венценосной супруги, в качестве душеприказчика и высокого покровителя интересам завещателя мог быть и иной представитель царствующего дома Романовых. Так, князь Иван Михайлович Мещерский в своем завещании, составленном 7 января 1718 г., определил своей душеприказчицей царевну Марью Алексеевну, родную сестру царевны Софьи и единокровную сестру Петра I. Ей он не только поручал «строить и поминать душу свою», но и передавал вотчины, полученные его отцом стольником князем Михаилом Васильевичем Мещерским, со всеми «угодьи, и со крестьяны, и з деловыми людьми». Напрямую обращаясь к «великой государыне, благородной царевне и великой княжне Марии Алексеевне», князь просил ее продать родовую вотчину в Московском уезде «сельцо Настасьино да село Большое Покровское», а вырученные деньги раздать на поминовение по душе его и родителей, выделив некоторую часть бабке завещателя княгине Евдокии Васильевне Мещерской. Прежде забота о княгине была возложена на ее внука И.М. Мещерского, когда тот наследовал вотчины своего отца, сына княгини, князя М.В. Мещерского («ему, князь Ивану, за те было вотчины поить и кормить»). Теперь же, передавая вотчины царевне, завещатель оставлял на ее попечение и княгиню Евдокию Васильевну. Забота царевны-душеприказчицы должна была оградить родовые

\footnotetext{
${ }^{26}$ Иван Лукич Воейков в то время был также вице-президентом московского надворного суда.
} 
вотчины от покушений как со стороны родственников отца (Мещерских), так и матери (Языковых). Их в своем завещании князь Иван предостерегает особо: «А родственником ево Мещерским и роду Языкова ни до чего дела нет и не вступатца» ${ }^{27}$. Защищенные покровительством царевны вотчины предназначались на поминальные службы по душе князя и его родителей. Забота о поминовении усопших, как и в прошлые столетия, оставалась важнейшей семейной ценностью и первейшим долгом.

Известно, что вотчина досталась отцу завещателя Михаилу Васильевичу Мещерскому в 1693 г. Вскоре новый хозяин отдал небольшой участок земли в десять десятин священнику и причетникам Покровской церкви. В переписных книгах 1704 г. сохранилась запись о том, что представляла собой тогда эта вотчина: «За князем Михаилом Васильевым сыном Мещерским село Покровское, Настасьино тож, а в селе церковь Покрова Пресвятой Богородицы, да в приделе Николая Чудотворца, у церкви во дворе поп Иван Степанов, во дворе дьячок Осип Яковлев; да в селе двор вотчинников с дворовыми деловыми людьми и крестьян 18 дворов».

Выбор царевны Марии в качестве высокой покровительницы родовым интересам Мещерских оказался неудачным, поскольку уже в июне 1718 г. она была арестована по делу царевича Алексея и отправлена в Шлиссельбургскую крепость, где и находилась до 13 мая 1721 г., а затем содержалась под домашним арестом в Санкт-Петербурге. В итоге вотчина продана не была и оставалась за Евдокией Васильевной Мещерской и ее дочерью Марьей Васильевной Головиной. В 1719 г. ее владельцем стал крупный петровский дипломат и государственный деятель, руководитель недавно созданной Тайной канцелярии П.А. Толстой, принимавший деятельное участие в следствии и в суде над царевичем Алексеем ${ }^{28}$.

Обращение в завещании к монарху с просьбой быть душеприказчиком для точного исполнения своей воли, хотя и редко, но все же встречалось и в наследственной практике высших кругов знати XVII в. И тогда побудительным мотивом становилось стремление решить вопросы наследования в обход действующему законодательству и обычаю. Примером является хорошо известная по публикации А.П. Барсукова духовная боярина Федора Ивановича Шереметева, который, вопреки существующему порядку, закре-

27 Дворяне Москвы... № 126. С. 209-210.

${ }^{28}$ В дальнейшем от Толстых вотчина перешла к супругам Д.А. и Д.И. Шепелёвым, при которых начал формироваться усадебный комплекс Валуево, позднее владельцем усадьбы стал граф А.И. Мусин-Пушкин. При нем на рубеже XVIII и XIX вв. в усадьбе был создан яркий ансамбль в стиле классицизма, отличающийся исключительной целостностью и гармоничностью (URL: http://www.bestreferat.ru/referat-220125.html (дата обращения: 05.01.2021)). 
плял родовые вотчины за младшей дочерью, остававшейся его единственной наследницей, а через нее за четырьмя своими внуками, сыновьями князя Н.И. Одоевского. Этим самым он отстранял от наследства трех троюродных племянников, сыновей своего двоюродного брата Петра Никитича Шереметева, законно претендовавших в качестве представителей мужской линии на земли и крестьян рода Шереметевых. Чтобы осуществить задуманное, Федор Иванович в своей духовной, составленной в 1645 г., просил царя Михаила Федоровича, своего свойственника по жене, быть его душеприказчиком, передав ему в благодарность свою обширную волость в Юрьев-Повольском уезде с более 1 тыс. крестьянских дворов. Решив, несмотря на существующий запрет на земельные вклады в монастыри, передать на помин души одну из своих вотчин в Кирилло-Белозерский монастырь, он также нуждался в особой поддержке государя ${ }^{29}$.

Федор Иванович умер в 1650 г., а потому реализация его распоряжений происходила уже в царствование Алексея Михайловича. Видимо, учитывая это обстоятельство, боярин Шереметев в 1649 г. дополнил ранее написанное завещание «изустной» памятью. Он также мог рассчитывать на поддержку своего зятя боярина Никиты Ивановича Одоевского, имевшего в этот период большое влияние в Думе и, конечно, заинтересованного в точном исполнении воли своего тестя. И хотя племянникам все же достались несколько сот дворов (в том числе и знаменитое в дальнейшем сельцо Кусково), но основные земельные и дворовые владения, как и хотел завещатель, перешли к дочери Евдокии и ее сыновьям, преимущественно младшему Якову ${ }^{30}$.

Итак, князья Прозоровские и князь Мещерский, а еще ранее боярин Ф.И. Шереметев как представители высших кругов знати, обращаясь в своих завещаниях к высокому покровительству венценосных особ, искали у них защиты семейным или родовым наследственным интересам. Другим стимулом было желание иметь гарантию точного исполнения своей воли, в том числе и относительно распоряжений о поминовении души, или когда эта воля не вполне соответствовала существующему порядку.

Иной расчет двигал виднейших представителей высшей бюрократии нового типа. Они уже как государственные мужи искали у монарха милосердного попечения и щедрот своим детям, братьям и племянникам. Такие

${ }^{29}$ Духовное завещание боярина Федора Ивановича Шереметева 1645 г. // Барсуков А.П. Род Шереметевых. СПб., 1883. Т. 3. С. 495-510. На эти важные детали духовной Ф.И. Шереметева внимание автора статьи обратила О.Е. Кошелева, за что приношу ей благодарность.

${ }^{30}$ Подробнее см.: Кошелева О.Е. Родственные связи в высших кругах знати XVII столетия и землевладение // Cahiers du Monde russe. 2016. Vol. 57. № 2/3. Р. 545-570. 
обращения в духовных завещаниях к монархам также были не редкостью. Так, Кирилл Алексеевич Нарышкин, ближний кравчий, первый комендант Санкт-Петербурга (1710-1716 гг.) и московский губернатор (1716-1719 гг.), в своей духовной, написанной незадолго до смерти в 1723 г., после пространной ссылки на Святое Писание и воспоминания о временном житие и дне Страшного Суда просил «всеусердно его императорского величества всемилостивого нашего манарха и государя... оставшия по мне дети мои, дабы в его равно отеческих милосердых щедротах оставлены не были» ${ }^{31}$. Далее следовали указания душеприказчикам, духовному отцу, протопресвитеру Большого Успенского собора Федору Панкратьевичу и Александру Львовичу Нарышкину, сыну боярина Л.К. Нарышкина, двоюродному брату Петра I, относительно погребения и поминальных служб. Все свое недвижимое имение (вотчины и московские дворы) К.А. Нарышкин завещал старшему сыну Семену (Симеону), а движимое распределил между младшим сыном и четырьмя незамужними дочерями (Авдотьей, Дарьей, Софьей, Натальей). Сыну Петру предназначалась серебряная посуда и деньги, что оставались после награждения дочерей. Денег, видимо, было немало, так как дочери получали очень крупную сумму в 20 тыс. руб. Петру же доставались и заемные деньги. Дочь Татьяна, выданная замуж за князя Михаила Михайловича (Меньшого) Голицына, из наследства исключалась как получившая приданое и деньги на покупку вотчины. Упомянутым в завещании сыновьям К.А. Нарышкина в то время было: Семену — 13 лет (1710-1775), Петру — 10 лет (1713-1770). Имущественные распоряжения Кирилла Алексеевича соответствовали действующим правовым нормам, и у него вряд ли были сомнения в точности их исполнения. Другое дело - перспективы служебной карьеры сыновей, еще не вступивших в службу и нуждавшихся в видах карьерного роста в сильном покровителе. Таковой был найден в лице душеприказчика А.Л. Нарышкина, назначенного также опекуном малолетних детей завещателя. Его как «милостивого» и «милосердного» своего государя К.А. Нарышкин просил: «Да милосердствует над оставшими детьми моими во всем призирает и попечение об них да имеет, и в чем принадлежит да просит об них его императорского величества милосердия (курсив мой. - Н.К.)».

Упование на будущие милости государя отражало изменение основ взаимоотношений дворянства, в том числе политической элиты с монархом. При отсутствии прямой связи между службой и земельными дачами и с учетом возможности получения новых земельных владений лишь в качестве пожалования государя немалое значение для статуса и благосостоя-

${ }^{31}$ Дворяне Москвы... № 280. С. 339-340. 
ния дворян начало играть и личное расположение монарха, близость к нему той или иной фигуры. Этот новый тип отношений и отразился в ряде духовных завещаний чиновной элиты в виде обращений к носителю верховной власти за покровительством и щедротами. Соответствовал он и патримониальному характеру власти российской монархии эпохи империи. В 1721 г. Сенат одновременно с титулами Императора Всероссийского и Великого вручил Петру I титул Отца Отечества. Это выражение в переводе с латинского pater patriae означало «духовный отец своей паствы» и подчеркивало роль Петра I как опекуна своих подданных. Как видно из рассмотренных духовных завещаний, верхи общества уже были готовы к восприятию и использованию подобных отношений с монархом.

\section{Литература}

Барсуков А.П. Род Шереметевых. СПб., 1883. Т. 3.

Вершинин А.А. Материалы к составлению родословной росписи дворян Римских-Корсаковых // Культура и быт русского дворянства в провинции XVIII в. Проект Германского исторического института в Москве (URL: http://adelwiki. dhi-moskau.de/index.php).

Владимирский-Буданов М. Ф. Обзор истории русского права. 3-е изд. Киев; СПб. 1900.

Воскресенский Н.А. Петр Великий как законодатель. Исследование законодательного процесса в России в эпоху реформ первой четверти XVIII века. М., 2017.

Дворяне Москвы: свадебные акты и духовные завещания петровского времени / Сост., очерки и коммент. Н.В. Козловой и А.Ю. Прокофьевой. М., 2015.

Законодательные акты Петра I. Редакции и проекты законов, замети, доклады, доношения, челобитья и иностранные источники. Сборник документов. В 3 т. / Сост. Н.А. Воскресенский. Т. 2: Акты об общественных классах; Т. 3: Акты о промышленности и торговле / Отв. ред. Е.В. Анисимов; предисл. и подгот. текста Д.О. Серов; археограф. предисл. А.А. Богданов. М., 2020.

Индова Е.И. К вопросу о дворянской собственности в России в поздний феодальный период // Дворянство и крепостной строй в России XVI-XVIII вв.: Сборник статей, посвященный памяти Алексея Андреевича Новосельского. М., 1975. С. 272-292.

Киприянова Н.В.К вопросу о дворянском землевладении в законодательстве XVIII века// Вестник Московского университета. Сер. 8. История. 1983. № 1. C. 57-69.

Козлова Н.В. Из истории семейно-имущественных отношений в среде привилегированного купечества в начале XVIII века // Экономика, управление, демография городов Европейской России XV-XVIII веков. История, историография, источники и методы исторического исследования: Материалы научной конференции, Тверь, 18-21 февраля 1999 г. Тверь, 1999. С. 56-63. 
Козлова Н.В. Имущественное право и положение женщины в купеческой семье Москвы XVIII в. // Столичные и периферийные города Руси и России в Средние века и раннее Новое время XI-XVIII вв. Проблемы культуры и культурного наследия: Доклады Третьей научной конференции (Муром, 17-20 мая 2000 г.). М., 2003. С. 259-275.

Козлова Н.В. Люди дряхлые, больные, убогие в Москве XVIII века. М., 2010.

Козлова Н.В. Семейно-имущественные отношения в среде московского купечества XVIII века (к постановке проблемы) // Столичные и периферийные города Руси и России в средние века и раннее новое время (XI-XVIII вв.): Доклады Второй научной конференции (Москва, 7-8 декабря 1999 г.) М., 2001. С. 148-159.

Кочелева O.E. Родственные связи в высших кругах знати XVII столетия и землевладение // Cahiers du Monde russe. 2016. Vol. 57. № 2/3. Р. 545-570.

Латкин В. Н. Учебник истории русского права периода империи (XVII-XIX вв.). 2-е изд. СПб., 1909.

Милашева Н.В., Самойлов В.О. Первые военные госпитали Санкт-Петербурга // Вестник Российской Военно-медицинской академии. 2020. № 3(71). С. 258-266.

Новицкая T. Е. Правовое регулирование имущественных отношений в России во второй половине XVIII века. М., 2005.

Прозоровский А.А. Записки генерал-фельдмаршала князя Александра Александровича Прозоровского, 1756-1776. М., 2004.

Савельев $A$. Юридические отношения между супругами по законам и обычаям великорусского народа. Н. Новгород, 1881.

Сергеевич В.И. Лекции и исследования по древней истории русского права. 3-е изд. СПб., 1903.

Цатурова М.К. Русское семейное право XVI-XVIII вв. М., 1991.

Якушкин В.Н. Очерки по истории русской поземельной политики в XVIII и XIX вв. М., 1890. Вып. 1: XVIII в.

Intinera petri: Биохроника Петра Великого день за днем. 06.05.1718, вт. П. в СПб (URL: https://spb.hse.ru/humart/history/peter/biochronic/228259731).

Lee A. Farrow. Peter the Great's Law of Single Inheritance: State Imperatives and Noble Resistance// Russian Review. Vol. 55. №. 3 (Jul., 1996). P. 430-447. 


\title{
А.И. Комиссаренко
}

\section{«УЧИНИЛИ НАПАДЕНИЕ И ОРУЖЕЙНУЮ И ИЗ ЛУКОВ СТРЕЛЬБУ» \\ (СОЦИАЛЬНЫЕ ДВИЖЕНИЯ В ВЯТСКОМ КРАЕ В ПЕРВОЙ ПОЛОВИНЕ XVIII В.)}

\begin{abstract}
Аннотация В статье исследуются социальные движения черносошных и церковных крестьян Вятской провинции в 20-40-х гг. XVIII в. Выявляются причины и факторы волнений, рассматриваются действия местной и центральной администрации - провинциальной канцелярии и Сената по их устранению.

Ключевые слова: Вятский край, провинциальная канцелярия, Сенат, крестьяне, дифференциальное расслоение, волнения, воинские команды.

Summary In article features of cocial movements and protest in peasants and differential. Reveal of factors in the amongst of peasants Vjatka region and function of province office and Russian Senat in the 20-40 years XVIII century.

Keywords: Vjatka region, province office, Senat, peasants, social different, agitation, military commands.
\end{abstract}

В историографии еще в дореволюционный период утвердился взгляд на широкий размах крестьянских волнений в середине и второй половине XVIII в. ${ }^{1}$ Но вопрос о социальных движениях вятского крестьянства не был исследован. Один из первых краеведов Вятки А. Вештомов - автор «Истории вятчан», написанной в 1824 г., лишь упоминал о волнениях местных крестьян ${ }^{2}$. В очерках по истории Вятской губернии, написанных членом местной архивной комиссии Андриевским в 1880 г. в связи со столетием переименования г. Хлынова в Вятку, сообщалось о «бунтах» церковных 
крестьян в середине XVIII в. ${ }^{3}$ Историки советского времени ${ }^{4}$ сделали первые шаги по осознанию сущности волнений на Вятке с середины XVIII в., но их подробности «из-за отсутствия источников остались неизвестными» ${ }^{5}$. Что касается более ранних попыток вятских крестьян выступить против правительственной и церковной политики в первой половине XVIII в., то они остались вне поля зрения историков и краеведов.

Источниками для нашего исследования послужили архивные материалы, хранящиеся в РГАДА. В фонде Вятской провинциальной канцелярии (ф. 425) отложились документы, характеризирующие начальный этап крестьянских выступлений на Вятке, приходящихся на 1730 - начало 1750-х гг. Особенно важны в этом отношении в качестве источника росписные списки вятских провинциальных администраторов - воевод Андрея Писарева 1744 г., Дубенского 1750 г., следственные дела по обвинению провинциального секретаря Аверкия Перминова и секунд-майора Федора Бестужева в различных служебных злоупотреблениях, челобитные крестьян церковных владений с жалобами на насильственную запись их во время ревизий 1720 -х и 1740-х гг. в разряд монастырских и архиерейских в качестве половников или срочных работников. Ценные источники хранит фонд Сената, среди них 29 дел Комиссии Полянского о волнениях церковных крестьян, считавших себя незаконно записанными за монастырями и архиерейским домом. Важны также грамоты и акты Вятского Успенского Трифонова монастыря, опубликованные в «Трудах Вятской ученой архивной комиссии» в 1906-1915 гг., до этого частично использованы А. Спицыным ${ }^{6}$ и А. Верещагиным

Доля церковных крестьян среди всего населения была значительной. Как явствует из росписного списка хлыновского воеводы Постельникова при передаче дел новому воеводе прапорщику Дубенскому, из 145453 д. м. п. 34459 д. м. п. считались церковными 8 . Крестьянство Вятки в социальноэкономическом отношении было дифференцировано, среди него имелись половники, срочные работники, но также и крестьяне «состоятельные», занимавшиеся торговыми операциями. Основная масса представляла черносошное (государственное) крестьянство, около $23 \%$ из них находились в ведении монастырей и архиерейского дома. Эта категория населения

3 Столетие Вятской губернии. Вятка, 1880. Т. 1. С. 76.

4 Токарев С.В. Крестьяне Вятской провинции в XVIII веке. Вятка, 1928. С. 38-45; Эммаусский А.В. Исторические очерки Вятского края XVII-XVIII вв. Киров, 1956. С. 129.

5 Столетие Вятской губернии. Т. 1. С. 27.

6 Спицын A. Вотчины вятского Успенского монастыря. Вятка, 1885.

7 Верещагин А. Послесловие к изданию грамот вятского Успенского Трифонова монастыря // Труды Вятской ученой комиссии. Вятка, 1906. Вып. 1-6.

8 РГАДА. Ф. 425. Оп. 2. Д. 130. Л. 515-516; Д. 178. Л. 78-79. 
испытывала двойной гнет — кроме уплаты подушных денег государству они обязаны были выполнять повинности в пользу церковных владельцев. По данным на 1722 г., например, с крестьян вятского Успенского Трифонова монастыря собиралось 1299 руб. К тому же крестьяне обрабатывали на монастырь 1206 четвертей пашни, собирали сено с 1 тыс. десятин и ставили 10385 копен. Жители архиерейской Кырмыжской вотчины жаловались: «В прошлом...745 году развели на архиерейские столовые расходы денежный оклад по рублю на осьмину... да за штрафные за невывоз прошлых лет потребовано... по 1 рублю 20 копеек... да собрано ружного ржаного и ярового хлеба 62 четверти с половиной» ${ }^{9}$. Такая же картина наблюдалась и в других церковных владениях. Так, верхочепецкий Воздвиженский монастырь в 20-х гг. XVIII в. владел 1612 д. м. п. и засевал более 300 четвертей пашни, собирал с крестьян 732 руб. в год ${ }^{10}$. За слободским Богоявленским монастырем было записано 1010 д. м. п., 250 четвертей пашни. Всего же за всеми вятскими монастырями по первой ревизии и данным Синода в конце 30-х гг. XVIII в. числилось 35113 д. м. п., 8349 четвертей пашни, 33783 копны сена, 71 мельница, 22273 рубля денежного дохода ${ }^{11}$.

Источники сохранили сведения о ряде социальных выступлений вятских крестьян в первой половине XVIII в. Тяжелые поборы, введение правительством подушной подати, насильственная процедура проведения ревизской переписи, рекрутчина и набор работников на строительство Петербурга, крепостей, каналов, а также неурожайные годы, голод в начале третьего десятилетия, незаконная запись черносошных крестьян в разряд церковных вызвали недовольство среди основной массы сельского населения края. Немало крестьян укрылось тогда в лесах, пополняя ряды «воров и разбойников». Протест выливался в форму нападений на представителей власти, церковных служителей, состоятельных крестьян - скупщиков, их дворы и торговые обозы. Такие выступления по официальной терминологии квалифицировались в качестве «разбоев», а их участники именовались «ворами и разбойниками». Они вынудили правительство учредить в стране своего рода округа в губерниях и провинциях по «искоренению воров и разбойников», в которые направлялись воинские команды. Острота крестьянских волнений в волостях волжско-камского бассейна, который рассматривался центральной и местной администрацией как связующее звено между Центром, Поволжьем, Уралом и Сибирью, беспокоила центральную и местную администрацию.

\footnotetext{
9 Там же. Ф. 248. Кн. 267. Л. 1223-1224, 1553-1553 об.

${ }^{10}$ Там же. Ф. 301. Оп. 1. Д. 202. Л. 34-44, 119-121.

${ }^{11}$ Труды Вятской ученой комиссии. Вятка, 1916. Вып. 1-2.
} 
3 июля 1733 г. вятский провинциальный воевода Чернавский получил уведомление из губернского города Казани «о посылки вверх и вниз» реки Вятки, а также по Волге и Каме военных отрядов (не менее 50 человек в каждом) во главе с обер-офицерами «для поимки и искоренения воров и разбойников» ${ }^{12}$. Воевода признал расширение крестьянских протестов в уездах провинции. Он рапортовал в Казань о появлении в Истобенском оброчном стане крестьян, укрывавшихся в лесах и создавших там вооруженные группы по 20-30 человек в каждой с целью нападения на «первостепенных» сельских жителей и купеческие обозы с товарами. Волнениями были затронуты и церковные вотчины в Верхошиженской и Ошетской волостях. Воеводская администрация сообщала о крестьянских отрядах Василия Коротких и Федота Телегина.

Попытки воеводы и воинских команд захватить участников протеста долго не удавались. Крестьяне, как сообщал воевода в Казань, «от поимания отбились и посланных... много переранили». Когда же был окружен двор Федота Телегина в деревне Янашной, вооруженные «толпы... учинили нападение и оружейную и из луков стрельбу, и тем многих переранили и, поймав, перевязали, и били, и одного убили до смерти» ${ }^{13}$. Часто подвергались нападениям хозяйства «первостатейных» селян и купцов - владельцев земли с крестьянами-половниками и срочными работниками. Так, в 1723 г. хлыновский купец Иван Семенов сын Злыгостев жаловался, что 5 августа на его деревню Желтые Пески в Ильганской волости совершил набег отряд «воров и разбойников», состоявший из беглых крестьян. Движимые социальными мотивами, чувством мести, нападавшие сожгли купеческие хозяйственные постройки, в том числе житницу с 36 четвертями ржи, 34 четвертями овса, 7 четвертями семян, 20 овчинами, 20 пудами патоки и меду ${ }^{14}$. В 1726 г. другой крестьянский отряд подверг разгрому мельницы хлыновского купца Данилы Яковлева сына Хохрякова в Чепецком оброчном стане и амбары при них. Убытки составили более 70 руб. Через 29 дней была сожжена и мельница хлыновского купца Александра Прозорова в Березовском оброчном стане, в феврале того же года была также разрушена мельница хлыновского купца-ростовщика Ивана Борисова сына Свешникова ${ }^{15}$. Регулярность подобных актов позволяет предположить, что они совершались обдуманно.

Жгучую ненависть крестьян вызывали ростовщики, наживавшиеся на народных страданиях в 1720-1730-е неурожайные годы. Ядро воору-

\footnotetext{
${ }^{12}$ РГАДА. Ф. 425. Оп. 1. Д. 27. Л. 54, 58-58 об.

${ }^{13}$ Там же. Оп. 2. Д. 6. Л. 60-61.

14 Там же.

${ }^{15}$ Там же. Оп. 1. Д. 19. Л. 2-10.
} 
женных крестьянских отрядов составляли половники и срочные работники. Именно они наносили деревенской верхушке ощутимые удары, вплоть до уничтожения хозяйств, а иногда и физического устранения их владельцев. К примеру, 22 марта 1726 г. в деревню купцов Болюловых в Березовском оброчном стане вошла вооруженная «толпа» из крестьян. Она подступила к хозяйскому двору и захватила владельца. Как рассказывал в провинциальной канцелярии его сын Стефан Евтиев Болюлов, «отца моево сожгли огнем», взяли имущество ростовщика: более 100 руб., 2 котла, шубу и множество мелких вещей. В это же время пострадали и другие купцы - Константин Плюснин, Андрей Белтюков, владевшие землей и хозяйством в Великорецком стане и Филипповой слободке. Нападавшие стремились уничтожить документы — «крепости» о половье и срочных работах ${ }^{16}$.

Через 20 дней такой же участи подверглась мельница видного хлыновского купца Александра Прозорова в Березовском оброчном стане. В январе 1730 г. мирской староста Истобенского оброчного стана Иван Трифонов жаловался провинциальной канцелярии о появлении из леса «неких» людей, захвативших у него немало «приходных и расходных книг и платежных казенных отписей... тако ж крепостей на пожни» ${ }^{17}$. В июне того года был сожжен двор с хозяйственными посройками жителя Косинской волости Филипповой слободки крестьянина-«скупщика» Ивана Иванова сына Казакова. При этом, как жаловался пострадавший в провинциальной канцелярии, «неведомо какие... люди» сожгли 50 концов холста, 10 кафтанов... да книги подушного збору прошлых 727 и 728 годов, книги доимочные и платеж кабальных долгов». В пожаре сгорели и «15 рублей денег серебрянных и 25 голов скота» ${ }^{18}$.

Как видно, в этих случаях речь шла об уничтожении хозяйств и имущества «первостатейных» крестьян - ростовщиков и скупщиков, а также купцов, имевших деревни в вятских уездах и станах. В начале 1731 г. провинциальная администрация расследовала дело о нападении на хозяйство хлыновского купца Семена Филиппова сына Калинина в деревне Новокопышенской Истобенского оброчного стана. Появившиеся из окрестных лесов «вооруженные люди», искавшие «крепости... всякие... на крестьян». Они изъяли у владельца 3 пуда соли, 2 короба льна и 2 тыс. «жемчугов». В мае 1735 г. купеческая вдова Настасья Машкина, жившая в Кырчанской вотчине вятского Успенского Трифонова монастыря, сообщила в провинциальную

\footnotetext{
${ }^{16}$ Там же. Л. 15 об.-16, 24-26.

${ }^{17}$ Там же. Оп. 2. Д. 31. Л. 3-9.

${ }^{18}$ Там же. Оп. 1. Д. 27. Л. 54, 58-58 об.
} 
канцелярию о разорении ее дома и двора, стоимость которых она определила в 236 руб. ${ }^{19}$

На массовое укрывательство крестьян в лесах указывает указ воеводской канцелярии от 30 марта 1734 г., предписывавший крестьянским выборным - старостам, десятским, чтобы они «о собрании и совещании к побегу крестьян проведывали тайно и явно накрепко, и ежели о том уведают... таких собравшихся к побегу крестьян удерживать». Особенно рекомендовалось обратить внимание на тех крестьян, которые использовали «паспорта» для «обычные отлучки» из своих деревень якобы для работ и торговли. Одновременно провинциальные чиновники старались выдворить с Вятки крестьян, пришлых из других мест. Случалось, что такие пришлые оказывали сопротивление этим попыткам. Например, в июне 1733 г. толпа собранных пришедших крестьян направилась в Великоустюжскую провинцию. Не успев отойти от Хлынова, она захватила своих конвоиров Г. Гмызина, П. Селюлина и, избив их, «бросила на дороге, разбежалась» по окрестным лесам.

Как правило, вооруженные группы состояли из беглых местных и пришлых крестьян, а также рекрутов, половников. Так, в 1744 г. казначей Богословского монастыря арестовал 10 крестьян, совершавших «набеги» на монастырскую вотчину. Среди них оказались крестьянин Каргопольского уезда Степан Мельников, вятского Великорецкого стана Павел Макаров, вятского Котельнического уезда Андрей Бурмаков, Петр Вересаев. Они были изобличены в разорении дворов богатых крестьян. В январе 1744 г. они совершили нападение на двор жителя Котельнического уезда Петра Ковалева. Хозяин потерял 80 руб., 90 аршин кружев шелковых, 580 аршин тонкого холста, 5 кокошников золотых, 13 овчин, 3 котла медных.

Нередко местные и «пришлые» крестьяне оказывали яростное сопротивление провинциальным и церковным властям. В качестве примера отметим события 1744 г. Для задержания беглых крестьян, поселившихся на землях подгородного Богословского монастыря, выехал канцелярист Иван Лобовиков. По приезде в вотчину оказалось, что в «толпе» было не менее 300 человек, собравшихся у мирской избы и имевших при себе «огненное ружье». На требование Лобовикова выдать инициаторов сходки - Илью Одинцова, Степана Долгих, Данилы Петухова, Василия Бачиранова, Дмитрия Герюшковского - последовал резкий отказ. Все они являлись выходцами из соседнего Устюжского уезда. Когда же Лобовиков потребовал передать ему списки жителей («кто откуда пришел») староста снова ответил отка-

\footnotetext{
${ }^{19}$ Там же. Д. 34. Л. 118.
} 
зом, заявив, что они поселились «на черный лес» по указанию Устюжской канцелярии и поэтому не считают себя «в послушании» ни монастырю, ни вятской «канцелярии». И. Лобовиков был схвачен и «забит... в колодки» ${ }^{20}$.

В начале 1740-х гг. участились случаи волнений нерусского населения, недовольного насильственным крещением. Созданная в 1742 г. в Казани контора Новокрещенских дел стремилась обратить «инородцев» в христианскую веру $^{21}$. В 1744 г. полномочия по обращению «остяков» (удмуртов, хантов. A.K.) в православие получил от Новокрещеной конторы архимандрит Свияжского Богородицкого монастыря Сильвестр (Гловацкий). На Вятке в Слободском уезде в деревне Глазовой он начал свою миссию. При этом не только увещевал жителей «ко святому крещению», но и искал удобные места для строительства храмов и монастырей. Действия миссионера вызвали слухи среди местного населения о намерения изъятия у него земли и передаче ее вместе с ними в ведение церковных учреждений. Когда же Сильвестр не нашел для строительства храма подходящего места и установил на нем «животворящий крест», толпа «иноверцев» численностью в 150 человек и «более» с кольями, вилами и ножами бросилась на холм и, выбив тот крест, его «ногами топтали». Затем жители осадили избу, в которой находился архимандрит с «духовными персонами», и, ворвавшись в нее, растоптали сумку со «священными... запасными святой Евхаристии дарами», после чего избили караульных солдат «смертно». В феврале 1745 г. староста Верхочепецкой остяцкой нижней доли заявил от имени жителей об отказе платить подушные деньги и принимать «святое крещение». Из Хлынова для прекращения волнений «иноверцев» власти отрядили воинскую команду с предписанием «взыскивать оставшихся в неверии по силе указов без упущения». О действиях этой команды, к сожалению, источников не обнаружено 22 .

Вышеуказанные факты активных социальных выступлений крестьян Вятки дополняют наблюдения П.К. Алефиренко о массовых крестьянских волнениях, считавшей, что в первой половине XVIII в. произошло не менее 57 выступлений крестьян ${ }^{23}$. С учетом волнений вятских крестьян в этот период их, конечно, было больше. Во второй половине столетия на Вятке произошли волнения более 11 тыс. церковных крестьян, считавших себя незаконно записанными в ведение церкви ${ }^{24}$.

${ }^{20}$ Там же. Д. 66. Л. 401-403.

${ }^{21}$ Государственные учреждения России в XVIII веке. Законодательные материалы / Сост. А. В. Чернов. М., 1960. С. 420.

${ }^{22}$ РГАДА. Ф. 425. Оп. 1. Д. 70. Л. 14-15 об.

${ }^{23}$ Алефиренко П.К. Крестьянское движение и крестьянский вопрос в России 30-50-х годов XVIII века. М., 1958.

24 Эммаусский А.В. Указ. соч. 


\section{Литература}

Алефиренко П.К. Крестьянское движение и крестьянский вопрос в России 30-50-х годов XVIII века. М., 1958.

Верещзагин А. Послесловие к изданию грамот вятского Успенского Трифонова монастыря // Труды Вятской ученой комиссии. Вятка, 1906. Вып. 1-6.

Вештомов А. История вятчан. Казань, 1824.

Государственные учреждения России в XVIII веке. Законодательные материалы / Сост. А.В. Чернов. М., 1960.

Семевский В.И. Крестьяне в царствование Екатерины II. СПб., 1904. Т. 2.

Соловьев С.М. История России с древнейших времен. СПб., 1874. Т. 24.

Спицын A. Вотчины вятского Успенского монастыря. Вятка, 1885.

Столетие Вятской губернии. Вятка, 1880. Т. 1.

Токарев C.B. Крестьяне Вятской провинции в XVIII веке. Вятка, 1928.

Эммаусский А.В. Исторические очерки Вятского края XVII-XVIII вв. Киров, 1956. 


\section{Н.А. Комочев}

\section{О ПЕРВОМ НАУЧНОМ ТРУДЕ Е.Н. ШВЕЙКОВСКОЙ}

Аннотация Статья посвящена рассмотрению студенческой дипломной работы, написанной Е.Н. Баклановой (Швейковской) в Московском государственном историко-архивном институте и защищенной под руководством С.О. Шмидта. Работа касается статей художника К.С. Петрова-Водкина как исторического источника. Дипломное исследование отражает высокий уровень владения автором принципами источниковедения, текстологии, археографии. Намеченные в студенческие годы методы исследования получили затем продолжение и развитие в трудах Е.Н. Швейковской, посвященных истории крестьянства и аграрной истории.

Ключевые слова: К.С. Петров-Водкин, Е.Н. Швейковская, Московский государственный историко-архивный институт, кафедра вспомогательных исторических дисциплин, источниковедение истории искусств, археография.

Summary The article is devoted to the student's thesis about the articles of K.S. PetrovVodkin as a historical source written by E.N. Baklanova (Shveykovskaya) at the Moskow State Institut for History and Archives under the supervision of S.O. Schmidt. This study shows a high level of proficiency in source studies, textology, archeography. Scientific research methods were then continued and developed in the works of E.N. Shveykovskaya, dedicated to the history of the peasantry and agrarian history.

Keywords: K.S. Petrov-Vodkin, E.N. Shveykovskaya, S.O. Schmidt, Moskow State Institut for History and Archives, Department of auxiliary historical disciplines, source study of art history, archeography.

На кафедре вспомогательных исторических дисциплин и археографии Историко-архивного института РГГУ хранится коллекция материалов преподавателей и студентов разных лет. Среди них дипломная работа Е.Н. Баклановой (Швейковской) на тему «Статьи К.С. Петрова-Водкина: опыт источни- 
коведческого анализа», защищенная 27 мая 1963 г. под руководством тогда еще доцента С.О. Шмидта ${ }^{1}$. Поскольку эта студенческая работа является первым крупным исследованием в биографии будущего профессора и доктора исторических наук, обратимся к преемственности содержания исследования с последующими научными трудами юбиляра.

Сразу отметим значительную для своего времени новизну темы. Научных трудов, посвященных творчеству К.С. Петрова-Водкина, на тот момент было крайне мало, архивные источники почти не были введены в научный оборот. После 1920-1930-х гг. творчество художника в официальном искусствоведении оценивалось критически и не вполне одобрялось. Сыграл свою роль и известный отзыв М. Горького о книге «Пространство Эвклида» ${ }^{2}$. Было не очень понятно, в какой «лагерь» зачислять К.С. Петрова-Водкина, произведения и тексты которого не слишком соответствовали господствующему в советском искусстве стилю. Подъем интереса приходится на более позднее время³ ${ }^{3}$ когда сочинения начали переиздаваться, появились статьи, книги и диссертации, посвященные творчеству художника.

Характерно, что дипломная работа «написана почти полностью на архивном материале» ${ }^{4}$, в том числе ранее не публиковавшемся. Рукописи К.С. Петрова-Водкина поступили в Центральный государственный архив литературы и искусства в 1952 г., а обработаны были в 1955 г. К моменту написания

${ }^{1}$ Бакланова Е.Н. Статьи К.С. Петрова-Водкина: опыт источниковедческого анализа. Дипломная работа / Руководитель С.О. Шмидт. М., 1963. 112 с. Машинопись с отдельными рукописными вставками. По информации, сообщенной А.В. Мельниковым, экземпляр работы сохранился также в личном архивном фонде С.О. Шмидта (Архив РАН. Ф. 2218).

2 В тексте статьи М. Горького «О прозе» (1933) есть, например, такие выражения об упомянутой книге: «Козьма Петров-Водкин выдумывает так плохо, что верить ему 一 невозможно. Плохо выдумывает он потому, что, при всей его непомерной хвастливости и самообожании, он человек всесторонне малограмотный. О нем можно бы не говорить, если б книга его не являлась вместилищем словесного хлама» (Горький М. Собрание сочинений. В 30 т. М., 1953. Т. 26. С. 399). Сам художник, судя по всему, отнесся к прозвучавшим эпитетам мудро, в письме к А. Белому от 27 октября 1933 г. он писал: «Залихватская статья Алексея Максимовича, напоминающая лузг семечек под гармошку, еще больше подзадоривает меня к работе» (Петров-Водкин К.С. Письма. Статьи. Выступления. Документы / Сост. Е.Н. Селизарова. М., 1991. С. 281). Очень вдохновляли К.С. Петрова-Водкина теплые отзывы о книгах. Так, М.В. Нестеров отмечал их «несравненную простоту, неподдельный тон, теплоту повествования» (Там же). Для сравнения приведем и современную цитату об оценке литературного стиля К.С. Петрова-Водкина, проза которого справедливо характеризуется «мастерством языка, глубиной мыслей, логически прочно увязанными картинами реальной жизни с метко обрисованными характерами и поэтическими пейзажами, с экскурсами в историю и теорию искусства, с поисками в нем своего места». Цит. по: Михайлова М. Путь к себе. О прозе Кузьмы Сергеевича Петрова-Водкина // Петров-Водкин К.С. Хлыновск. Пространство Эвклида. О «Мире искусства». М., 2011. С. 379.

3 Всплеск интереса наблюдался со второй половины 1960-х гг, и затем уже в 1990-2000-х гг.

4 Бакланова Е.Н. Указ. соч. С. 7. 
дипломной работы документы почти не использовались исследователями, и перед нами один из самых первых опытов обращения к этим материалам.

В архивном фонде художника в ЦГАЛИ (ныне РГАЛИ) Е.Н. Баклановой были изучены статьи К.С. Петрова-Водкина: «Живопись как ремесло» (1910-1911), «Живопись будущего» (1912), «Наука видеть» (1917-1920), «Высшая художественная школа» (1922), а также «Повороты искусства» (1908-1914), «О декоративности и психологичности живописи» (1911), «Проблема движения» (1922), «Академия художеств до 1917 г.» (1923), «Органическое значение искусства» (1924), «Мой ответ», «Письмо о живописи и об искусстве вообще», «При многочисленных встречах со своими старыми работами», «Налегке», тезисы различных докладов и др. Некоторые тексты представляют собой черновики, фрагменты и незаконченные произведения. Из примечаний по тексту работы следует, что использовались и другие архивные материалы, а также газетные статьи начала XX в. По первым изданиям изучались автобиографические произведения художника «Хлыновск» (1930), «Пространство Эвклида» (1932), отдельные статьи художника (по изданию 1916 г.).

Кроме того, привлекался широкий круг печатных работ о творчестве К.С. Петрова-Водкина, почти все из них вышли не позднее первой половины 1930-х гг. и многие опубликованы в редких изданиях. В библиографическом списке и сносках найдутся упоминания сочинений А.Н. Бенуа, А.С. Галушкиной, С.К. Маковского, Н.Э. Радлова, Я.А. Тугендхольда, М.С. Шагинян, а также современных авторов - Э.М. Белютина, Н.М. Молевой, Д.В. Сарабьянова. Использованы работы по источниковедению А.В. Арциховского, Е.П. Подъяпольской, М.Н. Тихомирова и др.

На основании анализа статей художника Е.Н. Бакланова поставила задачу «дать им оценку как историческому источнику, по возможности проследить, как менялись взгляды К.С. Петрова-Водкина на тот или иной вопрос» ${ }^{5}$. Сейчас такая работа однозначно получила бы оценку как междисциплинарная. На фоне тематики дипломных работ того времени обращение к литературным произведениям художника как историческому источнику, по самой постановке задачи, несомненно, сильно выделяется.

Структура работы классическая для Историко-архивного института, в ней присутствуют три научных направления: история (первая глава) - биография художника; архивоведение (вторая глава) - формирование и состав архивного фонда; источниковедение (третья глава) - текстологический анализ статей. Завершающий параграф («синтез») замыкает обозначенный

\footnotetext{
5 Там же. С. 2.
} 
цикл, вновь возвращая читателя к вопросам истории - эволюции взглядов художника.

Чтение первой главы работы ${ }^{6}$ сразу наводит на размышления об авторском подходе. Несмотря на то, что Е.Н. Бакланова стремится уйти от искусствоведческих вопросов ${ }^{7}$, здесь много говорится об искусстве, затрагиваются как его организационные формы (объединения художников, школы), так и творческие вопросы - поиски авторского стиля, влияния старины и современного искусства, отношение художника к происходящим политическим переменам, общественное назначение художника и т. д. Все это чрезвычайно интересно и наряду с источниковедением составляет основное содержание работы. Отметим отсутствие выраженной политизированности, что является не столь частым явлениям в студенческих дипломных работах 1960-х гг.

Вторая глава ${ }^{8}$ содержит интересные аналитические наблюдения об архивном фонде К.С. Петрова-Водкина (Ф. 2010). Так, в ед. хр. 107 оказалось не четыре самостоятельных статьи, как заявлено в описи, а только две, остальные тексты представляют собой варианты; в ед. хр. 98 нумерация листов не соответствует порядку следования текста; в ед. хр. 102 возникла необходимость перенумеровать листы, поскольку было установлено правильное время возникновение редакций произведений; из ед. хр. 103 стало необходимым изъять часть листов и включить в ед. хр. 102 в связи с уточнением содержания статей художника. По этому поводу Е.Н. Бакланова пишет: «О всех обнаруженных недочетах было сообщено работникам архива, и эти недочеты теперь устранены» ${ }^{9}$. Обзор состава фонда емкий и ясно характеризует содержание произведений.

Третья глава ${ }^{10}$ в дипломной работе наиболее объемна. Первый параграф ${ }^{11}$ посвящен текстологии, в нем подробно рассматриваются: время, история и обстоятельства создания каждой статьи (доклада); реакция современников; все списки, включая черновые, распределены автором работы по редакциям, показаны разночтения между ними; отдельно разобрана текстология каждой редакции. Внимание обращалось на палеографические

6 «Краткий очерк жизни и деятельности К.С. Петрова-Водкина» (С. 8-24).

7 «Работа не ставит своей целью дать характеристику художественного творчества К.С. Петрова-Водкина, его живописных приемов, искусствоведческого разбора его картин». См.: Бакланова Е.Н. Указ. соч. С. 2.

8 «Обзор фонда К.С. Петрова-Водкина» (С. 25-35).

9 Бакланова Е.Н. Указ. соч. С. 26.

10 «Статьи К.С. Петрова-Водкина “Живопись как ремесло”, “Живопись будущего”, “Высшая художественная школа", “Наука видеть”».

${ }^{11}$ «Текстологические наблюдения над статьями» (С. 36-82). 
особенности списков, их различия по стилю и содержанию. В ряде случаев параллельно рассматриваются черновые и беловые варианты. Особенно тщательно проанализированы те фрагменты текста, которые есть в черновиках, но отсутствуют в беловых экземплярах, поскольку именно такие высказывания, как правило, наиболее ярко характеризуют мировоззрение художника и объясняют принципы редактуры текста статей. В главе существенно уточнены датировки некоторых статей; установлены редакции и соотношение между ними; выявлены источники, которые использовал К.С. Петров-Водкин при написании статей.

Завершающий второй параграф третьей главы ${ }^{12}$ содержит отдельные наблюдения о художественной системе К.С. Петрова-Водкина, его отношении к передвижничеству, «Миру искусства», И.Е. Репину, зарубежным мастерам (П. Гогену, П. Сезанну) на основании изучаемых текстов. Параграф достаточно краток и по своему содержанию примыкает к заключению работы.

В приложении публикуется по архивному оригиналу текст статьи К.С. Петрова-Водкина «Живопись как ремесло», в примечаниях приведены исправления и вставки ${ }^{13}$. Отметим, что археографический дебют удался, поскольку благодаря внимательному отношению к передаче текста публикация источника выполнена профессионально и на высоком уровне.

Таким образом, в тексте дипломной работы Е.Н. Баклановой присутствуют основы тех исследовательских направлений, которые получат в дальнейшем развитие в трудах по истории крестьянства, аграрной истории, источниковедению, историографии, археографии. В основе лежит тщательный источниковедческий и текстологический анализ, внимание к формированию архивных фондов как исторически сложившихся комплексов, интерес к человеку в истории и вопросам искусства.

Текст дипломной работы написан хорошим литературным языком, вполне соответствующим художественности изучаемых сюжетов. Проведенная в отношении архивных источников текстологическая работа показывает высокий профессиональный уровень квалификации автора исследования.

Из приложенного к дипломной работе отзыва научного руководителя С.О. Шмидта следует, что подготовка работы осуществлялась в сжатые сроки - в течение пяти месяцев ${ }^{14}$. А это показывает высокий уровень подготовки специалистов в Историко-архивном институте.

\footnotetext{
12 «Некоторые замечания о взглядах К.С. Петрова-Водкина» (С. 83-91).

${ }^{13}$ Бакланова Е.Н. Указ. соч. С. 94-107.

${ }^{14}$ Отзыв представляет собой авторизованную машинопись и датирован 23 мая 1963 г., т. е. составлен за четыре дня до защиты.
} 
Читая дипломную работу по источниковедению истории искусств, казалось бы, трудно предположить, что ее автор окажется в будущем связан с Археографической комиссией, в то же время в своем отзыве С.О. Шмидт особенно отметил интерес Е.Н. Баклановой к археографии: «Автор обнаружил большие склонности и способности к археографической работе, и дипломная работа принесет значительную пользу всем тем, кто будет в дальнейшем изучать творчество К.С. Петрова-Водкина».

Невольно возникают параллели и неожиданные пересечения. Например, Е.Н. Швейковская в числе авторов, повлиявших на методологию ее исследований по источниковедению, называет труды А.С. Лаппо-Данилевского, младший сын которого, А.А. Лаппо-Данилевский (1898-1920), был одним из любимых учеников К.С. Петрова-Водкина ${ }^{15}$. Не случаен неизменный интерес Елены Николаевны к изобразительному искусству, классической музыке, междисциплинарным исследованиям.

Все это говорит о том, что обращение Е.Н. Швейковской к статьям об искусстве в дипломной работе в чем-то закономерно и именно изучение материалов творческого характера явилось той источниковедческой школой, последующими плодами которой стали фундаментальные труды по аграрной истории и истории повседневности. А дипломная работа Е.Н. Баклановой (Швейковской), хотя и не была опубликована, все же остается в историографии в числе первых исследований литературного наследия К.С. Петрова-Водкина, выступающего на страницах своих произведений как художник, философ, писатель.

\section{Литература}

Бакланова Е.Н. Статьи К.С. Петрова-Водкина: опыт источниковедческого анализа. Дипломная работа / Руководитель С.О. Шмидт. М., 1963. 112 с. (машинопись с рукописными вставками).

Горький М. О прозе // Горький М. Собрание сочинений в 30 томах. М., 1953. Т. 26. Статьи, речи, приветствия. 1931-1933. С. 387-408.

Петров-Водкин К.С. Письма. Статьи. Выступления. Документы / Сост., вступ. ст. и коммент. Е.Н. Селизаровой. М., 1991.

Петров-Водкин К.С. Хлыновск. Пространство Эвклида. О «Мире искусства». Литературное и художественное наследие. М., 2011.

${ }^{15}$ При деятельном участии К.С. Петрова-Водкина в 1920 и 1928 гг. были организованы две выставки работ А.А. Лаппо-Данилевского, вышел каталог (1928). Выдержки из доклада «Жизнь и творчество А.А. Лаппо-Данилевского», прочитанного 28 мая 1920 г., опубликованы: Петров-Водкин К.С. Письма. Статьи. Выступления. Документы. С. 295. 


\section{А.Л. Лифшиц}

\section{ОДНА СВАДЬБА, ДВЕ ГРАМОТЫ}

Аннотация Статья посвящена двум грамотам последней четверти XVII в., служащим иллюстрацией к процессам изменения норм наследования имущества, остающегося после смерти бездетной супруги. 28 января 1681 г. принимаются поправки в действующее законодательство, согласно которым бездетный вдовец оставляет за собой четверть приданого умершей жены. До того он должен был возвращать приданое полностью. Публикуемые документы фиксируют ранний случай применения новых правовых норм, которые и в дальнейшем многократно корректировались в поисках приемлемого для сторон решения. Ключевые слова: Россия, XVII век, семейное право, брак, приданное, наследование.

Summary The article is devoted to two documents of the last quarter of the 17th century, illustrating the processes of changing the norms of inheritance of property left after the death of a childless spouse. On January 28, 1681, amendments to the current legislation were adopted, according to which a childless widower retains a quarter of the dowry of his deceased wife. Before that, he had to return the dowry in full. The published documents record an early case of the application of new legal norms, which were subsequently repeatedly corrected in search of a solution acceptable to the parties.

Keywords: Russia, XVII century, family law, marriage, dowry, inheritance.

В конце XIX столетия Московский университет получил по завещанию библиотеку, принадлежавшую калужским и московским помещикам Александру Васильевичу Иевлеву (1822-1893) и его старшему брату Николаю Васильевичу (1819-1852)2. Вместе с библиотекой поступил и семейный

1 Исследование выполнено при поддержке Междисциплинарной научно-образовательной школы Московского университета «Сохранение мирового культурно-исторического наследия».

2 Речь и отчет, читанные в торжественном собрании Императорского Московского университета 12-го января 1894 года. М., 1894. С. 113; Сафонова Н.И. Личные библиотеки в собрании Отдела редких книг и рукописей Научной библиотеки им. А.М. Горького МГУ // Рукописная и печатная книга в фондах Научной библиотеки Московского университета. М., 1973. С. 79. 
архив $^{3}$, содержащий помимо других бумаг изрядное количество столбцов XVII в., относящихся в основном к этому дворянскому семейству, владевшему в то время землей в Алексинском, Дедиловском, Ефремовском, Тульском и иных уездах, в том числе - к известному деятелю Петровского времени стольнику, строителю и командиру гарнизона Новодвинской крепости Сильвестру Петровичу Иевлеву4

Среди этих выписей из писцовых книг, послушных грамот, меновых и поступных записей, сохраняющих подробности давно минувшей жизни людей, не оставивших иного следа, находятся и несколько документов о событиях, каждое из которых могло бы стать сюжетом рассказа или повести, порой вполне курьезных. Таков, например, Доезд 1697 г., в котором рассказывается, как ефремовские пушкари, приехавшие для совершения ареста, были избиты представителями дворянского семейства Субочевых, при этом арестант был отбит, а сами пушкари - побиты цепами и уехали ни с чем ${ }^{5}$. Такова Мировая запись 1691 г. «о грабеже лошади», отнятой у «ефремовца» Селиванова по пути в Москву не на дороге даже, а прямо при проезде через большое село ${ }^{6}$.

Но две грамоты в этом небольшом собрании необычны тем, что как будто нарочно обрамляют короткую историю женитьбы, длившуюся почти ровно два года, обозначая первую и последнюю страницы печальной повести.

Первый документ датирован 25 января 1680 г. ${ }^{7}$ Это Сговорная запись Тимофея Максимовича Писарева ${ }^{8}$ о женитьбе на дочери Михаила Афанасьевича Иевлева ${ }^{9}$ Елене (Алене). Столбец (16,4 х 39,1 см) записан не полностью: в нижней части остается чистое место для примерно 6 строк текста; лист надорван вдоль в верхней части, в нижней части виден фрагмент водяного знака «голова шута», который не удалось отождествить.

\footnotetext{
3 НБ МГУ. Ф. 62 (Иевлевы).

${ }^{4}$ Краткое описание этих материалов см.: Морозов Б.Н. Документы XVII - первой трети XVIII в. из архива Иевлева // Из фонда редких книг и рукописей Научной библиотеки Московского университета. М., 1993. С. 120-131.

5 НБ МГУ. Ф. 62. Ед. хр. 28.

6 Там же. Ед. хр. 53.

7 Там же. Ед. хр. 8.

8 Тимофей Максимович Писарев, с 1686 г. был стольником, скончался в 1703 г. (Алфавитный указатель фамилий и лиц, упоминаемых в Боярских книгах, хранящихся в I-ом отделении Московского архива Министерства юстиции, с обозначением служебной деятельности каждого лица и годов состояния, в занимаемых должностях. М., 1853. С. 320).

9 Михаил Афанасьевич Иевлев, сын Афанасия Юрьевича Иевлева, пожалованного вотчинами за московское осадное сидение, в 1662-1663 гг. был воеводой в Коротче (Барсуков А.П. Списки городовых воевод и других лиц воеводского управления Московского государства XVII столетия. СПб., 1902. С. 112) и московским дворянином с 1676 г. (Алфавитный указатель фамилий и лиц... С. 167).
} 


\section{Текст документа гласит ${ }^{10}$ :}

Се яз, Тимофеи Максимович Писарев, в нынешнем во 188-м году генваря в день зговорил я, Тимофеи, женитца у Михаила Афонасьевича Иевлева на дочери ево девице Елене Михаиловне. А женитиа мне, Тимофею у нево, Михаила Афонасьевича на дочери ево девице Елене Михаиловне на срок нынешнего 188-го году маия в 9 день.

А будет я, Тимофеи, у нево, Михаила Афонасьевича, на дочери ево девиие Елене Михаиловне не женюсь, на тои срок, кои срок писан выле сего, и ему, Михаилу Афонасьевичю взять на мне, на Тимофее, по сеи зговорнои записи шестьсот рублев денег.

А при сеи зговорнои записи сидели князь Тимофеи Иванович Волконскои ${ }^{11}$ да Андреи Юрьевич Татищев ${ }^{12}$, да Тимофеи Акимович Дуров ${ }^{13}$.

А зговорную запись писал Тулские съезжие избы подьячеи Венедикт Олшанскои ${ }^{14}$ лета седмь тысещ сто осмьдесят осмаго году генваря в 25 день.

На обороте столбца подпись отца жениха Максима Писарева ${ }^{15}$, сделанная весьма корявым к крупным почерком в три строки: «Максим Писорев сына своево зговорил и вместо ево руку приложил». Ниже расположены подписи свидетелей: «При сеи записи князь Тимофеи Волконскои сидел и руку приложил. Андреи Татищев руку приложил. При сеи записи Тимофеи Дуров сидел и руку приложил».

25 января 1680 г. приходилось на воскресенье. Свадьба была назначена на 9 мая, которое в том году также было воскресным днем - третьей неделей по Пасхе. Такая форма Сговора без росписи приданого была одной

\footnotetext{
10 Здесь и далее текст документов и помет на них приводится без сохранения графики и орфографии оригинала.

${ }^{11}$ Князь Тимофей Иванович Волконский в 1686 г. был пожалован «из житья» в стольники; в 1687 г. он показан начальником 1-й жилецкой роты в Крымском походе; он же числится стольником в 1686 г.; см.: Алфавитный указатель фамилий и лиц... С. 77; Волконская Е.Г. Род князей Волконских. СПб., 1900. С. 739.

${ }^{12}$ Андрей Юрьевич Татищев упоминается как стряпчий в 1676 г. и как стольник в 1680 -м (Алфавитный указатель фамилий и лиц... С. 405); в 1659 г. был в Конотопском походе, в полку А.Н. Трубецкого; в 1678-1679 гг. - в Чигиринских походах в полку князей Ромодановских; в 1680 г. — в Путивльском походе в полку В.В. Голицына; в 1682 г. — в Троицком походе; скончался в 1684 г.; см.: Татищев С.С. Род Татищевых. 1400-1900: Историко-генеалогическое исследование. СПб., 1900. С. 71.

${ }^{13}$ Тимофей Акимович (Якимович) Дуров упоминается как стряпчий в 1682 г. и как стольник в 1686 и 1692 гг.; см.: Алфавитный указатель фамилий и лиц... С. 125; Збарская Л.С. Род Дуровых // Исторический архив. 2001. № 3. С. 197-207.

${ }_{14}^{14}$ Венедикт Ольшанский (Альшанский) был подьячим Тульской приказной избы в 1673 1687 гг. (Демидова Н.Ф. Служилая бюрократия в России XVII века (1625-1700): Биографический справочник. М., 2011. С. 409).

${ }^{15}$ Максим Иванович Писарев с 1678 г. московский дворянин (Алфавитный указатель фамилий и лиц... С. 320).
} 
из возможных ${ }^{16}$, а как пишет Григорий Котошихин, сумма неустойки могла быть указана и в тысячу, и в 5 тыс., и даже в баснословные 10 тыс. руб. ${ }^{17}$

Свадьба, очевидно, была сыграна, и жениху не пришлось выплачивать 600 руб. несостоявшемуся тестю. Несомненно также, что за невестой было дано какое-то имущество, записи о котором не сохранилось.

В архиве Иевлевых находится документ, по которому можно составить представление, что могло быть дано за невестой примерно в это время. Рядная запись 1676 г. $^{18}$, перечисляет движимое и недвижимое имущество, которое вошло в состав приданого выходящей замуж за Богдана Емельяновича Толстого Екатерины Захарьевны Кабелевой. Документ сохранился в архиве Иевлевых, поскольку вторым браком Екатерина Захарьевна, по-видимому, была замужем за племянником Михаила Афанасьевича Иевлева Сильвестром Петровичем ${ }^{19}$ и, вероятно, позволял сравнить состав приданого при ее первом и втором браке.

Среди прочего в нем говорится, что невесту благословили двумя образами в серебряных золоченых окладах, а кроме того, она получила: «приданого платья и кузни: шапка олтобасноя - олтобас ${ }^{20}$ золотои, чепь со кресть: три креста золоченых, в том числе крест вызалачен з жемчюги. Двои серги: адни серги турские з жемчюги, другие двои на колцах. Ожерелья низаноя, двенатиать перснеи серебреных, в том числе три вызлочены. Шуба комчатоя ${ }^{21}$ зеленоя на куницах, пуговицы серебреные вызолочены; иуба товтяная ${ }^{22}$ осиновоя ${ }^{23}$ лисья черевья ${ }^{24}$, пуговицы серебреные золоченые; шуба

\footnotetext{
${ }^{16}$ Ср., например, рядную запись 1665 г., опубликованную Н.В. Калачовым: Акты, относящиеся до юридического быта древней России / изданы Археографическою комиссиею под редакцией Николая Калачова. СПб., 1884. Т. 3: Поступныя, посыльная, приговоры, приказы, промытная, протроп, проезжия, розбор, розводныя, роздельныя, розрубники, розъезды, росписки, росписи, роспросныя речи, рядныя, сговорныя, сделочныя, сказки, сметы, списки, срочная, ссудныя, ставка очная, ставленыя, статейные списки, указы, ценовная, челобитныя, явки. № 334. ІІ. Стб. 288.

${ }^{17}$ Котошихин Г. О России в царствование Алексея Михайловича. 4-е изд. СПб., 1906. С. 150.

${ }^{18}$ НБ МГУ. Ф. 62. Ед. хр. 6. См.: Славяно-русские рукописи XIII-XVII вв. в фондах Научной библиотеки им. А.М. Горького Московского государственного университета: Описание / Сост. Е.И. Конюхова. М., 1964. С. 19, № 1355.

${ }^{19}$ Морозов Б.Н. Указ. соч. С. 123.

${ }^{20}$ Алтабас - разновидность плотной парчи, шёлковая ткань с орнаментом или фоном из золотой волоченой или серебряной волоченой нити.

${ }^{21}$ Камчатая т. е. покрытая камкой - шелковой обычно тканью с богатым атласным рисунком на матовом фоне.

${ }^{22}$ Тафта - разновидность глянцевой ткани из туго скрученных нитей шёлка, хлопка, часто с цветочным орнаментом.

${ }^{23}$ Осиновый цвет - цвета осиновой коры, серебристо-серый.

${ }_{24}$ Черевья - из меха, растущего на брюхе (чреве) животного. Такой мех мягче и легче «хребтового».
} 
товтяноя алая белья черевья, пуговищы серебреные; шуба заячья под кинде$к о м^{25}$. Охобень ${ }^{26}$ дарогилнои ${ }^{27}$ краснои, пуговицы серебреные позалочены; охобень кумашнои червчетои; телогряя киндячноя червчетоя. Постеля з головьем и с подушки, и с одеялом; коробья з бельемъ. Да кобалноя ее девка к лориу».

Стоимость имущества была оценена в сто рублей, и, надо полагать, Елена Михайловна Иевлева получила едва ли меньше. Другая часть приданого Екатерины Захарьевны состояла из земли, людей и крестьян, и переход прав собственности на это имущество, безусловно, был зарегистрирован в Поместном приказе.

О количестве земли и людей, отданных за Аленой Иевлевой, мы узнаем из документа, датированного 15 января $1782 \Gamma^{28}$ В этот день была подписана Раздельная полюбовная запись ${ }^{29}$ Тимофея Максимовича Писарева с его тестем, Михаилом Афанасьевичем Иевлевым, составленная, очевидно, в соответствии с документами, присланными из Поместного приказа.

Столбец из двух сставов $(16,1 \times 54,6$ см) написан на полосах бумаги, которые когда-то составляли части одного листа. На сст. 1 видна значительная часть знака «герб Амстердама» (без короны) и нижняя часть контрмарки; на сст. 2 верхняя часть той же контрмарки ${ }^{30}$.

Документ сообщает:

Се яз, Тимофеи Максимович Писарев. В прошлом во сто осмьдесят осмомь году дал мне тесть мои Михаила Афонасьев сын Иевлев за дочерью своею Аленою в место приданого помесье свое в Соловском уезде в Псовском стану ${ }^{31}$ на Красивои Мечи сто четеи по обе стороны речки Красивои Мечи ${ }^{32}$, да вотчинных своих крестьян Алексинского уезду деревни Алексеевскои, Денисовское тож ${ }^{33}$, четыре двора.

${ }^{25}$ Киндяк - хлопчатобумажная набивная ткань, обычно красного или желтого цвета. При втором случае упоминания в документе этой ткани специально отмечается ее цвет червчатая - красная.

${ }^{26}$ Охабень - верхняя мужская и женская одежда, чаще из сукна, но может быть и из другой ткани.

27 Дорогильный - из плотного шелка.

28 Этот день также был воскресным.

${ }^{29}$ НБ МГУ. Ф. 62. Ед. хр. 9.

${ }^{30}$ Тип близкий знакам, датируемым 1677, 1678, 1683 гг. (Дианова Т.В. Филиграни XVIIXVIII вв. Герб города Амстердама. М., 1998. № 112) или 1685 г. (Дианова T.В., Костюхина Л.М. Водяные знаки рукописей России XVII в. М., 1980. № 141).

31 Уезд получил свое название по реке Солове, левому притоку Упы. Другое название уезда - Крапивенский - по городу Крапивна. Псовский стан - один из четырех, на которые делился уезд; располагался к юго-востоку от Крапивны и севернее г. Ефремова.

32 Река Красивая Меча - правый приток Дона. Судя по упоминанию ее в Псовском уеде, речь идет о верховьях реки.

${ }^{33}$ Алексеевская, иначе Денисовская Поляна или Денисовская, деревня в Бобошинском стане Алексинского уезда, который располагался к югу от Алексина и к западу от Тулы. 
И волею божию жены моеи Алены, а ево, Михаиловои, дочери не стало, а детеи после ее не осталось.

И по указу великого государя то мое приданое помесье велено у меня, Тимофея, поворотить ему, Михаилу: отказать три жеребья и со крестьяны. А мне, Тимофею, указано ис того моево приданого поместья оставить четвертои жеребеи и со крестьяны. И ныне я, Тимофеи, поговоря с ним, Михаилом, полюбовно и зверстав тех крестьян по земли.

И по тому нашему полюбовному розделу досталось мне, Тимофею, на четвертои мои жеребеи крестьянин Ефтюшка Кузмин з братом ево родным Ромашком; у Ефтюшка сын Левка. А тестю моему Михаилу по сему нашему полюбовному розделу достались крестьяне Антошка Кузмин, у него два сына, крестьянин Гераска Обросимов, унего брат Ивашка да два сына. Во дворе крестьянин Тимошка Григорьев. А те крестьяне з женами и со всеми детми.

А земля и усадьбы мне, Тимофею, достались по сему нашему полюбовному розделу. И против государева указу, и против дачь на дватиать на пять четеи в поле, а в дву по тому ж от БІвановои дачи Иевлева ${ }^{34}$.

А ему, Михаилу Иевлеву, достались усадьбы и земля от Андреевых дачь Татищева ${ }^{35}$ на семдесять на пять четеи в поле, а в дву по тому ж со всеми угодьи.

И в отказные книги написать поместья и крестьянъ против сего нашего полюбовного розделу и впредь мне, Тимофею, и жене моеи и детем и роду моему против сего намего полюбовного розделу на него, Михаилу и на жену ево, и на детеи, кому он, Михаила, похочет то поместь[!] здать или променить, и о переделе того поместья и о крестьянех, и о усадьбах великому государю не бить челомъ.

А будеть я, Тимофеи или жена моя, или дети мои, или сродичи мои на него, Михаилу и на жену ево, и на детеи или кому он похочет променить или здать, о том поместье и о крестьянех и о судбах, и об ыном переделе ныне и впредь учнем великому государю бить челом, или против сеи записи, что писано выше сего в чем не устоим, и ему, Михаиле, и жене ево, и детем, или кому променить похочет, взяти по сеи записи на мне, Тимофеи, и на жене моеи, и на детех двести рублев денег.

${ }^{34}$ Возможно, речь идет о Иване Захарьевиче Иевлеве, который с мая 1679 по декабрь 1680 г. был воеводой в Острогожске. В 1683 г. воеводой там же был назначен Сильвестр Петрович Иевлев, племянник Михаила Афанасьевича; см.: Барсуков А.П. Списки городовых воевод... С. 166. Где располагались Ивановские дачи, мне неизвестно.

${ }^{35}$ Очевидно, Андрей Татищев - это Андрей Юрьевич Татищев, обозначенный как свидетель в Сговорной записи. Где именно располагались его дачи, мне неизвестно. 
А ся запись и впредь в запись и поместья, и крестьяне крепки по сеи записи. А сии записи писаны у на[!] насъ по противным записям ${ }^{36}$. А на то послуси Микита Романов ${ }^{37}$, Анисим Алтухов. А запись писал Тулскои площеди подьячеи Сенка Иванов лета 7190-го году генваря в 15 день.

На обороте грамоты стоит подпись, сделанная от имени овдовевшего Тимофея Писарева ${ }^{38}$ : «К сеи записи города Туль соборныя иеркви поп Феодор ${ }^{39}$ места Тимофея Максимова сына Писарева по ево веленью руку приложил». Ниже подписи свидетелей: «Послух Микитка руку приложил. Послух Анисимка руку приложил».

Причина смерти Алены Михайловой дочери в документе не названа жизнь XVII в. предоставляла варианты в избытке; не указана и дата ее кончины, но упоминание царского указа говорит о том, что между смертью жены Тимофея Писарева и Раздельной записью прошло какое-то время, в течение которого, по-видимому, челобитные поступили в Поместный приказ и было принято решение о характере и способе раздела приданого. Однако время, прошедшее со дня свадьбы, и наше знание о скорости принятия решений по делам в Поместном приказе, позволяют предположить, что причиной смерти юной Алены Писаревой, урожденной Иевлевой, вполне могли стать неудачные роды.

Согласно Соборному уложению, «кто кому старинных своих или купленных людей даст в приданые за сестрою, или за дочерью, и судом Божиим тоя его сестры или дочери не станет, а детей после их не останется, и тех умерших мужьем таких приданых людей по рядным записям отдавати тем людем, кто их в приданые даст» (Глава 20 «Суд о холопех», ст. 62).

Эту практику подтверждает Григорий Котошихин: «А которой человек выдаст дочь свою или сестру замуж и в приданые за нею даст многие животы и вотчины, и в скором времяни дочь его или сестра замужем, не родя детей, или детей и родила, а померли, и сама умрет: и те все приданые животы емлют у мужа ее и отдают назад тем людям, кто выдает» ${ }^{40}$.

\footnotetext{
${ }^{36}$ Противные записи - одинаковые экземпляры записи, остающиеся в распоряжении сторон, заключивших юридически значимую сделку.

${ }^{37}$ Никита Романов, вероятно, Тульский площадной подьячий; см.: Демидова Н.Ф. Указ. соч. С. 483.

${ }^{38}$ Возможно, Тимофей Максимович Писарев не владел грамотой, поскольку и в документе 1680 года за него расписывается отец. Нельзя, однако, совсем исключить возможность того, что доверенные лица скрепляли своей подписью юридический документ в отсутствие контрагента.

${ }^{39}$ В писцовой книге 1685 г. при Успенском соборе Тулы значится поп Федор Никитин; см.: Святые храмы города Тулы: Историко-статистическое описание. Сборник, составленный под редакцией Н.И. Троицкого и Ю.В. Арсеньева. Тула, 1888. С. 23.

${ }^{40}$ Котошихин Г. Указ. соч. С. 157.
} 
Понятно, что практика отдачи приданого, как минимум, не была повсеместной, а решение связанных с возвратом приданого находилось в том числе и в ведении духовных властей ${ }^{41}$. Известно, что в 1678 году, например, патриарх Иоаким в ответ на челобитье некоего Трофима Лаврентьева о приданом его умершей бездетной дочери дает Зазывную грамоту, по которой зять обязывался вернуть «людей и платья, и всякой кузни, и низанья» ${ }^{42}$. Но это касалось движимого имущества бездетных жен.

В царствование Федора Алексеевича дважды (в 1676 и 1677 гг.) подтверждается, что «которые люди давали за дочерьми зятьям своим поместья вместо приданого, и тех поместей не поворачивать, а быть за зятьями» ${ }^{43}$.

Однако некоторое время спустя в закон вносятся исправления. 28 января 1681 г. принимаются «Статьи о поместных и вотчинных делах», в которых говорится, что «которые помещики и вотчиники и вдовы и девки поступились поместей своих место приданого, денег и платья за дочерьми и за сестрами, и за племянницами, и за внуками зятьям своим, и тех их дочерей и сестер, и племянниц, и внук за мужем не стало бездетных, а те люди, кто тех поместей поступился, учнут бить челом тех поместей о повороте, и тем людям и женам их вместо тех поместей на зятьях их указывать деньги за три жеребья приданаго, вместо которого того поместья поступились... а четвертой жеребей оставливать зятьям; а буде зятья денег дать не похотят, и у них взять из тех поступных поместей три доли и отдать поступщикам... а четверть тех поместей оставливать за зятьями» ${ }^{44}$.

В дальнейшем эта практика закрепляется в Указе Иоанна и Петра Алексеевичей от 25 апреля 1683 г. $^{45}$, в «Статьях о чернослободских и беломестцовых дворах» от 22 января 1686 г. $^{46}$

${ }^{41}$ Ланге О.Ф. О правах собственности супругов по древнерусскому праву. СПб., 1886. C. 73 .

42 Акты, относящиеся до юридического быта древней России... Т. 1. Стб. 143.

${ }^{43}$ ПСЗ-І. Т. 2. № 633, п. 16; № 700, п. 20.

${ }^{44}$ Там же. № 860. С. 302. Ср.: Котляров Г.М. Рядные-сговорные записи XVI-XVII вв. (Опыт историко-дипломатического описания актов) // Сборник статей, посвященных Александру Сергеевичу Лаппо-Данилевскому. Пг., 1916. С. 220, примеч. 5. Г.М. Котляров указывает на опубликованную Н.В. Калачовым Раздельную запись 1693 года, по которой зять оставляет себе после умершей бездетной жены «из того вышеписанного приданого и из деревень... по указу великих государей, четвертой жеребей» (Акты, относящиеся до юридического быта древней России... T. III. № 304.V. Стб. 117), и на Память 1691 г., по которой тесть оставляет «четвертой жеребей из того приданого платья и ларешной кузни и из низанья... против правил Св. Отец и Государева указу» и забирает себе вотчинных крестьян с женами и детьми (Старинные акты, служащие преимущественно дополнением к описанию города Шуи и его окрестностей. Собраны... Владимиром Борисовым. Изданы... Яковом Гарелиным. М., 1853. С. 320).

${ }^{45}$ ПСЗ-І. Т. 2. № 1008.

${ }^{46}$ ПСЗ-І. Т. 2. № 1157. С. 733: «Которые люди женятся и возьмут за женами своими приданые дворы, а после того жен их не станет, а детей после тех умерших жен не останется, 
Вероятно, предполагалось соблюдение некоторой юридической «симметрии»: в соответствии с первой статьей главы 17-й («О вотчинах») Соборного уложения бездетная вдова получала четверть имущества умершего супруга. А бездетный вдовец, в свою очередь, получал право на четверть имущества покойной жены - на жеребей ее приданого.

Как следует из публикуемого документа, Тимофеем Писаревым и Михайлой Иевлевым была реализована именно эта законодательная новелла.

Вероятно, вместо приданого Михайла Афанасьевич Иевлев «поступился» поместьем, а его овдовевший зять не счел возможным выплатить полагающиеся его тестю доли деньгами. И поскольку земельные наделы, переходящие во владение Иевлева, названы «дачами» Андрея Татищева, то можно думать, это были не земли, отданные за Еленой Михайловной, а те, о которых помещики «полюбовно» договорились. То, что крестьяне были «сверстаны по земле», как кажется, подтверждает такое понимание текста документа.

Но, как известно, споры о приданом не всегда кончались полюбовным розделом, законы о возвращении приданого многократно менялись, и еще спустя почти сто лет дворяне все еще требовали изменений в этой «области наследственного права» ${ }^{47}$.

\section{Литература}

Акты, относящиеся до юридического быта древней России / изданы Археографическою комиссиею под редакцией Николая Калачова. СПб., 1884. Т. 3.

Алфавитный указатель фамилий и лиц, упоминаемых в Боярских книгах, хранящихся в І-ом отделении Московского архива Министерства юстиции, с обозначением служебной деятельности каждого лица и годов состояния, в занимаемых должностях. М., 1853.

Барсуков А.П. Списки городовых воевод и других лиц воеводского управления Московского государства XVII столетия. СПб., 1902.

Богословский М.М. Дворянские наказы в Екатерининскую комиссию 1767 года // Русское богатство. 1897. № 6. С. 45-83.

Волконская Е.Г. Род князей Волконских. СПб., 1900.

Демидова Н.Ф. Служилая бюрократия в России XVII века (1625-1700): Биографический справочник. М., 2011.

Дианова Т.В. Филиграни XVII-XVIII вв. Герб города Амстердама. М., 1998.

Дианова Т.В., Костюхина Л. М. Водяные знаки рукописей России XVII в. М., 1980. Збарская Л.С. Род Дуровых // Исторический архив. 2001. № 3. С. 197-207.

и из таких приданых дворов давать после тех умерших жен мужьям их четвертой жеребей, в три доли отдавать тех дворов ближним умершей жены его родственникам».

${ }^{47}$ Богословский М.M. Дворянские наказы в Екатерининскую комиссию 1767 года // Русское богатство. 1897. № 6. С. 64. 
Котляров Г.М. Рядные-сговорные записи XVI-XVII вв. (Опыт историко-дипломатического описания актов) // Сборник статей, посвященных Александру Сергеевичу Лаппо-Данилевскому. Пг., 1916. С. 182-223.

Котошихин Г. О России в царствование Алексея Михайловича. 4-е изд. СПб., 1906. Ланге О.Ф. О правах собственности супругов по древнерусскому праву. СПб., 1886. Морозов Б.Н. Документы XVII — первой трети XVIII в. из архива Иевлева // Из фонда редких книг и рукописей Научной библиотеки Московского университета. М., 1993. C. 120-131.

Речь и отчет, читанные в торжественном собрании Императорского Московского университета 12-го января 1894 года. М., 1894.

Сафонова Н.И. Личные библиотеки в собрании Отдела редких книг и рукописей Научной библиотеки им. А.М. Горького МГУ // Рукописная и печатная книга в фондах Научной библиотеки Московского университета. М., 1973.

Святые храмы города Тулы: Историко-статистическое описание. Сборник, составленный под редакцией Н.И. Троицкого и Ю.В. Арсеньева. Тула, 1888.

Славяно-русские рукописи XIII-XVII вв. в фондах Научной библиотеки им. А.М. Горького Московского государственного университета: Описание / Сост. Е.И. Конюхова. М., 1964.

Татищев С.С. Род Татищевых. 1400-1900: Историко-генеалогическое исследование. СПб., 1900. 


\title{
П.В. Лукин
}

\section{ЗАБОЖНИЧЬЕ. НОВАЯ ПОПЫТКА ИНТЕРПРЕТАЦИИ ПОНЯТИЯ ${ }^{1}$}

\begin{abstract}
Аннотация Статья посвящена упоминанию загадочного «забожничьего» в известии Новгородской первой летописи под 6736 (1228) г. Обе предлагавшиеся в историографии концепции, трактующие это слово (социально-правовая и религиозная) не выглядят вполне убедительными. Автор предлагает свою интерпретацию, основанную на максимально возможном учете исторических и лингвистических данных, и приходит к выводу, что слово «забожничье», скорее всего, происходит от слова «божница» (храм), что было предложено еще Н.М. Карамзиным в начале XIX в., и означает судебное заседание у церкви во главе с княжеским судьей. Такие судебные заседания могли происходить в погостах — локальных центрах новгородской сельской периферии.

Ключевые слова: Новгород, смерды, Ярослав Всеволодич, Новгородская первая летопись.
\end{abstract}

Summary The article is devoted to the mention of the enigmatic «zabozhnich'e» in the account of 6736 (1228) AD in the Novgorod First Chronicle. Two theories explaining the word (the legal one and the religious one) are both far from being convincing. The author puts forward his own interpretation based on historical as well as linguistic data and comes to the following conclusion: «zabozhnich'e» most likely derives from the word «bozhnitsa» (a church) which was hypothesized by Nikolai M. Karamzin as early as in the beginning of the 19th century, and means a court hearing chaired by the prince's judge near a church. Such court hearings might have taken place in pogosty - territorial units of the Novgorod agrarian hinterland.

Keywords: Novgorod, smerdy, Yaroslav Vsevolodich, Novgorod First chronicle.

1 Автор выражает глубокую благодарность всем коллегам, принявшим участие в обсуждении этой работы или поделившимся своими советами и замечаниями, особенно С.В. Городилину, В.Б. Крысько, Д.В. Сичинаве. Больше всего мы, безусловно, обязаны А.А. Гиппиусу, не только советами, но и дружеской дискуссией. Никто из коллег, естественно, не несет ответственности за наши выводы (и возможные ошибки). 
В Новгородской первой летописи под 6736 г. от «сотворения мира» (что соответствует 1228 г. от Р.Х. ${ }^{2}$ ) имеется следующее известие: «Тьгда (новгородцы. - П.Л.) отяша тысячьское у Вячеслава и даша Борису Ньгочевичю, а къ князю послаша къ Ярославу [Всеволодичу] на томъ: “поеди к намъ, забожницье отложи, судье по волости не слати; на всеи воли нашеи и на вьсехъ грамотахъ Ярославлихъ ты нашь князь; или ты собе, а мы собе"»³. В нем, в принципе, все понятно, кроме того, что такое «забожничье», и почему против этого «забожничьего» протестовали новгородцы.

Известие принадлежит к официальной новгородской владычной летописи — основе НПЛ - и, скорее всего, как установил А.А. Гиппиус, связано с творчеством летописца архиепископов Спиридона и Далмата, причем записано оно было, по-видимому, в 1230 или 1231 гг. ретроспективно, в ходе описаний бурных событий нескольких предшествующих лет ${ }^{4}$. В любом случае, изучая нарративный источник, следует искать общую логику всего повествования в целом, а не предлагать для каждого отдельного его элемента объяснения ad hoc. Тем более это так, если анализируемые известия действительно продукт творчества одного летописца - автора повествования о бурных событиях в Новгороде в эти годы.

Исторический контекст известия таков. В 1225 г. новгородским князем вместо сына Всеволода Большое Гнездо и брата тогдашнего владимирского князя Юрия Всеволодича Ярослава становится Михаил Всеволодич из черниговских Рюриковичей. После этого, по словам летописца, «бысть льгько по волости Новугороду». Михаил надолго, однако, в Новгороде не задержался. Новгородцы вновь призывают Ярослава Всеволодича и в следующем, 1226 г., он вновь вступает на новгородский стол. Весной-летом того же года из-за внешнеполитических предприятий Ярослава опять обостряются отношения между ним и новгородцами. Не отказываясь от новгородского княжения, он уходит вместе с женой в Переяславль Суздальский (Залесский) и оставляет в Новгороде своих сыновей Федора и Александра (будущего Невского). В результате стихийных бедствий начинаются беспорядки, с владычной кафедры прогоняют управляющего ею Арсения и возвращают ушедшего на покой архиепископа Антония. После этого происходят события, о которых говорится в процитированном выше известии: новгородцы приглашают Ярослава при условии, в частности, отмены «забожничьего». Эти условия, однако, приняты не были

2 См. о дате: Бережков Н.Г. Хронология русского летописания. М., 1963. С. 269.

3 ПСРЛ. М., 2000. Т. 3: Новгородская первая летопись старшего и младшего изводов. С. 67.

4 Гиппиус A.A. Новгородская владычная летопись XII-XIV вв. и ее авторы (История и структура текста в лингвистическом освещении) // Лингвистическое источниковедение и история русского языка 2004-2005. М., 2006. С. 213-215. 
(или в Новгороде победила радикально настроенная антисуздальская партия), и сыновья Ярослава вместе с его людьми бегут из Новгорода, а в 1229 г. туда возвращается Михаил Черниговский. Летописец при этом подчеркивает, что новгородцы были рады «своему хотЊнию». Радость объясняется так: князь «цЂлова крестъ на всЂи воли новгородьстъи и на всђхъ грамотахъ Ярославлихъ; и вда свободу смьрдомъ на 5 льт дании не платити, кто сбежалъ на чюжю землю, а симъ повеле, къто сде живеть, яко уставили переднии князи, тако платите дань». Далее сообщается об избрании архиепископом Спиридона 5 .

Что касается самого известия о забожничьем, то в более позднем новгородском летописании оно остается практически неизменным ${ }^{6}$. Однако уже московские книжники XVI в. явно не понимали, что такое «забожничье» (мало отличаясь в этом, добавим, от современных ученых). В Московском летописном своде этого известия нет, а в Никоновской летописи (Ник.) новгородцы обращаются к Ярославу Всеволодичу так: «Господине княже Ярославе Всеволодиче! поиди къ намъ въ Новьградъ, сверЂпьства и гнъва не дръжи, судей по волостемъ не шли, на всей воль Новгородцкой нашей буди, и на всъхъ грамотахъ Ярославлихъ изстаринныхъ Новогородцкихъ живи у насъ, ино ты князь нашь, а мы твои; аще ли не тако, ино ты себъ, а мы себъ». Непонятное «забожничье» составитель Ник. заменил понятным, хотя и расплывчатым, «свирепством и гневом».

Относительно забожничьего выдвигались различные предположения ${ }^{8}$. В настоящее время актуальны две основные концепции, которые условно можно назвать социально-правовой и религиозно-языческой. Первую наиболее последовательно обосновал М.Н. Тихомиров. В своей трактовке он опирался на словарь В.И. Даля, гдепредставлено значение глагола «забожить» — «присвоить неправою божбою, где нет улик, забожиться — начать божиться, стать клясться». Историк выдвинул на этом основании осторожное предположение, что в летописи могли подразумеваться люди и земли, захваченные князем

5 ПСРЛ. Т. 3. С. 64-68.

6 ПСРЛ. Т. 3. С. 273 («забожничье отложи»); ПСРЛ. М., 2000. Т. 4. Ч. 1: Новгородская четвертая летопись. С. 207 («забожнічье отложи»); ПСРЛ. Пг., 1917. Т. 4. Ч. 2: Новгородская пятая летопись. Вып. 1. С. 202 («забожничье отъложи»). В Новгородской Карамзинской и Софийской I летописях это известие отсутствует. Не было его и в Кратком новгородском летописце, о чем свидетельствует его отсутствие в летописях, наиболее точно отражающих этот источник: Летописце епископа Павла и Новгородской Большаковской летописи, а также в Летописи Авраамки и Рогожском летописце.

7 ПСРЛ. СПб., 1885. Т. 10: Летописный сборник, именуемый Патриаршею или Никоновскою летописью. С. 96. Источником Никоновской в данном случае, видимо, была Новгородская V летопись (см.: Клосс Б.М. Никоновский свод и русские летописи XVI-XVII веков. М., 1980. C. 148).

${ }^{8}$ См.: Фроянов И.Я. Древняя Русь. Опыт исследования истории социальной и политической борьбы. М.; СПб., 1995. С. 461, сноска 112. 
и его людьми путем односторонней «клятвы» перед судом. С событиями в деревне связал Тихомиров и указание летописи на рассылку судей по волости 9 . Важным и ценным в этой интерпретации является обращение к зафиксированной в словаре лексике, учет контекста и попытка осмыслить стоящие за летописным известием социально-экономические и правовые реалии.

Религиозную трактовку «забожничьего», причем сразу в трех вариантах, активно продвигал Б.А. Рыбаков. Сначала он предположил, что забожничье было введенным Ярославом новым налогом на тех смердов, «которые открыто выполняли языческие обряды» ${ }^{10}$. В 1986 г. Рыбаков писал, что после «бурного народного мятежа новгородцы обратились к князю с просьбой о прекращении “забожничей” [sic!], судя по всему, репрессий за бесчинства против церкви» ${ }^{11}$. В 1987 г. историк уже уверенно утверждал, что «забожничье» было специальным налогом, которым откупались от князя люди, «вернувшиеся к языческой обрядности» ${ }^{12}$. Развил предположения Рыбакова И.Я. Фроянов. По его мнению, забожничье действительно было пошлиной, которая выплачивалась за отправление языческого культа, но распространялась она не только на тех, кто вернулся к язычеству, но и на «тех жителей Новгородской волости, которые не порывали с язычеством» ${ }^{13}$.

Языческая интерпретация «забожничьего» не только не имеет никаких оснований в источниках (единственным побудительным мотивом для ее появления послужил, видимо, предполагаемый корень -бог- в слове «забожничье»), она невероятна уже потому, что превращает клирика — владычного летописца фактически в заступника крипто-язычников. В летописи требования новгородцев излагаются вполне сочувственно, а характер новгородского летописания как владычного - доказанный факт ${ }^{14}$. Поэтому правильным представляется поиск возможной разгадки в русле социально-правовой концепции.

«Некий судебный сбор», платеж за осуществление княжеского суда видел в забожничьем Д.Г. Хрусталев, но почему он носил такое название, не пояснил ${ }^{15}$. Интересную трактовку забожничьего предложил А.А. Фролов. Им-

9 Тихомиров М.Н. Крестьянские и городские восстания на Руси ХІ-ХІІІ вв. // Тихомиров М.Н. Древняя Русь. М., 1975 (1-е изд. М., 1955). С. 220.

${ }^{10}$ Рыбаков Б.А. Языческое мировоззрение русского Средневековья // Вопросы истории. 1974. № 1. C. 24-25.

${ }^{11}$ Рыбаков Б.А. Культура средневекового Новгорода // Славяне и скандинавы. М., 1986. C. 305 .

${ }_{12}$ Рыбаков Б.А. Язычество Древней Руси. М., 1987. С. 686.

${ }_{13}$ Фроянов И.Я. Древняя Русь IX-XIII веков. Народные движения. Княжеская и вечевая власть. М., 2012. С. 406.

${ }^{14}$ Гиппиус А.А. Новгородская владычная летопись... С. 114-251.

${ }^{15}$ Хрусталев Д.Г. Северные крестоносцы. Русь в борьбе за сферы влияния в Восточной Прибалтике XII-XIII вв. СПб., 2009. Т. 1. С. 364-365, примеч. 536. 
плицитно подразумевая происхождение этого обозначения от выражения «за бога», исследователь отождествил забожничье с десятиной, которые князья пытались собирать с Заволочья (о посылке князьями судей туда идет речь в договорах Новгорода с князьями $)^{16}$. При совершенно верном, на наш взгляд, направлении поиска, конечный вывод исследователя должен быть несколько скорректирован. Может сложиться впечатление, что исследователь имеет в виду выдвинутое новгородцами требование отмены церковной десятины (а не передачи права на ее сбор «мужам новгородским», как и других даней). Кроме того, и эта интерпретация предполагает, по-видимому, загадочного *забожника (об этом будет говориться ниже). Недавно к теме забожничьего обратился В.В. Коршаков. Он правильно, на наш взгляд, основывается на трактовке М.Н. Тихомирова, развивая ее. В суждениях В.В. Коршакова есть немало нового и ценного. Он обратился к материалам народных говоров, собранных в «Словаре русских народных говоров», к данным договоров Новгорода с князьями, а также к историческому контексту, представленному в летописи. Исследователь пришел в итоге к следующему выводу: Ярослав Всеволодич попытался собрать налоги вторично, нарушив тем самым установленный порядок их сбора. Именно таким чрезвычайным налогом, вызвавшим возмущение новгородцев, и было забожничье. Само слово «забожничье» Коршаков объясняет как «нечто полученное в результате “выхода за края договора”, на котором “божились” стороны, то есть в результате нарушения договора ${ }^{17}$. Это, пожалуй, самое слабое место предложенной трактовки. Дело в том, что у слова «забожить», с которым автор предположительно связывает забожничье, судя по словарям говоров, значения «нарушить договор» нет ${ }^{18}$.

\footnotetext{
${ }^{16}$ Фролов А.А. Административная система центральных районов Новгородской земли в X - начале XVII века в контексте истории территориальных юрисдикций // Историческая география / Отв. ред. И.Г. Коновалова. М., 2012. Т. 1. С. 130-131.

${ }_{17}^{17}$ Мы ссылаемся на находящуюся в работе рукопись В.В. Коршакова, посвященную, в частности, этому сюжету и любезно присланную автором.

${ }^{18}$ Словарь русских народных говоров (далее- СРНГ). Л., 1972. Вып. 9. С. 261. Забожничьему посвятил только что вышедшую статью А.А. Гиппиус, с рукописью которой он любезно нас ознакомил. Исследователь предлагает видеть в «забожничьем» налог на военные нужды, название которого происходит от слова «забогъ» (фонетического варианта древнерусского «сапогъ») (Гиnпиус A.A. «Сапожный» налог Ярослава Всеволодича (1228 г.) // Dísablót: Сборник статей коллег и учеников к юбилею Елены Александровны Мельниковой. М., 2021. С. 297-305). Важную роль в построениях ученого играет наличие в латышском языке слова zābaks, которое может происходить от русского *забогъ, что подтверждает реальность бытования этого слова в древненовгородском диалекте. Здесь было бы некорректно вступать в развернутую полемику, но отметим, что, несмотря на остроумность этой гипотезы, мы не можем ее принять по целому ряду причин, главными из которых (но отнюдь не единственными) являются несоответствие историческому контексту (вне интерпретации оказываются даже княжеские судьи, прямо упоминающиеся в требованиях новгородцев) и отсутствие во всех списках летописей формы «сапожничье» при том, что форма «забогъ» (в отличие от сапога) в древнерусских источниках не встречается вообще.
} 
Приходится констатировать, что, несмотря на немалые усилия исследователей и сделанные ими разнообразные и весьма ценные наблюдения, имеющие отношение к теме, до сих пор убедительная интерпретация забожничьего в литературе отсутствует. Мы попытаемся предложить свою гипотезу, которая призвана по возможности учесть всю совокупность имеющихся фактов, не требовать конъектур или обращения к редким, не зафиксированным в источниках формам (и связанных с ними произвольных толкований) и не противоречить лингвистическим данным. Разумеется, речь идет только о гипотезе, которая ни в коей мере - в условиях исключительной скудости имеющихся у нас сведений - не претендует на то, чтобы быть истиной в последней инстанции и лишь должна стимулировать дальнейшую дискуссию.

Представляется, что в поисках ответа на интересующий нас вопрос надо опираться на две «реперные точки»: исторический контекст (интерпретация, сколь бы формально она ни была убедительной или яркой, не должна противоречить тому, что в критике текста называется Sitz im Leben, но, наоборот, должна максимально экономным образом объяснять всю совокупность имеющихся фактов) и значение самого слова.

Что касается значения слова, то «забожничье», к сожалению, - гапакс. Все словари древнерусского языка дают значение «особый вид налога» или «вид пошлины», но исходят они явно не из самого слова, а из контекста единственного известного упоминания ${ }^{19}$. Значительно более интересна ситуация с народными говорами. Еще в словаре В.И. Даля, на что в свое время ссылался М.Н. Тихомиров, содержится (с пометкой «ниж[егородское]») глагол «забожить» - «присвоить неправою божбою, где нет улик», с примерами: «Занял, да забожил, и пропали мои денежки. Забоженое ребром (боком) выпрет» ${ }^{20}$. В «Словаре русских народных говоров» также есть этот глагол: забожить, -божу, божишь - присвоить себе что-либо, божась при этом, что не брал; присвоить чужую вещь. Примеры приводятся из самых разных говоров (ярославских, олонецких, владимирских, нижегородских, пермских): «Забожил у меня вожжи, бог с им», «Дам топора, а только не забожи себе совсем» ${ }^{21}$. В новгородском и псковском областных словарях это слово не зафиксировано, но в карельском, который охватывает в том числе территорию, в Средневековье входившую в Новгородскую землю, оно есть: «Забожить - взять,

${ }^{19}$ Срезневский И.И. Материалы для словаря древнерусского языка по письменным памятникам. СПб., 1893. Т. 1. Стб. 896; Словарь русского языка XI-XVII вв. (далее - СлРЯ XI-XVII). М., 1978. Вып. 5. С. 136; Словарь древнерусского языка (XI-XIV вв.). М., 1990. T. 3. C. 281.

${ }^{20}$ Даль В. Толковый словарь живого великорусского языка. СПб.; М., 1880. Т. 1. С. 569.

${ }^{21}$ СРНГ. Вып. 9. С. 261. 
присвочть что-н. Вы наловили, а я вашу рыбу, присвою проще-то сказать»² Обращает на себя внимание то обстоятельство, что в приведенных в словарях примерах нет никакой «божбы», т. е. клятвы. Складывается впечатление, что, если она когда-то и подразумевалась, то к моменту фиксации память о ней выветрилась (как, например, о шлеме в глаголе «ошеломить»). «Забожить» в этом значении - это просто несправедливо присвоить, примерно то же, что в современном разговорном языке «зачитать» или «заиграть».

Можно ли установить какую-либо связь между «забожить»= «присвоить» и забожничьим статьи НПЛ? С точки зрения Sitz im Leben такая связь была бы практически идеальной. Если считать, что «забожничье» было неким побором, который с позиции новгородцев был незаконным, такое толкование объяснило бы всю ситуацию. Михаил Всеволодич в 1225 г. обеспечивает «легкость» для новгородских волощан-смердов, что, надо полагать, соответствует, с точки зрения новгородского летописца, «старине», установленной «передними князьями». Вокняжившийся в следующем году Ярослав заменяет легкость на тягость: вводит некий побор, воспринимающийся новгородцами как незаконный, и для его сбора или, может быть, скорее, для разбирательства с теми, кто его отказывается платить, рассылает княжеских судей по волости. Это становится одной из причин обострения отношений между ним и новгородцами, и вернувшийся Михаил провозглашает «оттепель». Суть ее вызывала споры между историками ${ }^{23}$, но, как нам кажется, вполне убедительное толкование было дано еще А.И. Никитским: смысл постановления Михаила Всеволодича состоял в освобождении смердов, бежавших в трудной ситуации из Новгородской земли в другие земли от даней на пять лет в случае возвращения, те же смерды, которые остались, должны платить столько, сколько было определено прежними князьями (т. е. теми, кто правил до Ярослава Всеволодича) ${ }^{24}$. По факту это, очевидно, было возвращение к той самой «легкости по волости», о которой применительно к действиям Михаила в 1225 г. говорилось в летописи. Элементом этого «облегчения» могла стать и отмена забожничьего. А.И. Никитский справедливо указывает на то, что в последующие времена такого рода льготы были совершенно обычными для привлечения сельского населения.

Такая трактовка имеет, однако, трудно преодолимый недостаток - саму лексему «забожничье». Если считать забожничье названием побора типа весчего, ловчего и т.д., оно по идее должно подразумевать наличие некоего *забожьника, который, так же, как весец или ловчий выступал бы в качестве должностного лица, в пользу которого осуществлялся такой сбор (и тогда

\footnotetext{
${ }^{22}$ Словарь русских говоров Карелии и сопредельных областей. СПб., 1995. Вып. 2. С. 82.

${ }^{23}$ См.: Фроянов И.Я. Древняя Русь. Опыт исследования... С. 461-464.

${ }^{24}$ Никитский А.И. Очерк внутренней истории Пскова. СПб., 1873. С. 280-281.
} 
«забожничье» нужно понимать, как субстантивированное притяжательное прилагательное). Теоретически представимы гипотетические конструкции, которые предусматривали бы такого «забожника», так же, как можно предположить, что «забожником» могли (пейоративно) называть самого князя, который обложил новгородских смердов невиданным доселе побором. Однако такие догадки будут в любом случае носить характер искусственных гипотез ad hoc: никакого *забожьника древнерусские источники не знают.

Аналогично обстоит дело с возможностью вывести забожничье из словосочетания «за бога» через посредство «забожника» как лица, типологически соответствующего известным по церковному уставу Владимира Святославича задушным людям или позднейшим захребетникам. Однако если о задушных людях неизвестно практически ничего, кроме того, что они, скорее всего, были вольноотпущенниками ${ }^{25}$, то важнейшая особенность статуса захребетников, как показывают новгородские писцовые книги XV в., состояла как раз в том, что они как раз не участвовали в тягле ${ }^{26}$.

Можно, конечно, представить, что раздражение у новгородцев вызвала попытка Ярослава обложить данью ранее необлагаемые ею группы сельского населения - лиц, у которых отсутствовало собственное устойчивое хозяйство, но для этого придется сделать целый ряд маловероятных допущений, в то время как никаких «задушных» или «захребетных» податей неизвестно. Но главное не в этом. С учетом того, что множество захребетников жило на чужих дворах ${ }^{27}$, приходится предполагать нечто совершенно невероятное для русского ХІІІ в. - что Ярослав Всеволодич попытался ввести даже не подворную подать, а нечто вроде подати подушной. Это было бы явным анахронизмом.

Существует, однако, еще одна возможность. Еще Н.М. Карамзин связал забожничье со словом «божница». В примечании к «Истории государства Российского» он предположил, что это могла быть дань, собиравшаяся с немецких церквей в Новгороде, поскольку божницами «преимущественно именовались у нас Латинские храмы» ${ }^{28}$. Объяснение, предложенное историком, совершенно невероятно (никаких даней с католических храмов на ганзейских дворах в Новгороде никогда не собиралось, а больше ника-

${ }^{25}$ Свердлов М.Б. Задушный человек // Древняя Русь в средневековом мире: энциклопедия. М., 2014. С. 286.

${ }^{26}$ Сергеевич В.И. Древности русского права. М., 2006 [1911]. Т. 3: Землевладение. Тягло. Порядок обложения. С. 113-115; Шапиро А.Л. Русское крестьянство перед закрепощением (XIV-XVI вв.). Л., 1987. С. 193.

${ }^{27}$ Сергеевич В.И. Древности... Т. 3. С. 113.

${ }^{28}$ Карамзин Н.М. История государства Российского в 12-ти томах. М., 1991. Т. 2/3. С. 622-623, примеч. 324. 
ких «немецких церквей» там не было; божницами могли называть и русские православные храмы, в том числе весьма известные ${ }^{29}$ ), но сама мысль о связи забожничьего с божницами кажется очень интересной.

Прежде всего, такое толкование подходит с лингвистической точки зрения и, видимо, существенно лучше, чем вариант с (нигде не зафиксированным) забожником. По своей форме «забожничье», скорее, может быть не субстантивированным притяжательным прилагательным (в таком случае ожидалось бы *забожьничее), а существительным типа заручье, залучье, Завеличье и т. д., где приставка за- указывает на географическое положение ${ }^{30}$. Таким образом, «забожничье» может быть чем-то, что совершалось «за божницей», т. е. за зданием церкви.

Можно ли обосновать такую связь с точки зрения Sitz im Leben? Думается, что да. Для этого надо обратиться не к летописи, а к другим источникам. В ряде договоров Новгорода с князьями содержится положение о закладниках. Впервые - в интересующей нас форме - оно встречается в договорной грамоте Новгорода с князем Ярославом Ярославичем 1268 г. ${ }^{31}$ : «А что закладниковъ за Гюргемь ${ }^{32}$ на Торожку или за тобою, или за кн[я]гынею, или за мужи твоими: кто купець, тоть въ сто; а кто смердъ, а тот потягнеть въ свои погостъ; тако пошло Новегородъ, отпустите ихъ проць» ${ }^{33}$. Устанавливается, таким образом, связь смердов с погостами.

О погостах существует большая литература и ведутся дискуссии. Однако очевидно, что это были податные и судебные центры на подвластной Новгороду территории.

Еще С.Б. Веселовский отмечал, что важнейшим атрибутом погоста в новгородских владениях была цзерковь. Для более позднего времени известно, что «трапезная погостской церкви была местом, где происходили суды, выборные старосты производили раскладку и сбор податей и где периодически по праздникам... происходили братчины и пиры» ${ }^{34}$. Предпо-

${ }^{29}$ Ср., например: «испьсаша божницю Антонову» о соборе в Антониевом монастыре, или в той же летописной статье о новгородских храмах: «и съ божниць [буря] вълны раздьра» (ПСРЛ. Т. 3. С. 21).

${ }^{30}$ Благодарю за консультацию В.Б. Крысько и Д.В. Сичинаву. Предположение о лингвистической связи «забожничьего» с божницей принадлежит В.Б. Крысько.

${ }^{31}$ О датировке см.: Янин В.Л. Новгородские акты XII-XV вв. Хронологический комментарий. М., 1991. С. 147-150.

${ }^{32}$ Имеется в виду племянник Ярослава Ярославича, сын его брата Андрея Ярославича Юрий Андреевич (см.: Янин В.Л. Новгородские акты... С. 150).

${ }^{33}$ Грамоты Великого Новгорода и Пскова / Под ред. С.Н. Валка. М.; Л., 1949 (далее ГВНП). № 3. С. 13.

${ }^{34}$ Веселовский С.Б. Село и деревня в северо-восточной Руси XIV-XVI вв. Историко-социологическое исследование о типах внегородских поселений. М.; Л., 1936 (Известия Государственной академии истории материальной культуры имени Н.Я. Марра. Вып. 139). С. 16. 
лагается, что в XIII-XV вв. приходские (погостские) центры становились местом сбора податей и, скорее всего, тесно связанного с этим проездного суда ${ }^{35}$. В XV-XVII вв. на Севере, в бывших новгородских владениях, в роли присутственного места выступала трапеза - пристройка к церкви. Она была «и волостным правлением, и полицейским участком, и нотариальной конторой, и местом мирского пития ссыпного пива» ${ }^{36}$.

Далее, достаточно очевидной представляется связь «забожничьего» с судом. Летописное известие, в котором фигурирует «забожничье» («забожницье отложи, судье по волости не слати») очень напоминает установление из проекта договора Новгорода с великим князем Михаилом Ярославичем (внуком Ярослава Всеволодича) 1305-1307 гг.: «А вязчего не пошло по Новгородьскои волости, то судиямъ твоимъ отложити» ${ }^{37}$. Попытки игнорировать это совпадение вряд ли могут быть убедительны. «Вязчее», между тем, - это, скорее всего, выплата представителю власти, служилому человеку князя, за задержание беглого холопа ${ }^{38}$. В договоре за сбор вязчего отвечают княжеские судьи, что вполне понятно, так как розыск, опознание и водворение беглого к хозяину подразумевали судебно-следственные процедуры. Характерно, что в этой роли фигурируют именно судьи, а не *вязец̧ь, к которому этимологически восходит, вероятно, название этой выплаты. Совершенно то же, как мы полагаем, относится и к забожничьему.

О том, что погосты имели отношение и к суду, свидетельствуют самые разные источники, в том числе и достаточно близкие по времени к событиям конца 20-х гг. XIII в. берестяные грамоты ${ }^{39}$. Известна, например, пространная берестяная грамота № 531, которая по стратиграфическим данным датируется концом XII - первой половиной XIII вв., а по внестратиграфическим первым 20-летием ХІІІ в. (!). В ней, в частности, говорится о вызове истцом ответчицы «во погосто» для официального судебного разбирательства ${ }^{40}$. В берестяной грамоте № 154 (20-е гг. XV в.), которая представляет собой протокол судебного заседания, прямо указывается, что оно «диялось на погость, на торгъ» ${ }^{41}$. Погостские «божницы», скорее всего, и стояли на торгу.

\footnotetext{
${ }_{35}$ Фролов А.А. Административная система... С. 140-141.

${ }^{36}$ Юшков С.В. Очерки из истории приходской жизни на Севере России в XV-XVII вв. СПб., 1913. С. 31-32.

${ }^{37}$ ГВНП. № 7. С. 18. О датировке см.: Янин В.Л. Новгородские акты... С. 152-155.

${ }^{38}$ Горский А.A. Русское средневековое общество: историко-терминологический справочник. СПб., 2019. С. 83.

${ }^{39}$ Платонова Н.И. Древнерусские погосты - новая старая проблема // Древнейшие государства Восточной Европы: 2010 год: Предпосылки и пути образования Древнерусского государства / Отв. ред. Е.А. Мельникова. М., 2012. С. 328-388.

40 Зализняк А.А. Древненовгородский диалект. 2-е изд. М., 2004. С. 416.

${ }^{41}$ Там же. С. 672.
} 
Статья 25 Псковской судной грамоты эксплицитно говорит о том, что вызов на судебное разбирательство должен совершаться на погосте у церкви (между прочим, из этого следует, что локация таких процедур, скорее всего, имела и символическое значение, связанное с принесением клятвы перед служителями культа и церковными зданиями, что могло стимулировать и выбор такого обозначения, как «забожничье»): «А которои позовник поидет исца звати на суд, и тои позваныи не поидет на погост к церкви позывницы чести, или стулится от позывницы, — ино позывница прочести на погосте пред попом $\rangle^{42}$.

Имеются, наконец, бесспорные свидетельства того, что суд новгородского тысяцкого в самом Новгороде вершился именно рядом с «божницей» - с церковью св. Иоанна на Опоках на Торгу. Это было установлено договором Новгорода с Любеком и Готландом 1269 г.: «А будет ссора между немцами и новгородцами, кончать ссору на дворе святого Иоанна (up sente Johannis hove) перед посадником, тысяцким и купцами» ${ }^{43}$. Из документов новгородско-ганзейской переписки мы узнаем, что такие судебные заседания проходили перед церковью св. Иоанна на Опоках. Есть даже крайне любопытный документ - послание немецкой купеческой общины в Новгороде властям Ревеля от 9 августа 1426 г., в котором ганзейские купцы жалуются на тысяцкого. Тот, вопреки «крестоцелованию» (krucekussinge) и «старому обычаю» (older wonheit), вершит суд не «перед церковью святого Иоанна» (vor Sunte Johannesse). В ответ на это рассерженный тысяцкий заявил, что и в немецких городах приговоры фогтов считаются законными, где бы их ни выносили - «будь то у ратуши, или в своих домах, или на улице» (alze under deme rathuse, offte in eren husen, offt oppe der straten $)^{44}$. Несмотря, однако, на полемический задор, становится понятным, что нормальным местом судебной процедуры считалась

42 Памятники русского права. М., 1953. Вып. 2: Памятники права феодально-раздробленной Руси / Сост. А.А. Зимин. С. 289.

${ }^{43}$ ГВНП. № 31. С. 60.

${ }^{44}$ Hansisches Urkundenbuch / Bearb. von K. Kunze. Leipzig, 1905. Bd. 6. № 638. S. 359. Союз under в средненижненемецком языке, на котором написано это послание (как и сохранившийся текст договора 1269 г.) мог означать как «под ч.-Л.», так и «в ч.-л.», и «рядом с ч.-л.» (Mittelniederdeutsches Handwörterbuch. Bd. 3. T. 2. Lfg. 36-37 / Bearb. von J. Meier und D. Möhn. Neumünster, 2013. Sp. 215). Первое значение, однако, не подходит по смыслу, второе же кажется маловероятным, так как рядом стоит обычное in [eren husen]. Да и общий контекст предполагает, что тысяцкий имел в виду именно возможность судить у себя дома vs суда в законном месте - у храма: тысяцким тогда был, по-видимому, Оникий Власьевич, о котором нам точно известно, что несколько ранее, летом 1425 г. он действительно разбирал дело ганзейских купцов в частном доме - в гостях у «старейшего посадника» Фомы (см. об этом: Лукин П.В. Ганзейский документ 1425 года и проблема новгородских «старых посадников» // Ученые записки Новгородского государственного университета имени Ярослава Мудрого. 2019. № 5(23) (URL: http://www.novsu.ru/univer/press/eNotes1/i.1086055/?id=1569488 (дата обращения: 06.05.2021)). 
площадка рядом с общественными зданиями. В Новгороде это были, прежде всего, храмы (божницы).

Подведем предварительные итоги. Наша интерпретация, которая, как представляется, не противоречит лингвистическим законам и историческому контексту, учитывает всю совокупность имеющихся фактов, не требует сложных допущений и цепочек гипотез ad hoc, состоит в следующем. Если южнорусские и смоленские князья уважали новгородскую «старину» и не стремились к расширению объема своей власти в Новгородской земле (следствием чего и была отмеченная в летописи «легкость» по волости), но зато и готовы были в любой момент бросить Новгород, то политика сына Всеволода Большое Гнездо, который в свое время фактически подчинил себе республику, была, очевидно, иной. Он стремился к реальной власти. Одним из рычагов для этого и стало, как нам кажется, забожничье - судебные заседания в новгородских погостах, которыми руководили княжеские судьи. Основным объектом юрисдикции князя было местное сельское население - смерды, судебные штрафы с которых он присваивал.

О том, что это могло быть именно так - и смерды могли совершать деяния, которые князь мог рассматривать как подлежащие его юрисдикции, и князь мог хотеть эту юрисдикцию осуществлять - свидетельствует отчет ганзейских посланников о миссии в Новгород 1292 г. Они, в частности, рассказали, что служилый человек новгородского князя (которым тогда был внук Ярослава Всеволодича Дмитрий Александрович) в ответ на претензии по поводу разграбленного у ганзейцев товара в Новгородской земле заявил в присутствии представителя Новгорода: «При чем тут князь? У господина князя этого имущества нет, это имущество у вас, новгородцев, и вы его поделили с вашими смердами. [Это] ваши смерды, и поэтому по закону вы должны отвечать» ${ }^{45}$. Естественно, при большем контроле ситуации князь мог сам заставить «отвечать» новгородских смердов в подобных случаях. Естественно, и сами новгородцы считали важнейшей обязанностью князя «блюсти смердов». Соответствующие претензии были прямо предъявлены еще в 1136 г. князю Всеволоду Мстиславичу, в ходе событий, приведших к так называемой новгородской «революции» ${ }^{46}$, и, как мы полагаем, подра-

${ }^{45}$ Quid ad regem? Dominus rex bona illa non habet, vos Nogardenses bona illa habetis, et ea cum smerdis vestris divisistis. Smerdi vestri sunt et idcirco de jure tenemini respondere (Лукин П.В., Полехов С.В. Латинское послание о новгородско-ганзейских посланий 1292 г.// Древнейшие государства Восточной Европы. 2019-2020 годы: Дипломатические практики античности и средневековья / Отв. ред. Б.Е. Рашковский. М., 2020. C. 366,369$)$.

46 «А се вины его творяху: 1, не блюдеть смердъ...» (ПСРЛ. Т. 3. С. 24). См. об этом: Нuкитский А.И. Очерк... С. 279-280. 
зумевались в требованиях об отмене забожничьего, адресованных Ярославу Всеволодичу.

Тут можно вспомнить и то, что эксплуатация сельской периферии была важнейшим источником дохода новгородского политического сообщества, и зафиксированные в договорах с князьями требования новгородцев «держати» новгородские волости не княжьими мужами, а мужами новгородскими, а также содержащиеся там ограничения - временные и локальные деятельности княжеских судей, чтобы понять всю степень их негодования, отразившуюся в летописи ${ }^{47}$. Не исключено, что временно́й контекст имеет прямое отношение к требованию об отмене забожничьего. В древнейшем сохранившемся договоре (точнее, проекте договора) Новгорода - с князем Ярославом Ярославичем (1264 г.) есть положение: «А куда пошл[о] судии твоему ездити по волости, ехат[и и]мъ межень по Петровь [д]ни» (т. е. в середине лета, после праздников апостолов Петра и Павла 12 июля) ${ }^{48}$. Требование отмены забожничьего было выдвинуто новгородцами зимой - тогда, когда по новгородской «старине» князь мог не иметь права рассылать по волости своих судей.

Мы не настаиваем на том, что «забожничье» было terminus technicus. Вполне возможно, это было окказиональное обозначение, коннотации которого для новгородцев были явно негативными ${ }^{49}$. И здесь какую-то роль могло сыграть и известное по говорам бытование глагола «забожить» (присвоить). Князь и его судьи, может быть, в этом контексте воспринимались (в рамках народной этимологии) как «забожники» - лица, незаконно присваивающие не принадлежавшие им по «старине» полномочия и соответствующие выплаты.

\section{Литература}

Бережков Н.Г. Хронология русского летописания. М., 1963.

Веселовский С.Б. Село и деревня в северо-восточной Руси XIV-XVI вв. Историко-социологическое исследование о типах внегородских поселений. М.; Л., 1936 (Известия Государственной академии истории материальной культуры имени Н.Я. Марра. Вып. 139).

${ }^{47}$ См. об этом: Флоря Б.Н. Новгородская земля в XII-XIII вв. // История России с древнейших времен до конца XVII века / Под ред. Л.В. Милова. М., 2006. С. 133-134; Фролов A.A. Административная система... С. 132.

${ }^{48}$ ГВНП. № 1. С. 10. О датировке см.: Янин В.Л. Новгородские акты... С. 142-146.

${ }^{49}$ Некоторое значение в плане параллели к «забожничьему» могут иметь загубский и заморский оброки, которые взимались на Русском Севере в XVI-XVII вв., и название которых, хотя образованы иначе, чем «забожничье», также связаны с наименованиями определенных местностей (за речной, озерной или морской губами) (СлРЯ XI-XVII. М., 1978. Вып. 5. C. 177, 244). 
Гиппиус A.А. Новгородская владычная летопись XII-XIV вв. и ее авторы (История и структура текста в лингвистическом освещении // Лингвистическое источниковедение и история русского языка 2004-2005. М., 2006. С. 114-251.

Гипnиус A.A. «Сапожный» налог Ярослава Всеволодича (1228 г.) // Dísablót: Cборник статей коллег и учеников к юбилею Елены Александровны Мельниковой. M., 2021. C. 297-305.

Горский А.А. Русское средневековое общество: историко-терминологический справочник. СПб., 2019.

Грамоты Великого Новгорода и Пскова / Под ред. С.Н. Валка. М.; Л., 1949.

Даль В.И. Толковый словарь живого великорусского языка. СПб.; М., 1880. Т. 1.

Зализняк А.А. Древненовгородский диалект. 2-е изд. М., 2004.

Карамзин Н.М. История государства Российского в 12-ти томах. М., 1991. Т. 2-3.

Клосс Б.М. Никоновский свод и русские летописи XVI-XVII веков. М., 1980.

Лукин П.В. Ганзейский документ 1425 года и проблема новгородских «старых посадников»//Ученые записки Новгородского государственного университета имени Ярослава Мудрого. 2019. № 5 (23) (URL: http://www.novsu.ru/univer/press/ eNotes1/i.1086055/?id=1569488 (дата обращения: 06.05.2021)).

Лукин П.В., Полехов С.В. Латинское послание о новгородско-ганзейских посланий 1292 г. // Древнейшие государства Восточной Европы. 2019-2020 годы: Дипломатические практики античности и средневековья / Отв. ред. Б.Е. Рашковский. M., 2020.

Никитский А.И. Очерк внутренней истории Пскова. СПб., 1873.

Памятники русского права. М., 1953. Вып. 2: Памятники права феодально-раздробленной Руси / Сост. А.А. Зимин.

Платонова Н.И. Древнерусские погосты - новая старая проблема // Древнейшие государства Восточной Европы: 2010 год: Предпосылки и пути образования Древнерусского государства / Отв. ред. Е.А. Мельникова. М., 2012. С. 328-388.

ПСРЛ. М., 2000. Т. 3, 4; Пг., 1917. Т. 4. Ч. 2. Вып. 1; 1885. Т. 10.

Рыбаков Б.А. Языческое мировоззрение русского Средневековья // Вопросы истории. 1974. № 1. С. 3-30.

Рыбаков Б.А. Культура средневекового Новгорода// Славяне и скандинавы. М., 1986. C. 298-313.

Рьбаков Б.А. Язычество Древней Руси. М., 1987.

Свердлов М.Б. Задушный человек // Древняя Русь в средневековом мире: энциклопедия. М., 2014.

Сергеевич В.И. Древности русского права. М., 2006 [1911]. Т. 3: Землевладение. Тягло. Порядок обложения.

Словарь древнерусского языка (XI-XIV вв.). М., 1990. Т. 3.

Словарь русских говоров Карелии и сопредельных областей. СПб., 1995. Вып. 2.

Словарь русских народных говоров. Л., 1972. Вып. 9.

Словарь русского языка XI-XVII вв. М., 1978. Вып. 5. 
Срезневский И.И. Материалы для словаря древнерусского языка по письменным памятникам. СПб., 1893. Т. 1.

Тихомиров М.Н. Крестьянские и городские восстания на Руси XI-XIII вв. // Тихомиров М.Н. Древняя Русь. М., 1975.

Флоря Б.Н. Новгородская земля в ХІІ-ХІІІ вв. // История России с древнейших времен до конца XVII века / Под ред. Л.В. Милова. М., 2006. С. 129-138.

Фролов А.А. Административная система центральных районов Новгородской земли в X - начале XVII века в контексте истории территориальных юрисдикций // Историческая география. Т. 1 / Отв. ред. И.Г. Коновалова. М., 2012. С. 110154.

Фроянов И.Я. Древняя Русь. Опыт исследования истории социальной и политической борьбы. М.; СПб., 1995.

Фроянов И.Я. Древняя Русь IX-XIII веков. Народные движения. Княжеская и вечевая власть. М., 2012.

Хрусталев Д.Г. Северные крестоносцы. Русь в борьбе за сферы влияния в Восточной Прибалтике XII-XIII вв. СПб., 2009. Т. 1.

Шапиро А.Л. Русское крестьянство перед закрепощением (XIV-XVI вв.). Л., 1987.

Юшков C.В. Очерки из истории приходской жизни на Севере России в XV-XVII вв. СПб., 1913.

Янин В.Л. Новгородские акты XII-XV вв. Хронологический комментарий. М., 1991. Hansisches Urkundenbuch/Bearb. von K. Kunze. Leipzig, 1905. Bd. VI. Mittelniederdeutsches Handwörterbuch. Bd. III. T. 2. Lfg. 36-37/Bearb. von J. Meier und D. Möhn. Neumünster, 2013. 


\title{
Т.В. Медведева
}

\section{ЛЮДИ НОВОГО ВРЕМЕНИ В ТРУДАХ Н.В. ГОЛИЦЫНА}

\begin{abstract}
Аннотация В статье рассматривается историографическое наследие Н.В. Голицына, посвященное проблемам истории Нового времени. Большинство его работ в той или иной мере имеет важный историко-антропологический компонент, в частности - представляют взгляд на происходящие процессы с позиции их участников, рассматривают социальные практики и «бытовую», повседневную историю. Исторические портреты деятелей XVII-XIX вв. в работах Н.В. Голицына характеризуют этапы формирования человека Нового времени.

Ключевые слова: Н.В. Голицын, историография, история Нового времени, история идей, Екатерина II.
\end{abstract}

Summary The article is based on scientific works of the historian N.V. Golitsyn, devoted to the problems of Modern times. Most of these works are related to historical anthropology: for example, they explore everyday history, the history of ideas, and social practices. N.V. Golitsyn presents historical portraits of people, both rulers and people of low classes, at different stages of the formation of the personality of the Modern times.

Keywords: N.V. Golitsyn, historiography, history of Modern times, history of ideas, Catherine II.

Николай Владимирович Голицын (1874-1942) известен сейчас, главным образом, как архивист, один из инициаторов архивной реформы 19171918 гг. и начинаний, связанных с сохранностью архивных документов. Его работы по истории России используются незаслуженно мало, а некоторые из них остались неизданными в архиве ученого и только планируются к публикации. При этом, круг вопросов, поднятых им в статьях и очерках, а также подходы и методы, использованные для изучения прошлого, безусловно представляют интерес.

Историописание Голицына почти никогда не является обезличенным оно всегда персонифицировано. При этом ему удается возвыситься над 
частными историями и на уровне обобщений говорить о масштабных процессах через бытовую и личную историю.

Голицына как ученого привлекала история социально-политических перемен, вопросы движущих механизмов тех или иных реформ и роли личности в этих механизмах, а также то, что сейчас называют историей идей. О чем говорит круг чтения верховника Д.М. Голицына; какие идеи считал необходимым сообщить императрице Анне Иоанновне воронежский поп Савва Дугин, а какие - Феофан Прокопович; чему мог и хотел научиться Игнатий Кучин «со товарищи» в Европе в Смутное время и почему не задалась эта учеба; как в голову императрицы Екатерины II пришла идея освободить крестьян от крепостной зависимости и как отговаривали ее литераторы А.П. Сумароков и М.М. Щербатов; что делал реформатор M.M. Сперанский в суде над декабристами и почему - ответы на эти вопросы составляют, в совокупности, в работах Н.В. Голицына обобщенный портрет человека Нового времени.

При этом Голицын-историограф безусловно актуален. Темы, затронутые и разработанные историком более столетия назад, в XXI веке вновь привлекают внимание исследователей, причем, нередко почти в тех же ракурсах и методических подходах. Так, выходят работы о Елизавете Петровне, впервые после Голицына повествующие о детстве будущей императрицы (однако, в большинстве случаев, не так подробно) ${ }^{1}$; по материалам Посольского приказа прослеживается биография русских студентов из Любека, «открытых» Голицыным², публикуются сочинения мятежного попа Саввы Дугина, которые Голицын планировал ввести в научный оборот в 1917 г.³, проходят переоценку выводы историка о деятельности М.М. Сперанского ${ }^{4}$

${ }^{1}$ Ср.: Голицын Н.В. Отроческие годы цесаревны Елисаветы Петровны (1900-е гг., 34 л. Рукопись из семейного архива А.К. Голицына) и Анисимов Е.В. Елизавета Петровна. М., 1999. Гл. 2 «Четвертная лапушка»; Лиштенан Ф.-Д. Елизавета Петровна. Императрица, не похожая на других. М., 2012. Гл. 1 «Маленькая Венера».

2 Ср.: Голицын Н.В. Дополнительные известия о русских студентах, отправленных в Любек Борисом Годуновым в 1603 г. (РГИА. Ф. 1686. Оп. 1. Д. 5. 45 л.) и Лисейцеев Д.В. Переводчик посольского приказа Игнатий Андреевич Кучин (К вопросу о судьбе одного из «Годуновских студентов») // Русский родословец. 2002. С. 4-8; Зверев С.В. Новые материалы о русских студентах в Любеке // Иноземцы в России в XV-XVII веках: Сборник материалов конференции. 2002-2004 гг. М., 2006. С. 260-269.

${ }_{3}$ Ср.: Статья Н.В. Голицына о священнике Савве Дугине (по материалам Тайной канцелярии 1730-х годов) (РГИА. Ф. 1686. Оп. 1. Д. 11. 173 л.) и Шамин С.М. «Доношения» воронежского священника Саввы Ивановича Дугина в документах Тайной канцелярии // Вестник церковной истории. 2015. № 3/4 (39/40). С. 116-139.

${ }^{4}$ Ср.: Голицын Н.В. Сперанский в верховном уголовном суде над декабристами // Русский исторический журнал. 1917. Кн. 1/2. С. 61-102 и Боленко К.Г. Об одной историографической развилке 1920-х гг:: Н. В. Голицын как историк Верховного уголовного суда по делу декабристов // Петербургский исторический журнал. 2019. № 2(22). С. 224-231. 
Наибольший интерес ученого всегда вызывал переменчивый XVIII век, причем, на всем его протяжении: события юности Елизаветы Петровны, проекты реформирования 1730-х гг., преобразования и внешняя политика времен Екатерины II. Однако, начинал свою научную карьеру Н.В. Голицын с работ, посвященных XVII столетию, причем с темы, носившей, казалось бы, частный характер.

Большая статья «Научно-образовательные сношения России с Западом в начале XVII века» ${ }^{5}$ была представлена в ОИДР, активно обсуждалась и по итогам этого обсуждения была продолжена молодым историком. Голицын рассмотрел обе стороны «сношений» - отправку русских дворян на обучение в Европу и привлечение Борисом Годуновым образованных иноземцев для работы в России. В истории о студентах Голицын первоначально сосредоточился на четырех учениках, живших в Англии, и проследил их судьбу как по архивным документам (прежде всего, статейным спискам), так и по зарубежным публикациям. Здесь, как и в последующих работах, проявился характерный стиль историка, совмещающий элементы историописания с археографией - в ткань исследования включены публикации архивных источников, дополняющие и иллюстрирующие статью. Голицын размышляет о столкновении взглядов, которое обнаружилось в ходе этого образовательного обмена: «столкнулась древнерусская религиозная нетерпимость с принципом свободы вероисповедания; такого-то рода столкновения и послужили одним из первых путей ознакомления русского общества до-Петровской эпохи с началами, на которых строилась западноевропейская жизнь. На примере русских юношей, — пишет Голицын, — “позадавневших" в Англии и “навыкших" английским обычаям до такой степени, что они утратили всякое национальное обличье, на этом примере ясно сказывается предчувствие того увлечения Западом, которое ознаменовало XVIII век» 6 . Историк замечает, что «попытка Бориса Годунова привить русским людям западноевропейскую образованность окончилась неудачно, или, лучше сказать, слишком удачно, так как предназначенные им к тому молодые люди дали себя через меру увлечь блеском западной цивилизации и забыли и родину свою, и веру своих соотечественников, и цель, с которой они были отправлены за границу» ${ }^{7}$.

Прямым продолжением этой работы стал доклад в ОИДР в 1899 г., составленный по материалам уже немецких архивов и посвященный студен-

5 Голицын Н.B. Научно-образовательные сношения России с Западом в начале XVII века. Исторический очерк // ЧОИДР. 1898. Кн. IV. С. 1-34 и отд. оттиск.

6 Там же. С. 16.

7 Там же. С. 18. 
там, направленным в Любек ${ }^{8}$ В нем раскрываются перипетии заграничной жизни русских юношей в Германии и их судьба в Смутное время. Примечательны изыскания, которые привели Голицына к этим документам: итогом предыдущего доклада стало знакомство с московским архивистом Августом Георгиевичем Нутом и немецким юристом и историком доктором Фелингом, которые помогли с поиском документов в любекских архивах. Таким образом, в распоряжение Голицына попали ведомости расходов на содержание русских учеников и их письма в Совет г. Любека. Здесь, в ином роде, но столь же выраженно обнаруживает историк конфликт интересов, ведущий к частичному провалу образовательной миссии. Голицын цитирует красноречивые сетования из грамоты бургомистров Любека: «робят давали учити, поили и кормили и одежду давали и чинили им по нашему возможению всё добро. А оне непослушны и поучения не слушали, и ныне двое робят от нас побежали неведомо за што» 9

Вскоре после этих работ Голицын издает подборку документов Митавского герцогского архива, характеризующую русско-шведские отношения середины XVII в., снабженную большим предисловием, посвященным вопросам атрибуции, датировки и критики этих текстов. В работу вошли несколько грамот (кн. Ивана Борисовича Черкасского - к Иоганну Шкуту, ливонскому губернатору; новгородцев - к воеводе г. Орешка, коллективные жалобы русских купцов шведскому правительству и др.). Здесь историк скуп на рассуждения, однако обращает внимание читателей на то, каким предстает «мир, мирской строй, которым жили корельские крестьяне». Голицын выделяет понятие «мира» из крестьянской челобитной шведской королеве: «писана ся наша мирская челомбитная из всего миру»; примечает подразделение крестьян на «лутчих, середних и молотчих» ${ }^{10}$. Историка привлекает в грамотах, наряду с фактографической информацией «живая картина крестьянского быта Корельской земли» ${ }^{11}$.

В том же архиве герцогов Курляндских в Митаве взгляд Голицына привлекает связка писем, случайно оказавшихся среди бумаг генерала Левенгаупта - послания фельдмаршала Федора Алексеевича Головина к курьеру Павлу Готовцеву (вероятно, перехваченные шведами), в которых, кроме служебных поручений, описывается участие автора в походах царя Петра,

8 Голицын Н.В. Дополнительные известия о русских студентах, отправленных в Любек Борисом Годуновым в 1603 г. (РГИА. Ф. 1686. Оп. 1. Д. 5.45 л.).

9 Голищын Н.В. Научно-образовательные сношения ... С. 6. Эту грамоту ученый цитирует по примечаниям к «Истории государства Российского» Н.М. Карамзина.

${ }^{10}$ Голищын Н.В. К истории русско-шведских отношений и населения пограничных с Швецией областей (1634-1648 гг.). М., 1903. С. 5.

${ }^{11}$ Там же. 
планы государя и политические события при дворе ${ }^{12}$. В этих же письмах Головин раскрывает подробности сооружения новой столицы, дополняющие известные ранее источники.

Частные письма XVIII в. становятся основным источником и для других работ Голицына. Наиболее примечательна тут неопубликованная статья об отроческих годах будущей императрицы Елизаветы, которая, возможно, готовилась вместе с публикацией двусторонней переписки юных царевен Анны и Елизаветы с родителями и писем приближенных лиц о воспитании девочек. Рукопись статьи сохранилась в архиве Н.В. Голицына вместе с копиями писем петровского времени из документов Государственного архива $^{13}$. Историк подробно исследует вопросы воспитания и образования царевен и те приоритеты, которые виделись царственным родителям в этом деле. Он также подчеркивает столкновение взглядов и новые смыслы, которые вкладывал Петр в обучение дочерей. «Велик был разрыв с московской стариной, если даже царские дочери, которых до сих пор ревниво оберегали стены кремлевских теремов от всякого влияния извне, теперь с детства окружались иноземцами, учились говорить на иностранных языках раньше своего родного, и первые письма свои к родителям, чтобы доставить им удовольствие, писали по-немецки, - замечал Голицын, - В деле воспитания дочерей мысль царя Петра провидела будущее, когда дочери его станут невестами и женами иностранных принцев, быть может королей; если он с одной стороны не желал, чтоб они уподобились его сестрам и теткам, рождением обреченным на безбрачие, то с другой он не мог не надеяться, что отныне и русские “принцессы” сделаются завидными партиями, войдут в семьи европейских государей, как вошла Россия в семью европейских государств... Поэтому, заставляя своих дочерей изучать иностранные языки и тем ставя их на один уровень со всеми прочими принцессами Европы, Петр несомненно руководился дальновидным намерением завязать благодаря им прочные родственные связи с нужными России дворами; это намерение сказалось уже в выдаче им замуж за иностранных принцев его племянниц, дочерей царя Ивана... Но не один расчет руководил им в этом отношении; лучше, чем кто-либо, он мог знать цену образованности, и возглас горького сожаления о том, что в детстве он не был выучен “как должно”, был искренним; тем более должен был он стараться дать детям своим нужное воспитание, чтобы они не оказались когда-нибудь в таком же поло-

${ }^{12}$ Голицььн Н.В. Петербург или Петрополь? (Новое свидетельство об основании Петербурга). СПб., 1903.

${ }^{13}$ Голищын Н.В. Отроческие годы цесаревны Елисаветы Петровны. 34 л. Рукопись и подготовительные материалы к ней находятся в семейном архиве А.К. Голицына. 
жении, в каком он был сам, слишком поздно узнавший, как “должно” быть выучену» ${ }^{14}$. В личном архиве историка сохранились многочисленные выписки по истории царствования Елизаветы Петровны, свидетельствующие о том, что он планировал продолжить изучение ее правления и проследить, какие плоды дало образование и воспитание царевны.

Из неизвестных трудов Н.В. Голицына об эпохе 1730-х гг. необходимо назвать статью и подготовленную им документальную публикацию, посвященные «диссиденту» первой трети XVIII в. Савве Дугину ${ }^{15}$. В исследовании, над которым историк работал в 1915-1916 гг, по материалам Тайной канцелярии восстанавливается биография и идеи священника Воронежской губернии Саввы Ивановича Дугина, не желавшего мириться со злоупотреблениями администрации. Главный герой характеризуется как «натура боевая», «одна из тех смелых и беспокойных натур, на которые косо смотрит всякое, даже самое снисходительное начальство» ${ }^{16}$. Голицын рассматривает личность Дугина, его представления об административном произволе и беспорядках. «Особенность протеста Дугина, — подчеркивает историк, - заключается в той форме, в какую он его облек; как человек образованный, сравнительно с окружающей средой, и как ум творческий, не могущий успокоиться на одном пассивном признании неприглядности житейской обстановки, среди которой ему приходилось действовать, одушевленный желанием применить доступные его познаниям средства к исправлению существующего строя» ${ }^{17}$.

К исследованию Голицын прилагает два документа, вышедшие из-под пера Дугина, предназначавшиеся к поднесению императрице Анне Иоанновне: «Устав христианского жития» и «Известительный доклад», содержащие кодекс политических и нравственных правил для организации местного управления. «“Устав” намечает те пути и способы, какими должна управляться Россия, “Доклад” рисует картину того, как она на самом деле управляется. Первый является любопытным памятником политической мысли одинокого и самостоятельного ума, второй дает яркое и мрачное изображение быта провинциального общества в рассматриваемую эпоху» ${ }^{18}$ - поясняет Голицын. Спор Дугина с Феофаном Прокоповичем Голицын называет «спором двух мировоззрений», в котором столкнулись

${ }^{14}$ Голицын Н.В. Отроческие годы цесаревны Елисаветы Петровны. Рукопись из семейного архива А.К. Голицына. Л. 31.

${ }^{15}$ Голищын Н.В. [Священник Савва Дугин и его проекты...] (РГИА. Ф. 1686. Оп. 1. Д. 11. 173 л.).

${ }^{16}$ Там же. Л. 3.

17 Там же. Л. 2 об.

18 Там же. Л. 3. 
«религиозный мистицизм безвестного сельского попа и церковно-государственный утилитаризм знаменитого иерарха» ${ }^{19}$. Среди материалов дела Дугина некоторые документы вызывают искреннее удивление Голицынаисторика. Он предлагает для публикации «объявление» (объяснение), составленное мятежным попом для Синода, подчеркивая, что оно «дышит такой искренностью, проникнуто таким лирическим подъемом и так полно и ярко характеризует наивную веру автора в свою правоту, что нельзя отказать себе в удовольствии привести полностью этот документ, по странной случайности затерявшийся среди сухих и бездушных протоколов следственного дела» ${ }^{20}$.

К истории идей относится и другая статья Голицына, посвященная переломному 1730 г. и позиции архиепископа Феофана Прокоповича, создавшего «Сказание»-памфлет о беззаконных действиях верховников, «Изъяснение, каковы были неких лиц умыслы, затейки и действия в призове на престол Ея Императорского Величества» и «Записку» о предполагаемом суде над верховниками ${ }^{21}$. Историк подчеркивает, что все три произведения архиепископа тесно связаны между собой внутренней логикой и целью привлечь верховников на суд современников, причем на суд исключительный, соответствующий их беспримерному преступлению. Археографическая и источниковедческая работа в этом исследовании Голицына неразрывно связаны с историческими рассуждениями: на основе документов рассматриваются политические взгляды оппозиционного архиепископа и его противостояние с Верховным Тайным советом.

Менталитет современников Петра I и Анны Иоанновны оказывается в центре внимания другой статьи, посвященной книговедческим вопросам. «Выбор книг для чтения настолько же определяет личность человека, как и выбор его знакомств, и нередко сухой перечень книг в библиотеке того или другого лица живей и ярче рисует вам его образ, чем сотни свидетельств его современников» ${ }^{22}$ - с этого положения Голицын начинает реконструкцию библиотеки и круга чтения верховника князя Д.М. Голицына. Особую ценность представляют размышления историка о важности изучения частных библиотек и их роли в культурном процессе.

19 Там же. Л. 14.

${ }^{20}$ Там же. Л. 15. Совсем недавно эти документы были рассмотрены в работе: Шамин С.М. Видения священника С. И. Дугина и «пасквиль» на архиепископа Феофана (Прокоповича) 1731 г. // Вестник церковной истории. 2019. № 1/2(53/54). С. 53-91.

${ }^{21}$ Голищын Н.В. Феофан Прокопович и воцарение императрицы Анны Иоанновны // Вестник Европы. 1907. Кн. 4. С. 519-543.

${ }^{22}$ Голицын Н.В. Новые данные о библиотеке кн. Д.М. Голицына (верховника). М., 1900. C. 1 . 
Наряду с антропологическими рассуждениями, эта небольшая статья оказалась весьма значимой и с библиографической точки зрения. Не смотря на обширную современную историографию по библиотеке Голицыных, вокруг книг верховника все еще существуют «легенды» и для развенчания их, в первую очередь, обращаются к краткой работе Н.В. Голицына как наиболее авторитетной в характеристике состава собрания ${ }^{23}$.

Екатерининское время представлено в работах Голицына несколькими фигурами, среди которых: Г.-Ф. Миллер, И.И. Шувалов, Д.И. Фонвизин и Сенак де Мейан, а также участники дискуссии об освобождении крестьян в середине $1760-$ х годов.

В статье «Великая княгиня Екатерина и камер-лакей Андрей Чернышев (1746-1747 гг.)» ${ }^{24}$ историк ставит вопрос о значении записок Екатерины II «как исторического и психологического документа» (выделено мной. T.M.), причем Голицын в конце статьи подчеркивает, что если на исторические факты в изложении императрицы стоит смотреть с большой долей критики, то вторая ипостась Записок представляется наиболее ценной. А историю взаимоотношений великого князя Петра Федоровича, молодой Екатерины Алексеевны и камер-лакея Андрея Чернышева он рассматривает не только на основе разных редакций записок императрицы, но и с привлечением дела из фонда Тайной канцелярии. «Дело это, - замечает Голицын, - дает прекрасную картину быта великокняжеского двора в 1744-1746 гг. и вместе с тем является яркой иллюстрацией к запискам Екатерины» ${ }^{25}$.

Против возможных ожиданий читателя, в центре статьи находятся не амурные дела будущей императрицы, а марсовы забавы ее супруга, наделавшие немало шума при дворе и характеризующие несдержанный нрав Петра. Показания Чернышева, подшитые к делу, написанные «весьма грамотно, даже литературно», дополняют образ молодого Петра Федоровича и его военных забав, во многом согласуются с поздними Записками Екатерины II. «Так сходятся свидетельства двух лиц, стоявших на совершенно различных плоскостях, писавших по совершенно различным побуждениям и вспоми-

${ }^{23}$ См., например: Боленко К.Г. Первый российский экслибрис «ЕX BIBLIOTHECA ARCANGELINA» (К вопросу о происхождении легенды) // Книга: исследования и материалы. М. 2005. Т. 84. С. 260-267; Плющ М.А. Использование интернета для поиска сведений о распространении и опровержении легенды о библиотеке Дмитрия Михайловича Голицына // Научно-техническая информация. Сер. 1: Организация и методика информационной работы. 2014. № 7. С. 26-31.

${ }^{24}$ Голицын Н.В. Великая княгиня Екатерина и камер-лакей Андрей Чернышев (17461747 гг.) // Огни: История. Литература / Под ред. Е.А. Ляцкого, Б.Л. Модзалевского и А.А. Сиверса. Пг., 1916. Кн. 1. С. 84-117.

${ }^{25}$ Там же. С. 93. 
навших о рассказанных событиях в совершенно различные эпохи» ${ }^{26}$ — подчеркивает Голицын, углубляясь в компаративное источниковедение.

В 1900 г. он готовит для ЧОИДР публикацию частных писем Дениса Ивановича Фонвизина к Алексею Михайловичу Обрескову за 1772 г. ${ }^{27}$, ориентируясь на то, что они «представляют интерес, как по личности писавшего их, так и по тому эпизоду русской придворной и политической истории... к которому они имеют отношение». В предисловии он затрагивает закулисные интриги, сопровождавшие дипломатическую деятельность А.М. Обрескова в Фокшанах и Бухаресте в 1772 г. и непосредственно отразившиеся в письмах, делает важные замечания о языке писем Фонвизина и их источниковой ценности. Соединение частной истории и крупных политических событий через документ, говорящий «от первого лица», становится для Голицына одним из важных методических приемов, который он использует во многих своих работах. Письма Фонвизина «подымают завесу над такими фактами, поступками и отношениями, какие мы не узнали бы без их посредства... в них проявляется та же двойственность, какая лежит на деятельности графа Н.И. Панина; политические соображения высшего свойства чередуются в них с известиями интимной придворной жизни и ставятся во взаимную между собою связь» - подчеркивает Голицын ${ }^{28}$.

Обращаясь к личности Герарда-Фридриха Миллера и его рукописям, историк отмечает тот неизменный и неутомимый Forschungsgeist (Дух исследования), который руководил ученым в течение всей его жизни ${ }^{29}$. Описанию трех Портфелей Миллера предшествует большая исследовательская статья об истории этой коллекции: о хлопотах немецкого ученого по устройству своего собрания и о дальнейшей истории миллеровских бумаг в XIX веке. Стоит заметить, что в современной историографии вклад Голицына в изучение архива Г.-Ф. Миллера в ряде работ игнорируется ${ }^{30}$.

\footnotetext{
${ }^{26}$ Там же. С. 96-97.

${ }^{27}$ Голицыьн Н.В. Письма Д.И. Фонвизина к А.М. Обрескову // ЧОИДР. 1902. Кн. 1. С. 1-9.

${ }^{28}$ Там же. С. 3.

${ }^{29}$ Вступительная статья к изд.: Голицын Н.В. Портфели Г.Ф. Миллера. М., 1899. 148 с.

${ }^{30}$ Например, Н.Ю. Болотина эту работу Голицына упоминает мельком лишь как публикацию описи архива. При этом сюжет статей исследовательницы почти в точности следует за работой Голицына, рассмотревшего вопрос на столетие раньше и значительно более подробно (Болотина Н.Ю. «После моей смерти посвятить публике». Судьба коллекции академика Г.Ф. Миллера // Исторический архив. 2006. № 1. С. 43-63; Болотина Н.Ю. Сохраненная коллекция: Из истории библиотеки академика Г.Ф. Миллера // Петербургская библиотечная школа. 2015. № 2(50). С. 30-35). Столь же утилитарно обращение к работе Голицына в статье И.В. Тункиной - обильно цитируются приводимые историком документы, но сама работа как историографический факт не учитывается (Тункина И.В. О судьбе рукописного наследия Г.Ф. Миллера // Вопросы истории естествознания и техники. 2008. Т. 29. С. 3-11).
} 
Другой фигурой, олицетворяющей середину XVIII века, становится у Голицына Иван Иванович Шувалов, сыгравший, по словам историка, «роль пионера... неофициального русского посла при той общеевропейской литературной державе», какой была Франция ${ }^{31}$. Работа о нем была задумана до революции, но увидела свет одной из последних - в 1939 г., а потому несет на себе отпечаток советских идеологических подходов, впрочем, мало выраженный. Характеризуя переписку Шувалова с европейскими корреспондентами, Голицын замечает: «это собрание писем типично для характеристики того предреволюционного придворно-аристократического общества Европы, которое нашло в это время общий язык для выражения своих мыслей, которое спешило жить беззаботной и легкомысленной жизнью, как будто в бессознательном предчувствии той революционной бури, которая скоро должна была смести и его и все то, чем оно жило... Письма очень ярко воспроизводят колорит изысканных и легких “causeries” последних салонов Франции; в этом отношении собрание писем к Шувалову является особенно типичным для предреволюционных годов XVIII столетия» ${ }^{32}$. Историк подчеркивает сходство вкусов и интересов русского вельможи и его корреспондентов, их уровня образованности и, в большинстве случаев, взаимную симпатию.

Доклад Голицына, посвященный проектам освобождения крестьян при Екатерине II, обращает на себя внимание, прежде всего, свободой формулировок и оценочных суждений ${ }^{33}$. Прочитанный в 1900 г. на Историческом конгрессе в Париже, на французском языке для иностранной публики, он представляет собой краткое изложение выпускной работы Голицына, написанной в Московском университете (рассмотрение крестьянского вопроса с привлечением широкого круга источников составляет более 400 листов университетского сочинения) $)^{34}$. Работа над этой темой подвела Голицына к идее сочинения о крестьянской общине, о чем он писал летом 1897 г. другу Н.В. Гагарину ${ }^{35}$. Однако, реализовать замысел в полной мере не получилось. Зато вопрос о дискуссиях вокруг крестьянского вопроса был вновь поднят историком на парижском конгрессе через три года.

${ }^{31}$ Голищын Н.В. И.И. Шувалов и его иностранные корреспонденты / Предисл., публ. Н.В. Голицына; пер. с фр. писем М. Неведомского // Литературное наследство. М., 1937. Т. 29/30: Русская культура и Франция. Кн. І. С. 259-342.

${ }^{32}$ Там же. С. 264-265.

${ }_{33}^{3}$ Galitzyne N. La question de l'émancipation des serfs sous l'impératrice Catherine II. Macon, 1902 (Mémoire presénté au Congrès international d’histoire comparée à Paris, 1900).

${ }^{34}$ Голицын Н.В. Очерк мнений по крестьянскому вопросу в царствование имп. Екатерины II в связи с судьбой этого вопроса в Комиссии для сочинения Проекта Нового Уложения 1767-1768 гг. ЦГА г. Москвы. ОХД до 1917 г. Ф. 418. Оп. 513. Д. 1978.

${ }^{35}$ Письма Н.В. Голицына к Н.В. Гагарину. 1897 г. ОПИ ГИМ. Ф. 361. Д. 9. Л. 56 об. 
История крестьянского вопроса во второй половине XVIII в. у Голицына предстает историей соперничества идей, выдвигаемых императрицей и отдельными дворянами (от А.П. Сумарокова и М.М. Щербатова до А.Я. Поленова и А.Н. Радищева), а неуспех в деле освобождения объясняется отсутствием у Екатерины системного подхода и точного понимания сути крепостного права. «Ей не хватало отваги, понимания последствий и проницательности, необходимых, чтобы поставить вопрос ребром»- считает историк.

При этом Голицын отдает должное Екатерине в другом вопросе о противоборстве с революционной Францией, заметное участие в котором отводилось французскому литератору Сенаку де Мейану ${ }^{36}$. Екатерина предполагала с его помощью тайно наладить связи и финансировать французских принцев в их войне против восставших. Историк прослеживает по документам контакты императрицы и писателя, историю их знакомства, расставания и объясняет почему Екатерина была разочарована в своем доверенном лице. Она обнаруживает его приверженность французской демократии, а после «издевается над его фатовством, над его манерой поучать всех, кто его слушает, над его самоуверенностью и легковесностью в отношении научных знаний» ${ }^{37}$ и, в итоге, отказывается от услуг де Мейана, даже не посвятив его в свои планы. Статья наполнена живописными цитатами из документов екатерининского времени, в первую очередь, из частной переписки самой императрицы, Сенака де Мейана и нескольких высокопоставленных лиц.

Из трудов, посвященных первой половине XIX столетия, стоит отметить две работы, во многом противоположные. Это, с одной стороны, исследование о деятельности Михаила Михайловича Сперанского в Верховном уголовном суде над декабристами, изданное в 1917 г. $^{38}$ - работа, построенная на синтезе собственно исторического исследования и источниковедческих выкладок, дополненных публикацией источников, выполненной на высоком археографическом уровне. Итогом работы становятся заключения о ведущей роли Сперанского в суде и в период подготовки работы суда. По мнению Голицына, основанному на приводимых им документах, такое положение Сперанский занял как в силу личных дарований, так и в силу инициативы молодого императора Николая I, желавшего максимально вовлечь бывшего государственного секретаря в подготовительную работу над

${ }^{36}$ Голицььн Н.В. Писатель Сенак де Мейан и Екатерина II (1791 г.) // Литературное наследство. М., 1939. Т. 33/34: Русская культура и Франция. Кн. III. С. 49-72.

${ }^{37}$ Там же. С. 66.

${ }^{38}$ Голищын Н.В. Сперанский в Верховном уголовном суде... 
процессом. Историк также прослеживает насколько мучительной и эмоционально напряженной была для Сперанского работа над документами, сопровождавшими суд.

С другой стороны, Голицын на материалах XIX столетия обращается к сугубо частной истории, к истории повседневности и делает это совершенно осознанно. Он публикует дневник Елизаветы Ивановны Поповой ${ }^{39}$, приживалки в богатом московском семействе 1840-х годов, объясняя его ценность следующим образом: «Действительно, в этом дневнике нет ни описаний крупных исторических событий... ни выдающихся по новизне данных о движении общественной мысли... И все-таки, несмотря на это видимое отсутствие строго научной ценности у дневника Е.И. Поповой, мы думаем, что издание его далеко не является делом бесполезным... внутренние достоинства этого дневника всецело оправдывают нашу решимость... Дневник Е.И. Поповой есть прежде всего памятник бытовой истории» ${ }^{40}$. Это пристальное внимание к «бытовой», семейной истории, для которого автор не без труда подбирает аргументы и основания, составляет особую ценность ряда публикаций, подготовленных Голицыным в предреволюционные годы.

Из двух десятков работ Николая Владимировича Голицына, посвященных событиям XVII - начала XIX вв. больше половины в той или иной мере имеют важный историко-антропологический компонент, в частности - представляют взгляд на происходящие процессы с позиции их участников, рассматривают социальные практики и «бытовую», повседневную историю. Через эти портреты проступает эпоха, по ним можно проследить этапы формирования человека Нового времени. Исторический факт и исторический источник в трудах Голицына неразрывно связаны - он мастерски дает читателю возможность увидеть эту связь. Историк публикует выносит на публику - обнаруженные в архивах тексты не для того, чтобы оставить их изучение следующим поколениям ученых, а для того, чтобы познакомить читателей с тем важным историческим фактом, неотъемлемой частью которого эти тексты являются.

Историография Голицына всегда одновременно персонифицирована и археографична. Люди и документы составляют основу его повествования. При этом, напрямую вопрос о роли личности в истории он поднимает только на материалах XIX века, говоря о М.М. Сперанском и М.Т. Лорис-Меликове.

${ }^{39}$ Попова Е.И. Из московской жизни сороковых годов. Дневник Елисаветы Ивановны Поповой / Под редакцией кн. Н.В. Голицына. СПб., 1911. 283 с.

${ }^{40}$ Там же. С. 18. 
Хочется надеяться на возвращение имени Н.В. Голицына современной науке как некой историографической целостности и более пристальное внимание к его трудам современных исследователей, а также на скорейшую публикацию неизданных работ историка, пока пребывающих в архивах.

\section{Литература}

Анисимов Е.В. Елизавета Петровна. М., 1999.

Боленко К.Г. Об одной историографической развилке 1920 -х гг.: Н. В. Голицын как историк Верховного уголовного суда по делу декабристов // Петербургский исторический журнал. 2019. № 2(22). С. 224-231.

Боленко К.Г. Первый российский экслибрис «ЕX BIBLIOTHECA ARCANGELINA» (К вопросу о происхождении легенды) // Книга: исследования и материалы. М., 2005. T. 84. C. 260-267.

Болотина Н.Ю. Сохраненная коллекция: Из истории библиотеки академика Г.Ф. Миллера // Петербургская библиотечная школа. 2015. № 2 (50). С. 30-35.

Болотина Н.Ю. «После моей смерти посвятить публике». Судьба коллекции академика Г.Ф. Миллера // Исторический архив. 2006. № 1. С. 43-63.

Голицын Н.В. Великая княгиня Екатерина и камер-лакей Андрей Чернышев (17461747 гг.) // Огни: История. Литература / Под ред. Е.А. Ляцкого, Б.Л. Модзалевского и А.А. Сиверса. Пг., 1916. Кн. 1. С. 84-117.

Голицын Н.В. И.И. Шувалов и его иностранные корреспонденты / Предисл., публ. Н.В. Голицына; пер. с фр. писем М. Неведомского // Литературное наследство. М., 1937. Т. 29/30: Русская культура и Франция. Кн. І. С. 259-342.

Голищын Н.В. К истории русско-шведских отношений и населения пограничных с Швецией областей (1634-1648 гг.). М., 1903.

Голицын Н.В. Научно-образовательные сношения России с Западом в начале XVII века. Исторический очерк // ЧОИДР. 1898. Кн. IV. С. 1-34.

Голицыны Н.В. Новые данные о библиотеке кн. Д.М. Голицына (верховника). М., 1900.

Голицын Н.В. Петербург или Петрополь? (Новое свидетельство об основании Петербурга). СПб., 1903.

Голицын Н.В. Писатель Сенак де Мейан и Екатерина II (1791 г.) // Литературное наследство. М., 1939. Т. 33/34: Русская культура и Франция. Кн. ІІІ. С. 49-72.

Голицын Н.В. Письма Д.И. Фонвизина к А.М. Обрескову // ЧОИДР. 1902. Кн. 1. C. $1-9$.

Голищын Н.В. Портфели Г.Ф. Миллера. М., 1899.

Голищын Н.B. Сперанский в верховном уголовном суде над декабристами // Русский исторический журнал. 1917. Кн. 1/2. С. 61-102.

Голицын Н.В. Феофан Прокопович и воцарение Императрицы Анны Иоанновны // Вестник Европы. 1907. Кн. 4. С. 519-543. 
Зверев С.B. Новые материалы о русских студентах в Любеке// Иноземцы в России в XV-XVII веках: Сборник материалов конференции. 2002-2004 гг. М., 2006. С. 260-269.

Лисейщев Д.В. Переводчик посольского приказа Игнатий Андреевич Кучин (К вопросу о судьбе одного из «Годуновских студентов») // Русский родословец. 2002. C. 4-8.

Лиштенан Ф.-Д. Елизавета Петровна. Императрица, не похожая на других. М., 2012.

Плющ М.А. Использование интернета для поиска сведений о распространении и опровержении легенды о библиотеке Дмитрия Михайловича Голицына // Научно-техническая информация. Сер. 1: Организация и методика информационной работы. 2014. № 7. С. 26-31.

Попова Е.И. Из московской жизни сороковых годов. Дневник Елисаветы Ивановны Поповой / Под редакцией кн. Н.В. Голицына. СПб., 1911.

Тункина И.В. О судьбе рукописного наследия Г.Ф. Миллера // Вопросы истории естествознания и техники. 2008. Т. 29. С. 3-11.

Шамин С.М. Видения священника С. И. Дугина и «пасквиль» на архиепископа Феофана (Прокоповича) 1731 г. // Вестник церковной истории. 2019. № 1/2 (53/54). C. 53-91.

Шамин C.M. «Доношения» воронежского священника Саввы Ивановича Дугина в документах Тайной канцелярии // Вестник церковной истории. 2015. № 3/4 (39/40). C. 116-139.

Galitzyne N. La question de l'émancipation des serfs sous l'impératrice Catherine II. Macon, 1902 (Mémoire presénté au Congrès international d'histoire comparée à Paris, 1900). 


\section{А.В. Мельников}

\section{ПЕРЕПИСКА С.Ф. ПЛАТОНОВА и М.М. БОГОСЛОвСКОГО}

Аннотация Статья посвящена источниковым особенностям уникального документального комплекса - переписки двух крупнейших российских историков С.Ф. Платонова (1860-1933) и М.М. Богословского (18671929). Эпистолярный диалог ученых представляет значительный интерес не только в плане изучения их жизни и творчества. В доверительной переписке отражены значимые события научной и общественной жизни России, Москвы, Петербурга-Петрограда-Ленинграда. Переписка - ценнейший исторический и историографический источник не только для понимания процессов развития исторической науки в России, формирования московской и петербургской исторических школ, но и изучения общественного сознания российской гуманитарной интеллигенции конца XIX - первой трети XX вв., углубленного познания культуры переломного периода в истории России. Письма содержат ценнейшие сведения о повседневной жизни и быте профессуры, организации научной жизни в Академии наук, Археографической комиссии, в Московском университете и Московской духовной академии, на Московских высших женских курсах, в Институте истории РАНИОН, Историческом музее, других высших учебных заведениях и научных обществах двух столиц, в них нашли отражение международные связи отечественной исторической науки с учеными Великобритании, Германии, Франции, США, Чехии.

Ключевые слова: С.Ф. Платонов, М.М. Богословский, история исторической науки, петербургская и московская школы историков, российская интеллигенция, Российская академия наук, научные сообщества.

Summary The article is devoted to the source features of a unique documentary complex - the correspondence of two major Russian historians S.F. Platonov (1860-1933) and M.M. Bogoslovsky (1867-1929). The epistolary dialogue of scientists is of considerable interest not only in terms of studying their life and work. The confidential correspondence 
reflects significant events in the scientific and social life of Russia, Moscow, Petersburg-Petrograd-Leningrad. Correspondence is a valuable historical and historiographic source not only for understanding the development of historical science in Russia, the formation of Moscow and St. Petersburg historical schools, but also for studying the public consciousness of the Russian humanitarian intelligentsia at the end of the 19th - first third of the 20th centuries, in-depth knowledge of the culture of a turning point in the history of Russia. The letters contain valuable information about the everyday life and life of the professors, the organization of scientific life at the Academy of Sciences, the Archaeographic commission, at Moscow university and the Moscow theological academy, at the Moscow higher courses for women, at the Institute of history of the RANION, the Historical Museum, other higher educational institutions and scientific societies two capitals, they reflect the international ties of domestic historical science with scientists from Great Britain, Germany, France, USA, Czech Republic.

Keywords: S.F. Platonov, M.M. Bogoslovsky, history of historical science, St. Petersburg and Moscow schools of historians, russian intelligentsia, Russian academy of sciences, scientific communities.

Переписка ученых как одна из разновидностей источников личного происхождения (эго-документов) все более востребована в исследованиях по истории исторической науки, науковедению, биографике, социальной истории ${ }^{1}$. Переписка двух крупнейших российских историков петербуржца С.Ф. Платонова (1860-1933) и москвича М.М. Богословского (1867-1929) - уникальный научный памятник, еще недостаточно введенный в оборот.

В личных архивных фондах М.М. Богословского в Архиве РАН (APAH. Ф. 636), Отделе письменных источников Государственного исторического музея (ОПИ ГИМ. Ф. 442) и С.Ф. Платонова в Отделе рукописей Российской национальной библиотеки (ОР РНБ. Ф. 585) отложилось немало ценных источников, свидетельствующих об их тесных научных и личностных взаимосвязях. Например, в фонде С.Ф. Платонова сохранились: черновики «представлений» М.М. Богословского в Российскою академию наук, выписка из протокола Общего собрания АН о выделении дополни-

${ }^{1}$ См., к примеру: Шумейко М.Ф. Переписка как исторический источник и особенности ее сохранения и публикации // Крыніцазнаўства, археаграфія, архівазнаўства ў XX-XXI ст. у Беларусі: зб. навук. артыкулаў, прысвечаных 100-годдзю $з$ дня нараджэння М.М. Улашчыка. Мінск, 2007. С. 172-183; Кобак А.В. Письма как исторический источник: задачи и приемы изучения // Вестник СПбГУ. Сер. 2. 2012. Вып. 2. С. 142-148; Долгова Е.А. Рождение советской науки: ученые в 1920-1930-е гг. М., 2020; и др. 
тельного средств М.М. Богословскому в размере 50 руб. на продолжение перепечатки на машинке в трех экземплярах копии с рукописи исследования «Петр Великий: Материалы для биографии» (1925), документы об участии М.M. Богословского в передаче книг бывшего Архангельского епархиального древлехранилища в Постоянную историко-археографическую комиссию, материалы С.Ф. Платонова и других ученых о помощи M.M. Богословскому в разрешении жилищно-бытовых вопросов, существенно усложнившихся в послереволюционные годы².

Сохранилась машинопись и подготовительные материалы к рецензии С.Ф. Платонова на второй том исследования М.М. Богословского «Земское самоуправление на русском Севере в XVII веке», опубликованной в 1913 г. (Гонорар за рецензию Платонов предложил Богословскому вручить в виде премии студенту историко-филологического факультета Московского университета по его выбору. Обладателем премии стал Н.М. Дружинин ${ }^{3}$.) В архиве М.М. Богословского имеются расписки С.Ф. Платонова о получении академического жалования для М.М. Богословского ${ }^{4}$, визитные карточки (6 экземпляров $)^{5}$, официальное письмо от Постоянной историко-археографической комиссии за подписью председателя С.Ф. Платонова и ученого секретаря А.И. Андреева с приглашением принять участие в исследовательском проекте - подготовке академического издания Русской Правды по всем имеющимся спискам ${ }^{6}$. Это обращение именно к М.М. Богословскому не было случайным. Он хорошо был известен как талантливый руководитель семинариев по этому источнику. С лекции по Русской Правде и статьи о варварских правдах, источнике схожего типа, М.М. Богословский начал путь в большую науку. К изучению Русской Правды М.М. Богословский привлекал и своих учеников, в частности В.П. Любимова, на которого впоследствии возложена будет значительная часть работы по подготовке текстов Русской Правды к изданию.

Известны и печатные свидетельства дружеской близости ученых. В 1903 г. М.М. Богословский опубликовал рецензию на книгу избранных трудов С.Ф. Платонова7 ${ }^{7}$ а в 1922 г. в «Сборнике статей по русской истории,

2 Архив академика С.Ф. Платонова в отделе рукописей Российской национальной библиотеки: Каталог / Сост. В.А. Колобков. СПб., 1994. Документы № 556, 584, 711, 990, 1288; Мельников А.В. Академик М.М. Богословский в капкане «жилищного вопроса» // Арбатский архив: Историко-краеведческий альманах. М., 2009. Вып. 2. С. 751-755.

3 Дружсинин Н.М. Избранные труды: Воспоминания, мысли, опыт историка. М., 1990. С. 190.

${ }^{4}$ ОПИ ГИМ. Ф. 442. Оп. 1. Д. 2. Л. 12-32 об.

5 Там же. Д. 6. Л. 18-24.

${ }^{6}$ АРАН. Ф. 636. Оп. 3. Д. 13. Л. 1-1 об.

7 Научное слово. 1903. №. 6. С. 120-123. 
посвященных С.Ф. Платонову», поместил статью «Заговор Цыклера» являвшуюся частью большой биографии Петра I, над которой он работал. Наиболее интересным документом, на наш взгляд, является некролог М.М. Богословскому, подготовленный С.Ф. Платоновым к печати в маеоктябре 1929 г., но так и неопубликованный в связи с разворачивающимися событиями «Академического дела»9.

Указанными неопубликованными и изданными материалами не могут, конечно, ограничиться наши представления о дружеских и научных взаимосвязях Богословского и Платонова - ведущих представителей московской и петербургской исторических школ. Следует подчеркнуть необходимость расширения источниковой базы для более полноценного и широкого охвата этого материала, в связи с чем необходимо дальнейшее изучение и иных архивных фондов. Особенно велико научное значение переписки ученых друг с другом.

В сочинениях биографического характера о С.Ф. Платонове имеется опыт использования эпистолярного архива ученого, в том числе переписки с московскими историками, и особенно с М.М. Богословским ${ }^{10}$. Не единожды отмечалась уникальная ценность этой переписки для понимания процесса формирования отношений С.Ф. Платонова и московских коллег и роль именно М.М. Богословского в сближении С.Ф. Платонова с «московским цехом историков». Отмечалась специально и необходимость комплексного изучения переписки С.Ф. Платонова и М.М. Богословского ${ }^{11}$.

Выявленный массив писем довольно значителен по объему и хронологическим рамкам. Крайние даты переписки 1909-1929 гг. В составе фондов М.М. Богословского обнаружено 326 писем и телеграмм С.Ф. Платонова за 1910-1929 гг. Большая часть их сосредоточена в ОПИ ГИМ - 303 кор-

8 Богословский М.M. Заговор Цыклера // Сборник статей по русской истории, посвященных С.Ф. Платонову. Пг., 1922. С. 330-340.

9 С.Ф. Платонов: Неизданный некролог М.М. Богословскому / Подгот. А.В. Мельников // АЕ за 1998 год. М., 1999. С. 388-396.

${ }^{10}$ Шмидт С.О. Доклад С.Ф. Платонова о Н.М. Карамзине 1926 г. и противоборство историков // Археографический ежегодник за 1992 год. М., 1994; Шмидт С.О. Сергей Федорович Платонов (1860-1933) // Шмидт С.О. Путь историка: избранные труды по источниковедению и историографии. М., 1997; Брачев В.С. Русский историк Сергей Федорович Платонов. 2-е изд. СПб., 1998; Глебова И.И. Отечественные публикации источников по истории внутренней политики России конца XIX - начала XX вв.: Автореф. дис. ... канд. ист. наук. М., 1994; Долгова E.A. Рождение советской науки: ученые в 1920-1930-е гг. М., 2020.

${ }^{11}$ Шмидт С.О. Жизнь и творчество историка С.Ф. Платонова в контексте проблемы «Петербург-Москва» // Россия в X-XVIII вв. Проблемы источниковедения: Тезисы докладов и сообщений вторых чтений, посвященных памяти А.А. Зимина. Москва 26-28 января 1995 г. М., 1995. Ч. 2. С. 674. 
респонденции за 1910-1928 гг. ${ }^{12}$ Двадцать три письма за 1924-1929 гг. хранятся в АРАН ${ }^{13}$.

В фонде С.Ф. Платонова в ОР РНБ находятся 181 письмо М.М. Богословского за 1909-1929 гг. ${ }^{14}$, еще одно письмо нами выявлено в фонде Конференции Академии наук в Санкт-Петербургском филиале Архива $\mathrm{PAH}^{15}$.

Значительная количественная разница в письмах объясняется в первую очередь тем, что С.Ф. Платонову приходилось писать гораздо чаще. В число 319 писем С.Ф. Платонова включено и множество записок на оборотах денежных переводов академического жалования М.М. Богословского, которое получал по доверенности С.Ф. Платонов. Это делалось, разумеется, регулярно, или же деньги передавались с оказией, тогда С.Ф. Платонов всегда старался передать М.М. Богословскому и письмо. Записи на денежных переводах содержат обычно весьма скупую информацию (о которой Платонов, как правило, более подробно пишет в последующей корреспонденции), подтверждения о скорой встрече, приветы знакомым и т.п. Тем не менее, показательно, что М.М. Богословский считал необходимым сохранение всех этих документов и, надо полагать, понимая, возможность их использования будущими исследователями, интересующимися изучением деятельности и контактов крупных ученых.

Количественный состав переписки неполон. Совершенно отсутствуют письма С.Ф. Платонова за 1909 г., 1917, 1920 гг., но о содержании их, как правило, можно судить по ответным письмам М.М. Богословского. Также нет письма М.М. Богословского за 1913 год. Ничего не известно о том, под-

${ }^{12}$ ОПИ ГИМ. Ф. 442. Оп. 1. Д. 54 (письма за 1910-1924 гг.): 1910 г. - 1 письмо; 1911 г. - 4 письма (октябрь-ноябрь); 1912 г. - 5 писем (июль-сентябрь 1 письмо б/д); 1913 г. - 1 письмо; 1914 г. - 2 письма (февраль-сентябрь); 1916 г. - 5 писем (февраль-август); 1921 г. - 11 писем (май-декабрь); 1922 г. - 17 писем (янв.-дек.); 1923 г. — 23 письма (янв.-дек.); 1924 г. - 47 писем (янв.-дек.). Д. 55 (письма за 1925-1926 гг.): 1925 г. 47 писем (из них три телеграммы) (янв.-дек.); 1926 г. - 40 писем (янв.-дек.). Д. 56 (письма за 1927-1928 гг.): 1927 г. - 42 письма (янв.-дек.); 1928 г. - 51 письмо (янв.-дек.); Д. 64. Л. 59-59 об.: 1925 г. - 1 письмо (янв.).

${ }^{13}$ АРАН. Ф. 636. Оп. 4. Д. 16 (письма за 1924-1929 гг.): 1924 г. - 1 письмо (янв.); 1928 г. - 1 письмо (янв.); 1929 г. - 21 письмо (янв.-апр.).

${ }^{14}$ ОР РНБ. Ф. 585. Оп. 1. Д. 2322 (письма за 1909-1922 гг): 1909 г. - 2 письма (сент.окт.); 1910 г. — 2 письма (март); 1911 г. - 3 письма (сент.-нояб.); 1912 г. - 2 письма (июльавг.); 1914 г. - 2 письма (февр.-сент.); 1916 г. - 2 письма (июнь-авг.); 1917 г. - 1 письмо (апр.); 1920 г. - 2 письма (июль-нояб.); 1921 г. - 12 писем (янв.-дек.); 1922 г. - 10 писем (янв.-дек. в том числе 1 б/д); Д. 2323 (письма за 1923 г.) - 10 писем (янв.-нояб., в том числе 1 б/д); Д. 2324 (письма за 1924 г.) - 17 писем (янв.-дек.); Д. 2325 (письма за 1925 г.) 26 писем (янв.-дек.); Д. 2326 (письма за 1926 г.) - 24 письма (янв.-дек.); Д. 2327 (письма за 1927 г.) - 29 писем (янв.-дек.); Д. 2328 (письма за 1928 г.) - 25 писем (янв.-дек.); Д. 2329 (письма за 1929 г.) - 11 писем (янв.-апр.).

${ }^{15}$ СПб ФА РАН. Ф. 1. Оп. 2-1922. Д. 1. Л. 32-32 об. (26.12.1921 г. / 8 .01.1922 г.) 
держивали ли переписку корреспонденты в 1918-1919 гг., писем за этот период не обнаружено, что не исключает, конечно, возможности нахождения их в составе иных фондов.

Динамика переписки отражает и развитие взаимоотношений корреспондентов. Обращает на себя внимание то, что бо́льшая часть писем относится к 1920-м гг, а со времени избрания М.М. Богословского в члены Академии наук переписка приобретает систематический характер.

Тематика писем самая разнообразная и охватывает множество сюжетов. Очень редко, когда письмо касается какого-либо одного вопроса. Переписка представляет несомненный интерес для характеристики научной и общественной жизни корреспондентов, их личных взаимоотношений и биографий, и главное, дает материал для изучения взглядов ученых на понимание и трактовку ключевых тем истории России. В доверительной переписке отражены значимые события научной и общественной жизни России, Москвы, Петербурга-Петрограда-Ленинграда. Переписка - ценнейший исторический и историографический источник не только для понимания процессов развития исторической науки в России, формирования московской и петербургской исторических школ, изучения общественного сознания российской гуманитарной интеллигенции конца XIX — первой трети XX вв., но и углубленного познания культуры переломного периода в истории России. Письма содержат подробные сведения о повседневной жизни и быте профессуры, организации научной жизни в Академии наук, Археографической комиссии, в Московском университете и Московской духовной академии, на Московских высших женских курсах, в Институте истории РАНИОН, Историческом музее, других высших учебных заведениях и научных обществах двух столиц, в ней отражены международные связи отечественной исторической науки с учеными Великобритании, Германии, Франции, США, Чехии

Письма свидетельствуют о теплых отношениях ученых, в 1920-е гг. перешедших в семейную дружбу. Платонов по приезде в Москву всегда останавливался у Богословского. Богословский, если ничего не становилось помехой, был гостем Платонова в Ленинграде. В письмах Платонова приглашение в «зеленый кабинет», Богословский зовет Платонова на «дедовский диван». Есть письма в стихах.

Корреспонденты сообщают часто о своих научных планах, например, работа над биографией Петра - сквозная тема у М.М. Богословского. Значительную часть писем пронизывают сюжеты, связанные с Академией наук. Это и описание совещаний, выборов, выработка совместных действий при проведении кандидатов на замещение академических вакансий, оценка нового устава 1927 г. и многое другое. 
М.М. Богословский сообщает о движении научной жизни в Москве, о заседаниях научных учреждений и обществ: секции русской истории Института истории РАНИОН, ОИДР, Исторического общества, о своей работе в ГИМ, в Главархиве, на факультете общественных наук Московского университета. С.Ф. Платонов пишет «краткие отчеты» об академических новостях. С момента создания в 1922 г. Экспертной комиссии при ЦЕКУБУ, представителем от Академии наук по гуманитарным наукам был М.М. Богословский. Вместе с С.Ф. Платоновым они помогали ученым добиваться справедливости в деле утверждения в достойной их имени в науке категории, на основании которой выплачивались социальные пособия, пенсии, премии и т.п. Среди этих лиц и известные историки и архивисты: П.Г. Васенко, С.В. Рождественский, Н.П. Лихачев, П.Г. Любомиров, Н.Д. Чечулин и многие другие, или же вдовы и ближайшие родственники скончавшихся ученых, обычно очень нуждавшиеся. Потому-то тема ЦЕКУБУ занимает значительное место в переписке ${ }^{16}$.

Имеются письма и неожиданного содержания, но по уникальные по информации, такие как, например, письмо С.Ф. Платонова от 25 сентября 1924 г. с описанием второго по величине наводнения в истории города на Неве, разразившегося 23 сентября. И при сопоставительном ознакомлении с впечатлением от этого происшествия выдающихся современников (художницы О.С. Остроумовой-Лебедевой, О.М. Фрейденберг, Б.Л. Пастернака и др.) письмо С.Ф. Платонова представляет несомненный интерес и для краеведения ${ }^{17}$. Все это характеризует информационное многообразие переписки.

Учитывая широту затрагиваемых в переписке сюжетов, рационально представляется выделить определенные темы. Понимая, что обзор от этого значительно проиграет, мы решились остановиться на одном лишь сюжете, представляющем определенный интерес для историографии. Оба историка сосредоточились тогда на работе по близкой тематике - изучении эпохи Петра $^{18}$. С начала 1910-х гг. М.М. Богословский систематически ведет работу по обработке материалов, относящихся к биографии Петра. С.Ф. Платонов уже в 1920-е гг. сообщал в статье «История» (помещенной в юбилейного характера книги о деятельности Академии наук в первое десятилетие со-

${ }^{16}$ Неберекутина Е.В. «Заступник рода исторического» (Деятельность М.М. Богословского в Экспертной комиссии ЦЕКУБУ) // Археографический ежегодник за 2004 год. М., 2005. С. 191-206.

${ }^{17}$ Подробнее см.: «С волнением читали мы Ваше описание наводнения!» (Из переписки академиков С.Ф. Платонова и М.М. Богословского) / Подгот. А.В. Мельников // Невский архив: Ист.-краевед. сб. СПб., 2001. Вып. 5. С. 517-525.

${ }^{18}$ Мельников A.B. К истории рукописи М.М. Богословского «Петр Великий: Материалы для биографии» (Предварительные археографические наблюдения) // Богословский М.M. Петр Великий: Материалы для биографии. В 6 т. М., 2005. Т. 1. С. $432-477$. 
ветской власти), что «М.М. Богословский и С.Ф. Платонов были заняты исследованиями главным образом в области культурной реформы XVIIXVIII веков» ${ }^{19}$.

Интересен и процесс складывания их взаимоотношений, переросших в 1920-е годы в семейную дружбу. В первом сохранившемся письме от 30 сентября 1909 г. М.М. Богословский благодарит С.Ф. Платонова за «доброе слово о своей книге» (о первом томе «Земского самоуправления на Русском Севере»). Он пересылает для руководимого С.Ф. Платоновым Женского педагогического института 40 экземпляров этого издания для участниц семинарских занятий. С.Ф. Платонов интересовался и датой докторского диспута М.М. Богословского. 18 ноября М.М. Богословский сообщал, что диспут назначен на 22 ноября: «Глубоко был бы рад Вашему присутствию на нем, а после диспута на трапезе нашего московского цеха историков» ${ }^{20}$.

Корреспонденты регулярно обменивались только что вышедшими трудами, в письме от 28 ноября 1910 г. М.М. Богословский благодарит С.Ф. Платонова за присылку третьего издания «Очерков по истории Смуты»: «От души радуюсь успеху этой книги, редкому для книг по русской истории. В ответ на Ваш ценный подарок могу Вам послать только нечто весьма малое и плохое, которое при сем препровождаю» ${ }^{21}$. К сожалению, установить точно о каком труде М.М. Богословского идет речь не удалось.

Дружественному сближению корреспондентов способствовало участие в совместных научных изданиях тех лет. Именно М.М. Богословский от имени москвичей приглашал С.Ф. Платонова принять участие в сборнике «Освобождение крестьян: деятели реформы», в котором «принимает участие кружок московских историков и, кажется, с В.О. Ключевским во главе. Ваше сотрудничество, Многоуважаемый Сергей Федорович, было бы для нас очень желательно» - о чем сообщал в письме от 3 марта 1910 г. ${ }^{22}$

С.Ф. Платонов, сославшись на занятость и ряд обязательств, отвечал 8 марта 1910 г.: «Я очень тронут Вашим предложением и, по своему к Вам внутреннему отношению, не хотел бы отказываться», но при этом предлагал и свои услуги: «Кто будет писать о в. кн. Константине Николаевиче? Не будет ли он нуждаться в Архивах? Не осталось ли об этом лице чего-нибудь в бумагах покойного Павлова-Сильванского? Наконец, не обратитесь ли за портретом его в Мраморный дворец» ${ }^{23}$.

\footnotetext{
${ }^{19}$ Шмидт С.О. Сергей Федорович Платонов (1860-1933). С. 534.

${ }^{20}$ ОР РНБ. Ф. 585. Оп. 1. Д. 2322. Л.1

${ }^{21}$ Там же. Л. 3.

22 Там же. Л. 4-4 об.

${ }^{23}$ ОПИ ГИМ. Ф. 442. Оп. 1. Д. 54. Л. 29-29 об.
} 
Также на М.М. Богословского была возложена дипломатическая обязанность склонить С.Ф. Платонова к участию в сборнике памяти В.О. Ключевского. В письме 25 сентября 1911 г. М.М. Богословский обращался к С.Ф. Платонову: «Многоуважаемый Сергей Федорович. Г.К. Рахманов, издатель "Научного слова" предпринимает издание сборника, посвященного памяти покойного В.О. Ключевского. В сборник войдут воспоминания о В.О. его учеников, статьи о его работах, характеристики его, как ученого и преподавателя и т.п. Может быть и Вы, многоуважаемый Сергей Федорович, не откажитесь принять участие в этой книге и дать для нее хоть несколько страниц. Ваше участие и для издателя и для нас, учеников В.О., было бы очень ценно. Позвольте надеяться, что не ответите на нашу просьбы отказом» ${ }^{24}$.

С.Ф. Платонов тотчас же ответил 1 октября 1911 г. письмом, в котором спрашивал: «Что я могу дать в сборник г. Рахманова Личное знакомство мое с В.О. было малое, воспоминания - обывательские. А писать о В.О., как об историке... москвичи, его слушавшие, сделают это лучше. Вот - это одна сторона дела. Другая: не хотелось бы отказываться от исполнения просьбы ученика В. О-ча, самого В. О-ча касающейся! Третья: я уже повинен дать на этих днях нечто о В. О-че в Ж.М.Н.Просв. Взвесьте все это и дайте совет: или освободите от Г.К. Рахманова или научите, что и когда можно дать» ${ }^{25}$.

М.М. Богословский в письме 5 октября 1911 г. уверял С.Ф. Платонова в необходимости принять участие в подготовке сборника: «Московским историкам Ваше участие всегда ценно и дорого. Решительно протестую, против Вашего утверждения, что москвичи лучше сумеют характеризовать В.О. Ключевского, как историка, чем Вы. Но приведенный Вами резон относительно Вашего обязательства для Ж.М.Н.П. нельзя не счесть, действительно, убедительным, в особенности потому, что Рахманов спешит со сборником, желает выпустить его непременно к январю. Торопить же Вас с работой было бы с нашей стороны непозволительным посягательством. Жаль, очень жаль, но виноваты мы сами: нам следовало бы приняться за дело ранее и опередить Ж[урнал] М[инистерства] н[ародного] пр[освещения]. Если все же Вы бы удосужились написать, что-либо хотя и не большое - очень обрадовали бы и издателя и сотрудников» ${ }^{26}$. В письме от 8 октября 1911 г. С.Ф. Платонов благодарит Богословского за «доброе слово». «Решительно смущаюсь необходимостью “выжать” скудные воспоминания,

\footnotetext{
${ }^{24}$ ОР РНБ. Ф. 585. Оп. 1. Д. 2322. Л. 5.

${ }^{25}$ ОПИ ГИМ. Ф. 442. Оп. 1. Д. 54. Л. 26-26 об.

${ }^{26}$ ОР РНБ. Ф. 585. Оп. 1. Д. 2322. Л. 6-6 об.
} 
независимо от (тоже скудного) некролога. По обычаю в октябре буду в Москве тогда и побеседуем» ${ }^{27}$. А 27 октября М.М. Богословский уже приносил С.Ф. Платонову «глубокую благодарность за присылку статьи». «Статья Ваша весьма подходит для нашего сборника. Будем только тревожить Вас двумя небольшими просьбами: 1) не найдете ли Вы возможным изменить первые 9-10 строк статьи, имеющих некрологическую форму. Дело в том, что в сборнике будет помещен некролог В.О. К[лючевского], написанный М.К. Любавским. 2) Может быть, Вы найдете также возможным, на заключительной странице не делать ссылки на статью А.А. Кизеветтера в Русск[их] Вед[омостях], так как он также участвует в сборнике, а читателями эти несколько строк могут быть приняты за полемику, что в одном и том же сборнике было бы не совсем удобно. Все остальное принимаем с большою благодарностью и очень ценим Ваше слово о В.О. Статью будем набирать с тем расчетом, что если Вы согласитесь сделать эти небольшие изменения, то сделаете их в гранках. Или может Вы пришлете оттиск из Ж.М.Н.Пр. с соответствующими помарками? черкните, пожалуйста, многоуважаемый Сергей Федорович, как Вы предпочитаете сделать и еще раз примите выражение самой искренней признательности за присланное» ${ }^{28} .9$ ноября 1911 г. С.Ф. Платонов передавал исправленный текст, сопровождая его письмом: «Прилагаю желаемую Вами переделку. Годится ли? Будет ли хорошо? На другое, ей-ей нет времени» ${ }^{29}$.

Сейчас уже ясно, что по переписке можно проследить, какие темы были центром внимания для обоих адресатов. Это интерес к действиям М.Н. Покровского, особенно его отношение к традиционным научным учреждениям и обществам, к так называемым спецам, к его тенденциям насаждения вульгарной социологии в преподавании истории в высшей и средней школе. С утверждением М.М. Богословского в ЦЕКУБУ регулярными стали просьбы и рассуждения о судьбе отдельных ученых и их родственников и конечно, вопросы об организации работы в академических учреждениях. Каждое из подобных сообщений, как правило, нуждается в специальном комментарии, опирающемся и на другие материалы фондов обоих адресатов, а также и на иные источники. Попытка такого комментирования предпринята в готовящемся к публикации в Археографической комиссии РАН завершающем втором выпуске второго тома издания «Академик С.Ф. Платонов: Переписка с историками».

\footnotetext{
${ }^{27}$ ОПИ ГИМ. Ф. 442. Оп. 1. Д. 54. Л. 27.

${ }^{28}$ ОР РНБ. Ф. 585. Оп. 1. Д. 2322. Л. 7-8 об.

${ }^{29}$ ОПИ ГИМ, Ф. 442. Оп. 1. Д. 54. Л. 28.
} 


\section{Литература}

Архив академика С.Ф. Платонова в отделе рукописей Российской национальной библиотеки: Каталог / Сост. В.А. Колобков. СПб. 1994.

Богословский М.M. Заговор Цыклера // Сборник статей по русской истории, посвященных С.Ф. Платонову. Пб., 1922. С. 330-340.

Брачев В.С. Русский историк Сергей Федорович Платонов. 2-е изд. СПб.,1998.

Глебова И.И. Отечественные публикации источников по истории внутренней политики России конца XIX - начала XX вв.:Автореф. дис. ... канд. ист. наук. М., 1994.

Долгова Е.А. Рождение советской науки: ученые в 1920-1930-е гг. М., 2020.

Дружинин Н.М. Избранные труды: Воспоминания, мысли, опыт историка. М.,1990.

Кобак A.B. Письма как исторический источник: задачи и приемы изучения // Вестник СПбГУ. Сер. 2. 2012. Вып. 2. С. 142-148.

Мельников A.B. Академик М.М. Богословский в капкане «жилищного вопроса» // Арбатский архив: Историко-краеведческий альманах. М., 2009. Вып. 2. C. $748-760$.

Мельников A.B. К истории рукописи М.М. Богословского «Петр Великий: Материалы для биографии» (Предварительные археографические наблюдения) // Богословский М.М. Петр Великий: Материалы для биографии. В 6 т. М., 2005. Т. 1. С. $432-477$.

Неберекутина E.B. «Заступник рода исторического» (Деятельность М.М. Богословского в Экспертной комиссии ЦЕКУБУ) // Археографический ежегодник за 2004 год. М., 2005. С. 191-206.

«С волнением читали мы Ваше описание наводнения!» (Из переписки академиков С.Ф. Платонова и М.М. Богословского) / Подгот. А.В. Мельников // Невский архив: Историко-краеведческий сборник. СПб., 2001. Вып. 5. С. 517-525.

Шмидт С.О. Доклад С.Ф. Платонова о Н.М. Карамзине 1926 г. и противоборство историков // Археографический ежегодник за 1992 год. М., 1994. С. 39-76.

Шмидт С.О. Жизнь и творчество историка С.Ф. Платонова в контексте проблемы «Петербург-Москва» // Россия в X-XVIII вв. Проблемы источниковедения. Тезисы докладов и сообщений вторых чтений, посвященных памяти А.А. Зимина. Москва 26-28 января 1995 г. М., 1995. Ч. 2. С. 673-677.

Шмидт С.О. Сергей Федорович Платонов (1860-1933)// Шмидт С.О. Путь историка: избранные труды по источниковедению и историографии. М., 1997. С. 495-553.

Шумейко М.Ф. Переписка как исторический источник и особенности ее сохранения и публикации // Крыніцазнаўства, археаграфія, архівазнаўства ў XX-XXI ст. у Беларусі: зб. навук. артыкулаў, прысвечаных 100-годдзю 3 дня нараджэння М.М. Улашчыка. Мінск, 2007. С. 172-183. 


\section{М.П. Мироненко}

\section{СУДЬБА РУССКОГО АРХЕОЛОГА НА ПЕРЕЛОМЕ ЭПОХ}

Аннотация Статья посвящена судьбе археолога, историка, сотрудника Румянцевского музея, краеведа, заведующего секцией охраны музеев и памятников искусства и старины в Архангельске, члена и активнейшего участника Архангельского Церковно-археологического комитета и Архангельского общества изучения Русского Севера К.Н. Любарского (1886-1920). В ОПИ ГИМ хранится его архив, проливающий свет на историю его борьбы за охрану погибавших на Севере России в годы революции и гражданской войны церквей и других памятников искусства и культуры, за создание Архангельского краевого музея.

Ключевые слова: К.Н.Любарский, археология, история, Румянцевский музей, краеведение, Архангельск, музейное дело, церкви, охрана памятников.

Summary The article is devoted to the fate of an archaeologist, historian, employee of the Rumyantsev Museum, local historian, head of the section for the protection of museums and monuments of art and antiquities in Arkhangelsk, member and active participant of the Arkhangelsk Church Archaeological Committee and the Arkhangelsk Society for the Study of Russian North K.N. Lyubarsky (1886-1920). The Department of Written Sources of the State Historical Museum stores his archive, which sheds light on the history of his struggle to protect churches and other monuments of art and culture dying in the North of Russia during the revolution and civil war, for the creation of the Arkhangelsk Regional Museum.

Keywords: K.N. Lyubarsky, archaeology, history, Rumyantsev Museum, local history, Arkhangelsk, museum affairs, the churches, protection of monuments.

В Отделе письменных источников Государственного исторического музея (ОПИ ГИМ) хранится личный архивный фонд археолога, историка, кра- 
еведа, музееведа Кассиана Николаевича Любарского (1886-1920) ${ }^{1}$. В нем выделяются два важных и совсем неизученных источника, позволяющих представить себе жизнь и труды этого человека. Первый из них - биографический очерк о Любарском «По дороге к вершине»², написанный с большой вероятностью его теткой Прасковьей Кассиановной Любарской. Именно она в 1928 г. сдала в Исторический музей архив своего племянника, однако далеко не весь, оставив у себя его письма и дневники. Она прекрасно знала все подробности его жизни, и ее очерк очень точен и подробен. Его главная ценность в том, что он содержит обширные, иногда на несколько листов отрывки из дневников и писем Любарского, которые не были переданы в Исторический музей, остались у П.К. Любарской и поэтому до нас не дошли. Они описывают подробности его военной службы, археологических поездок, жизни на Русском Севере, и в этом смысле очерк представляет собой ценный источник для биографии и изучения творческой деятельности Любарского. О другом важном источнике, содержащем работы Любарского, будет сказано позже.

Отец родившегося в 1886 г. в Москве Кассиана был французом, но брак родителей распался, и Кассиан носил фамилию матери, а отчество по дяде, крестному отцу. Закончив Московское реальное училище К.П. Воскресенского и юридический факультет Московского университета, он служил в МАМЮ, а затем в Румянцевском музее. С юных лет и до своей трагической гибели в августе 1920 г. больше всего он любил русскую старину и археологию. Эта любовь во многом сложилась под влиянием его тетки, Прасковьи Кассиановны Любарской, учившейся на Московских высших женских курсах и бывшей ученицей Ф.И. Буслаева, с которым она состояла в переписке и дружеских отношениях. Семья Любарских происходила из Рязани, и там находился их родовой дом. Касьян (Кассиан) стал членом Рязанской губернской ученой архивной комиссии и издал «Краткий обзор ризницы Рязанского архиерейского дома» (Рязань, 1912) и «Рязанский некрополь (Спасский мужской монастырь. Ч. 1)» (Рязань, 1914), собирал книги и предметы старины для создания в Рязани музея Рязанской ученой архивной комиссии. Летом 1914 г. он представлял Рязанскую губернскую ученую архивную комиссию на XVI Археологическом съезде в Пскове, но из-за начала войны съезд был отменен, и участники съезда могли только наблюдать панику на вокзале в Пскове.

1 Изучение архивных материалов К.Н. Любарского проводилось в рамках проекта РФФИ № 16-01-00342-ОГН.

2 ОПИ ГИМ. Ф. 315. Оп. 1. Д. 1. Л. 1a-96. 
В 1913 г. Любарский совершил поездку по Туркестану, во время которой он фотографировал исторические памятники и составил альбом фотоснимков, хранящийся ныне в отделе ИЗО в ГИМ. Он был членом Комиссии по изучению старой Москвы при Московском археологическом обществе, членом Тульской палаты древностей. Летом 1915 г. с хранителем Отделения доисторических, христианских и русских древностей Румянцевского музея С.О. Долговым был командирован на Кавказ для археологических раскопок, осмотра, снятия обмеров и фотографий древних памятников Кавказского края и приобретения предметов древности для музея. Во время этой командировки Любарский вел дневник с фотографиями раскопок и памятников и оставил путевые записки «Кавказское побережье»³.

Вернувшись с Кавказа, он искал для себя такое поле деятельности, чтобы приносить пользу обществу, и нашел: работал в организациях по приему беженцев, в детских столовых, устраивал концерты для раненых в госпиталях и, наконец, работал в Красном кресте по оборудованию и отправке транспортов в окопы передовых линий.

В феврале 1916 г. Любарский был призван в армию. Хотя он по закону мог отказаться от службы как единственный сын, но присущее ему чувство долга не позволило сделать это, он прошел военное обучение в качестве вольноопределяющегося и как знающий иностранные языки был направлен служить в Архангельское Главное артиллерийское управление, заниматься отправкой военных грузов, получаемых от союзников, водным путем. Во время взрыва боеприпасов на пароходе «Барон Дризен» в Архангельске он был ранен и чуть не лишился зрения. В начале 1917 г. он был направлен в командировку в Мурманск для отправки военных грузов по незамерзающим рекам (Кола, Северная Двина). Там 3 марта 1917 г. его встретило известие о Февральской революции, которому он был искренне рад. «Воображаю, как кипит, бурлит жизнь у вас теперь! Сколько новых горизонтов, новых возможностей, новых работ и применения сил!» - писал он родным ${ }^{4}$ Его глубоко поразило известие об артиллерийском обстреле Кремля, о самом факте, что на него подняли руку. «Люди всегда зверели во все революции. Думается, что разгромом Кремля большевики очень себе повредили в стране, где теории так мало значат, а нужны факты. Это неопровержимо, и многих вероятно приведет в ужас. Скоро наступит крах, и придет новая полоса в жизни», — надеялся он ${ }^{5}$.

\footnotetext{
3 Дневник «Кавказская поездка летом 1915 г.». Ч. 1, 2; Путевые записки «Кавказское побережье» // Там же. Д. 2-4.

4 Там же. Д. 1. Л. 55.

5 Там же. Л. 73-74.
} 
В Архангельске Любарский стал деятельным членом губернского Церковно-археологического комитета и Архангельского общества изучения Русского Севера, ездил по Архангельскому уезду для осмотра и снятия чертежей и фотографий с разрушающихся деревянных церквей, посещал отдаленные скиты, занимался в архивах. В фонде Любарского хранится его «Краткий отчет о поездке по Архангельскому уезду летом 1919 г.» (с чертежом церкви в с. Солуне) и удостоверение, выданное К.Н. Любарскому и заведующему Художественной студией писателю и этнографу С.Г. Писахову о том, что они командированы в с. Заостровье для осмотра, взятия на учет и вывоза предметов старины для краевого музея (14 мая 1920 г.). Любарский писал статьи по истории Русского Севера, основанные на изучении архангельских архивов («Крестьяне Архангельской губернии в XVII столетии», «Материалы по истории быта, экономической и государственной жизни России в XVII столетии», «Лопарские клейма», «Прогулка по Москве XVII столетия с монахами Сийского монастыря: (Опыт живописной систематизации материалов)», «Некоторые черты из деловых поездок монахов Сийского монастыря в Москву в XVII столетии»), которые он публиковал в местных изданиях (главным образом, в «Известиях Общества изучения Русского Севера»), читал для солдат в клубе лекции по истории с волшебным фонарем. Кроме того, он, как хорошо знающий французский язык, был прикомандирован к находившейся в Архангельске Французской военной миссии. Он был неустанным пропагандистом идеи охраны памятников старины на Русском Севере, с настоящей болью писал о разрушающихся деревянных церквях, о гибели помещичьих библиотек, о вывозе пудами за границу икон и рукописей. А главной целью его жизни стало создание Архангельского краевого музея, чему он посвящал все свои силы, в то время как охваченное тяготами гражданской войны даже образованное общество было довольно глухо к его призывам. Он работал за десятерых, пытался побудить окружающих музейщиков также работать в полную силу, пользовался всяким случаем, чтобы проводить свои идеи о пользе музеев и книжности и их огромном значении в жизни государства, старался пополнять коллекции будущего музея.

В ОПИ ГИМ хранится переплетенный том, составленный самим Любарским из автографов его многочисленных докладов, статей, заметок, писем по музейному делу и по поводу спасения памятников старины и искусства, которыми он бомбардировал различные руководящие организации ${ }^{6}$. Лист использования был пустым, видимо, никто не открывал его, кроме обрабатывавших фонд архивистов. Обложка любовно оформлена Любарским, заголовок вы-

${ }^{6}$ ОПИ ГИМ. Ф. 315. Оп. 1. Д. 5. 
веден тушью псевдо-руническими буквами: «Выброшенное в суету жизни». Главное содержание этих материалов - отчаянная борьба Любарского за создание в Архангельске Краевого музея Северного края. В работе «Охрана памятников искусства и старины» он писал: «По мног[им] историч[еским] и географич[еским] прич[инам] Арханг[ельск] имеет возм[ожность] создать у себя образцовый, исключит[ельный] по богатству и знач[ению] госуд[арственный] кр[аеведческий] м[узей], кот[орым] здесь, в портовом городе и центре обширн[ого] края, могли бы гордиться и правит[ельство], и населен[ие], и реальная госуд[арственно]-экономич[еская] роль кот[орого] была бы неоценима» ${ }^{7}$. Существовавший же городской музей, как писал Любарский в другой имеющейся в томе работе «Музей местной старины» (1918), не имея ни денежных средств, ни официальных полномочий, влачил печальное существование. Он был лишен возможности приобретать гибнущие на местах из-за невежества или скупаемые ловкими агентами для перепродажи за границу исторические материалы, и вынужден был перебираться из одного неудобного помещения в другое, еще менее подходящее. Не было возможности ни пополнять коллекции, ни проводить экскурсии, ни издавать труды. Любарскому удалось в 1918 г. получить согласие духовных лиц на передачу новому Краевому музею флигеля духовной семинарии. После небольшого ремонта и переселения жильцов это здание вместило бы в себя ютившиеся в неприспособленных помещениях небольшой городской музей и музейные коллекции Церковно-археологического комитета, собранные, как он искренне отмечал, не «благодаря чему-либо», а «несмотря ни на что».

Среди материалов тома - программный доклад «Значение археологии и областных музеев в жизни государства», читанный Любарским на заседании Общества изучения Русского Севера 29 декабря 1918 г., в котором он излагал принципиальную необходимость создания музея: «давно уже пора (и дай Бог, чтобы не поздно), настоятельно необходимо для самого нашего существования если не всему населению, то хоть части его, понять, что процветание государства без процветания науки немыслимо. Не можем мы, неучи, конкурировать с теми, кто вооружен всеми доступными человеку знаниями. В лучшем случае русская наука подвигалась вперед, запертая в стенах учреждений, доступная лишь тем, кто... ей посвящает всю жизнь. Но для государства этого еще далеко не достаточно. Категорически необходимо, чтобы наука раскрывала свои знания для широких масс, чтобы вся нация пользовалась плодами ее открытий» ${ }^{8}$.

\footnotetext{
7 Там же. Л. 145.

8 Там же. Л. 12.
} 
В мае 1918 г. им был подготовлен «Доклад Архангельскому губ[ернскому] комиссару народного просвещения о значении, положении и нуждах областного Церковно-археологического музея». Осенью 1919 г., когда войска союзников готовились покинуть Архангельск, встал вопрос о возможной эвакуации коллекции музея Церковно-археологического комитета. Любарский написал короткое, но выразительное «Ходатайство перед Временным правительством (Археологического комитета)», где указывал, что музей содержит драгоценные собрания рукописей и грамот (30 тыс. документов, книги, собрания икон и других церковных предметов в количестве 800 номеров, представляющих собой «незаменимую историческую и культурную ценность огромного общерусского значения» (подчеркнуто Любарским. - M.M. $)^{9}$. К счастью, эвакуация не состоялась.

В докладе «Нужды момента» (январь 1920 г.) он писал: «Пудами и вагонами вывозятся из России различные культурные ценности... Чужие страны, собравшие уже немало образцов русского искусства, положат их в свои музеи, и мы, чтобы изучать их, поедем в Германию, в Америку, в Англию... Обидно и глупо» ${ }^{10}$. Доклад был одобрен Обществом изучения Русского Севера, и было решено обратиться к правительству с предложением издания закона об охране памятников, имеющих государственное значение. В работе «Государство и музеи» Любарский выдвигал задачу создания сети широко поставленных, постоянно пополняемых и внимательно следящих за жизнью страны музеев с отделами естественных богатств и прикладных знаний. Его излюбленным аргументом, доказывающим необходимость музеев, была их важная роль в восстановлении исчезавшей местной промышленности, ремесел, народного искусства. Любарский возлагал большие надежды на идею государственного плана возрождения русского искусства через показ лучших образцов в музеях. Не раз писал он о том, что музей должен быть не складом старых любопытных вещей, предметом роскоши в государстве, а живым действенным организмом. В работе «Старожилам Архангельска» он призывал местных жителей помочь созданию музея и для раздела истории Архангельска приносить книги, письма, воспоминания, портреты и рисунки, фотографии, вещи, костюмы и проч.

В «Докладе в Москву о задачах, состоянии и нуждах Краевого музея гор[ода] Архангельска» он говорил о том, с каким трудом идет создание музея, о провинциализме, сепаратизме музейных работников, непонимании государственных задач. Не было людей - все были призваны на во-

9 Там же. Л. 28 об.

${ }^{10}$ Там же. Л. 70 об. 
енную службу, не было средств, связь с местными провинциальными музеями была плохая. «Словом, каждому археологу и музееведу знакомая еще по прежним временам картина, но, пожалуй, сгущенная в красках, п[отому] ч[то] теперь больше надежд и мечтаний», — с грустью заключал он ${ }^{11}$.

«Будем приучать себя не проводить ни одного дня, ни одного часа без пользы для общего блага», - писал он. Призывал к деятельной, созидательной работе на новых государственных и социальных началах, которые, как он искренне верил, теперь, после падения самодержавия, установятся в России, поскольку «в настоящее время... возрождается русская общественная жизнь и перестраивается на демократических началах под знаменем народного самоопределения». В Архангельске, как и на всем Севере России, в 1918-1919 гг. находились войска Антанты, действовало их Временное правительство, и связь с остальной Россией была весьма затруднена, хотя письма доходили, хоть и нерегулярно. Видимо, этим частично можно объяснить несколько наивное и преувеличенно оптимистичное представление Кассиана Николаевича о действительном положении дел в стране.

Любарскому приходилось бороться с равнодушием, ленью, непониманием окружающих. Он писал: «Никогда еще, ни в одном городе, не видел я более печальных условий существования [Археологического] к[омите]та и его М[узея] и более упорного, стойкого равнодушия общества, где даже, кажется, самый факт существования М[узея] едва лишь признается терпимым» ${ }^{12}$. Его охватывало чувство отверженности от окружавших его людей. В апреле 1918 г. он писал: «За последнее время мне часто здесь делается страшно. Кажется, что люди, как голодные собаки, накинутся на меня и разорвут, потому что от меня иначе пахнет. Я думаю и чувствую не так как все здесь; живу в непонятной, а потому смешной для них и часто неприятной плоскости. С каждым днем все это острее. Минутами нападает такой страх, что я готов спрятаться Бог знает куда. Лучше всего чувствовалось бы у французов, за гарантирующими, от всего изолирующими стенами миссии, если бы не остатки патриотизма, выражающегося в чувстве стыда перед ними... Ни во что не верится, все кажется грязным, призрачным... Кроме прошедшего, к которому еще больше начинаю обращаться, за невозможностью смотреть вперед. Это уже новый вид археологии. Так сказать, археология поневоле» ${ }^{13}$.

Любарский неплохо знал членов Французской миссии, к которой был прикомандирован. Получив для музея флигель семинарии, он предложил

\footnotetext{
${ }^{11}$ Там же. Л. 143.

12 Там же. Л. 12.

${ }^{13}$ ОПИ ГИМ. Ф. 315. Оп. 1. Д. 1. Л. 81-82.
} 
временно размещать там французов, возвращавшихся на родину, водил их в музей и рассказывал о русской истории. В томе его работ сохранились его речь, произнесенная при вручении ему французского военного креста и тост на праздновании Нового года. Покидавшие осенью 1919 г. Архангельск члены Французской миссии неоднократно официально и весьма настоятельно приглашали его уехать с ними во Францию и гарантировали там работу. Однако, считая текущий момент «слишком важным для России и открывающим такие широкие перспективы для его излюбленной деятельности» ${ }^{14}$, Любарский не счел возможным бросить родину и отказался от эмиграции.

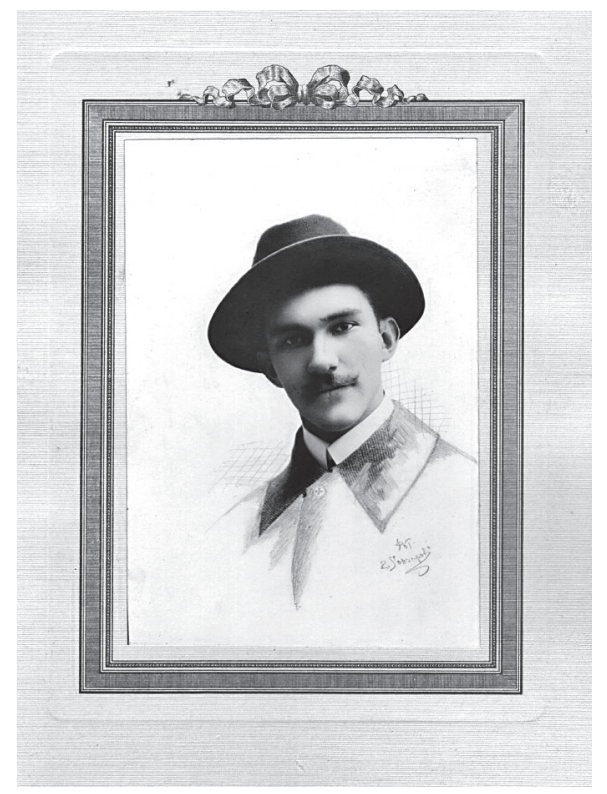

Кассиан Николаевич Любарский.

ОПИ ГИМ. Ф. 315. On. 1. Д. 1.

В марте 1920 г. он был назначен заведующим секцией музеев и охраны памятников искусства и старины при Архангельском губернском отделе Наркомпроса. Казалось бы, теперь для него открылись все возможности для воплощения идеи, которой он отдал столько сил. Однако исторические события, развивавшиеся на Российском Севере, привели к совсем другому повороту его судьбы.

\footnotetext{
${ }^{14}$ Там же. Л. 96.
} 
После установления советской власти в Северном крае К.Н. Любарский 26 июля 1920 г. был арестован. Его обвинили в том, что якобы летом 1918 г. при высадке союзников он утопил в реке замки от орудий красноармейских частей и сообщил о месте потопления союзникам. Единственным косвенным доказательством его вины были его связи с Французской миссией и вручение ему французского военного креста. По постановлению Архангельской ВЧК он был расстрелян 7 августа 1920 г. Хранящиеся в дневниках и статьях Любарского высказывания об иностранных интервентах делают подобные обвинения невозможными. «Ох уж эти мне союзники! Авантюра сменяет другую. Ни плана, ни цели, ни, главное, соглашения между собою. Полное недоверие», — писал он по поводу распоряжений союзников, занявших Архангельск в августе 1918 г. «Я вполне убедился в эгоистической неискренности “союзников” по отношению к России... В массе все это была преподлая авантюра». «Если никакие иностранные “благодетели” не ввяжутся в наше дело, то, может быть, все и пойдет на лад, к быстрому улучшению. Задатки, по-моему, для этого есть», — продолжал он ${ }^{15}$. В статье «Требование ответственного исторического момента», посвященной необходимости создания Книжной палаты, одной из целей которой он считал сохранение редких местных изданий, в том числе выходивших в годы гражданской войны, он с насмешкой задавал вопрос: «А где найдем мы теперь висевшие в свое время на каждом углу широковещательные объявления, приглашавшие добровольцев в иностранные легионы?.. А где достать теперь 1-2 экземпляра русских приказов, предлагавших жителям “исполнить свой гражданский долг и выйти навстречу союзным войскам для выражения радости по случаю их прихода?"» ${ }^{16}$.

Любарский оставил завещание, в котором выражал желание подарить свой семейный дом в Рязани городу для устройства в нем «на вечные времена» музея Рязанской губернской ученой архивной комиссии. Им было собрано в течение всей жизни много предметов для этого музея и 300 книг. Если же, как он опасался, по каким-то причинам разместить там музей не получится, то он предлагал устроить в доме городскую читальню-библиотеку имени Любарских. Но дом был отнят, много вещей пропало, часть вещей была продана матерью и теткой, которым не на что было жить. Через год после гибели Любарского его мать ездила в Архангельск, чтобы разузнать подробности дела, но ничего нового ей не сообщили. Узнала она только, что в городе не осталось ни одной семьи, где бы ни было погибших.

\footnotetext{
${ }^{15}$ Там же. Л. 89, 90 об.

${ }^{16}$ ОПИ ГИМ. Ф. 315. Оп. 1. Д. 5. Л. 132 об.-133.
} 


\section{О.В. Новохатко}

\section{РОССИЯ СЕРЕДИНЫ XVII В.: ЕЩЕ РАЗ ОБ АБСОЛЮТИЗМЕ}

Аннотация В статье рассматривается одна из наиболее дискутируемых проблем российской историографии - зарождение и развитие абсолютизма в России. Для раскрытия этой проблемы необходимо понять природу российского государственного устройства XVII в., место России в европейской политической системе, содержание и характер перемен, происходивших в русской жизни в этот период (конкретнее в середине столетия), когда по мнению многих исследователей в стране зарождалась или уже укреплялась такая форма правления, как абсолютная монархия.

Ключевые слова: абсолютизм, Россия, раннее Новое время, государственное устройство, государственное управление, история экономики, история военного дела.

Summary The article deals with one of the most debated problems of Russian historiography - the origin and development of absolutism in Russia. To solve this problem, it is necessary to understand the nature of the Russian state structure and the place of Russia in the European political system of the XVII century, the content and nature of the changes that took place in Russian life during this period (more specifically, in the middle of the century), when, according to many researchers, such a form of government as an absolute monarchy was born or was already being strengthened in the country.

Keywords: Absolutism, Russia, early Modern period, state structure, public administration, economic history, military history.

В Новое время в Европе продолжался активный процесс складывания национальных государств. Последствия этого процесса сказывались как на внешней, так и на внутренней их жизни, оказывая взаимное влияние на межгосударственные отношения. При пестроте и сложности политической и этнической структуры Европы становление национальных государств сопровождалось агрессивной внешней политикой - захватом соседних государств или их частей, подчинением одних государств другими. Внешняя политика была неразрывно 
связана с внутренней: характерной чертой европейского государства XVII в. являлась постоянная модернизация, перестройка всех сторон жизни общества.

Для сохранения государственного суверенитета в таких условиях следовало прежде всего создать большую и сильную армию, для содержания которой требовалось много денег. Значительное влияние на эту ситуацию оказала также происходившая в Европе с середины XVI до середины XVII в. так называемая военная революция, основными факторами которой были нововведения в военной доктрине, тактике ведения боя, обучении войск, быстром распространении и увеличении эффективности огнестрельного оружия и др. Эти изменения, в свою очередь, потребовали создания армий нового типа лучше обученных и существующих на постоянной основе. Такие армии требовали нового уровня и характера политического управления, который мог бы обеспечить их людьми, деньгами (в первую очередь для выплаты жалованья), снаряжением, оружием, провиантом ${ }^{1}$.

Последствия складывания национального государства отразились и на внутренней жизни прежде всего в объединении, часто насильственном, земель вокруг единого центра, в подавлении противодействия централизации со стороны местных самостоятельных или полусамостоятельных владетелей. Верховной власти требовалось, соответственно, централизованное управление, осуществляемое с помощью профессионального, развитого бюрократического аппарата.

Таким образом, оба процесса (становление национальных государств и создание армий нового образца) протекали параллельно, подкрепляя друг друга и нуждаясь в одних и тех же политических инструментах - централизации, усилении верховной власти, росте государственного административного аппарата.

Как уже отмечалось, создание новой «регулярной» армии и процессы централизации требовали значительных финансовых вложений. Но эти же явления становились факторами, которые способствовали созданию сильной центральной власти, самодержавных государей, поскольку война оправдывала введение экстраординарных мер, не предусмотренных законом, для сбора налогов, формирования армии. Эти меры могли быть проведены в жизнь только в рамках относительно жесткой социальной структуры с единым полновластным правителем во главе и с сильным государственным аппаратом.

1 Малов А.В. Московские выборные полки солдатского строя в начальный период своей истории. М., 2006; Кеннеди П. Взлеты и падения великих держав. Екатеринбург, 2018; Пенской В.В. Военная революция XVI-XVII вв. и ее изучение в зарубежной и российской историографии второй половины XX - начала XXI вв. // Научные ведомости Белгородского государственного университета. Сер.: История. Политология. 2008. Вып. 7. № 5(45). С. 67-73. 
Россия, как и ее западные соседи - Польша, Швеция, Австрия, Голландия, Франция, Англия - не стояла в стороне от этих процессов. Едва оправившись от потрясений Смутного времени (которое включало войны с Речью Посполитой 1609-1618 гг. и Швецией 1610-1617 гг.), Россия вела войны, чтобы вернуть потерянные территории и приобрести новые для доступа к европейским рынкам (русско-польские войны 1632-1634 гг., 1654-1667 гг., русско-шведская война 1656-1658 гг.). Хотя и не в столь большой степени, Россия оказалась втянута и в Тридцатилетнюю войну (1618-1648 гг. $)^{2}$. В это же время страна постоянно защищалась от татарских нападений и строила Белгородскую засечную черту - грандиозную цепь укреплений на рубежах со «степью»³. Понятно, что практически беспрерывное участие страны в военных действиях в середине XVII в. (13 из них пришлись на особенно тяжелые войны со Швецией и Речью Посполитой) не могло не сказаться на каждой из областей государственной жизни.

Одним из факторов, существенно влиявших на складывание единовластия в стране, являлось ее финансовое положение. Чем богаче была страна, чем больше денег поступало в казну, тем легче государство могло обеспечить свое военное превосходство, т. е. создать боеспособные войско и флот - нанять солдат, офицеров, военных инженеров, закупить вооружение и боеприпасы, стройматериалы и т.п., выстроить масштабные фортификационные сооружения. Если же казна испытывала недостаток в деньгах, для сбора средств через налоги приходилось применять принуждение, использовать жесткие меры.

Все эти явления мы наблюдаем в России середины XVII в. Хотя объединение русских земель вокруг Москвы в основном завершилось еще в конце XV в., присоединение соседних территорий продолжалось и в XVI в. (Казань, Астрахань, Сибирь), и особенно в XVII в. (области на северо-западе, продвижение на Украину ${ }^{4}$, Кавказ и Закавказье ${ }^{5}$, в Сибирь ${ }^{6}$, вглубь «Дикого поля» ${ }^{7}$, попытки присоединить часть молдавских земель ${ }^{8}$ и объединить

2 Вайнштейн О.Л. Россия и Тридцатилетняя война 1618-1648 гг.: Очерки из истории внешней политики Московского государства в первой половине XVII в. Л., 1947; Поршнев Б.Ф. Тридцатилетняя война и вступление в нее Швеции и Московского государства. М., 1976.

3 Новосельский А.А. Борьба Московского государства с татарами в первой половине XVII века. М.; Л., 1948; Загоровский В.П. Белгородская черта. Воронеж, 1969; Санин Г.А. Формирование южной границы и геополитические проблемы России (2-я половина XVII 1-я половина XVIII вв.) // Формирование территории Российского государства XVI - начало ХX в. (границы и политика). М., 2015. С. 61-98.

${ }^{4}$ ПСЗ-I. Т. 1. № 76, 104, 115, 119, 133, 175.

5 Там же. № 44, 98, 244, 308.

6 Там же. № 145, 281, 316, 367.

7 Там же. № 176.

8 Там же. № 180. 
Польшу с Россией9), а также войны с Польшей и Швецией за преобладание на торговых путях. Завоеванные или добровольно присоединившиеся национальные образования с различной степенью интеграции вливались в Русское государство, постепенно становясь его нераздельными частями. Это отразилось, в частности, в крестоприводных записях разных должностных лиц на верность русскому государю и в международных договорах России с соседними государствами, особенно в тех, где затрагивались вопросы титулатуры русского царя. Эти тексты ярко свидетельствует о суверенности Русского государства, его национальном характере, о стремлении к утверждению высокого статуса России на международной арене ${ }^{10}$. О том же национальном характере выстраиваемого правительством Алексея Михайловича государства говорит и такая деталь, как отвод особой земли под строение Немецкой слободы: русские были широко открыты для восприятия необходимых им западноевропейских новшеств, однако сознательно выстраивали границы, не позволявшие захлестнуть европейскому мировосприятию национальное ${ }^{11}$.

Особо следует отметить политику постепенного, мягкого вовлечения присоединяемых национальных территорий к Русскому государству, как бы обволакиванию их, с сохранением в них на то или иное время (иногда весьма длительное) давно устоявшихся административных, судебных и прочих исторически сложившихся особенностей (например, сохранение в завоеванных у Польши областях Магдебургского права) $)^{12}$, бережного и тактичного отношения к живущему на этих территориях населению (особенно в военное время) ${ }^{13}$. В то же время российская верховная власть отнюдь не была наивно альтруистичной и активно проводила политику ассимиляции новых подданных ${ }^{14}$, постепенного, но неуклонного включения их в русскую государственную систему, закрепления российского суверенитета над присоединенными территориями ${ }^{15}$.

Для контроля над этими процессами, для управления вновь обретенными землями была нужна крепкая центральная власть, которая сосредоточила бы в своих руках все рычаги управления.

9 Там же. № 193.

${ }^{10}$ Там же. № 69, 229, 241, 266; Талина Г.В. Русская самодержавная монархия первых Романовых глазами современников и потомков // Самодержавное царство первых Романовых. М., 2004. С. 11-20.

11 ПС3-I. T. 1. № 85.

12 Там же. № 119, 133, 232, 330, 377, 378, 379, 380, 447.

13 Там же. № 135, 136, 137, 146, 152, 165, 166, 179, 181, 182, 249, 363, 443.

14 Там же. № 70, 148, 198, 199, 243, 246, 401, 403, 417.

15 Там же. № 236, 239, 262, 265, 368, 375, 381, 382, 396, 413, 426, 427, 435, 447. 
К рубежу 50-60-х гг. XVII в. все полномочия в делах управления городами и уездами (судебные, административные и военные) находились у городовых воевод, назначение которых производилось государем через Разрядный приказ. В административной деятельности воевода использовал персонал своей канцелярии (приказной, или съезжей, избы), который составляли дьяк (для крупных городов, таких, например, как Великий Новгород или Астрахань) и подьячие трех статей («старые», «средней статьи» и «молодые»).

На местах центральная власть в лице воевод взаимодействовала с различными органами местного управления, назначенными из центра и выборными. Так, кроме сотрудников съезжей избы, воевода опирался на должностных лиц со специализацией в отдельных отраслях управления городом. Это были главы городовых гражданских и военных корпораций - ямской приказчик, пушкарский, стрелецкий и осадный головы, т. е. жители города и уезда, которые несли государственную службу, не будучи при этом избранными местным электоратом, а получившие назначение из соответствующих московских приказов.

Одной из важнейших функций местных властей являлся сбор налогов. Для этого местное население избирало специальных лиц (за редким исключением, из местных посадских и уездных людей); в этот круг входили кабацкие и таможенные головы и подчиненные им ларечные и рядовые целовальники. Хотя эти должностные лица выбирались местным сообществом, они обязаны были «целовать крест», т. е. приносить присягу государю в съезжей избе перед воеводой. В некоторых случаях кабацкие или таможенные головы присылались из Москвы или избирались в других уездах. Все официальные бумаги, имевшие отношение к работе кабацких и таможенных голов, а также целовальников, передавались в архив приказной избы, под контроль воеводы ${ }^{16}$. Таким образом, одна из главных функций государства, фискальная, в России XVII в. была также напрямую (несмотря на выборность непосредственных исполнителей) организована и контролируема центральной властью (московскими приказами и городовыми воеводами).

В своей деятельности воевода взаимодействовал с местными выборными органами власти, прежде всего губными старостами и подьячими губной избы ${ }^{17}$. Губных старост избирало население всех сословий определенной

${ }^{16}$ Булгаков М.Б. Государственные службы посадских людей в XVII веке. М., 2004; Мизис Ю.А. Формирование рынка Центрального Черноземья во второй половине XVII первой половине XVIII вв. Тамбов, 2006.

${ }^{17}$ Синелобов А.П. Персональный состав городовых приказчиков и губных старост Московского государства XVI-XVII вв. М., 2014. 
административной единицы, например, волости, но соискателем этой должности мог стать исключительно служилый человек по отечеству. Однако для вступления на должность выбранный в губные старосты обязан был лично представиться руководству Разбойного приказа и предъявить заверенные подписями избирателей и городового воеводы выборные списки. Если документы удовлетворяли требованиям, руководители Разбойного приказа утверждали кандидата в его должности и здесь же, в помещении приказа, приводили к присяге. В круг полномочий губного старосты входили розыск и наказание «ведомых разбойников». Под этим термином подразумевались не только уголовники, но и те, кто оказался причастен к антиправительственным выступлениям.

Еще одной частью местной административной структуры была земская изба во главе с земским старостой. Его избирателями, в отличие от губного старосты, являлись жители посадов и черносошные крестьяне. В обязанности земского старосты и его помощников входило рассмотрение дел, называющихся по современной терминологии судными гражданскими, а также той части уголовных дел, которые решались в «состязательном процессе» (подделка документов, кражи, побои, драки, ябедничество и т.п.). Земский староста, как и губной, опирался на штат помощников, с которыми он вел дела в рамках своей компетенции. В этот штат входили земский дьяк, земские подьячие и земские целовальники. Аппарат земской избы выбирался из числа «лучших людей», т. е. зажиточных посадских и состоятельных черносошных крестьян ${ }^{18}$.

Городовой воевода, таким образом, являлся эмиссаром центрального правительства в провинции, выбранным и назначенным непосредственно этим правительством, и занимал ведущее положение в местной администрации. Система государственного управления всей территорией обширного Русского государства в 40-60 гг. XVII в. была прямой, состоявшей всего из двух уровней: государь - городовой воевода ${ }^{19}$. При этом адаптивный и гибкий центральный управленческий аппарат, т. е. московские приказы, вкупе с органами местной выборной администрации уравновешивали жесткость властной вертикали.

К рубежу 40-50-х гг. XVII в. приказная система в значительной степени сформировалась и укрепилась. Если в 1620-1630-х гг. функционировало 44 приказа, то в 1640-х их число возросло до 49, в 1650-х — до 53, а в $1660-\mathrm{x}$ - до $57^{20}$. С ростом числа приказов увеличивалась и численность

18 Чичерин Б.Н. Областные учреждения в России в XVII в. М., 1856.

${ }^{19}$ Кузнеиов И.Н., Новохатко О.В., Шахова А.Д. Светское устройство и архитектурное благоустройство Переславля-Залесского в XVII в. М., 2014.

20 Демидова Н.Ф. Служилая бюрократия в России XVII в. и ее роль в формировании абсолютизма. М., 1987. С. 23. 
центральной администрации (судей, дьяков и подьячих): в 1633 г. их было 773 человека, в 1646 г. - 866, в 1656 г. - 762 (снижение численности вызвала эпидемия чумы 1654-1655 гг.), в 1664 г. - 882 человека ${ }^{21}$. Разумеется, с ростом приказной структуры и увеличением ее штатов возрастала и стоимость управленческого аппарата для казны: в 1639 г. суммарный размер денежных окладов думных дьяков составил 750 рублей, в 1657 г. (в связи с эпидемией чумы он снизился) - 600, в 1667 г. - 1080 рублей ${ }^{22}$. Сумма окладов приказных дьяков достигала в 1626/27 г. 4920 рублей, в 1656/57 г. — 8431 рубль (хотя размер оклада на одного человека в среднем упал с 100,5 до 84 рублей), в 1686/87 г. — 10290 рублей (средний оклад — 88 рублей) $)^{23}$. Наконец, московские подьячие обходились казне в 1626/27 г. в 8089,5 рублей, в 1656/57 г. — в 5361,5 рублей, в 1682/83 г. — в 9959,5 рублей. Общий объем государственных расходов на содержание центральной администрации составлял, по подсчетам Н.Ф. Демидовой, в 1627 г. 13 659,5 рублей, в 1656 г. — 14392,5 , в 1682 г. — 23207,5 рублей ${ }^{24}$.

Для того чтобы управлять территориально расширившимся государством, состав которого был весьма сложен в национальном и конфессиональном отношениях, требовался больший численно и представительный административный аппарат. Усиление роли последнего, рост веса чиновничества в глазах общества выразились в том, что с третьей четверти века думные чины возглавили почти все наиболее важные приказы, а также в том, что число думных дьяков возросло (в сравнении с царствованием первого Романова) почти в два с половиной раза ${ }^{25}$. Эти тенденции весьма наглядно и убедительно отразились в одном из частных постановлений Думы, зафиксированном как общепринятый закон. В апреле 1659 г. по боярскому приговору было установлено, что чин дьяков честью выше гостей ${ }^{26}$, что свидетельствовало о значительно более высоком статусе и престиже государственного чиновника, чем обычного человека, даже выполнявшего важные правительственные поручения.

Как отмечалось, для ведения успешных войн с западными соседями России необходимо было создание армии нового образца, которое, в свою очередь, потребовало модернизации администрирования этой армией, т. е.

${ }^{21}$ Там же.

22 Там же. С. 119.

${ }^{23}$ Там же. С. 122.

${ }^{24}$ Там же. С. $136-137$.

${ }^{25}$ Базилевич К.В., Богоявленский С.К., Чаев Н.С. Царская власть и Боярская дума // Очерки истории СССР. Период феодализма. XVII в. М., 1955. С. 344-360; Ерошкин Н.П. История государственных учреждений дореволюционной России. М., 1983. С. 48-70.

${ }^{26}$ ПС3-I. Т. 1. № 247. 
приказной системы. Естественно, что централизующие тенденции чаще проявлялись в военное время. Так, в феврале 1665 г. появился указ о переходе в ведомство Разрядного приказа полковников и начальных людей полков так называемого нового строя, находившихся до того под управлением Иноземского приказа. Этим же указом предписывалось доходы, собиравшиеся с подведомственных Разряду территорий (Севского и Белгородского полков), расходовать на жалованье ратным людям (полков и старого, и нового строя) по указанию Разряда на месте, а не направлять, как ранее, в приказы Большого прихода и Новой чети ${ }^{27}$. В следующем году из Иноземского приказа в Разряд была переведена Новая Немецкая слобода ${ }^{28}$, т. е. продолжено подчинение всего командного состава армии одному ведомству.

Для регулирования службы полков нового строя к существовавшему с 20-х гг. XVII в. Иноземскому приказу добавился вновь созданный в 1649 г. Рейтарский ${ }^{29}$; часть функций по обеспечению деятельности этих полков возложили, соответственно их компетенции, на Разрядный, Оружейный, Пушкарский, Ямской, Казенный, Конюшенный, Монастырский, Стрелецкий и другие приказы ${ }^{30}$.

Особое место в структуре центральных административных органов занимал приказ Тайных дел, созданный по инициативе Алексея Михайловича в 1655 г. и им же непосредственно управлявшийся ${ }^{31}$. Его место в приказной системе и роль в управлении не были зафиксированы законодательно, но фактически приказ Тайных дел занял положение не только над другими приказами, но и над всеми властными органами. Он осуществлял и негласный, и явный надзор за деятельностью как приказов, так и отдельных чиновников, например, послов. Компетенция приказа Тайных дел приобрела чрезвычайно широкий профиль - от личных дел царя до общегосударственных, в том числе международных. Вернее было бы сказать, что приказ занимался тем, к чему обращался интерес Алексея Михайловича, а сотрудники приказа приводили в исполнение соответствующие распоряжения государя. Такой характер деятельности приказа объясняется именно не закономерностями политического развития государства, поступательным усилением самодержавных тенденций, что зачастую объясняется процессами становления абсолютизма в России,

${ }^{27}$ Там же. № 370.

${ }^{28}$ Там же. № 386.

${ }^{29}$ Богоявленский С.К. Приказные судьи XVII века. М.; Л., 1946.

${ }^{30}$ Лисейцев Д.В., Рогожин Н.М., Эскин Ю.М. Приказы Московского государства XVIXVII вв.: Словарь-справочник. М.; СПб., 2015.

${ }^{31}$ Гурлянд И.Я. Приказ великого государя Тайных дел. Ярославль, 1902. 
а личными особенностями правящего монарха. Алексей Михайлович был чрезвычайно активен, любознателен по природе, но, главное, воспитан в духе гиперответственности за исполнение своей миссии русского православного государя, для которого важно любое дело в его государстве, а также судьба православия во всем мире. Указанная специфика приказа Тайных дел как личной канцелярии Алексея Михайловича подтверждается тем, что сразу после смерти царя, в январе 1676 г., приказ был расформирован, а его дела и сотрудники переданы в другие приказы. В принципе, сложившаяся к середине XVII в. приказная система не нуждалась в подобной «надстройке», успешно выполняя функции исполнительной управленческой структуры при государе и Боярской думе, являлась достаточно мобильной, гибкой и эффективной для решения задач, ставившихся перед ней правительством ${ }^{32}$.

Как уже отмечалось, период раннего Нового времени в европейских странах характеризовался появлением и распространением армий нового типа, получивших название регулярных, что теснейшим образом было связано с усилением централизации государственной власти. В России регулярные войска, или «полки нового строя», были организованы в относительно крупном масштабе после завершения Смуты, когда Русское государство получило возможность восстановиться и укрепиться ${ }^{33}$. Из-за территориальных проблем, оставшихся нерешенными после завершения Смоленской войны, Россию ждало неминуемое столкновение с Польшей ${ }^{34}$. При подготовке к этой войне Алексей Михайлович, опираясь на опыт своего отца и на действовавшие в составе русских вооруженных сил подразделения нового строя, провел в 1648-1654 гг. военную реформу. Стержневой ее частью являлось радикальное увеличение полков нового строя всех существовавших тогда видов (солдатских, рейтарских, драгунских и гусарских), которые составили основу новой русской армии. Для этого в Европе наняли военных специалистов, оставшихся без средств к существованию после окончания Тридцатилетней войны (1618-1648 гг.). В их число входили не только собственно военные люди, но теоретики военного дела, инженеры и мастера различных профессий, связанных с военным производством.

${ }^{32}$ Талина Г.В. Русская самодержавная монархия первых Романовых глазами современников и потомков. С. 8; Новохатко О.В. Разряд в 185 году. М., 2007. С. 581-596.

${ }^{33}$ Курбатов O.A. Западноевропейские военно-теоретические модели XVII в. и их место и реформировании русской армии // Феномен реформ на Западе и Востоке Европы в начале Нового времени (XVI-XVIII вв.). СПб., 2013.

${ }^{34}$ Малов А.В. Русско-польская война 1654-1667 гг. М., 2006. 
1650 -е гг. в связи с войнами России с Речью Посполитой и Швецией, в целом характеризуются особым вниманием власти к армии, расширением и модернизацией последней. Так, в середине - второй половине 1650-х гг. солдаты получили новейшие европейские мушкеты и «полупики» для изготовления холодного оружия нового вида - «шведских перьев» ${ }^{35}$. В ходе той же войны рейтар обеспечили более соответствующим для характера боевых действий в Восточной Европе оружием: шпаги были заменены на сабли ${ }^{36}$.

К концу русско-польской войны 1654-1667 гг. полки нового строя стали основой русской армии. В 1663 г. численность воинских людей полков нового строя составила 77764 человека ${ }^{37}$. В целом за 1630-1670-е гг. общая численность всего русского войска увеличилась в 5-6 раз, при этом полки нового строя составляли $60-75 \%$ от всего войска, являясь ведущей боевой силой ${ }^{38}$.

Существенной характеристикой всех видов войск нового строя являлось то, что это было постоянное наемное войско, получавшее жалованье из казны. Так, например, все рейтары, независимо от их социального происхождения - жильцов, городовых служилых по отечеству, казаков, татар, даточных людей - получали жалованье по единому рейтарскому окладу ${ }^{39}$. Кроме того, набранных в полки нового строя воинских людей государство обеспечивало «служилым платьем», латами, вооружением и боеприпасами, а конные войска - лошадьми (особенно высокого качества - для гусар) со всем необходимым снаряжением. Таким образом, полки нового строя находились практически на полном государственном обеспечении.

Очевидно, что содержание такого войска требовало огромных финансовых вложений. С 1630-х до 1670-х гг. расходы правительства на содержание армии в мирное время возросли с 275 до 700 тыс. рублей (в эти суммы входило содержание также стрелецкого войска и жалованье поместному войску $)^{40}$. Естественно, в годы войн траты многократно возрастали. Однако в это же время правительство уделяло огромное внимание поддержанию и поместной системы, поместного войска; за 30 лет было принято более

${ }^{35}$ Жук А.Б. Стрелковое оружие. М., 1992. С. 8-18, 453-480.

${ }^{36}$ Малов А.В. Московские выборные полки солдатского строя... С. 53.

37 Чернов А.В. Вооруженные силы Русского государства в XV-XVII вв. (с образования централизованного государства до реформ при Петре I). М., 1954. С. 168.

${ }^{38}$ Там же. С. 222.

${ }^{39}$ Малов А.В. Московские выборные полки солдатского строя... С. 53.

40 Чернов А.B. Вооруженные силы Русского государства в XV-XVII вв. (с образования централизованного государства до реформ при Петре I). С. 179. 
полусотни постановлений, направленных на эти цели (касавшиеся в первую очередь поместного и вотчинного землевладения $)^{41}$.

Главным и постоянным источником пополнения казны в России XVII в. были налоги (иностранные займы составляли мизерную часть в сравнении с налоговыми поступлениями). Усиливавшаяся централизация власти в России XVII в. проявлялась, разумеется, не только и не столько в том, кто занимался сбором налогов (люди, как выбранные населением, так и назначенные верховной властью), а в лицах или органах, их устанавливавших. Кроме исключительных обстоятельств, когда правительство нуждалось в поддержке общества, чтобы ввести по всей стране сверхобычные налоги (вроде «пятой» или «десятой» деньги), верховная власть обладала абсолютными полномочиями в области налогообложения. И в специальных случаях, например, назначения цен на стратегическое сырье во время войны или увеличения продажной цены на вино (находящееся в государственной монополии), финансовая прерогатива принадлежала исключительно царю и Думе; эти вопросы решались без привлечения каких-либо других, в том числе сословных органов ${ }^{42}$. Обычные, традиционные налоги определялись исключительно государем и Думой, без участия сословных представителей, что наиболее ярко свидетельствует об отсутствии в указанный период такой формы правления, как сословно-представительная монархия.

Наряду со старыми военными налогами (полоняничными, пищальными деньгами, сборами на городовое и засечное дело, за даточных людей и проч., главным из которых являлись так называемые стрелецкие деньги и стрелецкий хлеб), с появлением полков нового строя власти ввели и новый налог на жалованье ратным людям, сумма которого для крестьян и бобылей составляла от 25 коп. до одного рубля с двора. Кроме этих, постоянных, налогов, правительство, как упоминалось, практиковало и единовременные сборы. Посадских людей принуждали содержать регулярную армию, взимая с них «пятую», «десятую» деньгу. Военные денежные сборы составляли главный источник содержания войска в России 1640-1660-х гг., покрывая примерно 50\% всех военных расходов казны. Вторую половину составляли натуральные сборы, главным из которых был хлебный, шедший на содержание войска как в мирное, так и в военное время. Потребности армии в это время составляли около 11 млн пудов в год (более 180 тыс. т). При этом государство повышало и старые налоги: например, увеличился сбор ямских денег ${ }^{43}$.

${ }^{41}$ ПСЗ-І. Т. 1. № 14, 16, 17, 20, 26, 27, 30, 32, 33, 34, 42, 45, 46, 53, 54, 59, 63, 83, 89, 117 , $160,173,220,222,263,264,294,315,402$ и др.

${ }^{42}$ Там же. № 141, 223, 285, 310.

${ }^{43}$ Веселовский С.Б. Сошное письмо. М., 1915. Т. 1. С. 162-190. 
Благодаря росту и укреплению государственного административного аппарата (приказов, воевод с их штатом приказных, или воеводских изб и т.п.) центральная власть смогла изменить и сам характер налогообложения, проникнуть, если так можно выразиться, вглубь крестьянского мира и контролировать раскладку и сбор налогов. Еще с начала 1630-х гг. государственные налоги начали взимать не просто с определенной земельной площади, а в виде «живущей или дворовой четверти», т. е. в зависимости от количества населенных дворов и обрабатываемой земли; в 1638-1639 гг. был введен уже «подымный сбор». С начала 1640-х гг. и особенно после 1649 г. подворное налогообложение уже широко вводилось, хотя полностью перевод на него осуществился только в ходе реформы 1679-1681 гг. ${ }^{44}$

Хотя, по яркому выражению В.О. Ключевского, «рать вконец заедала казну» ${ }^{45}$, парадоксальным образом та же рать делала возможным для правительства усиление налогового гнета. Широко известно участие различных подразделений русской армии, в том числе и полков нового строя, в подавлении народных возмущений, например, московских восстаний 1648-164946 и 1662 гг. ${ }^{47}$ Получив в свои руки эту силу, правительство могло позволить себе вводить новые налоги, не опасаясь в той мере, как прежде, выступлений населения.

В казне денег постоянно не хватало не только из-за «рати», но и по причине отсутствия собственной добычи золота и серебра, поэтому правительство использовало все имеющиеся внутри страны средства для пополнения государственного бюджета. Проведение их в жизнь возможно было только при централизованной власти, располагавшей инструментами проведения реформ и принуждения к ним населения. Однако процесс установления такой власти шел не быстро и не равномерно. Пока царская власть укреплялась, пока происходила централизация властных ресурсов, правительству, особенно в первой половине царствования Алексея Михайловича, приходилось то отходить назад, делая уступки возмущенному обществу, то наступать снова, продвигая свои решения, подавляя народное сопротивление.

\footnotetext{
${ }^{44}$ Милюков П.Н. Спорные вопросы финансовой истории Московского государства. СПб., 1892. C. $90-124$.

${ }^{45}$ Ключевский В.О. Русская история. Полный курс лекций в двух книгах. М., 2004. Кн. 2. Лекция LI. C. 122.

46 Чистякова E.B. Городские восстания в России в первой половине XVII века (3040-е годы). Воронеж, 1975. С. 103; Городские восстания в Московском государстве XVII века / Под ред. К.В. Базилевича. М.; Л., 1936. С. 44-45.

${ }^{47}$ Буганов В.И. Московское восстание 1662 г. М., 1964. С. 84; Зериалов А.Н. О мятежах в городе Москве и в селе Коломенском в 1648, 1662 и 1771 гг. // Чтения в Обществе истории и древностей российских при Московском университете. 1890. Кн. 3(154). Отд. І. С. 360-361.
} 
Первым и, как казалось, самым очевидным способом пополнения казны стала экономия на жалованье государственным служащим, что и осуществило правительство Б.И. Морозова в 1645 г. Прежде всего государство ограничило денежные выплаты служилым людям: некоторым категориям была оставлена натуральная, хлебная часть жалованья, а денежная или резко убавлена, или не выплачивалась совсем; другие группы вместо выплаты денежного жалованья наделяли землей. Сократилась также номенклатура дворцовых чинов; части наемных иностранных офицеров прекратили выплату жалованья. Сокращению выплат подверглась и провинциальная администрация (городовые приказчики, подьячие городовых приказных изб). Очевидно, что эти меры не дали желаемых результатов в государственном масштабе.

Тогда власть обратилась к средству, которое не раз применялось в других странах - государственному регулированию цен на товары первой необходимости, т. е. к косвенным налогам; одним из главных в этой категории товаров являлась соль. В феврале 1646 г. вместо основных прямых налогов (стрелецких и ямских денег) был введен косвенный налог на ввоз и продажу соли. Однако эта мера окончательно расшатала государственные финансы и привела к крупным народным волнениям (так называемому Соляному бунту), в результате чего уже в декабре 1647 г. налог пришлось отменить.

Для большего поступления денег в казну правительство стремилось ликвидировать беломестные слободы, точнее, приписать их к городам. Тем самым жившие в них посадские люди становились налогоплательщиками, что значительно увеличивало поступление средств в казну. Без сильной власти монарха проведение такой операции оказалось крайне затруднительно, поскольку эта политика встретила ожесточенное сопротивление части землевладельцев, причем из числа элиты - бояр Стрешневых, Салтыковых, бояр и князей Лыковых, Мосальских, Черкасских и др. (многие из них были родственниками и свойственниками царской фамилии). В эту группу входили и собственно члены семьи Романовых: в 29 городах они владели 1707 дворами. О силе этого противостояния свидетельствует то, что информация о нем выплеснулась даже за границы России. В «Лейденской брошюре», вышедшей в Амстердаме в 1650 г., было написано, что лидером оппозиции царской реформе посадов являлся дядя царя, боярин Н.И. Романов, обиженный тем, «что его величество все те должности и почести, которые приходились ему, Н.И. Романову, по праву, отдал Морозову» ${ }^{48}$ (боярину Б.И. Морозову, бывшему дядьке и фактическому главе

48 Чистякова E.B. Городские восстания в России в первой половине XVII века (30-40-е годы). С. 16. 
правительства молодого Алексея Михайловича). Противником посадской реформы выступила и церковь, также владевшая беломестными слободами. Тем не менее к концу 1640-х гг. власть государя уже настолько окрепла, опираясь на большую часть служилых людей по отечеству в социальном плане и в, так сказать, тактическом - на государственный аппарат и мощные вооруженные силы, что посадская реформа была проведена, ее окончательное оформление закрепило Уложение 1649 г. Тем же кодексом к земле прикреплялось крестьянство, что диктовалось в первую очередь фискальными потребностями государства.

Затянувшаяся тяжелая война с Речью Посполитой 1654-1667 гг. и война со Швецией 1656-1658 гг. требовали огромных средств. С первого же года присоединения Украины к России (1654 г.) и впоследствии правительству приходилось неоднократно вводить единовременные экстраординарные сборы - «пятинные» деньги (их размер составлял не только пятую часть имущества, но также и 10 , и даже $20 \%)^{49}$. Однако война быстро «съедала» эти деньги, а вводить новые налоги на и так обнищавшее население не было смысла и, кроме того, таило опасность возмущения. Правительство прибегло к новой мере, к которой, стоит сказать ради справедливости, обращались и другие европейские власти - к перечеканке серебряной монеты и введению медных денег. В первые годы своего действия реформа принесла правительству ожидаемое значительное пополнение казны. Однако по прошествии нескольких лет бесконтрольный и неумеренный выпуск медных денег, выкачивание серебряных денег у населения вкупе с другими обстоятельствами (чума 1654-1655 гг.; была и вторая, чуть менее смертоносная вспышка 1666-1667 гг., унесшая до 800 тыс. жизней ${ }^{50}$; последовавшие за эпидемией неурожаи 1650-х гг, как следствие - обнищание населения и расстройство экономики) привели к потрясшему всю страну финансовому коллапсу, а затем и социальному кризису - восстанию, получившему название «Медный бунт».

Неудачи финансовых реформ второй половины 1640-х гг. можно оценивать с разных точек зрения. С одной стороны, молодой государь еще явно не был в достаточной мере опытен и тверд в управлении государством. Царь и его правительство пошли на серьезные уступки мятежникам и пода-

${ }^{49}$ Базилевич К.B. Денежная реформа Алексея Михайловича и восстание в Москве в 1662 г. М.; Л., 1936. С. 4-83; Буганов В.И. Московское восстание 1662 г. М., 1964. С. 33.

${ }^{50}$ Васильев К.Г., Сегал А.Е. История эпидемий в России. М., 1960; Медведь А.Н. Актовые материалы об эпидемиях XVII в. как источник по истории антропологии болезни в Московском государстве // Проблемы дипломатики, кодикологии и актовой археографии. Материалы XXIV международной научной конференции. М., 2012. С. 397-400. 
вавшим царю челобитные группам людей, введя требуемые ими изменения в законодательство (ликвидация белых слобод, изменения в судопроизводстве, закрепощение крестьян и др.). Так же осторожно, «уговорами», царь указывал усмирить и восстания в Новгороде и Пскове. С другой стороны, все вышеперечисленные народные возмущения прекратились не только благодаря переговорам царя и его эмиссаров с восставшими и уступкам их требованиям; в каждом случае были задействованы войска, в большей или меньшей мере принявшие участие в подавлении возмущений, в поимке и наказании мятежников.

Совершенно другая ситуация сложилась с проведением тоже не слишком успешной денежной реформы 1654-1663 гг. и последовавшим за этим народным восстанием. Здесь правительство во главе с Алексеем Михайловичем проявило, с одной стороны, бо́льшую, чем ранее, гибкость, ослабляя налоговый гнет на население, пытаясь компенсировать другими средствами ее издержки и отменив, наконец, зашедшую в тупик финансовую политику. С другой стороны, царь проявил гораздо большую твердость и даже жестокость в подавлении Московского восстания 1662 г. Очевидно, что к 1660-м гг. государственная власть окрепла, опираясь на полностью послушные ему, в отличие от ситуации 1648 г., войска, как старого строя (стрелецкие и поместные), так и нового (солдат и др.). Однако В.И. Буганов полагал, что выходящая за все мыслимые пределы - даже для современников событий жестокость и массовость казней мятежников во время подавления восстания 1662 г. и после него свидетельствует о чрезвычайном страхе Алексея Михайловича и его окружения перед народом, ненависти к нему, а значит, внутренней неуверенности в своем положении на вершине власти ${ }^{51}$.

Важным фактором, сыгравшим значительную роль в определении направления политического развития России в XVII в., безусловно стало Смутное время. В начале XVII столетия Российское государство оказалось на грани исчезновения. События Смуты показали всем социальным группам, составлявшим русское общество, что для удержания суверенитета государства не обойтись без общественного согласия. Таковое, соответственно менталитету людей того времени, могло сложиться только при наличии монарха, который виделся точкой схождения всех общественных течений и, одновременно, последним, главным арбитром в столкновениях интересов разных общественных групп.

Элита государства, представленная в основном Боярской думой и высшими придворными чинами, к началу царствования Алексея Михайловича и в

${ }^{51}$ Буганов В.И. Московское восстание 1662 г. С. 94-95. 
последующие годы его правления отличалась от элиты не только XVI в., но и времени правления первого царя новой династии. В политическом отношении верхушка общества 1640-1660-х гг. была в целом консолидирована, ее центробежные устремления сглажены. Во многом этому способствовали перемены в составе Боярской думы: в Смутное время исчезли с исторической сцены многие аристократические фамилии, при первых Романовых в Думу вошло значительное число царских фаворитов и родственников цариц из незнатных родов и даже городового дворянства (Милославские, Морозовы, Стрешневы, А.С. Матвеев, Ф.М. Ртищев, А.Л. Ордин-Нащокин и др.). Поэтому к середине XVII в. центр тяжести в конфликтах внутри элиты или между элитой и государем сместился из области политики в область клановых противостояний. Эта обновленная элита, представители которой не претендовали более на российский престол или на кардинальную смену политического строя, поддерживала централизацию власти в стране, получая от нее выгоды в виде занятия высших мест в государственной иерархии и вытекающих из этого властных и материальных преимуществ.

Еще более в сильном централизованном государстве была заинтересована основная масса служилых людей по отечеству и по прибору. Несмотря на опыт Смуты, высшие чины, приближенные государя, утвердившись на вершине властной лестницы, быстро забыли о мятежах, могущих угрожать и им самим, и государству в целом. «Сильные люди», как их называли в XVII в., не нуждаясь более в опоре на все общество, вновь стали пренебрегать его интересами, в том числе интересами наиболее близких им в социальном отношении служилых людей по отечеству. Главными проблемами для последних стали побеги крестьян на земли крупных землевладельцев, светских и духовных, скупка, а часто и захват ими земель рядовых служилых людей.

Прикрепление крестьян к земле не только гарантировало представителям служилого сословия обеспечение их боеспособности. Все большее число землевладельцев самых разных чинов втягивались в торговлю продукцией, производимой в их поместьях и вотчинах ${ }^{52}$. В стремлении к более успешной и свободной торговле соединялись и переплетались интересы феодалов и торгово-промышленного сословия, от высших представителей последнего, гостей, до рядовых посадских людей ${ }^{53}$. Наиболее крупным препятствием

${ }^{52}$ Кузьмичев А.Д., Шапкин И.Н. Отечественное предпринимательство: очерки истории. М., 1995; Акты хозяйства боярина Б.И. Морозова. М.; Л., 1940. Ч. 1; М.; Л., 1945. Ч. 2; Архив стольника Андрея Ильича Безобразова. М., 2012. Ч. 1; М., 2013. Ч. 2.

${ }^{53}$ Торговля, купечество и таможенное дело в России в XVI-XVII вв.: Сборник материалов Третьей международной научной конференции. Коломна, 2015. T. 1: XVI-XVIII вв. 
на этом пути для указанных социальных групп было существование «белых слобод», пользовавшихся привилегиями в налогообложении.

Таким образом, без авторитарной власти оказалось невозможно организовать аграрную экономику, основанную на подневольном труде и на земельной экспансии: необходимо было удерживать крепостных в их состоянии, ограничивать произвол и привилегии «сильных людей», защищать осваиваемые земли и торговые пути, помогать отечественным торговцам в их конкуренции с иностранными и т.д.

Разрешением большей части этих противоречий, особенно сильно проявившихся в 1640-х гг., стали постановления Земских соборов 1648 и 1649 гг. и принятое в 1649 г. Соборное уложение, а также последовавшие за ним специальные законодательные акты.

Уложение было подготовлено законодательной деятельностью правительства предыдущего периода. В течение 1640-х гг. власть уже предпринимала отдельные шаги в указанных выше направлениях. Многое делалось для модернизации устаревшей феодальной системы, препятствовавшей развитию российской экономики: отменялись права тарханщиков на беспошлинную торговлю ${ }^{54}$, твердая цена выкупа вотчины заменялась на рыночную ${ }^{55}$, был отменен указ 1639 г., затруднявший обмен поместьями между московскими и городовыми землевладельцами ${ }^{56}$, без срока и без сыска отписывались на государя «белые» торговые и ремесленные слободы, принадлежавшие светским и духовным феодалам в Москве и некоторых других городах ${ }^{57}$, возвращались на посады закладчики ${ }^{58}$ и др. Верховная власть поддерживала отечественную торговлю и предпринимательство: был введен штраф за бесчестье торговых людей суконной сотни ${ }^{59}$, приняты меры протекционистского характера в отношении русских торговцев ${ }^{60}$, облегчены кредитные операции ${ }^{61}$ и проч.

В то же время парадоксальным образом специфика русской экономики, в которой к середине XVII в. большую роль уже играла внутренняя и внешняя торговля (в ней участвовали и казна, и служилые люди, и посад), сформировались внутренний и внешний рынки, заключалась в том,

\footnotetext{
54 Законодательные акты Русского государства второй половины XVI - первой половины XVII века. Тексты. Л., 1986. № 306.

${ }_{55}^{55}$ Там же. № 316.

${ }^{56}$ Там же. № 320.

${ }^{57}$ Там же. № 317, 341, 342, 343, 345.

${ }^{58}$ Там же. № 338.

59 Там же. № 304.

${ }^{60}$ Там же. № 309, 314.

${ }^{61}$ Там же. № 315.
} 
что она испытывала недостаток сырья и товаров на продажу ${ }^{62}$. Единственным и «естественным» способом увеличить товарность хозяйств оказалось опять же усиление эксплуатации крестьян и их закрепощение. Русское законодательство с начала царствования Алексея Михайловича до Уложения 1649 г. многое сделало для осуществления этих целей: уже в 1645 г. был подтвержден указ 1641 г. о 10-летнем сроке сыска беглых крестьян ${ }^{63}$, затем изданы указы о составлении новых переписных книг и укреплении крестьян без урочных лет ${ }^{64}$, о дополнительном занесении утаенных и вновь поселившихся крестьян в переписные книги ${ }^{65}$ и другие распоряжения той же направленности ${ }^{66}$, в том числе соборный приговор 1649 г. (до Уложения) об отмене урочных лет для сыска беглых крестьян ${ }^{67}$.

Наконец, событием огромного значения в истории России стало принятие Соборного уложения. Одной из главных характеристик раннего Нового времени было упорядочение и унификация государственного устройства во всех областях жизни, от землевладения до социального положения разных общественных групп в масштабах всего государства. Уложение как раз отвечало этим требованиям.

Главное значение этого кодекса - его соответствие характеру сложившегося к этому моменту государства раннего Нового времени. Это государство стало в значительной степени единым не только территориально (хотя эти процессы продолжались в течение всего XVII в.), но и политически, структурно. Был преодолен партикуляризм, характерный для предшествующих периодов, и юрисдикция в форме единого государственного закона стала преобладающей в сравнении с сохранявшимся кое-где обычным правом $^{68}$. Провозглашенное в предисловии к Уложению кредо, «чтобы Московского государьства всяких чинов людем от болшаго и до меншаго чину суд и расправа была во всяких делех всем ровна», не являлось только популистским лозунгом, но отвечало на настойчивые и весьма явственно высказанные (особенно в ходе восстаний 1648 г.) требования разных социальных групп. Разумеется, это требование не могло быть реализовано в полной мере в XVII в., в России или где-либо еще. Тем не менее Уложение в значительной степени удовлетворило эти запросы применительно

${ }^{62}$ Кузьмичев А.Д., Шапкин И.Н. Отечественное предпринимательство: очерки истории. C. $12-13$.

63 Законодательные акты Русского государства... № 307.

${ }^{64}$ Там же. № 311.

${ }^{65}$ Там же. № 321.

${ }^{66}$ Там же. № 322, 327, 343.

67 Там же. № 344.

${ }^{68}$ Маньков А.Г. Уложение 1649 года. Кодекс феодального права России. Л., 1980. С. 250. 
к отдельным социальным группам, главным образом служилого сословия и посада, убрав наиболее архаичные и вызывающие острые противоречия элементы феодального государственного устройства. Даже в таком несовершенном виде Уложение приближало жизнь к некой ожидаемой социальной справедливости, пусть лишь для части общества. В частности, собор учел жалобы на произвол судей и, вообще, больших вельмож - в главе «О суде» скрупулезно, для каждого этапа была прописана процедура судопроизводства, во многом ограничившая самоуправство и злоупотребления приказных чиновников и градоначальников.

К середине XVII в. государственная власть в России значительно окрепла, и в то же время существующие внутри- и внешнеполитические реалии требовали дальнейшего ее усиления. Все это нашло отражение в Соборном уложении. Впервые в истории российского государственного правотворчества в едином законодательном кодексе были отчетливо определены структура властных органов и статус каждой из ее частей, от монарха до органов выборного местного самоуправления.

Государственная иерархия представляла собой четкую вертикаль, на вершине которой находился монарх. Еще в Судебнике 1550 г. статьей 61 устанавливалась смертная казнь «государьскому убойце, и градскому здавцу, и коромолнику, и церковному татю, и головному татю, и подметчику, и зажигалнику, ведомому лихому человеку» ${ }^{69}$, подчеркивалась равная опасность для государственной целостности убийства главы государства и других упомянутых в статье преступлений. В Уложении 1649 г. акцент в оценке покушения на государя усилился, покушению на здоровье (жизнь) и честь (а, вернее, власть) государя посвящена целая глава, причем первостепенным преступлением считается покушение на государя, а прочие преступные деяния рассматриваются как средства достижения этой цели. Впервые в русском законодательстве дано систематическое определение этим преступлениям как политическим, а статусу государя - как верховной власти, высшей и неотъемлемой части государственной структуры. Вся вторая глава Уложения проникнута идеей единства государя и государства, невозможности второго без первого, что полнее всего выражено в формулировке понятия измены: «Кто при державе царского величества, хотя Московским государьством завладеть и государем быть» ${ }^{70}$, т. е. узурпация царской власти приравнивалась к покушению на разрушение государства.

${ }^{69}$ Судебники XV-XVI веков. М.; Л., 1952.

${ }^{70}$ Соборное Уложение 1649 года. Текст. Комментарии. Л., 1987. С. 20. 
Особому положению царя в государственной иерархии соответствовали его прерогативы и регалии, четко сформулированные в Уложении и имевшие, таким образом, силу общегосударственного закона. Важность этого фактора для царской династии подтверждается тем, что и после 1649 г. до конца 1660-х гг. регулярно принимались разного рода указы, направленные на повышение статуса царя и обоснование легитимности и крепости династии в целом ${ }^{71}$.

Не будучи, разумеется, идеальным кодексом, Уложение стало реально работающим законом, регулировавшим жизнь чрезвычайно сложного государственного образования - России XVII в. Его успешность, адекватность государственной жизни, гибкость, адаптивность подтверждены двумя веками практического применения — на такой срок Уложение стало и своего рода конституцией, и главным сводом законов для России.

На 40-60-е гг. XVII в. пришлось и такое важное для жизни всей страны и для последующей ее истории событие, как церковная реформа и церковный раскол. Выбор царя Алексея Михайловича между двумя направлениями развития страны - традиционным и новым, «грекофильским» в пользу последнего ${ }^{72}$ раскололи страну на два непримиримо враждующих лагеря, что в значительной степени подорвало авторитет центральной власти и единство русского общества ${ }^{73}$.

Не менее важным стало противостояние глав двух основных в то время ветвей власти - светской и духовной, царя Алексея Михайловича и патриарха Никона, тем более что последний принял от царя титул великого государя, что раньше было позволено только патриарху Филарету, отцу основателя династии Романовых. В государстве на некоторый срок установилось как бы двоевластие. Однако со временем этот союз перерос в свою противоположность. Проявилось это прежде всего на личностном уровне — царь возмужал, а патриарх становился все более не сдержан в проявлении отрицательных свойств своей натуры, властной и нетерпимой. Но корни конфликта были более глубокими. Никон считал «священство», церковь выше «царства»; по его убеждению, ведущей в государстве должна была быть роль церкви, а следовательно, и его лично. С детства воспитанный как единственный властитель страны, Алексей Михайлович не мог принять такой идеологии. За идейными коллизиями

${ }^{71}$ ПСЗ-I. Т. 1. № 116, 134, 164, 167, 171, 178, 190, 233, 235, 298, 372, 406, 415, 416, 421, 429, 430, 434, 444, 446, 451, 458.

72 Ченцова В.Г. Восточная церковь и Россия после Переяславской рады. 1654-1658: Документы. М., 2004.

${ }^{73}$ История старообрядческой церкви: Краткий очерк. М., 1991; Зеньковский С.А. Русское старообрядчество. М., 1995; Глинчикова А.Г. Раскол или «срыв русской Реформации»? М., 2008; Крамер А.B. Раскол русской Церкви в середине XVII в. СПб., 2011. 
стояли и сугубо практические: церковь обладала огромными материальными богатствами, а также привилегиями в отношении государственных повинностей. Такое положение противоречило интересам и служилых людей по отечеству, конкурировавших с духовными феодалами за земли и крестьян, и посаду, недовольному тем, что многие члены общин переходят в «белые» слободы духовенства. Очевидно, что в ослаблении церкви были заинтересованы многие социальные силы и главная - верховная власть. Никон лишился патриаршего престола, а царь и Дума приняли законы (в том числе, Соборное уложение), во многом лишившие церковь ее прежнего экономического могущества и влияния в обществе. Верховная светская власть удержала за собой и укрепила лидирующие позиции в государстве ${ }^{74}$. Однако у светской власти в 60-х гг. XVII в. оказалось недостаточно сил, чтобы удержать свой приоритет над властью духовной в полной мере. На церковном Соборе 1667 г. вопреки Соборному уложению. было решено оставить духовенство неподсудным светской власти, сохранив все полномочия в церковных делах за патриархом ${ }^{75}$. В то же время, реформирующаяся Русская Православная Церковь действовала вполне в духе Нового времени: она осуществляла модернизацию сверху, проводила стандартизацию обрядов и своего устройства (что поддерживали и патриарх Филарет, и патриарх Никон), и, не имея своей политической организации, включалась в ходе преобразований в общую систему государственного управления ${ }^{76}$.

Таким образом, 40-60-е гг. XVII в. характеризовались, во-первых, строительством суверенного национального государства, деятельной политикой правительства в колонизационной сфере, результатом чего стал в высшей степени активный территориальный рост страны; во-вторых, модернизационными процессами: увеличением численности и обновлением армии, ликвидацией тормозящих развитие экономики феодальных элементов социально-экономической структуры, ростом и усилением роли государственного административного аппарата в жизни страны, постепенным, но уверенным подчинением церкви светской власти.

Опираясь на армию, государство решительнее и жестче проводило необходимую ему политику, подавляя сопротивление населения. Выстраивалась четкая властная вертикаль, к которой эффективно подключалась выборная местная администрация. Государство все более вторгалось в сферу экономи-

${ }^{74}$ Устинова И.А. Русское государство и православная церковь в $\mathrm{X}$ - начале $\mathrm{XX}$ в. М.; СПб., 2012. С. 112-125.

${ }^{75}$ Каптерев Н.Ф. Патриарх Никон и царь Алексей Михайлович. Сергиев Посад, 19091912. Т. 1-2; Заозерский А.И. Никон // Христианство: Энциклопедический словарь. В 3 т. М., 1995. Т. 2; Стефанович П.С. Приход и приходское духовенство в России XVI-XVII вв. M., 2002.

${ }_{76}$ Устинова И.А. Русское государство и православная церковь... С. 112-150. 
ки, проводя политику протекционизма и меркантилизма. Верховную власть в значительной степени занимало утверждение как внутри страны, так и за рубежом высокого статуса русского монарха. Рассматриваемый период характеризуется также большим влиянием на внутреннюю и внешнюю политику властей увеличения роли России в качестве импортера сырья на европейском рынке. Комплекс по большей части внутренних и некоторых внешних факторов (рост и перестройка армии, жесткая фискальная политика, коммерциализация поместного и вотчинного хозяйства, рост эксплуатации крепостного крестьянства, вовлечение в мировую торговлю), привели к окончательному установлению в стране крепостного права.

В целом середину XVII в. можно определить как время укрепления единой центральной власти, усиления государственных структур, от монарха до местного государственного управления, увеличением роли государства во многих сферах жизни страны, что полностью находилось в русле изменений, происходивших в европейском обществе, кардинальными из которых были становление и развитие капитализма. Алексей Михайлович, безусловно, обладал огромными полномочиями. При этом говорить о вседозволенности, всевластии царя, что ассоциируется с абсолютной монархией, не представляется возможным. Одним из наиболее ярких и доказательных свидетельств того, что Алексей Михайлович не был абсолютным монархом, являются материалы, собранные в исследовании П.В. Седова «Закат Московского царства» ${ }^{77}$. Приведенные автором факты указывают на деятельнейшее участие окружения царя в формировании и практическом осуществлении внутренней и внешней политики государства.

Собственно говоря, термины «абсолютизм, «абсолютная монархия», являются идеологическим конструктом, впервые появившимся во времена Великой Французской революции для использования в политической борьбе со «старым порядком». Из политики термин перешел в исторические труды, где так и не обрел твердых критериев (особенно в отношении российского абсолютизма). По основным из них - определение и классовая сущность абсолютизма, время, способы и этапы его образования и развития, формы монархии, предшествовавшие абсолютной, социальная база абсолютизма, соотношение понятий «абсолютизм» и «самодержавие» и др. так и не была найдена единая точка зрения ${ }^{78}$. Таким образом, фактически вся формальная доктрина абсолютизма (по крайней мере, применительно к русской истории XVII в.) распадается.

${ }^{77}$ Седов П.В. Закат Московского царства. Царский двор конца XVII века. СПб., 2006.

${ }^{78}$ Ключевский В.О. Сочинения. В 8 т. М., 1957. Т. 2; Покровский М.Н. Русская история в самом сжатом очерке. М., 1920-1923. Ч. 1-3; История СССР. Т. 1 / Под ред. В.И. Пичеты, М.Н. Тихоми- 
На практике абсолютной власти монарха не было ни во Франции, стране «органического» абсолютизма, ни в России XVII в. Попытки «приложить» к России искусственный термин с крайне расплывчатым содержанием ведут лишь к затемнению реальных исторических процессов, происходивших в стране в XVII в. При этом речь, разумеется, не идет об отказе от осмысления этих конкретных процессов.

\section{Литература}

Аврех А.Я. Русский абсолютизм и его роль в утверждении капитализма в России // История СССР. 1968. № 2. С. 82-104.

Акты хозяйства боярина Б.И. Морозова. М.; Л., 1940. Ч. 1; М.; Л., 1945. Ч. 2.

Архив стольника Андрея Ильича Безобразова. М., 2012. Ч. 1; М., 2013. Ч. 2.

Базилевич К.В. Денежная реформа Алексея Михайловича и восстание в Москве в 1662 г. М.; Л., 1936.

Базилевич К.В., Богоявленский С.К., Чаев Н.С. Царская власть и Боярская дума // Очерки истории СССР. Период феодализма. XVII в. М., 1955.

Богоявленский С.К. Приказные судьи XVII века. М.; Л., 1946.

Буганов В.И. Московское восстание 1662 г. М., 1964.

Булгаков М.Б. Государственные службы посадских людей в XVII веке. М., 2004.

Вайнштейн О.Л. Россия и Тридцатилетняя война 1618-1648 гг.: Очерки из истории внешней политики Московского государства в первой половине XVII в. Л., 1947. Васильев К.Г., Сегал А.Е. История эпидемий в России. М., 1960.

Веселовский С.Б. Сошное письмо. М., 1915. Т. 1.

Глинчикова А.Г. Раскол или «срыв русской Реформации»? М., 2008.

Городские восстания в Московском государстве XVII века / Под ред. К.В. Базилевича. М.; Л., 1936.

Гурлянд И.Я. Приказ великого государя Тайных дел. Ярославль, 1902.

Демидова Н.Ф. Служилая бюрократия в России XVII в. и ее роль в формировании абсолютизма. М., 1987.

Ерошкин Н.П. История государственных учреждений дореволюционной России. M., 1983.

Жук А.Б. Стрелковое оружие. М., 1992.

Загоровский В.П. Белгородская черта. Воронеж, 1969.

рова, А.В. Шестакова. М., 1941; Юиков С.В. К вопросу о сословно-представительной монархии в России // Советское государство и право. 1950. № 10. С. 39-51; Аврех А.Я. Русский абсолютизм и его роль в утверждении капитализма в России // История СССР. 1968. № 2. С. 82-104; Троиикий С.М. Финансовая политика русского абсолютизма во второй половине XVII и XVIII вв. // Абсолютизм в России (XVII-XVIII вв.): Сборник статей к семидесятилетию со дня рождения и сорокапятилетию научной и педагогической деятельности Б.Б. Кафенгауза. М., 1964. С. 281319; Троицкий C.M. Русский абсолютизм и дворянство в XVIII в. Формирование бюрократии. М., 1973; Шмидт С.О. Становление российского самодержавства: Исследование социальнополитической истории времени Ивана Грозного. М., 1973; Черепнин Л.В. Вопросы методологии исторического исследования. Теоретические проблемы истории феодализма (Сборник статей). М., 1981; Исаев И.А. История государства и права России. М., 2004. 
Законодательные акты русского государства второй половины XVI - первой половины XVII века: Тексты. Л., 1986.

Заозерский А.И. Никон // Христианство: Энциклопедический словарь. В 3 т. М., 1995. Т. 2.

Зеньковский С.А. Русское старообрядчество. М., 1995.

Зериалов А.Н. О мятежах в городе Москве и в селе Коломенском в 1648, 1662 и 1771 гг. // Чтения в Обществе истории и древностей российских при Московском университете. 1890. Кн. 3(154). Отд. І.

Исаев И.А. История государства и права России. М., 2004.

История СССР. Т. 1 / Под ред. В.И. Пичеты, М.Н. Тихомирова, А.В. Шестакова. М., 1941.

История старообрядческой церкви: Краткий очерк. М., 1991.

Каптерев Н.Ф. Патриарх Никон и царь Алексей Михайлович. Сергиев Посад, 1909-1912. T. 1-2.

Кеннеди П. Взлеты и падения великих держав. Екатеринбург, 2018.

Ключевский В.О. Русская история. Полный курс лекций в двух книгах. М., 2004. Кн. 2. Лекция LI.

Ключевский В.О. Сочинения. В 8 т. М., 1957. Т. 2.

Крамер А.В. Раскол русской Церкви в середине XVII в. СПб., 2011.

Кузнеиов И.Н., Новохатко О.В., Шахова А.Д. Светское устройство и архитектурное благоустройство Переславля-Залесского в XVII в. М., 2014.

Кузьмичев А.Д., Шапкин И.Н. Отечественное предпринимательство: очерки истории. М., 1995.

Курбатов О.А. Западноевропейские военно-теоретические модели XVII в. и их место и реформировании русской армии // Феномен реформ на Западе и Востоке Европы в начале Нового времени (XVI-XVIII вв.). СПб., 2013.

Лисейиев Д.В., Рогожин Н.М., Эскин Ю.М. Приказы Московского государства XVIXVII вв.: Словарь-справочник. М.; СПб., 2015.

Малов A.B. Московские выборные полки солдатского строя в начальный период своей истории. 1656-1671 гг. М., 2006.

Малов А.В. Русско-польская война 1654-1667 гг. М., 2006.

Маньков А.Г. Уложение 1649 года. Кодекс феодального права России. Л., 1980.

Медведь A.Н. Актовые материалы об эпидемиях XVII в. как источник по истории антропологии болезни в Московском государстве // Проблемы дипломатики, кодикологии и актовой археографии. Материалы XXIV Международной научной конференции. М., 2012. С. 397-400.

Мизис Ю.А. Формирование рынка Центрального Черноземья во второй половине XVII - первой половине XVIII вв. Тамбов, 2006.

Милюков П.Н. Спорные вопросы финансовой истории Московского государства. СПб., 1892.

Новосельский А.А. Борьба Московского государства с татарами в первой половине XVII века. М.; Л., 1948.

Новохатко О.В. Разряд в 185 году. М., 2007. 
Пенской В.В. Военная революция XVI-XVII вв. и ее изучение в зарубежной и российской историографии второй половины XX — начала XXI вв. // Научные ведомости Белгородского государственного университета. Сер.: История. Политология. 2008. Вып. 7. № 5(45). С. 67-73.

Покровский М.Н. Русская история в самом сжатом очерке. М., 1920-1923. Ч. 1-3. Полное собрание законов Российской империи. СПб., 1830. Т. 1.

Поршнев Б.Ф. Тридцатилетняя война и вступление в нее Швеции и Московского государства. М., 1976.

Санин Г.А. Формирование южной границы и геополитические проблемы России (2-я половина XVII - 1-я половина XVIII вв.)// Формирование территории Российского государства XVI - начало XX в. (границы и политика). М., 2015. C. 61-98.

Седов П.В. Закат Московского царства. Царский двор конца XVII века. СПб., 2006.

Синелобов А.П. Персональный состав городовых приказчиков и губных старост Московского государства XVI-XVII вв. М., 2014.

Соборное Уложение 1649 года: Текст. Комментарии. Л., 1987.

Стефанович П.С. Приход и приходское духовенство в России XVI-XVII вв. М., 2002. Судебники XV-XVI веков. М.; Л., 1952.

Талина Г.В. Русская самодержавная монархия первых Романовых глазами современников и потомков // Самодержавное царство первых Романовых. М., 2004.

Торговля, купечество и таможенное дело в России в XVI-XVII вв.: Сборник материалов Третьей международной научной конференции. Коломна, 2015. Т. 1: XVI-XVIII вв.

Троицкий С.M. Русский абсолютизм и дворянство в XVIII в. Формирование бюрократии. М., 1973.

Троиџкий С.М. Финансовая политика русского абсолютизма во второй половине XVII и XVIII вв. // Абсолютизм в России. (XVII-XVIII вв.): Сборник статей к семидесятилетию со дня рождения и сорокапятилетию научной и педагогической деятельности Б.Б. Кафенгауза. М., 1964. С. 281-319.

Устинова И.А. Русское государство и православная церковь в X - начале XX в. М.; СПб., 2012.

Ченцова В.Г. Восточная церковь и Россия после Переяславской рады. 1654-1658: Документы. М., 2004.

Черепнин Л.В. Вопросы методологии исторического исследования. Теоретические проблемы истории феодализма (Сборник статей). М., 1981.

Чернов А.В. Вооруженные силы Русского государства в XV-XVII вв. (с образования централизованного государства до реформ при Петре I). M., 1954.

Чистякова E.B. Городские восстания в России в первой половине XVII века (30-40-е годы). Воронеж, 1975.

Чичерин Б.Н. Областные учреждения в России в XVII в. М., 1856.

Шмидт С.О. Становление российского самодержавства: Исследование социально-политической истории времени Ивана Грозного. М., 1973.

Юшков С.В. К вопросу о сословно-представительной монархии в России // Советское государство и право. 1950. № 10. С. 39-51. 


\author{
К.В. Петров
}

\title{
СОЦИАЛЬНАЯ (СОСЛОВНАЯ) МОБИЛЬНОСТЬ ДВОРЯН И ДЕТЕЙ БОЯРСКИХ В РОССИИ второй половины XVI-XVII вв.
}

\begin{abstract}
Аннотация В работе исследуются способы и необходимые условия приобретения прав дворян и детей боярских, перехода из дворян и детей боярских в другие сословия. Автором делается вывод о том, что концепция «распада служилого города» является частью марксисткой парадигмы в изучении отечественной истории, и в настоящее время вне данной парадигмы она не может рассматриваться. В работе отмечается, что наследование не являлось способом вхождения в социальную группу дворян и детей боярских, ключевым фактом в данном случае следует считать особую юридическую процедуру «верстания» поместным и денежным окладом. В свою очередь, это означает, что сыновья детей боярских не были детьми боярскими, но, будучи сыновьями служилых отцов, обладали приоритетом при прохождении процедуры «верстания». Причем, не имея обязанности несения службы, сыновья детей боярских могли войти в состав любой другой категории населения. В работе делается вывод о том, любое общество является стабильным при наличии социальной мобильности, т. е. возможности перехода из одной социальной категории в другую.

Ключевые слова: история России, XVI в., XVII в., социальная мобильность, сословие, дворяне, дети боярские, сословная мобильность.
\end{abstract}

Summary The work examines ways and necessary conditions for acquiring the rights by nobles and «boyar children», the transition from nobles and «boyar children» to other classes. The author concludes that the concept of the «collapse of the service city» is part of the Marxist paradigm in the study of Russian history, and at present it can not be considered outside this paradigm. The work notes that the inheritance was not a way of entering 
the social group of nobles and «boyar children». The key factor, in this case, should be considered a special judicial procedure for «verstaniye» by local and monetary salary. In turn, this means that the sons of the «boyar children» were not «boyar children», but, being the sons of serving fathers, had priority when going through the «verstaniye» procedure. Moreover, not having the duty of serving, the sons of the «boyar children» could become part of any other category of the population. The paper concludes that any society is stable in the presence of social mobility, that is, the possibility of transition from one social category to another.

Keywords: history of Russia, 16th century, 17th century, social mobility, estate, nobles, «boyar children», class mobility.

Теория «социальной мобильности», впервые была разработана французским демографом А. Дюмоном ${ }^{1}$, но вошла в мировую науку благодаря работе «Социальная мобильность», написанной в 1927 г. Питиримом Сорокиным ${ }^{2}$, основателем гарвардской социологической школы. В настоящее время под «вертикальной социальной мобильностью» понимают изменение социального статуса, в который включается уровень дохода, должность, звание и т.п.; «горизонтальная социальная мобильность» - перемещения в социальном пространстве, не меняющие его социальный статус ${ }^{3}$. Иначе говоря, социальная мобильность - это изменение положения человека в социальном пространстве. В настоящее время теория «социальной мобильности» в рамках социальных наук направлена на решение ряда прогностических задач, связанных с устойчивостью общества в целом, его экономическим ростом ${ }^{4}$. Более того, социальная мобильность как фактор стабильности общественных отношений обусловлена культурно-специфическими представлениями о социальной стратификации ${ }^{5}$ и социальной

${ }^{1}$ Носкова А.В., Кузьмина Е.И. Социальная мобильность в трудах ведущих социологов Франции ХХ в. // Социологические исследования. 2019. № 4. С. 99-108.

2 Сорокин П.А. Социальная мобильность / Пер. с англ. М., 2005.

3 Громова Е.И. Эвристический потенциал концепции социальной мобильности Питирима Сорокина // Вопросы политологии. 2020. Т. 10. № 6(58). С. 1689-1699.

4 Урри Дж. Мобильности / Пер. с англ. А. В. Лазарева. М., 2012; Урри Дж. Социология за пределами обществ: виды мобильности для XXI столетия. М., 2012; Шеллер М. Новая парадигма мобильностей в современной социологии // Социологические исследования. 2016. № 7. С. 3-11; Епихина Ю.Б. Переопределение концептуальных оснований в исследованиях социальной мобильности // Многомерная социальная мобильность в современной России. М., 2018. С. 29-34; Черныши М.Ф. Социальная мобильность и неравенство // Многомерная социальная мобильность... С. 9-28.

5 Вебер М. Основные понятия стратификации // Социологические исследования. 1994. № 5. С. 147-156; Лебедева Д.А. Социальная стратификация // Format. Социология. 2019. № 3(3). C. 17-21. 
справедливости ${ }^{6}$. Во всяком случае, в современной социологии и политологии теория «социальной мобильности» включена в контекст многофакторного анализа общественных процессов ${ }^{7}$.

Стоит указать на то, что в отечественной историографии можно встретить несколько работ, посвященных изучению российской истории, в которых используется термин «социальная мобильность». Одним из первых его применил Б.Н. Миронов в работе «Социальная история России», вызвавшей дискуссии по поднятым в ней проблемам и выдержавшей три издания ${ }^{8}$. Сравнительно недавно вышли работы С.Н. Смирнова, посвященные способам изменения правового статуса населения Российской империи в XVIII — первой половине XIX в. ${ }^{9}$, и труды Е.Н. Козловской, рассмотревшей те же проблемы на материалах правовых текстов X-XIII вв. ${ }^{10}$ Наконец, непосредственно к проблемам, которым посвящена настоящая статья, хронологически относится статья Е.В. Акельева и А. Жуковской ${ }^{11}$. Однако исследователи, используя термин «социальная мобильность», не указывают его значение и границы применения к фактам и событиям прошлого ${ }^{12}$.

${ }^{6}$ Канари Г.Ю. Социальная справедливость. Философские концепции и российская ситуация. М., 2011; Вайпан В.А. Теория справедливости: Право и экономика. М., 2017; Саенко А.С. Концепция социальной справедливости и ее понимание в современности // Социальная справедливость: утопии и реалии: Материалы Всероссийской научной конференции, посвященной 150-летию со дня рождения В. И. Ленина. М., 2020. С. 373-376.

${ }^{7}$ См.: Черныли М.Ф. Проблематизация социального: исследования социальной структуры и российская социология // Россия реформирующаяся. 2019. № 17. С. 48-60; Никишин E.A. История и перспектива исследований социальной мобильности после мобильного поворота // Журнал социологии и социальной антропологии. 2019. Т. 22. № 2. С. 93-117.

8 Миронов Б.Н. Социальная история России периода империи (XVIII - нач. XX в.). Генезис личности, демократической семьи, гражданского общества и правового государства. СПб., 1999. Т. 1. С. 82-133.

9 Смирнов С.Н. Некоторые правовые аспекты социальной мобильности помещичьих крестьян в Российской империи в конце XVIII - начале XIX вв.: политика законодателя и факты повседневной истории // Право и государство: теория и практика. 2019. № 8(176). С. 70-72; Смирнов С.Н. К вопросу о формировании образования в качестве канала вертикальной социальной мобильности в Российской империи в 1801-1860 годах: нормативная основа и практика функционирования // Вестник Тверского государственного университета. Серия: Право. 2019. № 3(59). С. 95-103; Смирнов С.Н. К вопросу о развитии системы образования России в первой половине XVIII века в качестве канала изменения индивидуального правового статуса // Закон и право. 2020. № 12. С. 68-71.

${ }^{10}$ Козловская E.Н. Социальная мобильность в Древней Руси (по материалам законодательных актов X-XIII вв.) // Вестник Удмуртского университета. Сер. История и филология. 2019. T. 29. № 1. C. 135-140.

${ }^{11}$ Akelev E., Joukovskaia A. From cossak to noble: The Shagarovs, a microhistory of social mobility in Russia, $17^{\text {th }}-18^{\text {th }}$ centuries // Cahiers du Monde russe. 2016. Vol. 57. № 2-3. P. 457-504. Категорически не могу согласиться с тезисом о наследственной службе подьячих в XVIIXVIII вв. и с рядом других выводов.

${ }^{12}$ Б. Н. Миронов ограничился ссылкой на труды П. А. Сорокина. 
Между тем использование этой категории применительно к истории России XVI-XVII вв. имеет свои пределы ${ }^{13}$. Во-первых, в распоряжении исследователей нет надежных данных об уровне доходов людей той эпохи; наши знания в этом направлении фрагментарны как в статическом, так и в динамическом аспектах. Денежные и поместные оклады дворян и детей боярских носили формально-юридический и фактический характер («в даче»). Во-вторых, должности и звания (чины) имели узкое значение, обозначая принадлежность к более широкой социальной классификации - сословной. Например, вполне очевидно, что на должность походного воеводы мог быть назначен только представитель сословия дворян и детей боярских, но не посадский человек или крестьянин. В-третьих, при рассмотрении исторического процесса XVI-XVII вв. не может быть использовано деление социальной мобильности на горизонтальную и вертикальную. Нет оснований отнести к той или иной ее разновидности переход человека из крестьян в посадские люди. Наконец, в-четвертых, для любого доиндустриального (добуржуазного, древнего) общества, в противоположность индустриальному (буржуазному, современному) характерно правовое неравенство отдельных категорий населения. Указанные категории населения в настоящей работе будут называться сословиями ${ }^{14}$. Лишь с эпохи Нового времени постепенно формируются и распространяются идеи формального равенства людей перед законом, а затем постепенно эта идея облекается в форму правовых принципов и вносится в законодательные акты. Таким образом, «социальная мобильность» как специальный научный термин с учетом исторической специфики будет в настоящей работе рассматриваться как переход из одного сословия в другое; задача настоящего исследования заключается в установлении способов и видов сословной мобильности в России XVI-XVII вв. Однако автор далек от мнения о возможности в рамках настоящей работы решить поставленную задачу в полном объеме, поэтому выводы будут иметь предварительный характер.

Следует также указать на границы использования термина «сословие», который в отечественной и зарубежной исторической науке понимается иначе $^{15}$, нежели в настоящей работе. В частности, помимо закрепления

${ }^{13} \mathrm{O}$ корректности применения специальных терминов. см.: Петров К.В. Подлинное и мнимое: проблемы реконструкции прошлого в исторических исследованиях // Русское средневековье. Сборник статей в честь Ю.Г. Алексеева. М., 2012. С. 81-102.

${ }^{14}$ Подробнее см.: Петров К.В. Принцип правового равенства/неравенства в исторической перспективе // Принципы права: Материалы XI международной научно-практической конференции. М., 2017. Ч. 1. С. 286-294.

${ }^{15}$ Макс Вебер: «Сословием мы будем называть некое множество людей, которые в рамках организованного общества успешно претендуют на... сословное уважение и... сословные монополии» (Вебер М. Сословия и классы // Ab Imperio. 2002. № 3. С. 23). 
в праве (законах или обычаях) за отдельными категориями населения прав и обязанностей - мнение, которого мы придерживаемся ${ }^{16}$, - в литературе указывается еще два признака ${ }^{17}$. Первый — наличие представительных органов власти, с помощью которых сословия доносят свои идеи до высшей власти и ограничивают ее. Второй признак - осознание своей принадлежности к сословию, некий «единый корпоративный дух». В первом случае, думается, справедливо мнение Г. Бермана о том, что деление групп населения на сословия «совершенно независимо от политического представительства» ${ }^{18}$. Полагаю, что наличие или отсутствие представительного органа власти определяет особенности развития государства, но не правового статуса населения. По поводу второго признака следует заметить, что он носит субъективный (оценочный) характер, следовательно, не является научным $^{19}$.

Между тем Д.В. Лисейцев в новейшей работе утверждает, что сословия в рассматриваемое время не сформировались, поскольку осознание сословного единства «не утвердилось в сознании подданных русского царя» ${ }^{20}$. Это высказывание историк доказывает исключительно умозрительно, личным убеждением в том, что посадский человек Пскова не осознавал свою общность с посадским человеком Твери. Думается, все зависело от конкретной жизненной ситуации, в которой тот или иной человек находился. Но, во всяком случае, несомненно, что сам посадский человек осознавал то, что он являлся посадским человеком - ему об этом «напоминали» его обязанности по уплате тягла.

Следует отметить также некоторые сложности, которые возникают с представлением о сословии как части общества с закрепленными в праве особыми правами и обязанностями. С ними столкнулся В.А. Аракчеев, задавшись вопросом: «Может ли существовать сословие, состоящее из одних мужчин, даже если их права прописаны в законе полнее, чем права женщин? И можно ли отрицать факт существования сословия, если закон

${ }^{16}$ Алексеев Ю.Г. К вопросу о сословиях в России XV-XVI вв. Некоторые черты сословной политики Ивана III // Государство и общество в России XV - начала XX в.: Сборник статей памяти Н.Е. Носова. СПб., 2008. С. 66.

${ }^{17}$ Б.Н. Миронов выделяет шесть признаков сословия (Миронов Б.Н. Социальная история России периода империи (XVIII - нач. XX в.). Т. 1. С. 78-79, 85, 140). В настоящей работе не ставим целью их специальное изучение. С.В. Волков, отождествляет право и закон, и полагает, что «“номенклатура" сословий определяется законом» (Волков С.В. Элитные группы традиционных обществ. М., 2017. С. 17).

${ }^{18}$ Берман Г.Д. Западная традиция права. Эпоха формирования. М., 1998. С. 381.

${ }^{19}$ См.: Гладкий А.В. Введение в современную логику. М., 2001. С. 177, 178 и др.

20 Лисейцев Д.В. Почему Земский собор - не парламент? // Российская история. 2020. № 4. C. 149. 
гарантирует женщине сохранение ее социального статуса посредством материального обеспечения в случае потери кормильца?» ${ }^{21}$ В данном случае очевидно, что в России XVI-XVII вв. и в других странах правовой статус женщин следовал правовому статусу ее мужа или отца. При этом важно напомнить, что сословное деление не является делением общества по физическим параметрам человека (пол, возраст и др.) $)^{22}$.

Вместе с тем автор далек от мысли настаивать на обязательном использовании термина «сословие» в предложенном значении. Не будем формалистами. В случае, если использование термина «сословие» в значении, которое оговорено в настоящей работе, вызывает у читателя несогласие, оно может быть им заменено на любое иное, например, «социальная категория населения» ${ }^{23}$.

Социальная структура российского общества в XVI-XVII вв. известна достаточно хорошо благодаря трудам поколений отечественных исследователей. В фокусе внимания ученых — изучение карьерного роста представителей привилегированной социальной группы — дворян и детей боярских ${ }^{24}$;

${ }^{21}$ Аракчеев В.А. Демография провинциальной дворянской семьи в России середины XVII в.: удельный вес боевых потерь и роль прожитка в функционировании поместной системы // Русь, Россия: Средневековье и Новое время. М., 2019. Вып. 6: VI чтения памяти академика Л.В. Милова. Материалы к международной научной конференции. С. 255.

22 Тот факт, что в XVI в. после смерти первых помещиков стал формироваться институт «прожитка», означает постепенное формирование института правовых льгот и привилегий, цель которых заключается в предоставлении равных фактических и юридических возможностей для удовлетворения потребностей отдельным лицам. Подобные правовые институты в большей степени характерны для современных государств, которые предоставляют возможность пенсионерам, сиротам, инвалидам и др. удовлетворять свои потребности наравне с прочими людьми. Этот правовой институт является одним из способов достижения правового равенства. См.: Бахрах Д.Н. Правовые льготы // Справедливость и право. Свердловск, 1989. С. 74-82; Морозова И.С. Льготы в российском праве: Автореф. дис. ... канд. юрид. наук. Саратов, 2000; и др.

${ }^{23}$ Некоторые историки полагают, что сословия появились вместе с появлением термина «сословие» (Последняя по времени работа, где высказана подобная позиция: Границы и маркеры социальной стратификации России XVII-XX вв.: векторы исследования. СПб., 2018. С. 147). Данный подход представляется методологически неверным (См.: Петров К.В. Подлинное и мнимое... С. 81-102). Критически к подобным подходам относятся медиевисты (Хачатурян Н.А. Общественная система и принцип относительности. К вопросу о содержании концепт-явления «феодализм» // Средние века. М., 2017. Вып. 68(1). С. 6-35; Цатурова С.К. О пользе презентизма, или Как изучать истоки национального государства в ожидании его отмирания // Диалог со временем. 2018. Вып. 65. С. 59-72 и др.).

${ }^{24}$ Например: Андреев И.Л. О проблеме сословной организации и сословном самосознании служилого «города» в XVII столетии // Сословия и государственная власть в России. XV - середина XIX вв. Международная конференция - Чтения памяти Л.В. Черепнина: Тезисы докладов. М., 1994. Ч. 1. С. 13-20; Андреев И.Л. Дворянство и служба в XVII в.// Отечественная история. 1998. № 2. С. 164-175; Глазьев В.Н. Особенности социальной структуры населения и административного устройства Южной окраины России XVI-XVII вв.// Вестник Воронежского государственного университета. Сер.: История. Политология. Социология. 2013. № 1. С. 24-32; и др. 
их вхождение в состав Государева двора и перемещение по чинам «московского списка» ${ }^{25}$.

В зарубежной славистике большее внимание уделялось и уделяется неформальным отношениям как фактору, с одной стороны, определяющему экономический, социальный и политический успех конкретных лиц, семейных кланов, родов; с другой, - предопределяющему основное направление внешней и внутренней политики страны ${ }^{26}$. В постсоветское время эти же подходы стали активно использоваться отечественной наукой ${ }^{27}$.

При всех достижениях историографии проблема перехода из одного сословия в другое, т. е. сословной мобильности, рассматривалась сравнительно слабо. В советское время этот вопрос в контексте формирования землевладения и землепользования на территории южных уездов страны в XVII в. исследовал В.М. Важинский ${ }^{28}$. Работы Я.Е. Водарского посвящены межсословным переходам в первой половине XVII в. ${ }^{29}$ В постсоветской историографии почти единственными работами, в которых вопросам социальной мобильности дворян и детей боярских (без использования термина «мобильность») было уделено значительное внимание, остаются труды Т.А. Лаптевой. В них рассмотрены социальное положение дворян и детей боярских, указы о верстании, практические мероприятия по верстанию в дети боярские сыновей дворян и детей боярских, случаи злоупотреблений при проведении данной процедуры; верстание

${ }^{25}$ Например: Зимин А.A. Формирование боярской аристократии в России во второй половине XV - первой трети XVI в. М., 1988; Станиславский А.Л. Труды по истории государева двора в России XVI-XVII вв. М., 2004; Павлов А.П. Государев двор и политическая борьба при Борисе Годунове (1584-1605 гг.). СПб., 1992; и др.

${ }^{26}$ Crummey R.O. Aristocrats and Servitors. The Boyar Elite in Russia, 1613-1689. Princeton, 1983; Kollmann N.S. Kinship and Politics. The Making of the Muscovite Political System, 13451547. Stanford, 1987; Kivelson V.A. The Effects of Partible Inheritance: Gentry Families and the State in Muscovy // Russian Review. 1994. Vol. 53. № 2. P. 197-212; Martin J.B. Mobility, Forced Resettlement and Regional Identity in Muscovy // Culture and Identity in Muscovy, 1359-1584. М., 1997. Р. 431-449; Коллманн Н.Ш. Соединенные честью. Государство и общество в России раннего Нового времени. М., 2001; и др.

${ }^{27}$ Седов П.В. «Он мне свой...». Свойство при московском дворе XVII в. // Нестор. 2005. № 7. С. 190-199; Седов П.В. Закат Московского царства. Царский двор конца XVII в. СПб., 2006; Лаптева T.A. Повседневная жизнь провинциального дворянства в XVII в. // Российская история. 2010. № 4. С. 107-117; Павлов А.П. Патронатно-клиентельные отношения при московском дворе в годы царствования Михаила Федоровича // Петербургский исторический журнал. 2018. № 4(24). С. 83-97; Павлов А.П. Думные и комнатные люди царя Михаила Романова: просопографическое исследование. В 2 т. СПб., 2019; и др.

${ }^{28}$ Важинский В.M. Землевладение и складывание общины однодворцев в XVII в. (По материалам южных уездов России). Воронеж, 1974.

${ }^{29}$ Водарский Я.Е. О межсословных переходах в первой половине XVIII в. // Сословия и государственная власть в России... Ч. 1. С. 70-74. 
в дети боярские солдат выборных полков, бывших крестьян, служилых казаков и стрельцов ${ }^{30}$.

Несмотря на то что первые работы Т.А. Лаптевой, в которых рассматривались вопросы социальной мобильности детей боярских, выходили на протяжении последних 20 лет, она все же не сделала вывод о том, что происхождение само по себе не влекло возникновение прав и обязанностей сына боярского, и что сыновья детей боярских - лишь потенциальные дети боярские. Парадоксальным образом, приводя в пример верстание на Коротояке в 1652/53 г., Лаптева писала о верстании в дети боярские гулящих людей и полковых казаков. Причем она отметила, что полковые казаки вместо себя оставили детей и братьев ${ }^{31}$. Но ведь это значит, что полковые казаки перестали быть таковыми и были верстаны в дети боярские в качестве «вольных» или «гулящих людей»! Исследовательница же, рассматривая случаи злоупотреблений при верстании, приводит в пример ситуацию в Ефремове в 1643/44 г., где шесть ефремовских казаков верстались, «утоя свои казачьи службы». Подобное случалось в Ефремове и прежде - верстали «из розных городов беглых казаков» ${ }^{32}$. Резюмируя, Лаптева писала: «Царские указы нередко запрещали верстать... казаков и стрельцов в дети боярские» ${ }^{33}$.

При всей значимости исследований, проведенных отечественными историками и в первую очередь Т.А. Лаптевой, их недостатком, как представляется, является отсутствие различения человека и социального статуса, который ему принадлежит в данный конкретный момент времени. Видимо, поэтому многие историки считали и считают само собой разумеющчимя то, что сын крестьянина является крестьянином, сын дворянина - дворянином, сын посадского человека - посадским человеком. Случаи перехода из сословия в сословие скорее рассматриваются как исключение (выделено мной. - К.П.). Вот почему в работах можно встретить два прямо противоположных утверждения. Например, говоря о воеводских рассыльщиках, М.Б. Булгаков утверждал, что «их статус был наследственным и автоматически переходил от отца к сыну», а следом писал: «Сыновья рассыльщика

${ }^{30}$ Лаптева Т.А. Поверстание в дети боярские представителей других сословий. К вопросу о расширении социальной базы дворянского сословия в XVII веке // Отечественная история. 2003. № 5. С. 81-96; Лаптева Т.А. Провинциальное дворянство России в XVII веке. М., 2010. С. 480-507; Лаптева T.A. Эволюция служилого «города» // Сословия, институты и государственная власть в России (Средние века и раннее Новое время): Сборник статей памяти Л. В. Черепнина. М., 2010. С. 684-693.

${ }^{31}$ Лаптева Т.А. Провинциальное дворянство России в XVII веке. С. 485.

${ }^{32}$ Там же. С. 486, 487.

${ }^{33}$ Там же. С. 486. 
по достижению 15-летнего возраста “верстались” (определялись) в ту же должность, а если не было вакансий, то их “верстали” в другие категории приборных служилых людей и не обязательно в родном городе» ${ }^{34}$. Второе утверждение прямо противоречит первому.

Судя по имеющимся данным, основание принадлежности к сословию дворян и детей боярских, т. е. приобретению прав (например, на поместье) и обязанностей (например, по несению службы), возникало не с момента рождения и не после смерти отца. Такими основаниями следует считать индивидуальное (персональное) пожалование царя, «верстание» в службу и решение Разрядного приказа о переводе в дворяне и дети боярские служилых казаков, стрельцов, поместных атаманов.

В первом случае речь идет об исключительных случаях, пожаловании за определенные заслуги. Таковым, например, было пожалование Кузьмы Минина из посадского человека в думные дворяне ${ }^{35}$, в 1649 г. дьяка Семена Дохтурова пожаловали в дворяне по московскому списку с сохранением должности дьяка и др. ${ }^{36}$ Судя по всему, пожалование царя как способ получения сословных прав и обязанностей не зависело от прежнего сословного положения как самого жалуемого, так и его отца.

«Верстание» детей боярских являлось особой юридической процедурой; порядок ее проведения известен по наказным грамотам, по вводной части текста десятен и других документов Разрядного приказа ${ }^{37}$. В Коломенской десятне 1577 г. читаем следующее: по царскому «наказу» верстание проводили боярин Петр Васильевич Морозов и дьяк Василий Низовцов; им было предписано «смотреть и верстать» «которые наперед сего поместным окладом верстаны, и тех верстали денежным жалованьем». Следовательно, верстание - процедура определения (назначение и пересмотр) размера поместного и денежного оклада. Данный размер выясняется путем опроса окладчиков относительно конкретного лица, при необходимости проводится «сыск», т. е. установление фактов о том, «хто кому службою и отечеством в версту» ${ }^{38}$.

\footnotetext{
${ }^{34}$ Булгаков М.Б. Воеводские рассыльщики в XVII веке // Русь, Россия: Средневековье и Новое время. М., 2017. Вып. 5: Пятые чтения памяти академика Л. В. Милова. Материалы к международной научной конференции. С. 236.

${ }^{35}$ Буганов В.И. «Выборный человек всею землею» Кузьма Минин // Вопросы истории. 1980. № 9. С. 90-102; Кузнецов А.А., Морохин А.В. Кузьма Минин. Человек и герой в истории и мифологии. М., 2017.

${ }^{36}$ Лаптева T.A. Новые дворянские роды в России в XVII в. // Памяти Лукичева: Сборник статей по истории и источниковедению. М., 2006. С. 580 и др.

${ }^{37}$ См.: Русская историческая библиотека. Т. 10. Записная книга Московского стола 1640 г. СПб., 1888. С. 240-241.

${ }^{38}$ Сторожев В.Н. Десятни и Тысячная книга XVI в. // Описание документов и бумаг Московского архива Министерства юстиции. М., 1891. Кн. 8. Отд. 3. С. 1-58.
} 
Наконец, десятни ${ }^{39}$ содержат указания на лиц, которые не могут быть «верстаны». В Муромской десятне 1606 г. есть запись: «Неслужилых отцов детей и холопей боярских не верстати и подставою к верстанью никого не ставити»; в Епифанской десятне 1606 г. добавлено: «и братью, и племяников, и посадских людей, и пашенных крестьян» ${ }^{40}$. В XVII в. требования к лицам, которые могут быть «верстаны», более определенны - дети и близкие родственники дворян и детей боярских, «от отцов детей, от братьи братью, от дядь племяники» ${ }^{41}$. Итак, в первую очередь верстались сыновья детей боярских.

На протяжении XVI в., особенно во второй половине столетия, продолжался рост территории Московского государства. 1550-1560-е гг. отмечены строительством городов и формированием уездов в Поволжье; осваивались территорий к югу от Оки, были построены Мценск и Михайлов (1551 г.), Шацк (1553 г.), Белев и Дедилов (1554 г.), Болхов (1555 г.), Пронск и Ряжск (1557 г.), Карачев и Крапивна (1561 г.), Таруса, Тула и Новосиль (1563 г.), Одоев, Орел, Чернь и Епифань (1566 г.), Венев и Данков (1568 г.). В 15801590-х гг. началось строительство новых городов и формирование уездов: Воронеж и Ливны (1585/86 г.), Елец (1592 г.), Белгород и Старый Оскол (1593 г.), Кромы и Курск (1596 г.), Царев-Борисов (1599 г.). С этим связано увеличение числа служилых людей по отечеству и формирование новых «служилых городов» ${ }^{42}$. Причем нет ничего удивительного в том, что в состав дворян и детей боярских верстались не только их сыновья.

Т.А. Лаптева, разбирая десятню по Коротояку 1648/49 г., отметила, что кроме сыновей детей боярских были верстаны казачьи дети, которые сами себя называли «гулящими» или «свободными» людьми ${ }^{43}$. Следовательно, как и сыновья дворян и детей боярских, дети представителей других сословий были свободными от обязанностей в пользу государства, они не несли службу, не платили тягло и не являлись холопами - все они могли верстаться в дети боярские.

39 Лаптева T.A. Десятни XVII в. как исторический источник: особенности составления и научного использования // Вестник архивиста. 2012. № 4(120). С. 19-29; Лаптева Т.А. Десятни как источник по истории приказного делопроизводства XVII в. // Проблемы дипломатики, кодикологии и актовой археографии. К 80-летию Сергея Михайловича Каштанова. Материалы XXIV международной научной конференции. М., 2012. С. 378-379; Козляков В.Н. Служилые люди России XVI-XVII вв. М., 2018. С. 293-309; и др.

${ }^{40}$ Сторожев В.Н. Десятни и Тысячная книга XVI в. С. 90, 131.

${ }^{41}$ Наказ о верстании на Москве новиков всех городов от 20 октября 7161 г. окольничему князю Д.А. Долгорукому и дьяку Ивану Тимашеву (ПС3-І. Т. 1. № 86. С. 273-280).

${ }^{42}$ Общие сведения см.: Петрухиниев Н.Н. Структура, динамика и иерархия служилых «городов» в XVII веке // Cahiers du Monde russe. 2015. Vol. 56. № 1. P. 137-174.

43 Лаптева Т.А. Провинциальное дворянство России в XVII веке. С. 484. 
В связи с верстанием в дети боярские представителей других сословий Т.А. Лаптева пришла к выводу о том, что власть была «бессильна остановить приток в южные города нововерстанных из других социальных страт детей боярских ${ }^{44}$. Татьяна Александровна привела примеры запретов верстания в дети боярские казаков и стрельцов; возврата в прежнее состояние козловцев посадских людей ${ }^{45}$. Например, в 1656 г. не удалось вернуть в посад курчан детей боярских, так как они были верстаны из драгун, а до этого являлись приписными по своим промыслам к посаду. Иначе говоря, на самом деле не удалось вернуть в посад курчан детей боярских именно потому, что они были верстаны из драгун, а не с посада! Во всех случаях, которые привела Лаптева, речь идет о возврате из детей боярских действующих казаков и стрельцов; ничего не говорится о детях казаков и стрельцов, верстание которых было возможно в зависимости от наказа о верстании.

Важно подчеркнуть, что до тех пор, пока люди являлись представителями других сословий - служилых или тяглых, - они обладали правами и обязанностями представителей этих сословий. Для этих лиц переход в другое сословие, в том числе в дети боярские, оказывался возможен лишь в случае передачи ими сословных прав и обязанностей. Например, для посадского человека таким способом передачи прав была возможность оставить за себя на тягле гулящего человека ${ }^{46}$.

Незаконные способы (побег) передачи или отказа от прав и обязанностей не делали человека юридически свободным от сословных прав и обязанностей. Этот вывод следует из многочисленных примеров. В 1652/53 г. беглых стрельцов и казаков, верстанных в дети боярские, следовало вернуть в прежние службы ${ }^{47}$. В соответствии с указом от 18 июня 1683 г. крестьян и холопов полагалось возвращать в прежнее состояние, если записаны они в службу (полковую, солдатскую, копейную, городовую) после разбора 1675/76 г. ${ }^{48}$

В 1653 г. состоялось рассмотрение судного дела, из которого следовало, что Фома Филяков, беглый крестьянин курского сына боярского Галактиона Зорина, скрыв свое истинное положение, в соседнем Короченском уезде верстался в дети боярские. В соответствии с государевым указом Филяковы были возвращены на прежнее место ${ }^{49}$. В челобитной 1623 г. о побеге

${ }^{44}$ Там же. С. 490.

${ }^{45}$ Там же. С. 488-489, 500-501.

${ }^{46}$ См. подробнее: Петров К.В. Свободное население Московского государства во второй половине XVI-XVII вв.: «вольные и гулящие люди» // Петербургский исторический журнал. 2021. № 2.

${ }^{47}$ ПСЗ-І. Т. 1. № 83. С. 271.

${ }^{48}$ РГАДА. Ф. 210. Оп. 12 (Столбцы Белгородского стола). № 1028. Л. 361-362.

${ }^{49}$ Там же. Оп. 14 (Столбцы Севского стола). № 379. Л. 8-15. 
крестьян указывается, что беглые крестьяне братья Ширяевы «переменя... имена свои и поверстались в дети боярские, и нынеча государь те мои беглые крестьяня поверстався в дети боярские и живут на Осколе» ${ }^{50}$. При осуществлении процедуры «отказа поместья» Юрия Никитина Шумакова его детям и внукам 27 июня 1562 г. в Курском уезде ${ }^{51}$, оказалось, что несколько крестьянских семей бежали из поместья. При этом, по «скаскам тутошних и сторонних людей, 2 крестьян в Новом Осколе в драгунах, 1 в Карпове в драгунах, 1 в Ахтырском в драгунах, а Петрушка Рыженков, Першко Щелкун 3 женами и $з$ детми... ныне они в Обоянском в детех боярских» ${ }^{52}$. Как разрешилась данная ситуация с беглыми крестьянами, неизвестно. Однако очевидно, что в случае суда между Шумаковыми и их беглыми крестьянами, последние вернулись на прежнее место. Такое решение было принято вовсе не потому, что «феодальное государство стояло на страже интересов господствующего сословия», а потому, что незаконные действия влекли незаконные последствия.

Возможность верстания сыновей казаков, стрельцов или вольных людей определялась формулировками текста наказов. В соответствии с наказом о верстании на Москве новиков всех городов от 20 октября 1652 г., данным окольничему князю Дмитрею Алексеевичу Долгорукому и дьяку Ивану Тимашеву ${ }^{53}$, верстать «у которых отцы были в детех боярских и служили с городы» ${ }^{54}$, « «не служилых отцов, поповых детей, и холопей боярских, и иных никаких неслужилых, мимо государева указу, поместными денежными оклады не верстать» ${ }^{55}$. В данном случае верстанию подлежали сыновья детей боярских.

Иные требования содержатся в наказе о верстании детей боярских Владимира, Суздаля, Юрьева Польского, Луха, Мурома, Нижнего Новгорода, Гороховца, Арзамаса от декабря 1675 г. стольнику князю Семену Андреевичу Хованскому и подьячему Максиму Дмитриеву ${ }^{56}$ : «А холопей боярских и стрелецких и козачьих и неслужилых никаких чинов и пашенных мужиков отнюдь» не верстать ${ }^{57}$. Здесь ничего не говорится о детях служилых и не служилых чинов и гулящих людях.

\footnotetext{
${ }^{50}$ Там же. Оп. 12. № 9. Л. 77-80.

${ }^{51}$ Там же. Ф. 1209. Оп. 2 (Отказные книги по Курску). № 15688. Л. 161-166 об.

${ }^{52}$ Там же. Л. 163 об.

${ }^{53}$ ПС3-I. Т. 1. № 86. С. 273-280.

${ }^{54}$ Там же. С. 274-275.

55 Там же.

56 Там же. № 615. С. 1019-1028.

${ }^{57}$ Там же. С. 1026.
} 
Уже в конце XVI в. известны случаи (Ряжская десятня 1597 г.), когда к «верстанью» были допущены и верстаны стрелецкий сын Родка Михайлов Павлов, «ямщиков сын» Микитка Григорьев Балашев ${ }^{58}$. Обоянцы дети боярские Емельян и Панкрат Буняевы в распросе указали, что их отец - служилый казак Матвей Буняев ${ }^{59}$. Верхотурские дети боярские Г.Г. Лишарев и М.И. Мещеряков, судя по скаскам 1679/80 г., были детьми подьячих, но при этом заявили, что они «верстаны в дети боярские не из какого чину»; верстанный тогда же В.И. Протопопов приходился сыном протопопу соборной церкви, Н.М. Стадухин - якутскому атаману ${ }^{60}$. В дети боярские по указу были верстаны также дети казаков ${ }^{61}$. Григорий Потапов Лазарев находился под Смоленском в солдатах, после не служил «от бедности», и был «верстан из вольных людей» в 1641/42 г. в курский служилый город ${ }^{62}$. Важно заметить, что дети стрельц̧ов и дети ямщиков юридически не являлись представителями сословий стрельцов и ямщиков (выделено мной. - К.П.), поскольку не были «прибраны»; иначе им не удалось бы «верстаться» в дети боярские ${ }^{63}$.

Т.А. Лаптева писала о том, существовала возможность купить чин сына боярского ${ }^{64}$. Она привела сведения о челобитной детей боярских ливенцев Тимофея и Анания Огарковых в крестьянстве на ливенца сына боярского Никифора Огаркова. В ней утверждается, что отец Никифора Андрей, будучи помещичьим крестьянином, подкупил воеводу и благодаря этому был верстан «с городом» ${ }^{65}$. На самом деле приведенный случай не позволяет сделать вывод, к которому пришла Лаптева. Если обвинения не являлись ложными, речь может идти о злоупотреблении со стороны воеводы, но никак не о покупке как «законном» действии человека.

Стоит остановиться на юридическом феномене XVII в. - неверстанные служилые дети боярские, входившие в состав «служилых городов». Их число, судя по десятням, в течение века постоянно возрастало. Официальная процедура верстания проходила нерегулярно. Почти всегда эти дети боярские несли службу вместо своих близких родственников, иногда

\footnotetext{
${ }^{58}$ Сторожев В.Н. Десятни и Тысячная книга XVI в. С. 423-424.

${ }^{59}$ Куц О.Ю. Дело о «крестьянстве» братьев Фомы и Калины Севастьяновых как источник по изучению нравов русского общества середины XVII в. // Российское государство в XIVXVII вв.: Сборник статей, посвященный 75-летию Ю.Г. Алексеева. СПб., 2002. С. 459-460.

${ }^{60}$ Акты, относящиеся до юридического быта Древней России / Под ред. Н.В. Калачова. СПб., 1884. Т. 3. № 341. II. С. 346-347.

${ }^{61}$ Там же. № 355. С. 400.

${ }^{62}$ РГАДА. Ф. 210. Оп. 4 (Десятни). Д. 188. Л. 537 об.

${ }^{63}$ См.: Петров К.В. Свободное население Московского государства...

${ }^{64}$ Лаптева T.A. Провинциальное дворянство России в XVII веке. С. 496.

${ }^{65}$ Там же.
} 
давно умерших. Например, в верстальной десятне по Курску 1654 г. указано: «Тит Иванов сын Заволишин, служит с отца своего поместья десять лет... в отца своево место», «Гардей Мортинов сын Переверзев служит... 3 деда своево поместья девять лет», «Володимер Максимов Наумов служит... пятнатцать лет без поместья», «Василей Фолимонов Сароколетов служит... с деда своево поместья пятнатцать лет» ${ }^{66}$. Судя по сохранившимся документам XVI в., можно полагать, что подобная ситуация имела место и тогда: «Новики неслужилые, которые служат с Коломны года по два... и по десяти, а государевым жалованьем поместьем и деньгами наперед сего не верстаны, а ныне они поместьем и деньгами поверстаны» ${ }^{67}$. Следует отметить, что, по крайней мере в XVII в. (1637/38 г.), разрешение нести службу за отца принималось Разрядным приказом по индивидуальным челобитным; часто разрешение давалось в случае, если отец испомещен в фактической даче ${ }^{68}$.

Если же при проведении смотра служилого города наказом Разрядного приказа не предусматривалось осуществление процедуры «верстанья» (а только лишь, например, денежная раздача), указанных неверстанных детей боярских вносили в десятни отдельным разделом. Например, в Курском уезде, смотры служилого города проходили относительно регулярно (обязательно при смене воеводы), но процедура «верстанья» не проводилась с 1638 по 1653 гг. По данным смотра на январь 1637 г. дворян и детей боярских полковых Курска оказалось 1074 человека ${ }^{69}$. В ходе «верстания» 1 октября 1653 г. было «верстано» денежным и поместным окладом 208 человек («поместных» и безпоместных») $)^{70}$.

Отметим, что фактическое несение службы не делало служилых людей «верстанными», т. е. у них не возникало право на поместье, они выступали лишь представителями своих «верстанных» родственников. Этим обстоятельством обусловлены челобитные неверстанных сыновей детей боярских, которые служили за своих отцов и дедов об «отказе» им поместий умерших родственников и верстании в службу ${ }^{71}$.

\footnotetext{
${ }^{66}$ РГАДА. Ф. 210. Оп. 6д (Книги Белгородского стола). Кн. 10. Л. 374, 376 об.

${ }^{67}$ Сторожев В.Н. Десятни и Тысячная книга XVI в. С. 28.

${ }^{68}$ См.: Акты Московского государства / Под ред. Н.А. Попова. СПб., 1894. Т. 2. С. 49-50. № 93.

${ }^{69}$ РГАДА. Ф. 210. Оп. 9 (Столбцы Московского стола). № 1132. Л. 32 (итоговые данные Смотренного списка стольника и воеводы Д. С. Яковлева).

${ }^{70}$ РГАДА. Ф. 210. Оп. 6д. Кн. 10. Л. 373-401.

${ }^{71}$ См. также: Петров К.В. Переформатирование сословия «дворян и детей боярских» в петровскую эпоху (к постановке проблемы) // Сборник статей по русской истории в честь А.И. Гамаюнова к его 60-летию от друзей и коллег. М., 2019. С. 25-45.
} 
Наконец, третий способ приобретения прав и обязанностей сына боярского - решение Разрядного приказа о переводе в дворяне и дети боярские служилых казаков, стрельцов, поместных атаманов. Подобный массовый перевод собственно казаков в дети боярские известен по Епифанской десятне 1585 г., когда в дети боярские были верстаны 300 действующих служилых казаков ${ }^{72}$.

Термин «казак» в XVI в. использовался для обозначения «наемного человека», который подряжался на выполнение разных работ, в том числе для участия в военных действиях ${ }^{73}$. Иначе говоря, в тот период казак - вид деятельности ${ }^{74}$. В 1571-1577 гг. (по М.Ю. Зенченко — в 1574-1580 гг.) состоялось реформирование станичной (сторожевой) службы ${ }^{75}$. Думается, что в процессе ее проведения были сформированы служилые казаки в качестве сословия служилых приборных людей.

Очевидно, решения о переводе служилых казаков в дети боярские принимались нечасто, лишь в связи с текущими военными потребностями. Во всяком случае, о проведении подобных мероприятий в XVII в. мне неизвестно, хотя не совсем понятные для интерпретации случаи встречаются. Например, в Курской десятне 1642 г. разбора и раздачи жалованья стольника и воеводы Г.Г. Образцова указано: «Государева денежного жалованья дать было ему не довелось, потому что он верстан ис казаков, а в дети боярские с курчаны не справлен», или «верстан ис казаков до Смоленской службы на Москве» ${ }^{76}$. Возможно, данный пример также связан с экстренной ситуацией, вызванной Смоленской войной.

Я.Е. Водарский полагал, впрочем, не приводя конкретных примеров, что таким образом в первой половине XVII в. формировались служилые города некоторых новых южных уездов. При этом историк использовал термин «перевод», а не «верстание» ${ }^{77}$. В последнем случае с ученым можно согласиться,

72 Лаптева Т.А. Провинциальное дворянство России в XVII веке. С. 482.

${ }^{73}$ Ключевский В.О. Русская история. Полный курс лекций. М.; Минск, 2002. Т. 1. С. 266. См. также: Тюменщев И.О. Россия и появление казачества на Волге и на Дону в XV — первой половине XVI в. // Cahiers du Monde russe. 2005. Vol. 46. № 1/2. Р. 75-82.

${ }^{74}$ О.В. Комаров указал еще одно значение термина «казак», которое использовалось в поморских уездах - наемный работник на отхожие промыслы (Комаров О.В. Военный потенциал Поморских городов и дворцовых земель Верхнего Поволжья в XVI в. (социально-экономические аспекты) // Русь, Россия: Средневековье и Новое время. Вып. 6. С. 550).

${ }^{75}$ Станиславский А.Л. Гражданская война в России XVII в.: Казачество на переломе истории. М., 1990. С. 14-16; Зенченко М.Ю. Южное российское порубежье в конце XVI начале XVII в.: Опыт государственного строительства. М., 2008. С. 41-54.

${ }^{76}$ РГАДА. Ф. 210. Оп. 4. Д. 188. Л. 536 об., 560.

${ }^{77}$ Водарский Я.Е. Численность, состав и размещение дворянства в первой половине XVII в. // Дворянство России и его крепостные крестьяне. XVII - первая половина XVIII в. M., 1989. С. 128. 
но с определенной оговоркой. С одной стороны, реализация решения Разрядного приказа не связывает его исполнителей с необходимостью учитывать мнение самих казаков, поэтому ее следует назвать «переводом». С другой стороны, процедура «верстания» все равно проводится, поскольку требуется определить размеры поместных и денежных окладов.

Возможно, Водарский все же имел в виду так называемых сведенцев, перевод детей боярских, стрельцов и служилых казаков в состав нового «служилого города» и испомещение на территории вновь образуемых уездов. Однако, во-первых, в этом случае сословное положение «сведенцев» не менялось: дети боярские оставались детьми боярскими, служилые казаки - служилыми казаками, а стрельцы - стрельцами. Во-вторых, «сведенцы» выбирались из числа служилого города самими детьми боярскими. Сохранились документы по формированию служилых городов Царева-Алексеева, Карпова, Обояни и др. ${ }^{78}$, на основании которых можно сделать данный вывод, например, список «Орляне дети боярские выбранные в Карпов на вечное житье» ${ }^{79}$. Конечно, избрание служилым городом не всегда совпадало с желанием самих детей боярских ${ }^{80}$. Впрочем, «сведенцы» из числа стрельцов и казаков избирались иначе: «воевода князь Иван Волконской да стрелецкой и казачей голова Савостьян Протасов выбрали на Осколе в новой Царев Олексеев город на вечное житье з женами и з братьями и племянники и со внучаты и с приемыши и зятьями и с половинщики и с соседьми с подсоседники» ${ }^{81}$.

Стоит остановиться на так называемой концепции «распада служилого города». Она была разработана А.А. Новосельским в рамках общего подхода к проблеме зарождения капиталистического уклада и «нисходящего развития» феодальной экономической формации. По мнению Новосельского, характерная для феодализма корпоративная замкнутость дворянского сословия, проявлявшаяся в ограниченности землевладения, постепенно «распадалась». Этот процесс проявлялся в получении детьми боярскими служилых городов поместий и вотчин за пределами их уездов. На основании анализа десятен историк сделал вывод о том, что к концу XVII в. произошел «распад» служилых городов ${ }^{82}$. В современной историографии теория

\footnotetext{
${ }^{78}$ РГАДА. Ф. 210. ОП. 12. № 328; № 354 и др.

${ }^{79}$ Там же. Оп. 4. Д. 258. Л. 2, 54, 63, 66а, 79 (Десятни сведенцев Орла Курска Мценска и др. в Карпов $7155-7156$ гг.)

${ }^{80}$ См.: Челобитная сына боярского Воина Анненкова, курчанина, «сведенца» в ЦаревАлексеев о возвращении в состав курчан (Там же. Оп. 12. №. 354. Л. 58-61).

${ }^{81}$ РГАДА. Ф. 210. ОП. 6д. Кн. 20. Л. 1-1 об.

${ }^{82}$ Новосельский А.А. Феодальное землевладение. Боярство, дворянство и церковь// Очерки истории СССР. XVII в. М., 1955. С. 139-164; Новосельский А.А. Распад землевладения служилого «города» в XVII в. (по десятням) // Русское государство в XVII в. M., 1961. C. 231-253.
} 
«распада служилого города» в том аспекте, который разрабатывался в работах Новосельского, не обсуждается ${ }^{83}$, однако формулировка о распаде служилого города продолжает использоваться. В свое время Р. Хелли задался вопросом о том, что позволило Московскому государству, имея ограниченные ресурсы, в течение XVI-XVII вв. совершить значительный рывок в военной сфере. Одной из причин, помимо прочих ${ }^{84}$, по мысли Хелли, является распад служилого города как неэффективной военной организационной структуры в результате военных реформ второй половины XVII в. ${ }^{85}$

Н.Н. Петрухинцев также полагает, что «служилый город» был деформирован в ходе военной реформы: «Былое “единство службы”, которое сильнее всего цементировало и сплачивало структуры служилых “городов”, остававшихся в первую очередь военно-территориальными корпорациями, было основательно разрушено на юге в период пика военной реформы Алексея Михайловича» ${ }^{86}$. По наблюдениям Д.А. Ляпина, во второй половине XVII в. большая часть детей боярских служилых городов страны лишилась «своего привилегированного статуса» ${ }^{87}$.

Т.А. Лаптева была совершенно права, утверждая, что никакого «распада» служилого города во второй половине XVII в. не произошло; следы его существования сохранились даже в XVIII в. ${ }^{88}$ Доказывая свой вывод, исследовательница отметила, что создание новых полков (солдатских, рейтарских) привело к возникновению нового вида службы, подобной сотенной и полковой; принадлежность к городу «продолжала учитываться и применительно к рейтарской и солдатской службе» ${ }^{89}$. В подтверждение мнения Лаптевой можно привести документы 1655 (начальной стадии реформы) ${ }^{90}$

${ }^{83}$ Об этом см.: Лаптева Т.А. Эволюция служилого «города». С. 684-685.

${ }^{84}$ Hellie R. Warfare, Changing Military Technology, and the Evolution of Muscovite Society // Tools of War. Instruments, Ideas, and Institutions of War, 1445-1871. Urbana, 1990. P. 74-99; Hellie R. The Expanding Role of the State in Russia // Modernizing Muscovy: Reform and Social Change in Seventeenth-Century. L.; N. Y., 2004. P. 29-56.

${ }^{85}$ Сахаров А.Н. Рец. на: Hellie Richard. Enserfment and Military Change in Muscovy. L.: Chicago: University of Chicago Press, 1971 // История СССР. 1973. № 2. С. 194-196.

${ }^{86}$ Петрухинцев Н.H. Структура, динамика и иерархия служилых «городов» в XVII веке. Р. 172-174; Петрухинцев Н.Н. «Разрядная» военная реформа Алексея Михайловича и ее влияние в 1658-1660 гг. на южные служилые «города» России (по материалам городов Липецкого края) // История: факты и символы. 2018. № 3(16). С. 126.

87 Ляпин Д.А. Расслоение провинциального дворянства в России и социально-политическая борьба во второй половине XVII в. // Российская история. 2015. № 5. С. 43.

88 Лаптева Т.А. Эволюция служилого «города». С. 692-693.

${ }^{89}$ Там же. С. 692.

${ }^{90}$ Курбатов O.A. Смотренные десятни полка Елисея Цыклера 1655 г. // Единорогъ. Материалы по военной истории Восточной Европы эпохи Средних веков и раннего Нового времени. М., 2011. Вып. 2. С. 309 и др. 
и 1692 гг. ${ }^{91}$, из которых следует, что в учете личного состава полков учитывалась принадлежность служилых людей к «служилому городу».

В соответствии с наказом 1678 г. разбора Белгородского полка боярину И.Б. Милославскому, «салдатские, драгунские, копейные и рейтарские полки» формировались из числа действующих стрельцов, служилых казаков и детей боярских. При этом, начиная с разбора 1678/79 г., солдатские и драгунские полки формировались только из казаков и стрельцов, а также малопоместных детей боярских. Непонятно, кто такие малопоместные дети боярские - с небольшими окладами или с «малыми дачами». Копейщики и рейтары должны были сформироваться из числа «полных» детей боярских ${ }^{92}$. При этом действие наказа не распространялось на прошедшее время: «А которые казачьи и стрелецкие дети до нынешняго разбору написаны в копейщиках и в рейтарех, а впредь по нынешнему разбору с такую службу их будет, и тем быть в тех чинех по прежнему». При разборе встала проблема, решение которой решили оставить на усмотрение Разряда: «Ныне у разбору копейщиков и рейтар оскудалых детей боярских в салдатцкую службу писати поневоле или волею переписывать». Ответ Разряда был однозначный: только если сами дети боярские пожелают записаться в солдаты ${ }^{93}$.

Важным представляется вопрос о том, насколько самостоятельны были дети дворян и детей боярских в возможности отказаться от «верстания». Очевидно, в случае если сын дворянина не желал «верстаться» и в этом с ним был согласен отец, то он мог стать представителем любого другого сословия - стрельцов, служилых казаков, и т.П. Иначе говоря, сыновья дворян и детей боярских по сути были вольными людьми ${ }^{94}$ и могли по своему желанию перейти в любое другое сословие. Однако, видимо, чаще всего они в случае нежелания верстаться в службу оставались в одном дворе с отцом или другим родственником сыном боярским. По источникам XVII в. известны так называемые пашенные люди, к которым относились не верстанные в службу родственники сына боярского, живущие в его дворе. При этом «пашенные люди» оставались свободными, не несущими тягла и не обязанными нести службу.

Известно дело 1682 г., из которого следует, что в 1678 г. писец Никита Бунин и подьячий Иван Оловяников «пашенных людей» записали в каче-

${ }^{91}$ Малов A.B. Смотренный список начальных людей московских выборных полков солдатского строя 1692 г. // Единорогъ... Вып. 2. С. 460 и др.

92 РГАДА. Ф. 210. ОП. 12. №. 876. Л. 206.

93 Там же. Л. 206 об.-207.

94 См.: Петров К.В. Свободное население Московского государства... 
стве крестьян за их родственником сыном боярским Гаврилом Карповым Зориным. Ошибка была обнаружена и устранена в административном порядке ${ }^{95}$. О.Ю. Куц издал фрагмент судебного дела 1656-1662 гг., в котором два брата - Фома и Калина Севастьяновы Старковы - оспаривали свое состояние в крестьянах у троюродного брата Ивана Максимова. Приказ Тайных дел, рассматривая жалобу на решение Разрядного приказа, приказал выяснить, работали ли Старковы вместе с крестьянами? ${ }^{96}$ Очевидно, что в случае, если жалобщики не работали «в ряд с крестьяны», они могли считаться «пашенными людьми». Здесь имеет место интересный критерий фактического разграничения принадлежности к сословию, который использовался в приказной практике.

Стоит также рассмотреть вопрос о том, можно ли было утратить права и обязанности дворян и детей боярских, т. е. перейти в другое сословие. Причем речь не идет о так называемом нетстве, т. е. неявке на конкретную службу, и о бегстве со службы во время военных действий и т. П. Применительно к родственникам детей боярских, их неверстанным детям, племянникам и др. данный вопрос, как представляется, решается однозначно - он не мог утратить права и обязанности сына боярского, поскольку он их не имел. Иначе говоря, находясь под властью отца - сына боярского, он был сыном сына боярского; уйдя от него, он становился вольным человеком и мог войти в состав любого сословия.

Курчанин Лука Алексеев Писклов, верстанный в 1605/06 г., во время разбора в 1642 г. в сведениях о родственниках указал: «А живет де за ним брат двоюродной во крестьянех» ${ }^{97}$. В 1660/61 г. курченин Иван Семенов Рагулин в своей челобитной писал о том, что его отец служил в детях боярских по Мосальску, а сам Рагулин «пожил по записи небольшое время добровольно у сына боярского Созона Проскурнина в деревне», а ныне новые помещики той деревни «приставливают... во крестьянстве», в то время как он «ни за кем во крестьянстве не жил» ${ }^{98}$. В ответ на челобитную послана грамота к курскому воеводе С.А. Хитрово о требованием «не принуждать» Рагулина в крестьянство 99 . В другом случае во время разбора обоянских детей боярских в 1700 г. С.А. Есков в своей «скаске» указал, что служил неверстанным с городом более 50 лет, ныне «стар и древен, и на ноги худ», сын

\footnotetext{
${ }^{95}$ РГАДА. Ф. 210. Оп. 12. № 1024. Л. 661-679; № 1051. Л. 155-159.

${ }^{96}$ Куи О.Ю. Дело о «крестьянстве» братьев Фомы и Калины Севастьяновых... С. 437-463.

${ }^{97}$ РГАДА. Ф. 210. Оп. 4. Д. 188. Л. 523 об.

${ }^{98}$ Там же. Оп. 12. №. 441. Л. 121, 123

${ }^{99}$ Там же. Л. 124.
} 
его «Лучка живет по коболе лет шесть и больше, меня покинул, кормить меня некому» ${ }^{100}$.

Более сложным является ответ на вопрос о том, может ли верстанный сын боярский перейти в другое сословие на «законных» основаниях. Прежде всего следует отметить, что сын боярский, отставленный от службы в результате очередного разбора служилого города по увечью или старости, остается сыном боярским, несмотря на то что он не несет службу, а вместо поместья получает прожиток ${ }^{101}$.

Известны случаи, когда верстанные дети боярские «били челом в холопи и служилые кабалы на себя давали» ${ }^{102}$. В 1635/36 г. рязанский сын боярский А.Ф. Якимов «не хотя государевы службы служить», «дал на себя служилую кабалу». В памяти по этому делу из Разрядного приказа в Поместный указано: «По государеву указу детей боярских, которые верстаны и служат с городы, в холопи принимать никому не велено, а о поместьях их никакова государева указа в Розряде нет» ${ }^{103}$. Это указание Разрядного приказа представляется важным, поскольку означает, что независимо от фактических действий сына боярского, он сохраняет права на поместье в случае, если нет специального указа в отношении его поместья. Таким образом, по общему правилу, если сын боярский покидает службу, он сохраняет поместную дачу.

Случаи ухода из служилого города можно встретить на протяжении конца XVI - начала XVIII в. В десятне 1592 г. по Ряжску о некоторых верстанных детях боярских указано следующее: Степан Иванов сын Евдокимов «сшел безвестно» ${ }^{104}$, Матюша Пахомов «сшел в вольные казаки», Данила Филипов сын Мелентьев «от службы отбыл, волочитца меж двор», Иван Тарасов сын Соловкин «обнищал, волочитца меж двор» ${ }^{105}$.

По разбору курского служилого города, который проводили 31 августа 1642 г. стольник и воевода Григорий Григорьевич Образцов и подьячий Василий Тархов, выяснилось, что «сошли на Хотмыш» восемь детей боярских: В.Л. Лохтионов (оклад 300 чети), О.И. Стоянов (250 чети), Д.А. Звегинцов, Т.С. Тутов (250 чети), Н.П. Ерголской (250 чети), П.К. Климов (250 чети), Ф.Я. Непочетой (250 чети), Н.С. Жиронкин (100 чети) ${ }^{106}$; «сошли»

${ }^{100}$ Там же. №. 1743. Л. 455.

${ }^{101}$ См.: Петров К.В. Некоторые виды земельной собственности и русское право до начала XVIII в. Прожиток // Российское государство в XIV-XVII вв. ... С. 115-153.

${ }^{102}$ РГАДА. Ф. 210. Оп. 9. Д. 147. Л. 148-155.

${ }^{103}$ Акты Московского государства / Под ред. Н.А. Попова. СПб., 1894. Т. 2. № 41. С. 22-23.

${ }^{104}$ Описание документов и бумаг Московского архива Министерства юстиции. 1891.

Кн. 8. Отд. 3. С. 315.

105 Там же. С. 316, 317.

${ }^{106}$ РГАДА. Ф. 210. Оп. 4. Д. 188. Л. 614 об., 615 об., 620. 
на Корочу двое детей боярских: Ф.С. Агафонов (100 чети) и И.Г. Игнатов $(100 \text { чети })^{107}$; «сошли в Рыльск на житье»: Д.С. Затолокин (150 чети) и безпоместный и неверстанный Б.С. Озаров ${ }^{108}$; «сшел» на Орел А.К. Заволишин (250 чети $)^{109}$; «сшел» на Волной Г.К. Стоянов (150 чети $)^{110}$; «сшел» на Чугуев С.И. Головин (150 чети $)^{111}$; «сшел» на Яблонов безпоместный и неверстанный Т.С. Гапонов ${ }^{112}$; «сшел» безвестно Л.И. Фомин $(250 \text { чети })^{113}$; ушел самовольно в Чугуев Г.А. Мезинцов, «окладчики сказали на Чюгуеве в съезжей избе в дьячках» ${ }^{144}$; сын боярский Мосей Никитин сын Полянской (250 четей) верстался в московские стрельцы ${ }^{115}$. О.Ю. Куц привел примеры «сходцев» верстанных детей боярских и их сыновей к донским казакам ${ }^{116}$.

В приведенных примерах дети боярские оставили свой «служилый город». Последствия подобных действий неизвестны. Но, во всяком случае, можно предположить, что Мосей Полянский, «верстаясь» в московские стрельцы, скрыл свою принадлежность к верстанным детям боярским. Непонятно, что стало с поместными дачами ушедших людей.

Во время «большого разбора служилых городов» 1697 г. староосколец Петр Калинин сын Гранкин подал «скаску», из которой следовало, что его отец «сошел» в Оскол из Одоева, бросив свое поместье (10 четей) в селе Петровском Плошенского стана, «ныне в пусте» ${ }^{117}$. В ходе разбора служилого города Курска в феврале-мае 1697 г., по «скаске» Ананья Аверкиева сына Кизилова, он «сшел» из Корчаковского стана Орловского уезда, на момент подачи «скаски» жил у сына в поместье, в службе не состоял ${ }^{118}$. Во время разбора служилого города в Курске в весной 1697 г., по «скаске» Кирея Иванова сына Дуракова, он «сшол» из Кромского уезда Речицкого стана, где его отец, служивший в рейтарах, имел поместье 20 четей, «ныне в пусте» ${ }^{119}$. Во всех приведенных случаях непонятно, являлись ли податели сказок верстанными детьми боярскими - действительно, кто станет признаваться в том, что он оставил службу в служилом городе. Но в одном

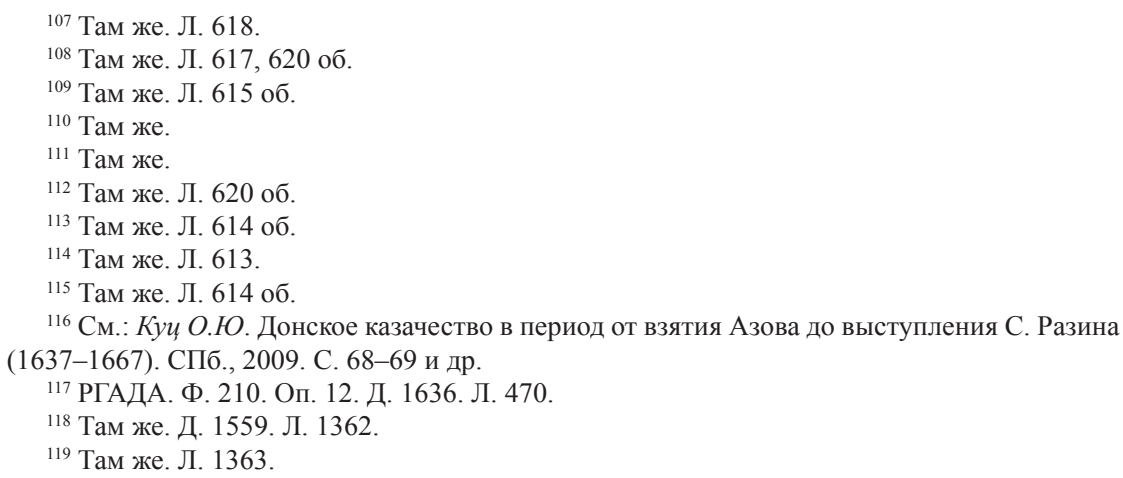


случае податель «скаски» Иван Артемов сын Мезенцев признался, что оставил рейтарскую службу, в которой прослужил около 15 лет, и, оставив поместье в 10 четей в Погорельском стане Белевского уезда, «сшол» в Курск, где не служит, живет на поместной даче сына в селе Лещинская плота ${ }^{120}$.

Во всех указанных случаях можно предположить, что, если сын боярский «покинул» свой служилый город, он сможет вернуться в свое поместье и продолжить несение службы в составе своего служилого города при условии, что его поместная дача «не пущена в роздачу». Действительно, в своих «скасках» старооскольцы дети боярские Михаил Романов сын Гранкин, имеющий в даче 10 четей поместной земли, и Аврам Алифанов сын Еремин указали, что долгое время «в скудости» жили, «переходя по людем для работы из найму» ${ }^{121}$. Курченин сын боярский городовой службы Парфен Мелентьев Поликарпов, 40 лет от роду, нанялся в работники к священнику Богоявленской церкви Владимиру ${ }^{122}$. Однако, как отмечалось выше, специального «закона» в отношении поместий ушедших и переставших служить с городом детей боярских не существовало (во всяком случае, на 1636 г.).

Подводя некоторые итоги, необходимо отметить, что при изучении социальной (сословной) структуры общества следует различать человека и его социальную роль (статус), который определялся правами и обязанностями; они в свою очередь формировали образ жизни, модели поведения и другие возможности человека даже в ситуации его низких доходов.

На протяжении второй половины XVI-XVII вв. существовали разные способы приобретения сословных прав дворян и детей боярских (cм. cxeмy). Сословные права и обязанности не приобретались по факту рождения и не наследовались, поскольку со смертью отца сын не становился членом Государева двора или служилого города. Основным способом приобретения сословных прав и вхождения в состав сословия была процедура «верстания», т. е. определения поместного и денежного оклада. Приоритет в этом процессе имели сыновья детей боярских - он проявлялся в установлении высоких новичных денежных и поместных окладов. В некоторых случаях к верстанию допускались только сыновья детей боярских. При этом на них не возлагалась обязанность участвовать в «верстании». Это вполне логично, поскольку до «верстания» в дети боярские сыновья детей боярских были свободны от несения службы и, в силу этого, могли войти в состав других сословий (служилых казаков, стрельцов и др.). Вхождение в состав сословия дворян и детей боярских в результате пожалований царя

\footnotetext{
120 Там же. Л. 597

${ }^{121}$ Там же. Ф. 350. Оп. 1. Д. 385. Л. 113 об., 168 об.

${ }^{122}$ Там же. Д. 215. Л. 1418.
} 


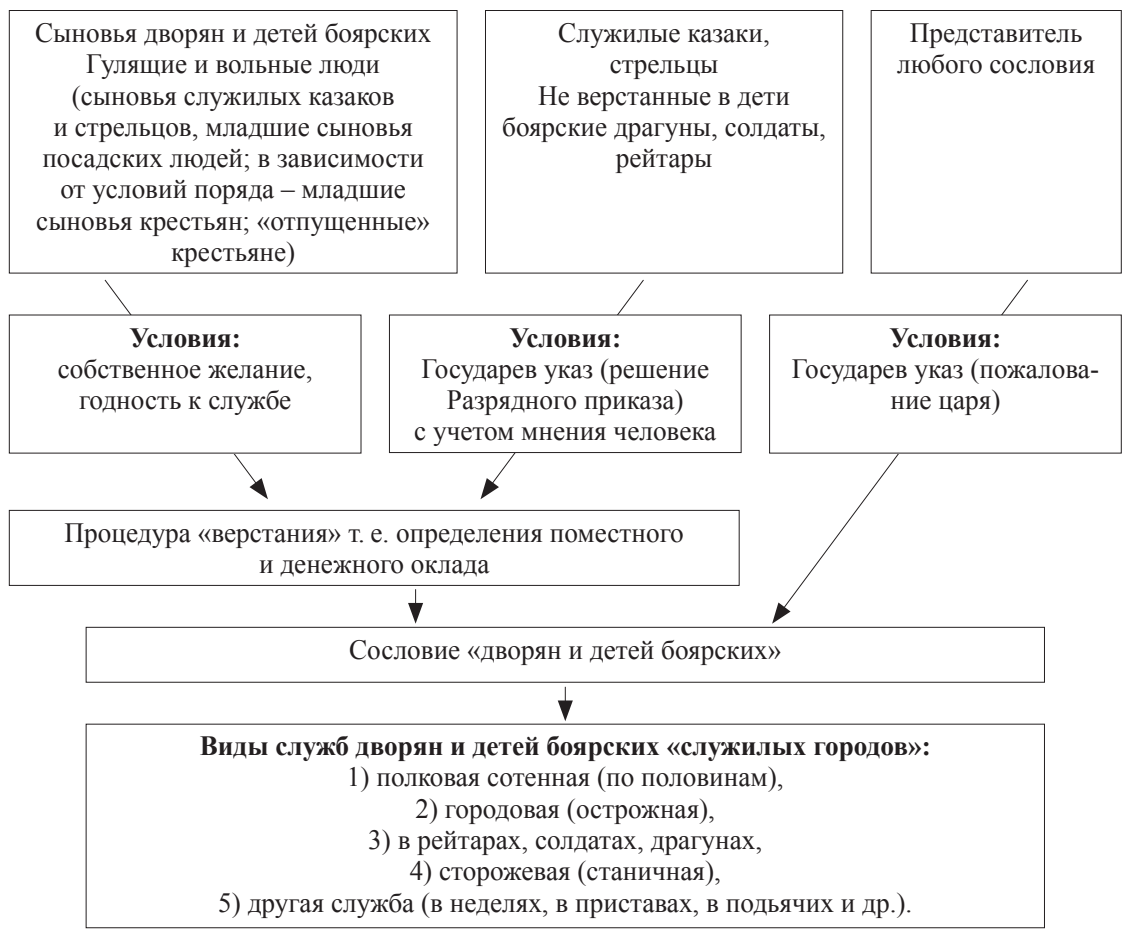

носило персональный характер, учитывало заслуги данного человека и не учитывало его желание. По всей видимости, для второй половины XVI в. было характерно административное решение Разрядного приказа о переводе в дворяне и дети боярские служилых казаков, стрельцов и поместных атаманов не зависимо от их желания. Однако и в этом случае перевод предполагал прохождение процедуры «верстания» для установления поместных и денежных окладов «переведенцам».

Утрата сословных прав и обязанностей, по-видимому, была связана, во-первых, со смертью дворянина или сына боярского; во-вторых, - с фактическим уходом человека от любого совместного «со-бытия» в составе служилого города, с последующей раздачей его фактической поместной дачи как «покинутой». В случае, если поместье не было «отказано» другому сыну боярскому, у человека оставалась возможность вернуться и вновь принять участие в жизни служилого города. Отставка сына боярского от несения службы не вела к утрате сословных прав и обязанностей; сын боярский получал прожиток, права в отношении которого были даже шире, 
нежели в отношении обычного поместья: в отличие от прожитка, поместье нельзя было «сдать». Кроме того, в ситуации военной опасности отставные дети боярские привлекались к городовой осадной службе. Случаи добровольного ухода из состава Государева двора неизвестны; поместное и денежное благосостояние членов Государева двора было таковым, что желания покинуть его не возникало.

Следует согласиться с мнением Т.А. Лаптевой о том, что изучение сословия дворян и детей боярских в значительной мере детерминировано историографической традицией. Причем определенный вектор в развитии представлений о дворянстве (дворянах и детях боярских) был задан еще в XIX в. В значительной степени историография XIX в. довлеет над современной исторической наукой ${ }^{123}$ : в меньшей степени - отечественной, в большей степени - зарубежной (в частности, работы В.О. Ключевского). В советское время историографическая традиция в изучении дворянства не прервалась, но на нее наложились концепции, выработанные в рамках марксистской парадигмы исторического развития общества. Одной из них является теория «распада служилого города», концептуально оформленная в работах А.А. Новосельского. В настоящее время, как представляется, она не может быть принята.

Констатируя, что теория «распада служилого города» не находит своего подтверждения в источниках, Т.А. Лаптева писала о том, что правительство должно «удерживать стабильность общества, препятствуя размыванию сословий и закрепляя их на той службе, в которой они находятся, или на том тягле которое они несут» ${ }^{124}$. Однако у нас нет убежденности в том, что исследовательница знала реальные планы правительства XVII в. Стремясь освободиться от «установившихся в исторической литературе клише и штампов» ${ }^{125}$, Лаптева, к сожалению, не смогла уйти от оценки событий с позиций определенной заданной теории. Как отметил по этому поводу В. Вжозек, за «так называемую прошлую реальность принимается реальность, легализованная в воображении историков. Это особенное мысленное представление предполагаемой реальности. Она является результатом нагромождаемых особо ценимых научным сообществом воображений», теорий и концепций ${ }^{126}$.

${ }^{123} \mathrm{O}$ необходимости корректировки взглядов на проблемы допетровской истории России см. также: Курбатов О.А. О новой книге Ю.Г. Алексеева // Единорогъ... Вып. 2. С. 528.

${ }^{124}$ Лаптева Т.A. Провинциальное дворянство России в XVII веке. С. 483.

${ }^{125}$ Лаптева Т.А. Эволюция служилого «города». С. 685.

${ }^{126}$ Вжсозек $B$. Исторический источник как реалистическое алиби историка // Мир историка: Историографический сборник. Омск, 2010. Вып. 6. С. 286. 
Использование теории «социальной мобильности», разработанной в социологии, дает основание осмыслить полученные результаты настоящей работы в следующем виде. Во второй половине XVI-XVII вв. социальная (сословная) структура российского общества не была замкнутой; существовали разные действующие и легальные способы перехода из одного сословия в другое, в частности в привилегированное сословие дворян и детей боярских. Наличие социальной (сословной) мобильности является фактором стабильности общественных отношений и общества в целом ${ }^{127}$. Более того, как отмечено в историографии, существовала возможность (так называемый «социальный лифт» ${ }^{128}$ ) продвижения к наиболее экономически состоятельной части сословия (Государев двор), зависевшая от собственных усилий (результатов службы) человека, его родственных связей и неформальных отношений.

\section{Литература}

Akelev E., Joukovskaia A. Из казаков в дворяне. Шагаровы, микроистория социальной мобильности в России, XVII - XVIII вв. // Cahiers du Monde russe. 2016. Vol. 57. № 2-3. P. 457-504.

Алексеев Ю.Г. К вопросу о сословиях в России XV-XVI вв. Некоторые черты сословной политики Ивана III // Государство и общество в России XV - начала XX в. Сборник статей памяти Н.Е. Носова. СПб., 2008. С. 65-81.

Андреев И.Л. Дворянство и служба в XVII в. // Отечественная история. 1998. № 2. C. $164-175$.

Андреев И.Л. О проблеме сословной организации и сословном самосознании служилого "города" в XVII столетии // Сословия и государственная власть в России. XV - середина XIX вв. Международная конференция - Чтения памяти Л.В. Черепнина. Тезисы докладов. М., 1994. Ч. 1. С. 13-20.

Аракчеев B.A. Демография провинциальной дворянской семьи в России середины XVII в.: удельный вес боевых потерь и роль прожитка в функционировании поместной системы // Русь, Россия: Средневековье и Новое время. Вып. 6. VI чтения памяти академика Л.В. Милова. Материалы к международной научной конференции. М., 2019. С. 249-255.

Бахрах Д.Н. Правовые льготы // Справедливость и право. Свердловск, 1989. С. 74-82. Беленький В.Х. Социальная структура общества: социально-философские и социологические проблемы // Философия и общество. 2007. № 3. С. 49-63.

${ }^{127}$ См.: Сорокин П.А. Преступление и кара, подвиг и награда. Социологический этюд об основных формах общественного поведения и морали. СПб., 1914. С. 314-316; Беленький B.X. Социальная структура общества: социально-философские и социологические проблемы // Философия и общество. 2007. № 3. С. 49-63.

${ }^{128}$ См.: Романова К.С. Социальные лифты как средство социальной мобильности // Дискурс-Пи. 2015. № 2(19). С. 30-34. 
Берман Г.Д. Западная традиция права. Эпоха формирования. М., 1998.

Буганов В.И. «Выборный человек всею землею» Кузьма Минин. // Вопросы истории. 1980. № 9. С. 90-102.

Булгаков М.Б. Воеводские рассыльщики в XVII веке // Русь, Россия: Средневековье и Новое время. Вып. 5. Пятые чтения памяти академика Л.В. Милова. Материалы к международной научной конференции. М., 2017. С. 232-250.

Важинский B.M. Землевладение и складывание общины однодворцев в XVII в. (По материалам южных уездов России). Воронеж, 1974.

Bайпан B.A. Теория справедливости: Право и экономика. М., 2017.

Вебер $M$. Основные понятия стратификации//Социологические исследования. 1994. № 5. С. 147-156.

Вебер М. Сословия и классы // Ab Imperio. 2002. № 3. С. 17-24.

Вжозек В. Исторический источник как реалистическое алиби историка // Мир историка. Историографический сборник. Омск, 2010. Вып. 6. С. 272-294.

Водарский Я.Е. О межсословных переходах в первой половине XVIII в. // Сословия и государственная власть в России. XV — середина XIX вв. Международная конференция — Чтения памяти Л.В. Черепнина. Тезисы докладов. М., 1994. Ч. 1. C. $70-74$.

Водарский Я.Е. Численность, состав и размещение дворянства в первой половине XVII в. // Дворянство России и его крепостные крестьяне. XVII - первая половина XVIII в. М., 1989. С. 120-130.

Волков С.В. Элитные группы традиционных обществ М., 2017.

Гладкий А.В. Введение в современную логику. М., 2001.

Глазьев В.Н. Особенности социальной структуры населения и административного устройства Южной окраины России XVI-XVII вв. // Вестник Воронежского государственного университета. Серия: История. Политология. Социология. 2013. № 1. С. 24-32.

Громова Е.И. Эвристический потенциал концепции социальной мобильности Питирима Сорокина // Вопросы политологии. 2020. Т. 10. № 6(58). С. 1689-1699.

Епихина Ю.Б. Переопределение концептуальных оснований в исследованиях социальной мобильности // Многомерная социальная мобильность в современной России. М., 2018. С. 29-34.

Зенченко М.Ю. Южное российское порубежье в конце XVI — начале XVII в. Опыт государственного строительства. М., 2008.

Зимин А.А. Формирование боярской аристократии в России во второй половине XV - первой трети XVI в. М., 1988.

Канарш Г.Ю. Социальная справедливость. Философские концепции и российская ситуация. М., 2011.

Козловская E.Н. Социальная мобильность в Древней Руси (по материалам законодательных актов X-XIII вв.) // Вестник Удмуртского университета. Серия История и филология. 2019. Т. 29. № 1. С. 135-140.

Козляков В.Н. Служилые люди России XVI-XVII вв. М., 2018. 
Коллманн Н.Ш. Соединенные честью. Государство и общество в России раннего Нового времени. М., 2001.

Комаров О.В. Военный потенциал Поморских городов и дворцовых земель Верхнего Поволжья в XVI в. (социально-экономические аспекты) // Русь, Россия: Средневековье и Новое время. Вып. 6. VI чтения памяти академика Л.В. Милова. Материалы к международной научной конференции. М., 2019. С. 548-551.

Кузнеиов A.A., Морохин A.B. Кузьма Минин. Человек и герой в истории и мифологии. М., 2017.

Курбатов О.А. О новой книге Ю.Г. Алексеева // Единорогъ. Материалы по военной истории Восточной Европы эпохи Средних веков и раннего Нового времени. М., 2011. Вып. 2. С. 521-528.

Курбатов О.А. Смотренные десятни полка Елисея Цыклера 1655 г. // Единорогъ. Материалы по военной истории Восточной Европы эпохи Средних веков и раннего Нового времени. М., 2011. Вып. 2. С. 303-341.

Куц О.Ю. Дело о “крестьянстве” братьев Фомы и Калины Севастьяновых как источник по изучению нравов русского общества середины XVII в. // Российское государство в XIV-XVII вв. Сборник статей, посвященный 75-летию Ю.Г. Алексеева. СПб., 2002. С. 459-460.

Куц О.Ю. Донское казачество в период от взятия Азова до выступления С. Разина (1637-1667). СПб., 2009.

Лаптева T.A. Десятни XVII в. как исторический источник: особенности составления и научного использования // Вестник архивиста. 2012. № 4(120). С. 19-29.

Лаптева T.A. Десятни как источник по истории приказного делопроизводства XVII в. // Проблемы дипломатики, кодикологии и актовой археографии. К 80-летию Сергея Михайловича Каштанова. Материалы XXIV международной научной конференции. М., 2012. С. 378-379.

Лаптева T.A. Новые дворянские роды в России в XVII в. // Памяти Лукичева. Сборник статей по истории и источниковедению. М., 2006.

Лаптева T.A. Поверстание в дети боярские представителей других сословий. К вопросу о расширении социальной базы дворянского сословия в XVII веке // Отечественная история. 2003. № 5. С. 81-96.

Лаптева Т.А. Повседневная жизнь провинциального дворянства в XVII в. // Российская история. 2010. № 4. С. 107-117.

Лаптева Т.А. Провинциальное дворянство России в XVII веке. М., 2010.

Лаптева T.А. Эволюция служилого «города»// Сословия, институты и государственная власть в России (Средние века и раннее Новое время). Сборник статей памяти Л.В. Черепнина. М., 2010. С. 684-693.

Лебедева Д.А. Социальная стратификация // Format. Социология. 2019. № 3(3). С. 17-21 Лисейцев Д.В. Почему Земский собор - не парламент? // Российская история. 2020. № 4. С. 142-150.

Ляпин Д.А. Расслоение провинциального дворянства в России и социально-политическая борьба во второй половине XVII в. // Российская история. 2015. № 5. С. 42-53. 
Малов А.В. Смотренный список начальных людей московских выборных полков солдатского строя 1692 г. // Единорогъ. Материалы по военной истории Восточной Европы эпохи Средних веков и раннего Нового времени. М., 2011. Вып. 2. С. 432-492. Миронов Б.Н. Социальная история России периода империи (XVIII - нач. XX в.). Генезис личности, демократической семьи, гражданского общества и правового государства. СПб., 1999. Т. 1.

Морозова И.С. Льготы в российском праве: Автореф. дис. ... канд. юрид. наук. Саратов, 2000.

Никишин E.A. История и перспектива исследований социальной мобильности после мобильного поворота// Журнал социологии и социальной антропологии. 2019. Т. 22. № 2. С. 93-117.

Новосельский A.A. Распад землевладения служилого “города” в XVII в. (по десятням) // Русское государство в XVII в. М., 1961. С. 231-253.

Новосельский А.А. Феодальное землевладение. Боярство, дворянство и церковь // Очерки истории СССР. XVII в. М., 1955. С. 139-164.

Носкова А.В., Кузьмина Е.И. Социальная мобильность в трудах ведущих социологов Франции ХХ в. // Социологические исследования. 2019. № 4. С. 99-108.

Павлов А.П. Государев двор и политическая борьба при Борисе Годунове (15841605 гг.). СПб., 1992.

Павлов А.П. Думные и комнатные люди царя Михаила Романова: просопографическое исследование. В 2 т. СПб., 2019.

Павлов А.П. Патронатно-клиентельные отношения при московском дворе в годы царствования Михаила Федоровича // Петербургский исторический журнал. Исследования по российской и всеобщей истории. 2018. № 4(24). С. 83-97.

Петров К.В. Некоторые виды земельной собственности и русское право до начала XVIII в. Прожиток// Российское государство в XIV-XVII вв. Сборник статей, посвященный 75-летию Ю.Г. Алексеева. СПб., 2002. С. 115-153.

Петров К.В. Переформатирование сословия «дворян и детей боярских» в петровскую эпоху (к постановке проблемы)//Сборник статей по русской истории в честь А.И. Гамаюнова к его 60-летию от друзей и коллег. М., 2019. С. 25-45.

Петров К.В. Подлинное и мнимое: проблемы реконструкции прошлого в исторических исследованиях // Русское средневековье. Сборник статей в честь Ю.Г. Алексеева. М., 2012. С. 81-102.

Петров К.В. Принцип правового равенства/неравенства в исторической перспективе // Принципы права. Материалы XI международной научно-практической конференции. М., 2017. Ч. 1. С. 286-294.

Петров К.В. Свободное население Московского государства во второй половине XVI - XVII вв.: «вольные и гулящие люди»// Петербургский исторический журнал. 2021. № 1. С. 230-248.

Петрухинцев Н.Н. «Разрядная» военная реформа Алексея Михайловича и ее влияние в 1658-1660 гг. на южные служилые «города» России (по материалам городов Липецкого края) // История: факты и символы. 2018. № 3(16). 
Петрухинцев Н.Н. Структура, динамика и иерархия служилых «городов» в XVII веке // Cahiers du Monde russe. 2015. Vol. 56. No. 1. P. 137-174.

Романова К.С. Социальные лифты как средство социальной мобильности // Дискурс-Пи. Екатеринбург, 2015. № 2(19). С. 30-34.

Саенко A.C. Концепция социальной справедливости и ее понимание в современности // Социальная справедливость: утопии и реалии. Материалы Всероссийской научной конференции, посвященной 150 -летию со дня рождения В. И. Ленина. М., 2020. C. 373-376.

Сахаров А.Н. Рец. на: Hellie Richard. Enserfment and Military Change in Muscovy. L.: Chicago: University of Chicago Press, 1971 // История СССР. 1973. № 2. С. 194-196.

Седов П.В. «Он мне свой...». Свойство при московском дворе XVII в. // Нестор. Ежеквартальный журнал истории и культуры России и Восточной Европы. 2005. № 7. C. 190-199.

Седов П.В. Закат Московского царства. Царский двор конца XVII в. СПб., 2006.

Смирнов С.Н. К вопросу о развитии системы образования России в первой половине XVIII века в качестве канала изменения индивидуального правового статуса // Закон и право. 2020. № 12. С. 68-71.

Смирнов С.Н. К вопросу о формировании образования в качестве канала вертикальной социальной мобильности в Российской империи в 1801-1860 годах: нормативная основа и практика функционирования // Вестник Тверского государственного университета. Сер. Право. 2019. № 3(59). С. 95-103.

Смирнов С.Н. Некоторые правовые аспекты социальной мобильности помещичьих крестьян в Российской империи в конце XVIII - начале XIX вв.: политика законодателя и факты повседневной истории // Право и государство: теория и практика. 2019. № 8(176). С. 70-72.

Сорокин П.А. Преступление и кара, подвиг и награда. Социологический этюд об основных формах общественного поведения и морали. СПб., 1914.

Сорокин П.А. Социальная мобильность / Пер. с англ. М., 2005.

Станиславский А.Л. Гражданская война в России XVII в.: Казачество на переломе истории. М., 1990.

Станиславский А.Л. Труды по истории государева двора в России XVI-XVII вв. М., 2004.

Тюменцев И.О. Россия и появление казачества на Волге и на Дону в XV - первой половине XVI в. // Cahiers du Monde russe. 2005. Vol. 46. N 1-2. P. 75-82.

Урри Дж. Мобильности / Пер. с англ. А.В. Лазарева. М., 2012.

Урри Дж. Социология за пределами обществ: виды мобильности для XXI столетия. М., 2012.

Хачатурян Н.А. Общественная система и принцип относительности. К вопросу о содержании концепт-явления «феодализм»// Средние века. М., 2017. Вып. 68(1). C. 6-35.

Цатурова С.К. О пользе презентизма, или Как изучать истоки национального государства в ожидании его отмирания // Диалог со временем. 2018. Вып. 65. С. 59-72. 
Черныл М.Ф. Проблематизация социального: исследования социальной структуры и российская социология // Россия реформирующаяся. 2019. № 17. С. 48-60.

Черныли М.Ф. Социальная мобильность и неравенство // Многомерная социальная мобильность в современной России. М., 2018. С. 9-28.

Шеллер М. Новая парадигма мобильностей в современной социологии // Социологические исследования. 2016. № 7. С. 3-11.

Crummey R.O. Aristocrats and Servitors. The Boyar Elite in Russia, 1613-1689. Princeton, 1983.

Hellie R. The Expanding Role of the State in Russia // Modernizing Muscovy: Reform and Social Change in Seventeenth-Century. L.; N. Y.; Routledge Curzon, 2004. P. 29-56.

Hellie R. Warfare, Changing Military Technology, and the Evolution of Muscovite Society// Tools of War. Instruments, Ideas, and Institutions of War, 1445-1871. Urbana, 1990. P. 74-99.

Kivelson V.A. The Effects of Partible Inheritance: Gentry Families and the State in Muscovy // Russian Review. 1994. Vol. 53. No. 2. P. 197-212

Kollmann N.S. Kinship and Politics. The Making of the Muscovite Political System, 1345-1547. Stanford, 1987.

Martin J.B. Mobility, Forced Resettlement and Regional Identity in Muscovy // Culture and Identity in Muscovy, 1359-1584. M., 1997. P. 431-449. 


\title{
И.В. Пугач
}

\section{ВОЛОГОДСКИЙ ГАРНИЗОН в XVII в. ${ }^{1}$}

\begin{abstract}
Аннотация В статье рассмотрены основные параметры вологодского гарнизона на протяжении 20-80-х годов XVII в. На основе архивного материала, дана его структура, численный состав отдельных категорий служилых людей по прибору - стрельцов, пушкарей, воротников и казаков, их вооружение и материальное обеспечение - денежное и хлебное жалованье, размер и порядок его выплаты и др. В Приложении представлен персональный командный и рядовой состав вологодского гарнизона второй половины XVII в.

Ключевые слова: русский феодальный город, сметные списки, воеводские росписи, государственный бюджет, военный гарнизон, служилые по прибору.
\end{abstract}

Summary The article examines the main parameters of the Vologda garrison during the $20-80$ s of the 17 th century. On the basis of archival material, its structure is given, the numerical composition of individual categories of service people according to the device - archers, gunners, collars and cossacks, their weapons and material support - monetary and bread salary, the amount and procedure for its payment, etc. and the rank and file of the Vologda garrison 2 halves. XVII century.

Keywords: Russian feudal city, estimated lists, voivodeship murals, state budget, military garrison, service personnel.

Одним из важнейших предназначений феодального города в системе государственной власти Московской Руси была его военно-административная функция с соответствующими атрибутами - крепостью и постоянным военным гарнизоном. Более того, именно наличие крепости и придавало официальный статус самому поселению как городу. Становление Российского государства привело к формированию особого военного сословия -

1 Работа выполнена при финансовой поддержке РФФИ — грант № 18-09-00350-а «Сметные списки городов Русского Севера XVII в.: исследования и тексты». 
служилых людей. Различное по своим политическим, социально-экономическим и нормативно-правовым характеристикам, оно распадалось на два разряда - служилые по отечеству (дворянское ополчение) и служилые по прибору (стрельцы, казаки, пушкари, затинщики и воротники).

Именно служилые люди по прибору составляли постоянный военный гарнизон крепости уездного города. Они добровольно поступали на государеву службу, несли ее лично и получали за это государево денежное и хлебное жалованье.

В Вологде служилые люди по прибору — стрельцы, пушкари и воротники - появились, видимо, в третьей четверти XVI в., во времена возведения крепости при Иване Грозном. Грандиозное крепостное строительство, развернувшееся в Вологде в 1566-1671 гг., сопровождалось и формированием соответствующего военного гарнизона. Для обеспечения крепости артиллерией в Москве были отлиты и привезены в Вологду около 300 пушек и сформирован отряд опричных стрельцов численностью до 500 человек².

Военный потенциал Вологды после отмены опричнины и утраты царем интереса к городу был, видимо, незначителен, а перспективы его сохранения и развития весьма сомнительны. Трагическим свидетельством служат события так называемого «Вологодского разорения» сентября 1612 г., когда относительно небольшой отряд тушинцев смог взять и разграбить город и его окрестности практически без всякого сопротивления ${ }^{3}$.

Реакцию местной власти на столь очевидные просчеты в организации обороноспособности города и мероприятия по укреплению вологодского гарнизона косвенным образом отражает дозорная книга Вологды 16161617 гг. В ней зафиксированы бывшие владельцы посадских дворов, которые после вологодского разорения «стали на Вологде в стрельцы и государевых податей не платят». По моим подсчетам, только в 1612/13 г. не менее девяти посадских тяглецов поменяли свой социальный статус и перешли в разряд служилых людей по прибору ${ }^{4}$ В целом, для второй половины XVI - первой четверти XVII в. исторические свидетельства об истории Вологды и особенно ее служилого сословия довольно скудны и отрывочны.

${ }^{2}$ Кукушикин И.П. Вологодская крепость. Вологда, 2018. С. 50-63; Вологда в минувшем тысячелетии. Очерки истории города. Вологда, 2004. С. 52.

3 Вологда в минувшем тысячелетии... С. 59; Старая Вологда. XII-XX в. Сборник материалов и документов. Вологда, 2004. С. 195-197.

4 Дозорная книга была опубликована дважды: Дозорная книга посада Вологды князя П.Б. Волконского и подьячего Л. Софонова. 1616-1617 г. / Публ. Ю.С. Васильева // Вологда: Историко-краеведческий альманах. Вологда, 1994. Вып. 1. С. 333-370; Писцовые и переписные книги Вологды XVII - начала XVIII века. В 3т. Т. 3. Писцовые, переписные и дозорные книги Вологды XVII века / Сост. И.В. Пугач. Вологда, 2018. С. 242-274. 
Кардинальным образом ситуация изменилась с 20-х гг. XVII в. Сохранившиеся описания Вологды 1626-1628, 1646, 1678 и 1685 гг. ${ }^{5}$, воеводские сметные росписи 1657, 1665-1668, 1674 и 1681 гг. ${ }^{6}$ и сметные списки Вологды за 20-80-е гг. XVII в. ${ }^{7}$ дают возможность достаточно подробно рассмотреть историю вологодского гарнизона.

Каждый из этих источников обладает своей информационной спецификой. Так, материалы государственных кадастров дают нам персональный состав вологодских служилых людей по прибору, но далеко не полный, а только владельцев или совладельцев дворов, либо дворников в дворах других собственников. Напротив, воеводские сметные росписи, которые имели военно-мобилизационный характер, позволяют выявить полный персональный состав всех категорий служилых людей, в том числе и по прибору, и их вооружение. У вологодских сметных списков своя особенность, по ним в полной мере можно определить как реальный численный состав находившихся на службе в вологодском гарнизоне за отдельные годы, так и их материальное обеспечение, виды и размер государева жалованья.

Таким образом комплексный анализ данных источников позволяет в полной мере рассмотреть структуру служилого гарнизона Вологды и его эволюцию, численный и персональный состав, вооружение и материальное обеспечение и т. д. на протяжении всего столетия.

Важнейшими параметрами вологодского гарнизона были его структура и численный состав. Первые подробные свидетельства об этом содержатся в сметном списке $1627 / 28$ г. ${ }^{8}$, а последние - в воеводской сметной росписи за 1681 г. ${ }^{9}$ Общие параметры вологодского гарнизона, его структура, численный состав и динамики за XVII в. приведены в табл. 1.

5 В настоящее время все известные писцовые, переписные и дозорные книги Вологды за XVII в. опубликованы: Писцовые и переписные книги Вологды... Т. 1. Писцовые и переписные книги Вологды XVII века / Подгот. к изд. И.В. Пугач, М.С. Черкасова. М., 2008 (описания 1646, 1678 и 1685 гг.); Т. 3 (описания 1616-1617 и 1626-1628 гг.).

6 За вторую половину XVII в. сохранились семь отчетов воевод Вологды о военно-мобилизационном состоянии города. Все они находятся в фонде Разрядного приказа РГАДА. Самая ранняя - сметная роспись 1657/58 г. - опубликована: Писцовые, переписные и дозорные книги Вологды... Т. 3. С. 179-233; РГАДА. Ф. 210. Оп. 7а. Кн. 1. Л. 1-915 об.

7 За XVII в. сохранилось не менее 17 сметных списков по Вологде. Для данного исследования наибольшую ценность имеют 11 городовых сметных списков, которые в расходной части бюджета дают полную информацию о расходах государевой казны на содержание служилых людей: РГАДА. Ф. 137. Оп. 1. Новгород 16. Ч. 1. Л. 375-454 об.; Новгород 18. Ч. 1. Л. 401-490; Новгород 31. Л. 309-386 об.; Вологда 2. Л. 1-912 об.

8 РГАДА. Ф. 137. Оп. 1. Новгород 16. Ч. 1. Л. 428-431.

9 Там же. Ф. 210. Оп. 7а. Кн. 1. Л. 723-915 об. 
Таблица 1.

Структура и численный состав вологодского гарнизона в XVII в.

\begin{tabular}{|c|c|c|c|c|c|}
\hline \multirow[t]{2}{*}{ Год } & \multicolumn{4}{|c|}{ Состав } & \multirow[t]{2}{*}{ Всего } \\
\hline & стрельцы & пушкари & воротники & черкасы & \\
\hline $1627 / 28$ & 266 & 20 & 8 & 31 & 325 \\
\hline $1628 / 29$ & 266 & 20 & 8 & 31 & 325 \\
\hline $1644 / 45$ & 150 & 20 & 5 & 9 & 184 \\
\hline $1652 / 53$ & 150 & 18 & 4 & 8 & 180 \\
\hline $1653 / 54$ & 150 & \multicolumn{2}{|c|}{18} & 8 & 176 \\
\hline $1654 / 55$ & 150 & \multicolumn{2}{|c|}{11} & - & 161 \\
\hline $1655 / 56$ & 133 & \multicolumn{2}{|c|}{12} & - & 145 \\
\hline $1656 / 57$ & 73 & \multicolumn{2}{|c|}{13} & - & 86 \\
\hline $1657 / 58$ & 65 & 2 & - & - & 67 \\
\hline $1658 / 59$ & 50 & - & - & - & 50 \\
\hline $1659 / 60$ & 40 & - & - & - & 40 \\
\hline $1665 / 66$ & 37 & - & - & - & 37 \\
\hline $1666 / 67$ & 55 & - & - & - & 55 \\
\hline $1667 / 68$ & 56 & - & - & - & 56 \\
\hline $1668 / 69$ & 56 & - & - & - & 56 \\
\hline $1674 / 75$ & 100 & - & - & - & 100 \\
\hline $1681 / 82$ & 118 & - & - & - & 118 \\
\hline
\end{tabular}

Составлено по: РГАДА. Ф. 137. Оп. 1. Вологда 2; Новгород 16. Ч. 1;

Новгород 18. Ч. 1; Новгород 31; Ф. 210. Оп. 7а. Кн. 1.

Изначально, во второй четверти XVII в., структура военного гарнизона Вологды была традиционной и привычной для любого северно-русского города. Она состояла из вооруженной пехоты (стрельцов, артиллеристов), пушкарей и городовой стражи - воротников. Анализ статистических данных позволяет говорить о том, что наибольшая общая численность вологодского военного гарнизона - 325 человек - приходится на конец 20-х гг. XVII в. ${ }^{10}$ Еще одной отличительной особенностью этого периода являлось наличие в его составе отряда «колуских черкасов».

За весь XVII в. в жизни вологодского гарнизона наиболее кризисными стали вторая половина 1650-1660-е гг. Во-первых, видимо, упал престиж стрелецкой службы и довольно неустойчивым стал личный состав. Это привело к новым наборам стрельцов: в 1655/56 г. — 58 человек, в 1656/57 г. —

${ }^{10}$ Там же. Ф. 137. Оп. 1. Новгород 16. Ч. 1. Л. 428-431; Новгород 18. Ч. 1. Л. 459-463. 
15 человек, в 1657/58 г. - 11 человек, а в 1658/59 г. - 4 человека ${ }^{11}$. До середины 1650-х гг. категория «новоприборные» стрельцы в сметных списках отсутствовала. Во-вторых, в середине 50-х гг. XVII в. из состава служилых людей по прибору исчезли пушкари и воротники, что является свидетельством полного упадка военного значения крепости. В-третьих, в середине 1660-х гг. численный состав вологодского гарнизона, состоящего уже только из стрельцов, достиг своего минимума -37 человек ${ }^{12}$.

В середине 1670-х — начале 1680-х гг. ситуация несколько улучшилась, численность стрельцов увеличилась сначала до 100, а затем и до 118 человек ${ }^{13}$. Однако это было связано не столько с военными потребностями города, сколько с ростом социальных противоречий и усилением административно-полицейских и фискальных функций, возлагаемых на стрельцов.

Основу вологодского гарнизона XVII в. всегда составляли стрельцы. Как правило, они несли караульную и гарнизонную службу в пределах вологодского округа, но в ряде случаев могли быть отправлены на службу или в служебные командировки и в другие регионы. Так, в 1633/34 г. часть вологодских стрельцов вместе с семьями была «послана к Москве на житье». Сметный список не указывает их количество, но всем им была выплачена подмога из вологодских доходов «за наемные подводы, что наняты под тех стрельцов, и под жен, и под детей их, и под животы» ${ }^{14}$. В 1674/75 г. половина вологодского гарнизона - 50 стрельцов из 100 - участвовали в подавлении Соловецкого восстания и находились на Соловецких островах не менее одного года ${ }^{15}$.

Помимо гарнизонной службы стрельцы выполняли и другие функции. Одной из наиболее привычных для них было сопровождение денежных и иных доходов государевой казны в Москву. Еще одна функция, которая возлагалась на стрельцов, - сопровождение государственных высокопоставленных лиц. В конце 1689 г. отряд вологодских стрельцов численностью в 40 человек под командованием Ивана Любимова и Андрея Мингаля сопровождал князя В. В. Голицина и его сына Алексея от Вологды до Тотьмы. После свержения Петром I царевны Софьи Алексеевны их отправили в ссылку в Еренский городок. До этого роль почетной стражи, от Москвы до Вологды, выполняли московские стрельцы Стременного полка под командованием Василия Заворухина и Евсея Грибцова ${ }^{16}$.

\footnotetext{
${ }^{11}$ Там же. Вологда 2. Л. 360, 463 об., 559, 670 об.

${ }^{12}$ Там же. Ф. 210. Оп. 7а. Кн. 1. Л. 31-32 об.

${ }^{13}$ Там же. Л. 636-640, 758 об.-765.

${ }^{14}$ Там же. Ф. 137. Оп. 1. Новгород 22. Л. 86 об.

${ }_{15}$ Там же. Ф. 210. Оп. 7а. Кн. 1. Л. 640.

${ }^{16}$ Там же. Ф. 137. Оп. 2. № 284. Л. 21-22.
} 
Важнейшим параметром боевых возможностей вологодского гарнизона было вооружение служилых людей по прибору. Сметные росписи вологодских воевод довольно лаконично упоминают об их личном огнестрельном и холодном оружии и то только во второй половинеXVII в. Личным оружием командного состава - городовых приказщиков, осадных и стрелецких голов, стрелецких сотников - могли быть пищаль или карабин и всегда один или пара пистолей, сабля (cм. табл. 2). Эти должности всегда занимали «служилые люди по отечеству», как правило представители местного дворянства. Все огнестрельное и холодное оружие приобреталось ими за счет собственных средств.

Таблица 2.

Вооружение командного и рядового состава вологодского гарнизона во второй половине XVII в.

\begin{tabular}{|c|c|c|c|c|}
\hline \multirow[t]{2}{*}{ Год } & \multicolumn{4}{|c|}{ Должность } \\
\hline & $\begin{array}{l}\text { городовой } \\
\text { приказчик }\end{array}$ & осадный голова & $\begin{array}{l}\text { стрелецкий } \\
\text { сотник }\end{array}$ & $\begin{array}{l}\text { стрельцы (пяти- } \\
\text { десятник, десят- } \\
\text { ник, рядовой) }\end{array}$ \\
\hline $1657 / 58$ & $\begin{array}{l}\text { пищаль, сабля, } \\
\text { пистоль }\end{array}$ & - & пищаль, сабля & пищаль, шпага \\
\hline $1665 / 66$ & - & - & - & мушкет, шпага \\
\hline $1666 / 67$ & - & $\begin{array}{l}\text { сабля, } \\
\text { пара пистолей }\end{array}$ & - & - \\
\hline $1667 / 68$ & - & - & - & пищаль, шпага \\
\hline $1668 / 69$ & - & $\begin{array}{l}\text { сабля, пара } \\
\text { пистолей }\end{array}$ & - & пищаль, шпага \\
\hline $1674 / 75$ & - & $\begin{array}{l}\text { сабля, } \\
\text { пара пистолей }\end{array}$ & $\begin{array}{l}\text { сабля, } \\
\text { пара пистолей }\end{array}$ & мушкет, бердыш \\
\hline $1681 / 82$ & - & $\begin{array}{l}\text { сабля, карабин, } \\
\text { пара пистолей }\end{array}$ & $\begin{array}{l}\text { сабля, пара пи- } \\
\text { столей }\end{array}$ & мушкет, бердыш \\
\hline
\end{tabular}

Составлено по: Писцовые и переписные книги Вологды... Т. 3. С. 186-188; РГАДА. Ф. 210. Оп. 7а. Кн. 1. Л. 27 об., 33, 192 об., 368, 504, 509 об., 633 об., 721, 751 об., 765.

Личное оружие стрельцов - пятидесятников, десятников и рядовых - было для всех одинаковым и предоставлялось за счет государства. Это всегда подчеркивается в источнике: «а то ружье у них государя» или «даны великого государя ис казны». Комплект стрелецкого вооружения всегда состоял из двух единиц - огнестрельного и холодного. В разные периоды оно могло значительно отличаться, особенно холодное. Так, в 1657 г. это были пищаль и шпага, в 1665 г. - мушкет и шпага, a c 1674 г. — мушкет и бердыш. Сведений о военной форме, как и других 
воинских атрибутах вологодских стрельцов - знаменах, музыкальных инструментах и др. - нет ${ }^{17}$.

Вторым важнейшим компонентом, обеспечивавшим во многом престиж службы, являлось материальное обеспечение служилых людей по прибору. Оно всегда выплачивалось по государевой грамоте за приписью дьяка Новгородской четверти из вологодских доходов и зависело как от рода службы, так и от занимаемой должности. Состояло из «государева денежного жалования» и «государева хлебного жалования», которое так же выплачивалось деньгами (см. табл. 3). Денежное и хлебное жалованье вологодские стрельцы получали два раза в год - первую половину к «сергиевскому сроку» (25 сентября), вторую половину к «благовещенскому сроку» (25 марта). Бывали и исключения. Так, в 1658/59 и 1659/60 гг. жалованье стрельцам было выплачено сразу за весь год.

Таблица 3.

Оклады служилых людей по прибору Вологды в XVII в.

\begin{tabular}{|c|c|c|c|c|c|c|}
\hline \multirow[t]{3}{*}{$\begin{array}{l}\text { Категория } \\
\text { служилых людей }\end{array}$} & \multirow{2}{*}{\multicolumn{2}{|c|}{$\begin{array}{c}\text { Денежное жалованье } \\
\text { (руб.) }\end{array}$}} & \multicolumn{4}{|c|}{$\begin{array}{c}\text { Хлебное жалованье } \\
\text { (четвертей) }\end{array}$} \\
\hline & & & \multicolumn{2}{|c|}{ рожь } & \multicolumn{2}{|c|}{ овес } \\
\hline & $1627 / 28$ г. & $1659 / 60$ г. & $1627 / 28$ r. & $1659 / 60$ г. & $1627 / 28$ г. & $1659 / 60$ г. \\
\hline $\begin{array}{l}\text { Стрелецкий } \\
\text { голова }\end{array}$ & 30 & - & - & - & - & - \\
\hline $\begin{array}{l}\text { Стрелецкий } \\
\text { сотник } \\
\text { Стрельшы: }\end{array}$ & 10 & - & - & - & - & - \\
\hline $\begin{array}{l}\text { Стрельцы: } \\
\text { пятидесятник }\end{array}$ & 4 & 4 & 7 & 7 & 7 & 7 \\
\hline десятник & 3,5 & 3,5 & 6,5 & 6,5 & 6,5 & 6,5 \\
\hline рядовой & 3 & 3 & 6 & 6 & 6 & 6 \\
\hline Пушкари & 2 & - & 3 & - & 3 & - \\
\hline Затинщики & 2 & - & 3 & - & 3 & - \\
\hline Черкасы: & 6,5 & - & 10 & - & 10 & - \\
\hline $\begin{array}{l}\text { десятник большой } \\
\text { статьи }\end{array}$ & 6 & - & 10 & - & 10 & - \\
\hline $\begin{array}{l}\text { десятник малой } \\
\text { статьи }\end{array}$ & 5 & - & 8 & - & 8 & - \\
\hline
\end{tabular}

Составлено по: РГАДА. Ф. 137. Оп. 1. Новгород 16. Ч. 1. Л. 427 об.-435 об.; Вологда 2. Л. 786-788.

На протяжении XVII в. размер денежного жалования для командного и рядового состава стрельцов не менялся и всегда выплачивался вовремя.

${ }^{17}$ Писцовые и переписные книги Вологды... Т. 3. С. 188; РГАДА. Ф. 210. Оп. 7а. Кн. 1. Л. 31-32 об., 636-640. 
Размер хлебного жалованья так же оставался неизменным, но в денежном выражении он мог за разные годы существенно отличаться. Для разных категорий служилых людей он составлял четко определенное количество четвертей ржи и овса «в государеву отдаточную меру», а их стоимость исчислялась «по вологодской по торговой по меншей цене». Накануне выплаты хлебного жалования вологодский таможенный голова подавал воеводе «оценную память», по которой и определялась стоимость 1 четверти ржи и 1 четверти овса, что составляло 1 юфть. Иногда такая оценка проводилась дважды в год. Так, в 1644/45 г. стрельцам хлебное жалованье «сергиевского срока» выплачивалось исходя из стоимости 1 юфти хлеба в 81,75 коп., а «благовещенского» $-77,75$ коп. ${ }^{18}$

В ряде случаев оценочная стоимость хлеба для отдельных категорий служилых людей вологодского гарнизона могла быть разной. В 1628/29 г. для черкасов стоимость 1 юфти хлеба составляла 40,5 коп., а для стрельцов и пушкарей — 41,5 коп. ${ }^{19}$ Аналогичная ситуация возникла и в 1644/45 г., когда стоимость 1 юфти хлеба для пушкарей составила 67,5 коп., что на 10,25 коп. ниже, чем у стрельцов ${ }^{20}$.

Значительные колебания цен вологодского рынка на хлеб, приводили к существенной разнице выплаченной суммы денег за «хлебное жалование» (см. табл. 4).

Таким образом, в 20-50-х гг. XVII в. стоимость 1 юфти хлеба колебалась в пределах от 33,75 коп. до 1 руб. 9,5 коп. Следовательно, денежная компенсация за «хлебное жалование» у стрельцов могла составлять сумму для рядовых от 4 руб. 5 коп. до 13 руб. 14 коп., для десятников - от 4 руб. 38,75 коп. до 14 руб. 23,5 коп., а для пятидесятников — от 4 руб. 72,5 коп. до 15 руб. 33 коп. В целом размер хлебного жалованья в денежном эквиваленте всегда превышал размер денежного жалованья даже в те годы, когда цены на хлеб были самыми низкими.

Порядок выплаты жалованья командному составу — стрелецким головам и сотникам несколько отличался. Во-первых, его размер был значительно выше. У голов денежный оклад составлял 30 руб., у сотников 10 руб. Во-вторых, хлебное жалованье они не получали. Это говорит о том, что данные должности в Вологде занимали представители дворянского сословия. Хлебное жалованье никогда не выплачивалось, если служилый человек - стрелецкий голова или сотник - имел уже государево пожалование в виде поместья.

\footnotetext{
${ }^{18}$ РГАДА. Ф. 137. ОП. 1. Новгород 31. Л. 361 об.-367.

${ }^{19}$ Там же. Новгород 18. Ч. 1. Л. 459 об.-465.

${ }^{20}$ Там же. Новгород 31. Л. 361 об.-365.
} 
Таблица 4.

Денежный размер хлебного жалованья вологодских стрельцов в XVII в.

\begin{tabular}{|c|c|c|c|c|c|c|}
\hline \multirow[t]{2}{*}{ Год } & \multicolumn{3}{|c|}{$\begin{array}{c}\text { Стоимость } 1 \text { четверти хлеба } \\
\text { (руб.) }\end{array}$} & \multicolumn{3}{|c|}{$\begin{array}{c}\text { Размер хлебного жалованья для одного человека } \\
\text { (руб.) }\end{array}$} \\
\hline & рожь & овес & юфть & пятидесятник & десятник & рядовой \\
\hline $1627 / 28$ & 0,34 & 0,11 & 0,45 & 6,30 & 5,85 & 5,40 \\
\hline $1628 / 29$ & 0,295 & 0,12 & 0,415 & 5,81 & 5,395 & 4,98 \\
\hline $1644 / 45$ & 0,5625 & 0,255 & 0,8175 & 11,165 & 10,3675 & 9,57 \\
\hline $1644 / 45$ & 0,5075 & 0,27 & 0,7775 & & & \\
\hline $1652 / 53$ & 0,30 & 0,135 & 0,435 & 6,09 & 5,655 & 5,22 \\
\hline $1653 / 54$ & 0,225 & 0,1125 & 0,3375 & 4,725 & 4,3875 & 4,05 \\
\hline $1654 / 55$ & 0,285 & 0,15 & 0,435 & 6,09 & 5,655 & 5,22 \\
\hline $1655 / 56$ & 0,27 & 0,15 & 0,42 & 5,88 & 5,46 & 5,04 \\
\hline $1656 / 57$ & 0,345 & 0,15 & 0,495 & 6,93 & 6,435 & 5,94 \\
\hline $1657 / 58$ & 0,525 & 0,27 & 0,795 & 11,13 & 10,335 & 9,54 \\
\hline $1658 / 59$ & 0,495 & 0,225 & 0,72 & 10,08 & 9,36 & 8,64 \\
\hline $1659 / 60$ & 0,795 & 0,30 & 1,095 & 15,33 & 14,235 & 13,14 \\
\hline
\end{tabular}

Составлено по: РГАДА. Ф. 137. Оп. 1. Новгород 16. Ч. 1; Новгород 18. Ч. 1; Новгород 31; Вологда 2.

Стрелецкий голова возглавлял крупное военное формирование из нескольких сотен стрельцов, именуемое приказом. В Вологде в конце 1620-х гг. стоял приказ Афанасия Бердяева (1627-1629 гг.). Последнее свидетельство о вологодском стрелецком голове относится к 1633/34 г. В его подчинении находились сотники: в 1627/28 г. — Матвей Кобелев, Степан Шилов и Хотен Есипов; в 1628/29 г. вместо Степана Шилова эту должность занимал Григорий Хвалевский ${ }^{21}$. С середины 1640-х гг., когда стрелецкий гарнизон Вологды значительно сократился, его стали возглавлять сотники и даже пятидесятники. Известны имена некоторых из них. Так, в 1644/45 г. командиром стрелецкого отряда был сотник Симон Перфирьев с денежным окладом в 10 руб. ${ }^{22}$

В целом организационная структура и численный состав вологодских стрельцов представлены в табл. 5.

${ }^{21}$ Там же. Новгород 16. Ч. 1. Л. 428; Новгород 18. Ч. 1. Л. 459 об.

22 Там же. Новгород 31. Л. 361 об. 
Таблица 5.

Структура и численный состав вологодских стрельцов

\begin{tabular}{|c|c|c|c|c|c|c|}
\hline \multirow[t]{2}{*}{ Год } & \multicolumn{5}{|c|}{ Состав } & \multirow[t]{2}{*}{ Всего } \\
\hline & голова & сотник & пятидесятник & десятник & рядовой & \\
\hline $1627 / 28$ & 1 & 3 & 5 & 21 & 236 & 266 \\
\hline $1628 / 29$ & 1 & 3 & 5 & 21 & 236 & 266 \\
\hline $1644 / 45$ & - & 1 & 3 & 12 & 134 & 150 \\
\hline $1652 / 53$ & - & - & 3 & 12 & 135 & 150 \\
\hline $1653 / 54$ & - & - & 3 & 12 & 135 & 150 \\
\hline $1654 / 55$ & - & - & 3 & 12 & 135 & 150 \\
\hline $1655 / 56$ & - & - & 2 & 10 & 121 & 133 \\
\hline $1656 / 57$ & - & - & 1 & 6 & 66 & 73 \\
\hline $1657 / 58$ & - & - & 1 & 5 & 59 & 65 \\
\hline $1658 / 59$ & - & - & 1 & 4 & 45 & 50 \\
\hline $1659 / 60$ & - & - & 1 & 3 & 36 & 40 \\
\hline $1665 / 66$ & - & - & 1 & 3 & 33 & 37 \\
\hline $1666 / 67$ & - & - & 1 & 4 & 50 & 55 \\
\hline $1667 / 68$ & - & - & 1 & 5 & 50 & 56 \\
\hline $1668 / 69$ & - & - & 1 & 6 & 61 & 68 \\
\hline $1674 / 75$ & - & - & 2 & 8 & 90 & 100 \\
\hline $1681 / 82$ & - & 1 & 2 & 10 & 105 & 118 \\
\hline
\end{tabular}

Составлено по: РГАДА. Ф. 137. Оп. 1. Новгород 16. Ч. 1; Новгород 18. Ч. 1 ; Новгород 31; Вологда 2; Ф. 210. Оп. 7а. Кн. 1.

Воеводские сметные росписи второй половины XVII в. дают нам уникальную возможность установить полные списки личного состава вологодского гарнизона, в том числе и командного состава за 7 отдельных лет, с 1657/58 по 1681/82 г., который представлен в Приложении. Так же сметные списки и воеводские росписи позволяют увидеть и некоторые детали праздничных событий в повседневной службе вологодских стрельцов. Так, весной 1654 г. на день ангела царя Алексея Михайловича «для государевы радости» с кружечного двора всему стрелецкому гарнизону Вологды - 150 стрельцам были пожалованы вино, пиво и мед на 1 руб. 98 коп. ${ }^{23} 4$ сентября 1668 г. в Вологде состоялся торжественный салют, на который было издержано 30 фунтов пороху. Причиной стала государева грамота из приказа Тайных дел за приписью дьяка Федора Михайлова, по которой всему личному со-

${ }^{23}$ Там же. Вологда 2. Л. 190. 
ставу вологодского гарнизона было велено стрелять из пушек и из ружья «о победе на врагов татар и крестопреступников и изменников черкас» ${ }^{24}$.

Военная служба, особенно участие в боевых действиях, всегда была сопряжена с возможностью гибели или ранения. В сметном списке 1655/56 г. зафиксирован один из таких случаев. Вологодский стрелец Логинко Онофреев получил денежную компенсацию по ранению в размере одной трети годового оклада. По государевой грамоте ему было дано «за рану на лечбу рубль» ${ }^{25}$.

Численный состав вологодского гарнизона, несущий службу в крепости, в конце 20-х гг. XVII в. составлял 20 пушкарей и 8 воротников, «городовых ворот». На протяжении 20-40-х годов он был довольно устойчив, а в 1650х гг. их общая численность стала стремительно сокращаться (см. табл. 1). Как отдельная штатная структура вологодского гарнизона пушкари исчезли к осени 1658 г. Чуть раньше, в 1657 г., исчезли городовые воротники.

Личное вооружение пушкарей и воротников состояло только из холодного оружия и, видимо, приобреталось самостоятельно. В числе такового сметные росписи называют саблю, рогатину и копье. Материальное обеспечение пушкарей и воротников Вологды уже к концу 20-х гг. XVII в. ухудшилось, и стало меньше, чем у рядовых стрельцов. Начиная с 1627/28 г. их оклады, как денежные, так и хлебные, были урезаны в два раза и составляли соответственно 2 рубля и 6 четвертей хлеба - по 3 четверти ржи и овса на человека. Выплачивалось денежное и хлебное жалованье один раз в год. Дальнейшее ухудшение их материального обеспечения произошло в середине XVII в. Если в 1644/45 г. они еще получали прежние оклады, денежный — 2 руб., хлебный — 6 четвертей, то уже с 1652/53 г. осталось только денежное жалование в размере 2 руб. на одного человека ${ }^{26}$.

В служебные командировки могли отправляться не только стрельцы, но и пушкари. В 1657/58 г. «на государеву службу в Великий Новгород по государеве грамоте ис Пушкарсково приказу» были отправлены четыре вологодских пушкаря - Иван Аталыков, Василий Соколов, Роман Зубецкой и Иван Степанов $^{27}$. Двое из них погибли, кто именно - неизвестно. Но, как указывает сметный список за 1657/58 г., они получили «в зачет для той новгородцкой службы великого государя денежново жалованья» половину годового оклада — по 1 руб., и «на той великого государя службе побиты» ${ }^{28}$. В ряде случаев пушкари могли выполнять административно-финансовые поруче-

\footnotetext{
${ }^{24}$ Там же. Ф. 210. Оп. 7а. Кн. 1. Л. 502.

${ }^{25}$ Там же. Ф. 137. Оп. 1. Вологда 2. Л. 393 об.

${ }^{26}$ Там же. Л. 59.

${ }^{27}$ Там же. Ф. 210. Оп. 7а. Кн. 1. Л. 319.

${ }^{28}$ Там же. Ф. 137. Оп. 1. Вологда 2. Л. 563 об.
} 
ния. В апреле 1626 г. Казаринко Махаев, а в августе Семейка Олферьев по приказу вологодского воеводы князя В. Т. Долгоруково и дьяка Т. Агеева отчитывались в Новгородской четверти о доимочных деньгах прошлых лет ${ }^{29}$.

С утратой вологодской крепостью в середине XVII в. реального военного значения исчезли и пушкари как структурная единица вологодского гарнизона. Но в воеводских сметных росписях второй половины столетия они числились в качестве отставных пушкарей и зачастую выполняли административно-полицейскую работу: «а ныне в съезжей избе ходят в розсылке» ${ }^{30}$.

Не вполне традиционно для городов Русского Севера наличие в составе гарнизонов казаков. В Вологде это были «калуские черкасы» - запорожские казаки, переведенные на службу в Вологду, по всей видимости, из-под Калуги, которые занимали особое служебное и материальное положение в составе вологодского гарнизона. Причины и время их перевода в Вологду неизвестны, не исключено, что это произошло после Смуты. В источниках казаки впервые упоминаются на службе в городе с 1627/28 г., всего 31 человек - 2 десятника, 15 казаков большой статьи и 14 - малой статьи.

Как и стрельцы, денежное и хлебное жалованье черкасы получали два раза в год: первую половину к «сергиевскому сроку», вторую - к «благовещенскому сроку». Их оклады, как денежные, так и, особенно, хлебные, были значительно выше стрелецких. Для десятников денежный оклад составлял 6,5 руб., а хлебный - 20 четвертей, для казаков большой статьи 6 руб. и 20 четвертей хлеба, а малой статьи -5 руб. и 16 четвертей хлеба ${ }^{31}$.

С 1644/45 по 1653/54 г. сложилась несколько иная ситуация: в Вологде уже находились так называемые кормовые черкасы. В середине 40-х гг. на службе в вологодском гарнизоне их насчитывалось 9 человек - казаки из Адашкова и Чаплинского полков. Они получали «поденный корм», и их материальное содержание оказалось значительно выше, чем у черкасов в конце 1620-х гг. Вряд ли это были рядовые казаки: поденный корм одного из них составлял 5,5 коп. в день, а остальных восьми - по 5 коп. в день, т. е. минимум 1,5 руб. в месяц или 18 руб. в год на человека. Более того, каждому из казаков было положено по 4,32 руб. на корм одной лошади (по 72 коп. на 6 месяцев). Всего в 1644/45 г., учитывая еще и поденный корм черкаской вдовы с детьми, все их содержание обошлось государству в приличную сумму - 191,8 руб. ${ }^{32}$

В 1652/53 и в 1653/54 гг. «поденный корм» из государевой казны получали восемь кормовых черкасов. Размер корма не изменился, правда

\footnotetext{
${ }^{29}$ Там же. Новгород 15. Л. 185-161.

${ }^{30}$ Там же. Ф. 210. Оп. 7а. Кн. 1. Л. 509 об.

${ }^{31}$ Там же. Ф. 137. Оп. 1. Новгород 16. Ч. 1. Л. 433-435 об.; Новгород 18. Ч. 1. Л. 465-467 об.

32 Там же. Новгород 31. Л. 368-369.
} 
несколько сократились выплаты на содержание лошадей. Теперь на одну лошадь полагалось по 60 коп. на месяц. Общие расходы на их содержание в 1652/53 г. составили 154,42 руб., а в $1653 / 54$ г. - 148,32 руб. ${ }^{33}$

Таким образом, структура, численность вологодского гарнизона, их материальное обеспечение в XVII в. зависели от многих факторов как военно-административного, так и социально-экономического характера. Государству приходилось затрачивать значительные средства как на его содержание, так и на сохранение в боеспособном состоянии крепостных укреплений и артиллерийского наряда. Только на денежное и хлебное жалованье всем служилым людям вологодского гарнизона, не считая вооружения, боеприпасов и снаряжения, в 1627/28 г. из государевой казны было потрачено 1910,485 руб. Для сравнения, данная сумма значительно превосходила весь сошный оклад вологодского посада и уезда на этот год, который составлял 1192,40 руб. ${ }^{34}$ Хотя в целом для вологодского бюджета с его доходной частью примерно в 12200 руб. это составляло примерно 15,7\%.

Это был самый большой годовой расход на содержание вологодского гарнизона в XVII в., в дальнейшем он постоянно уменьшался. В целом можно говорить о том, что эти расходы были вполне посильны и не представляли финансовых проблем для государственного бюджета и местных властей. Общая картина расходов на содержание вологодского гарнизона представлена ниже (см. табл. б).

Значительное сокращение численного состава и упрощение структурной организации вологодского гарнизона было связано в первую очередь с утратой военно-стратегического значения вологодской крепости. Последний раз государство проявило заботу о восстановлении ее боевых возможностей в 1631-1632 гг., накануне Смоленской войны ${ }^{35}$.

Bсе описания крепости второй половины XVII в., а их сохранилось 8 за 1657-1685 гг. ${ }^{36}$, говорят о ее фактическом разрушении. Как итог, каменные стены и башни по описаниям напоминают развалины — все осыпались «на сажень и больше», т. е. на два и более метра. Из 11 каменных башен только у одной не обвалился свод, а количество деревянных башен сократилось с 12 до 3. Деревянная стена после пожаров 1635/36, 1640/41 и 1660/61 гг. так и не была восстановлена. Еще более печальное зрелище представлял

\footnotetext{
33 Там же. Вологда 2. Л. 59 об., 60, 150 об.-151 об.

34 Там же. Новгород 16. Ч. 1. Л. 391-393.

${ }^{35}$ Кукушикин И.П. Вологодская крепость. С. 71-86.

${ }^{36} \mathrm{C}$ описания вологодской крепости, артиллерийского наряда, ядер и пороха начинаются все воеводские сметные росписи Вологды второй половины XVII в. Кроме того, такого же рода начальный раздел о крепости есть и в описаниях 1626-1628 и 1685-1686 гг.
} 
из себя вологодский крепостной наряд второй половины XVII в. Из 93 скорострельных и затинных пищалей в боеспособном состоянии находились только 5 медных пушек, остальные 88 были свалены в каменной палате так давно, что все «поржавили», и станки и колеса у них «згнили» ${ }^{37}$. Конечно, это не могло не сказаться на составе и численности вологодского гарнизона.

Таблица 6.

Государственные расходы на содержание вологодского гарнизона в XVII в.

\begin{tabular}{|c|c|c|c|c|c|}
\hline \multirow{2}{*}{ Год } & \multicolumn{3}{|c|}{ Общий размер жалованья (руб.) } & \multirow{2}{*}{ Всего } \\
\cline { 2 - 5 } & стрельцы & пушкари & воротники & черкасы & \\
\hline $1627 / 28$ & 1515,875 & 67,91 & 26,80 & 299,90 & 1910,485 \\
\hline $1628 / 29$ & 1460,31 & 64,90 & 25,90 & 283,295 & 1834,405 \\
\hline $1644 / 45$ & 1173,8825 & 79,825 & 20,125 & 191,80 & 1465,6325 \\
\hline $1652 / 53$ & 854,415 & 44,00 & 154,42 & 1052,835 & \\
\hline $1653 / 54$ & 765,785 & 38,00 & 148,32 & 952,105 & \\
\hline $1654 / 55$ & 854,415 & 22,00 & - & 876,415 & \\
\hline $1655 / 56$ & 511,05 & 23,00 & - & 534,05 & \\
\hline $1656 / 57$ & 397,0075 & 24,33 & - & 421,3375 & \\
\hline $1657 / 58$ & 497,7325 & 2,00 & - & - & 499,7325 \\
\hline $1658 / 59$ & 360,79 & - & - & - & 360,79 \\
\hline $1659 / 60$ & 388,0375 & - & - & - & 388,0375 \\
\hline
\end{tabular}

Составлено по: РГАДА. Ф. 137. Оп. 1. Новгород 16. Ч. 1; Новгород 18. Ч. 1;

Новгород 21; Вологда 2.

Определенное значение для сокращения численности служилых людей по прибору, и не только в Вологде, имели социально-политические мероприятия середины XVII в. - прежде всего посадская реформа, значительно подорвавшая привилегированный статус этого служилого сословия. Ограничение социальной базы для новых наборов, отрыв от хозяйства и постоянного места проживания значительно сократили привлекательность данного вида «государевой службы» и, как следствие, это привело к значительному сокращению численности военного гарнизона Вологды во второй половине XVII в. В его составе остались только стрельцы, количество которых к началу 1680-х гг. даже несколько увеличилось, но в городе и уезде они стали выполнять уже не военные, а прежде всего административно-полицейские и фискальные функции.

${ }^{37}$ См.: Фалин Н.В. Вологодская крепость в XVII в. // Север. 1924. № 1. С. 5-32; Писцовые и переписные книги Вологды... Т. 1. С. 172-177; Т. 3. С. 181-186. 


\section{Личный состав гарнизона Вологды второй половины XVII в. (по воеводским сметным росписям)}

\section{5/66 год}

(Л. 27 об.) Осадной голова Василей Баташев.

(Л. 31-32 об.) Вологоцкие стрелцы.

Пятидесятник Иван Анисимов, Микифор Якимов сын Чарондин, // Ивашко Митрофанов сын Чекмен, Давыдко Логинов сын Чос, Тимошка Васильев сын Бабин, Елфимко Павлов сын Пан, Фомка Иванов сын Кубасов, Деянко Михеев, Федка Романов сын Шадра, Ивашко Назаров сын Ситников.

Десятник Лука Ефремов сын Дрокунов, Мишка Павлов сын Плотников, Васка Дементьев сын Колесов, Пашка Елфимов, Ивашко Фомин, Баженко Феопентов сын Табай, // Макарко Прохоров сын Субота, Ондрюшка Моисеев сын Колоков, Исачко Новик.

Десятник Федотко Яковлев сын Рудаков, Тимошка Аввакумов сын Диянов, Ивашко Захаров сын Таран, Сенка Федотов сын Шибкой, Кмрилко Семенов сын Сапожников, Петрушка Кирилов сын Сапожников, Ивашко Никитин сын Черен, Ромка Романов сын Поспелов, Кузка Анкидинов сын Осос, // Софонко Семенов.

Десятник Карп Григорьев сын Бурков, Ивашко Степанов сын Боров, Осташка Савельев сын Блохин, Ивашко Павлов, Кондрашка Иевлев сын Дрокулин, Ивашко Исаков сын Голыга, Гришка.

И всего на Вологде стрелцов тритцать семь человек, великого государя ружья у них по мушкету да по шпаге, а то ружье у них великого государя. //

(Л. 33 об.) Отставные пушкари.

Иван Костянтинов, ружья у него сабля.

Евсевей Медведев, ружья у него рогатина.

Иван Аталыков, ружья у него копье.

\section{6/67 год}

(Л. 192 об.) Осадной голова Василей Баташев, ружья у него сабля, пара пистолей.

(Л. 196-198) Вологодцкие стрелцы.

Пятидесятник Ивашко Анисимов, Микифор Якимов, Ивашко Митрофанов, Давыдко Логинов, у него два пасынка Кирилко да Петрушка, один 15 лет, другой 12 лет, Тимошка Васильев сын Бабин, Деянко Михиев, сын 
у него Митрошка, Федорка Романов, Елфимко Павлов Пан, Ивашко Назарьев Ситников. //

Десятник Лучка Ефремов, Мишка Павлов, пасынок у него Степка 15 лет, Васка Дементьев, сын у него Мишка 10 лет, Пашка Елфимов Кривой, Ивашко Романов, Баженко Феопентов Табаев, Макарко Прохоров Субота, Андрюшка Моисеев, Исачко Микитин, Гришка Иванов. //

Десятник Федотко Яковлев Круговой, Тимошка Аввакумов, Ивашко Назарьев, Сенка Федотов, Кмрилко Семенов сын Коркун, Ивашко Никитин, Ромашка Романов, Кузка Анкидинов Осипов, Софонко Семенов Шишов.

Десятник Карпунка Григорьев, Ивашко Белобородов, сын у него Акинка 15 лет, // Осташка Савельев, Ивашко Павлов, Ивашко Петров, Ивашко Стефанов, Сысойко Мартьянов, Кондрашка Иевлев, Ивашко Исаков Голыга, сын у него Алешка 10 лет, Мартынка Кондратьев.

Десятник Ивашко Васильев, Зиновейко Ларионов сын Воин, Корнилко Ортемьев, два сына Оска да Фролко, один 15 лет, другой 12 лет, // Ивашко Миниев, Ларка Нестеров, Омелка Яковлев, сын у него Оска 10 лет, Ивашко Стефанов, Сенка Семенов Шибкой, Куска Осипов сын Салник, Ивашка Федоров, Лучка Иванов, Петрушка Юдин, Гаврилко Яковлев, пасынок у него Максимко 13 лет, Ярафейко Игнатьев, Васка Стефанов Попов.

И всего на Вологде стрелцов пятдесят пять человек, детей и пасынков десять человек. //

(Л. 199) Отставные пушкари.

Иван Костянтинов, ружья у него сабля.

Евсевей Медведев, ружья у него рогатина.

\section{$1667 / 68$ год}

(Л. 365 об.-368) Вологоцкие стрелцы.

Пятидесятник Иван Анисимов, а у него сын Антон шти лет, Микифор Якимов, Иван Митрофанов, Давыд Логинов, сын у него Григорей семи лет, у него два пасынка Петр 15 лет, Кирило 20 лет, Емельян Алферьев, сын у него Иван 7 лет, Елфим Павлов, Илья Иванов, Федор Романов, Иван Назаров, сын Василей 6 лет. //

Десятник Лучка Ефремов, Михайло Павлов, пасынок Степан 15 лет, Павел Елфимов, сын Микита осми лет, Иван Фомин, Андрей Моисеев, Григорей Иванов, Карп Григорьев, два сына Федор шти лет, Козьма осми лет, Кондратей Иевлев, Дмитрей Денисов, два сына Федюнка 6 лет, Васка осми лет, // Акинфей Иванов. 
Десятник Федот Яковлев, Тимофей Аввакумов, Иван Захаров, сын пяти лет, Семен Федотов, сын Федюнка 5 лет, Петр Кирилов, Иван Никитин, Роман Романов, Софонко Семенов, Михайло Парфеньев, Иван Васильев.

Десятник Иван Васильев, сын Сергей 5 лет, // Семен Семенов, сын Сергей 7 лет, Емельян Яковлев, Данило Артемьев, два сына Осип 15 лет, Флор 13 лет, Ярофей Игнатьев, Василей Стефанов, Иван Стефанов, Гаврило Яковлев, пасынок 15 лет Максимко, Петр Юдин.

Десятник Иван Степанов, сын Иван 6 лет, Сысой Мартьянов, Ларион Нестеров, сын Осип 15 лет, Иван Миниев, // Иван Федоров, Иван Петров, Макар Прохоров, сын Вахрамей 8 лет, Исак Никитин, сын Федор 6 лет.

Десятник Зиновейко Ларионов, Мартын Дементьев, Козма Анкидинов, Иван Павлов, Бажен Феопентов, сын Олексей шти лет, Василей Дементьев, сын Никифор десяти лет, Тимофей Васильев, // Кирило Семенов, Иван Исаков, сын Алексей десяти лет, Деян Михайлов, сын Митрофан десяти лет.

И всего на Вологде стрельцов пятдесят шесть человек, ружья у них по пищале да по шпаге, даны великого государя ис казны, детей их дватцать три человека, пасынков четыре человека.

(Л. 368 об.) Отставные пушкари.

Иван Аталыков, ружья у него сабля.

Иван Костянтинов, ружья у него сабля.

Евсевей Медведев, ружья у него рогатина.

\section{8/69 год}

(Л. 504) Осадной голова Спиридон Иванов сын Свашевской, ружья у нево сабля, пара пистолей.

(Л. 506 об.-509) Вологоцкие стрельцы.

Пятидесятник Евдоким Юдин, Ивашко Митрофанов сын Зекмен, // Давыдко Логинов, Емелка Олферьев, Елфимко Павлов, Илюшка Иванов, Ивашко Назарьев, Фомка Кубасов, Илюшка Яковлев, Ивашко Федосиев.

Десятник Антонко Иванов, Ивашко Фомин, Андрюшка Мосиев, Ларка Трофимов, Колка Иевлев, Колка Кирилов, Дмитрейко Денисов, // Окинко Иванов, Софронко Семенов, Ивашко Михайлов.

Десятник Петрушка Кирилов, Мишка Парфеньев, Колка Анисимов, Макарко Прохоров, Исачко Никитин, Стенка Григорьев, Баженко Феолентев Табай, Васка Дементьев Колесо, Кирилко Семенов, Тимошка Васильев.

Десятник Мишка Павлов, Ивашко Исаков, Ивашко Пркофьев, Корнилко Иванов, // Ивашко Максимов, Сергушка Емельянов, Петрушка Семенов, Ивашко Иванов, Петрушка Григорьев, Алешка Дмитриев. 
Десятник Микифорко Якимов, Мишка Федотов, Оска Павлов, Митка Степанов, Петрушка Сергеев, Стенка Евдокимов, Колка Мартьянов, Петрушка Иванов, Ивашко Кондратьев, Фетка Алексеев.

Десятник Ивашко Захарьев, Алешка Иванов, // Кузка Дмитреев, Карпунка Калинин, Якимко Иванов, Анисимко Иванов, Ивашко Ильин, Ромашко Алексеев, Фетка Иванов, Ивашко Григорьев.

Десятник Карпунка Григорьев, Харка Михайлов, Пиминко Гарасимов, Максимко Моисеев, Ивашко Васильев, Алешка Алферьев, Ивашко Самойлов, ...емка Деянов. //

И всего на Вологде стрелцов шездесят восмь человек, великого государя ружья у них по пищале да по шпаге у человека.

(Л. 509 об.) Отставные пушкари, а ныне в съезжей избе ходят в розсылке. //

Ивашко Аталыков, ружья у нево сабля.

Евся Медведев, ружья у нево рогатина.

\section{4/75 год}

(Л. 633 об.) Осадной голова Микита Порошин, ружья у него сабля, пара пистолей.

Вологоцких стрелцов сотник Иван Павлов сын Морин, ружья у него сабля да пара пистолей.

(Л. 636-640) Да на Вологде стрелцов.

Пятидесятник Антонко Иванов, // Ивашко Михайлов, Давыдко Логинов, Емелка Олферьев, Илюшка Иванов, Фомка Иванов, Илюшка Яковлев, Стенка Иванов, Ивашко Иванов, Антонко Сидоров.

Десятник Федотко Семенов, Софронко Семенов, Петрушка Кирилов, Микифорко Костянтинов, Стенка Карпов, // Сенка Иванов, Ивашко Максимов, Викулко Семенов, Петрушка Семенов, Ивашко Иванов.

Десятник Митка Денисов, Фролко Романов, Алешка Дмитреев, Ивашко Денисов, Оска Павлов, Митка Степанов, Ивашко Ильин, Стенка Овдокимов, Фочка Еремиев, // Петрушка Иванов.

Десятник Ивашко Митрофанов, Ивашко Кондратьев, Фетка Алексеев, Алешка Иванов, Коземка Дмитреев, Флорко Митрофанов, Анисимко Иванов, Ивашко Кирилов, Ромашко Алексеев, Фетка Иванов.

Десятник Корнилко Иванов, Родка Иванов, Максимко Моисеов, // Кондрашка Мартьянов, Ивашко Самойлов, Тимошка Яковлев, Савастьянко Вавилин, Андрюшка Васильев, Андрейко Иванов, Ивашко Михайлов.

Пятидесятник Карпунка Григорьев, Данилко Яковлев, Гришка Иванов, Ганка Андреев, Кондрашка Иевлев, Фетка Михайлов, // Якунко Иванов, Якимко Иванов, Матюшка Иванов, Васка Сидоров. 
Десятник Микешка Якимов, Титка Оксенов, Ивашко Иванов, Баженко Яковлев, Кипрюшка Вахрамиев, Тишка Семенов, Филка Карпов, Пронка Осипов, Фетка Тимофеев, Якушка Иванов. //

Десятник Мишка Парфеньев, Ситка Денисов, Филка Агиев, Микитка Микулаев, Ивашко Васильев, Сергушка Логинов, Якушко Афонасьев, Афонка Дмитреев, Фетка Дмитреев, Ивашко Емельянов.

Десятник Мишка Павлов, Ларка Максимов, Петрушка Родионов, Микитка Тимофеев, // Ивашко Иванов, Мишка Семенов, Васка Михайлов, Тараско Матвеев, Лучка Яковлев.

Десятник Алешка Иванов, Лучка Григорьев, Ивашко Афонасьев, Митрошка Семенов, Васка Трофимов, Костка Космин, Еремка Диянов, Васка Андреев, // Калинка Пантелев, Мишка Яковлев.

И всего на Вологде стрелцов пятидесятников и десятников и рядовых сто человек, ружья у них по мушкету да по бердышу.

\section{1/82 год}

(Л. 751 об.) Осадной голова Степан Самойлов сын Илищев, ружья у него сабля, карабин, пара пистолей.

Сотник вологоцких стрелцов Матвей Дмитреев сын Холопов, ружья у него сабля, пара пистолей.

(Л. 758 об.-765) Вологоцкие стрельцы.

Пятидесятник Микифорко Якимов,// рядовые: Софронко Семенов, Ивашко Шемяка, Ивашко Андреев, Фочка Еремеев, Баженко Яковлев, Родка Иванов, Анисимко Иванов, Антонко Сидоров, Федотко Семенов.

Десятник Гришка Давыдов, рядовые: Ивашко Ильин, // Алешка Дмитриев, Офонка Дмитриев, Ивашко Шемякин, Федка Алексеев, Стенка Караулов, Васка Трофимов, Конка Мартьянов, Сенка Степанов.

Десятник Ивашко Петров, рядовые: Петрушка Михайлов, Федка Микифоров, // Ивашко Спиридонов, Алешка Михайлов, Тошка Иванов, Ерошка Микулаев, Харка Любимов, Давыдко Иванов, Онтонко Иванов.

Десятник Илюшка Яковлев, рядовые: Тимошка Федоров, Ивашко Двиницын, Власко Михеев, Васка Титов. // Мишка Парфеньев, Филка Агеев, Пронка Ряшин, Федка Дмитриев, Петрушка Иванов.

Десятник Алешка Иванов, рядовые: Корнилко Иванов, Пронка Митрофанов, Васка Сидоров, Гараска Феменов, // Савасьянко Вавилин, Фролко Митрофанов, Якимко Бородин, Филка Карпов.

Десятник Ивашко Михайлов, рядовые: Илюшка Иванов, Митка Степанов, Алешка Иванов, Сенка Иванов, Петрушка Колмогор, // Петрушка Татаринов, Гришка Антонов, Левка Прокопьев. 
Пятидесятник Спирка Рудинцов, рядовые: Родка Леонтьев, Якушка Иванов, Мишка Васильев, Микитка Карпов, Ивашко Блинков, Петрушка Степанов, Филка Петров, Степка Сошников. //

Десятник Микулка Петров, рядовые: Федка Бобоша, Ивашко Любимов, Тимошка Давыдов, Алешка Широлапов, Якимко Кондратьев, Лучка Григорьев, // Федка Федоров, Андрюшка Васильев, Андрюшка Фомин.

Десятник Кирилко Матвеев, рядовые: Митка Осипов, Федка Петров, Сенка Иванов, // Тимошка Кипреянов, Алешка Лошкин, Аристко Сидоров, Карпунка Квасников, Еремка Иванов, Ивашко Григорьев.

Десятник Алешка Темной,// рядовые: Мишка Яковлев, Кипрюшка Вахромеев, Куска Иванов, Костюнка Козмин, Ромка Васильев, Алешка Филипов, Федка Иванов, // Максимко Моисеев, Ганка Гаврилов.

Десятник Мишка Павлов, рядовые: Микифорко Костянтинов, Оска Павлов, Данилко Яковлев, Ивашко Емельянов, Ивашко Семенов, // Лучка Васильев, Флорко Романов, Стенка Белянкин, Стенка Евдокимов.

Десятник Иашко Кондратьев, рядовые: Петрушка Белянкин, Савка Иванов, // Андрюшка Савельев, Лучка Михайлов, Сенка Иванов Железной, Ганка Афонасьев, Петрушка Иванов.

Ружья у них по мушкету да по бердышу.

РГАДА. Ф. 210. Оп. 7а.Кн. 1. Л. 1-915 об.

\section{Литература}

Вологда в минувшем тысячелетии. Очерки истории города. Вологда, 2004.

Дозорная книга посада Вологды князя П. Б. Волконского и подьячего Л. Софонова.

1616-1617 г. / Публ. Ю.С. Васильева // Вологда: Историко-краеведческий альманах. Вологда, 1994. Вып. 1. С. 333-370.

Кукушкин И.П. Вологодская крепость. Вологда, 2018.

Писцовые и переписные книги Вологды XVII - начала XVIII века. Т. 1. Писцовые и переписные книги Вологды XVII века. / Подгот. к изд. И.В. Пугач (отв. редактор), М.С. Черкасова. М., 2008; Т. 3. Писцовые, переписные и дозорные книги Вологды XVII века / Сост. И.В. Пугач. Вологда, 2018.

Старая Вологда. XII - начало XX в.: Сборник документов и материалов / Сост. Л.Н. Мясникова (отв. сост.), Ю.А. Смирнов, О.В. Якунина. Вологда, 2004. Фалин Н.В. Вологодская крепость в XVII в. // Север. 1924. № 1. С. 5-32. 


\title{
М.Ф. Румянцева
}

\section{ИСТОЧНИКИ (ПО) ИСТОРИИ КРЕСТЬЯНСТВА: ИСТОЧНИКОВЕДЧЕСКИЕ НАБЛЮДЕНИЯ}

\begin{abstract}
Аннотация Анализируются дискурсивные различия формулировок: источники по истории крестьянства/источники истории крестьянства. Выдвигается гипотеза о парадигмальных основаниях этих различий, о проявившейся в них оппозиции классической и неоклассической моделей науки. Гипотеза апробируется на материале классических европейских и российских исследований по истории крестьянства.

Ключевые слова: крестьянство, исторический источник, классическая модель науки, неоклассическая модель науки.

Summary The article analyzes the discursive differences in the wording: sources on the history of the peasantry/sources of the history of the peasantry. A hypothesis is put forward about the paradigmatic basis of these differences, about the opposition between the classical and neoclassical models of science. The hypothesis is tested on the material of classical European and Russian studies on the history of the peasantry.

Keywords: peasantry, historical source, classical model of science, neoclassical model of science.
\end{abstract}

Лингвистический поворот, под знаком которого проходят трансформации гуманитарного - и не только - знания, начиная с середины XX века, заставляет профессионального (не по диплому, а по квалификации) историка быть внимательным к дискурсу, поскольку он понимает, что дискурс выдает (и часто помимо его воли) парадигмальные предпочтения автора научной работы.

В настоящей статье рассматривается один дискурсивный «нюанс»: источники по истории крестьянства/источники истории крестьянства. Очевидно, что эти две формулировки различаются только предлогом «по». Есть ли разница? Попытаемся разобраться, исходя из гипотезы, что предлог «по» в формулировках такого типа выступает как дискурсивный маркер 
парадигмальных различий. Работа имеет дискуссионный, если не сказать — провокативный, характер.

\section{Теоретические размышления}

В теоретической основе данного вопроса, на мой взгляд, необходимо выделить две взаимосвязанные составляющие: (1) собственно источниковедческую и (2) относящуюся в большей степени к теории исторического процесса.

Источниковедческая основа. В исторической науке на протяжении XIXXX вв. сложились два основных подхода к определению понятия «исторический источник». Первый: исторический источник - это все, откуда можно почерпнуть информацию об историческом прошлом. Радикальный вариант определения этого типа: «все, что может источать историческую информацию, (т. е. информацию исторического характера, полезную (sic! - здесь и далее замечания по тексту мои. — M.P.) для работы историка)» ${ }^{1}$. Этот тип определений отсылает нас к классическому типу рациональности / классической модели науки, изжившей себя уже к концу XIX в. Второй — восходит к русской версии неокантианства с ее преимущественным вниманием, в отличие от неокантианства Баденской школы, - к объекту исторического познания: «исторический источник - объективированный результат творческой деятельности человека / продукт культуры, используемый для изучения / понимания человека, общества, культуры как в исторической, так и в коэкзистенциальной перспективе» ${ }^{2}$. Этот подход соответствует неоклассической модели науки, в качестве реперной точки возникновения которой может рассматриваться публикация в 1911 г. статьи Э. Гуссерля (1859-1938) «Философия как строгая наука» ${ }^{3}$. Эта модель актуализирована в конце XX в., при выходе из ситуации постмодерна ${ }^{4}$.

Не буду подробно останавливаться на обосновании концептуальных различий двух подходов к определению исторического источника ${ }^{5}$. Отмечу только два момента.

1 Шмидт С.О. О классификации исторических источников // Вспомогательные исторические дисциплины. Л., 1985. Вып. 16. С. 8.

2 Теория и методология исторической науки: терминологический словарь / Отв. ред. А.О. Чубарьян, Л.П. Репина. 2-е изд., испр. и доп. М., 2016. С. 205.

3 Гуссерль Э. Философия как строгая наука // Логос: международный ежегодник по философии культуры. М., 1911. Кн. 1. С. 1-56.

${ }^{4}$ См.: Лубский А.В. Альтернативные модели исторических исследований. М., 2005. C. $256-339$.

5 Подробнее см.: Источниковедение: учебное пособие / [И.Н. Данилевский, Д.А. Добровольский, Р.Б. Казаков], отв. ред. М.Ф. Румянцева. 2-е изд., испр. М., 2019. С. 90 и след. 
Первый. Тот же самый принцип парадигмального различения применим к определениям массовых (серийных) исторических источников, данные, с одной стороны, И.Д. Ковальченко (1923-1995), а с другой - Б.Г Литваком (1919-2002)6. Это важно, поскольку именно массовые источники могут иметь особое значение в изучении истории крестьянства. В частности, подворные описи крестьянских хозяйств полномасштабно задействованы Ковальченко в изучении российского крестьянства XIX в. ${ }^{7}$

Второй. Научно-педагогическая школа источниковедения, концептуально восходящая к эпистемологической концепции (в рамках русской версии неокантианства) А.С. Лаппо-Данилевского (1863-1919), не только углубляла в течение XX - начала XXI в. понимание природы исторического источника (и соответственно, уточняла его определение), но и обогатила представление об объекте источниковедческого изучения: исторический источник - система видов исторических источников - эмпирическая реальность исторического мира.

Акцентируем внимание на практическом применении концепта эмпирическая реальность исторического мира, предложенного О.М. Медушевской (1922-2007) в работах, опубликованных в 2008 г. Размышляя о макрообъекте исторической науки, исследовательница пишет: «Человек — живая система, способная целенаправленно и осознанно создавать продукт, придавая ему структуру, пригодную для выполнения функций, к осуществлению которых этот продукт предназначен... Человек создает материальный продукт, и этот продукт сохраняется, остается в сообществе людей и может быть востребован вновь и вновь. Он функционирует в обществе, оставаясь в нем навсегда» ${ }^{9}$. Эксплицируя имманентные свойства этого макрообъекта, О.М. Медушевская обращает внимание на принципиальную значимость

6 Литвак Б.Г. Очерки источниковедения массовой документации: XIX - начало XX в. М., 1979. С. 8; Массовые источники по социально-экономической истории России периода капитализма / Отв. ред. И.Д. Ковальченко. М., 1979. С. 6; подробнее см.: Источниковедение... С. 223-227.

${ }^{7}$ Например: Ковальченко И.Д. Крестьяне и крепостное хозяйство Рязанской и Тамбовской губерний в первой половине XIX в. (К истории кризиса феодально-крепостнической системы хозяйства). М., 1959; Ковальченко И.Д. Русское крепостное крестьянство в первой половине ХІХ в. М., 1967; Ковальченко И.Д., Селунская Н.Б., Литваков Б.М. Социально-экономический строй помещичьего хозяйства Европейской России в эпоху капитализма: источники и методы изучения. М., 1982.

${ }^{8}$ Медушевская О.М. Эмпирическая реальность исторического мира // Вспомогательные исторические дисциплины - источниковедение - методология истории в системе гуманитарного знания: Материалы XX международной научной конференции. Москва, 31 января - 2 февраля 2008 г. В 2 ч. М., 2008. С. 24-34; Медушевская О.М. Теория и методология когнитивной истории. М., 2008.

9 Медушевская О.М. Теория и методология... С. 48. 
объективации человеческого мышления в интеллектуальном продукте / историческом источнике: «Единство цели создания, структуры и функции составляет универсальное общее свойство любого интеллектуального продукта, созданного человеком, человеческим мышлением. Системообразующий принщип любого интеллектуального продукта универсален (выделено автором. - M.P.). Иначе говоря, человеческое мышление как особый феномен живой человеческой натуры имеет свое материальное, эмпирическое воплощение. И, следовательно, доступен человеческому познанию» ${ }^{10}$.

Таким образом, понимание того, что исторический источник объективирует индивидуума - во взаимосвязи с культурой, к которой тот принадлежит, через деятельность, направленную на создание обусловленного этой культурой интеллектуального продукта, — лежит в основе грамотного формирования репрезентативной источниковой базы научного исторического исследования.

Очевидны, на мой взгляд, концептуальные различия: определение исторического источника в рамках классического типа рациональности предполагает формирование источниковой базы по принципу «источник по истории», а неоклассическая модель науки предусматривает, в первую очередь, обращение к источникам, порожденным исследуемой деятельностью.

Конечно же, нельзя не признать, что формула «источники по истории» является устоявшейся, практически приобретшей характер клише; впрочем, как и многие дискурсивные штампы классического типа рациональности, зачастую используемые без какой-либо рефлексии. Источники истории, вероятно, несколько неуклюжее выражение (или пока непривычное?), но за неимением лучшего мы использовали его, в частности, при подготовке двух учебных пособий, представлявших понимание источниковедения как метода, как научной дисциплины / субдисциплины исторической науки и как научного направления - Научно-педагогической школой источниковедения. Выражение «источники российской истории» вошло и в название одного из них ${ }^{11}$.

Итак, мы обозначили позицию: в рамках неоклассической феноменологической концепции источниковедения источниковую основу исследования любого исторического феномена / деятельности акторов исторического

${ }^{10}$ Там же. С. 49. Цитаты приведены в точном соответствии с текстом книги, которая вышла в свет уже после кончины Ольги Михайловны и несет следы небрежности редактуры.

${ }^{11}$ Источниковедение: Теория. История. Метод. Источники российской истории: учебное пособие / И.Н. Данилевский, В.В. Кабанов, О.М. Медушевская, М.Ф. Румянцева. М., 1998 [доп. изд. 2000, 2004]; Источниковедение: учебное пособие / И.Н. Данилевский, Д.А. Добровольский, Р.Б. Казаков, С.И. Маловичко, М.Ф. Румянцева, О.И. Хоруженко, Е.Н. Швейковская; отв. ред. М.Ф. Румянцева. М., 2015 (2-е изд., испр. М., 2019). 
процесса составляют, в первую очередь, источники, порожденные этими акторами в ходе и как результат соответствующей деятельности.

Но история крестьянства создает дополнительные трудности... Для понимания их природы необходимо обратиться к одному их аспектов теории исторического процесса.

\section{«История» крестьянства в контексте теории исторического процесса}

Связующим звеном между источниковедением и теорией исторического процесса является тот неоспоримый факт, что история пишется преимущественно (практически - исключительно) по письменныл историческим источникам. Точнее - не сам факт, а понимание природы этого историографического феномена.

Еще в конце XIX в. Ш.-В. Ланглуа (1863-1929) и Ш. Сеньобос (18541942) в «Введении в изучение истории» (1898) зафиксировали знаменитую формулу: «История пишется по документам. Документы - это следы, оставленные мыслями и действиями некогда живших людей... Всякая же мысльь и всякий поступок, не оставивший прямого или косвенного следа, или видимый след которого исчез, навсегда потерян для истории, как если бы он никогда не существовал (выделено мной. - М.P.)... Ничто не может заменить документов: нет их, нет и истории» ${ }^{12}$. Правда, Л. Февр (1878-1956), например, подверг эту формулу сокрушительной критике: «“Историю изучают при помощи текстов”. Знаменитая формула: и по сей день она не утратила всех своих достоинств, а они, без сомнения, неоценимы. Честным труженикам, законно гордящимся своей эрудицией, она служила паролем и боевым кличем в сражениях с легковесными, кое-как состряпанными опусами. Но, если вдуматься, формула эта представляется опасной: она как бы противостояла общему направлению различных, но действующих заодно гуманитарных дисциплин. Она предполагала тесную связь между историей и письменностью (выделено мной. - М.Р.)»» ${ }^{13}$.

Эту мысль в контексте своей концепции когнитивной истории развивает и О.М. Медушевская: «Вещественная природа культурных объектов едина для всего исторического процесса. Общая цель их создания - фиксирование информационного ресурса, овеществление его. При данном подходе снимается то неправомерное противопоставление различных исторических

${ }^{12}$ Ланглуа Ш.-В., Сеньобос Ш. Введение в изучение истории. 2-е изд. М., 2004. С. 49.
${ }^{13}$ Февр Л. Суд совести истории и историка // Февр Л. Бои за историю. М., 1991. С. 11. 
эпох в истории человечества, которое выражено в дописьменной эпохе (собственно неисторической) как альтернативе эпохам последующим» ${ }^{14}$.

Не буду вступать здесь в полемику ни с Л. Февром, ни с О.М. Медушевской, ни с другими авторами, разделяющими этот скепсис по отношению к особой роли письменных исторических источников, но - даже при полном согласии с концепцией Медушевской - невозможно не признать значение письменных исторических источников в историческом познании. Для понимания этого значения достаточно хотя бы бегло взглянуть на источниковую базу любой научной работы по истории.

Обоснование деления народов / культур на исторические и неисторические выстраивали многие выдающиеся мыслители: Г.В.Ф. Гегель, Э. Гуссерль, К. Ясперс. А ближе к концу ХХ в. представители трех разных историографических культур предложили свои оригинальные, но явно имеющие общую основу, концепции деления культур: на письменную и бесписьменную (Ю.М. Лотман), историю и память (П. Нора), разные типы памяти память-воспоминание / память-повторение (П. Хаттон).

И здесь важно понять, что этот раздел проходит не только между разными народами (например, европейцами с их пресловутым европоцентризмом и папуасами, которых изучал Н.Н. Миклухо-Маклай), а и - по крайней мере, вплоть до ХХ в. - между исторической частью народа и «безмолвствующим большинством» (выражение А.Я. Гуревича).

И на этой проблеме - деления народов на исторические и неисторические - не буду останавливаться сколько-нибудь подробно: любую из этих концепций можно оспорить, но каждая из них качественно разработана ее автором и имеет системное подтверждение. Обращусь только к размышлениям Ю.М. Лотмана (1922-1993), поскольку именно он сосредоточил внимание на письменном механизме фиксации культуры исторического типа. Лотман афористично утверждал: «Можно сказать, что история - один из побочных результатов возникновения письменности» ${ }^{15}$. Автор выделял/ противопоставлял два типа культур (обладающих социальной памятью разного типа): традиционную, основанную на обряде, и историческую, казуальную по содержанию и письменную по механизму фиксации. При этом известный советский культуролог подчеркивал корректность понятия бесписьменная культура в противовес понятию — дописьменная.

${ }^{14}$ Медушевская О.М. Теория и методология... С. 49.

${ }^{15}$ Лотман Ю.М. Альтернативный вариант: Бесписьменная культура или культура до культуры? // Лотман Ю.М. Внутри мыслящих миров: человек - текст - семиосфера история. М., 1996. С. 345. 
И проблема в том, что крестьянство на протяжении практически всей своей истории (за исключением, может быть, XX в.) почти не оставляет письменных источников. Или, - скажем предельно осторожно, - корпус письменных исторических источников, порожденных крестьянством, неизмеримо меньше массивов письменных исторических источников, порожденных иными социальными общностями - теми социальными общностями, которые непосредственно вовлечены в исторический процесс.

\section{Апробация}

Для апробации теоретических размышлений обратимся к историографии по истории крестьянства, к ее источниковой базе. Я, естественно, ни в коей мере не претендую на полноценный историографический анализ (и даже обзор) - эта часть работы выполнена, можно сказать, в духе модных нынче case studies, а проще говоря, - рассмотрим образцы историографии, уже признанные классическими. Причем, оставим вне поля зрения труды по социально-экономической истории. Их источниковую базу кратко, но весьма емко охарактеризовала Е.Н. Швейковская: «Проблемы решались в основном на материале источников, из которых можно извлечь более или менее массовые данные, пригодные для количественной обработки и статистических выкладок, получения временных сопоставительных срезов, их анализа и построения моделей. Можно сказать, что в области социально-экономических исследований преобладали работы, сходные с исследованиями этапа “сериальной”, социально-структурной истории в зарубежной историографии» ${ }^{16}$. Я уже упоминала труды И.Д. Ковальченко о крестьянстве, - точнее, об аграрном строе, - XIX в. Характеристику, данную Е.Н. Швейковской, подтверждает и Л.В. Милов (1929-2007): «Проведено фронтальное исследование производственных возможностей крестьянского хозяйства практически на всей европейской территории расселения великорусского этноса. Опорой для такой проработки был материал XVIII столетия, то есть наиболее раннего периода, по которому была бы возможна перспектива создания прочной и полной источниковой базы, способной охарактеризовать все стороны сельскохозяйственной деятельности социума» ${ }^{17}$. И это неслучайно: именно в XVIII в. Российское государство проявляет интерес к своей экономике и народонаселению, в результате

${ }^{16}$ Швейковская Е.Н. Русский крестьянин в доме и мире: Северная деревня конца XVIначала XVIII века. М., 2012. С. 7.

${ }^{17}$ Милов Л.В. Великорусский пахарь и особенности российского исторического процесса. М., 1998. Аннотация. 
чего создаются мощные системы учетной документации (например, ревизский учет) и начинается становление статистики. В целом же, хотя мы, ориентируясь на название книги, вправе ожидать исследование истории крестьянства, но истории именно крестьянства посвящены, по сути, лишь отдельные, хотя и очень тонкие, и интересные, наблюдения.

Присмотримся к трудам по социокультурной истории, или, - точнее, новой социальной истории. Для компенсации отсутствия системности в рассмотрении историографии замечу, что Е.Н. Швейковская охарактеризовала, по сути, этап второго поколения Школы «Анналов», а мы обратимся сразу к этапу третьего поколения.

И здесь не могу не начать с абсолютной классики - книги Э. Ле Руа Ладюри «Монтайю. Окситанская деревня (1294-1324)», опубликованной в 1975 г. ${ }^{18}$ Описание источниковой базы исследования по истории крестьянства автор дает в первых строках предисловия к работе, которое носит примечательное название «От инквизиции к этнографии». В этом названии объединены две составляющих предложенных выше теоретических размышлений: в основе исследования - материалы инквизиции, т. е. источники, порожденные отнюдь не крестьянской средой; эти источники дают возможность изучения этнографии, но не истории окситанской деревни.

Характеризуя источниковую базу истории крестьянства Э. Ле Руа Ладюри пишет: «Для того, кто хотел бы понять крестьянина давних и стародавних времен, нет недостатка в крупных обобщающих трудах регионального, национального, западноевропейского масштаба... Единственно порой недостает взгляда прямого: неопосредованного свидетельства крестьянина о самом себе (выделено мной. - M.P.)» ${ }^{19}$. Автор продолжает: «Для периода после 1500 года я искал такой взгляд у мемуаристов». А что касается первой четверти XIV в. - периода, исследуемого в работе «Монтайю...», то «к счастью для нас и к несчастью для них, в XIV ... веке был человек, который дал высказаться поселянам и даже изелой деревне как таковой (выделено мной. - M.Р.)». Речь идет о епископе Жаке Фурнье (будущем папе Римском Бенедикте XII): «Как этнограф и блюститель порядка, он во время своего епископата сумел выслушать [sic!] крестьян графства Фуа, и в особенности верхней Арьежи; он дал вкусить им хлеба скорби и воды терзаний, но пытками не увлекался [sic!]; он допрашивал [sic!] их въедливо и подолгу, вытравливая в их среде катарскую ересь и просто отклонения от официального католицизма. Его слушание дошло до нас в виде

\footnotetext{
18 Ле Руа Ладюри Э. Монтайю. Окситанская деревня (1294-1324). Екатеринбург, 2001.

${ }^{19}$ Там же. С. 6.
} 
объемистого латинского (обратим внимание и на язык источника. - M.P.) манускрипта... Таким образом, в распоряжении историков и латинистов оказалось свидетельство окситанской земли о самой себе [sic!]; свидетельство, далеко выходящее за рамки узкой сферы гонений на ересь» ${ }^{20}$. Не стоит продолжать источниковедческий комментарий, тем более что особенности источниковой базы действительно замечательной репрезентации Э. Ле Руа Ладюри отмечали многие критики его работы. Аналогичная источниковая база и в основе другого классического исследования - книги Карло Гинзбурга о мельнике XVI в. ${ }^{21}$

Традицию изучения культуры средневекового крестьянства подхватывает А. Я. Гуревич (1924-2006). Его работа в рамках нашей темы имеет особый смысл, поскольку понятие «безмолвствующее большинство» (читаем - бесписьменное) вынесено автором в название книги «Средневековый мир...»22. Интересующая нас работа была опубликована в 1990 г., но опыт историко-антропологического исследования к этому времени у А.Я. Гуревича уже был значительный. Любопытна характеристика, данная российскому ученому одним из авторитетных исследователей истории культуры П. Бёрком (р. 1937): «Один из ранних примеров обращения к антропологии имел место в тогдашнем Советском Союзе. Российский медиевист Арон Гуревич, специалист по Скандинавии, первоначально был ориентирован на аграрную историю, но постепенно его стало интересовать понимание собственности в раннесредневековых Норвегии и Исландии. В поисках объяснения устойчивой системы передачи движимого имущества он обратился к антропологии» ${ }^{23}$.

А.Я. Гуревич в работе «Средневековый мир...» отмечает иной темп истории «безмолвствующего большинства»: «Мироощущение, видение мира человека аграрного по своей природе общества изменялось несравненно медленнее, нежели культура людей образованных, — оно изменялось, но ритмы изменений были совершенно иными» ${ }^{24}$. Характеризуя источниковую базу и метод своей работы, А.Я. Гуревич пишет: «Содержание духовной жизни простолюдина, крестьянина, горожанина, монаха, приходского священника в той мере, в какой оно может быть обнаружено в средневековых текстах

${ }^{20}$ Там же. С. 6-7.

${ }^{21}$ Гинзбург К. Сыр и черви: картина мира одного мельника, жившего в XVI веке. M., 2000.

${ }^{22}$ Гуревич А.Я. Средневековый мир: культура безмолвствующего большинства. М., 1990.

${ }^{23}$ Бёрк П. «Антропологический поворот» в гуманитарных науках: индивидуальные версии и конфигурация целого // Новое литературное обозрение. 2005. №5 (75) (URL: https:// magazines.gorky.media/nlo/2005/5/istoricheskaya-antropologiya-i-novaya-kulturnaya-istoriya. $\mathrm{html}$ (дата обращения - 30.01.2021)).

${ }^{24}$ Гуревич А.Я. Средневековый мир... С. 10. 
разного происхождения (выделено мной. - M.P.)... такова тема очерков» ${ }^{25}$. Автор уточняет: «Из среды крестьян до нас, естественно [sic!], почти вовсе ничего не дошло (выделено мной. - M.P. ${ }^{26}$ ), и они оставались "безмолвствующим большинством" средневекового общества. Источники, исходящие от представителей социальных верхов, также очень скупо упоминают крестьян, - кроме тех случаев, когда речь идет об их повинностях, формах зависимости или неповиновении» ${ }^{27}$. Но и источники, вышедшие из среды «социальных верхов» (а я бы добавила: источники, - в значительной степени государственного происхождения) не многое сообщают о крестьянах: «Существование крестьянства, простого люда молчаливо предполагается источниками, но прямо о нем почти не говорят. Далеко не всегда ясно, идет ли речь в том или ином тексте о крестьянах, и только о них, ибо в сравнительно редких случаях, когда, казалось бы, передаются сведения именно такого рода, авторами источников, представляющих для нас особый интерес, являются не крестьяне (выделено мной. - М.P.)» ${ }^{28}$. И в границах проблематики своего исследования А.Я. Гуревич резюмирует: «Крестьянин словно “вынесен за скобки". Если он даже и подразумевается в литературных текстах эпохи, то о нем не было нужды и привычки думать или упоминать» ${ }^{29}$.

Елена Николаевна Швейковская, изучая северную русскую деревню, преимущественно XVII в., вовлекает в исследование обширнейший корпус исторических источников. В книге «Государство и крестьяне России. Поморье в XVII веке» это материалы РГАДА: столбцы и книги приказного делопроизводства (в том числе Устюжской четверти) из фонда «Приказные дела старых лет» (ф. 141); финансово-налоговые материалы центральных и местных учреждений (ф. 137); писцовое описание 1625 г. (ф. 1209). Особую группу составили акты, фиксировавшие сделки крестьян: купчие, меновые, закладные $\mathrm{e}^{30}$. Такой подбор источников - преимущественно государственного происхождения - вполне соответствует проблематике книги, обозначенной уже в названии — «Государство и крестьяне...».

Обращаясь к истории повседневности русского крестьянина в рамках новой социокультурной истории в работе «Русский крестьянин в доме и мире...», Е.Н. Швейковская подчеркивает: «Предпринимаемое исследо-

${ }^{25}$ Там же. С. 13.

${ }^{26}$ Как историк-архивист по квалификации, не могу не оспорить дискурс А.Я. Гуревича: не «не дошло», а не было создано.

${ }^{27}$ Гуревич А.Я. Средневековый мир... С. 16.

${ }^{28}$ Там же.

${ }^{29}$ Там же. С. 18.

${ }^{30}$ Швейковская Е.Н. Государство и крестьяне России. Поморье в XVII веке. М., 1997. C. $8-9$. 
вание диктует свои требования к источниковой информации, которая добывается не путем увеличения ее количества, а за счет качественно иного, чем это практиковалось в историографии ранее, набора задаваемых источникам вопросов (выделено мной. - M.P.)» ${ }^{31}$. При всей несомненности этого утверждения для реализации исследования по истории повседневности автор не только углубляет источниковедческий анализ, но и расширяет круг исторических источников, вовлеченных в исследование. Е.Н. Швейковская подчеркивает, что «пристального внимания заслуживают документы и сведения, возникшие непосредственно в крестьянской среде (выделено мной. - M.P.) $)^{32}$ ». К этой группе можно отнести используемые в работе документы земских миров (в частности, «расходные [книги] земских миров середины - конца XVII в. - черносошных Тотемского, Сольвычегодского, Устюжского у[ездов]»), акты межкрестьянских поземельных сделок конца XVI - конца XVII в., челобитные крестьян уездным воеводам и в Устюжскую четверть, а также церковно-монастырским властям. Но все же основу исследования в значительной степени составляют источники отнюдь не крестьянского происхождения: документация XVII в. центральных учреждений — четвертей и уездных приказных изб; законодательные источники (Русская Правда, Судебники 1550 и 1589 гг, узаконения за период 1550-1649 гг., Соборное уложение 1649 г.), писцовые книги 16221625 гг. Сольвычегодского уезда, подворная ландратская перепись 1717 г. Вологодского уезда, судебные дела, а также Стоглав 1551 г. и Домострой ${ }^{33}$.

Перейдем к более близким к нам временам. Для нашей темы значительный интерес представляет работа Марины Михайловны Громыко (19272020 ) «Мир русской деревни» ${ }^{34}$. Работа имеет популярный характер (об этом свидетельствует и издательство - «Молодая гвардия»), что не отменяет ее научную фундированность, однако не дает возможности в полной мере эксплицировать источниковую базу исследования. Но в обращении к читателю «Предварительный разговор» (своего рода Введение), отвечая потенциальному оппоненту, утверждающему сложность, если не невозможность, воспроизведения крестьянской истории, М.М. Громыко пишет (весьма пафосно): «Ошибаетесь, коллега. Вы принимаете желаемое за действительное. Сохранилось и лежит в архивах (а иные материалы опубликованы еще в прошлом веке) множество описаний современников, подробнейиих отве-

${ }^{31}$ Швейковская Е.Н. Русский крестьянин в доме и мире: северная деревня конца XVI начала XVIII века. М., 2012. С. 11.

${ }^{32}$ Там же.

${ }^{33}$ Там же. С. 11-12.

${ }^{34}$ Громыко М.М. Мир русской деревни. М., 1991. 
тов на программы различных научных обществ (выделено мной. - M.Р.), решений общинных сходок, прошений, писем и других документов, по которым можно очень подробно представить жизнь старой деревни». И особо выделяет «публикации современников, непосредственно наблюдавших [sic!] тогдашнюю деревню» ${ }^{35}$.

\section{Вывод}

Опираясь на изложенные выше теоретические подходы, — как из сферы источниковедения, так и теории исторического процесса, - мы вынуждены признать, что история крестьянства в определенном смысле неисторична. Или, - скажем аккуратнее, — обладает иной степенью историчности, чем традиционная (это важно подчеркнуть!) история событий. Таким образом, изучение крестьянства в историческом процессе предполагает обращение, по большей части, к источникам, вышедшим из иной социальной и культурной среды, что, несомненно, требует от авторов работ по истории крестьянства - и особенно в рамках культурной истории социального, в том числе и истории повседневности, - не только тщательного соблюдения алгоритма работы с историческим источником, предполагающим особое внимание к его авторству и породившей его социальной и культурной среде, но и изощренных методик анализа и изощренных подходов к интерпретации источников, в том числе (и в первую очередь?) порожденных иной/инаковой по отношения к крестьянству социокультурной средой.

\section{Литература}

Бёрк П. «Антропологический поворот» в гуманитарных науках: индивидуальные версии и конфигурация целого // Новое литературное обозрение. 2005. № 5(75) (URL: https://magazines.gorky.media/nlo/2005/5/istoricheskaya-antropologiya-inovaya-kulturnaya-istoriya.html).

Гинзбург К. Сыр и черви: картина мира одного мельника, жившего в XVI веке. М., 2000

Громыко М.М. Мир русской деревни. М., 1991.

Гуревич А.Я. Средневековый мир: культура безмолвствующего большинства А.Я. Гуревич. М., 1990.

Гуссерль Э. Философия как строгая наука // Логос: международный ежегодник по философии культуры. М., 1911. Кн. 1. С. 156.

${ }^{35}$ Там же. С. 8. 
Источниковедение: Теория. История. Метод. Источники российской истории: учебное пособие / И.Н. Данилевский, В.В. Кабанов, О.М. Медушевская, М.Ф. Румянцева. М., 1998.

Источниковедение: учеб. пособие / И.Н. Данилевский, Д.А. Добровольский, Р.Б. Казаков, С.И. Маловичко, М.Ф. Румянцева, О.И. Хоруженко, Е.Н. Швейковская; отв. ред. М.Ф. Румянцева. М., 2015 (2-е изд., испр. М., 2019).

Ковальченко И.Д. Крестьяне и крепостное хозяйство Рязанской и Тамбовской губерний в первой половине XIX в. (К истории кризиса феодально-крепостнической системы хозяйства). М., 1959.

Ковальченко И.Д. Русское крепостное крестьянство в первой половине XIX в. М., 1967.

Ковальченко И.Д. Социально-экономический строй помещичьего хозяйства Европейской России в эпоху капитализма: источники и методы изучения / И.Д. Ковальченко, Н.Б. Селунская, Б.М. Литваков. М., 1982.

Ланглуа Ш.-В. Введение в изучение истории. 2-е изд. М., 2004.

Ле Руа Ладюри Э. Монтайю. Окситанская деревня (1294-1324). Екатеринбург, 2001.

Литвак Б.Г. Очерки источниковедения массовой документации: XIX — начало XX в. М., 1979.

Лотман Ю.М. Альтернативный вариант: Бесписьменная культура или культура до культуры? // Лотман Ю.М. Внутри мыслящих миров: человек - текст - семиосфера - история. М., 1996. С. 344-356.

Лубский А.В. Альтернативные модели исторических исследований. М., 2005.

Массовые источники по социально-экономической истории России периода капитализма / [В.И. Бовыкин, С.В. Воронкова, А.Г. Голиков и др.]; отв. ред. [и авт. предисл.] И.Д. Ковальченко. М., 1979.

Медушевская О.М. Теория и методология когнитивной истории. М., 2008.

Медушевская O.M. Эмпирическая реальность исторического мира // Вспомогательные исторические дисциплины - источниковедение - методология истории в системе гуманитарного знания: Материалы XX международной научной конференции. Москва, 31 января - 2 февраля 2008 г. В 2 ч. М., 2008. С. 24-34.

Милов Л.В. Великорусский пахарь и особенности российского исторического процесса. М., 1998.

Теория и методология исторической науки: терминологический словарь / Отв. ред. А.О. Чубарьян, Л.П. Репина. 2-е изд., испр. и доп. М., 2016.

Февр Л. Суд совести истории и историка // Февр Л. Бои за историю. М., 1991. С. 10 23.

Швейковская Е.Н. Государство и крестьяне России. Поморье в XVII веке. М., 1997.

Швейковская E.H. Русский крестьянин в доме и мире: северная деревня конца XVI - начала XVIII века. М., 2012.

Шмидт С.О. О классификации исторических источников // Вспомогательные исторические дисциплины. Л., 1985. Вып. 16. С. 3-24. 


\section{М.Б. Свердлов}

\section{ЧЕЛОВЕК И ЗАКОН НА РУСИ ПЕРВОЙ ТРЕТИ ХІІ В. ${ }^{1}$}

Аннотация Автор исследует историю судебного натурального и денежного штрафа за преступление, его нравственное и социальное содержание с VI до первой трети XII в. в позднем племенном славянском обществе и раннесредневековом Русском государстве в контексте истории содержания Правды Русской. Он анализирует содержание социальной и правовой политики в киевское великое княжение Владимира Мономаха (1113-1125) и, вероятно, его сына Мстислава (1125-1132). Вероятно, тогда была издана Пространная Правда Русская. Она обеспечила правовую защиту всех слоев населения, в том числе женщин, детей, бедных людей, на основах социальной справедливости и принципов Евангелия. В ней были сохранена древняя гуманная традиция денежного штрафа за преступление, вместо членовредительства и смертной казни, которые были распространены в Византии и в средневековых государствах Западной Европы.

Ключевые слова: Правда Русская, судебный штраф, преступление, князь Владимир Мономах, социальная политика, правовая политика, социальная справедливость, мораль, Евангелие.

Summary The author studies the history of the judicial natural and money forfeit for the criminal offence, moral and social content of this criminal offence in the late tribal Slavic society and in early medieval Russian state the context of the history of the Pravda Russkaya's content. He analyzes the content of the social and legal policy during the rule of Grand Prince Vladimir Monomakh in Kiev or the rule of his son Mstislav. Probably at that time the Vast Pravda Russkaya was issued. It made judicial rights secured of all social strata including women, children, poor men on the principles of social justice and the Evangel. It kept old human tradition of the money forfeit for a crime instead of to cut off any limb or to execute as in Byzantine and in medieval vest European countries. Keywords: Pravda Russkaya, judicial forfeit, criminal offence, Prince Vladimir Monomakh, social policy, legal policy, social justice, morality, the Evangel.

1 Исследование выполнено при финансовой поддержке РФФИ, проект № 20-09-00134. 
За 50-летний период знакомства и последующего сотрудничества с Еленой Николаевной Швейковской в Институте истории СССР АН СССР (ныне ИРИ РАН), в Ленинградском отделении, научным сотрудником которого являлся автор этих строк, а также участия в одной секции Симпозиума по аграрной истории Восточной Европы, многократно убеждался в обширности ее научных интересов от истории русской общины до истории Русского государства и права, начиная с XII в. Памятен ее положительный отзыв в качестве члена редакции журнала «История СССР» о моей статье, посвященной древнерусской семье и общине. Она была издана в этом журнале в 1981 г., а в 1982 г. перепечатана из него в переводе в США. Поэтому я благодарен за возможность посвятить Елене Николаевне Швейковской новую статью 40 лет спустя.

Текстологической основой данной статьи является исследование «От закона Русского к Русской Правде», дважды переизданного в немного отредактированном виде ${ }^{2}$. В соответствии с новейшими тенденциями в истории исторической науки ${ }^{3}$ в данной статье особое внимание уделено человеческому фактору в истории государства и права.

Князь Владимир Всеволодович Мономах (1053-1125), который после правления в Чернигове и Переяславле вокняжился в 1113 г. в Киеве и стал во главе еще сохранявшего относительное политическое единство Русского (Древнерусского) государства ${ }^{4}$, написал, вероятно, в 1117 г. «Поучение». Оно было обращено не только к своим детям, но также к родичам, князьям Рюриковичам. В «Поучении» содержались слова, вдохновленные евангельскими заповедями: «Избавити обидима, судите сироть, оправдаите вдовицю... Всего же паче убогых не забываите, но елико могуще по силь кормите, и придаите сиротъ, и вдовицю оправдите сами, а не вдаваите силным погубити человъка». Поделился он и своим жизненным опытом, в частности, в управлении государством и в суде: «Тако похвалю Бога! И сьдше

2 Свердлов М.Б. От Закона Русского к Русской Правде. М., 1988; то же с небольшими редакционными изменениями: Правда Русская. История текста. Великий Новгород, 2015; Свердлов М.Б. «Правда Русская». История текста // Свердлов М.Б. Латиноязычные источники по истории Древней Руси IX-XIII вв. Германия. «Правда Русская»; История текста. Избранные статьи. СПб., 2017. С. 331-485; см. там же текстологический анализ и историографию исследуемых проблем.

3 Свердлов М.Б. Историческое исследование и историческая антропология (к характеристике нового метода изучения истории средневековой России) // Петербургский исторический журнал. 2020. № 2. С. 177-188.

${ }^{4}$ Понятие «Русская земля» в его изначально многоэтничном, географическом и политическом содержании использовалось в русской письменности XI-XIII вв. Социально-политические, экономические, политические и этнокультурные термины с определением «древнерусский» относятся к научной лексике, распространившейся в XX в. 
думати с дружиною, или люди оправливати». Для тех, кто недостаточно знает древнерусский язык, следует привести перевод Д.С. Лихачевым этого текста: «Так я хвалю Бога и тогда, когда сажусь думать с дружиною, или собираюсь творить суд людям». В завершении этой темы Владимир вернулся к своей защите тех, кто в ней нуждался: «Тоже и худаго смерда и убогыъ вдовиць не далъ есмъ силным обидьти» ${ }^{5}$.

Эти слова Владимира Мономаха постоянно привлекали внимание исследователей в связи с определением значения князя в управлении Русским государством и княжеским участием в его судебной системе первой трети XII в. Они значимы также в связи с тем, что преемником Владимира на киевском столе стал его сын Мстислав Великий (1125-1132 гг.), продолжатель внутренней и внешней политики отца.

С.М. Соловьев, характеризуя княжескую деятельность Владимира Мономаха, ограничился переводом и интерпретацией приведенного ранее текста его «Поучения»: «Мономах не давал сильным обижать ни худого смерда, ни убогой вдовицы, сам оправливал (давал правду, суд) людей. При грубости тогдашних нравов люди сильные не любили сдерживать своего гнева, причем подвергнувшийся ему платил жизнью» ${ }^{6}$.

В конце XIX - начале XX в., когда в российской исторической науке большое внимание стало уделяться социальным и экономическим процессам, В.О. Ключевский особое внимание уделил анализу объективно сформировавшейся сложной структуры Правды Русской. По его мнению, ее древнейшие части выражали «интересы и отношения состоятельных городских классов, т. е. отношения холопо-владельческого и торгово-ремесленного мира». Поэтому он назвал Правду Русскую «кодексом капитала». Участие Владимира Мономаха в истории ее текста он обоснованно видел в ограничении ростовщических процентов, а также в отсутствии свойственной византийскому праву смертной казни ${ }^{7}$. Младший современник В.О. Ключевского А.Е. Пресняков под влиянием событий Первой русской революции 1905-1907 гг. охарактеризовал в своих лекциях 1907-1908 гг. содержание законодательства Владимира Мономаха как отражения в княжом праве «народного движения» против «эксплуататорских инстинктов» «социальных верхов киевского общества». По словам

5 Владимир Мономах. Поучение / Подгот. текста О.В. Творогов, пер. и коммент. Д.С. Лихачева // Библиотека литературы древней Руси. СПб., 1997. Т. 1: XI-XII века. С. 458, 460, 462, $464,465,538-540$.

6 Соловьев С.М. История России с древнейших времен. М., 1959. Кн. 1. С. 372.

7 Ключевский В.О. Сочинения. В 8 т. М., 1956. Т. 1: Курс русской истории. С. 225-247. 
историка, «уставы Мономаха были актом самозащиты социальных верхов от народного раздражения» ${ }^{8}$.

В советской историографии 30-х — начала 50-х гг., в период сталинского режима, Правда Русская характеризовалась преимущественно как законодательство классового государства - орудия угнетения одного класса другим, а правотворческая деятельность Владимира Мономаха - как выражение его демагогического «нищелюбия». В значительно смягченном виде его деяния сформулированы в годы хрущовской «оттепели»: после подавления киевского восстания 1113 г., князь «вынужден был законодательным путем несколько смягчить положение низов». Его закон о резах-процентах (см. далее) «стремился хотя бы декларативно облегчить положение должников и закупов», а его «Поучение» «выступает за установление классового мира» ${ }^{9}$. В постсоветское время близкая по содержанию характеристика была повторена: после вокняжения в Киеве Владимир Мономах «был вынужден принять меры по ограничению ростовщичества (злоупотребления ростовщиков вызвали Киевское восстание 1113 г.)» ${ }^{10}$.

Количество мнений, характеризующих правовое положение русских людей в связи с определением значения князя в управлении Русским государством и княжеским участием в его судебной системе в первой трети XII в., можно было бы значительно умножить. Но ранее приведенные суждения историков XIX - начала XXI в. свидетельствуют о том, что исследование данной научной проблемы нуждается в продолжении.

Чтобы раскрыть содержание правового положения русских людей в первой трети XII в., следует по необходимости кратко рассмотреть конкретное содержание становления системы русского (древнерусского права) к этому времени. Иначе будут неясны новации созданной тогда Пространной Правды Русской (ППР).

Уже в лексике праславянского периода (V-VI вв.) содержались основные понятия, относившиеся к суду и судопроизводству. Они продолжали существовать в лексике и древнерусского периода: *sodъ — 'суд', *zakonъ ‘закон', *pravo — 'право', *pravьda — 'правда'11. Эта лексика отражала

8 Пресняков А.Е. Княжое право в Древней Руси: очерки по истории Х-ХІІ столетий. Лекции по русской истории: Киевская Русь. М., 1993. С. 458.

9 Будовнии И.У. Владимир Всеволодович Мономах // Советская историческая энциклопедия. М., 1963. Т. 3. С. 526.

${ }^{10}$ Назаренко А.В. Владимир Всеволодович Мономах // Древняя Русь в средневековом мире: Энциклопедия. М., 2014. С. 132.

${ }^{11}$ Преображенский А.Г. Этимологический словарь русского языка. М., 1959. Т. 1. С. 241; Т. 2. С. 121, 129; Фасмер. Т. 2. С. 75; Т. 3. С. 352, 792; Брищын М.А. Из истории восточнославянской лексики. Киев, 1965. С. 83-95; Степанов Ю.С. Слова «правда» и «цивилизация» в русском языке // Известия АН СССР. Серия литературы и языка. 1972. Т. 31. Вып. 2. С. 171-172. 
также систему представлений, относившихся к правонарушениям и наказаниям за преступления ${ }^{12}$. Они представляли собой обычное право племен на поздней стадии их социального развития. Оно хорошо известно по записям начала IX в. германских племенных Правд, Саксонской, Фризской, Тюрингской, Правды франков-хамавов и более ранней Салической Правды. Эти Правды не содержат следов влияния римской правовой культуры или их крайне мало, хотя такие судебники сформировались на землях римской Галлии после образования Франкского государства ${ }^{13}$.

Праславянская и восточнославянская юридическая лексика свидетельствует о том, что в восточнославянских племенах, а в VIII-IX вв. в племенных княжениях также сформировались комплексы обычноправовых норм, которые становились обязательным к исполнению законом - восточнославянской племенной Правдой. В процессе формирования во второй половине IX - начале X в. Русского государства нормы этих племенных Правд становились законом молодого, изначально многоэтничного государства на огромном пространстве от Приладожья до Среднего Поднепровья. Его этнокультурную основу составляли восточные славяне, но правящими князьями являлись избранный ими на княжение конунг Рюрик Фрисландский и его потомки, которые в третьем поколении славянизировались. Византийский император Константин VII Багрянородный в середине X в. называл

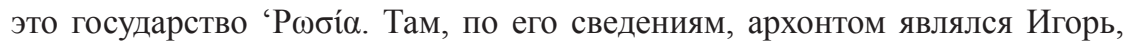
а в Новгороде находился его сын Святослав ${ }^{14}$.

Вероятно, в этом государстве во время полюдья ${ }^{15}$ правящей знатью осваивались и систематизировались обычноправовые нормы восточнославянских племенных княжений. Можно предположить, что они были обобщены в еще устной Правде Русской, которая в обратном древнерусском переводе с греческого языка русско-византийских договоров 911 и 944 гг. названа Закон Русский. Нормы устной Правды Русской, существовавшей в первой половине X в. и сохранившейся в практическим применении до первой половины XI в., учитывались при составлении так называемой Древнейшей Правды или Правды Ярослава.

${ }^{12}$ Иванов В.В., Топоров В.Н. Древнее славянское право: архаичные мифопоэтические основы и источники в свете языка // Формирование раннефеодальных народностей. М., 1981. С. 10-31.

${ }^{13}$ Неусыхин А.И. Возникновение зависимого крестьянства как класса раннефеодального общества в Западной Европе VI-VIII вв. М., 1956. С. 48-58.

${ }^{14}$ Константин Багрянородный. Об управлении империей: Текст, перевод, комментарий / Под ред. Г.Г. Литаврина, А.П. Новосельцева. М., 1989. С. 44, 45. О данных социально-политических и этнокультурных процессах, о процессе становления Правды Русской в X в. см.: Свердлов М.Б. Домонгольская Русь: Князь и княжеская власть на Руси VI - первой трети XIII в. СПб., 2003. С. 83-163; см. там же литературу.

${ }^{15}$ Там же. С. 50, 51. 
Указание Законом Русским (Правдой Русской) денежного штрафа как выкупа за совершенное преступление аналогично штрафам ранее названных германских Правд. Денежные штрафы за эти преступления содержатся и в Краткой Правде Русской (см. далее) ${ }^{16}$ в отличие от византийских законов с постановлениями в качестве наказаний о членовредительстве и смертной казни.

Русско-византийский договор 911 г. сообщает об активном участии киевских князей в регулировании русско-византийских политических и торговых отношений. При «великом князе русском» Олеге официальное положение послов удостоверялось золотыми печатями, а купцов - серебряными. Эти печати имели верительное значение. Серебряные подвески с геральдическим двузубцем первых Рюриковичей, Олега, Игоря, Святослава, найдены во время археологических исследований ${ }^{17}$. Как написано в договоре 944 г., «ныне же увьдЂль (повелел - перевод Д.С. Лихачева) есть князь вашь посылати грамоты ко царству нашему» (здесь и далее курсив в цитатах мой. M.C.). В этих грамотах должно было быть указано точное количество кораблей из Руси, чтобы в византийские власти знали, что они прибыли с миром. Суда без таких грамот будут задержаны, «донде же възвъстимъ князю вашему». В случае сопротивления такие люди будут убиты, а их смерть не должна быть «взыскана» от «князя вамего». Если они убегут на Русь, византийские власти напишут «князю вамему». Князь должен запретить своим послам и другим русским людям совершать «бесчинья» в Византии ${ }^{18}$.

Таким образом, в первой половине $\mathrm{X}$ в. русская и византийская договаривающиеся стороны исходили из того, что великий князь русский обладал значительными властными функциями, а нормы Закона Русского учитывались при регулировании правовых отношений.

Символом великокняжеской власти и иерархического подчинения на Руси в русско-византийском договоре 911 г. указана рука князя: «Мы от рода рускаго... иже послани от Олга, великого князя рускаго, и от всьх, иже суть под рукою его, свђтлых и великих князь и его великих бояръ». Рука как символ покровительства, управления, власти имела такие смыслы еще в индоевропейский период ${ }^{19}$. Она сохранила эти значения у европейских народов индоевропейского происхождения и в средние века, на что обратил внимание

${ }^{16}$ Свердлов М.Б. «Правда Русская»... С. 359-381.

${ }^{17}$ Белеикий С. Древнейшая геральдика Руси // Повесть временных лет / Пер. Д.С. Лихачева, статья и коммент. А.Г. Боброва. СПб., 2012. С. 443.

${ }^{18}$ Повесть временных лет / Подгот. текста, перевод, статьи и коммент. Д.С. Лихачева. СПб., 1996 (далее - ПВЛ). С. 24.

${ }^{19}$ Indo-Eropean Culture / Ed. J.P. Mallory and D.Q. Adams. London and Chicago: Fitzroy Dearbory Publishers. W. Y. P. 254-255. 
еще Я. Гримм ${ }^{20}$. В странах Западной Европы рука стала составной частью церемониально-обрядового действа, символизирующего установление сеньориально-вассальных отношений.

Таким образом, в первой половине $\mathrm{X}$ в. в Русском государстве существовала система юридических норм, которые регулировали правовые отношения, в том числе при заключении русско-византийских договоров. Она называлась Правда Русская и существовала в устной форме.

После того как христианство стало государственной религией и была учреждена Русская митрополия, входившая в состав Константинопольской патриархии, в Русском государстве стало распространяться византийское культурное влияние, которое, впрочем, переосмыслялось в соответствии с русскими политическими и культурными потребностями ${ }^{21}$. В этом контексте произошло событие, на содержание которого историки древнерусского права обращали недостаточно внимания, лишь упоминая его.

В Повести временных лет (ПВЛ) под 6505/996 г. сообщается о том, что на Руси увеличилось число разбоев. Поэтому епископы, которые тогда были приезжими греками, спросили Владимира Святославича, почему он не казнит разбойников. В этом вопросе изложена одна из норм византийского права. Князь ответил: «Боюсь греха». Тогда епископы стали настаивать на осуществлении казней после судебного расследования. По этому совету Владимир отверг традиционные судебные денежные наказания виры. Но оказалось, что не хватает средств на обеспечение воинов оружием и конями. Так что Владимир по совету епископов и «старцев» вернулся к судебному взиманию вир 22 .

В этом литературном по форме повествовании содержится важная историческая информация. О ее достоверности как исторического источника свидетельствует отнесение А.А. Шахматовым данного текста к древнейшему Киевскому своду 1039 г. в редакции 1073 г. ${ }^{23}$ В данной связи следует поддержать возвращение А.А. Гиппиуса к анализу истории древнейшего летописания и к определению степени достоверности его известий ${ }^{24}$. О таком же социально-политическом назначении судебных штрафов, справед-

${ }^{20}$ Grimm J. Deutche Rechtsalterthümer. B., 1956. Bd. 1. S. 190-196.

${ }^{21}$ Соболевский А.И. Древнерусская переводная литература: Курс лекций / Издание подгот. Д.М. Буланин. СПб., 2019; История русской литературы X-XVII веков. М., 1980. С. 3659; Pannonopm П.А. Древнерусская архитектура. СПб., 1993. С. 28-45; и др.

${ }^{22}$ ПВЛ. С. 56.

${ }^{23}$ Шахматов А.А. Разыскания о древнейших русских летописных сводах. СПб., 1908. С. 570.

${ }^{24}$ Гиппиус A.A. До и после Начального свода: ранняя летописная история Руси как объект текстологической реконструкции // Русь в IX-X веках: Археологическая панорама. М.; Вологда, 2012. С. 36-62. 
ливых вир и продаж, которые взимали «древние князья», написал автор Начального свода (1093-1095 гг.). По его словам, князья давали эти деньги «дружинь на оружье» ${ }^{25}$.

Из этих сообщений следует, что византийские императоры, шурья киевского князя, и/или константинопольский патриарх попытались оказать воздействие на Владимира Святославича с тем, чтобы он ввел на Руси по византийскому образцу не только церковную организацию, но также законы. Но значение судебных денежных штрафов в пополнении княжеской казны и ее перераспределение для материального обеспечения служилых княжих людей было столь значительно, что Владимир Святославич сохранил эту древнюю по происхождению восточнославянскую систему. Тогда нормативную основу княжеского судопроизводства продолжала составлять устная Правда Русская.

С распространением и утверждением на Руси кириллицы, заимствованной из Первого Болгарского царства, как основной системы письменности появилась возможность излагать юридические постановления в письменном виде. Таким древнейшим сохранившимся памятником писаного права стала так называемая Правда Ярослава или Древнейшая Правда (Краткая Правда Русская - далее КПР, ст. 1-17; ст. 18, вероятно, была добавлена к основному тексту позднее $)^{26}$. Поводом для ее написания стала, вероятно, ситуация в Новгороде после восстания новгородцев в 1015 г,, направленного против насилий среди разместившихся в городе наемников-варягов, приглашенных Ярославом, который готовился к борьбе со своим двоюродным братом Святополком Ярополковичем, когда тот после смерти Владимира Святославича вокняжился в Киеве. О таком назначении Правды Ярослава свидетельствует ее содержание, ограниченное городской средой, конфликтными ситуациями в ней с участием варягов-скандинавов и колбягов (вероятно, купцов-финнов), что было свойственно Новгороду как центру торговли на северо-западе Восточной Европы. Основное содержание некоторых ее статей совпадало с нормами германских Правд Салической, Алеманской, Баварской. В них в равной мере за членовредительство, оскорбления, бегство зависимого человека (челядина), за нарушение прав собственности следовал денежный судебный штраф. Эти совпадения являлись следствием не заимствований,

\footnotetext{
${ }^{25}$ Новгородская первая летопись старшего и младшего изводов / Под ред. А.Н. Насонова. М.; Л., 1950. С. 104.

26 Здесь и далее академическое издание Правды Русской, ее деление на статьи см.: Правда Русская. Комментарии / Сост. Б.В. Александров, В.Г. Гейман, Г.Е. Кочин, Н.Ф. Лавров, Б.А. Романов. Под ред. Б.Д. Грекова. М.; Л., 1947. Т. 2; см. также последующие издания Правды Русской с делением на статьи в соответствии с данной публикацией.
} 
а близких по содержанию правовых отношений славян и германцев на раннегосударственной стадии социально-политического развития ${ }^{27}$.

Вероятно, правотворчество Ярослава Мудрого в его киевское княжение продолжалось. Был издан так называемый Домениальный устав (в научной литературе он ошибочно назван Правдой Ярославичей), защищавший судебными штрафами княжеское господское хозяйство, а также занятых в нем служилых и зависимых людей (КПР, ст. 19-40). В нем правонарушения последовательно наказывались судебным денежным штрафом. В конце правления Ярослава Древнейшая Правда была соединена с Домениальным уставом. Дополнены они были указанием отчислений княжим служилым людям, мечнику и емцу, законом, который обеспечивал вирника во время сбора им виры, а также постановлением для мостников (КПР, ст. 41-43). Правотворчество Ярославичей и их доверенных служилых мужей заключалось в отмене мести за убийство и замене ее выкупом деньгами. Таким образом, они абсолютизировали в писаном праве древнее гуманное право выкупа за убийство.

При этом древнерусские правоведы особо отметили, что все остальные нормы остались без изменений, как Ярослав судил, так и сыновья его установили (ППР, ст. 2) ${ }^{28}$. Так сформировался писаный свод законов, которым руководствовались княжеские суды во второй половине XI в.

Между тем в это время после смерти Ярослава произошли значительные по последствиям события. Начали сказываться отрицательные следствия раздела Ярославом перед смертью своего обширного государства между сыновьями в отчину - наследственное владение по воле отца. Соседние русские княжества стали для князей «чужими». Они враждовали, а «чужие» княжества разоряли. Поэтому князья говорили в 1097 г. на Любечском съезде: «Почто губим Русьскую землю, сами на ся котору (распри. - М.С.) дъюше? А половци землю нашю несуть розно, и ради суть, оже межю нами рати. Да нонъ отсель имемся въ едино сердце, и блюдем Рускьъ земли; кождо да держить отчину свою» ${ }^{29}$.

Но продолжались наведения половцев на Русскую землю, разорения князьями соседних княжеств, совершались страшные преступления князей по отношению одного к другому. Распространилось своеволие княжих служилых людей не только в чужих, но и в своих княжествах. Как писал Владимир Мономах, «куда же ходяще путемъ по своимъ землямъ, не даите

\footnotetext{
${ }^{27}$ Свердлов М.Б. «Правда Русская»... С. 355-391.

${ }^{28}$ В этой гипотезе мы поддерживаем мнение А.А. Зимина (См.: Зимин А.A. Русская Правда // Советская историческая энциклопедия. М., 1969. Т. 12. Стб. 329).

${ }^{29}$ ПВЛ. С. $109-110$.
} 
пакости дъяти отрокомъ, ни своимъ, ни чюжимъ, ни в сельх, ни в житьх, да не клясти вас начнуть» ${ }^{30}$.

Тему бедствий Русской земли в новый период ее истории со знанием их конкретного содержания изложил автор Начального свода во времена киевского княжения Святополка Изяславича. По его словам, теперь князья собирают многие богатства, осуждают людей на выплату неправедных судебных вир и продаж. Жены княжих служилых людей ходят в золотых «обручах». За нашу ненасытность, продолжил летописец, Бог навел на нас «поганых» (язычников половцев), которые разоряют наши скот, села, имущество, «а мы своих злыхъ дълъ не останемъ» ${ }^{31}$. К тому же Святополк Изяславич покровительствовал ростовщикам, которые взимали немыслимые проценты. Был он корыстолюбивым и жестоким ${ }^{32}$.

Все эти его свойства стали причиной восстания киевлян против княжеской администрации Святополка, тысяцкого и сотских, против ростовщиков-евреев. Грабили дома всех этих людей. Опасность угрожала княжескому дворцу, боярским хоромам и монастырям, которые также могли разграбить. Поэтому «совет» киевлян, вероятно, людей знатных и богатых, обратился к Владимиру Мономаху с предложением стать князем в Киеве. Для этого были веские династические основания. Его отец, Всеволод Ярославич, до своей смерти в 1093 г. княжил в Киеве. Политическим основанием являлось то, что в 1093 г. Владимир Мономах добровольно уступил киевское княжение Святополку Изяславичу, представителю старшей княжеской ветви, чтобы не было распри за первенство, и 20 лет поддерживал Святополка как князя Киевского ${ }^{33}$. Представляется, что недавно появившаяся в научной литературе характеристика такого союза князей в особой династической и политической ситуации средневековой Руси как дуумвиров (дуумвират) терминологически некорректна. В республиканском и императорском античном Риме дуумвиры - члены подразделения структур управления, следствия или контроля. Оно состояло из двух мужчин с юридическими, религиозными или административными властными функциями. То есть, дуумвират относился к цивилизационно иной социально-политической системе управления.

После вокняжения в Киеве Владимир Мономах совместно с узким кругом представителей южнорусской знати постановил, чтобы тот, кто берет проценты на третий рез, т. е. 50\%, имеет право взять два реза, т. е. $100 \%$ от долга,

\footnotetext{
${ }^{30}$ Владимир Мономах. Поучение. С. 462.

${ }^{31}$ НПЛ. С. 104.

${ }^{32}$ Соловьев С.М. История России... Кн. 1. С. 399-400.

${ }_{33}$ Свердлов М.Б. Домонгольская Русь... С. 484-491; см. там же литературу.
} 
и саму сумму долга («исто»). Кто брал три реза от долга, т. е. 150\%, терял право на получение денег, данных в долг. 20\% долга (10 кун за год на гривну) разрешалось взимать, как и раньше. Таким образом, был отменен ненавистный «третной рез», но тяжелые формы ростовщичества оставлены. Верными представляются мнения о принадлежности к законодательству Владимира Мономаха только ранее приведенного постановления в ст. 53 ППР. Суждения о принадлежности к нему ст. 54, 55 ППР о возмещении утрат по вине доверенного лица в купеческих сделках вызывает сомнения ${ }^{34}$.

Отмена «третного реза» являлась срочной мерой Владимира Мономаха, нужной, чтобы успокоить киевлян. Но необходимость составления нового обобщающего свода законов осталась. Она обострялась еще и тем, что политическая структура Русского государства в первой трети XII в. оказалась двуединой. Оно было разделено, но его политические и этнокультурные основы утверждали единство. Только Рюриковичи могли быть правящими в своих княжествах. Единой являлась жестко централизованная структура Русский митрополии с центром в Киеве. Этнокультурную основу многоэтничного государства составлял русский народ, «язык русский» (древнерусский этнос). Летописи, разного рода материалы юридического и литературного содержания на всем этом обширном пространстве были написаны на литературном древнерусском языке. Так что Святополк Изяславич, пользовавшийся в период своего киевского княжения поддержкой Владимира Мономаха, сам Владимир Мономах, его сын и преемник Мстислав стремились сохранить особое значение Киева и его князя как объединяющих начал в русских землях.

Только после такого краткого изложения истории русского права в $\mathrm{X}$ XI вв. раскрывается в полной мере юридическое положение русского человека в первой трети XII в.

В сложнейших обстоятельствах этого времени Владимир Мономах или, вероятно, его сын Мстислав решили соединить русские земли единым источником права, Правдой Русской, чтобы жители разных княжеств находились в единой системе юридических норм. Этот источник права должен был объединить все предшествующее княжеское законодательство и современное для первой трети XII в. нормотворчество ${ }^{35}$. Такая задача была выполнена созданием Пространной Правды Русской.

Насколько хорошо она удовлетворяла позднее потребности регулирования правовых отношений, княжеских и новгородских республиканских су-

${ }^{34}$ Свердлов М.Б. «Правда Русская»... С. 444-452; см. там же историографию и текстологический анализ.

${ }^{35}$ Там же. С. 423-480. 
дов, свидетельствует включение ее в юридические сборники XIII-XV вв. Кормчие, Мерило Праведное, в Судебник Ивана III 1497 г. Она широко распространилась во всех землях Руси как основной источник светского права и стала одной из основ юридических норм, включенных в договоры XII-XIV вв. Новгорода и Смоленска с немецкими и ливонскими городами, с островом Готланд ${ }^{36}$. Списки ППР распространялись еще в XV-XVI вв.

В ст. 1 ППР объединены нормы ст. 1, 19, 22 КПР ${ }^{37}$. Как это характерно для средневековых компиляций, она сначала указала древнее право кровной мести, но далее регламентировала установленные еще в XI в. судебные виры 80 гривен за убийство высших княжеских должностных лиц, 40 гривен за жизнь княжих служилых людей среднего и низшего уровня, а также простых свободных людей. Но уже в ст. 2 ППР приведено постановление трех старших Ярославичей, Изяслава, Святослава и Всеволода, их доверенных мужей, о запрете кровной мести и замене ее княжеской судебной вирой при сохранении всех прочих установлений их отца (см. ранее).

Ст. 3 ППР объединила содержание ст. 19, 20 КПР о разбойном убийстве княжеского огнищанина, руководителя княжеского господского хозяйства, и распространила ее действие за убийство всех знатных служилых людей («мужей»), указывая виру за них в 80 гривен, тогда как за простых свободных она составляла 40 гривен. Таким образом, различие в их социально-правовом положении сохранялось в законодательстве последовательно.

В ст. 4-8 ППР новой стала регламентация отношений между государством, общиной-вервью и преступником, членом верви, в зависимости от видов убийства — «в разбое», «в обиду» и т. д. При этом были учтены административно-судебные функции общины в делах, касающихся сроков уплаты виры, виды участия в ней общинников. В этих статьях указывалось на необходимость уплаты виры общиной-вервью, где совершено убийство, если она не ищет или укрывает преступника. Таким образом, законодательно фиксировалась круговая ответственность общины-верви за убийство всех знатных служилых людей на ее территории.

Создавая совершенный для своего времени источник права, древнерусские правоведы перечислили в ст. 11-17 ППР людей княжеского господского хозяйства с указанием виры в 80 гривен за убийство тиуна огнищного

${ }^{36}$ Свердлов М.Б. Система русского права как основа международных договоров Руси X первой трети XIII вв. // От древней Руси к новой России: юбилейный сборник, посвященный чл.-корр. РАН Я.Н. Щапову. М., 2005. С. 109-122.

${ }^{37}$ По мнению А.П. Толочко, текст ППР первичен по отношению к КПР (Толочко $A$. Краткая редакция Правды русской: Происхождение текста. Київ, 2009). Такое мнение или следствие недоразумения, или свидетельствует об отсутствии у автора опыта в текстологии и историографии Правды Русской последних 90 лет. 
(огнищанина), тиуна конюшего, 40 гривен - за княжеского отрока, конюха, повара, а также судебных штрафов в 12 гривен - за сельского и пашенного тиуна, ремесленника и ремесленницы, кормильца и кормилицы, 5 гривен - за рядовича, смерда, холопа, 6 гривен - за «робу» (холопку). Такой широкий круг свободных и зависимых людей - следствие натурального господского хозяйства. При этом древнерусские правоведы в ст. 12-14, 16, 17 ППР повторяли и редактировали нормы ст. 24-27 КПР.

Данный комплекс статей о наказаниях за убийство завершался статьями 18-19 ППР о «Поклепной вире» - недоказанном обвинении в убийстве. В них уточнены формулировки и значительно смягчены наказания. В случае недоказанного обвинения достаточно было семи свидетелей, чтобы это обвинение отвести. Верви теперь не надо было платить за неопознанный труп, найденный на ее территории. В делах о воровстве и клевете при отсутствии реальных доказательств ответчик подлежал теперь Божьему суду «железом» или «водой» (ст. 22 ППР).

Основным источником ст. 23-31 ППР об оскорблении действием и телесных повреждениях являются соответствующие статьи КПР, нормы которой лишь редактировались при включении в ППР. Но решительно были изменены юридические права иноземцев. В особых условиях 1015-1016 гг. варягам и колбягам было достаточно произнести клятву в невиновности за толчки и удары в отличие от русских людей, обязанных предъявить двух свидетелей (ст. 10 КПР). Теперь они должны тоже представить на суде двух свидетелей (ст. 31 ППР).

В ст. 33-46 ППР о воровстве и следственных действиях в этой связи, в основном, корректировались и дополнялись соответствующие статьи КПР, тогда как ее ст. 47-52 о долговых и ростовщических операциях существенно расширили их нормативное содержание. А.А. Зимин отнес данный комплекс статей ко времени киевского княжения Святополка Изяславича, который покровительствовал ростовщикам ${ }^{38}$. Это мнение представляется в полной мере обоснованным. Неясно, впрочем, были эти постановления изданы Святополком в таком виде или санкции смягчились в результате последующего редактирования в киевское княжение Владимира Мономаха или его сына Мстислава.

Ст. 47, 48 ППР свидетельствует об активном вмешательстве государства в регламентацию норм обязательственного права, облегчая кредитору получение долга, регулируя долговые отношения между купцами. Ст. 49 ППР предоставляла ответчику, хранителю товара, право клятвы в свое оправда-

\footnotetext{
${ }^{38}$ Памятники русского права. М., 1952. Вып. 1 / Сост. А.А. Зимин. С. 159.
} 
ние в ответ на недоказанные требования владельца этого товара. Таким образом, закон управлял социально-экономическими процессами, сдерживая силы, ведущие к разрушению купеческих объединений, допуская совершение внутренних заемных операций без свидетелей.

Продолжением этих статей о взимании долга и денежных отношениях стали ст. 50-52 ППР о резах-процентах. Теперь должнику следовало выплачивать огромные проценты, но допускалось их ограничение (ст. 51). По ст. 52 в случае отсутствия свидетелей можно было произнести судебную клятву в подтверждение долга в три гривны. Если долг оказывался более значительным, то судья должен был сказать истцу: «Сам виноват, что давал в долг без свидетелей» (этот древнерусский текст ст. 52 сложен, поэтому приведен в современном переводе) $)^{39}$, т. е. княжеский суд стремился урегулировать стихию ростовщических операций. Но до восстания 1113 г. и вокняжения в Киеве Владимира Мономаха эти попытки были безуспешны ${ }^{40}$.

Ст. 53 ППР является принятым Владимиром законом о резах-процентах (см. ранее). В последующем тексте ППР ясно прослеживаются три комплекса статей, два из которых обоснованно названы в предшествующей научной литературе Уставами.

Ст. 56-62, 64 ППР - Устав о закупах. В соответствии с нашими исследованиями закупы - лично свободные крестьяне, которые попали в зависимость из-за невыплаченного денежного долга (купы), т. е. экономическим путем. Они могли иметь собственное хозяйство, коня и сельскохозяйственный инвентарь, но также взять их у господина в качестве подмоги. Все эти виды купы следовало отрабатывать с процентами. Господину разрешалось за бегство или тайный уход превращать закупа в холопы, т. е. лично зависимого, а также бить закупа «про дьло».

Но ППР защищала личность закупа, его права и имущество. Ему разрешалось открыто уходить в поисках княжеского суда, если господин его оскорблял, если закупу надо было найти деньги для возвращения долга, чтобы вернуть долг с процентами. Закупу не надо было платить за скот, если его украдут из запертого им хлева. Господин должен был заплатить штрафы по княжескому суду, если господин необоснованно увеличит долг (купу) закупа, нанесет вред его собственности. Если господин продаст закупа в полные холопы, то закуп освобождается от долга, а господин должен будет заплатить значительный штраф по княжескому суду. Если господин

\footnotetext{
${ }^{39}$ Свердлов М.Б. Пространная Правда Русская // Ярославский список Правды Русской. Законодательство Ярослава Мудрого / Сост. Н.А. Грязнова, Д.К. Морозов. Ярославль; Рыбинск, 2010. С. 83.

${ }^{40}$ Свердлов М.Б. «Правда Русская»... С. 444-447.
} 
бьет закупа без его вины, не соображая, или пьяный, то он должен заплатить по княжескому суду «яко же въ свободньмь».

Так в эпоху средневековья княжеский суд Владимира Мономаха и его сына Мстислава защищал права зависимого закупа, его личность и собственность, хотя, как и сейчас пишут в современной либеральной историографии, в раннее средневековье в феодальном хозяйстве «силой принуждения земельный сеньор преобразовывал свое владение во власть» ${ }^{41}$, а в марксистской историографии писали о «внеэкономическом принуждении».

ППР, ст. 110-121 - Устав о холопах. «Обельный» (полный) холоп не считался субъектом права. Но ППР конкретизировала виды превращения свободного человека в холопы. Это - добровольная самопродажа, женитьба на «робе» (холопке) и поступление на службу тиуном (управляющим господским хозяйством) без договора. Но в двух последних случаях ППР ограничивала превращение таких людей в холопы: можно было заключить с господином договор о сохранении им свободы. Она запрещала превращать должника в холопы, если должник отработает долг с процентами.

Ст. 88, 92-94 ППР защищали жизнь женщины такой же вирой, что и за убийство мужчины. ППР указывала обязанности детей к исполнению завещания отца по разделу его хозяйства. Если завещания не было, то хозяйство следовало разделить на всех детей. Они должны были выделить вдове часть наследства. Если часть наследства завещал жене муж, то она становилась «госпожой», т. е. полной владелицей этой части наследства. Дети от первой жены обязательно должны были получить наследство своей матери. Вероятно, в этих нормах княжеского закона отразилась мудрость и справедливость народного обычного права, а также евангельских заповедей.

Таким образом, юридические нормы ППР свидетельствует о том, что Владимир Мономах и его сын Мстислав действительно стремились к справедливому по средневековым понятиям регулированию социальных отношений, следуя также народным традициям и евангельским заповедям. Эти начала соответствовали их жизненным принципам. Впрочем, они допускали и свойственные Средневековью насилия над людьми зависимыми.

Этим принципам Владимир Мономах следовал и в своем «Поучении», определяя нормы повседневной и семейной жизни своих сыновей. По его словам, где бы они не находились, им следовало напоить и накормить нищего. Следовало с почестью принимать гостя, откуда бы он ни пришел и кем бы он ни был, от простого человека до знатного и посла. Его следова-

${ }^{41}$ Альбертони Дж. Феодальное хозяйство и сельская сеньория // Цивилизация Средневековья: энциклопедия под ред. Умберто Эко / Пер. с итал. Т. Никитинской и др. М., 2016. С. 14. 
ло почтить подарком или пищей и питьем. Далее он поучал навещать больного человека и провожать в последний путь покойника, всех встречных приветствовать и сказать ему доброе слово. Основной принцип семейной жизни Владимир сформулировал в понятиях своего времени: «Жену свою любите, но не даите имъ надъ собою власти».

Владимир Мономах сформулировал основу жизни по совести на все времена - «есть Божий Суд» (М.Ю. Лермонтов): «Страхъ Божии имЂите выше всего» ${ }^{42}$.

Таким образом, в первой трети XII в. были последовательно смягчены правовое положение человека перед княжеским законом и система наказаний, уточнены формулировки юридических норм, значительно расширена зона регулирования ими межчеловеческих правовых отношений. Такое содержание ППР как свода княжеских законов значительно расширило его правоприменение на Руси территориально и во времени, в XIII — первой половине XVв.

\section{Литература}

Альбертони Дж. Феодальное хозяйство и сельская сеньория // Цивилизация Средневековья: энциклопедия под ред. Умберто Эко / Пер. с итал. Т. Никитинской и др. М., 2016.

Белеикий С. Древнейшая геральдика Руси // Повесть временных лет / Пер. Д.С. Лихачева, статья и коммент. А.Г. Боброва. СПб., 2012.

Брицььн М.А. Из истории восточнославянской лексики. Киев, 1965.

Будовниц И.У. Владимир Всеволодович Мономах // Советская историческая энциклопедия. М., 1963. Т. 3.

Владимир Мономах. Поучение/Подгот. текста О.В. Творогов, пер. и коммент. Д.С. Лихачева // Библиотека литературы древней Руси. СПб., 1997. Т. 1: ХІXII века.

Гиппиус A.A. До и после Начального свода: ранняя летописная история Руси как объект текстологической реконструкции // Русь в IX-X веках. Археологическая панорама. М.; Вологда, 2012.

Зимин А.А. Русская Правда // Советская историческая энциклопедия. М., 1969. Т. 12.

Иванов B.B., Топоров В.Н Древнее славянское право: архаичные мифопоэтические основы и источники в свете языка // Формирование раннефеодальных народностей. М., 1981.

История русской литературы X-XVII веков. М., 1980.

Ключевский В.О. Сочинения. В 8 т. М., 1956. Т. 1: Курс русской истории.

Константин Багрянородньй. Об управлении империей: Текст, перевод, комментарий / Под ред. Г.Г. Литаврина, А.П. Новосельцева. М., 1989.

\footnotetext{
42 Владимир Мономах. Поучение. С. 462.
} 
Назаренко А.В. Владимир Всеволодович Мономах // Древняя Русь в средневековом мире. Энциклопедия. М., 2014.

Неусыхин А.И. Возникновение зависимого крестьянства как класса раннефеодального общества в Западной Европе VI-VIII вв. М., 1956.

Правда Русская. Комментарии / Сост. Б.В. Александров, В.Г. Гейман, Г.Е. Кочин, Н.Ф. Лавров, Б.А. Романов / Под ред. Б.Д. Грекова. М.; Л., 1947. Т. 2.

Преображенский А.Г. Этимологический словарь русского языка. М., 1959. Т. 1, 2.

Пресняков A.E. Княжое право в Древней Руси: очерки по истории X-XII столетий. Лекции по русской истории: Киевская Русь. М., 1993.

Paпnопорт П.А. Древнерусская архитектура. СПб., 1993.

Свердлов М.Б. Домонгольская Русь: Князь и княжеская власть на Руси VI — первой трети XIII в. СПб., 2003.

Свердлов М.Б. От Закона Русского к Русской Правде. М., 1988.

Свердлов М.Б. Система русского права как основа международных договоров Руси X — первой трети XIII вв. // От древней Руси к новой России: юбилейный сборник, посвященный чл.-корр. РАН Я.Н. Щапову. М., 2005.

Свердлов М.Б. Пространная Правда Русская// Ярославский список Правды Русской. Законодательство Ярослава Мудрого / Сост. Н.А. Грязнова, Д.К. Морозов. Ярославль; Рыбинск, 2010.

Свердлов М.Б. Правда Русская. История текста. Великий Новгород, 2015.

Свердлов М.Б. «Правда Русская». История текста // Свердлов М.Б. Латиноязычные источники по истории Древней Руси IX-XIII вв. Германия. «Правда Русская»; История текста. Избранные статьи. СПб., 2017.

Соболевский А.И. Древнерусская переводная литература. Курс лекций / Изд. подгот. Д.М. Буланин. СПб., 2019.

Соловьев С. М. История России с древнейших времен. М., 1959. Кн. 1.

Степанов Ю.С. Слова «правда» и «цивилизация» в русском языке // Известия АН СССР. Серия литературы и языка. 1972. Т. 31. Вып. 2.

Толочко A. Краткая редакция Правды русской: Происхождение текста. Київ, 2009.

Фасмер М. Этимологический словарь русского языка в четырех томах / Пер. и доп.

О.Н. Трубачева. 2-е изд., стереотип. М., 1986. Т. 2.

Фасмер М. Этимологический словарь русского языка в четырех томах / Пер. и доп. О.Н. Трубачева. 2-е изд., стереотип. М., 1986. Т. 3.

Шахматов А.А. Разыскания о древнейших русских летописных сводах. СПб., 1908. Grimm J. Deutche Rechtsalterthümer. B., 1956. Bd. 1.

Indo-Eropean Culture / Ed. J.P. Mallory and D.Q. Adams. London and Chicago: Fitzroy Dearbory Publishers. W. Y. [б.г.]. 


\title{
А.В. Сиренов
}

\section{КАМЕНЬ ПРОКОПИЯ УСТЮЖСКОГО В НАЧАЛЕ XIX В.}

\begin{abstract}
Аннотация Статья посвящена проблеме изучения камней Прокопия Устюжского. Согласно средневековой легенде, эти камни являлись метеоритами. Русский историк начала ХІХ в. К.Ф. Калайдович изучил один из таких камней и доказал, что он имеет известняковую природу.

Ключевые слова: источниковедение, российская историография, К.Ф. Калайдович, история исторической науки, Прокопий Устюжский, метеорит.
\end{abstract}

Summary The paper deals with the problem of study of the Stone of Procopius Ustyuzhsky. According to a medieval legend, these stones are meteorites. Russian historian of the early 19th century K. Kalajdovich studied one of these stones. He proved that the stone is limestone.

Keywords: source study, Russian historiography, K. Kalajdovich, history of historical science, Procopius Ustyuzhsky, meteorite.

Почитание Прокопия Устюжского представляет собой уникальное явление в истории древнерусской культуры. Молитва об отведении от города каменного дождя, передававшаяся из уст в уста память о святом, жившем в XIII в., народное почитание на протяжении многих лет и некоторые другие черты подчеркивают необычность этого культа для Русского Севера. Е.Н. Швейковская исследовала ритуал так называемой Прокопьевской трапезы - посвященного Прокопию Устюжскому коллективного общинного праздника, получившего распространение в Устюге и его окрестностях в XVII в. ${ }^{1}$ Особое отношение к фигуре Прокопия Устюжского и оставшимся после него реликвиям имело место не только в средневековой культуре, но и в традиции Нового времени. Причем особенный интерес вызывали так называемые камни Прокопия

1 Швейковская Е.Н. Прокопьевская трапеза: праздник и повседневность на Русском Севере в XVII веке // Одиссей. Человек в истории. 1999. М., 1999. С. 14-20. 
Устюжского. Впервые на эту загадку природы было обращено внимание в изданиях начала XIX в.: в журнале «Лицей» в 1806 г., в книге А.И. Стояновича «О воздушных камнях и их происхождении» в 1807 г., в «Технологическим журнале» в 1811 г., в книге И. Мухина «О чудесных дождях (или необыкновенных) и о ниспадающих из воздуха камнях (аэролитах)» в 1819 г.

Эта волна публикаций о камнях Прокопия Устюжского вскоре сошла на нет, и следующий всплеск интереса к данной теме относится к середине XIX в. Так, в 1847 г. Вологодский епископ Иннокентий поручил протоиерею вологодского Софийского собора Тимофею Скворцову собрать данные о «каменном дожде», выпавшем в 1290 г. в окрестностях Устюга, и отослать ему в Петербург образцы камней для исследования их состава. Результатом этой деятельности стало устройство часовни в местечке Котовалово на предполагаемом месте падения с неба камней². Камни Прокопия Устюжского хранились и во владимирском Успенском соборе. В.И. Доброхотов в своем описании Успенского собора, изданном в 1849 г., среди хранившихся в соборе достопримечательностей упоминал «шесть кругловатых камней, похожих на белые. Они лежат за деревянною решеткою у второго столпа с левой стороны от входа в западные врата храма. По преданию, эти камни привезены из Великого Устюга, от которого в 20 верстах при жизни св. Прокопия Христа ради юродивого (см. Чет[ьи] Мин[еи] за октябрь месяц) пала на лес каменная туча, отвращенная от города мольбами этого угодника Божия» ${ }^{3} .21$ марта 1861 г. владимирский краевед К.Н. Тихонравов писал в Русское археологическое общество: «Покорнейше прошу Общество напечатать в "Известиях", если окажутся того заслуживающими, составленные мною сведения об упраздненном Борисоглебском монастыре близ Мурома и заметку о камнях, хранящихся во владимирском Успенском соборе» ${ }^{4}$. Эта статья была опубликована. В ней Тихонравов предположил, что так называемые «камни Прокопия Устюжского» из владимирского Успенского собора являются старинными каменными ядрами, а некоторые из них - каменными шарами, какими была украшена соборная колокольня постройки начала XIX в. В начале XX в. историк Успенского собора А.И. Виноградов привел текст описи соборного имущества, в которой фигурирует уже меньшее количество камней: «Три камня, присланные в давнее время во владимирский Успенский собор из Великого Устюга, близ ко-

2 Попов А. Котовальская часовня, приписная к Великоустюжскому Успенскому собору // Вологодские епархиальные ведомости. 1879. № 12. Прибавления. С. 262-270.

3 Доброхотов В.И. Памятники древности во Владимире Клязменском. М., 1849. С. 97.

4 Тихонравов К.Н. Письмо в Русское археологическое общество. Владимир, 21 марта 1862 г. (ОР РНБ. Ф. 659 (Русское археологическое общество). Оп. 2. Ед. хр. 39. Л. 1). 
торого пал каменный град, отвращенный от города молитвами Прокопия Христа ради юродивого Устюжского чудотворца» ${ }^{5}$. Что случилось с этими камнями в послереволюционное время - неизвестно. В недавно изданном исследовании Т.П. Тимофеевой, посвященном владимирскому Успенскому собору и его достопримечательностям, о камнях Прокопия Устюжского не упоминается ${ }^{6}$.

Можно указать еще один случай исследования «камней Прокопия Устюжского», хранившихся во владимирском Успенском соборе. В архиве историка и археографа первой половины XIX в. К.Ф. Калайдовича есть текст его доклада, сделанного 20 ноября 1816 г. в Московском обществе естествоиспытателей. Объектом исследования стал некий камень, который историк вывез из Владимира.

Начало научной деятельности выдающегося археографа и историка первой половины XIX в. Константина Федоровича Калайдовича до сих пор изучено недостаточно. Один из трех сыновей известного в свое время врача, Ф.П. Калайдовича, выходца из Хорватии, Константин Федорович с ранних лет увлекся изучением российских древностей. Еще будучи студентом Московского университета, он опубликовал обзор собрания древнерусских рукописей, принадлежавших московскому букинисту купцу-старообрядцу Ферапонту Ферапонтову. Когда грянула Отечественная война 1812 года, Калайдович записался в ополчение и принимал непосредственное участие в боевых действиях. Вернувшись в Москву после победы, молодой историк поступил на службу в Московский архив Коллегии иностранных дел - самый значительный в Москве того времени центр исторической науки. Знакомство с графом Н.П. Румянцевым определило последующее участие К.Ф. Калайдовича в деятельности знаменитого кружка Румянцева, особенно в археографических экспедициях в Иосифо-Волоколамский и Воскресенский Новоиерусалимский монастыри. Однако экспедиционная деятельность Калайдовича началась еще ранее его поездок, финансированных Румянцевым ${ }^{7}$. В конце 1814 г. историк отправился в гости к своему брату Ф.Ф. Калайдовичу, который в то время служил учителем гимназии в г. Владимире. Следует иметь в виду, что Константин Федорович к этому времени только что вернулся с Отечественной войны, где служил в ополчении. Тем более вызывает интерес его стремление заняться обследованием отечественных древностей.

\footnotetext{
5 Виноградов А.И. История Успенского собора. Владимир, 1905. С. 83.

6 Тимофеева Т.П. Успенский собор во Владимире. Владимир, 2018. В 2 т.

7 Бессонов П.А. К.Ф. Калайдович. Биографический очерк // Чтения в Императорском общества истории и древностей российских при Московском университете. 1862. Кн. 3. Отд. 1.
} 
Свою поездку к брату К.Ф. Калайдович предварил несколькими письмами, в которых интересовался сочинением об истории Суздаля, которое в 1791 г. было опубликовано в «Древней российской вивлиофике» ${ }^{8}$. Называя этот текст Суздальским летописцем, Константин Федорович просил брата навести справки о его списках, однако тому ничего определенного узнать не удалось. И все же молодой историк приехал во Владимир. За несколько дней он смог побывать не только во Владимире, но также в Суздале, Коврове и Боголюбове. С собой он вез открытый лист, подписанный председателем Общества истории и древностей российских Бекетовым, и этот документ придал в общем-то частной поездке статус научной экспедиции. К сожалению, у Калайдовича не имелось средств на передвижения, и он пустился на подделку подорожных, в чем был уличен ковровским почмейстером, задержан властями и выслан в Москву под конвоем. Далее последовало заключение в доме для умалишенных и годичное пребывание в Николо-Пешношском монастыре на покаяниия.

Во время недолгого обследования владимирских и суздальских древностей Калайдович собрал довольно пеструю коллекцию письменных и вещественных памятников. Так, в Суздале он получил отдельные документы Ризположенского монастыря, два списка «Исторического собрания о богоспасаемом граде Суждале» Анании Феодорова (один из них ему дал на время сын автора священник суздальской Козьмодемьянской церкви Никифор Ананьин), экземпляр Библии издания Франциска Скорины (из библиотеки Спасо-Евфимиева монастыря), список Кормчей книги и другие рукописные и печатные книги, а также жалованные грамоты времени царя Алексея Михайловича, обнаруженные за несколько лет до этого в ларце, замурованном в стене Успенской церкви. Епископ Владимирский и Суздальский Ксенофонт (Троепольский) подарил Калайдовичу старинную железную стрелу и некий камень, а настоятель Дмитриевского собора дал на время жалованную грамоту Василия III.

О всех этих приобретениях историка мы знаем из двух источников: из переписки с суздальским архимандритом Мельхиседеком о возвращении издания Франциска Скорины, со священником Никифором Ананьиным о возвращении списка «Исторического собрания», а также из письма

8 Летопись о построении града Суздаля и в нем монастырей, и о бытии, и о преставлении суздальских чудотворцев и о родословии российских князей вкратце // Древняя российская вивлиофика. М., 1791. Ч. 19. С. 358-367.

9 О поездке К.Ф. Калайдовича во Владимир и Суздаль см.: Сиренов А.В. Экспедиция К.Ф. Калайдовича и начало изучения владимиро-суздальских древностей // Города и веси: Сборник статей к 60-летию академика Н.А. Макарова. М., 2016. С. 569-573. 
Ф.Ф. Калайдовича, в котором тот спрашивает брата, что делать с оставшимися после него вещами и перечисляет их: «Книги твои и бумаги я давно уже переслал к батюшке; железное же копье, один камень, два образа желез[ные] и... (далее слово неразборчиво. - A.C.) сукном портрет Петра I-го находятся у меня, но к пересылке их на почте не принимают, а потому я и буду стараться при первом удобном случае с ездоками отправить в Москву» ${ }^{10}$. Среди памятников древности, которые Калайдович получил от владимирского и суздальского духовенства, труднее всего оказалось атрибутировать упомянутый братом в письме «камень». Текст доклада со всей очевидностью свидетельствует о том, что имеется в виду один из так называемых камней Прокопия Устюжского. Из текста доклада можно вынести впечатление, что Калайдович проводил естественнонаучные опыты над несколькими камнями Прокопия Устюжского, хранившимися во владимирском Успенском соборе. Так, он пишет, что камни «вскипают в кислоте, не дают огня при ударе сталью». Если постучать по камням стальным предметом при своем кратковременном посещении Успенского собора он вполне мог, то воздействовать на камни кислотой у него определенно не было ни времени, ни возможности. Тем более что увезенный в Москву камень химическим опытам он не подвергал. Остается предположить, что о воздействии кислоты на камни Калайдовичу сообщили его владимирские знакомые, что также представляет определенный интерес для истории владимирского краеведения.

По всей видимости, для К.Ф. Калайдовича доклад в Обществе испытателей природы, членом которого он был с 1811 г., явился одним из первых научных мероприятий после возвращения из монастыря. В архиве историка хранится еще один документ, косвенно связанный с Обществом испытателей природы - гравированная копия миниатюры, изображающей сиамских близнецов, с текстом известия 1538 г., восходящего к Новгородской летописи Дубровского. Оригинал листа был обнаружен соратником Калайдовича по археографическим экспедициям П.М. Строевым в рукописном сборнике XVI в. из собрания Воскресенского Новоиерусалимского монастыря (ныне ОР ГИМ. Воскр. собр. Д. 1546 ${ }^{11}$ ). Этот уникальный источник К. Ф. Калайдович подготовил для факсимильной публикации, которую

${ }^{10}$ Письма Ф.Ф. Калайдовича к К.Ф. Калайдовичу (ОР РНБ. Ф. 328 (К.Ф. Калайдович). Д. 378. Л. 18 об.). Мое предположение, что здесь имеется в виду белокаменный рельеф, ошибочно (Сиренов А.В. Экспедиция К.Ф. Калайдовича... С. 572).

${ }^{11}$ Сиренов А.В. Изображение сиамских близнецов в новгородской летописи XVI века // Ученые записки Новгородского государственного университета имени Ярослава Мудрого. 2019. № 5 (23). C. 1-5. 
намеревался осуществить в московской типографии С.И. Селивановского в 1824 г. Свое издание исследователь посвятил московскому палеонтологу Григорию Ивановичу Фишеру фон Вальгейму, причем посвящение сопроводил следующими словами: «Мужу, глубокими сведениями в естественных науках и добротою сердца украшенному», которые, как представляется, свидетельствуют о его личных отношениях с основателем и многолетним председателем московского Общества испытателей природы. Упомянутая Калайдовичем в посвящении «доброта сердца» Фишера проявилась, в частности, и в поддержке вернувшегося в Москву после «монастырского покаяния» Калайдовича в 1816 г. Вчерашнему узнику Фишер предоставил возможность выступить с докладом в научном обществе, рассказать о своих исследованиях. В конце доклада исследователь сообщает о намерении предпринять изучение известий древнерусских летописей о падении метеоритов и других «небесных знамениях». Он планировал составить таблицы «небесных явлений, мора и голода, бывших в России», т. е., по существу, составить некую тематическую базу данных на основе летописей.

Отмечу, что актуальность такого информационного ресурса сохраняется до настоящего времени. К.Ф. Калайдович не выполнил своего намерения, вероятно, потому, что в 1817 г. был привлечен Н. П. Румянцевым к организации археографических экспедиций по подмосковным монастырям ${ }^{12}$. Beроятно, его желание издать миниатюру с изображением родившихся в Новгороде в 1538 г. сиамских близнецов является еще одним проявлением благодарности московскому Обществу испытателей природы, поддержавшему его в трудное время.

Публикуемый ниже текст доклада восполняет лакуну в истории изучения такого феномена русского Средневековья как камни Прокопия Устюжского. Последняя по времени статья на эту тему содержит обстоятельный историографический экскурс, в котором, однако, доклад К.Ф. Калайдовича не упоминается ${ }^{13}$.

Доклад известен в единственной рукописи: ОР РНБ. Ф. 328 (К.Ф. Калайдович). Ед. хр. 237, которая имеет черновой характер. Текст писан К.Ф. Калайдовичем на двойном листе с филигранью Pro Patria и контрамаркой «Berens 1816». Подчеркнутый в рукописи текст в издании передаем курсивом.

${ }^{12}$ Барсуков Н.П. Жизнь и труды П.М. Строева. СПб., 1878. С. 23-29; Козлов В.П. Колумбы российских древностей. М., 1981. С. 69-70.

${ }^{13}$ Маслов К.И. Исследование «Устюжского события» и чудо избавления Великого Устюга от угрозы истребления «каменным дождем» // EIK $\Omega$ N KAI TEXNH: Церковное искусство и реставрация памятников истории и культуры / Сост. и науч. ред. К.И. Маслов. М., 2011. T. 2. C. $233-245$. 


\section{Историческая и минералогическая записка о каменном дожде, упавшем в XIII столетии близ города Великого Устюга, с образцом одного из сих воздушных камней, читанная 22 ноября 1816 года в обыкновенном собрании Императорского Московского общества испытателей природы адъюнкт-членом оного Константином Калайдовичем}

Не входя в исследование о начале и образовании воздушных камней и не исчисляя примеров низвержения на землю сих явлений, ужасающих природу, испрашиваю токмо теперь благосклонного внимания почтеннейших членов сего знаменитого сословия к слову краткому, простому, перечнем здесь излагаемому из Истории естественной науки в России, которую в непродолжительном времени буду иметь честь представить Обществу ${ }^{14}$.

В XIII столетии жил в Великом Устюге, и теперь существующем довольно известном городе в Вологодской губернии, один благочестивый муж именем ${ }^{15}$ Прокопий, родом норманн (варяг), крещенный и наставленный в вере святым Варлаамом, игуменом Хутынского новгородского монастыря, и скончавшийся в 1303 году ${ }^{16}$ июля $8^{16}$, который под видом притворного юродства скрывал святость жития своего, приятную Богу, внимавшему его теплым молениям. Один пример сего ${ }^{17}$ повествуется в Прологе (содержащем сокращенные известия о житиях св. отцев) ${ }^{18}$ и в Четьи-Минеи (заключающей в себе те же самые жития, только подробнее описанные) ${ }^{19}$ под 8 числом июля месяца, в которое празднуется Российскою церковию память преподобного Прокопия. Когда грехи и беззакония жителей Великого Устюга прогневали долготерпение Божие, то Всевышний положил в праведном совете Своем низпустить каменную тучу на нещастных жителей. Пророк духом, предвидя кару Бога Вышняго, когда граждане не очистятся от грехов своих, увещевал их прибегнуть к покаянию. Беззаконные слепотствовали - и се мрачная туча по прошествии двух недель его предсказания в средине дня надвинулась над самым городом; становилась мрачнее и мрачнее, и молнии, из нее излетавшие, сопровождались страшными

\footnotetext{
14 Далее между строками более темными чернилами вписано: № 5.

15 Исправлено из: по имени.

16-16 Виисано над строкой.

17 Далее зачеркнуто: для нас любопытный.

${ }^{18}$ Скобки вписаны в строке, изначально этот текст был выделен запятыми.

${ }^{19}$ Скобки вписаны в строке, изначально этот текст был выделен запятыли.
} 
громами, между собою сражавшимися и заглушавшими голос человеческий. Жители трепетали... но праведник вместе с народом, в прахе повергшись пред иконою Богоматери ${ }^{20}$, молился, и Бог, вняв его слезам и воздыханиям, хотел помиловать чрез него нещастных граждан. Побагровевшая туча, прошед за город, опустилась в 20 милях (поприщах) от оного на поля и дикой густой бор и, попалив деревья, завалила их раскаленными камнями. Так рассказывает предание, помещенное в прежде помянутых книгах, уверяя, что и теперь еще цела сия каменная громада, готовившаяся поглотить нещастный город.

${ }^{21}$ По прош[ествии] многого времени ${ }^{21}$ в Успенской собор ${ }^{22}$ прислано было до 20 сих воздушных камней при записке, объяснявшей сие происшествие, которая однако же от времени утрачена, и память о ${ }^{23}$ ней достигла до нас в одном токмо 23 предании. Самые же камни и теперь там в алтаре хранятся. Преосвященный Ксенофонт ${ }^{24}$ подарил мне на память один из сих воздушных камней ${ }^{25}$. Он довольно велик, шарообразен, с небольшими двумя плоскостями и одною впадиною, поверхность имеет неровную и весит 6 фунтов. По внутреннему свойству принадлежит к плитовыл, из плотных песчинок составившимся камням (Arena ${ }^{26}$ fundamentalis), почему при ударении сталью дает хороший огонь ${ }^{27}$. Замечу, что в числе сих минералогических редкостей, во владимирском Успенском соборе хранящихся, некоторые совершенно принадлежат к известковой породе, вскипают в кислоте, не дают огня при ударе сталью и все вообще шарообразны. ${ }^{28}$ Хотя предание и относит сии камни к воздушным, но я не приметил в оных хромового железа, во всех таковых находящегося, а посему и почитаю их обыкновенными $^{29}$, из кременной и известковой породы состоящими (с мнением моим были согласны члены Им[ператорского] М[осковского] об[щества] и[спытателей] п[рироды] (*)30 может быть при химическом разрешении, которому я не в силах был их подвергнуть, откроется тому противное ${ }^{28}$ ). Таблиц,

\footnotetext{
${ }^{20}$ Слог «но» в слове дописан над строкой более светльми чернилами.

21-21 Написано над строкой вместо зачеркнутой фразы: По прошествии многого времени.

22 Далее зачеркнуто: находящийся в губернском городе Владимире.

23-23 Исправлено из: них сохранилась токмо в одном.

${ }^{24}$ Далее зачеркнуто: нынешний епископ Владимирский и Суждальский, в бытность мою в первом городе в начале генваря 1815 года.

${ }^{25}$ Далее зачеркнуто: теперь пред глазами почтеннейшего сословия находящийся.

${ }^{26}$ Буквы «епа» вписаны над строкой.

27 Далее зачеркнуто приписанное над строкой: К сему описанию недостает химического исследования, коему я не смогу подвергнуть мой воздушной камень $(*)$.

${ }^{28-28}$ Написано между строками и на левом поле вместо зачеркнутого: Лестное для меня внимание почтеннейших членов побудить [меня] к скорейшему сочинению (заключенное в квадратные скобки вымарано).

${ }^{29}$ Далее одно слово вымарано и не читается.

${ }^{30}$ Текст сноски отсутствует.
} 
извлеченных из рукописных и печатных русских летописей о подобных камнях, упавших с неба, с наблюдениями всех естественных перемен, замеченных нашими летописателями, которые вместе с Таблицами небесных явлений, мора и голода, бывших в России и могущих объяснить иностранные сочинения по сему предмету, мною теперь составляются, по окончании коих приятнейшим удовольствием и честию поставлю подвергнуть их особенному суду почтеннейших членов; и одно уже благосклонное внимание будет лучшею за труд мой наградою.

Москва. 20 ноября 1816 года.

ОР РНБ. Ф. 328 (К.Ф. Калайдович). Д. 237. Л. 1-2.

\section{Литература}

Барсуков Н.П. Жизнь и труды П.М. Строева. СПб., 1878.

Бессонов П.А. К.Ф. Калайдович. Биографический очерк // Чтения в Императорском общества истории и древностей российских при Московском университете. 1862. Кн. 3. Отд. 1.

Виноградов А.И. История Успенского собора. Владимир, 1905.

Доброхотов В.И. Памятники древности во Владимире Клязменском. М., 1849.

Козлов В.П. Колумбы российских древностей. М., 1981.

Маслов К.И. Исследование «Устюжского события» и чудо избавления Великого

Устюга от угрозы истребления «каменным дождем» // EIK $\Omega N$ KAI TEXNH: Церковное искусство и реставрация памятников истории и культуры / Сост. и науч. ред. К.И. Маслов. М., 2011. Т. 2. С. 233-245.

Попов А. Котовальская часовня, приписная к Великоустюжскому Успенскому собору // Вологодские епархиальные ведомости. 1879. № 12. Прибавления. С. 262-270. Сиренов A.B. Экспедиция К.Ф. Калайдовича и начало изучения владимиро-суздальских древностей// Города и веси: Сборник статей к 60-летию академика Н.А. Макарова. М., 2016. С. 569-573.

Сиренов A.B. Изображение сиамских близнецов в новгородской летописи XVI века // Ученые записки Новгородского государственного университета имени Ярослава Мудрого. 2019. № 5(23). С. 1-5.

Тимофеева T.П. Успенский собор во Владимире. Владимир, 2018. В 2 т.

Швейковская E.H. Прокопьевская трапеза: праздник и повседневность на Русском Севере в XVII веке // Одиссей. Человек в истории. 1999. М., 1999. С. 14-20. 


\section{Е.Б. Смилянская}

\section{ПРОСТОЛЮДИНЫ САНКТ-ПЕТЕРБУРГА В ЗАПИСКАХ БРИТАНСКОЙ «ПОСОЛЬШИ» ДЖЕЙН КАТКАРТ (I768-I770 ГГ.)}

Аннотация Статья основана на рукописных материалах из архива британского посла в России лорда Чарльза Каткарта, хранящегося в Национальной библиотеке Шотландии (прежде всего «Записках о Петербурге» 1768-1770 гг. супруги посла леди Джейн Каткарт). В дневниковых записях леди Джейн содержатся важные наблюдения, касающиеся российского двора, императрицы Екатерины II, образа жизни аристократического общества, к которому «посольша» принадлежала. Но в отличие о многих сочинений о России этого времени записи Джейн Каткарт позволяют представить, как «посольша» знакомилась и с простонародьем столицы, описывала его развлечения, фольклор, стремилась составить первые выводы об особенностях «простых русских».

Ключевые слова: Россия XVIII в., Петербург, социальные структуры России XVIII в., праздники, британский образ России.

Summary The study is based on unpublished manuscripts of the Cathcart's archive from the National Library of Scotland (above all the Memoranda of St.Petersburg, 1768-1770, by the ambassadrice Lady Jane Cathcart). In her Memoranda the British ambassador's wife observed the Russian court, her close contacts with the Empress Catherine the Great, the «lifestyle» of aristocrats of the Russian capital, but her writings also show, how the ambassadrice got to know «natives» / «common people» of the Russian capital, described their entertainment, their folk music and made her first conclusions on characteristics of Russian «lower classes». Keywords: Russia in the Eighteenth Century, St.Petersburg, social structures of the eighteenth century Russia, Russian entertainments, British image of Russia. 
Два года пребывания в этой стране в значительной степени сгладили ощущения новизны. Я теперь стараюсь уловить то, что может дать постоянное повторение одного и того же, и посредством этого в точности ухватить настоящий характер тех, среди которых мы живем.

Джейн Каткарт, супруга британского посла в России. 26 июля 1770 г.

3/14 августа 1768 г. в Кронштадт прибыл новоназначенный британский посол сэр Чарльз Каткарт (Cathcart) с супругой Джейн (урожд. Гамильтон), с чадами и их воспитателем Уильямом Ричардсоном, с прислугой и с большим багажом. Навстречу семейству была прислана императорская яхта и вскоре всем открылся Санкт-Петербург, где «городские набережные и мосты создают прекрасную перспективу на воде» ${ }^{1}$. В столице Российской империи им предстояло прожить почти четыре года, а «посольше» Каткарт судьба уготовила родить здесь девятого ребенка и уйти из жизни осенью 1771 г.

Все время пребывания в России леди Джейн вела дневники, как это делала с юности; она писала в дневниках преимущественно по-французски ${ }^{2}$, но в Петербурге завела еще отдельную тетрадь для записей своих впечатлений о России («относительно характеров и особенностей, которые поразили меня как иностранку и как наблюдателя»), и стала писать в ней на английском ${ }^{3}$ Очевидно, эти ее записи (Memoranda of St. Petersburg) не предназначались для публикации, делались по свежим впечатлениям от увиденного, без определенного плана и не были подвергнуты никакой ни прижизненной, ни посмертной редакции. Они сохранились в Национальной библиотеке Шотландии в семейном архиве Каткартов ${ }^{4}$ и только в последние годы

${ }^{1}$ National Library of Scotland. Acc. 12686/5 (Papers of the family of Cathcart). Memoranda of St. Petersburg. Листы ненумерованы. Здесь и далее, если специально не оговорено, цитируется этот источник.

2 В фонде Каткартов сохранились 24 тетради дневников леди Джейн за 1745-1771 гг. (Ibid).

3 Вероятно, привычка леди Каткарт к ведению дневников повлияла на создание и ее записок о России. О влиянии на литературу путешествий мемуарно-автобиографической прозы см., например: Batten Ch. L. Jr. Pleasurable Instruction: Form and Convention in EighteenthCentury Travel Literature. Berkeley, 1978. P. 1.

${ }^{4}$ О структуре фонда Каткартов в Национальной библиотеке Шотландии и месте в нем «Memoranda of St. Petersbourg» см.: https://digital.nls.uk/catalogues/guide-to-manuscriptcollections/inventories/acc12686.pdf. Объем записок, написанных в два столбца на 28 листах мельчайшим почерком, составляет около 160 тыс. знаков. О месте этих записок в зарубежных описаниях России можно судить по: Cross A. In the Lands of the Romanovs: An Annotated Bibliography of First-Hand English-Language Accounts of the Russian Empire (1613-1917). Cambridge, 2014 (об опубликованных материалах Каткартов см. p. 94-95). Высоко оценив записки Джейн Каткарт, Кросс, однако, почти их не использовал в своих исследованиях о британцах в России (Cross A. By the Banks of the Neva. Chapters from the Lives and Careers of the British in Eighteenth-century Russia. Cambridge, 1997. P. 24, 25, 369). 
стали объектом исследования ${ }^{5}$, перевод и издание документов из этого обширного архива, как и записок леди Каткарт о Петербурге еще предстоит завершить. Скромная цель данной статьи - показать информационный потенциал нового источника, прежде всего записей «посольши», касающихся простонародья Петербурга, представив их перевод 6 .

Записки и дневники Джейн Каткарт примечательны по ряду причин. Они создавались просвещенной начитанной дамой, ставшей заметной фигурой в петербургском высшем обществе. После официального представления императрице ${ }^{7}$ «посольша» Каткарт заняла второе по значению место в придворной иерархии, но помимо формального статуса она приобрела личное расположение императрицы, как и посол Чарльз Каткарт, нередко приглашалась в ближний круг Екатерины II, дважды принимала императрицу в своем доме, а ее заметки о занятиях и развлечениях петербургской аристократии точны и нередко весьма остроумны. Но высокое положение и этикетные нормы, соблюдавшиеся британской посольской четой, предопределили и ограничение возможностей для познания страны, которая, без сомнения, вызывала интерес и желание рассказать о подданных императрицы Екатерины. Каткарты в отличие от путешественников, которые по делам их российской службы, по торговым надобностям и в образовательных вояжах посещали города и веси обширной империи, не выезжали за пределы Петербурга и пригородов. Помимо дворца, домов знатнейших фамилий столицы они бывали гостями лишь в домах английской колонии (кварталы Галерной) и у представителей дипломатического корпуса. А потому, трудно было бы ожидать, что записки «посольши» могут содержать оригинальную информацию о том Петербурге, который английская леди видела либо из кареты, либо из окон особняка на Мойке, ставшего на время британской посольской резиденцией (местоположение особняка указано в депеше - TNA. SP 91/81. P. 265 a) (улицы Петербурга, не имевшие еще тротуаров, были, по словам Каткартов, опасны для пешеходов, и леди сетовала на недостаточность мест для привычных англичанке пеших прогулок). Между тем, ее записки о Петербурге стали не только сборником наблюде-

${ }^{5}$ Смилянская Е.Б. Англофилия Екатерины II и «исключительное посольство» лорда Каткарта в Санкт-Петербург в 1768-1772 гг. // Journal of Modern Russian History and Historiography. 2019. Vol. 12. P. 224-244; Смилянская Е.Б. Дипломатический церемониал при дворе Екатерины II // Quaestio Rossica. 2020. Т. 8. № 4. С. 1255-1273. Мне также известно, что записками Джейн Каткарт последние годы занимается и украинский исследователь Н.В. Волошкова.

${ }^{6}$ Я благодарна доктору Юлии Лейкин за помощь и советы по переводу записок Джейн Каткарт.

7 Об этом см.: Смилянская Е.Б. Дипломатический церемониал при дворе Екатерины II. 
ний о дворе Екатерины II и об окружении императрицы, в сочинении появляются колоритные словесные зарисовки петербургского люда (common people, common sort, natives) в его будничных занятиях и праздничном неистовстве. Особую ценность этой коллекции словесных этюдов и жанровых зарисовок придает непосредственная фиксация свежих впечатлений, из чего, правда, следует и известная хаотичность помещенной в записки информации (они строились по принципу: что увидела - то и записала). Единственное, что заметки Джейн Каткарт объединяет - это хронологическая последовательность, позволяющая вслед за англичанкой постепенно приоткрывать Россию 1768-1770 гг. и изучать механизмы создания образа чужого этноса и социума ${ }^{8}$.

Первые словесные зарисовки простонародья Петербурга у леди Джейн исполнены интереса к внешности, пище и статусу людей двух профессий: лодочников на Неве и извозчиков, т. е. тех, кого семья посла нанимала и за кем с сочувствием могла наблюдать вблизи:

«Гребцы на воде так сгибаются при каждом движении, что почти касаются дна лодки, поэтому выглядят униженными, и больно видеть, что они не чувствуют никакого беспокойства и гребут хорошо.

Они едят черный хлеб, по виду напоминающий то, что ирландцы и шотландцы называют peat (торфяные брикеты). Их зубы превосходны по силе и белизне.

Лошади малы и всегда в работе, головы вытягивают вперед, ими превосходно управляет племя людей, именуемых извозчики (ichvo), которые управляют лошадьми или ездят как форейтеры. Они и все низшие классы носят бороду (за разрешение носить бороду они платят императрице рубль в год)

8 Об особенностях восприятия англичанами России и населявших ее народов написано немало, и только перечисление названий работ заняло бы значительный объем. См., например, историографические обзоры и библиографию в диссертациях: Константинова C.C. Русские реформаторы и Россия в восприятии британских авторов второй половины XVIII века. Дис. ... канд. ист. наук. Саратов, 2006; Гунякова И.В. Записки Уильяма Кокса второй половины XVIII века о его путешествии в Россию как исторический источник. Дис. ... канд. ист. наук. Рязань, 2009.

916 января 1705 г. был издан именной указ Петра I, который предполагал обязательное брадобритие для всех категорий городского населения Московского государства, но желавшим сохранить свою бороду предлагалось заплатить годовую пошлину, размер которой разнился в зависимости от социального статуса бородача. Извозчики и ямщики относились ко третьей категории и должны были платить 30 рублей в год (ПСЗ-І. Т. 4. № 2015). Ответственным учреждением за сбор бородовых денег являлся Приказ земских дел. 6 апреля 1722 г. Петр I именным указом подтвердил прежний указ о взыскании с бородачей годовой пошлины, но теперь речь шла о единой ставке в 50 рублей для всех категорий (Там же. Т. 6. № 4034). В 1724 г. был создана Раскольническая контора - специальная канцелярия при Сенате для сбора податей и пошлин с «раскольников» и «бородачей» (Там же. Т. 7. № 4596; Олевская В.В. Раскольническая контора // Государственность России (конец XV в. — февраль 1917 г.): Словарь-справочник. М., 
и коричневый сюртук (surtout) - закрытое пальто, по форме со спины как женское платье с чем-то типа золотого шнура или кружева (lace), и цветной красный или полосатый пояс вокруг талии. Упряжь у всех извозчиков (ichvochek) или на нанятых лошадях украшена латунными пластинками с изображениями разных животных и очень красива... Они носятся с молниеносной скоростью по улицам; многие из улиц широкие, хорошо мощеные (без тротуаров) и все пересекаются под прямым углом».

По-видимому, и в дальнейшем, извозчики были из тех редких русских простолюдинов, с которыми англичанка могла сталкиваться в доме ${ }^{10}$. Извозчиков леди Джейн отделяет от иных простолюдинов («мужиков»), и сообщает в 1769 г. об их визитах в дом и «обмене» пасхальными подношениями: «Мы этим утром были осаждены целой толпой русских извозчиков и му-

2001. Кн. 4. С. 17-18). Петровский указ 1722 г. о взыскании с бородачей годовой пошлины в 50 рублей впоследствии подтверждался указами от 27 ноября 1728 г. (ПСЗ-І. Т. 8. № 5349), от 19 февраля 1743 г. и 2 декабря 1752 г. (Там же. Т. 11. № 8707). Однако бородовой сбор никогда не составлял сколь-либо существенную статью дохода, о чем свидетельствуют финансовые отчеты Приказа земских дел 1705-1708 гг., а также документы Раскольнической конторы. Так, по одной справке, составленной в Раскольнической конторе в 1754 г., по состоянию на 1726 г. во всей империи числилось 57 плативших годовую пошлину бородачей, из которых к 1754 г. осталось лишь двое (остальные умерли, бежали, были сосланы на каторгу за неуплату или обрили бороды) (подробнее см.: Akelev E. Is It Possible to Make Money from Beards? The Beard Tax and Russian State Economics at the Beginning of the Eighteenth-Century // Cahiers du Monde Russe. 2020. Vol. 61. № 1-2. Р. 81-104). 14 декабря 1762 г. в указе Екатерины II о вызове «раскольников» из Польши и других заграничных мест содержится следующий пункт: «как в бритье бороды, так и в ношении указнаго платья, никакаго принуждения им чинено не будет, но оное употребляют по их обыкновению беспрепятственно» (ПСЗ-І. Т. 16. № 11725). Е.В. Акельев и Е.Н. Трефилов предположили, что бородовой сбор окончательно прекратил свое существование с упразднением Раскольнической конторы указом от 15 декабря 1763 г. (Там же. № 11989; см.: Акельев E.B., Трефилов E.Н. Проект европеизации внешнего облика подданных в России первой половины XVIII в.: замысел и реализация // Феномен реформ на западе и востоке Европы в начале Нового времени (XVI-XVIII вв.): Сборник статей. СПб., 2013. С. 173). Откуда леди Джейн могла почерпнуть сведения о рублевом бородовом сборе не совсем ясно. Возможно, ей приходилось читать Джона Перри, который писал: «Царь, желая преобразовать этот глупый обычай и привести их к тому, чтобы они с виду походили на прочих европейцев, повелел обложить податью всех дворян, купцов и других подданных своих (за исключением священников и простых крестьян или рабов), чтобы каждый из них за право носить бороду платил ежегодно 100 рублей; также и простолюдины в России обязаны были платить по одной копейке каждый раз, когда проходили через ворота такого города, где приставлено было лицо для сбора пошлины» (Perry John. The State of Russia. London, 1716; Перри Дж. Состояние России при нынешнем царе. В отношении многих великих и замечательных дел его по части приготовлении к устройству флота, установления нового порядка в армии, преобразования народа и разных улучшений края // ЧОИДР. М., 1871. №. 1. С. 126). Можно предположить, что у леди Джейн смешались цифры 100 коп. $=1$ руб. и 100 руб. (бородой сбор по Джону Перри). Выражаю благодарность Е.В. Акельеву за этот комментарий.

${ }^{10}$ Вместе с семьей посла прибыла из Британии и прислуга. Не в последнюю очередь это связано с тем, что иностранные дипломаты в России превосходно осознавали, что за ними установлена постоянная слежка, а потому и ограничивали доступ в резиденцию новых лиц. 
жичков (ichvochecks and muschecheks), 14 или 15 из них пришли с крашеными яйцами и обычными русскими поздравлениями с праздником, за что на всех получили в подарок 10 рублей».

Из представителей других ремесленных профессий Санкт-Петербурга внимание и одобрение англичанки заслужили плотники, впрочем, искусное владение топором казалось леди Каткарт чуть не универсальным признаком «русскости»:

«Я не должна упустить достойную одобрения вещь, касающуюся людей из нижних классов этой страны. Все они поголовно плотники, и только со своим излюбленным инструментом - топором, без помощи гвоздей, шурупов или любого железа сами могут построить дом из нескольких комнат самой точной и хитрой конструкции, при их простоте им нужно очень мало мебели; та одежда, что они носят днем, служит им ночью для сна или они ею накрываются, лежа, как некоторые всегда делают, на печи (the peach or the stove), которая наверху плоская, как большой сундук».

«Деревянные дома очень милы. Я верю, что их можно сделать с одним топором - любимым и раньше единственным инструментом русских, до сих пор они ходят по улицам с топором за поясом. Они могут закончить пустой дом без гвоздя, очень изобретательно вставляя все деревянные бревна одно в другое, многие другие деревянные вещи также необыкновенно хорошо придуманы».

Леди Джейн еще не раз напишет о плотниках и искусстве строительства из дерева, но со временем удивление мастеровыми людьми у «посольши» начинает меняться: все больше ее глаз замечает несовершенства в производстве, особенно незавершенность начатого или небрежность в исполнении. В сентябре 1769 г. она записывает: «Я не могу сказать, присмотревшись, что моя оценка этих бедных людей поднялась, напротив, они ничего не делают ради усовершенствования». А еще через год посетует: «Я должна признать, хотя всегда избегала сатирических высказываний, так и должна продолжать, но в этот второй год [пребывания в России] знакомство и узнавание реальных характеров и действительности углубило, но не добавило мне уважения и одобрения». Поводов для разочарования англичанка находила все больше: это бывали и дурно мощеные улицы Петербурга, и отсталость в промышленном производстве, и вороватость торговцев, и пьянство, и проч.:

«Улицы мостят заново ежегодно, а некоторые площади и чаще, мостят усилиями жителей каждого дома, но они делают это и любую другую работу так небрежно (superficially), что результат недолговечен, и в конце концов оказывается очень дорогим... 
Ни кустарь, ни рабочий ничего не делает здесь без одного или нескольких помощников. К этому хорошо подходит сказанное в насмешку в одном собрании бездельников: “Что ты делаешь?”- спросил работник. Ответ: “Ничего”. “А ты?” - обратились к его сотоварищу: “Я ему помогаю”.

Короче говоря, всю торговлю ведут иностранцы. Работа местных отличается отсталостью (behind hand), все по-старинке, то, что со времени Петра Великого они используют из новых изобретений, вначале кажется довольно хорошим, но из-за нужды в прочных материалах и в добром окончании все рассыпается и рушится. На это они никогда не обращают внимания и, ничего иного не представляя, начинают все с начала, как на улицах, которые всегда находятся в состоянии ремонта. И это стоит для всех жителей значительно больше, чем, если бы они сразу сработали крепко и прочно».

Самые яркие зарисовки, как и в большинстве сочинений иностранцев, касаются праздничной культуры городского простонародья ${ }^{11}$. Английская леди с зимы 1768/69 гг. наблюдала и записывала свои впечатления о главных календарных развлечениях петербургского люда: катаниях на ледяных горках на Неве, сопровождавшихся особенным неистовством на Масляницу, о пасхальных гуляниях и традиционном праздновании весны (1 мая) и Троицы в Екатерингофе.

Объем настоящей публикации не позволяет поместить здесь полное и весьма пространное описание ледяных гор, о которых, впрочем, немало писали оказавшиеся в зимнем Петербурге иностранцы и в XVIII, и в XIX вв. ${ }^{12}$ Но о завершении масляничных катаний на Неве английская леди, как и другие ее соотечественники с опаской взиравшая в стороне, приводит и малоизвестные сведения, в частности, о прибыльности для полиции и для подрядчиков этих популярных развлечений:

«Простой люд развлекался, и эти три дня катался с ледяных горок с таким рвением, что у них едва хватало времени, чтобы дать спуститься с горки тому, кто катился впереди, и слишком быстро следуя за ним, они сбивали друг друга; было много примеров тому, что многие погибали на месте и еще чаще ломали конечности. Многие катились вниз, другие стояли в их маленьких лотках, короче говоря, они показывали такие выступления, как искусные танцоры на канате, но в целом принимали участие в этом развлечении с большой легкостью... Чтобы вернуться к рассказу о занятиях эти дней, которые, как

${ }^{11}$ О подобных описаниях праздников в сочинениях иностранцев см., например: Burgess M. Fairs and Entertainers in 18th-Century Russia // The Slavonic and East European Review. 1959. Vol. 38. № 90. P. 95-113. Из новейших работ: Конечный А. Былой Петербург. Проза будней и поэзия праздника. М., 2021. С. 58-115.

${ }^{12}$ Конечный А. Былой Петербург... С. 62-64. 
мне сказали, должны закончиться в 12 часов [с наступлением поста], я слышала, что три человека лишились жизни вчера при несчастном случае на этих ледяных горках, а также, что число тех, кто с них спускался, достигало 200 человек за каждые пять минут, и что прибыль для тех, за счет кого сооружались горки, в течении многих часов достигает по 150 рублей в час, хотя сколько-то из этого должно выплачиваться полиции за право соорудить на льду деревянные подмости. Цена, которую выплачивают мужику (musheeck) и прочим те, кто катается, составляет в общей сложности 2 копейки... Этим вечером на реке проходили также скачки. Все пригороды подражают центральной части города и там есть свои ледяные горки в разных местах и везде великие толпы людей. В этот прекрасный день на реке зрелище всех этих увеселений представляло более живую и занятную картину».

Если с началом Великого поста «зрелища» и «увеселения» в столице прекращались, то пасхальные гуляния вновь оживляли город и притягивали внимание английской леди:

«Пасха, воскресенье 19 апреля 1769 г. Возвращаясь домой по одному из главных проспектов города, [мы наблюдали, что он] весь наводнен простонародьем в праздничных дневных одеждах, люди качались в деревянных machines, coоруженных по всей длине улицы. Перед ними - палатки, в которых они веселились на каруселях (escarpolettes) до головокружения, голова кружится только от вида деревянных конструкций, на которых подвешены кабины (sedan chairs) по шесть на каждой машине, они поворачиваются на опорном штыре и в каждой кабинке сидят по одному, по два или по три человека ${ }^{13}$.

Несколько человек тянут за веревку и под действием механизма, я не знаю, как описать, они поворачиваются вокруг, но не переворачиваются вниз головой, кажется, они наслаждаются на них [каруселях] так же, как на ледяных горках, а для меня это выглядело как значительно более занимательная картина. Забавной казалась важность мужчин с их бородами и в высоких шапках, сидящих на открытых сидениях или в кабинках, так как там были и то, и другое, и было больше мужчин, чем женщин, занятно и то, как некоторые качались на веревках, другие на деревянных лошадках (wooden hobbyhorses) связанных веревками и сильно шатающихся, один человек скачет и другой стоит позади на крупе лошади.

Bсе женщины, что ходят по улицам, носят туфли без задников (slippers), и нужно обладать большим мастерством, чтобы они не сваливались, например, в нынешнюю оттепель, которая делает улицы едва проходимыми [даже] для карет. Что до тротуаров, то таковых, помимо одного-двух мест, трудно сыскать в Петербурге...

${ }^{13}$ Там же. С. 70 (иллюстрации). 
Улицы ежедневно теперь и до конца недели наводнены гуляющими людьми разного сорта, карусели с лошадками и вертящимися кабинками заполнены, и немало зевак окружает их круглые сутки. Вначале я думала, что не смогу на них наглядеться, но через два-три дня их вид уже вызывал дурноту: после первого мимолетного взгляда так много пьяных женщин и мужчин всех возрастов, кричаще ярко и по-дурацки одетых, показались уже не занимательными, а отвратительными. У большинства простых женщин их обувь (slippers) и шапки отделаны блестками, также и нижние юбки у них отделаны золотом и серебром, когда они могут это себе позволить, в особенности на шубах и плащах разных фасонов отделка всех цветов, кроме черного, который используется исключительно редко, и что касается тех, кто держит траур, то их, должно быть, меньше, чем у нас, так как я едва могла увидеть дворянина, носящего траур. Хотя говорят, что они строго соблюдают траур, когда умирает близкий родственник, я предполагаю, что их очень немного и они живут до преклонного возраста».

По прошествии года свои впечатления от пасхального Петербурга Джейн Каткарт излагала уже куда более сдержанно:

«12/23 апреля 1770. Простой народ воспользовался прекрасной погодой всю пасхальную неделю, улицы и качели всегда были наводнены людьми, поначалу это веселит глаз, но неделя таких [гуляний] кажется ужасно утомительной. Все дело в быстром верчении и подъеме, что восхищает здешний народ круглый год, и у женщин повсюду весьма вызывающие одежды и накрашенные лица».

Когда подошло время екатерингофских гуляний, англичанка впервые задается вопросом о происхождении наблюдаемых ею «действ». Она подмечает, что в троицком обряде участвуют «молодые женщины», что некую роль играет «дерево», позднее опускаемое в реку ${ }^{14}$, но справедливо предположив в этом обряде связь с «древними обычаями», англичанка сочла их уходящими из современной ей жизни и обращаться к славянским древностям не сочла для себя возможным:

«4 июня 1769 г. Весь двор отправился в Катерингоф так же, как и 1 мая. Был четверг перед Троицей, когда весь двор и город будут здесь вновь. Процессия из различных групп молодых женщин носит дерево, которое после исполнения различных обрядов бросают в воду. И считается, что начинается

${ }^{14}$ Троицкие обрядовые действия хорошо описаны литературе. Об их символике см.: Azanкина Т.A. Мифопоэтические основы славянского народного календаря. Весенне-летний цикл. М., 2002. С. 610-612. 
лето, как 1 мая почитается началом весны. Это древний русских обычай, который, как многие другие, понемногу забывается (дословно: изнашивается wearing away), но в духе народа использовать любой из вообразимых поводов, чтобы организовать представление и праздник.

NB. У тех, кто носит шапки или туфли, или нижние юбки и прочее, украшенные мишурой, а также стеклянные серьги, лица раскрашены, и у каждого в руке веер, без которого не появляются в праздники».

Запискам посольши Каткарт мы обязаны описанием еще одного вида развлечений петербургского простонародья, о котором ранее почти не писали. Речь идет о соревнованиях в удали петербургских жителей, которые англичанка с ужасом наблюдала осенью, когда на Неве устанавливался непрочный лед, и весной перед ледоходом; в эти периоды временно прерывалось сообщение с Васильевским островом. Перебегание через Неву по льдинам или тонкому льду — трижды удостоилось внимания Джейн Каткарт не только в качестве мерила безрассудности и отсутствия у простонародья страха смерти ${ }^{15}$, но и для того, чтобы подчеркнуть предпринимаемые императрицей меры по «цивилизации» дикостей простонародья. Вот первое из ее описаний:

1768 г. «Когда река начинает замерзать и то же после оттепели, они столь стремятся пересечь ее, что правительство вынуждено на каждом берегу поставить часовых, и те иногда столь строги в исполнении приказов, что, когда запрещено переходить и кто-то добрался на другую сторону благополучно, часовой там заставляет его вернуться, или они пропадают до того, как доберутся туда, откуда пришли. Без часовых только наблюдение за происходящим не отвратило бы остальных от следования этому примеру. Вероятно, они говорят: удача будет на нашей стороне и, если умрем, то это наша судьба, которой мы не можем противиться. Вот они и идут, и каждый год это повторяется снова и снова».

Год за годом английская аристократка Джейн Каткарт не только наблюдает за городом и его обитателями, но и вслушивается в русскую речь ${ }^{16}$ и, особенно, в музыкальные звуки и пение, постоянно звучавшие во время празднеств и в период белых ночей. Лето семья посла по протекции графа Н.И. Панина проводила на Каменном острове в недавно подаренных наследнику Павлу бывших покоях канцлера Бестужева. И именно к летнему времени 1769 и 1770 гг. относятся заметки «посольши» о музыкальности простолюдинов («of the common sort»):

${ }^{15} \mathrm{Cp}$. у баронессы де Боде (The Baroness de Bode 1775-1803. By William S. ChildePermberton. L., 1900. P. 203).

${ }^{16}$ Джейн Каткарт сама брала уроки русского (Cross A. By the banks of the Neva. P. 393). 
«Примечательны способности простолюдинов петь хором или на воде или ночью, когда они возвращаются с работ, или в любой из их праздников, игр или гуляний. Часто шествуя процессиями, они иногда с выражением поют грустную сбивчивую мелодию (a melancholy confused tune), только в ней нет радости и развлечения, а только и постоянное изменение в темпе, по каденции (ритму, тону) это никогда ни смех, ни плачь, но пение скорее грустное, чем веселое, очевидно, оно успокаивает, и им это приятно; национальные танцы производят такое же печальное впечатление или даже более тяжелое, это то, как можно вообразить забаву, когда тигр и тигрица, один набрасывается, а другой отбивается, страшно довольные друг другом. И подобный танец сопровождаются одной из выше описанных мелодий.

Что более всего меня поразило в характере жителей этой части мира, это то, что они всегда поют, они поют in parts ${ }^{17}$ и почти во время всех работ или занятий, когда по меньшей мере двое оказываются вместе: когда поют, кто-то может предположить, что они веселятся, но только тот, кто никогда не слышал, как русские поют. То, что они называют пением, напоминает что-то вроде рыданий (a sort of howling) и исполняется с самым серьезным выражением лица. Для тех, кто не знает их языка, все песни кажутся одинаковыми, но чуть больше прислушаешься, если и найдешь различия, то всегда меланхолию и грубость, не меньшую, чем в сопровождении ансамбля роговых инструментов, которые они очень любят в качестве аккомпанемента. Когда они на веслах, на сенокосе или на другой работе, или когда праздник собирает мужчин и женщин вместе, они никогда не устают от своей любимой музыки».

«26 июля 1770 г. К примеру, год за годом, во всех праздниках они любят пение чего-то типа баллад, весьма для них необычных, которые, как и их танцы кажутся иностранцам унылыми, но на них они навевают покой и развлекают $^{18}$. У них трубы и дудки очень простой конструкции, именно они часто сопровождают их голоса, особенно на воде в сильную жару».

С самого начала своих наблюдений за жизнью обитателей столицы Российской империи в конце первого десятилетия правления Екатерины II Джейн Каткарт, записывая подмеченные ею сценки, детали быта и поведения окружавших ее горожан, не оставляет и стремления обобщить увиденное, или, по ее словам, «в точности ухватить настоящий характер тех, среди которых мы живем». Эти обобщения меняются по мере привыкания

${ }^{17}$ Возможно два варианта перевода: либо «они поют, где придется», либо «они поют, перекликаясь, партиями».

18 Через несколько лет это же впечатление сложится у Уильяма Кокса (Путевые записки от Москвы до С.-Петербурга одного англичанина в царствование императрицы Екатерины II, заключающие в себе весьма любопытные исторические сведения, относящиеся к России в XVIII столетии: Пер. с фр. М., 1837. С. 47-49). 
к стране, с накоплением усталости от чужой среды, и, вероятно, с болезнью самой «посольши», которая с 1770 г. все реже бралась за перо.

Первую попытку обобщить свои впечатления о простонародье, сопоставив личные наблюдения с собранной обрывочной информацией о пище, одежде, непременных банях ${ }^{19}$, пьянстве и проявлениях религиозных чувств, леди Джейн сделала, не пробыв и четырех месяцев в России:

«29 ноября [1768]. Я увидела столько всего к этому времени, что первые впечатления стерлись. Я привыкла ко всему новому, о чем должна была записать с самого начала и сразу, и к тому, что составляет сердцевину воспоминаний. Местные жители (natives), те, что не умирают в детстве, тверды, как железо, способны противостоять голоду и холоду, плохой пище и одежде (хотя, чтобы существовать зимой, абсолютно необходимы шерсть или мех, закрывающие их тела, ноги и стопы). Они здоровы и деятельны, не красивы ни формами, ни конечностями, ни лицом, но были бы таковыми, по всей видимости, если бы не были подвержены суровым климатическим условиям, не были бы испорчены плохой пищей и не слишком бы много парились в горячих паровых банях, которые все они посещают и которые некоторым образом защищают их, иначе бы их уничтожили паразиты и грязь всех сортов. Они хлещут себя в банях березовыми ветками, и это дает им ощущение, будто это щетка для тела. Этим обычаем они наслаждаются. Мужчины и женщины выбегают из этих бань, как я понимаю [со слов тех,] кто видел их ${ }^{20}$, без одежды, разгоряченные, как раки, и бросаются в реку или в бассейн с холодной водой; они считают, что так нужно поступать еженедельно или чаще.

Они едят мало мяса, имеют суровые посты большую часть года. Едят различные блюда из овса, ржи или других грубых зерен, мне кажется, что в их пищу входит мало пшеницы, но немереное количество чеснока, который делает их непереносимыми соседями для тех, кто не выносит этот овощ. Женщины, как и мужчины, любят выпивать, говорят, что они как нация очень преданы пьянству, когда могут найти деньги. Они также самые умелые воры в мире, когда им подворачивается возможность присвоить что-либо, попавшееся на пути.

Больше всего их религия, кажется, состоит из того, что они крестятся, очень низко кланяются и повторяют некие благочестивые восклицания каждый раз, проходя мимо церквей или образа святого, или других такого рода изображений, резных фигур и проч. У них есть изображение или картина

${ }^{19}$ Об интересе иностранцев к русским баням см.: Cross A. The Russian Banya in the Descriptions of Foreign Travelers and in the Depictions of Foreign and Russian Artists // Oxford Slavonic Papers. New Series. 1991. Vol. 24. P. 34-59.

${ }^{20}$ Когда через шесть лет «публичные бани» Петербурга увидел Натаниель Рэкселл, они вызвали у него «отвращение» и «любопытство» (Екатерининский Петербург глазами иностранцев. Неизданные письма 1770-х годов / Сост. А.Н. Спащанский. СПб., 2013. С. 133-135). 
Спасителя, Богородицы с младенцем или некоторых их святых, которых множество во всех их домах...

Они очень верят в предзнаменования. Смерть, кажется, вызывает у них большее безразличие, чем я где-либо видела, возможно, потому (говорю о бедных), что в их жизни так мало радости и разнообразия, она - лишь пустое существование и ничего боле».

Наступление зимы и морозы дали англичанке новую пищу для размышлений о бедном люде, его выносливости и о «железном характере» русских:

«7 ноября ст.ст. [1770 г.] Зима установилась, порой она сурова, но приятна... У всех на улицах лица выражали удовлетворение, как будто холод для них естественное состояние, и они вовсе не стремятся поспешить с мороза домой, но в своих тулупах, когда с их бород и волос свисают сосульки, совершенно довольны прохаживаться или спокойно стоять в сапогах (boots), в варежках ${ }^{21}$ и в меховые шапках, не обращая внимания на сильный мороз».

«Я продолжаю в воскресенье 25 января/6 февраля [1769 г.]. Много человек умерли на улицах и на реке, восемь бедных рабочих, пришедших с пропуском для работы, до смерти замерзли, немного не добравшись до Петербурга, единственное обстоятельство, которое отличает одного молодого человека, найденного мертвым на мосту неподалеку от нашего дома, это то, что у него во рту был кусок пирога (это вид хлеба, что они продают на улице), когда его до смерти схватил мороз... можно предположить, что он выпил спиртной напиток, что и привело к тому, что он замерз в таком необыкновенном виде».

«...около дворца... разрешается разжигать костры, чтобы не дать извозчикам замерзнуть. И они, и их лошади продолжают оставаться на улицах, пока их наниматели отсутствуют, что кажется очень жестоким, но они в целом отлично это переносят, слуги спят на ступеньках, завернувшись в их овчины и поразительно мало отличаются от грубых созданий: собака, к примеру, так же следует за хозяином и ее можно обучить достигать нескольких разных целей».

Далее в той же записи, датированной январем 1769 г., от замечаний, как «усталые лакеи на шубах у подъезда спят» (А.С. Пушкин), Джейн Каткарт впервые обращается к теме русского крепостничества, или скорее того, что она о нем слышала (к сожалению, источников ее информации для подобных заключений мы не знаем 22$)$ :

${ }^{21}$ Дословно: «в перчатках без разделения пальцев».

${ }^{22}$ Возможно, с миледи делился информацией У. Ричардсон. Его взгляд на положение крепостного крестьянства в России см.: Richardson W. Anecdotes of the Russian Empire: In a Series of Letters, Written, a Few Years Ago, from St. Petersburg. L., 1784. P. 192-200. 
«Крепостные (serfs), и мужчины, и женщины, во всех семьях русских дворян рождаются и растут как их рабы, и живут, и умирают и оставляют своих детей, если имеют их, в том же положении. Между собой они считают количество душ, или крестьян, как количество денег: так, много тысяч душ и много тысяч рублей являются понятиями равнозначными. Они дают им либо торговать, либо образование, пригодное для имеющихся целей или различных надобностей. Но владельцы связаны и с неудобством, ибо, если крепостные окажутся праздными, никчемными, вороватыми, пьяницами, они не могут с ними расстаться. Они, хорошо это или плохо, но им принадлежат, и все оказываются в одинаковом положении, а это делает необходимым устанавливать строгую дисциплину для этих бедных, подневольных, необученных созданий, которых содержат в трепете более или менее жестокими побоями, и, если в конечном итоге они не уступают, то у владельцев остается единственная возможность избавиться от них, записав в матросы или солдаты».

Свои этнографические и социальные наблюдения о «русских» Джейн Каткарт продолжит с наступлением Великого поста. После масляничного неистовства она замечает изменение в нравах «русских», правда, несколько опрометчиво относя ритуальные формы поведения в Прощеное воскресенье к привычным «добронравию» и «вежливости» столичных жителей:

«Для нас, иностранцев, оказалось, что русские по отношению к иноземцам и между собой - очень мягкий, веселый и добронравный народ. Я снова должна отметить, что поражают их любезность, хорошие манеры и вежливость друг к другу, это каждый видит ежедневно, когда они проходят по улицам. Приятно посмотреть из экипажей на улицах, проспектах и базарах, заполненных, в это время (завершение Масленицы. - E.C.) людьми, как никогда, на этих бедняг, как они, снимая свои шляпы или, скорее, меховые шапки, низко кланяясь, пожимая руки и обнимая друг друга, выражают самые добрые пожелания, какие позволяет русский язык» ${ }^{23}$.

Впрочем, и во время Великого поста «необычное» добропорядочное поведение простонародья англичанка принимает не только за благочестие, но и за «любезность»:

«На улицах среди простых людей я вижу значительные признаки необычной для них любезности, и, действительно, весьма примечательны их величайшее добродушие и добронравие друг к другу».

${ }^{23}$ О том же: Кокс У. Путевые записки. С. 43. 
В Великий пост 1769 г. леди Джейн Каткарт делится общими наблюдениями относительно особенностей «русских», и ритуальные ограничения этого периода церковного года дают ей повод обратиться к описанию пищевых запретов и предпочтений, а также вновь писать о «грубости» и «простоте» повседневной жизни простолюдинов.

«St. Petersburgh 7 марта 1769. В эту первую неделю поста у русских особенно строго с пищей, они не едят ничего животного происхождения или имеющее даже самое отдаленное отношение к животному — молоко, масло, яйца, никаких сортов рыбы, короче, бедняки все живут на своем черном хлебе и соли, приправленных луком и особенно чесноком, воде, и, если добавляют что-то еще, то только кашу из грубого зерна».

Далее она повторяет свои замечания о том, как русские согреваются, лежа на горячих печах, о том, что «ужасно воняют благодаря чесноку, которым они в основном питаются», о банях и купаниях в ледяной воде и продолжает об одежде простонародья:

«Работники идут по улицам, руки за поясом или за разноцветным кушаком, которые носит весь простой люд. Меховая шапка с ушами зимой, а когда сходят морозы - высокая шапка, как у грубых мужиков. Все содержат свои ноги в тепле, зимой надевают сапоги (boots) и все время, что я здесь с августа, я замечаю, что их ноги обернуты в несколько слоев грубой льняной или шерстяной материи, так что невозможно увидеть их настоящего размера».

Размышления англичанки о религиозных чувствах русских в целом продолжают традицию западно-христианской россики, в которой обычно порицаются «внешние» проявления благочестия православных. Поклонение изображениям святых, горящие лампады вызывают у Джейн Катарт «меланхолию», и она, как и многие ее предшественники, винит «бедные создания» Петербурга в «непонимании» ими основ христианского учения:

«У них, как кажется, нет иного понимания [религии], чем простосердечно поклоняться какому-то невидимому существу, которое, как они думают, видит их и учтет это должным образом. Некоторые из них от невзгод кончают свою жизнь, обычно бросаясь в воду, что хорошо известно, но это мало замечают. Их держат в страхе перед полицией. И многие молодые извозчики и мужики (ischvoschiks and mushicks) скажут, что они никого, кроме полиции, больше не боятся. Вся их религия состоит из постов, очень коротких восклицаний, когда они осеняют себя крестом, низких поклонов, слушания церковных служб, которые они не понимают, а также они пребывают в большом почтении к их 
священнослужителям и попам еtс. В высшем обществе (those in high life), вероятно, этого меньше [т. е. простоты религиозного чувства], но взамен они ничего лучшего не находят, а от того должно происходить и ослабление моральных обязанностей».

Последние заметки в тетради «Memoranda», обобщающие наблюдения англичанки за русскими, относятся к июлю 1770 г. В них она еще менее расположена хвалить и восхищаться простонародьем Петербурга, чем это было даже годом ранее. Но, стремясь оставаться нейтральным наблюдателем, Джейн Каткарт так и не решила, как отнестись к народу, который с самого начала так ее интересовал, а потому до конца своих записок она так и не смогла избавиться от противоречий в оценках и суждениях о русских:

«Русские чрезвычайно жаждут использовать их погоду для занятий, так как [хорошая] погода длится так недолго. Зимой люди разных чинов, кажется, почитают свои развлечения во многом за занятия делом. Короче говоря, они представляются мне самыми беспутными (dissipated) людьми, каких я когда-либо видела, и они не склонны исправляться, так как позволяют иностранцам делать все для себя во всех видах ремесел, промышленности и любого вида предпринимательства не потому, что нуждаются в способностях, так как способностей у них вполне достаточно и в быстроте и в исполнении, но в них совсем нет упорства, и изменить что-то приносит им удовольствие.

Низшие классы из-за их рабского состояния хуже всех, тем не менее, обладают в целом многими хорошими качествами, за исключением тех, а их довольно много и среди женщин, и среди мужчин, кто придается пьянству. Они замечательно добры и весьма любезны друг с другом, величайше преданы и покорны своим господам и тем, кому они принадлежат. За маловажные дела они спрашивают в три-четыре раза больше суммы, на которую согласятся. Один господин, к примеру, спросил у двух человек, сколько они хотят за расчистку заросшего лесом участка земли, один [сказал], что не возьмется за это меньше, чем за 300 рублей, другой долго стоял на 35 рублях, и наконец согласился на 20 рублей. Аршин шелка и т.п. покупается в каждой лавке на рынке... но цена в одной лавке весьма отличается от другой. И они непрерывно, как по прихоти, нахваливают товар, и чтобы подорвать торговлю соседа, когда видят, что покупатель может предпочесть другую лавку, спускают свои товары за цену значительно более низкую, чем та, которой вначале крепко держались».

Этими записями тетрадь посольши Джейн Каткарт «Memoranda of St. Petersbourg» по сути и завершается. За ними следует только краткое примечание от ноября 1770 г.: «Первый снег в этом году, почитается, что выпал 
замечательно поздно и что подобного и близко не бывало уже двадцать восемь лет».

$$
* * *
$$

Читатель записок Джейн Каткарт может во многом упрекнуть английскую даму в том, что она не пожелала или не успела многое описать из реалий современного ей Петербурга. Действительно, она «не заметила» многообразия этнических типов и конфессиональных культур города, казалось бы, она не смогла или не захотела обратить внимание на неправославных подданных императрицы, на различия в облике и быте недворянских сословно-статусных групп столичных обитателей. Знала ли она описания России, изданные ее предшественниками, знакома ли была с уже существовавшими опытами изображения городских жителей Российской империи А. Дальштейна, Христиана Рота (последний как раз в 1770-е гг. работал над серией гравюр с «костюмными изображениями» для сборников «Открываемой России» $\left.{ }^{24}\right)$ ? К сожалению, из имеющихся источников трудно об этом судить ${ }^{25}$. Очевидно, что и записки Джейн Каткарт едва ли могли найти отклик у читателей и повлиять на будущие описания России. Предположительно, лишь Уильям Ричардсон, живший с семьей Каткартов в Петербурге, мог быть свидетелем или участником разговоров о том, что миледи записывала в свою тетрадь ${ }^{26}$. Хотя приводимые ею сведения находят параллели в сочинениях второй половины XVIII в. (в 1770-е гг. у Уильяма Кокса и Натаниэлля Рэкселла), нет никаких оснований считать, что кто-то из английских авторов имел возможность познакомиться с заметками Каткарт о России. Очевидно, что в своем стремлении понять и описать простонародье екатерининской России леди Каткарт была одной из первых, и тем примечательней, что только спустя 250 лет образ Петербурга 1768-1770 гг,, созданный английской посольшей, все-таки находит своего читателя.

\section{Литература}

Агапкина T.A. Мифопоэтические основы славянского народного календаря. Весенне-летний цикл. М., 2002.

${ }^{24}$ Вишленкова Е.А. Визуальное народоведение империи, или «Увидеть русского дано не каждому». М., 2011. С. 42-63.

25 Джейн Каткарт в своей тетради ограничилась лишь небольшими выписками из только что опубликованного в 1768 г. «Путешествия в Сибирь» Шапп д’Отроша, которое она «бегло посмотрела», но по поводу которого, по ее замечанию, «много говорили в английской колонии Петербурга и были весьма рассержены на это сочинение».

${ }^{26}$ Richardson $W$. Anecdotes of the Russian Empire. Частично сочинение Ричардсона переведено на русский: Екатерининский Петербург глазами иностранцев. Неизданные письма 1770-х годов... С. 17-102. 
Акельев E.B., Трефилов Е.Н. Проект европеизации внешнего облика подданных в России первой половины XVIII в.: замысел и реализация // Феномен реформ на западе и востоке Европы в начале Нового времени (XVI-XVIII вв.): Сборник статей. СПб., 2013. С. 153-173.

Вишленкова E.A. Визуальное народоведение империи, или «Увидеть русского дано не каждому». М., 2011.

Гунякова И.В. Записки Уильяма Кокса второй половины XVIII века о его путешествии в Россию как исторический источник. Дис. ... канд. ист. наук. Рязань, 2009.

Екатерининский Петербург глазами иностранцев. Неизданные письма 1770-х годов / Сост. А.Н. Спащанский. СПб., 2013.

[Кокс Уильям]. Путевые записки от Москвы до С.-Петербурга одного англичанина в царствование императрицы Екатерины II, заключающие в себе весьма любопытные исторические сведения, относящиеся к России в XVIII столетии / Пер. с франц. М., 1837.

Конечный А. Былой Петербург. Проза будней и поэзия праздника. М., 2021.

Константинова С.C. Русские реформаторы и Россия в восприятии британских авторов второй половины XVIII века. Дис. ... канд. ист. наук. Саратов, 2006.

Олевская В.В. Раскольническая контора // Государственность России (конец XV в. февраль 1917 г.): Словарь-справочник. М., 2001. Кн. 4. С. 17-18.

Смилянская Е.Б. Англофилия Екатерины II и «исключительное посольство» лорда Каткарта в Санкт-Петербург в 1768-1772 гг. // Journal of Modern Russian History and Historiography. 2019. Vol. 12. Р. 224-244.

Смилянская Е.Б. Дипломатический церемониал при дворе Екатерины II // Quaestio Rossica. 2020. T. 8. № 4. C. 1255-1273.

Akelev E. Is It Possible to Make Money from Beards? The Beard Tax and Russian State Economics at the Beginning of the Eighteenth-Century//Cahiers du Monde Russe. 2020. Vol. 61. № 1/2. P. 81-104.

Batten Ch. L. Jr. Pleasurable Instruction: Form and Convention in Eighteenth-Century Travel Literature. Berkeley, 1978.

Burgess M. Fairs and Entertainers in 18th Century Russia// The Slavonic and East European Review. 1959. Vol. 38. № 90. P. 95-113.

Cross A. By the Banks of the Neva. Chapters From the Lives and Careers of the British in Eighteenth-century Russia. Cambridge, 1997.

Cross A. In the Lands of the Romanovs: An Annotated Bibliography of First-Hand English-Language Accounts of the Russian Empire (1613-1917). Cambridge, 2014.

Cross A. The Russian Banya in the Descriptions of Foreign Travelers and in the Depictions of Foreign and Russian Artists // Oxford Slavonic Papers. New Series. 1991. Vol. 24. P. 34-59.

Perry J. The State of Russia. L., 1716.

Richardson $W$. Anecdotes of the Russian Empire: In a Series of Letters, Written, a Few Years Ago, from St. Petersburg. L., 1784.

The Baroness de Bode 1775-1803. By William S. Childe-Permberton. L., 1900. 


\section{Н.В. Соколова}

\section{«... А ДРУГУЮ КРОШКУ ВЗЯТЬ В МИР» (О ФУНКЦИЯХ КРЕСТЬЯНСКОЙ ОБЩИНЫ В ПЕРВОЙ ЧЕТВЕРТИ XVIII В.)}

Аннотация Статья посвящена изучению важнейших функций общины. Анализ контекстно-зависимых значений лексемы «крошка» и определение содержания данного понятия в источниках, касающихся крестьянского землепользования и тяглого обложения в монастырской деревне Центра России, показали повсеместное сохранение в практике первой четверти XVIII в. системы вытного тягла. Констатируется значимая роль мирского самоуправления в определении принципов, организационных форм и механизмов раскладки тягла и наделении крестьян пашенной землей и прочими угодьями.

Ключевые слова: налоги, община, крестьянское самоуправление, административно-хозяйственная функция, финансово-фискальная функция.

Summary The article is devoted to the study of the most important functions of obschina. The analysis of the «kroshka» lexeme's context-dependent meanings and the definition of this concept in the sources related to peasant land use and taxation in the monastic village of Central Russia has demonstrated the widespread preservation of the vytnoye tyaglo tax allocation system in practice of the first quarter of the 18th century. The article states the significant role of community self-government in determining the principles, organizational forms and mechanisms of tax allocation and allotting peasants with arable and other land.

Keywords: taxes, obschina, peasant self-government, administrative and land allocation function, financial and fiscal function.

В источниках конца XVII - первой четверти XVIII в. из архивов монастырей Центральной России лексема «крошка» встречается в связи с различными ситуациями, касающимися крестьянского землепользования и тяглого обложения. Так, в «Книгах старосты мирскова Семена Титова 
приемных мирским денгам, что с которой выти принято» (1696-1697 гг.), сохранившихся среди документов приписной к московскому Донскому монастырю Медведевой пустыни в Дмитровском уезде среди прочего помечено: «Перваго гривеннаго збору... Запазинские выти у десяцкова Федора Добычи с 18 полуосмаков с крошкой принято 1 руб. 31 алт. 4 д., ... Чернеивские выти у десяцкого Семенки Любимова с 14 полуосмаков с крошкой принято 1 руб. 15 алт.» ${ }^{1}$. Очевидно, что речь идет о некоем превышении тягла, указанного в «полуосмаках». Однако в ставшей уже хрестоматийной статье А.Л. Шапиро, который особо отмечал многообразие терминов, применявшихся для обозначения единиц тяглого обложения, и привел довольно-таки длинный их перечень - выть или ее доли, «кость», «рубль», «алтын», «деньга», «десятина» и т.д., «крошка» не упомянута². Значения, отвечающего приведенному выше контексту, нет ни в «Словаре русского языка XVIII века», ни в «Словаре русского языка XI-XVII вв.»³.

Целью статьи является изучение контекстно-зависимых значений данной лексемы, определение содержания понятия «крошка» в документах, касающихся различных сторон функционирования общины и мирского самоуправления в монастырских вотчинах в первой четверти XVIII в. Весьма информативным источником для решения вытекающих из такого целеполагания задач является рукопись, включающая в качестве главного документа мирскую окладную книгу вотчины Медведевой пустыни 1718 г. ${ }^{4}$ История ее возникновения вкратце такова. 29 июля 1718 г. житенный староста Минеевской выти Андрей Федосеев и крестьяне деревень Тишина, Прокохова, Назарова и Исакова подали в московский Донской монастырь челобитную. По их утверждению, крестьяне входивших в ту же всевотчинную общину деревень Новое село, Липина, Ступина, Борцова, Маншина, Куминова и Карамышева, сложив с себя тягло, продолжают владеть земельными наделами. Челобитчики просили их «с вышеписанными деревнями в тяглой земле, и в сенных покосах, и во всяких угодьях и их же братья крестьян поверстать в равенстве» ${ }^{5}$.

Результатом крестьянского обращения стал указ монастырских властей о проведении подворного описания, по итогам которого надлежало «тягла

1 ОПИ ГИМ. Ф. 440. Оп. 1. Д. 447. Л. 18-19.

2 Шапиро А.Л. Переход от повытной к повенечной системе обложения крестьян владельческими повинностями // Ежегодник по аграрной истории Восточной Европы. 1960 год. Киев, 1962. С. 207.

${ }^{3}$ Словарь русского языка XI-XVII вв. Вып. 8. Крада - Лящина. М., 1981. С. 77; Словарь русского языка XVIII века. Вып. 11. Крепость - Льняной. СПб., 2000. С. 36-38.

${ }^{4}$ ЦГА Москвы. Ф. 421. Оп. 1. Д. 551.

5 Там же. Л. 1, 1 об. 
их крестьянские пустые меж ими поверстать в жило». Для проведения тяглого обложения («для окладу») предписывалось привлечь «вотчинных лутчих и постоянных и правдивых крестьян, что пристойно» ${ }^{6}$. В тексте окладных книг они неоднократно названы «выборными окладчиками», что позволяет думать, что они были избраны общиной на мирском сходе Выборность «окладчиков» подтверждает и текст скрепы на включенном в данную рукопись мирском приговоре об утверждении нового оклада от 3 августа 1718 г.: «К сему приговору монастыря Медведевы пустыни подьячей Иван Садыков вместо старосты, и соцкого, и выборных окладчиков, кои имена писаны в сем приговоре, по их велению руку приложил» ${ }^{8}$.

Следует подчеркнуть, что в источнике прямо указано, что мирские выборные из «лутчих и постоянных и правдивых крестьян» не только производили оклад, но и присутствовали на предварявшем его подворном описании: «И при оных крестьянех досматривано и переписывано» ${ }^{9}$. Их участие подтверждается и скрепой по листам рукописи: «К сим книгам села Раменок поп Федор вместо старосты Ивана Иванова, и соцкого Андрея Емельянова, и окладчиков Лазаря Алфериева, Симеона Амвросиива, Василия Силина с товарыщи по их прошению руку приложил». В скрепе перечислены три «выборных окладчика», однако в рукописи содержится и полный их перечень, в который включено 20 имен с указанием места проживания. В составе окладной комиссии были представлены 10,4\% дворохозяйств и 60,6\% поселений данного всевотчинного «мира», что, безусловно, означало высокую степень ее осведомленности о тяглоспособности крестьянских хозяйств.

По распоряжению монастырских властей к проведению описания вотчины были привлечены монастырские приказчики и подьячие. Их имена зафиксированы в скрепах по листам рукописи: «К сим книгам Донского монастыря подьячей Григорей Гоминицкий руку приложил»; «К сим книгам монастыря Медведевы пустыни подьячей Иван Садыков вместо себя

6 Там же. Л. 1 об.

7 О выборных приговорах мирских сходов на «окладчиков» см., например: Соколова Н.B. Община в монастырской деревне Центра России в начале XVIII в. (К вопросу о поземельно-хозяйственной функции крестьянского мира) // Ежегодник по аграрной истории Восточной Европы. 2012 год: Типология и особенности регионального агарного развития России и Восточной Европы X-XXI вв. М.; Брянск, 2012. С. 94-100; Соколова Н.В. Окладные книги как источник для изучения социальных микроструктур нижегородской монастырской деревни 60-90-х гг. XVII в. // Лествица: Материалы научной конференции по проблемам источниковедения и историографии памяти В.П. Макарихина. Нижегородский государственный университет (22 мая 2003 г.). Н. Новгород, 2005. С. 218-221.

8 ЦГА Москвы. Ф. 421. Оп. 1. Д. 551. Л. 53-53 об.

9 Там же. Л. 3. 
и вместо прикащиков Сидора Максимова и Федора Осетрова руку приложил». Судя по почерку второй скрепы, сохранившийся беловик окладных книг писал тот же Иван Садыков. Скрепы нанесены на нижнее поле листов и заканчиваются на л. 151, после итоговых данных по сельцу Васнево. Далее в рукописи следуют общие итоги тяглого обложения, а также мирской приговор от 3 августа 1718 г. и приговор соборных старцев Донского монастыря, которыми результаты оклада были утверждены. Приговор монастырского собора имеет рукоприкладство архимандрита Донского монастыря Лаврентия. Многократно повторенная на боковом поле всей рукописи скрепа «Донского монастыря казначей монах Варлаам», по-видимому, была нанесена перед отправкой окладных книг из Донского монастыря наместнику Медведевой пустыни. Отвез рукопись 30 ноября 1718 г. крестьянин монастырской деревни Липина Федор Иванов ${ }^{10}$.

Хорошая сохранность и прозрачность всей истории происхождения источника позволяют, исследовав его методами внешней и внутренней критики, сделать вывод о высокой степени достоверности содержания документа. Окладные книги представляют собой совокупность описаний всех существовавших на тот момент поселений монастырской вотчины. Каждая из 33 рубрик состоит из вводной формулы с названием села, сельца или деревни, подворных записей и итогового текста. Анализ показал, что записи, относящиеся к отдельному дворохозяйству, составлены с соблюдением определенного формуляра. Начальная статья включает имя дворовладельца, его возраст и семейное положение (женат, вдов), имена братьев, сыновей, внуков, племянников, зятьев, пасынков - с указанием их возраста и, для достигших брачного возраста, семейного положения (женат, холост), а в необходимых случаях - индивидуальных особенностей, прежде всего касающихся их трудоспособности, которые, по-видимому, учитывались при окладе («хвор», «ногами увечен», «хвор ногами и вдов», «крив», «глух», «слеп»). Наиболее информативна и разнообразна по содержанию следующая статья, которая представляет собой запись сказки дворовладельца о тягле, прежнем и нынешнем, о причинах, по которым оно было «збавлено», о наличии/отсутствии соответствующего решения общины или монастырских властей. В завершающей части зафиксировано содержание принятого выборными окладчиками приговора о новом окладе, иногда - какие-то особые его условия, решение о предоставленной льготе, о необходимости раздела двора и т. п.

10 54-летний сын дворовладельца Ивана Миронова (Там же. Л. 11). 
Посвященный тому или иному поселению итоговый текст содержит сопоставление общего тягла по крестьянской «скаске» и по новому окладу («Итого в вышеписанной деревне Быкова явствует по скаске их Прокофия с товарыщи 5 полуосмака прежнего тягла. А по нынешнему новому окладу в той деревне тягла пять же полуосмаков» ${ }^{11}$; «Итого в вышеявленной деревне Куминовой явствует по скаске их, Афонасия с товарыщи, 4 полуосмака прежнего тягла. А по нынешнему новому окладу в той деревне 3 полуосмака без полукрошки. А за тем окладом в остатках полуосмак с полукрошкою» ${ }^{12}$ ).

$$
* * *
$$

В первой четверти XVIII в. во владениях Медведевой пустыни в Дмитровском уезде за единицу тягла был принят «полуосмак». Так, в приходных книгах всевотчинного старосты Лариона Моисеева под датой 26 октября 1700 г. записан сбор «в ямские и полоняничные денги по 6 алтынов по 4 денги с полуосмака», а под 28 марта 1701 г. - сбор «по 3 алтына по 2 денги с полуосмака в сенные государевы копенные денги» ${ }^{13}$. В 1718 г. «полуосмак» оставался самой крупной единицей тягла. В итоговых записях по поселениям составители окладных книг «полуосмаки» суммируют, но никогда не переводят в более крупные единицы («Итого в помянутой деревне Прокоховой явствует по скаске их, Григорья с товарыщи, четыре полуосмака прежнего тягла. А по нынешнему новому окладу в той деревне 4 полуосмака»; «Итого в вышеявленной деревне Борцово явствует по скаске их, Патрекея с товарыщи, тринатцать полуосмаков прежнего тягла. А по нынешнему новому окладу в той деревне тягла осмь полуосмаков бес трети. За тем окладом в остатке пять полуосмаков с третью» ${ }^{14}$. Несмотря на явную генетическую связь существующей системы тяглого обложения с традиционной вытной, в источнике не фигурируют ни «выть», ни «осмак».

В качестве дворового тягла «полуосмак» встречается редко, а крестьянские хозяйства, тягло которых превышает данное значение, - единичны. Большинство дворов живет на тягле, которое представляет собой ту или иную долю полуосмака. В частности, распространенным было тягло $1 / 3$ и 2/3 полуосмака. Для обозначения более мелкой доли тягла в данной общине использовали редко встречающуюся лексему «шестырка», значение которой, впрочем, расшифровывается в самих окладных книгах: «Да ис пустовытной доли владеют шестою долькою полуосмака тое ж доли, что жил

\footnotetext{
${ }^{11}$ Там же. Л. 33 об.

12 Там же. Л. 25 об.

${ }^{13}$ ОПИ ГИМ. Ф. 440. Оп. 1. Д. 447. Л. 87-89.

${ }^{14}$ ЦГА Москвы. Ф. 421. Оп. 1. Д. 551. Л. 13 об., 31.
} 
Иван Ларионов. А ныне приговорили выборные окладчики быть им впредь на крошке, а шестырку пустовытную взять в мир» ${ }^{15}$.

В источнике немало дворов с тяглом «крошка». В самом простом случае оно составляло «крошку» по предыдущему тяглому обложению и не изменилось в результате нового оклада. К таким хозяйствам относится, например, двор Тимофея Осипова из деревни Быкова. Согласно «скаске» 37-летнего дворовладельца, имевшего на момент описания маленького сына и неженатого 15-летнего брата, «тягла де под ним крошка прежнего окладу». Оценив тяглоспособность двора, мирские выборные оставили тягло прежним: «А ныне приговорили выборные окладчики быть ему на крошке ж» ${ }^{16}$.

Однако, для того чтобы определить, что скрывается под лексемой «крошка», нам придется обратиться к анализу фрагментов с более сложным контентом. В силу указанных выше причин для немалого числа дворов тягло по предыдущему окладу, тягло на момент начала описания и вновь определенное выборными окладчиками тягло - это разные величины. Данное обстоятельство позволяет выяснить содержание понятия «крошка», прибегнув к простым и интуитивно понятным расчетам. Так, живущий в селе Раменье 52-летний Иван Андреев (во дворе также записан его 20-летний зять) сказал выборным окладчикам, что «тягла де под ним крошка. А в прошлых годех было у него тягла полосмака. И ис того де прежнего тягла збавил с себя крошку в прошлом 706 году по умертвии брата своего» ${ }^{17}$. Таким образом, из текста следует, что «полуосмак» в данной общине состоял из двух «крошек». Немного более сложный «пример на дроби» в случае с тяглом Савелия Тарасова (65 лет) из деревни Мишуково подтверждает, что «крошка» рассматриваемого источника равна $1 / 2$ полуосмака (или, условно, 1/32 выти): «А сказал тягла де под ним крошка. А в прошлых годех было у него тягла полосмака без трети. И ис того прежнего тягла в прошлом 715 году збавил шестую дольку полуосмака самоволием. И та де збавочная земля за ним же по прежнему») ${ }^{18}$.

К такому же выводу приводит анализ итоговых статей, в которых отражен результат деятельности выборных окладчиков. Например, в сельце Пантелеево на момент описания было всего два двора - Михаила Анисимова (65 лет) и Петра Анисимова (49 лет). В книгах записан приговор окладной комиссии: «А ныне приговорили выборные окладчики быть им, Михаилу з братом Петром, на полуосмаке по крошке обоим в равенстве.

\footnotetext{
15 Там же. Л. 7.

${ }^{16}$ Там же. Л. 33.

17 Там же. Л. 26 об.

${ }^{18}$ Там же. Л. 9.
} 
Итого в помянутом селце явствует по скаске их, Михаила с товарыщи, полосмака прежнего тягла. А по нынешнему новому окладу в том селце полосмака ж» ${ }^{19}$. В другом поселении зафиксирована ситуация, когда мирским выборным не удалось полностью распределить прежнее тягло на имеющиеся 3 двора: «Итого в вышепомянутой деревне Русанова явствует по скаске их, Василия с товарыщи, два полосмака. А по нынешнему окладу в той деревне тягла полосмака с крошкою. За тем окладом в остатке крошка» ${ }^{20}$.

В некоторых монастырских деревнях «крошка» оказалась самым распространенным тяглом (в деревне Русанова — это 3 из 3 дворов, в деревне Липина - 3 из 4, в деревне Прокохова - 6 из 7). Например, на таком тягле сидели два Михаила из деревни Русанова, имевшие дополнительных работников в лице 15-летних неженатых сыновей. Михаил Агеев (59 лет, всего во дворе 5 д. м. п.) в 1716 г. был переведен из деревни Исакова на тягло умершего крестьянина Филипа Антропова («А сказал тягла под ним крошка... А сверх де оного тягла пашни и сенных покосов за ним во владении нет. А ныне приговорили выборные окладчики быть ему на старом тягле на одной крошке») $)^{21}$. Михаил Алексеев (49 лет, всего во дворе 3 д. м. п.) пришел на выморочное тягло двумя годами позже: «А сказал тягла де под ним с нынешнего 718 году во взятье крошка ис пустоты без оржаного и без ярового севу после умершего крестьянина Костянтина Федорова». В ходе нового оклада «приговорили выборные окладчики быть ему на крошке и льготы дать ему на год в податях и во всяком монастырском зделье как с той доли будет питатца хлебом, а прошед год велеть ему все отправять с крошки» ${ }^{22}$. Однако в источнике описаны дворы и на тягле вдвое меньшем - «полукрошке», т. е. 1/4 «полуосмака». Так, в деревне Дятловка, которая, похоже, восстанавливалась после периода запустения, оба двора записаны на «полукрошке». Таково ж было тягло 2 из 5 дворов, например, в деревнях Федоровка, Тишина, Ступина.

В источнике не называются критерии, которыми руководствовались окладчики при определении дворового тягла. В историографии неоднократно отмечалось, что трудовые ресурсы крестьянского хозяйства являлись важнейшим, но далеко не единственным фактором ${ }^{23}$. В этом контексте обратим внимание на «скаску» 50-летнего Григория Дмитриева из дерев-

${ }^{19}$ Там же. Л. 7 об.

${ }^{20}$ Там же. Л. 5 об.

${ }^{21}$ Там же. Л. 5.

${ }^{22}$ Там же. Л. 5 об.

${ }^{23}$ См., например: Горская Н.A. Монастырские крестьяне Центральной России в XVII в. М., 1977. С. 26-32; Назаров В.Д., Тихонов Ю.А. Крестьянский и бобыльский двор в светских владениях центральных уездов I половины XVII в. // История СССР. 1977. № 4. С. 152-162; Соколова Н.В. Окладные книги как источник... С. 221-228; Соколова Н.В. Социальные 
ни Федоровка: «А в прошлых де годех было под ним тягла полкрошки, а в 714 году положено на него тягла крошка, и с тое де накладной полкрошки он, Григорей, с помянутого 714 году пашню по нынешней 718 год не пахал и сена не косил. А ныне приговорили выборные окладчики быть ему на крошке». При этом мирские выборные особо отметили в окладных книгах, что до 1 сентября 1719 г. он платит с полкрошки, а затем - с крошки. Настойчивость крестьянского мира в увеличении тягла данного двора, по-видимому, означает, что потенциальные ресурсы хозяйства были обусловлены не только количеством мужчин - полных работников (дворовладелец имел сыновей 14, 10 и 7 лет), но и какими-то другими обстоятельствами ${ }^{24}$.

Иная ситуация сложилась в хозяйстве крестьянина той же деревни 67-летнего Леонтия Степанова, с которым жили его сыновья 12, 7 и 4 лет. Согласно его «скаске», «тягла де под ним полкрошки. А в прошлых де годех было у него треть полуосмака, а с прошлого 713 году ис того тягла збавил от взятья сына своего в матрозы... А ныне приговорили выборные окладчики быть ему на трети впредь, а подати с него брать с полукрошки по 720 год за сущею ево скудостью, а с оного году брать с трети» ${ }^{25}$. Таким образом, в данном случае выборные окладчики вернули двору тягло в 1/3 полуосмака, а следовательно, и землю, что важно с учетом числа едоков, возраста дворовладельца и его детей, и предоставили более длительную льготу в податях — «за сущею ево скудостью».

Живущая в деревне Дрочева солдатка Аксинья Федоровская жена Никифорова, единственным мужчиной-работником во дворе которой был 14-летний сын, сообщила мирским выборным, что «тягла под нею полкрошки да четверть крошки. А податей де не платит». Окладчики приговорили «быть ей на полукрошке, а подати брать с четверть крошки прошед два года, а 3 другой не брать еще два года» ${ }^{26}$. В крестьянской «скаске» жителя сельца Васнево Якова Афонасьева сообщается, что его тягло - «полкрошки бес трети». Это самое маленькое тягло по «скаскам». Однако ниже в тексте зафиксировано, что «збавочная» треть полукрошки «с прошлого 713 году

микроструктуры монастырской деревни в Центральной России конца XVII - первой четверти XVIII в. (Некоторые источники и методы исследования) // Северо-Запад в аграрной истории России: Межвузовский тематический сборник научных трудов. Калининград, 2005. С. 15-17; Черкасова М.С. Зажиточные крестьяне Троице-Сергиева монастыря в конце XVI - XVII в.: тягло, наделы, денежная рента // Зажиточное крестьянство России в исторической ретроспективе. Материалы XXVII сессии Симпозиума по аграрной истории Восточной Европы. Вологда, 2001. С. 76-77.

${ }^{24}$ ЦГА Москвы. Ф. 421. Оп. 1. Д. 551. Л. 6.

${ }^{25}$ Там же. Л. 6 об.-7.

${ }^{26}$ Там же. Л. 19 об. 
за ним же во владении», т. е. фактически он продолжал пользоваться всей землей, приходившейся на $1 / 2$ «крошки» ${ }^{27}$.

Следует подчеркнуть, что упоминания более мелких долей «крошки» $1 / 3,1 / 4,1 / 6$ и 1/8 - встречаются обычно при описании тягла, снятого с себя крестьянами, или, наоборот, принятой на себя части тягла другого двора или из «пустовытных» земель. Например, 45-летний крестьянин из деревни Ступина Матвей Иванов сказал, что «тягла де под ним полкрошки да четверть крошки. А в прошлых де годех было у него тягла крошка. Ис того прежнего окладу збавил он с себя четверть крошки в прошлом 716 году, как помре дядя ево Семион Аристов да взят сын у него в салдаты. А ныне же оная збавочная четверть за ним же во владении» ${ }^{28}$. Крестьянских дворов на тягле 1/4 крошки, т. е. 1/8 полуосмака или, в терминологии источника, «осмушка», в данной общине нет. Но таково льготное тягло, с которого после нового оклада должна платить, например, вдова Анна Семенова дочь из села Чернеево. Согласно ее «скаске», «тягла де под нею крошка, податей не платит с прошлаго 710 году от взятья дву сынов своих в салдаты да по умертвии мужа своего». Выборные окладчики приговорили «быть ей на полукрошке, а подати брать с осмушки, а з другой осмушки не брать два года» ${ }^{29}$.

«Связь вытного обложения с земельным наделом, - отмечал А.Л. Шапиро, - привела к запутанности в терминологии, ибо вытью называли то окладную единицу, то тот или иной участок земли, с которого крестьяне тянули вытное тягло» ${ }^{30}$. Наглядной иллюстрацией справедливости этого наблюдения и для иных единиц тяглого обложения является запись о дворе Макара Федорова (деревня Борцова). В ней лексемой «крошка» обозначены и тягло по «прежнему» и по новому окладу, и то, что можно вспахать «под оржаной сев», т. е. земля («А сказал тягла де под ним крошка прежнего окладу, да ис пустых де доль за ним же, Макаром, во владенье прошлых лет полосы по две и по три в поле пустой крошки. А нынешнего 718 году под оржаной сев вспахал де всю крошку. А ныне приговорили выборные окладчики быть ему на одной крошке, а другую взять в мир») $)^{31}$. Практически как равнозначные выступают понятия «покидочное тягло» и «збавочная земля» в описании хозяйства Матвея Никитина (село Чернеево): «А сказал тягла де под ним полкрошки, а в прошлых де годех было под ним тягла полосмака.

\footnotetext{
27 Там же. Л. 49 об.-50.

28 Там же. Л. 14 об.

29 Там же. Л. 45 об.

${ }^{30}$ Шапиро А.Л. Переход от повытной к повенечной системе обложения... С. 208.

${ }^{31}$ ЦГА Москвы. Ф. 421. ОП. 1. Д. 551. Л. 30 об.
} 
И ис того де числа збавил с себя крошку да полкрошки. И тою де збавочною землею владеет он же, Матвей. Да ис того же покидочного тягла сосед ево Влас посеял в прошлом 717 году рожью одну полосу полуосмашную да в пару нынешнего 718 году вспахал одну ж полосу» ${ }^{32}$.

В деревне Маншина окладчики определили для 70-летнего Кондратия Варфоломеева, с которым живет семья его 20-летнего зятя (дети мужского пола у обоих, похоже, отсутствовали), быть «на трети полуосмака, а пахать крошку два года, а прошед два года подати брать с крошки» ${ }^{33}$. Иными словами, данное хозяйство обложено тяглом в $1 / 3$ «полуосмака» и с него два года следует платить подати, но «пахать» Кондратий с зятем будут больший надел, соответствующий $1 / 2$ полуосмака («крошка»). Данная лексема используется также с глаголом «владеть» или в составе формулы «во владение в распашку», как, например, в записи о хозяйстве Изота Иванова из сельца Васнево: «А сказал тягло де определено ему с нынешнего 718 году крошка пустовытная во владение в распашку. А ныне приговорили выборные окладчики и всем миром владеть ему крошкою, а податей с него и монастырского всякого изделья не спрашивать с него три года, пакамест распашет и завод возмет. А прошед оные годы брать с него с крошки» ${ }^{34}$. Фактически прямое отождествление «прибавочной полкрошки» с землей и пашенным наделом обнаруживаем в описании двора Леонтия Васильева из деревни Короваева, которому по новому окладу определено быть «на полуосмаке с полукрошкою... А оная прибавочная полкрошки взять им в той же деревне у салдатки Авдотьи Васильевской жены для того, что оная земля надлежит быть к их тяглой пашне смежна» ${ }^{35}$.

Необходимо остановиться особо на понятии «рыбачья крошка». Оно встречается в источнике лишь однажды, в итоговой записи по деревне Косилова: «Итого в оной деревне Косилове с пустошью Сорокиным полосмака с крошкою. Ис того числа рыбачья крошка без податей». Объяснение находим в описании двора 70-летнего Федора Осипова, с которым жил 27-летний сын и два маленьких внука: «А сказал тягла де под ним крошка прежнего окладу, збавки нет. А вместо де податей отправляет в монастырь рыбную ловлю. А ныне приговорили выборные окладчики быть ему по-прежнему» ${ }^{36}$. При этом рубрика имеет стандартное начало: «Деревня Косилова, а в ней крестьян». Впрочем, появление такого двора именно

\footnotetext{
${ }^{32}$ Там же. Л. 42 об.

33 Там же. Л. 34 об.

${ }^{34}$ Там же. Л. 50.

${ }^{35}$ Там же. Л. 36 об.

${ }^{36}$ Там же. Л. 39.
} 
в данной деревне неслучайно, поскольку это расположенное на берегу реки Сестры поселение - ближайшее к монастырю.

Согласно окладным книгам 1718 г., такое же тягло — «крошку» — имели все 8 дворов подмонастырской слободы, где жили служебники, рыбаки и квасовары. Составителями документа во всех случаях использована стандартная формула: «А сказал тягла де под ним крошка прежнего окладу» ${ }^{37}$. Однако условия, на которых монастырские «служебники» пользовались своими земельными наделами, принципиально отличаются от крестьянских: «И оныя де рыбаки и квасовары с тех помянутых тягл податей не платят. А вместо податей отправляют в монастыре: рыбаки рыбу ловят, а квасовары квасы и пива варят, и огороды пашут, и сторожу они ж отправляют, переменяясь по два человека понедельно». Тем не менее слобода не просто формально включена в окладные книги. Согласно представлениям сельского мира, служебники хозяйствуют на волостной земле, потому в книгах записано: «А ныне выборные окладчики и всем миром приговорили быть им по-прежнему» ${ }^{38}$.

Точно так же - с упоминанием не только выборных окладчиков, но и «всего мира» - в книгах записано о выделении земли отставным драгунам в селе Чернеево: «Ис тех остаточных пустых тягл приговорили выборные окладчики и всем миром отставным драгуну Стахию Никифорову владеть бес податей треть полуосмаком, на пропитание с маткою и с сиротами, которая треть осталась при долке у Марка з братом, да драгуну Родиону Заваруеву приговорили владеть бес податей же четверть крошки на пропитание, которая прилична к тяглу Ивана Дементьева» ${ }^{39}$. Как и в приведенном выше эпизоде оклада в деревне Короваева, связанном с передачей «полкрошки» от солдатки Авдотьи Тимофеевой дочери Васильевской жены Захарова, в тексте указано, где именно находится земля, которую следует отдать отставным драгунам. Как представляется, это важная деталь, свидетельствующая о том, что за новым тяглым обложением в данном случае не последуют всеобщая мера земли и ее всеобъемлющее перераспределение, т. е. полный земельный передел.

«Общественный дуализм» общины ${ }^{40}$, которая, с одной стороны, являлась защитником интересов сельского мира in corpore, a с другой - выступала в качестве инструмента фискальной политики государства и землевладельца, отчетливо проявлялся в механизмах, выработанных ею с целью выпол-

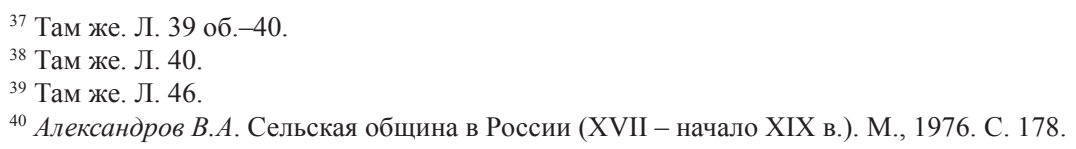


нения важнейших функций по организации крестьянского землепользования и тяглого обложения. Одним из таких механизмов была практика частичных «поравнений» тягла (и, соответственно, земли), подобных тому, что нашел отражение в окладных книгах 1718 г. При этом речь не шла об уравнении хозяйственного положения членов сельского или волостного мира, в том числе обеспеченности их основным средством производства землей. Принцип уравнительности применительно к русской общине рассматриваемого периода следует понимать как уравнение соотношения между трудовыми и хозяйственными ресурсами крестьянского двора и его тяглом (и, соответственно, земельным наделом). Именно с возвращением к общепринятой норме связаны приговоры выборных окладчиков о передаче тем или иным двором тягла и земли «в мир», в том числе и вынесенный в заголовок данной статьи, с упоминанием «крошки» («А ныне приговорили выборные окладчики быть ему на крошке. А другую крошку взять в мир»; «А ныне приговорили выборные окладчики быть ему на крошке. А протчую землю взять в мир» $\left.{ }^{41}\right)$. В тексте мирского приговора от 3 августа 1718 г. содержится важное положение, призванное в условиях круговой поруки защитить интересы всей общины: «А ежели кто из них, крестьян, против нынешнего окладу тягла своего самоволием своим збавит, и с таких складчиков имать пени монастырской в мир, что власти укажут, и чинить жестокое наказание» ${ }^{42}$. Соборные старцы Донского монастыря в своем приговоре не только установили процедуру отказа от тягла или его части, но и определили размер пени, предписав впредь со «сбавленного самоволием» тягла подати брать «вдвое» ${ }^{43}$.

Традиционность крестьянской общины и мирского самоуправления в монастырских вотчинах Центральной России в первой четверти XVIII в. бесспорна. Причины сходства — как основных общинных практик, так и на уровне понятийного аппарата — в вотчинах различных монастырей, относящихся к разным уездам, могут быть предметом особого исследования ${ }^{44}$. В частности, лексема «крошка» использовалась для обозначения некоей доли вытного тягла в документах различной территориальной и владельческой принадлежности.

${ }^{41}$ ЦГА Москвы. Ф. 421. Оп. 1. Д. 551. Л. 25, 25 об.

${ }^{42}$ Там же. Л. 53 об.

${ }^{43}$ Там же. Л. 52.

${ }^{44}$ Соколова Н.В. Община в монастырской деревне Центра России... С. 91-105; Соколова Н.В. Окладные книги как источник... С. 217-228; Соколова Н.В. Роль крестьянской общины в системе налогово-повинностных практик XVII - первой четверти XVIII в. (на материалах монастырских вотчин Центральной России) // Ежегодник по аграрной истории Восточной Европы. 2014 год. Фискальная политика и налогово-повинностные практики в аграрной истории России X-XXI вв. М.; Самара, 2015. С. 65-76. 
Так, в подворной росписи тягла от 16 июня 1702 г. из архива Переславского Федоровского женского монастыря среди прочего упоминается и «крошка»: «В первой полувыти Григорей Федоров с товарыщи. У Григорья тягла осмак с крошкою. У Назара Андреева тягла осмак с крошкою. У Степана Прокофьева $з$ братьями ево с Иванком Большим и с Иванком Меньшим тягла у них осмак с крошкою. У Якима Михайлова з братом ево Андроном тягла у них осмак. В другой полувыти 3 другонатцаткою Кирило Иванов с товарыщи. У Кирила тягла осмак. У Калины Лукьянова другонатцатка с крошкою. У Бориса Микитина тягла осмак бес крошки» ${ }^{45}$. Типичные записи дворового тягла крестьян деревни Потанина того же корпоративного земельного собственника от июня 1703 г. выглядят следующим образом: «У Прокофья Устинова 2 сына, тягла осмак бес крошки», «У Алексея Медведева сын, у него ж зять, тягла осмак бес крошки») ${ }^{46}$.

Сохранилась челобитная 1699 г., поданная крестьянином той же деревни Потанина Иваном Петровым, о сложении им тягла «в мир»: «А я сирота, человек немолодой, а тягло подо мною, сиротою, большое, осмак, и мне, сироте, одному ныне и старому, того осмака держать и тягла с нево тянуть никоими делы невмоч». Как следует из текста, один его женатый сын умер, другой («и с женой») - лежат при смерти, поэтому он просит снять с него тягла крошку, а ему оставить три крошки («против моей мочи»). Прошение было удовлетворено: «207-го году маия в 7 день Данилова монастыря отец архимандрит Варфоломей, слушав сий челобитной, приказал Федоровского девичья монастыря строителю старцу Дорофею, буде можно, деревни Потанина у крестьянина Ивашка Петрова снять тягло четверть осмака в мир, а ему, Ивашку з детми, жить на трех четвертях осмака» ${ }^{47}$. Можно констатировать, что в данной вотчине, во-первых, содержание понятий «крошка» и «четверть осмака» тождественны, во-вторых, «крошка» здесь, как и в вотчине Медведевой пустыни в Дмитровском уезде, равна 1/32 выти, хотя за единицу тягла принят «осмак», а не «полуосмак».

В источниках, которые отражают результаты земельного передела, произведенного крестьянами данной монастырской вотчины в 1703-1704 гг., зафиксировано использование в том же контексте лексемы «кроха»: «Деревни Лусниковы вновь тягла прибавлено осмак с полукрохою. Деревни Пешкова вновь тягла прибавлено полтора осмака и полкрохи. Деревни Тощебулова вновь тягла прибавлено два осмака без полуторы крохи. Деревни Самкова вновь тягла прибавлено полтора осмака с крохою. Деревни Гулина

\footnotetext{
${ }^{45}$ Архив СПбИИ РАН. Колл. 102. Картон 7. Д. 34.

${ }^{46}$ Там же. Д. 223, 241.

${ }^{47}$ Там же. Картон 6. Д. 13.
} 
вновь тягла прибавлено четверуха без двух крох. Деревни Петриловы вновь тягла прибавлено полтора осмака» ${ }^{48}$.

Использование лексемы «кроха» также выявлено в источниках крестьянского происхождения, возникших в вотчинах Иосифо-Волоколамского монастыря. В приговор мирского схода, состоявшегося 13 сентября 1721 г. в селе Новое, входившем в заопределенную вотчину монастыря в Рузском уезде, включена, вероятно, для удобства сборщиков, подробная роспись норм вытных платежей «на майскую треть в рублевой збор, что збираетца в разные приказные платежи»: «И... приговорили с той вотчины со крестьян собрать с выти по 16 руб., с полувыти по 8 руб., з дву осмаков по 4 руб., с осмака по 2 руб., с полуосмака по 1 руб., с крохи по 16 алт. по 4 ден.». Очевидно, что «кроха» здесь также представляла собой $1 / 2$ «полуосмака» или $1 / 4$ «осмака». В другом мирском приговоре той же общины, от 19 ноября 1721 г., дополнительно указан сбор с «полукрохи»: «И в оной платеж приговорили с вышеписанной вотчины со крестьян собрать с вытного тегла по 12 руб. с выти, с полувыти по 6 руб., з дву осмаков по 3 руб., с осмака по 1 руб. по 16 алт. 4 ден., с полуосмака по 25 алт., с крохи по 12 алт. по 3 ден., с полукрохи по 6 алт. по пол 2 ден.» ${ }^{49}$. По итогам произведенного на мирском сходе «разруба» («по мирской роскладке и по заручному приговору») осуществлялся сбор денег с поселений данного сельского «мира». Так, в «Книге приходной Рузского уезда вотчины Иосифова монастыря села Нового зборщика Ивана Семенова» 1722 г. отмечено поступление денег с деревень, совокупное тягло которых описано с использованием лексемы «кроха»: «Деревни Медветкова с семи крох февраля в 21 день принято у Ивана Данилова рубль шесть алтын полшесты денги. Росписка дана»; «Деревни Любятина с трех осмаков с крохою февраля в 20 день принято у зборщика Артамона Дмитриева два рубли четыре алтына полторы денги»; «Деревни Крюкова с трех крох марта в 3 день принято у Ивана Иванова четырнатцать алтын полтретьи денги. Росписка дана. За пустотою не взято 2 алтына 5 денег» ${ }^{50}$.

В вотчинах данной духовной корпорации «кроха» и «полкрохи» являлись довольно распространенным тяглом дворов, где жила и хозяйствовала малая крестьянская семья. Так, 7 февраля 1724 г. Федор Тимофеев, крестьянин из деревни Пристанина Рузского уезда, подтверждал при свидетелях: «Здал я тяглой свой жеребей полкрохи и с пожитками своими и 3 детми своими, с сыном и $з$ дочерью своею, для того, что я овдовел третью женою, а здал я свояку своему села Покровское Агапу Потапову... А отдал я ему, Агапу,

\footnotetext{
${ }^{48}$ Там же. Д. 131.

${ }^{49}$ РГАДА. Ф. 1192. Оп. 3. 1721 г. Д. 11. Л. 16, 29.

${ }^{50}$ Там же. 1722 г. Д. 48. Л. 1-7.
} 
на десять лет» ${ }^{51}$. О том, что «кроха» дробилась на более мелкие доли, свидетельствуют крестьянские «скаски» о пустых тяглых жребиях, поданные в январе 1722 г. Например, в деревне Родионова зафиксирована «пустая долька без четверти кроха, что владел Егор Михайлов, а покинул де он, Егорей, тое дольку впусте от скудости своей». В деревне Чаща «полторы крохи» Самойлы Михайлова «запустело в 1721 году для того, что он, Самойла, монастырю не крепок, и его выслали за помещика». В деревне Чеклеева впусте полторы крохи Ивана Кузмина, который «з женою и 3 детми своими сшел неведомо куды». В деревне Никольская как пустое тягло записано шесть «покинутых» 1/3 долей «крохи» («А покинули де они, вышеписанные крестьяне, те свои тягла впусте от скудости своей и за одиночеством для того, что де ныне у них ерового хлеба нету и сеять и государевых податей платить стало нечем»). В селе Шестаково в «скасках» зафиксировано «впусте» тягло «полкрошки» Степана Захарова, в деревне Кондратово «полполкрошки» Прокофия Степанова ${ }^{52}$.

Последние записи свидетельствуют, что известная нам по дмитровским владениям Донского монастыря и деревням Федоровского монастыря в уезде Переславля Залесского лексема «крошка» использовалась и в вотчинах Иосифо-Волоколамского монастыря. О том, что понятия «кроха» и «крошка» выступают здесь как равнозначные, свидетельствует, например, челобитная, поданная в 1724 г. крестьянином деревни Медведкова Рузского уезда Аврамом Ивановым: «Тягла подо мной крошка с шестою долею крошки, а за саседом моим, Иваном Петровым, кроха без шестой доли» ${ }^{53}$. Следует также подчеркнуть, что в данной общине обе лексемы нередко употреблялись наряду с традиционными долями выти. Так, в упомянутых выше «скасках» 1722 г. как запустевшие в 1721 г. отмечены четыре «пустые дольки полчетверти осмака» крестьян деревни Родионова. При этом Афонасий Федоров сложил с себя это тягло «на весне за скудостью своею, а себе де он оставил тягла и живет в той деревне Родионове на полукрохе», а Петр Дементьев, отказавшийся от той же «полчетверти» «в прошлом 721 году на весне за скудостью своею», живет в той деревне Родионове на «получетверти осмака» ${ }^{54}$.

Система вытного тяглообложения как инструмент, с помощью которого община выполняет свою поземельно-фискальную функцию, продолжала существовать и после введения подушной подати. Так, крестьяне Иосифо-Волоколамского монастыря из деревни Ефремова Волоцкого

\footnotetext{
${ }^{51}$ Там же. 1724 г. Д. 20. Л. 10.

${ }^{52}$ Там же. 1722 г. Д. 33.

${ }^{53}$ Там же. 1724 г. Д. 20. Л. 34.

${ }^{54}$ Там же. 1722 г. Д. 33.
} 
уезда в 1724 г. сообщали в челобитной, что «пашни у нас в деревне только пять крох и с пустотою. И нам в таких лишних платежах и могуты не стало». «Пустота» возникла из-за соседей, которые покинули деревню, живут «в розных местах и кормятца в наймех», но подушную подать со своей общиной не платят. Однако в челобитной описан и уже знакомый нам сюжет. Крестьянин Дорофей Иванов попытался «сложить» с себя часть тягла: «Умыслом своим покидает доли своей половину крохи, на нас же уваливает. А сам толко хочет быть на полукрохе. И то он собою, а мы так разоряемся». Данный случай интересен тем, что в источнике приведены аргументы, которые деревенская община приводит для объяснения своего отказа уменьшить тягло: «А ему, Дорофею, возможно и всею долею своею владеть, понеже у него лошедь и скотина есть, и работать есть кому» ${ }^{55}$.

В том же 1724 г. крестьяне деревни Чеклеева Рузского уезда Алексей Степанов, Василий Ефремов, Иван Фатеев, Митрофан Федоров, Василий Петров, Григорий Макаров и Михаил Фадеев написали в своей челобитной: «Тягла под нами малое число, а детей мужеска полу много... За мною, за Алексеем, полторы крохи, а платил с шести душ. А за мною, Василием, кроха, а платил за четыре души. А за мною, Иваном, кроха, а платил за четыре души. А за мною, Митрофаном, треть полуосмака, а платил за четыре души. А за мною, Василием, кроха, а платил за три души. А за мною, Григорием, кроха, а платил за пять душ. А за мною, Михаилом Фадеевым, треть осмака, а платил с пяти душ». Они настаивали на необходимости «в том подушном окладе землею поверстатца против подушных наших платежей» с соседями, поскольку в той же деревне два двора сидят на тягле в 1,5 крохи и платят с 4 д. м. п., пять дворов на «крохе» платят с 2 д. м. п., еще один двор на трети полуосмака - с 1 д. м. П. При работоспособном крестьянском самоуправлении монастырь-землевладелец, как правило, не вмешивался в мирские процедуры, связанные с организацией уплаты государственных налогов и владельческих платежей, а также выполнением натуральных повинностей. 18 июня на челобитной появилась резолюция монастырских властей, разрешающая «учинить вам в земле равенство, поверстатца безобидно против душ» ${ }^{56}$. Впрочем, довольно скоро в крестьянских общинах в монастырских владениях Центра России возник и противоположный тренд, суть которого заключалась в возврате к прежней системе, учитывающей при наделении землей не число душ мужского пола, а реальную тяглоспособность двора. Л.Н. Вдовина, изучая общину на материалах монастырских архивов первой

\footnotetext{
55 Там же. 1724 г. Д. 29. Л. 1-1 об.

${ }^{56}$ Там же. 1724 г. Д. 20. Л. 16-17.
} 
половины XVIII в., пришла к выводу, что использовавшиеся как окладные единицы выть и ее доли (осмак, полуосмак, кроха и т. д.) «начинают исчезать» к середине столетия ${ }^{57}$.

\section{Литература}

Александров В.А. Сельская община в России (XVII - начало XIX в.). М., 1976.

Вдовина Л.Н. Крестьянская община и монастырь в Центральной России в первой половине XVIII в. М., 1988.

Горская Н.А. Монастырские крестьяне Центральной России в XVII в. М., 1977.

Назаров В.Д., Тихонов Ю.А. Крестьянский и бобыльский двор в светских владениях центральных уездов I половины XVII в. // История СССР. 1977. № 4. С. 152-162.

Словарь русского языка XI-XVII вв. Вып. 8. Крада - Лящина. М., 1981.

Словарь русского языка XVIII века. Вып. 11. Крепость - Льняной. СПб., 2000.

Соколова Н.В. Община в монастырской деревне Центра России в начале XVIII в. (К вопросу о поземельно-хозяйственной функции крестьянского мира) // Ежегодник по аграрной истории Восточной Европы. 2012 год: Типология и особенности регионального агарного развития России и Восточной Европы X-XXI вв. М.; Брянск, 2012. С. 91-104.

Соколова Н.В. Окладные книги как источник для изучения социальных микроструктур нижегородской монастырской деревни 60-90-х гг. XVII в. // Лествица: Материалы научной конференции по проблемам источниковедения и историографии памяти В.П. Макарихина. Нижегородский государственный университет (22 мая 2003 г.). Н. Новгород, 2005. С. 217-228.

Соколова Н.В. Роль крестьянской общины в системе налогово-повинностных практик XVII - первой четверти XVIII в. (на материалах монастырских вотчин Центральной России)//Ежегодник по аграрной истории Восточной Европы. 2014 год. Фискальная политика и налогово-повинностные практики в аграрной истории России X-XXI вв. М.; Самара, 2015. С. 65-76.

Соколова Н.В. Социальные микроструктуры монастырской деревни в Центральной России конца XVII - первой четверти XVIII в. (Некоторые источники и методы исследования) // Северо-Запад в аграрной истории России: Межвузовский тематический сборник научных трудов. Калининград, 2005. С. 12-26.

Черкасова М.С. Зажиточные крестьяне Троице-Сергиева монастыря в конце XVI XVII в.: тягло, наделы, денежная рента// Зажиточное крестьянство России в исторической ретроспективе. Материалы XXVII сессии Симпозиума по аграрной истории Восточной Европы. Вологда, 2001. С. 74-85.

Шапиро А.Л. Переход от повытной к повенечной системе обложения крестьян владельческими повинностями // Ежегодник по аграрной истории Восточной Европы. 1960 год. Киев, 1962. С. 207-217.

${ }^{57}$ См.: Вдовина Л.Н. Крестьянская община и монастырь в Центральной России в первой половине XVIII в. М., 1988. С. 77-78. 


\title{
Б.Н. Флоря
}

\section{СТРОИТЕЛЬСТВО СМОЛЕНСКОГО КРЕМЛЯ И ОТНОШЕНИЯ ВЛАСТИ И ОБЩЕСТВА В РОССИИ НА РУБЕЖЕ XVI-XVII Вв.}

\begin{abstract}
Аннотация На примере разбора свидетельств о мобилизации разных групп населения для строительства Смоленского кремля автор выявляет важные особенности отношений государственной власти России с торгово-ремесленным населением и духовными и светскими землевладельцами при решении важных государственных задач.

Ключевые слова: государственная власть, дворянство, духовенство, каменщики кирпичники, мобилизация.

Summary By the example of analyzing the evidence of the mobilization of different groups of the population for the construction of the Smolensk Kremlin, the author reveals important features of the relations of the Russian state authorities with the commercial and craft population and spiritual and secular landowners in solving important state tasks.

Keywords: state power, nobility, clergy, bricklayers, mobilisation.
\end{abstract}

Хорошо известно, что важной особенностью исторического развития России в эпоху позднего средневековья является сильная позиция центральной государственной власти по отношению к таким важным частям общества, как дворянство, духовенство и городское население. Важной задачей исторической науки является изучение системы взаимоотношений власти с этими частями общества. Как представляется, сохранившийся комплекс известий о строительстве Смоленского кремля на рубеже XVI и XVII вв. дает возможность выделить некоторые важные черты взаимоотношений между ними и государственной властью и проследить определенную эволюцию этих отношений.

Строительство очень важной пограничной крепости, которое следовало осуществить на высоком профессиональной уровне и в сжатые сроки, побудило русское правительство прибегнуть к особым мерам, которые 
привлекли к себе внимание современников, писавших уже в XVII в. о событиях Смуты и отмечавших важные события, предшествующие Смуте.

Строительство Смоленского кремля было таким важным событием, о котором специальные известия читаются в «Новом Летописце» - главном официальном рассказе о событиях русской истории конца XVI - XVII вв. В этом рассказе специально отмечено, что, когда в конце правления царя Федора было принято решение о строительстве кремля в Смоленске, царь «во все грады посла, повеле имати каменщиков и кирпичников поимати, а повеле их послать в Смоленеск для каменново и кирпишнового дела» ${ }^{1}$. Подробный комментарий к этому известию дает текст грамоты от 5 марта 1600 г. Ивану Михайловичу Толбузину, отправленному для производства такой мобилизации в г. Кашин ${ }^{2}$. Для производства соответствующих мер Толбузину был послан список: «которые наши писменные каменщики и кирпичники из Кашина бывали у нашего у смоленского городового дела и у иных наших дел». Из этого текста следует, что «каменщики» и «кирпичники» из Кашина (как очевидно, и из других русских городов) были внесены в составленные в Москве списки таких мастеров (даже в тексте они фигурируют, как «записные... каменщики и кирпичники») и многократно мобилизовались для выполнения различных «дел», связанных, очевидно, со строительством.

Эти «записные» мастера должны были сообщить посланцу имена мастеров и их учеников, которые еще не внесены в списки. На этот раз должны были быть мобилизованы не только строители, но и «горшечники и кувшинники, и печники, и гончары, и жерновные и точильные мастера», и даже мастера, которые делают доски «на гробы», а в списки следовало внести «детей и братью, и дядью, и племянников, и учеников, и козаков, которые те дела умеют делать». Таким образом, речь шла об учете как можно большего круга людей, которых можно было бы использовать на работах, связанных со строительством крепости, если не теперь, то в будущем. Тем «записным» мастерам, которые скрыли бы сведения о таких людях, угрожала смертная казнь.

В наказе определялись и условия содержания таких мастеров при исполнении ими «государева дела». Для проезда мастеров к Смоленску царский посланец должен был нанять «подводы под их снасти», но корм по дороге они должны были покупать на свои деньги по цене, «как крестьяне меж себя купят». На время работы мастерам полагался корм - «на день по четыре

${ }^{1}$ ПСРЛ. М., 2000. Т. 14. С. 47.

2 Акты служилых землевладельцев XV - начала XVII века / Сост. А.В. Антонов. М., 2002. T. 3. № 434 . 
денги», а «всяким мастерам от кирпичу» полагалось за 1 тыс. кирпичей по 11 алт. 4 ден. На время строительства Смоленского кремля в городе Кашине и в уезде запрещалось строить «церковь или погреб каменный или иное что каменное дело», а также изготовлять кирпич и изделия из глины. Нарушителям этого запрета также угрожала смертная казнь.

Интересы каких слоев общества затрагивали эти действия, связанные со строительством Смоленского кремля? Во-первых, речь шла, конечно, о ремесленниках русских городов, которые «живут на посаде», причем не только о полноправных членах посадской общины, но и о тех, «кто живет в черных местех в захребетниках». Это показывает характер отношений государства и посадских людей - мастеров. Можно попытаться выяснить, как складывались такие отношения с течением времени.

В России XV - раннего XVI в. строительство крепостей, как правило, деревянных (строительство каменного кремля в Москве в XIV в. воспринималось как чрезвычайное событие), состоявших из «городен» - деревянных срубов заполненных землей, — не представляло больших трудностей. Для этого достаточно было использовать труд приписанного к «граду» податного населения, жителей как государственных, так с частновладельческих земель, отдельным группам которых великокняжский «городчик» устанавливал сколько «городен» они должны были поставить ${ }^{3}$. Для людей, хорошо знакомых с работой по дереву в собственном хозяйстве, такая работа, при наличии соответствующих компетентных указаний, вероятно, не представляла серьезных трудностей.

Новые сложные задачи появились во второй половине XV в. со строительством больших каменных крепостей в Москве, а затем - в других крупных центрах (как в Новгороде в начале XVI в.). Для такого строительства требовалось прежде всего большое количество строительных материалов, которые следовало заготовить и доставить на место. Отсюда наложение новых обязанностей на податное население. Об этих обязанностях говорилось в документах из церковных архивов первой половины XVI в., когда отдельные владения освобождались от таких обязанностей временно или постоянно ${ }^{4}$. Для крепостного строительства следовало заготовлять камень и известь и доставлять их на место строительства, подчас

3 См. об этом: Носов Н.Е. Очерки местного управления Русского государства в первой половине XVI века. М.; Л., 1957. С. 76 и след.

${ }^{4}$ Акты феодального землевладения и хозяйства (далее - АФЗиХ). М., 1955. Ч. 1. № 25; Акты феодального землевладения и хозяйства. Акты Московского Симонова монастыря. Л., 1983. № 75, 147. 
на достаточно далекие расстояния. Так, по грамоте 1545 г. следовало везти известь в Москву из сел в Ржевском и Волоцком уездах ${ }^{5}$.

Однако помимо такого материала нужны были мастера, которые занимались бы изготовлением кирпича и кладкой стен, и их, как представляется, было не так легко в нужном количестве найти в стране с традициями деревянного строительства. Неслучайно Иван III был вынужден искать «мастеров... каменосечець» из Италии 6 . Усилия по привлечению «стенных» мастеров продолжались вплоть до начала XVI в. ${ }^{7}$ O том, как итальянские мастера руководили рабочими при строительстве Московского Кремля, сохранилось много сведений. Для выполнения столь масштабных работ они, очевидно, должны были готовить каменщиков и кирпичников из среды местного населения, но об этой стороне дела и тем более об условиях работы русских мастеров имеющиеся источники ничего не сообщают. Отсутствуют и известия на этот счет в сообщениях о строительстве каменных стен Китай-города в 30-х гг. XVI в. и других крепостей 8 .

Уже в середине XVI в. возникла необходимость собирать мастеров для строительства больших каменных крепостей. Так, после взятия Казани, как известно, в 1555 г. было приказано «прибрать двесте человек псковских каменщиков, стенщиков и ломцов» «к весне новый город Казань камен делати». Новгородские кузницы должны были изготовить для «ломцов» «всякие снасти, как камень ломати» ${ }^{9}$. Таким образом, для крепостного каменного строительства стремились использовать мастеров из западных областей Русского государства, где более широко была распространена практика каменного строительства. При этом другие ремесленники должны были изготовить для них орудия труда. Но это были отдельные поручения, выполнив которые мастера возвращались к своим обычным занятиям.

Как представляется, с течением времени, когда на смену деревянным укреплениям в XVI в. все чаще стали приходить каменные крепости, власть столкнулась с новыми сложными задачами. Так, нужны были специалисты, которые должны были поддерживать эти укрепления в порядке. Так, в Коломне, где каменный кремль был построен в 20-х гг. XVI в., по писцовой

5 АФЗиХ. М., 1956. Ч. 2. № 184.

${ }^{6}$ ПСРЛ. М.; Л., 1949. Т. 25. С. 302.

7 Таких мастеров привезло еще посольство в 1504 г. (ПСРЛ. СПб., 1910. Т. 20: Первая половина. С. 375).

${ }^{8}$ См. об этом строительстве: Кром М.M. «Вдовствующее царство»: политический кризис в России 30-х - 40-х годов XVI века. СПб., 2010. С. 555-560.

9 Дополнения к Актам историческим, собранные и изданные Археографической комиссией. СПб., 1846. Т. 1. № 82. 
книге 1577-1578 гг. находились 8 казенных каменщиков и 9 кирпичников ${ }^{10}$. Разумеется, таких мастеров требовалось во много раз больше, когда вставал вопрос о строительстве большой каменной крепости, а вопрос становился все более актуальным с усилением с течением времени возможностей артиллерии. Между тем в стране, где исторически преобладало деревянное строительство, не могло быть значительного количества каменщиков и кирпичников.

По-видимому, проблему первоначально пытались решить, налагая новые обязанности на податное население. Характерно, что по грамоте 1565 г. жители подмосковного села Коровничьево Симонова монастыря получили возможность «кирпичю на Москве и по городом не делати и не возити» ${ }^{11}$. Такая практика, однако, как представляется, не могла обеспечить крепостное строительство квалифицированными специалистами. Положение изменилось, по-видимому, в начале 70-х гг. XVI в. Исследователи давно обратили внимание на свидетельство Д. Горсея о том, что после разорения Москвы крымскими татарами в 1571 г. царь «подрядил семь тысяч каменщиков и строителей построить красивую каменную стену вокруг Москвы, что и было сделано за 4 года» ${ }^{12}$. Исследователи справедливо предполагают, что здесь ошибочно приведены сведения о строительстве в Москве Белого города во второй половине 80 -х гг. XVI в. (об этом говорят упоминание «каменной стены» и четырехлетнего срока работ) $)^{13}$. Вместе с тем нельзя отвергать свидетельство Горсея о восстановлении укреплений Москвы после событий 1571 г. Укрепления эти понесли серьезный ущерб. По свидетельству «Пискаревского летописца», была взорвана даже часть стен Кремля и Китай-города ${ }^{14}$. Следовало выполнить большую работу, и при этом срочно, так как в 1572 г. Москве угрожало новое татарское нашествие. Очевидно, тогда и была предпринята срочная мобилизация «каменщиков и строителей» со всей территории Русского государства.

Эта мобилизация имела определенные важные последствия, сведения о которых содержатся в указанной грамоте Ивана IV 1575 г. ${ }^{15}$ Появление грамоты было вызвано жалобами властей Покровского Суздальского монастыря

\footnotetext{
10 Чечулин Н.Д. Города Московского государства в XVI веке. СПб., 1889. С. 156.

${ }^{11}$ Акты феодального землевладения и хозяйства. Акты Московского Симонова монастыря.... № 147.

${ }^{12}$ Горсей Д. Записки о России. XVI - начало XVII в. М., 1990. С. 59.

${ }^{13}$ См.: Косточкин В.В. Государев мастер Федор Конь. М., 1964. С. 47-48; Сперанский А.Н. Очерки по истории Приказа каменных дел Московского государства. М., 1930. С. 11-12.

${ }^{14}$ Материалы по истории СССР / Отв. ред. А.А. Новосельский. М., 1955. Т. 2. С. 80.

${ }^{15}$ Акты Российского государства. Т. 3: Акты Покровского Суздальского девичья монастыря XVI - начала XVII в. / Сост. А.В. Антонов, А.В. Маштафаров. М., 2019. № 79 (3 марта 1575 г.)
} 
на каменщиков, которые поселились в монастырском селе, но «тягла никоторые не тянут и изделья не делают». В царской грамоте они фигурируют как «каменщики, которые написаны к нашему делу». Таким образом, предпринятая мобилизация сопровождалась внесением собранных каменщиков в списки. И этих людей в дальнейшем можно было привлекать «к нашему делу». Важно при этом отметить, что учету, а затем и мобилизации подлежали не только каменщики, живущие на государственных землях, но и каменщики на землях частновладельческих.

Когда встал вопрос, что таких мастеров следует постоянно привлекать к несению «службы», возник вопрос о предоставлении им особого статуса, который бы заинтересовал их в ее несении. Как показал в своем исследовании A.Н. Сперанский, в конце правления Ивана IV и в начале правления Федора Ивановича изменился социальный статус мастеров, записанных в составленные ранее списки. Перемены были связаны со стремлением власти обеспечить себе «службы» этих людей. В отношениях с торговоремесленным населением государственная власть, когда она нуждалась в каких-то особых «службах», изымала из состава городской общины людей нужных специальностей и освобождала их от уплат и обязанностей обычных членов городской общины, чтобы они могли сосредоточить свои силы на выполнении «службы» ${ }^{16}$.

Так было сделано и со строителями. О переменах позволяют судить грамоты Михаила Федоровича кирпичникам разных городов (Костромы и Тулы), получавших после Смуты подтверждения жалованных грамот Ивана IV и Федора Ивановича 1586 г. ${ }^{17}$ Перемены касались всего большого слоя строителей разных местностей и разных специальностей. Так, в грамоте костромским кирпичникам указывалось, что им даются права «против иных каменщиков и кирпичников». Они освобождались «от черных от тяглых от всяких дел» и от податей, а также от уплаты проезжих пошлин, «как они пойдут к нашему каменному и кирпичному делу». Одновременно они изымались из юрисдикции местных властей и подчинялись суду нового центрального государственного учреждения - Приказа каменных дел. Что такие права были получены уже в конце XVI в., а не после Смуты, показывает их отражение в писцовом описании Тулы 1586-1589 гг., где при описании имущества кирпичника отмечалось, что ранее он был «черной человек» ${ }^{18}$.

\footnotetext{
${ }^{16}$ См.: Флоря Б.Н. «Служебная организация» и ее роль в развитии феодального общества у восточных и западных славян // Отечественная история. 1992. № 2. С. 68-71.

${ }^{17}$ См.: ДАИ. СПб., 1846. Т. 2. № 78; Сахаров И.П. История общественного образования Тульской губернии. М., 1832. Ч. 1. С. 7-45.

${ }^{18}$ Сперанский А.Н. Указ. соч. С. 7-11.
} 
Окончательно характер «служб» строителей, как представляется, был установлен в конце 80 -х гг. XVI в.

Первые годы правления царя Федора были отмечены большими строительными работами. Прежде всего это было строительство каменных стен Белого города - огромное строительство, растянувшееся на ряд лет ${ }^{19}$. Именно для него и было мобилизовано 7 тыс. каменщиков. Другое крупное строительство было предпринято тогда же в Астрахани. Как отмечено в «Пискаревском летописце», для строительства Астраханского кремля в город были привезены остатки каменных построек из столицы Золотой Орды - Сарая, «и зделан город безчисленно хорош, округом (его) пояс мраморен да красен» ${ }^{20}$. Работа была также большой и сложной. Из переписки Москвы с астраханскими воеводами видно, что еще в 1591 г. здесь имели место острые споры об изготовлении извести для строительства ${ }^{21}$. Как представляется, именно в этих условиях правительство, стремясь добиться заинтересованности мастеров в выполнении их «служб», приняло решение об оплате их работы. Важные сведения на этот счет содержит наказ Данилу Ивановичу Исленьеву, направленному в Польско-Литовское государство в 1591 г. В нем отмечалось, что благодаря заслугам Бориса Годунова имело место «строение во всей земле, како никогда не бывало, города каменные в Москве и в Астрахани поделал». В дальнейшем, в связи с этим сообщением, в тексте читается, что теперь «не делают посохи ни к какому делу, городовые дела всякие делают из казны наймом» ${ }^{22}$. Отказ от «посохи» неквалифицированного бесплатного труда податного населения - остался, как увидим, благим пожеланием, а оплата «городовых дел», очевидно, с конца 1580-х гг. стала реальностью. В декабре 1595 г. в наказе князю Василию Звенигородскому, отправленному в Смоленск организовать на месте производство кирпича и извести, предписывалось: «Там все дела делати наймом и наймовати им на все дела охочих людей, уговариваяся с ними» ${ }^{23}$. О выдаче платы за работу говорилось и в приведенной в начале статьи грамоте 1600 г. В переписке Москвы с астраханскими воеводами упоминается о посылке в Астрахань 3 тыс. руб. «на городовое на каменное дело» ${ }^{24}$. Сложившаяся

${ }^{19}$ О строительстве Белого города см.: Косточкин В.В. Указ. соч. С. 44-71.

${ }^{20}$ Материалы по истории СССР. Т. 2. С. 91.

${ }^{21}$ Акты исторические, собранные и изданные Археографической комиссией (далее АИ). Ч. 1. № 239. Стб. 239.

${ }^{22}$ Цит. по: Соловьев С.М. История России с древнейших времен. М., 1960. Кн. 4. С. 288. См. также известие «Пискаревского летописца», что в 1594/95 г. царь Федор в Китай-городе «лавки велел ставити каменныя своею казною» (Материалы по истории СССР. Т. 2. С. 91).

${ }^{23}$ Акты, собранные в библиотеках и архивах Российской империи Археографической экспедициею Императорской Академии наук (далее - ААЭ). М., 1836. Т. 1. № 365. С. 410.

${ }^{24}$ АИ. Т. 1. № 230. Стб. 443. 
в то время система отношений продолжала функционировать и на рубеже XVI и XVII вв. В летописных известиях о строительстве Смоленского кремля отмечается как новое небывалое явление не сам факт мобилизации мастеров, а лишь ее непривычно большой масштаб.

К этому времени относится и правовое определение «каменщиков» как особой группы служилых людей, связанных с обеспечением военных нужд государства. В так называемом Судебнике 1589 г., составленном на Русском Севере, об установлении штрафа за «бесчестие» указывалось: «А стрелцам и ратным людем... и каменщикам, что царь государь укажет» ${ }^{25}$. Это свидетельство показывает, что к этому времени «каменщики» наряду со стрельцами вошли в состав служилых людей по прибору, которые несли важную для государства «службу». То, что «служба» эта была временной, от случая к случаю, не имело в данном случае принципиального значения.

Политика государственной власти по отношению к мастерам-строителям определялась противоречием между необходимостью осуществления масштабного каменного строительства в сжатые сроки и недостатком в стране кадров для осуществления таких планов. Искались разные способы разрешения этого противоречия. Так, предполагалась мобилизация возможно более широкого круга участников. Из наказа И.М. Толбузину видно, что для производства кирпича следовало мобилизовать всех мастеров, занятых изготовлением изделий из глины, одних кирпичников явно не хватало. С помощью разных мер стремились сделать участие мастеров в строительстве обязательным. Этой цели в наказе И.М. Толбузину служила такая мера, как запрет соответствующих работ на месте проживания строителей, чтобы у них не было другого выхода, кроме как идти на «службу» К этому добавлялись суровые дисциплинарные меры. Тем, которые «от нашего дела утаятся», угрожала смертная казнь, а условия «найма» указывались уже в наказе Толбузину так, что о какой-либо договоренности здесь не приходилось говорить. Городское самоуправление при установлении таких порядков ни в какой связи не упоминалось.

Все это достаточно определенно говорит о сильном подчинении торгово-ремесленного городского населения государственной власти, что давало широкие возможности для использования его отдельных слоев для решения стоявших перед государством важных задач.

Сложившаяся в концу XVI в. система отношений власти к такой части городского населения, как каменщики и кирпичники, продолжала действо-

${ }^{25}$ Памятники русского права. М., 1956. Вып. 4. С. 421. 
вать и в XVII в., когда эти мастера продолжали находиться на учете Приказа каменных дел ${ }^{26}$.

Однако (и на это следует обратить внимание) мобилизация мастеров касалась не только мастеров - членов посадской общины; мобилизации подлежали, судя по наказу посланцу в Кашин, и тех, кто живут «в слободах во всех за патриархом и за митрополиты, и за монастыри, и за дворяне, и за дьяки, и за детьми боярскими». В этой части наказа, явно воспроизводившей общегосударственное постановление (никаких «слобод» патриарха в Кашинском уезде не было), перечислялись категории церковных землевладельцев, начиная с патриарха, две главных части дворянского сословия - дворяне и дети боярские, — а также дьяки. Мобилизация не распространялась только на владения членов Боярской думы. Смертная казнь, согласно наказу, угрожала тому, кто «утаит» нужного мастера или устроит в своем владении запрещенные работы («тем людям, у кого те дела учнут делати... быть кажненными смертью»). Суровые санкции угрожали, таким образом, не только мастерам, но и их хозяевам.

Определенный комментарий к этой части предписаний наказа дает отписка слуги Покровского Суздальского монастыря Василия Второго от 25 марта 1599 г. $^{27}$ Слуга ходатйствовал о том, чтобы оставить в монастыре двух мастеров-печников, которые делали печи «в монастырских обиходах». С такой просьбой он обратился к дьяку Нечаю Перфирьеву, ведавшему работами по строительству смоленской крепости ${ }^{28}$. Но от дьяка слуга услышал, что есть «государев приказ и боярский приговор» забирать мастеров везде «и у князей, и у бояр, и в монастырех и в своих государевых селех», и узнал, что царь велел «казнить без милости смертною казнью» тех, кто «тех людей государеву посланнику не дадут». И дьяк настоятельно советовал передать мастеров посланнику, «не издержав». Из этого следовало, что не позднее начала 1599 г. были приняты очень жесткие решения о принудительной мобилизации мастеров всех категорий земель и лишь позднее, судя по грамоте 1600 г., они были несколько смягчены. Отписка служит одновременно и свидетельством того, что эти решения выполнялись. С санкциями, по-видимому, не торопились, но они были установлены.

Но дело не ограничивалось мобилизацией мастеров - строителей из владений церковных и светских землевладельцев. Подлежало безвозмездной конфискации и имущество, нужное для организации работ

\footnotetext{
${ }^{26}$ Сперанский А.Н. Указ. соч. С. 29 и след.

${ }^{27}$ Акты Российского государства. Т. 3. № 287.

${ }^{28}$ О посылке Н. Перфирьева в Смоленск см. в «Пискаревском летописце» (Материалы по истории СССР. Т. 2. С. 94-95.
} 
по строительству. Так, в наказе В.А. Звенигородскому 1595 г. предписывалось отобрать «в Смоленске на посаде и в уезде сараи и печи все владычни и монастырские и всяких людей... где делывали кирпичь и известь и кирпичь жгли» ${ }^{29}$. Таким образом, конфискации подлежали даже сараи и печи во владениях смоленского архиепископа.

Разумеется, и в других государствах частновладельческое население должно было участвовать в укреплении крепостей. Несмотря на широкие привилегии дворянства Великого княжества Литовского, на нем также лежало обязательство нести «роботы на будованье городов наших новых... a старых поправление» ${ }^{30}$. Эти обязательства были подтверждены особым решением сейма 1551 г., однако многие представители знати еще раньше добивались освобождения от этих обязательств; как показала ревизия 1545 г. замков в южных областях государства, на практике соответствующие обязательства часто не выполнялись и теми, кто не имел освобождения $^{31}$. Не могло быть речи о том, чтобы великокняжеская администрация вмешивалась в жизнь имения, мобилизуя нужных мастеров, и тем более о карательных санкциях по отношению к их владельцам, как и о конфискации имущества. Очевидна сильная позиция власти России по отношению к светским и церковным землевладельцам.

Разумеется, для строительства огромной крепости со стенами толщиной в 4,9 м и высотой 9,6 м и 38 трехъярусными башнями работы одних мобилизованных мастеров было недостаточно. Как отмечено в «Пискаревском летописце», материал для их работы, «каменья и известь везет из дальних городов вся земля» 32 . В «Новом летописце» также отмечено, что «камень возили изо всех городов, а камень имали, приезжая из городов, в Старице да в Рузе ${ }^{33}$. Употребленные формулировки говорят о том, что эта отработочная повинность охватывала все податное население страны. Почему составители летописных текстов обратили на это особое внимание, выясняется при обращении к источникам из церковных архивов более раннего времени.

Хорошо известно, что в раннем XVI в. продолжала сохраняться практика использования неквалифицированного труда податного (крестьянского и городского) населения в «городовом деле». Как известно, в грамотах Иосифо-Волоколамскому монастырю 1575 г. отмечалось, что «город делати»

${ }^{29}$ ААЭ. Т. I. № 365. C. 450.

30 Законодательные акты Великого княжества Литовского XV-XVI в. Л., 1936. С. 8-9 (привилей 1457 г.).

31 Любавский М.К. Очерки истории Литовско-Русского государства до Люблинской унии включительно. М., 1910. С. 210-213.

${ }_{32}^{32}$ Материалы по истории СССР. Т. 2. С. 95.

${ }^{33}$ ПСРЛ. Т. 14. С. 54. 
обязаны крестьяне всех сел, «что за бояры и за детьми боярскими и за служилыми людьми в поместье, и митрополичьи, и владычними, и вотчинами, и купляни, и монастырскими, и черными» ${ }^{34}$. Таким образом, подчеркивалось, что соответствующая повинность лежит на населении не только государственных - «черных», но и на всех категориях честновладельческих земель Исключений, к числу которых принадлежал Иосифо-Волоколамский монастырь, было немного. В рассказе официальной летописи о строительстве в 1534-1553 гг. в Москве «землена града», вероятно, не случайно подчеркивалось, что было приказано «делати град и ров копати митрополичьим и боярским и княжим всем людем без выбора» ${ }^{35}$.

Сохранившийся для более позднего времени такой содержательный источник, как приходно-расходные книги Болдина Дорогобужского монастыря, позволяет установить, что при этом соблюдались определенные правила. Наиболее ранние монастырские книги относятся ко второй половине 80-х гг. XVI в., когда происходило большое строительство каменных стен Белого города. Как видно из записей в этих книгах, монастырские крестьяне участвовали в перевозке камня «к городовому делу» и в перевозке извести из Мячкова в Москву ${ }^{36}$. В этих работах участвовали, однако, только крестьяне подмосковных сел этой смоленской обители. Очевидно, что обычным порядком было привлечение к «городовому делу» крестьян тех владений, которые располагались в районе города, в котором строилась крепость. При строительстве Смоленска эта практика была пересмотрена и к участию в строительстве были привлечены частновладельческие крестьяне «из дальних городов».

Это утверждение летописцев подкрепляют свидетельства документов из архива Покровского Суздальского монастыря. Расположенная в Суздальском уезде обитель никаких владений на территории Смоленской земли не имела. Однако крестьяне владений монастыря приняли участие в строительстве. Так как никакой платы монастырским крестьянам за работу не полагалось, то крестьяне занимали у властей монастыря деньги «в смоленскую каменую возку» ${ }^{37}$. От января-февраля 1600 г. сохранился ряд расписок о получении от крестьян разных владений монастыря определенного количества камней и дров, доставленных ими в Смоленск из Старицы ${ }^{38}$.

${ }^{34}$ АФЗиХ. Ч. 2. № 62, 63.

${ }^{35}$ ПСРЛ. СПб., 1906. Т. 13: Вторая половина. С. 82.

${ }^{36}$ Русская историческая библиотека. Пг., 1923. Т. 37. Стб. 29, 39, 79. О Мячкове и его роли в Московском строительстве см.: Сперанский А.Н. Указ. соч. С. 36-37.

${ }^{37}$ Акты Российского государства. Т. 3. № 291, 292.

${ }^{38}$ Там же. № 297-299, 300-305. 
Свидетельство документов Покровского Суздальского монастыря важно и в другом отношении. Монастырь являлся привилегированной аристократической обителью, среди его монахинь в 80-х гг. XVI в. были члены царской семьи - вдовы царевича Ивана Ивановича. Если население владений такого монастыря вынужденно принимало участие в смоленском строительстве, то тем более в нем участвовали и менее привилегированные церковные землевладельцы.

На работах были задействованы даже крестьяне самой почитаемой, близкой к царскому двору обители - Троице-Сергиева монастыря. Сохранились сведения о некоторых льготах, предоставленных обители в связи с этим. Нормы соответствующих работ устанавливались в зависимости от размера пашни (количества сох) во владении. К 1598 г. относятся распоряжения об освобождении от повинности $9^{35} / 36$ сох монастырской земли, «что пашут детеныши на монастырь», но это не касалось остальных 70 77/96 сох монастырской вотчины ${ }^{39}$.

Рассмотрение и этого аспекта отношений показывает очевидное усиление позиций центральной власти по отношению к церковным и светским землевладельцам Русского государства. В свете этих наблюдений становится особо очевидным контраст между положением в Великом княжестве Литовском и в России в отношении исполнения «городового дела», что, конечно, было связано с разным характером отношений между государственной властью, с одной стороны, духовенством и дворянством - с другой.

Благодаря принятым чрезвычайным мерам, несмотря на серьезные трудности, связанные с очевидным дефицитом кадров квалифицированных строителей, в сжатые сроки в 1598-1600 гг. в Смоленске была поставлена мощная каменная крепость, которую затем долгое время (в течение двух лет) безуспешно осаждала польско-литовская армия.

\section{Литература}

Акты исторические, собранные и изданные Археографической комиссией. СПб., 1841. Ч. 1.

Акты Российского государства. М., 2019. Т. 3: Акты Покровского Суздальского девичья монастыря XVI - начала XVII в. / Сост. А.В. Антонов, А.В. Маштафаров. Акты служилых землевладельцев XV - начала XVII века / Сост. А.В. Антонов. М., 2002. T. 3.

Акты феодального землевладения и хозяйства. Акты Московского Симонова монастыря. Л., 1983.

39 Черкасова М.С. Землевладение Троице-Сергиева монастыря в XV-XVI вв. М., 1996. C. 189. 
Акты феодального землевладения и хозяйства. М., 1955. Ч. 1; М., 1956. Ч. 2.

Акты, собранные в библиотеках и архивах Российской империи Археографической экспедициею Императорской Академии наук. М., 1836. Т. 1.

Горсей Д. Записки о России. XVI - начало XVII в. М., 1990.

Дополнения к Актам историческим, собранные и изданные Археографической комиссией СПб., 1846. Т. 1.

Законодательные акты Великого княжества Литовского XV-XVI в. Л., 1936.

Косточкин В.В. Государев мастер Федор Конь. М., 1964.

Кром M.M. «Вдовствующее царство»: политический кризис в России 30-х $-40-\mathrm{x}$ годов XVI века. СПб., 2010.

Любавский М.К. Очерки истории Литовско-Русского государства до Люблинской унии включительно. М., 1910.

Материалы по истории СССР / Отв. ред. А.А. Новосельский. М., 1955. Т. 2.

Носов Н.Е. Очерки местного управления Русского государства в первой половине XVI века. М.; Л., 1957.

Памятники русского права. Вып. 4. М., 1956.

ПСРЛ. СПб., 1906. Т. 13. Вторая половина; М., 2000. Т. 14; М.; Л.,1949. Т. 25; СПб., 1910. T. 20.

Сахаров И.П. История общественного образования Тульской губернии. М., 1832. Ч. 1.

Соловьев С.М. История России с древнейших времен. М., 1960. Кн. 4.

Сперанский А.Н. Очерки по истории Приказа каменных дел Московского государства. М., 1930.

Флоря Б.Н. «Служебная организация» и ее роль в развитии феодального общества у восточных и западных славян // Отечественная история. 1992. № 2. С. 68-71.

Черкасова М.С. Землевладение Троице-Сергиева монастыря в XV-XVI вв. М., 1996.

Чечулин Н.Д. Города Московского государства в XVI веке. СПб., 1889. 


\section{Д.А. Хитров}

\section{ВОЛОГОДСКИЙ УЕЗД \\ И АДМИНИСТРАТИВНАЯ РЕФОРМА I775-I783 гг.}

Аннотация В статье на основе картографических материалов и хозяйственных описаний реконструируются границы Вологодского уезда в первой половине - середине XVIII в. и рассматривается вопрос о характеpe тех изменений, которые произошли в административном устройстве этих территорий при открытии Вологодского наместничества в 1780 г. Показано, что Вологодский уезд составил основу обширной западной части нового наместничества, и основная часть его территории вошла в состав четырех уездов Вологодской области Вологодского наместничества - Вельского, Кадниковского, Вологодского и Грязовецкого. Небольшие участки были также переданы Пошехонскому, Тотемскому и Череповецкому уездам, а в состав Грязовецкого уезда вошел ряд территорий Пошехонского, а также приграничные поселения Ярославского, Галичского и Любимского уездов.

Ключевые слова: губернская реформа 1775-1783 гг, Вологодский уезд, Вологодское наместничество, историческая картография.

Summary On the basis of cartographic materials and economic descriptions, the article reconstructs the boundaries of the Vologda Uyezd in the first half — middle of the XVIII century and considers the nature of the changes that occurred in the administrative structure of these territories when the Vologda viceroyalty was opened in 1780. It is shown that the Vologda uyezd formed the basis of the vast western part of the new viceroyalty, and the main part of its territory became part of the four uyezds of the Vologda region of the Vologda viceroyalty - Velsky, Kadnikovsky, Vologda and Gryazovets. Small areas were also transferred to Poshekhonsky, Totemsky and Cherepovets counties, and Gryazovets County included a number of territories of Poshekhonsky, as well as border settlements of Yaroslavl, Galichsky and Lyubimsky counties. Keywords: Provincial Reform of 1775-1783, Vologda uyezd, Vologda viceroyalty, historical cartography.

1 Исследование выполнено при финансовой поддержке РФФИ, проект № 19-09-00462 (а). 
Работы Е.Н. Швейковской показывают, какие широкие возможности открывают перед исследователями демографических и социальных процессов в северорусской деревне XVII-XVIII вв. разного рода материалы государственного учета земель и налогоплательщиков этого времени. В ее исследованиях на основании этих внешне суховатых статистических данных перед нами предстает сложный, пронизанный внутренними связями мир - эти связи, увиденные глазами историка, соединяют не только современников, но и людей разных поколений и даже разных эпох. Длительной устойчивости социального устройства северного «мира» соответствовала и стабильность традиционного административно-территориального деления, которое, оформившись в период присоединения северорусских земель к Московскому государству, без существенных изменений просуществовало вплоть до екатерининской реформы 1775-1783 гг.

Знание того, какие территории относились в XVI-XVIII вв. к той или иной административной единице, важно со многих точек зрения. Во-первых, без этого трудно представить себе происходившие процессы в территориальном разрезе, а методы исторической картографии и пространственного анализа приобретают все большее значение в современных исследованиях. Во-вторых, агрегированные статистические данные, от писцовых итогов до уездных табелей Генерального межевания, относятся, естественно, к существовавшему на момент их создания административному делению, и знание этого деления необходимо для их корректного анализа. Кроме того, необходимо иметь в виду и практическое значение этого вопроса для исследователей, занимающихся архивными поисками в рамках разного рода микроисторических работ - краеведческих, биографических или генеалогических. Комплексы массовых источников этой эпохи, таких как ревизии, материалы Генерального межевания, губернаторские отчеты и многие другие, структурированы именно в соответствии с существовавшим на момент их создания административным делением, и одна из главных трудностей, с которыми сталкивается работающий с ними исследователь, связана именно с неизученностью истории этого деления.

Реконструкции административного деления того или иного периода обычно опираются на карты соответствующей эпохи. Правда, картографические съемки XVIII-XIX вв., не говоря о более ранних, нередко далеки от современного стандарта — прежде всего из-за отсутствия в распоряжении геодезистов того времени аэро- или космических снимков, несовершенства методов определения координат и неточности самих координатных систем. Тем не менее, если сама съемка, лежащая в основе карты, была осуществлена качественно и включала достаточно большое количество измерений, 
современные средства работы с историческими картами позволяют выправить большую часть подобных искажений. Указав некоторое количество контрольных точек (их число прямо зависит от качества исходной карты - скажем, для уездных карт начала XX в. чаще всего достаточно 10-15, а карта конца XVIII-го, как правило, требует нескольких сотен) и подобрав подходящий алгоритм трансформации, мы можем с достаточно высокой точностью совместить историческую карту с современной к геооснове, осуществить так называемую привязку: программа, использовав данные о положении заданных точек на образе (скане) карты и их положение на современной координатной сетке, «выправит» искажения. С привязанной карты можно перенести на современную основу и отмеченные на ней объекты, в частности границы.

Однако для реконструкции административных границ XVI - первой половины XVIII вв. такой подход мало применим. Причина в том, что, как известно, губернская реформа 1775-1783 гг. была сопряжена с весьма решительным пересмотром границ губерний и уездов, и использовать «пореформенные» карты при рассмотрении «дореформенного деления невозможно. Между тем карты, отражающие «дореформенное» деление, есть не по всем уездам, а там, где они имеются, их использование сопряжено с серьезными затруднениями.

До второй половины XVIII в. уровень развития русской крупномасштабной картографии был, как известно, не слишком высок². Большие работы были предприняты под эгидой Академии наук в 1720-1750-х гг., но, хотя замысел Петра I предполагал использование самых современных на тот момент методик картографической съемки, и в результате было составлено значительное число уездных карт, так называемых карт петровских геодезистов. Эти карты мало пригодны для привязки, поскольку в их основе лежало сравнительно небольшое число полевых измерений ${ }^{3}$. Геодезисты, работая в определенном уезде, пересекали его территорию одним или двум «инструментальными ходами», а все остальные объекты, прежде всего реки и поселения, восстанавливались на основе составлявшихся на основе ревизских материалов списков населенных мест, а также рассказов местных жителей. Близкой методикой составления отличались и карты, созданные Межевым департаментом Сената по ряду территорий в 1760-х гг.,

2 См.: Фель С.Е. Картография России XVIII в. М., 1960; Постников А.В. Развитие крупномасштабной картографии в России. М., 1989.

3 Багров Л. История русской картографии. М., 2005; Гольденберг Л.А. Первый академический атлас России и картографические работы Географического департамента Академии наук // Очерки истории географической науки в СССР. М., 1976. 
до начала массовых работ Генерального межевания. Понятно, что точность расположения на карте таких объектов была крайне невысока: направление рек часто показывалось неверно, а локализация поселений и вовсе была приблизительной. В сущности, карты этой эпохи представляют собой довольно приблизительные схемы систем расселения: авторы стремились отобразить существовавшие населенные пункты и примерно показать их взаимное расположение.

Однако хуже всего на этих картах отображались границы: в сущности, нанеся на лист поселения, картограф просто обводил их общей, примерной округлой линией. В результате возникали ситуации, когда территории, на которых, в силу причудливости очертаний границ, существовали поселения двух разных уездов, изображались на картах двух смежных уездов дважды: на каждую из них наносились только относившиеся к этому уезду села и деревни. Понятно, что, даже если такую карту удается более или менее приемлемым образом «привязать», смысла в том, чтобы анализировать расположение показанной на ней границы, немного: сама эта линия не была результатом полевой съемки и не отражает существовавшую «на местности» реальность.

В силу этого исследователи, занимающиеся историей административно-территориального деления XVI-XVIII вв., чаще всего идут по другому пути - составляют списки поселений на основе того или иного налогового описания, а затем локализуют их, используя более поздние карты (иногда даже современные $)^{4}$. У такого подхода, имеющего длительную традицию в историографии, есть очевидные плюсы, но и не менее серьезные ограничения.

Во-первых, список поселений, извлеченный из писцовой или переписной книги, почти никогда не удается локализовать полностью - всегда обнаруживается какое-то количество поселений, которые либо исчезли, либо поменяли название к тому времени, как были составлены первые карты, которые могли бы зафиксировать локализацию соответствующего топонима (особенно это существенно для описаний XVII — начала XVIII в., поскольку, как отметил еще М.В. Витов, проведение первой ревизии было сопряжено с решительным отказом от старой традиции преемственных друг по отношению к другу описаний XVII в., и в силу этого с существенным

${ }^{4}$ Подробно о методике такой работы см.: Водарский Я.Е. Население России в конце XVII - начале XVIII века: Численность, сословно-классовый состав, размещение. М., 1977. Приложение 11. Схемы уездов России конца XVII - начала XVIII в.; Кабузан B.M. Обзор историко-географических источников по административно-территориальному делению России в 1720-1770 гг. // Историческая география России XVIII в. М., 1981. С. 45-56. 
обновлением топонимики) $)^{5}$. Следовательно, исследователь всегда сталкивается с опасностью «не увидеть» какую-то часть уезда, стана или волости, расположенную на некотором отдалении от остальных; тяжелее всего в этом случае, конечно, найти анклавы или просто дальние, расположенные в окружении территорий соседнего уезда поселения.

Во-вторых, в подавляющем большинстве случаев такая реконструкция охватывает только один уезд. Это означает, что его границу исследователи обозначают примерно так же, как это делали геодезисты XVIII века - совокупность локализованных поселений обводится приблизительным общим контуром. Это отчасти оправданно, когда такая граница проходит по обширным незаселенным пространствам; но если речь идет о более или менее плотно заселенной территории, подобная реконструкция может ввести читателя в заблуждение, отнеся к исследуемому уезду земли и поселения, принадлежавшие на самом деле к соседнему.

Как представляется, этих ошибок позволяет избежать следование двум важным принципам при создании подобных реконструкций. Во-первых, при нанесении на карту границы следует использовать данные о положении крайних поселений обоих граничащих уездов. Часто это проще всего сделать при помощи карт первой половины XVIII в. Во-вторых, границу следует реконструировать с учетом данных более позднего времени. Как известно, при проведении реформы 1775-1783 гг. старая система деления не была полностью ликвидирована, стерта и создана заново: реформа осуществлялась путем передачи определенных участков от одних центров к другим. Картина этой «пересборки» административных единиц зачастую довольно сложна и мозаична, но значительная часть границ сохраняется и после реформы.

Между тем с картами «пореформенного» административного деления дело обстоит значительно лучше, чем с «дореформенными», что связано с началом в 1765 г. работ Генерального межевания. Для подавляющей части территорий, исключая только Московскую провинцию Московской губернии, межевание вышло на стадию составления уездных и губернских планов и атласов уже после открытия новых наместничеств, и эти планы и атласы отражают уже новое деление. Хотя в литературе существует мнение, что межевая картография в техническом отношении уступала работам более раннего времени (прежде всего из-за отсутствия требования определения координат), практика работы с этими картами показывает, что их привязка, хотя

5 Витов М.B. Приемы составления карт поселений XV-XVII вв. по данным писцовых и переписных книг (на примере Шунгского погоста Обонежской пятины) // Сборник Института этнографии АН СССР. М., 1958. Вып. 29. С. 30-37. 
и требует большого числа контрольных точек, позволяет достаточно точно позиционировать многочисленные объекты, расположенные на этих картах.

Отсутствие точно определенных координат (хотя, следует сказать, точность их определения в XVIII в. так или иначе была довольно относительной) вполне компенсировалось огромным количеством полевых измерений, причем эти измерения касались в первую очередь именно границ отдельных земельных дач. Распространенное мнение, что при сведении первичных картографических материалов, планов дач, в генеральные уездные планы и, далее, в карты наместничеств, допускались искажения, исключающие успешную привязку последних, также не подтверждается практикой. Такие искажения присутствуют, однако они весьма успешно корректируются алгоритмами привязки - измерения, лежащие в основе планов дач, учитывались при их сведении в единое полотно и выступали в качестве своеобразного «жесткого каркаса» сводной карты. Правда, и на межевых картах административные границы, нередко проходившие (особенно на Севере) по удаленным лесам и заболоченным водоразделам, измерялись и, соответственно, отображались не вполне точно - но в любом случае это были результаты полевых измерений, которые отражали (хотя, возможно, и не всегда идеально) существовавшую на местности реальность.

Вологодский уезд, занимающий одно из центральных мест в творчестве Е.Н. Швейковской, дает интересную возможность проверить действенность этого подхода. С одной стороны, по нему нет «дореформенных» карт XVIII в. (точнее, имеется обобщенная карта Вологодской провинции, на которой поселения нанесены выборочно, а граница показана очень приблизительно $)^{6}$. С другой стороны, он давно привлекает внимание исследователей, имеется целый ряд работ, посвященных истории его формирования и развития ${ }^{7}$, и, в частности, Я.Е. Водарским еще в 1970-х гг. был опубликован перечень поселений уезда, учтенных в переписных книгах 1678 г, а А.Л. Грязнов на основе этих данных составил его достаточно детальную карту ${ }^{8}$ Границы на ней, однако, показаны с той приблизительностью,

6 ОР БАН. Картографическое собрание Географического департамента АН. Оп. 1. Ед. хр. 556 (Ландкарта, сочиненная Вологодской провинции Вологодского и Тотемского уездов... 1736 года).

7 Грязнов А.Л., Черкасова М.С. О формировании межуездных границ на Русском Севере в XV-XVI вв.: Белоозеро-Вологда-Устюг // Северная Русь и проблемы формирования Древнерусского государства: Сборник материалов международной научной конференции. Вологда-Кириллов-Белозерск 6-8 июня 2012 г. Вологда, 2012. С. 178-192; Черкасова М.С. Северная Русь: История сурового края XIII-XVII вв. М., 2017.

${ }^{8}$ Водарский Я.Е. Вологодский уезд в XVII в. (К истории сельских поселений) // Аграрная история Европейского Севера СССР. Вологда, 1970. С. 253-366; Грязнов А.Л. Карта «Вологодский уезд в XVII в.» // Мой родной Вологодский район. Вологда, 2009. С. 96-97. 
которая, как мы говорили выше, неизбежна при такой методике реконструкции. Посмотрим, можно ли уточнить эти данные.

Как известно, дореформенный Вологодский уезд охватывал обширную территорию, составившую позже западную часть Вологодского наместничества, и граничил со следующими уездами (начиная с севера и двигаясь по часовой стрелке): Важским, небольшим участком Устюжского, Тотемским, Галичским и Любимским, небольшим участком Ярославского, Пошехонским, Белозерским, Чарондским, Каргопольским.

Как уже говорилось, подробной, отражающей всю сеть поселений «дореформенной» карты уезда в нашем распоряжении нет, хотя, она, видимо, была составлена (В.М. Кабузан выражал надежду, что такая карта обнаружится в собраниях Ж.-Н. Делиля в Париже или в Венсене, но ее, видимо, нет и там) ${ }^{9}$. Зато большие участки его границ видны на картах многих смежных территорий. Прежде всего, это подробная карта другого уезда Вологодской провинции, Тотемского, датируемая 1730-ми гг. ${ }^{10}$ Затем, это две большие карты значительных территорий Архангелогородской губернии, составленные в Межевом департаменте Сената в 1760-х гг. На одной из них, изображающей Среднее Подвинье с прилегающими землями, видна северо-восточная часть уезда, граничащая с Каргопольским, Важским, Устюжским и Тотемским уездами ${ }^{11}$, а на другой, охватывающей Костромское Заволжье, видны границы с Галичским уездом, Любимской осадой Костромского и участок границы с Ярославским ${ }^{12}$. Несколько более обобщенная карта тех же мест имеется в составе рукописного Лесного атласа 1782 г. $^{13}$ Западные границы - с Белозерским, Чарондским и Каргопольским уездами - видны на печатных картах И.К. Кирилова ${ }^{14}$.

9 Постников А.В. Новые данные о российских картографических материалах XVIII начала ХІХ вв. во Франции // Вопросы истории естествознания и техники. 2005. № 3; Голубинский А.А. Специфика работы представителей семьи Делиль над текстовыми материалами и черновой картографической информацией // Делили в России: сборник статей. СПб., 2019. C. 117-120.

${ }^{10}$ ОР БАН. Картографическое собрание Географического департамента АН. Оп. 1. Ед. хр. 533. Ландкарта Архангелогороцкой губернии Вологоцкой провинцыи Тотемскаго уезду... 1733 г.

${ }^{11}$ РГВИА. Ф. 846. Оп. 16. Ед. хр. 21224. Карта западной половине Архангелогородской губернии, в которой замыкается Устюжской, Двинской, Важеской, Кевролской, часть Тотемскаго, Вологодскаго и Каргополскаго уездов. Сочинена на 1765 году.

${ }^{12}$ РГВИА. Ф. ВУА. 846. Оп. 16. Ед. хр. 21226. Карта, представляющая южную часть Архангелогородской губернии с прилегающими к оной уездами по реку Волгу. Сочинена 1769 года.

${ }^{13}$ ОР РНБ. Эрм. 610. Карта 44. Карта Нижегородской губернии, содержащая Галицкую провинцию... 1751 г.

${ }^{14}$ Атлас Всероссийской империи. Собрание карт И.К. Кирилова. СПб., 1722-1737. Белозерской уезд и провинция. 1731; Ландкарта Каргопольского уезду. 1730. 
Таким образом, совсем отсутствует на картах XVIII в. только одна из границ Вологодского уезда - пошехонская.

Попробуем оценить, в какой степени использование карт первой половины XVIII в. и соотнесение границ, существовавших до реформ 1775 1783 гг., с пореформенными позволяют уточнить положение границ «старого» уезда, и для этого последовательно «пройдем» вдоль уездной границы, двигаясь по часовой стрелке.

Начнем с западной границы уезда. Здесь он граничит с Белозерским уездом, а далее к северу — с Чарондским и Каргопольским.

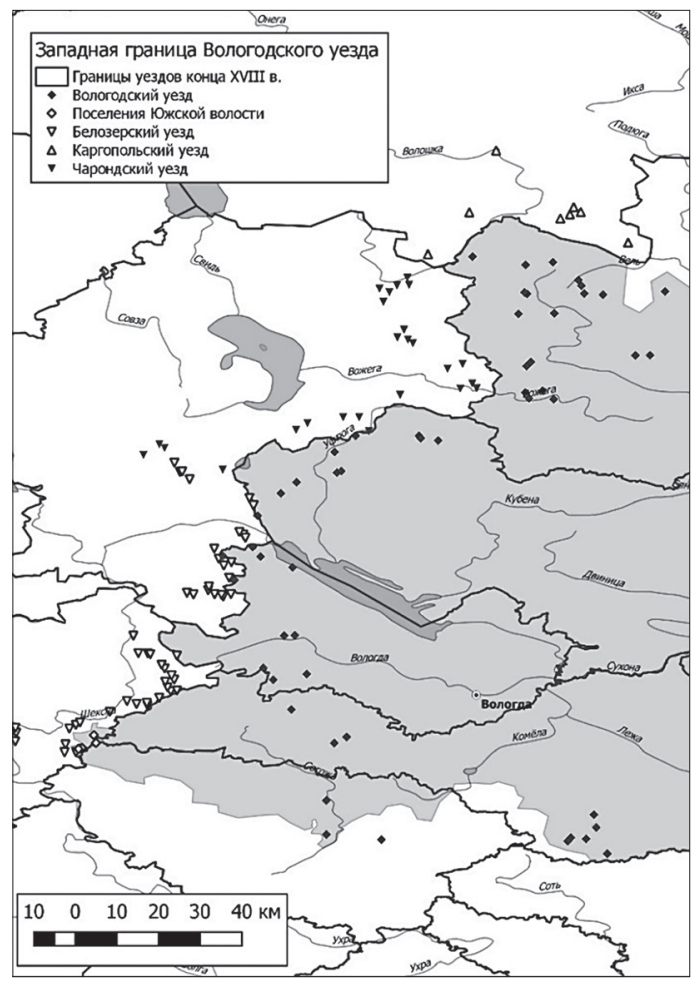

Карта 1. Западная граница Вологодского уезда

Как уже говорилось, все эти уезды отражены на печатных картах И.К. Кирилова; расположение поселений Вологодского уезда частично реконструируется на основании карты Вологодской провинции (правда, юго-западный угол этой карты практически не заполнен), а также отражено на карте А.Л. Грязнова. Поселения, отмеченные на картах И.К. Кирилова, прекрасно 
локализуются; значительная часть топонимики сохраняется даже на современных картах, а в тех случаях, когда она почему-либо утрачена (например, в связи с затоплением многих территорий по течению Шексны) - используются карты XVIII и XIX вв., прежде всего 10-верстная карта Стрельбицкого, а также карты Вологодского наместничества и Ярославской губернии из коллекции РГИА ${ }^{15}$.

Наложение границ уездов конца XVIII в. на эту картину показывает, что практически на всем протяжении западная граница дореформенного Вологодского уезда совпадает с границей пореформенного Вологодского наместничества (Грязовецкого, Вологодского, Кадниковского и, частично, Вельского уездов). Севернее Судьбицкого погоста (38.401; 59.152) вплоть до окрестностей каргопольского Валдиевского погоста и деревни Иванкинская (40.514; 60.268) более 100 поселений, показанных в качестве пограничных на картах Кирилова, плотно примыкают к этой линии с запада, и ни одно не локализуется восточнее ее; равным образом, карта А.Л. Грязнова не показывает вологодских владений западнее.

Следует отметить, что территория уезда простиралась на север несколько дальше, чем предполагал Я.Е. Водарский. Как на его схемах, так и на основанной на его материалах карте Грязнова к вологодским землям (Давыдовской волости) принадлежит только бассейн верхней Кубены. Между тем к ним следует, видимо, отнести и обширный водораздел Кубены и Волошки - на карте Вологодской провинции здесь отмечены деревня Зеленая, соотносимая с деревней Дальняя Зеленая (39.868; 61.005), село Спасское на оз. Глубоком, которое, видимо, следует соотнести с Глубоковским погостом и селом Фатуново (40.096; 60.972), и деревня Верхняя на оз. Верхнее (примерно 40.208; 60.984). Еще важнее то, что карта провинции определенно показывает, что большой участок вологодско-каргопольской границы проходит по течению р. Волошки, включая место впадения в нее р. Долгуши (39.893; 61.098) - это соответствует участку позднейшей каргопольско-вельской границы между точками 39.760; 60.966 и 40.071; 61.163.

В то же время, небольшой участок, перешедший после реформы к Череповецкому уезду Новгородского наместничества, все-таки обнаруживается. Это западная часть Южской волости в юго-западном углу уезда: деревни Гойша (38.338; 59.055), Вытежор, идентифицируемая как современная д. Витержево (38.290; 59.002), Чернево (38.276; 58.997), а также Очинико-

${ }^{15}$ См. об этом: Golubinsky A.A., Alyabina I.O., Shalashova O.V., Khitrov D.A. From survey plans to land cover maps: Data generalization in the cartographic materials of the General Land Survey in Russia (1765-1800) // 26 International Cartographic Conference. Dresden. Germany, August 25 - 30, 2013. Proceedings. Dresden, 2013. 
во, отмеченное Я.Е. Водарским как нелокализуемое, но вполне уверенно соотносимое с деревней Очениково $(38.248 ; 59.023)^{16}$.

Перейдем к северо-восточной границе уезда. Карта Вологодской провинции обозначает этот участок как пограничный с Важским и Тотемским уездами.

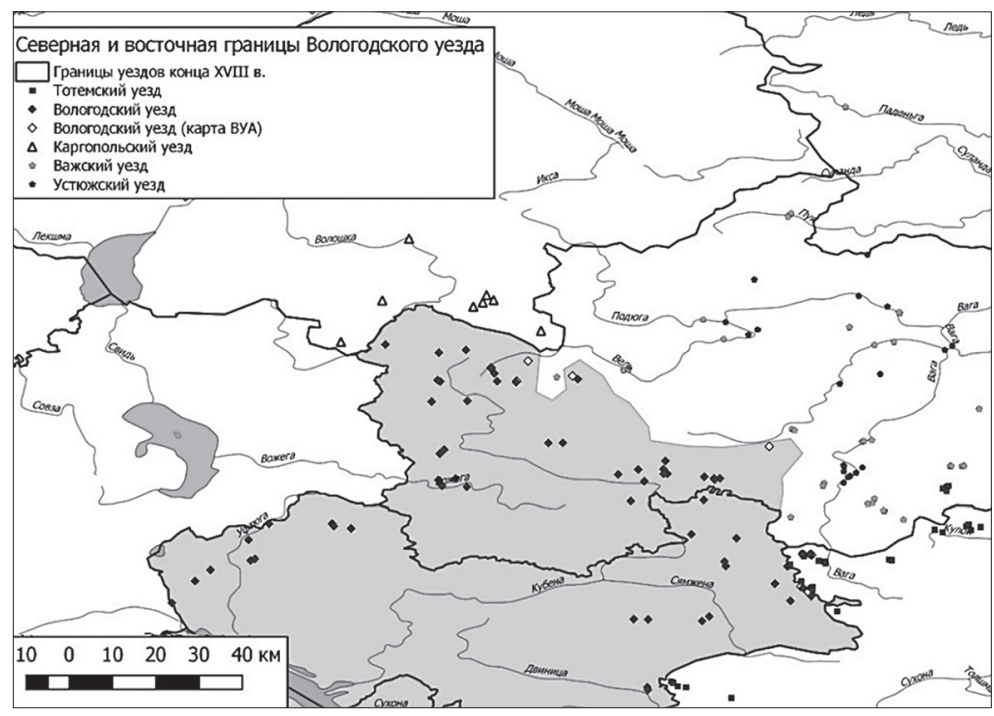

Карта 2. Северная и восточная границы Вологодского уезда

Начнем с вологодско-важского участка. В данном случае у нас нет возможности «опереться» на более поздние карты - исследуемая территория была объединена в составе Вельского уезда, и существовавшая до реформы граница исчезла. Зато этот район, помимо карты Вологодской провинции, отражен на карте северной части Архангелогородской губернии из РГВИА.

Согласно карте БАН, граница проходит по водоразделу систему Кубены и Ваги, с двумя отступлениями: во-первых, к вологодским владениям отнесены верховья рек Велги (Вели) с деревней Кузьминка $(40.309 ; 60.910)$ и Вотченицы (Вотчицы) с селом Ильинским (погост Ильинский недалеко от деревни Даниловская (40.662; 60.864). Во-вторых, показано, что важские владения подходят к верховьям р. Ембы; ниже по ее течению показан ряд вологодских поселений, в частности, деревня Дубровинская (41.245; 60.460). Карта РГВИА позволяет несколько уточнить эти границы: на ней видно,

${ }^{16}$ Водарский Я.Е. Вологодский уезд... С. 365. 
что деревня Толстая в верховьях Вотчицы $(40.577 ; 60.873)$ относится к важским владениям и, таким образом, Важский уезд образует здесь значительный выступ к югу. Кроме того, на этой карте вологодские владения выходят за пределы бассейна Ембы, и за водоразделом, на р. Пенжема, показана принадлежащая к Вологодскому уезду деревня Ереминская (соотносимая, видимо, с Ереминским починком на карте Стрельбицкого и современной деревней Ереминское $(41.445 ; 60.591)$. В районе соединения границ пореформенных Вельского, Тотемского и Кадниковского уездов (41.524; 60.181) или немного севернее этой точки граница снова начинает соответствовать позднейшей — в данном случае, восточной границе Кадниковского уезда.

Участок вологодско-тотемской границы реконструируется значительно более уверенно: во-первых, в нашем распоряжении появляется подробная карта Тотемского уезда ${ }^{17}$, а во-вторых, авторы карты Вологодской провинции явно стремились подробно отразить приграничную топонимику и с вологодской стороны границы. Частично эта граница видна и на карте РГВИА.

Как хорошо видно на карте 2, она по большей части совпадает с позднейшим кадниковско-тотемским рубежом. Существенное отличие касается только области вдоль течения Сухоны: дореформенный рубеж проходил немного выше впадения в Сухону Векшенги, оставляя с. Мотыри (41.336; 59.402), Шуйск с Шуйским ямом (41.040; 59.378) и течение рек Шуи и Шейбухты за Вологдой, а после реформы он сместился выше, так что эти территории отошли к Тотьме.

Реконструкция протяженной южной границы Вологодского уезда вызывает наибольшие сложности (см. Карту 3).

Восточная ее часть отражена на другой части карты Архангелогородской губернии из РГВИА; сложность, однако, состоит в том, что сама эта карта, видимо, довольно приблизительно отражает реальную ситуацию на пограничных с Вологодским уездом территориях, где до екатериниской реформы чересполосно располагались поселения сразу трех уездов, причем приналежавших к разным провинциям - Ярославского, Галицкого и Любимского (Костромской провинции). В общих чертах граница близка к границе Грязовецкого уезда с Любимским, Буйским и Солигалическим уездами Костромского наместничества в пореформенное время. В то же время целый ряд фактов не укладывается в эту простую схему.

Прежде всего, в верховьях р. Монза к территории Галичского уезда отнесены Успенский погост и деревня Шабалкова, которые, видимо, следует идентифицировать как погост Успения на Монзе (41.232; 59.107)

${ }^{17}$ ОР БАН. 533. 


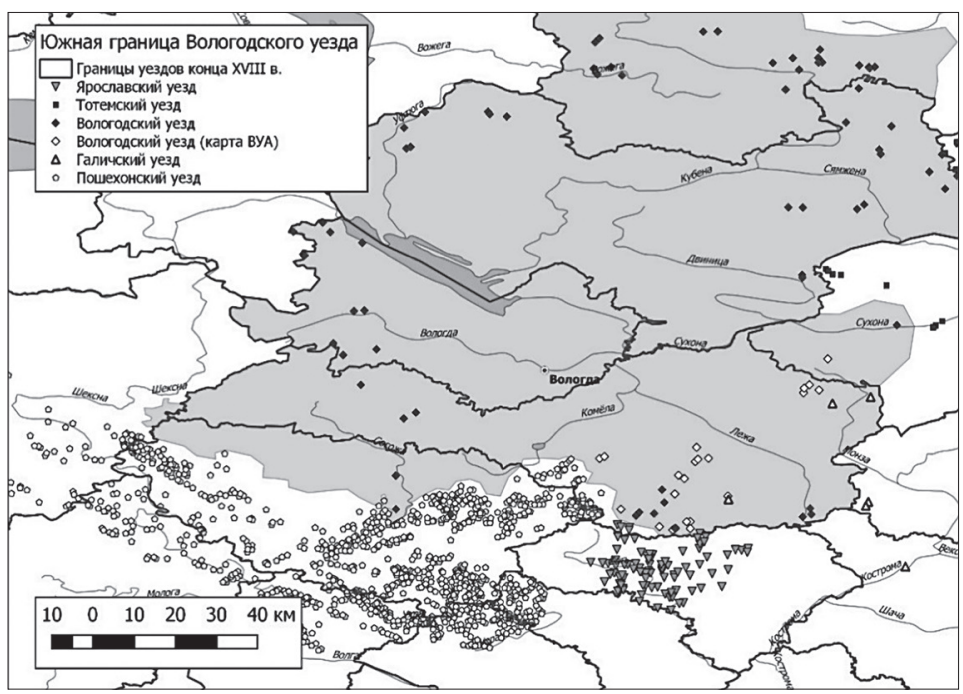

Карта 3. Южная гранииа Вологодского уезда

и Шабалкин починок $(41.074 ; 59.072)$. Если принять это известие, то получится, что при проведении реформы граница вологодских владений сместилась южнее, к с. Демьянову (41.123; 58.884). С другой стороны, в 1618 г. Монзенский Успенский погост числился в Шилегодской волости Вологодского уезда ${ }^{18}$; очевидно, этот вопрос нуждается в дальнейшем исследовании. Имеется и еще одно подобное известие. Западнее, показаны как пограничные деревни Починок (с вологодской стороны) и Заречье (с Галицкой). По карте Стрельбицкого, они могут быть локализованы как $(40.642 ; 58.746)$ и $(40.695 ; 58.642)$. Это также значило бы, что в этом пустынном лесном краю отдельные небольшие галичские поселения могли отойти во время реформы к Вологодскому уезду. Впрочем, не исключена и простая ошибка локализации: подобные названия встречаются довольно часто.

Западнее, имеется небольшой участок границы Вологодского и Ярославского уездов, обозначенный на карте провинции. К сожалению, ее изображение в этой части имеет слишком общий характер, и определить положение границы по ней не удается, других же карт, отражающих дореформенное

${ }^{18}$ Суворов Н. Несколько статистических и топографических сведений о Вологодской епархии от начала XVII столетия до настоящего времени. // Вологодские епархиальные ведомости. 1865. № 21. Прибавления. С. 814. Фото церкви 1734 г. см.: Известия Императорской археологической комиссии, 1916 г. Вып. 59. С. 174. 
деление, в нашем распоряжении нет. Далее следует весьма протяженная граница с Пошехонским уездом, которая также не отражена на картах. В обоих случаях потребовалась достаточно обширная работа, чтобы локализовать все прилегающие к границе поселения: в случае Ярославского уезда Служня стана ${ }^{19}$, в случае Пошехонского - всех поселений уезда ${ }^{20}$. Соотнеся полученные результаты с картой А.Л. Грязнова, мы имеем возможность реконструировать этот участок границы.

Выясняется, что вологодские владения насколько расширились за счет ярославских — села Турыгино (40.191; 58.588), деревень Погорелка (40.206; 58.578), Полянки (40.240; 58.565) и Скалино (40.241; 58.577) после реформы перешли от Ярославского уезда к Грязовецкому. На вологодско-пошехонском рубеже граница, напротив, сильно сместилась к северу - к Пошехонскому уезду отошли среднее течение р. Согожи и весь бассейн р. Большой Юг.

Посмотрим на полученные данные с точки зрения механики осуществления реформы 1775-1783 гг.

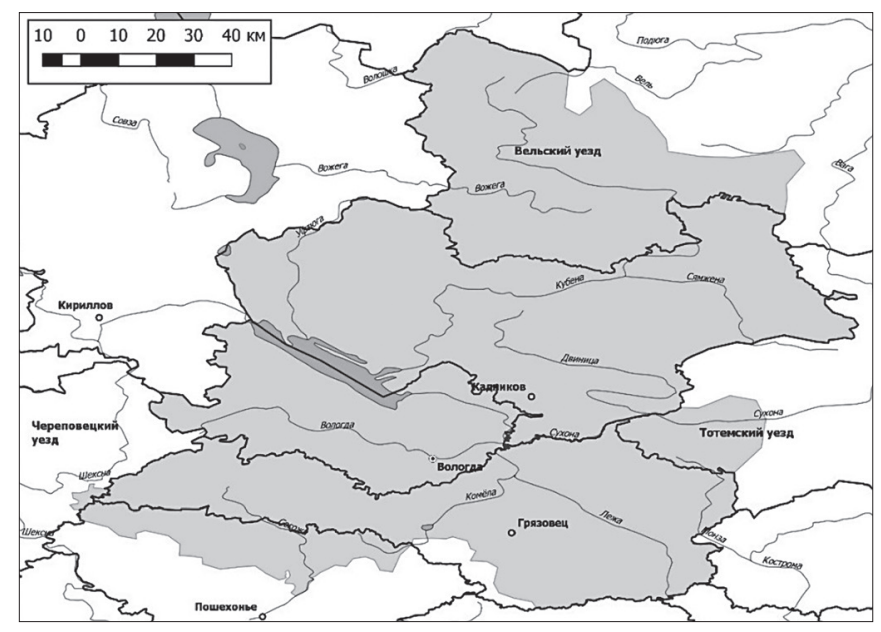

Карта 4. Перераспределение территорий Вологодского уезда в ходе губернской реформы

${ }^{19}$ Перечень поселений по данным 3 ревизии был взят из: РГАДА. Ф. 455. Оп. 1. Ед. хр. 1344. Ведомости о названных селениях Ярославского уезда и о числе душ, находящихся в них.

${ }^{20}$ Использован список поселений по данным 1 ревизии: Ельчанинов И.Н. Помещики и вотчинники Пошехонского уезда по переписной книге комиссара И.У. Мещеринова в 1719 г. // Летопись историко-родословного общества в Москве. 1909. Вып. 4. С. 24 47. Результаты этой реконструкции будут опубликованы отдельно. 
Как мы видели, губернская реформа 1775-1783 гг. привела к глубокому переустройству существовавшей ранее системы административных границ. В то же время нельзя сказать, что старая система деления была полностью ликвидирована, стерта и создана заново, поскольку реформа осуществлялась путем активной передачи определенных участков от одних центров к другим.

Еще до момента открытия Вологодского наместничества часть территорий Вологодского уезда была отчислена от него: при открытии Ярославского ${ }^{21}$ от Вологодской губ. к Пошехонскому уезду отошло 6 тыс. душ. Впрочем, в указе оговаривалось, что, «хотя от Вологодской вышеписанное число к Ярославской ныне по способности присоединится, но токмо для наполнения губернии в числе душ; а действительно уравнять между оными границу тогда, когда Ярославская губерния со всем размежуется». Возмоно также, что небольшой участок отошел к Череповецкому уезду еще при открытии Новгородского наместничества ${ }^{22}$, хотя в указе об этом ничего не говорилось об обмене территориями с Вологодским уездом.

При открытии в 1780 г. Вологодского наместничества «назначение границ сего наместничества с прикосновенными ему» было оставлено «на соглашение генерал-губернаторов и правящих ту должность» ${ }^{23}$, но нового крупного перераспределения территорий не произошло: Вологодский уезд составил основу обширной западной части нового наместничества, и основная часть его территории вошла в состав четырех уездов Вологодской области Вологодского наместничества - Вельского, Кадниковского, Вологодского и Грязовецкого (небольшой участок был также передан Тотемскому). Одновременно в состав Грязовецкого уезда вошли некоторые поселения Ярославского, Любимского, Пошехонского и, вероятно, Галицкого уездов. Тем не менее, как мы видели, основная часть периметра названных четырех пореформенных уездов может быть с большой долей уверенности отождествлена с существовавшими ранее границами старого Вологодского уезда.

Таким образом, можно заключить, что губернская реформа 1775-1783 гг., крупнейшее в истории России дореволюционной эпохи вмешательство государства в систему административного деления страны, не уничтожила традиционную систему территориальных связей на Вологодчине. В силу этого использование карт XVIII в., как до- так и пореформенных, позволяет существенно уточнить расположение границ уездов, существовавших до открытия наместничеств.

\footnotetext{
${ }^{21}$ ПСЗ-І. Т. 20. № 14637.5 августа 1777 г. С. 544.

${ }^{22}$ Там же. № 14500. 24 августа 1776 г. С. 408.

${ }^{23}$ Там же. № 14973. 25 января 1780. С. 911.
} 


\section{Литература}

Атлас Всероссийской империи. Собрание карт И.К. Кирилова. СПб., 1722-1737. Багров Л. История русской картографии. М., 2005.

Buтов M.B. Приемы составления карт поселений XV-XVII вв. по данным писцовых и переписных книг (на примере Шунгского погоста Обонежской пятины) // Сборник Института этнографии АН СССР. М., 1958. Вып. 29. С. 30-37.

Водарский Я.Е. Вологодский уезд в XVII в. (К истории сельских поселений) // Аграрная история Европейского Севера СССР. Вологда, 1970. С. 253-366.

Водарский Я.Е. Население России в конце XVII - начале XVIII века: Численность, сословно-классовый состав, размещение. М., 1977.

Голубинский A.A. Специфика работы представителей семьи Делиль над текстовыми материалами и черновой картографической информацией // Делили в России: сборник статей. СПб., 2019. С. 117-120.

Гольденберг Л.А. Первый академический атлас России и картографические работы Географического департамента Академии наук// Очерки истории географической науки в СССР. М., 1976.

Грязнов А.Л. Карта «Вологодский уезд в XVII в.» // Мой родной Вологодский район. Вологда, 2009. С. 96-97.

Грязнов А.Л., Черкасова М.С. О формировании межуездных границ на Русском Севере в XV-XVI вв.: Белоозеро-Вологда-Устюг// Северная Русь и проблемы формирования Древнерусского государства: Сборник материалов международной научной конференции. Вологда-Кириллов-Белозерск 6-8 июня 2012 г. Вологда, 2012. С. 178-192.

Ельчанинов И.Н. Помещики и вотчинники Пошехонского уезда по переписной книге комиссара И.У. Мещеринова в 1719 г. // Летопись историко-родословного общества в Москве. 1909. Вып. 4. С. 24-47.

Кабузан В.М. Обзор историко-географических источников по административнотерриториальному делению России в 1720-1770 гг.// Историческая география России XVIII в. М., 1981. С. 45-56.

Постников A.B. Новые данные о российских картографических материалах XVIII начала XIX вв. во Франции // Вопросы истории естествознания и техники. 2005. № 3 .

Постников А.B. Развитие крупномасштабной картографии в России. М., 1989.

Суворов Н. Несколько статистических и топографических сведений о Вологодской епархии от начала XVII столетия до настоящего времени. // Вологодские епархиальные ведомости. 1865. № 21. Прибавления. С. 814.

Фель С.Е. Картография России XVIII в. М., 1960.

Черкасова М.С. Северная Русь: История сурового края XIII-XVII вв. М., 2017.

Golubinsky A.A., Alyabina I.O., Shalashova O.V., Khitrov D.A. From survey plans to land cover maps: Data generalization in the cartographic materials of the General Land Survey in Russia (1765-1800) // 26 International Cartographic Conference. Dresden. Germany, August 25-30, 2013. Proceedings. Dresden, 2013. 


\title{
М.С. Черкасова
}

\section{СПАСО-ПРИЛУЦКИЙ МОНАСТЫРЬ И ТОРГОВЫЕ ЛЮДИ В КОНЦЕ XVI В.}

\begin{abstract}
Аннотация В статье рассмотрены социальные и экономические связи СпасоПрилуцкого монастыря с торговыми людьми Вологды и Сольвычегодска в конце XVI в. Среди них были представители одной из ветвей фамилии Строгановых. Работа построена на анализе трех новых актов, выявленных в Государственном архиве Вологодской области. Источники опубликованы в приложении.

Ключевые слова: торговля и промыслы, деньги и имущество, монастырь, город, торговые люди.

Summary In the article examines the social and economic ties of the Spaso-Prilutsky Monastery with the trading people of Vologda and Solvychegodsk at the end of the 16th century. Among them were representatives of one of the branches of the surname Stroganov. The work is based on the analysis of three new acts identified by the state archive of the Vologda region. Sources are published in the app.

Keywords: trade and crafts, money and property, monastery, city, trade people.
\end{abstract}

Среди многочисленных северно-русских монастырей едва ли найдется второй такой, масштаб документального наследия которого за XV-XVII вв. просто поражает воображение. Речь идет о вологодском Спасо-Прилуцком монастыре. Его акты и в особенности разнообразная по видам хозяйственная документация обильно рассредоточены практически во всех федеральных и ряде региональных архивов. Это и РГАДА, и ОПИ ГИМ, и ОР РГБ, и ОР РНБ, и Архив Санкт-Петербургского института истории РАН, а также несколько крупных фондов в архивохранилищах Вологды - Государственного архива Вологодской области (ГАВО) и Сектора письменных источников Вологодского государственного музея-заповедника. За пределами Вологды обширная совокупность источников из архива Спасо-Прилуцкого 
монастыря представлена в Отделе фондов музея-заповедника «Ростовский кремль» ${ }^{1}$.

В силу сказанного не выглядит случайным неоднократное обращение историков к прилуцкому архиву, в том числе и на уровне специальных монографий по многим проблемам социально-экономической и демографической истории XVI-XVII вв. - Л.С. Прокофьевой ${ }^{2}$, Е.Н. Баклановой (Швейковской) $)^{3}$, М.М. Дадыкиной ${ }^{4}$. Пока рано говорить о его исчерпывающей систематизации, хотя ряд шагов в этом направлении за последнее время был сделан ${ }^{5}$. Особо следует отметить новейшее описание грамот Коллегии экономии, выполненное А.В. Антоновым на самом высоком научно-археографическом уровне. В издании отмечено около 130 актов Спасо-Прилуцкого монастыря XVI-XVII вв., относящихся к Вологодскому, Двинскому, Сольвычегодскому и Тотемскому уездам ${ }^{6}$.

Главное внимание в настоящей статье будет нескольким актовым источникам конца XVI в. из ГАВО, отразившим связи этой духовной корпорации с торговыми людьми Русского севера. Роль торговли и промыслов (в особенности соляного) в его экономике вообще и северно-русских монастырей в частности с учетом высокой степени природообусловленности земледелия и его малопродуктивности была неоспорима. На эту тему имеется подготовленное Л.С. Прокофьевой издание комплекса приходо-расходных и других «вотчинных хозяйственных книг» Прилуцкой корпорации за конец XVI в. ${ }^{7}$ В них мне удалось отыскать дополнительные сведения для комментариев к некоторым из приведенных ниже актам.

${ }^{1}$ Виденеева А.Е., Сазонова Е.И. Документы Спасо-Прилуцкого монастыря в собрании Ростовского музея // Материалы научных чтений памяти Петра Андреевича Колесникова. Вологда, 2000. С. 80-92.

2 Прокофьева Л.С. Вотчинное хозяйство в XVII в. По материалам Спасо-Прилуцкого монастыря. Л., 1959.

${ }^{3}$ Бакланова Е.Н. Крестьянский двор и община на Русском севере. Конец XVII — начало XVIII в. М., 1976; Швейковская Е.Н. Русский крестьянин в доме и мире: северная деревня конца XVI - начала XVIII в. М., 2012.

4 Дадыкина М.M. Кабалы Спасо-Прилуцкого монастыря второй половины XVI-XVII в. исследование. Тексты. СПб., 2011.

5 Рыков Ю.Д. Новые акты Спасо-Прилуцкого монастыря XV в. // Записки Отдела рукописей ГБЛ. М., 1982. Вып. 43. С. 85-105; Крестьянские челобитные XVII в. Из собраний Государственного исторического музея / Отв. ред. Е.И. Индова. М., 1994. С. 95-145. № 96-179; Жучкова И.Л. Материалы Спасо-Прилуцкого монастыря в фондах РГАДА (обзор) // Вологда: краеведческий альманах. Вып. 2. Вологда, 1997. С. 634-642; Черкасова М.С. Архивы вологодских монастырей и церквей XV-XVII вв.: Исследование и опыт реконструкции. Вологда, 2011. С. 121-196.

6 Описание грамот Коллегии экономии / Подгот. А.В. Антонов. М., 2016. Т. 1. С. 468-590 (Вологда); С. 763 (Двина); М., 2020. Т. 3. С. 16-17 (Сольвычегодск); С. 238-244 (Тотьма).

7 Вотчинные хозяйственные книги XVI в. Приходные, расходные окладные книги Спасо-Прилуцкого монастыря 1574-1600 гг. / Сост. Л.С. Прокофьева. М.; Л., 1979. Вып. 1-2. 
Опубликованный в Приложении к данной статье документ № 1 необычен и по форме, и по содержанию. Это своего рода «двойная память» от 20 февраля 1571 г. Некто Бажен Тарасов «со Спаса Прилука» занимает у своего деда, священника Аникея Федосьева, себе «на московский подъем» 30 руб. на короткий срок - с 20 февраля до Николы вешнего 9 мая того же 1571 г. «Привязка» Бажена к «Спасу с Прилука» дает основание видеть в нем по крайней мере обитателя Прилуцкой округи (возможно, состоятельного крестьянина) подмонастырского торгово-ремесленного села Выпрягова-Коровничья. Село совпадало с приходом (церкви во имя Всех святых и свт. Николая Чудотворца), а заимодавец, поп Аникей Федосьев, вероятно, в одной из них и служил. В качестве заклада Бажен Тарасов дает собственному деду память на 18 мехов красной соли уны и луды». Это были расположенные в нижнем Подвинье Унский и Лудский посады, где Спасо-Прилуцкий монастырь частью производил, частью покупал соль, доставляя затем ее на дощаниках и насадах до Вологды. В памяти Б. Тарасова указан объем соли, находящейся в 18 мехах, - 550 пудов, что в пересчете дает вместимость меха в 30,5 пудов, и это в принципе соответствует установленным в исторической метрологии данным о мехе/мешке соли в ту пору - примерно по 30-33 пудов, хотя случались отклонения в меньшую или большую сторону. Помимо запакованных, отмечен один «початой» мех, что позволяет предположить розничную торговлю солью Баженом Тарасовым непосредственно в Прилуцкой округе, где располагалось село Выпрягово-Коровничье и собирались таможенные пошлины ${ }^{8}$, либо ее потребительское использование им самим или предоставление в своеобразный «кредит» (такие случаи известны ${ }^{9}$ ) нуждающимся со стороны.

В памяти говорится, что та соль была поставлена в некой «пустыни у церкви под левым крылосом». В писцовых и таможенных книгах XVII в. пустынью называлось принадлежавшее Николо-Угрешскому монастырю пригородное село Дюдикова пустынь с церковью Рождества Иоанна Предтечи, в котором также проживало много предприимчивых торгово-промысловых крестьян ${ }^{10}$.

Коль скоро речь идет о «московском подъеме», Бажен Тарасов, полагаю, планировал за короткий срок (менее 3-х месяцев) нанять подводы для доставки соли в Москву, продать ее там и вернуть деду заемную сумму. Важно

8 Таможенная книга города Вологды 1634-1635 гг. / Отв. ред. М.Я. Волков. М., 1983. Вып. 2. С. 234, 236, 259, 296, 368.

9 См., например: Крестьянские челобитные XVII в... № 158.

${ }^{10}$ Писцовые и переписные книги Вологды XVII - начала XVIII в. Вологда, 2018. T. 3 / Отв. ред. И.В. Пугач. С. 32, 43, 49. 
иметь в виду, что цена на соль в центре России была существенно выше, нежели в местах ее добычи в Беломорском крае, Сольвычегодске и Тотьме, а также на вологодском рынке. Это становилось источником торговой прибыли ${ }^{11}$. Наблюдения над ценами в комплексе прилуцких приходных книг показывают также, что временем наиболее активной продажи соли нередко были зимние и весенние месяцы (декабрь-апрель).

Под № 2 в Приложении приведена «поставленная отпись» властей Спасо-Прилуцкого монастыря от 15 ноября 1582 г. братьям Петру и Гавриле Олферьевым в приеме у них на сохранение 200 руб., которыми их благословил дед, некий Андрей Стрелицкий. «Фамилия» его имеет явно топонимический оттенок, отсылая, быть может, к Стрелицкой волости Тотемского уезда, расположенной вдоль реки Стрелицы, левого притока Сухоны. На усть-Стрелице располагалась крупная прилуцкая вотчина - село Никольское. Писцом отписи указан казенный дьяк Жданец Козмин, словно «доверенное лицо» братьев Олферьевых, хотя наличие игуменской печати и подписей нескольких соборных старцев говорит о подлинности документа и составлении его в монастырской канцелярии.

О самоназвании отписи как «поставленной» следует сказать особо. Оно близко к распространенным на севере разновидностям данных-положенных операции не только на земельные угодья, но и разное имущество, вещи, денежные суммы. В «Описании грамот Коллегии экономии» А.В. Антонова десятки подобных актов за конец XVI - первую треть XVIII в. отмечены по Двинскому, Устюжскому, Сольвычегодскому уездам, а отложились они в архивах Николо-Корельского, Николо-Моржегорского, Николо-Коряжемского, Троице-Телегова монастырей, Усть-Недумской и Троице-Соезерской пустыней, ряда приходских церквей ${ }^{12}$. В приходе Иоанно-Предтеченской церкви в тотемской волости Толшме вдова-попадья в 1620-х гг. передавала жалованную царскую грамоту на земельные угодья далекого уже на тот момент 1548 г. служившим в 1620-х гг. священникам. Передача этой грамоты, сохранявшей актуальность для экономической жизни причта, всякий раз оформлялась выдачей вдове священниками «положенHblх отписей» ${ }^{13}$.

11 Черкасова М.С. Монастыри и предпринимательство в Московской Руси (XVI-XVII вв.) // Православный монастырский мир: история и современность. Материалы международной научно-практической конференции. Ярославль, 2017. С. 220-221.

${ }^{12}$ Описание грамот Коллегии экономии. Т. 3. С. 372-451, 473-482.

${ }^{13}$ Акты Архангельской и Устюжской епархий // Русская историческая библиотека. СПб., 1894. Т. 14. Стб. 886-887. 
Углубляясь в контекст документа № 2, предположу, что Петр и Гаврило были еще малыми детьми, и корпорация обязалась вернуть им принятую в свою казну на сохранение немалую сумму в 200 руб., когда они «придут в совершенный разум и похотят промышлять собою, торговати». Последняя фраза указывает на торговый профиль их семьи, хотя доступные нам источники не позволяют расширить эту информацию. В расходной книге казначея Мисаила от 25 января 1595 г. есть запись о даче Петру Олферьеву для его «нужи из их денег, деда их благословенья, 18 руб.» ${ }^{14}$, за что с Петра была взята соответствующая отпись. В январе 1596 г. в книге «холмогорского судового ходу» отмечено, что Петру Олферьеву снова была выдана «для его нужи» денежная сумма, размер которой в источнике не указан ${ }^{15}$. В расходной книге казначея Исайи находим запись от 9 апреля 1600 г. о выдаче Клуше (это явно прозвище) Олферьеву 1 руб. «деда его благословенье» и также со взятием отписи ${ }^{16}$. К кому из братьев - Петру или Гавриле - относилось приведенное прозвище, судить не берусь.

Окончательно братья получили из монастырской казны поровну каждый свою «выть» (по 100 руб.) позднее: Петр (видимо, как старший) - 14 апреля 1603 г.; Гаврило - 5 апреля 1606 г. Об этом известно по их собственноручным приписям, тогда как в изначальной отписи 1582 г. их рукоприкладств, в силу малого возраста, не могло быть. Считаем также важным, что в обоих приписях к поставленной отписи 1582 г. дается ссылка на благословение их деда - прилуцкого старца Андреяна. Такое имя удалось отыскать в расспросном списке прилуцкой братии по поводу имущественного положения игумена Гурия 1604 г. ${ }^{17}$ По словам братии, они не знали, поставил ли у кого Гурий какие-либо вещи или «чья у него поклажая лежит ли». Значит, практика поставления/положения своего имущества кому-то на сторону либо принятия чужого имущества на свое сохранение (поклажа) была известна в монашеско-крестьянском сообществе монастыря в рассматриваемое время. Подкреплением этого вывода служит духовная прилуцкого старца Иосифа Коптева 1608 г., в которой он упомянул о своей «поклажае», поставленной у бывшего зятя, крестьянина Ш.В. Смолина. Она представляла собой «коробочку с животом» - 5 руб. плюс два «деланых бобра», «нагольная черевья шапка», ткани ${ }^{18}$.

\footnotetext{
${ }^{14}$ Вотчинные хозяйственные книги XVI в... Вып. 2. С. 349.

${ }^{15}$ Там же. Вып. 1. С. 135.

${ }_{16}^{16}$ Там же. Вып. 2. С. 363-364.

${ }^{17}$ ГАВО. Ф. 1260. Оп. 2. № 143.

${ }^{18}$ Акты юридические, или собрание форм старинного делопроизводства. СПб., 1838.
} № 423. 
Таким образом, при анализе поставленной отписи братьев Олферьевых перед нами словно промелькнула растянутая во времени, с 1582 по 16031606 гг., история двух детей, возможно, оставшихся сиротами (коль скоро речь идёт о деде, а не о родителях), повзрослевших под эгидой Прилуцкого монастыря. С этим обстоятельством можно предположительно связать их грамотность. Как сложилась их дальнейшая судьба, при нынешнем состоянии доступных нам источников пока не известно.

Интересные сведения об экономических отношениях Спасо-Прилуцкого монастыря с представителями одной из ветвей (не самой богатой и удачливой, не достигшей высокого статуса именитых людей ${ }^{19}$ ) рода Строгановых сообщает документ, опубликованный в Приложении под № 3. Документ нестандартно начинается с некой делопроизводственной записи о назначении в 1586/87 г. старца Дорофея Езовского на промысел в Сольвычегодск (до этого он же исполнял должность купчины-казначея в самом монастыре, а по возвращении из Сольвычегодска вновь работал купчиной-казначеем, «закончив карьеру» соборным старцем в 1597 г. $^{20}$ ). Затем приводится вкладная память прилуцких властей Афанасию Владимирову сыну Строганову и его сыну Ивану на 30 руб. вклада, дающего им право на пострижение в обители. Память датирована 9 марта 1594 г., написал ее часто фигурирующий в документах того времени прилуцкий казенный дьячок Филя Исаков ${ }^{21}$.

Документ отражает практикуемые в 1587-1589 гг. между Строгановыми и приказными старцами монастыря Дорофеем и Никоном в Сольвычегодске отношения «россольной кортомы», т. е. использование монастырем на своей варнице соляного рассола Строгановых. Аренда («кортома») монастырем в течение трех лет их соляного раствора была приравнена к 30 руб., за которые 9 марта 1594 г. решением соборных старцев обитель взяла на себя обязательство постричь при желании Афанасия и Ивана Строгановых и поминать их семью. Во вкладной перечислено 15 мужских и женских имен, из которых 1 схимник, 2 схимницы и 3 младенца. Среди имен удалось

\footnotetext{
${ }^{19}$ Введенский А.А. Происхождение Строгановых // Север: Орган научного краеведения. Вологда, 1923. Кн. 2. С. 75.

${ }^{20}$ Вотчинные хозяйственные книги XVI в... Вып. 2. С. 320-322, 332-337, 348-350; Вып. 1. C. $137,140,160$ (в первом и втором выпусках данного издания хозяйственные книги представлены не в хронологическом порядке).

${ }^{21}$ Он, например, известен как писец описи Спасо-Прилуцкого монастыря 1593 г. Он же составил отпись о выплате кормового содержания ратным людям 1610 г. (Переписные книги вологодских монастырей XVI-XVIII вв.: исследование и тексты / Изд. подгот. О. Н. Адаменко, Н.В. Башнин, М.С. Черкасова при участии А.П. Анишиной, Н.А. Бараевой, Е.А. Виноградовой, А.Н. Красикова, С.Н. Смольникова, И.Н. Шаминой. Вологда, 2011. С. 44; Старая Вологда. XII - начало XX в.: Сборник документов и материалов / Отв. сост. Л.В. Мясникова. Вологда, 2004. С. 40. № 36).
} 
заметить несколько совпадений в обширном поминальном перечне Строгановского рода, приведенном в более ранней вкладной памяти властей Николо-Коряжемского монастыря Якову, Григорию, Семену Аникеевым детям Строганова от 11 января 1570 г. Это Феодосий схимник, Еуфимия, Владимир, Феодосия ${ }^{22}$. Вместе с тем в более поздней вкладной представителя следующего поколения Строгановых Федора Петровича 1643/44 г. в поминальном перечне фигурирует имя «Иванна» ${ }^{23}$. Возможно, под ним следует понимать Ивана Афанасьева сына Строганова публикуемой мною памяти 1594 г.

Приведем и более ранние документальные известия об Афанасии Владимирове Строганове. Это оброчная грамота ему, простому на тот момент «усолцу Афонке», от царя Ивана IV Грозного 2 апреля 1564 г. на оброчное пользование «присадным песком» с подтверждениями царем Федором Ивановичем в 1596 г. и Борисом Годуновым в январе 1599 г. ${ }^{24}$ Смерть же Афанасия Владимирова сына Строганова (инока Антония) отмечена в кормовой книге Николо-Коряжемского монастыря под 17 января 1607 г. (по другим данным, 12 января 1622 г.), а похоронен он был в Успенской церкви Сольвычегодска ${ }^{25} .1607$ год может считаться более точной датой, поскольку упомянутая царская грамота была подтверждена уже не ему, а сыну, Ивану Афанасьеву, в 1608 г. царем Василием Ивановичем Шуйским, а в 1619 г. царем Михаилом Федоровичем. В сольвычегодских актах 1613-1619 гг. он фигурирует как один из «лучших» (т. е. состоятельных и платежеспособных) людей местной посадской общины ${ }^{26}$. Судя по комплексу таможенных книг Сухоно-Двинского пути первой трети XVII в., он также активно занимался торговлей ${ }^{27}$.

До сих пор было известно о связях Строгановых с другими монастырями - Соловецким, Кирилло-Белозерским, Спасо-Пыскорским в Соликамске,

${ }^{22}$ Вкладная опубликована: Черкасова М.С. Вклады Строгановых в севернорусские монастыри // Грани русского Средневековья: Сборник статей к 90-летию Юрия Георгиевича Алексеева. М., 2016. С. 327.

${ }^{23}$ Там же. С. 329.

24 Дмитриев А. Строгановские грамоты XVI-XVII вв. // Пермская старина. Пермь, 1895. Вып. 6. С. 129-130.

${ }^{25}$ Безроднов В.С. Вкладная и кормовая книга коряжемского Никольского монастыря // Вестник церковной истории. 2011. № 1/2(21/22). С. 71, 96 (примеч. 80).

${ }^{26}$ Указные грамоты воеводам и приказным людям 1613-1626 гг. / Сост. и отв. ред. И.В. Пугач. М., 2012. С. $316,319,346,350$.

${ }^{27}$ См. по именным указателям, хотя характер записей не всегда позволяет уверенно отличить Ивана Максимова сына от Ивана Афанасьева сына Строгановых: Таможенные книги Сухоно-Двинского пути XVII в. / Сост. С.Н. Кистерев, Л.А. Тимошина. СПб., 2013. Т. 1. С. 347; СПб., 2014. Т. 2. С. 302; СПб., 2016. Т. 4. С. 334; СПб., 2017. Вып. 5. С. 329; СПб., 2018. Вып. 7. С. 393; Таможенная книга города Вологды... Вып. 3. С. 398, 450 и др. 
Введенским и Борисоглебским в Сольвычегодске, Николо-Коряжемским между Сольвычегодском и Устюгом. Их же контакты (в частности ветви Афанасьевичей) с вологодским Спасо-Прилуцким монастырем до сих пор подробно не рассматривались. Полагаю, что этот новый документ, имеющий отношение к истории данного рода и его хозяйственной деятельности, может быть учтен при дальнейших историко-генеалогических разработках. Во всяком случае обширная поминальная глава «Род Афонасья Владимирова сына Строганова» в Синодике Спасо-Прилуцкого монастыря (хоть он и довольно поздний -1745 г. $)^{28}$ получает дополнительное объяснение. В ней как раз перечислены имена лиц, отмеченные в отписи 1594 г. Следовательно, взятые на себя перед Афанасием Владимировым Строгановым и его сыном Иваном обязательства корпорация выполнила.

\section{Приложение}

\section{№ 1}

\section{1 г. февраля 20. - Память Б. Тарасова, занявшего 30 руб. у своего деда, попа А. Федосьева, под заклад «соляной памяти» на 18 мехов соли}

(л. 1) Се яз, Бажен Тарасов сын от Спаса с Прилука, взял есми у деда своего у Аникия у попа у Федосьева сына тритцет рублев денег на подъем московской. А заложил есми ему в тех денгах паметь на соль на осьмнатцать мехов и на початой мех. А соль в них красная уна да луда, а соли в них пол-шесть ста пуд, а соль стоит в пустыне под церковью под левым крыласом. А денги есми взял февраля в 20 день на паметь Лва епископа да до Николина дни до вешнаго. А не заплачу яз денег на срок, ино ся паметь моего писма на соль на пол-шесть ста пуд и купчая.

А на то послуси: Филип Афонасьев сын да Занка Сидоров сын.

А паметь писал на паметь на соляную на закладную паметь Андрейко Истомин сын лета 7089-го.

ГАВО. Ф. 1260. On. 2. № 18 .

Подлинник.

\footnotetext{
${ }^{28}$ Вологодский государственный музей-заповедник. Сектор письменных источников. Собрание рукописных книг. № 93 (2013). Л. 309. Характеристику рукописи см.: Памятники письменности в музеях Вологодской области. Каталог-путеводитель. Вологда, 1987. Ч. 1. Вып. 2. С. 205-206. Покупка калачей на поминальный корм по «Аникию Строганову с родом» 30 октября отмечена в расходной книге Прилуцкого монастыря 1633 г. (ГА ВО. Ф. 512. Оп. 1. Кн. 34. Л. 18 об.).
} 
1582 г. ноября 15. — «Поставленная отпись» властей Спасо-Прилуцкого монастыря в получении 200 руб. от внуков Андрея Стрелицкого Петра и Гаврилы Олферьевых с позднейшими приписями 1603 г. апреля 5 и 1606 г. апреля 14

(л. 1) Лета 7091-го года ноября 15 де[нь] память Спаскаго Прилуцкаго монастыря игумену Сергию да келарю Ионе, да казначею Гурью и соборным старцем - старцу Макарье, старцу Протасию, старцу Кирилу, старцу Стахее, старцу Мисаилу и всем соборным старцем Прилуцкаго монастыря.

Что у нас положили в монастырьскую казну Петр да Гаврило Олферьевы дети, а Ондреева внучата Стрелицкого, своих денег двесте рублев до своего возрасту, доколе они, в монастыре живучи, предут в разум и как похотят промышляти собою торговати. И мне, игумену Сергею з братьею, или по мне иные игумены будут и соборные старцы, из монастырьские казны Петру и Гаврилу те их денги двесте рублев отдати сполна. А у них в тех денгах взята отпись. А не придут в совершенный разум, и нам денег не отдати, доколе их Бог вразумит в совершенный возраст.

К сей поставленной отписи игумен Сергий печать свою приложил.

А отпись писал казенной дияк Жданец Козмин Петра и Гаврила Олферьевых.

Далее черная игуменская печать.

На обороте разным почерком: Казначей Гурей руку приложил.

Старец Макарей руку приложил.

Старец Протасей руку приложил.

Старец Стахия руку приложил.

Старец Кирило руку приложил.

По сей памети меня, Гаврила, по приказу деда моего благословение старца Андреяна моя выть сто рублев Прилуцкого монастыря ис казны дошли все сполна при игумене Якове з братьею. А на памяти подписал я, Гаврило, своею рукою лета 7100 четвертаго на десять году апреля в 5 де[нь].

По сей памяти меня, Петрушку, по приказу деда моего благословение старца Андреяна моя выть сто рублев Прилуцкого монастыря ис казны дошли все сполна при игумене Гурие з братьей. А на памяти подписал я, Петрушка, своею рукою лета 7111-го априля в 14 де[нь].

ГАВО. Ф. 1260. On. 2. № 34 .

Подлинник. 
1594 г. марта 9. - Вкладная память властей Спасо-Прилуцкого монастыря Афанасию Владимирову с. Строганову и его сыну Ивану на получение от них вклада в 30 руб. за рассол их трубы в Соли Вычегодской, используемый монастырем в течение трех лет

(л. 1) Лета 7095-го году Прилуцкого монастыря старец Дорофей Езовской был из монастыря послан на Вычегду соли варити. И в прошлом 95-м и в 96-м году давал старцу Дорофею Афонасей Володимеров сын Строганово из своея трубы на монастырьской црен росол лити и соль варити. Да в прошлом же 97-м году Афонасей же Володимеров давал старцу Никону из тое ж трубы, а лили без ряды. И в нынешном 102-м году Афонасей Володимеров приездил в Прилуцкой монастырь, чтобы ему, Афонасью, та росолная кортома записати за вклад за тритцать рублев за него, Афонасья, и за его сына Ивана.

И Прилуцкого монастыря келарь Иосиф, и казначий Кирило, и вся братья у старца Дорофея да у старца Никона о том доспрашивали. И старец Дорофей да старец Никон перед всею братьею келарю Иосифу сказали, что оне росол три годы из Афонасьевы трубы лили и соль варили, и кортомою не рядилися, по чему дати на год. И келарь Иосиф да казначей Кирило и вся братия, приговоря на соборе, да тот его росол почли за вклад за тритцать рублев за него, Афонасья, и за его сына Ивана. И похочет Афонасей и его сын Иван в монастырь, и келарю Иосифу и всей братии его, Афонасья, и сына его Ивана за тот вклад в монастырь приняти и постричи и покоити, как и прочих вкладчиков, и родителей его написати в сенаник в вечной поминок: Феодосья схимника. Владимера. Иноку Пелагею. Феодосью. Татьяну. Еуфимью. Бориса младенца. Федору младенца. Ивана. Пахомья. Костянтина. Дарью. Антониду схимницу. Евгению схимницу. Филипа младенца.

А вкладную писал Прилуцкого монастыря казенной дьячек Филя Исаков сын лета 102-го году марта 9 де[нь].

На обороте: Келарь Иосиф руку приложил.

Казначий старец Кирило руку приложил.

Чернец Дорофей руку приложил.

Старец Евфимей руку приложил.

ГАВО. Ф. 1260. On. 2. № 68 . Подлинник.

Упом.: Черкасова М.С. Архивы вологодских монастырей... С. 191. № 140. 


\section{Литература}

Акты Архангельской и Устюжской епархий // Русская историческая библиотека. СПб., 1894. Т. 14.

Бакланова Е.Н. Крестьянский двор и община на Русском севере. Конец XVII — начала XVIII в. М., 1976.

Безроднов В.С. Вкладная и кормовая книга коряжемского Никольского монастыря // Вестник церковной истории. 2011. № 4.

Введенский A.A. Происхождение Строгановых // Север: Орган научного краеведения. Вологда, 1923. Кн. 2.

Виденеева A.E., Сазонова Е.И. Документы Спасо-Прилуцкого монастыря в собрании Ростовского музея // Материалы научных чтений памяти Петра Андреевича Колесникова. Вологда, 2000.

Вотчинные хозяйственные книги XVI в. Приходные, расходные окладные книги Спасо-Прилуцкого монастыря 1574-1600 гг. Вып. 1-2/Сост. Л.С. Прокофьева / Под ред. А.Г. Манькова. М.; Л., 1979.

Гейман В. Несколько новых документов, касающихся истории сельского населения Московского государства ХУ1 столетия // Сборник Российской Публичной библиотеки. Пг., 1924. Т. 2. Материалы и исследования. Вып. 1.

Дадыєина М.M. Кабалы Спасо-Прилуцкого монастыря второй половины XVI-XVII в. исследование. Тексты. СПб., 2011.

Дмитриев А. Строгановские грамоты XVI-XVII вв.// Пермская старина. Пермь, 1895. Вып. 6.

Жучкова И.Л. Материалы Спасо-Прилуцкого монастыря в фондах РГАДА (обзор) // Вологда: краеведческий альманах. Вологда, 1997. Вып. 2.

Описание грамот Коллегии экономии / Подгот. А.В. Антонов. М., 2016. Т. 1.

Описание собрания свитков, находящихся в Вологодском епархиальном древнехранилище. Вологда, 1903. Вып. 6.

Памятники письменности в музеях Вологодской области. Каталог-путеводитель. Вологда, 1987. Ч. 1. Вып. 2.

Переписные книги вологодских монастырей XVI-XVIII вв.: Исследование и тексты. Вологда, 2011.

Писцовые и переписные книги Вологды XVII - начала XVIII в. T. 3 / Отв. ред. И.В. Пугач. Вологда, 2018.

Прокофьева Л.С. Вотчинное хозяйство в XVII в. По материалам Спасо-Прилуцкого монастыря. Л., 1959.

Рыков Ю.Д. Новые акты Спасо-Прилуцкого монастыря XV в. // Записки Отдела рукописей ГБЛ. М., 1982. Вып. 43.

Сборник князя Хилкова. СПб., 1979.

Старая Вологда. XII - начало XX в.: Сборник документов и материалов / Отв. сост. Л.Н Мясникова. Вологда, 2004.

Суворов Н. Описание вологодского Спасо-Прилуцкого монастыря. Вологда, 1884. 
Таможенная книга города Вологды 1634-1635 гг. / Отв. ред. М.Я. Волков. М., 1983. Вып. 1-3.

Таможенные книги Сухоно-Двинского пути XVII в. СПб., 2013. Вып. 1; СПб., 2014. Вып. 2; СПб., 2016. Вып. 4; СПб., 2017. Вып. 5; СПб., 2018. Вып. 7.

Указные грамоты воеводам и приказным людям 1613-1626 гг./Сост. и отв. ред. И.В. Пугач. М., 2012.

Черкасова М.С. Архивы вологодских монастырей и церквей XV-XVII вв.: Исследование и опыт реконструкции. Вологда, 2012.

Черкасова М.С. Вклады Строгановых в севернорусские монастыри // Грани русского Средневековья: Сборник статей к 90-летию Юрия Георгиевича Алексеева. М., 2016.

Черкасова М.C. Монастыри и предпринимательство в Московской Руси (XVIXVII вв.) // Православный монастырский мир: история и современность. Материалы международной научно-практической конференции. Ярославль, 2017.

Швейковская E.H. Русский крестьянин в доме и мире: северная деревня конца XVI - начала XVIII в. М., 2012. 


\title{
Д.А. Черненко
}

\section{ЗЕМЛИ ГОРОДОВ ВОЛОГОДСКОЙ ГУБЕРНИИ В КОНЦЕ XVIII В.: РАЗМЕРЫ, ТИПОЛОГИЯ, ВЛАДЕЛЬЧЕСКАЯ ПРИНАДЛЕЖНОСТЬ ${ }^{1}$}

\begin{abstract}
Аннотация В статье рассматриваются сведения Экономических примечаний к Генеральному межеванию о размерах, типах и собственниках городских земель Вологодского наместничества. Результатами исследования являются выводы о преобладании в этом регионе простых по составу пригородных земельных комплексов площадью 0,5-2,5 тыс. дес. со значительной долей лесов, принадлежащих представителям городского сословия либо как «градскому обществу» в целом, либо как представителям влиятельных купеческих фамилий.

Ключевые слова: аграрная история России, история городов, социально-экономическая история России, историческая география, Вологодская губерния.
\end{abstract}

Summary The information of the Economic Notes to the General Survey on the size, types and owners of urban land in the Vologda governorship is discussed in the article. Conclusions about the prevalence in this region of simple suburban land complexes with an area of 0,5-2,5 thousand hectares with a significant share of forests belonging to representatives of the urban class either as a «city society» in general, or as representatives of influential merchant families are the results of the study.

Keywords: agrarian history of Russia, history of cities, socio-economic history of Russia, historical geography, Vologda province.

Русский город конца XVIII - начала XIX в. как объект исторического изучения представлен в крупных исследованиях, содержащих его социально-демографическую и социокультурную характеристику, анализ городского самоуправления, различных сторон повседневной жизни, правительственной

\footnotetext{
1 Исследование выполнено при финансовой поддержке РФФИ, проект № 19-09-00462(а).
} 
политики в отношении городов ${ }^{2}$. Данное исследование является продолжением исследования городского хозяйства Российской империи на материалах Экономических примечаний к Генеральному межеванию, создававшихся преимущественно в последней четверти XVIII - начале XIX в. ${ }^{3}$, хранящихся в ф. 1355 (Экономические примечания к Генеральному межеванию) РГАДА. Главное преимущество этих материалов заключается в подробной фиксации ими городских земель ${ }^{4}$. В данном исследовании анализируются сведения примечаний по Вологодской губернии, фактически - Вологодскому наместничеству в части Великоустюжской и Вологодской областей (1780-1796 гг.). Отметим, что различные стороны жизни городов этого региона также активно исследуются в последние десятилетия, в том числе и на основе материалов Экономических примечаний к Генеральному межеванию5.

Архивная опись ф. 1355 предлагает в качестве рамочной датировки документов по Вологодской губернии 1782-1796 гг. ${ }^{6}$, которые традиционно

2 Миронов Б.Н. Русский город в 1740-1860 гг. Л., 1990; Козлова Н.В. Городская семья XVIII в.: Семейно-правовые акты купцов и разночинцев Москвы. М., 2002; Козлова Н.В. Люди дряхлые, больные, убогие в Москве XVIII века. М., 2010; Середа Н.В. Реформа управления Екатерины Второй: Источниковедческое исследование. М., 2004; Водарский Я.Е. Исследования по истории русского города: Факты, обобщения, аспекты. М., 2006; Каменский А.Б. Повседневность русских городских обывателей: исторические анекдоты из провинциальной жизни XVIII в. М., 2006; Четьрина Н.A. Сергиевский Посад в конце XVIII - начале XIX в. (Посад как тип городского поселения). М., 2006; Куприянов А.И. Городская культура русской провинции (конец XVIII - первая половина XIX в.). М., 2007; Кошман Л.В. Город и городская жизнь в России XIX столетия. М., 2008; Белов А.В. Реформа города Екатерины II (по материалам губерний Центральной России). М., 2019.

3 Города Российской империи в материалах Генерального межевания: Центральная Россия / Сост. Д.А. Черненко, А.А. Голубинский, Д.А. Хитров. Тула, 2016.

${ }^{4}$ Важность аграрной составляющей в жизни городов подчеркивалась Л.В. Миловым: Милов Л.В. О так называемых «аграрных городах» России XVIII века // Вопросы истории. 1968. № 6. C. 54-64.

${ }^{5}$ Камкин А.В. Вологда 1780-х годов в воспоминаниях современников (А.А. Засецкий. Исторические и топографические известия; Экономические примечания к Генеральному межеванию) // Вологда. Историко-краеведческий альманах. Вологда, 1994. Вып. 1. С. 279-301; Козина Г.Н. Вологодские купцы - фабриканты и заводчики (XVIII - начало XX века) // Вологда. Историко-краеведческий альманах. Вологда, 1997. Вып. 2. С. 85-148; Черкасова М.С. Севернорусский город в переходную эпоху от Средневековья к раннему Новому времени: К вопросу о типологии // Особенности российского исторического процесса: Сборник статей памяти академика Л.В. Милова. М., 2008. С. 171-185; Черкасова М.С. Обывательские книги как источник для изучения купечества и торговли Вологды в конце XVIII - первой трети XIX в. // Торговля, купечество и таможенное дело России XVI-XIX вв.: Сборник материалов Второй международной конференции. Курск, 2009. С. 166-172; Черненко Д.А., Хитров Д.А. Сведения материалов Генерального межевания о жилой городской застройке на Севере и Северо-Западе России в конце XVIII в. // Историческая информатика. 2019. № 4. С. 1-11.

${ }^{6}$ Опись № 1 фонда № 1355 РГАДА. С. 8. См. публикацию на сайте РГАДА (URL: http:// rgada.info/opisi/1355-opis_1/0024.jpg (дата обращения - 15.02.2021)). 
принимаются и как датировка самого межевания в данном регионе. Среди материалов фонда могут быть выделены следующие типы Экономических примечаний, созданных в разное время ${ }^{7}$.

Tun A. Классические «краткие» примечания, написанные почерком второй половины XVIII в. Эти описания имеются по всем городам и в большинстве случаев в архивной описи ф. 1355 числятся первыми среди томов по данному городу. В ряде томов имеются поправки почерками XIX в. и записи об изменениях границ уездов, вносившиеся вплоть до 1880-х гг. Этот тип представлен в описаниях следующих городов: Великий Устюг (кн. 84), Вельск (кн. 92), Вологда (кн. 101), Грязовец (кн. 110), Кадников (кн. 120), Красноборск (кн. 127), Лальск (кн. 136), Никольск (кн. 147), Сольвычегодск (кн. 158), Тотьма (кн. 167), Усть-Сысольск (кн. 176), Яренск (кн. 186).

Tunь $Б$ и В. Классические «примечания к генеральным планам». Имеются два неполных комплекта. Первый (тип Б) написан почерком второй половины XVIII в., заметно выцветшими чернилами, второй (тип В) более поздним почерком на сероватых листах. Эти типы представлены по следующим городам: Великий Устюг (кн. 85, 86), Вельск (кн. 93, 94), Вологда (кн. 102, 103), Грязовец (кн. 111), Красноборск (кн. 128, 130), Лальск (кн. 137, 138), Никольск (кн. 148, 150), Сольвычегодск (кн. 160, 161), Тотьма (кн. 168, 169), Усть-Сысольск (кн. 177, 179), Яренск (кн. 187, 188).

Tun $Г$ - краткие примечания, составленные в ХІХ в. Их особенностью является указание численности населения по VIII ревизии. Этот тип представлен по следующим городам: Вельск (кн. 95), Вологда (кн. 104), Никольск (кн. 151), Тотьма (кн. 170).

Tun Д. Поздние Краткие примечания, написанные явно почерком XIX в. Визуально от типа А они отличаются еще и тем, что графы таблицы оформлены на разворот, а не на один лист. Этот тип представлен по следующим городам: Великий Устюг (кн. 87), Грязовец (кн. 112), Кадников (кн. 121), Красноборск (кн. 129), Лальск (кн. 139), Никольск (кн. 149), Сольвычегодск (кн. 159), Тотьма (кн. 171), Усть-Сысольск (кн. 178), Яренск (кн. 189).

Tun E. «Описания уездного города с экономическим журналом». Подробное, но позднее и сильно отличающееся от классических Примечаний описание города. Этот тип представлен по следующим городам: Кадников (кн. 124), Сольвычегодск (кн. 157).

В ходе реализации проекта по подготовке к публикации описаний городов Северо-Запада и в рамках данной работы при отборе материалов

\footnotetext{
7 Классификация Экономических примечаний разработана и предоставлена Д.А. Хитровым, которому я выражаю глубокую признательность.
} 
ф. 1355 предпочтение было отдано типам Экономических примечаний, обозначенных в этой классификации как «Б» и «В»8 .

Описание города в этих материалах открывает собой описание уезда. От территории уезда город отделяется обозначением его земель латинскими буквами, тогда как земельные владения различных собственников за пределами города («в уезде») обозначены арабскими цифрами. Таким образом, город в Экономических примечаниях предстает как сложный земельный комплекс, состоящий из этих «литерных» дач с их землями и населением, юридически зафиксированный в пределах «градской межи» на Генеральном уездном плане. При этом Экономические примечания выделяют территорию собственно городской застройки, обозначенную в них как дача «А» и именуемой «градской селидебной землею», к которой примежеваны выгон, поселения, пустоши и прочие «литерные дачи». Пространственное соотношение «градской селидебной земли» и общей площади городской земли в пределах «общей градской межи» на примере г. Никольска представлено на рис. 1.

На нем хорошо видно, что в материалах Генерального межевания г. Никольск представлен как комплексная земельная дача, в которую, помимо собственно городской территории, входили четыре деревни. Эти поселения располагались в нескольких километрах от города на расчищенной от леса пашенной земле, окруженной довольно крупным массивом лесов (на схеме показан сплошной заливкой серого цвета). При этом площадь собственно города («градской селидебной земли») составляла менее $1 \%$ от общей площади территории «в градской меже».

Не в столь выраженном виде похожая ситуация характерна для всех городов губернии: территория собственно города как бы «тонула» в массиве примежеванных к ней земель. В старых городах соотношение площади собственно города и общей площади городских земель было не столь ассиметричным, но и здесь территория городской застройки составляла лишь меньшую часть от общей площади городских земель. В Великом Устюге этот показатель составлял $8 \%$, в Тотьме - $13 \%$, а в губернском центре - $25 \%$. Но особенно характерна данная ситуация для новообразованных городов.

8 РГАДА. Ф. 1355. Оп. 1. Экономические примечания к Генеральному межеванию. Великоустюжский уезд. Кн. 86. Л. 1-11 об.; Вельский уезд. Кн. 94. Л. 1-2; Вологодский уезд. Кн. 102. Л. 1-9; Грязовецкий уезд. Кн. 111. Л. 1-2 об.; Кадниковский уезд. Кн. 122. Л. 1-2 об.; Красноборский уезд. Кн. 130. Л. 1-1 об.; Лальский уезд. Кн. 138. Л. 1-3; Никольский уезд. Кн. 148. Л. 1-3; Сольвычегодский уезд. Кн. 160. Л. 1-5 об.; Тотемский уезд. Кн. 168. Л. 1-2 об.; Усть-Сысольский уезд. Кн. 177. Л. 1-9 об.; Яренский уезд. Кн. 187. Л. 1-3 об. Исключение составляет только Тотьма, по этому городу дополнительно использована статистика из описания, относящегося к «варианту Д», поскольку в ней более подробно классифицированы земельные угодья. 


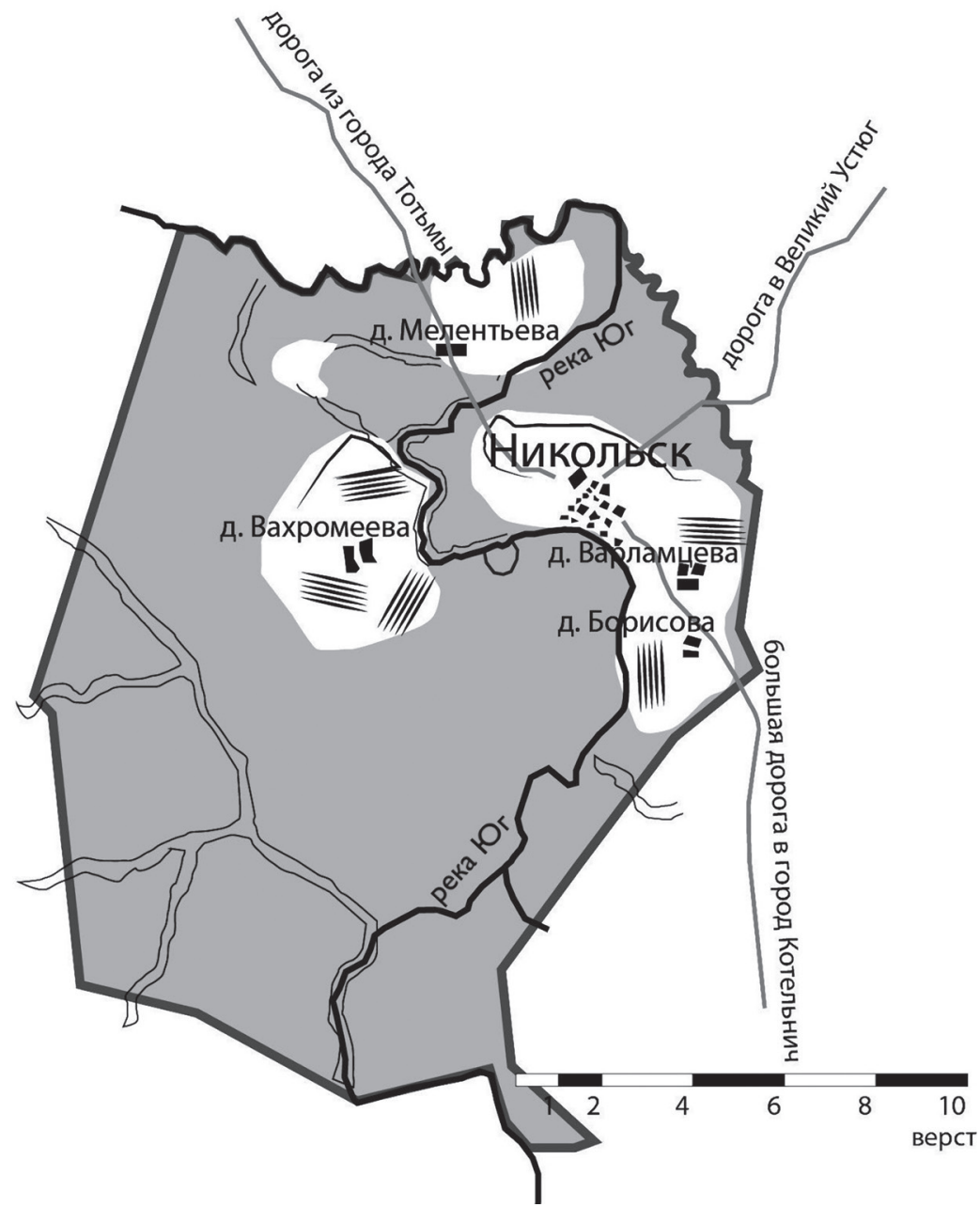

Рис. 1. Схема отображения города Никольска на уездном плане Генерального межевания ${ }^{9}$

Так, в Вельске этот показатель составлял 5\%, в Кадникове и Усть-Сысольске - $4 \%$, в Грязовце - $2 \%$. В среднем по городам Вологодской губернии доля территории городской застройки в общей площади городских земель составляла 6\%. Таким образом, с пространственно-статистической точки зрения город в материалах Генерального межевания - это, в первую очередь, примежеванные к нему земли «литерных дач», многократно превосходящие его по площади.

9 Никольский уезд. Уездный план. Масштаб 1 верста в дюйме (РГАДА. Ф. 1356. Оп. 1. Ед. хр. 418-423). 
Таблица 1.

Количество дач, примежеванных к городам Вологодской губернии ${ }^{10}$

\begin{tabular}{|l|c|c|c|}
\hline \multicolumn{1}{|c|}{ Город } & $\begin{array}{c}\text { Количество примеже- } \\
\text { ванных населенных } \\
\text { «литерных» дач }\end{array}$ & $\begin{array}{c}\text { Количество примеже- } \\
\text { ванных ненаселенных } \\
\text { «литерных» дач }\end{array}$ & $\begin{array}{c}\text { Всего примежеванных } \\
\text { «литерных» дач }\end{array}$ \\
\hline Великий Устюг & 3 & 10 & 13 \\
\hline Вельск & 0 & 1 & 2 \\
\hline Вологда & 1 & 1 & 1 \\
\hline Грязовец & 0 & 1 & 1 \\
\hline Кадников & 0 & 1 & 0 \\
\hline Красноборск & 0 & 0 & 2 \\
\hline Лальск & 0 & 2 & 10 \\
\hline Никольск & 1 & 1 & 1 \\
\hline Сольвычегодск & 2 & 8 & 17 \\
\hline Тотьма & 0 & 1 & 3 \\
\hline Усть-Сысольск & 2 & 15 & 4,5 \\
\hline Яренск & 0 & 3 & 2,7 \\
\hline В среднем & 0,8 & & 2 \\
\hline
\end{tabular}

Особенностью региона можно считать то, что здесь к городам было примежевано совсем небольшое количество дач, а у Красноборска таковых не зафиксировано вовсе. Количество дач отнюдь не равносильно количеству примежеванных к городу объектов (поселений, пустошей, лугов) или, тем более, площади примежеванных земельных угодий. Собственно, «литерная дача» - это, в первую очередь, отражение некой хозяйственной и / или юридической обособленности части пригородных земель внутри «общей градской межи». Рассмотрим, что представляли собой пригородные земли Вологодской губернии с точки зрения типологии и размерности.

Очевидно, что город как комплекс земель в Вологодской губернии практически в обязательном порядке включал в себя два элемента: собственно городскую дачу («городская селидебная земля, “дача А”») и городской выгон («городская незаселенная выгонная земля»). Исключение составляет только город Красноборск, изученное описание которого не содержит в себе характеристику городского выгона.

${ }^{10}$ Все таблицы составлены на основе сплошной обработки материалов, перечисленных в сноске 7. 
Таблица 2.

Типы объектов, примежеванных к городам Вологодской губернии

\begin{tabular}{|l|c|c|c|c|c|c|c|c|c|c|c|c|}
\hline & $\mathbf{I}^{11}$ & $\mathbf{I I}^{12}$ & $\mathbf{I I I}^{13}$ & $\mathbf{I V}^{14}$ & $\mathbf{V}^{15}$ & $\mathbf{V I}^{16}$ & $\mathbf{V I I}^{17}$ & $\mathbf{V I I I}^{18}$ & $\mathbf{I X}^{19}$ & $\mathbf{X}^{20}$ & $\mathbf{X I}^{21}$ & $\mathbf{B c e г о ~}^{\text {Великий }}$ \\
Устюг & 1 & 3 & 4 & 1 & & & 6 & & 1 & & & 16 \\
\hline Вельск & 1 & 1 & & & & & & & & & & 2 \\
\hline Вологда & 1 & 1 & & & & & & & & & & 2 \\
\hline Грязовец & 1 & 1 & & & & & & & & & & 2 \\
\hline Кадников & 1 & 1 & & & & & & & & & & 2 \\
\hline Красноборск & 1 & 0 & & & & & & & & & & 1 \\
\hline Лальск & 1 & 1 & & & & & 2 & & & & & 4 \\
\hline Никольск & 1 & 1 & & & 4 & & & 2 & & & & 8 \\
\hline Сольвычегодск & 1 & 1 & & & 2 & & 4 & & 1 & 1 & 1 & 11 \\
\hline Тотьма & 1 & 1 & & & & & & & & & & 2 \\
\hline Усть-Сысольск & 1 & 1 & & & & 2 & & 14 & & & & 18 \\
\hline Яренск & 1 & 1 & & & 1 & & & 1 & & & & 4 \\
\hline Всего & 12 & 13 & 4 & 1 & 7 & 2 & 12 & 17 & 2 & 1 & 1 & 72 \\
\hline
\end{tabular}

За исключением города Никольска городской выгон представлял собой незаселенные земли, включавшие в себя пашенные, сенокосные, лесные угодья, а также «неудобья». Массивы этих земель могли быть довольно значительными. Например, у Великого Устюга «незаселенная градская выгонная земля» насчитывала 1059 дес., у Яренска - 1300 дес., у Сольвычегодска - 1437 дес., у Грязовца - 1919 дес. Наибольший размер «незаселенной градской выгонной земли» составлял в Усть-Сысольске, где он достигал 14292 дес. Специфика региона проявляется в том, что большую часть этих земель составляли явно не пастбищные угодья.

\footnotetext{
${ }^{11}$ Город (городская селидебная земля).

12 Городская выгонная земля (незаселенная).

${ }^{13}$ Слободы, «слободки».

${ }^{14}$ Село.

15 Деревня.

16 Усадебная пустошь.

17 Полянка.

18 Пожня.

${ }^{19}$ Писцовая церковная земля.

20 Дворовое место.

${ }^{21}$ Кирпичный завод.
} 
Как известно, классификация земельных угодий в Экономических примечаниях к Генеральному межеванию в принципе не выделяет такую категорию земли, как «пастбища». Однако в наших материалах по городу Лальску такой вид земель указан, в этом описании они называются просто «выгон» и составляют 239 дес. При этом в описании данного города указаны пашенные земли, лес, но не указан сенокос, что позволяет предположить, что собственно городские пастбища межевщиками записывались именно в сенокосные угодья.

При этом подавляющую часть городских выгонных земель составляли леса: в Кадникове, Лальске, Сольвычегодске, Великом Устюге - 60-65\%, а в Грязовце, Вельске, Усть-Сысольске и Яренске - 70-80\%. Сенокосные угодья при этом составляли ничтожную часть городских земель, показанных в Экономических примечаниях как «выгонные», их доля колебалась от 1 до 14\%. Все это ясно показывает, что термин «городской выгон» в межевых материалах имеет не буквальное хозяйственное, а формальноюридическое значение, подразумевающее наличие угодий любых типов, максимально близко расположенных к городу.

К городам Вологодской губернии в конце XVIII в. примежевывались сельские населенные пункты (села, слободы, деревни), что характерно, конечно, и для других регионов. Однако, как правило, они примежевывались к новым городам, чтобы увеличить численность их населения. Классический пример такой ситуации мы видели применительно к Никольску. Однако в Вологодской губернии большая часть сельских населенных пунктов была примежеваны к старым городам, имевшим статус уездного центра еще до губернской реформы 1775 г. — к Великому Устюгу, Сольвычегодску и Яренску. То, что 3/4 всех примежеванных сельских поселений вошли в состав старых, а не новых городов можно интерпретировать как юридическое оформление в ходе Генерального межевания неких давних прочных связей между городами и их округой на момент его проведения.

В целом заметной взаимосвязи между количеством примежеванных объектов и тем, насколько давно существовал город, не наблюдается. Ненаселенные земли примежевывались к городу достаточно редко и, как правило, это были либо обособленные участки пашенной земли («полянки»), либо сенокосы (пожни). Но и в этих случаях большая часть таких земель была примежевана не к новообразованным городам, а к старым центрам - Великому Устюгу и Сольвычегодску.

Для дальнейшего анализа земельная статистика Экономических примечаний переводилась в электронную базу данных с последующей стати- 
стической обработкой и ГИС-картографированием на основе «Материалов для электронного атласа России XVII-XVIII вв.»².

Таблица 3.

Население и земли городов Вологодской губернии в конце XVIII в. ${ }^{23}$

\begin{tabular}{|c|c|c|c|c|c|c|c|c|}
\hline Город & $\begin{array}{l}\text { 䓂 } \\
\text { : } \\
\text { 兽 }\end{array}$ & 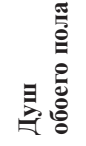 & 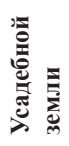 & 吾 & 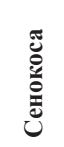 & 导 & 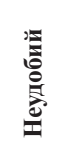 & 远 \\
\hline $\begin{array}{l}\text { Великий } \\
\text { Устюг }\end{array}$ & 1327 & 5084 & 117 & 68 & 77 & 701 & 364 & 1327 \\
\hline Вельск & 60 & 329 & 22 & 32 & 5 & 359 & 25 & 443 \\
\hline Вологда & 724 & 4585 & 501 & 0 & 601 & 672 & 247 & 2021 \\
\hline Грязовец & 226 & 824 & 42 & 192 & 16 & 1375 & 373 & 1998 \\
\hline Кадников & 199 & 1978 & 36 & 260 & 45 & 503 & 49 & 893 \\
\hline Красноборск & 95 & 304 & 3 & 3 & 0 & 0 & 3 & 9 \\
\hline Лальск & 194 & 1003 & 60 & 20 & 243 & 466 & 81 & 870 \\
\hline Никольск & 59 & 249 & 18 & 406 & 83 & 1996 & 138 & 2641 \\
\hline Сольвычегодск & 210 & 906 & 47 & 50 & 25 & 919 & 534 & 1575 \\
\hline Тотьма & 369 & 1977 & 45 & 0 & 252 & 0 & 31 & 328 \\
\hline Усть-Сысольск & 328 & 1679 & 549 & 847 & 1120 & 11525 & 800 & 14841 \\
\hline Яренск & 155 & 678 & 0 & 68 & 186 & 961 & 40 & 1255 \\
\hline
\end{tabular}

Все данные в табл. 3 являются суммой в рамках «общей градской межи». На показатель численности населения городов это практически не влияет (за исключением Никольска), поэтому приходится констатировать, что крупнейшим по населению городом губернии в конце XVIII в. была не Вологда, а Великий Устюг. Конечно, аномально огромный по меркам губернии пригородный земельный массив Усть-Сысольска в северо-восточном углу ее территории привлекает внимание, однако в целом карта показывает, что никакой ожидаемой тенденции нарастания площади пригородных земель от более освоенного юго-запада на восток не наблюдается (cм. puc. 2). В структуре земельных угодий городов региона преобладали леса, причем это справедливо как для районов старого освоения с высоким уровнем земледель-

${ }^{22}$ Хитров Д.А., Черненко Д.А., Голубинский А.А., Пахунов С.Н., Красиков А.Н., Жуков В.Д., Хацкевич М.В., Яфарова М.Р., Калинин М.В., Кулагина М.В. Материалы для электронного атласа России XVII-XVIII вв. (URL: http://www.hist.msu.ru/Departments/RusHis19/maps/ maps.html (Дата обращения 15.02.2021)).

${ }^{23}$ Все земельные угодья исчислены в десятинах. 

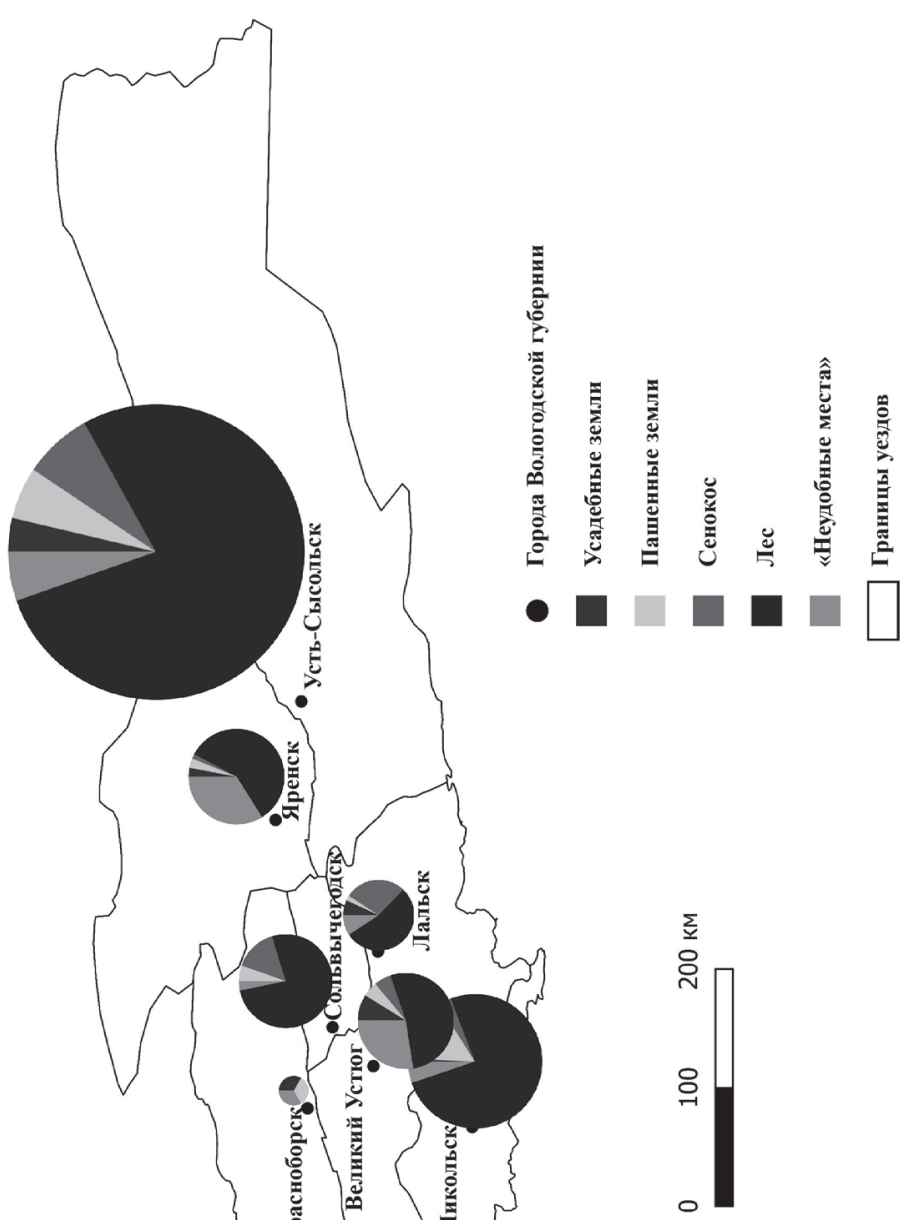

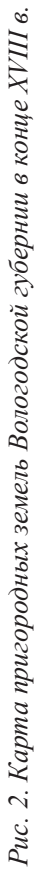


ческой колонизации (Грязовец, Кадников) так и для восточных районов, где крестьянское население было крайне редким, а сами города только что основаны (Усть-Сысольск). То, что количество примежеванного леса никак не связано с уровнем освоения территории подтверждается парадоксальным отсутствием примежеванных лесов у Тотьмы и Красноборска. Как уже говорилось, весь или почти весь пригородный лесной массив примежевывался непосредственно к городу как часть «градской выгонной земли», ясно показывает, что пригородные леса были необходимы именно горожанам, а не крестьянам близлежащих слобод и деревень. Этот лес был преимущественно дровяной - лишь в 3 городах из 12 имелся строевой лес. При этом упоминание медведей среди обитателей пригородных лесов в описаниях 6 городов (в том числе и Вологды), а волков - в описаниях 10 городов губернии показывает, что степень антропогенного воздействия на флору и фауну к концу XVIII в. оставалась довольно низкой даже на ближайшей территории рядом с городом.

Кто же выступал собственниками пригородных земель?

В тексте Экономических примечаний, как правило, почти никогда не указывается владельческая принадлежность «градской селидебной земли» (литерная дача А) и далеко не всегда указывается принадлежность «градской незаселенной выгонной земли» (литерная дача В). Известно два случая, когда владельческая принадлежность литерной дачи А все-таки указывается. Так, в Грязовце владельцами литерной дачи А показаны «купечество и мещане», а в Сольвычегодске совладельцами дачи А показаны барон Александр Николаевич Строганов и княгиня Варвара Александровна Шаховская.

Информация о владельцах пригородных земель содержится в описаниях 9 городов губернии из 12 применительно к 50 «литерным дачам». В 17 случаях владельцами земель показаны поименованные купцы. Одним из них выступал купец Степан Иванов Шубин, владевший крошечной полянкой Ямской рядом с Великим Устюгом площадью 1 дес. пашни. Остальные случаи очень показательны. Все они относятся к городу Усть-Сысольску, в котором 16 пригородными дачами владели представители одной купеческой семьи Сухановых, при этом большая часть этих владений были единоличными. Так, 6 дач принадлежали Афанасию Елисееву Суханову, 5 дач - Степану Григорьеву Суханову, 3 дачи - Ивану Петрову Суханову, 1 дача Михайле Петрову Суханову ${ }^{24}$, и 1 дача показана как совместное владение Ивана Петрова, Афанасия Елисеева Сухановых и мещанки Ульяны Григорьевой Сухановой. В целом семье Сухановых принадлежало 548 дес. земли.

\footnotetext{
${ }^{24}$ Показан как мещанин.
} 
Что это были за земли? Две дачи представляли собой фактически небольшие сельские поселения с 4 дворами, показанные, тем не менее, как «усадебные пустоши». Остальные дачи этой купеческой семьи представляли собой пожни, поэтому сенокосные угодья составляли половину всех земель данной фамилии.

В пяти случаях владельцами городских земель показаны «купечество и мещанство» четырех городов: Вельска, Великого Устюга, Грязовца и Тотьмы. Во всех случаях речь идет об указании владельцев городского выгона. Мещане практически не фигурируют как поименованные собственники пригородных земель региона. Исключение составляет только мещанская вдова Фекла Мостовская, владевшая полянкой рядом с Сольвычегодском.

Интересно, что Экономические примечания Генерального межевания в полной мере используют достаточно дробную классификацию городского населения, известную по «Жалованной грамоте городам», поэтому при описании Сольвычегодска отдельной категории владельцев городской земли (помимо купцов и мещан) являются посадские люди. Так, посадский человек Аникей Мезенцев владел небольшой дачей площадью 1 дес., на которой располагался его кирпичный завод, а неназванные посадские люди владели «писцовой полянкой» площадью 2 дес. Также рядом с Сольвычегодском показано коллективное совладение пяти посадских людей «дворовым местом»- небольшим поселением с 4 дворами и 2 дес. земли. В целом нам достоверно известно о том, что за различными группами городского сословия (купцы, мещане, посадские люди) было зафиксировано 1054 дес. пригородных земель Вологодской губернии (4\% от их общей площади).

Последствия секуляризации церковного землевладения выразились в том, что в Великом Устюге владельцами пригородных земель показаны экономические крестьяне («економическаго ведомства крестьяне»), которые до 1764 г. принадлежали Устюжскому архиерейскому дому, устюжскому Ивановскому монастырю, устюжскому Сретенскому собору и церквям Святых Жен мироносиц, Дмитрия Солунского и Сергия Радонежского. В результате в собственности Коллегии экономии здесь оказались не только маленькие участки пашни (полянки), но и сельские поселения (слобода, село и деревня). Также государство выступало собственником небольших участков пригородных земель в лице уездного казначейства трех городов: Лальска, Никольска и Яренска. В целом государственным ведомствам достоверно принадлежало 10 пригородных дач в 4 городах губернии общей площадью всего 160 дес.

Особняком стоит такая группа землевладельцев, как «крестьяне, записанные в мещанство» города Никольска. В состав «городской выгонной земли» 
Никольска были включены 4 деревни с населением 37 дворов и 245 человек, что составило более половины суммарного населения города на момент Генерального межевания (59 дворов).

Несмотря на секуляризацию церковного землевладения, крошечными участками пригородных земель продолжали владеть представители духовенства. В Великом Устюге архиерейскому дому и «священно- и церковнослужителям» принадлежали 3 дачи общей площадью 6 дес., а в Сольвычегодске 2 дачи общей площадью 22 дес. Дворянское землевладение в данном регионе практически отсутствовало, единственный его пример обусловлен чисто историческими обстоятельствами. Так, в описании Сольвычегодска в составе дачи А показаны уже упомянутые владения барона А.Н. Строганова и генерал-майорши княгини В.А. Шаховской.

Приходится констатировать, что в Экономических примечаниях не указаны владельцы большей части пригородных земель севернорусских городов. Так, не показаны владельцы пригородных дач общей площадью 21757 дес., что составляет $77 \%$ площади всех городских земель. Тем не менее можно предположить, что большая часть этих земель также принадлежала в первую очередь купцам и мещанам, поскольку 20792 дес. - это городские выгоны семи городов (Великий Устюг, Грязовец, Кадников, Лальск, Сольвычегодск, Усть-Сысольск, Яренск). В описаниях других городов земли этой категории, как правило, записаны именно за купцами и мещанами (Великий Устюг, Вельск, Никольск, Тотьма).

Подведем итоги. В Экономических примечаниях к Генеральному межеванию города Вологодской губернии описаны как земельные комплексы, относительно простые по структуре - в большинстве случаев они состояли из собственно городской застройки и городского выгона с редкими случаями включения в «общую градскую межу» небольших поселений или пустошей. За вычетом «аномальных» случаев, площадь этих комплексов, как правило, колебалась в интервале от нескольких сотен до 2-2,5 тыс. дес. земли. Большую часть этих земель составляли леса, включенные межевщиками в состав выгонных земель. Примеры городов с наиболее крупными земельными массивами показывают, что в северных городах важнейшим фактором количества зафиксированных в ходе Генерального межевания примежеванных к городу земель был не «административный возраст» города, а статус собственника пригородных земель (духовные вотчины, перешедшие в собственность Коллегии Экономии или исключительно влиятельная купеческая семья). При этом основным собственником этих земель выступали представители городского сословия: либо как городское сообщество в целом (применительно к крупным массивам выгонных земель), либо как индивидуальные 
владельцы или группы совладельцев отдельных небольших пригородных дач, преимущественно сенокосов или небольших пашенных участков.

\section{Литература}

Белов А.B. Реформа города Екатерины II (по материалам губерний Центральной России). М., 2019.

Водарский Я.Е. Исследования по истории русского города: Факты, обобщения, аспекты. М., 2006.

Города Российской империи в материалах Генерального межевания: Центральная Россия / Сост. Д.А. Черненко, А.А. Голубинский, Д.А. Хитров. Тула, 2016.

Каменский А.Б. Повседневность русских городских обывателей: исторические анекдоты из провинциальной жизни XVIII в. М., 2006.

Камкин А.В. Вологда 1780-х годов в воспоминаниях современников (А.А. Засецкий. Исторические и топографические известия; Экономические примечания к Генеральному межеванию) // Вологда: Историко-краеведческий альманах. Вологда, 1994. Вып. 1.

Козина Г.Н. Вологодские купцы - фабриканты и заводчики (XVIII - начало XX века)// Вологда: Историко-краеведческий альманах. Вологда, 1997. Вып. 2. C. $85-148$.

Козлова Н.В. Городская семья XVIII в.: Семейно-правовые акты купцов и разночинцев Москвы. М., 2002.

Козлова Н.В. Люди дряхлые, больные, убогие в Москве XVIII века. М., 2010.

Кошман Л.В. Город и городская жизнь в России XIX столетия. М., 2008. Куприянов А.И. Городская культура русской провинции (конец XVIII - первая половина XIX в.). М., 2007.

Милов Л.В. О так называемых «аграрных городах» России XVIII века// Вопросы истории. 1968. № 6. С. 54-64.

Миронов Б.Н. Русский город в 1740-1860 гг. Л., 1990.

Середа Н.В. Реформа управления Екатерины Второй. Источниковедческое исследование. М., 2004.

Черкасова М.С. Обывательские книги как источник для изучения купечества и торговли Вологды в конце XVIII - первой трети XIX в.// Торговля, купечество и таможенное дело России XVI-XIX вв.: Сборник материалов Второй международной конференции. Курск, 2009. С. 166-172.

Черкасова М.С. Севернорусский город в переходную эпоху от Средневековья к раннему Новому времени: К вопросу о типологии // Особенности российского исторического процесса: Сборник статей памяти акад. Л.В. Милова. М., 2008. С. 171-185.

Черненко Д.А., Хитров Д.А. Сведения материалов Генерального межевания о жилой городской застройке на Севере и Северо-Западе России в конце XVIII в. // Историческая информатика. 2019. № 4. С. 1-11.

Четырина Н.А. Сергиевский Посад в конце XVIII — начале XIX в. (Посад как тип городского поселения). М., 2006. 


\title{
С.В. Черников
}

\section{ФАМИЛЬНЫЙ СОСТАВ КАШИРСКОГО ДВОРЯНСТВА В ПЕРИОД І РЕВИЗИИ \\ (В СРАВНЕНИИ С ДЕСЯТНЯМИ И ПИСЦОВОЙ КНИГОЙ втоРой половины XVI в.) ${ }^{1}$}

\begin{abstract}
Аннотация Статья посвящена изучению изменений в родовом составе каширского дворянства второй половины XVI — начала XVIII в. Как показал анализ, открытость Каширского уезда для московских чинов, рост вотчин представителей правящей элиты и активная мобилизация земельной собственности не помешали укреплению позиций «коренных» каширских фамилий. Городовые дворяне, дослужившиеся до столичных чинов, могли приобретать поместья и вотчины в других уездах страны, но, тем не менее, сохраняли прочные связи со своим «родным» регионом. Даже к началу XVIII в. две трети вотчин и крепостных крестьян в Каширском уезде принадлежали фамилиям, владевшим здесь собственностью еще во второй половине XVI столетия. Ключевые слова: дворянство, землевладение, Каширский уезд, родовая структура.
\end{abstract}

Summary The article is devoted to the study of changes in the patrimonial structure of the Kashira nobility in the second half of the 16th — beginning of the 18th century. As the analysis shows, the openness of Kashira district for Moscow nobility, the growth of landed property of the ruling elite and active land holdings mobilization didn't prevent to strengthening of the positions of the «native» Kashira families. Kashirian nobles, who had risen to the Moscow ranks, could acquire estates in other district, but, nevertheless, retained strong ties with their «native» region. Even in the early 18 th century two thirds of estates and serfs in Kashira district belonged to the families, which had property there already in the second half of the 16th century.

Keywords: nobility, land ownership, Kashira district, patrimonial structure.

1 Исследование выполнено при финансовой поддержке РФФИ в рамках научного проекта № 19-09-00002 (a). 
В исторической литературе сложилось прочное и аргументированное мнение о высокой мобильности земельных владений российского дворянства $^{2}$. Как писал Г.А. Евреинов, «движение поземельной собственности в дворянской среде совершалось с такой быстротой, что редкое имение оставалось в том же роде более трех поколений» ${ }^{3}$. По расчетам Ю.В. Готье, в Замосковном крае в XVII в. во владении родственников спустя 50-60 лет оставалась лишь третья часть поместий и вотчин. Автор подчеркивал, что дворянин, постоянно занятый на службе, «не был особенно привязан» к своей собственности и «между ними не было связи, которая заставляла человека дорожить этим клочком земли, переходящим из поколения в поколение» ${ }^{4}$. Схожее мнение высказал А.В. Романович-Славатинский: «Служилые люди тянули к Москве, в поместьях своих они были временными гостями, пока воевода или царский гонец не потребует их на службу царскую» 5 .

Лишь в отдельных случаях исследователи приходили к выводу, что, несмотря на активную мобилизацию имений, родовой состав владельцев в том или ином уезде оставался относительно устойчивым. Так, В.М. Воробьев и А.Я. Дегтярев убедительно показали, что состав новгородского дворянства был весьма стабилен, а на протяжении XVII в. шло «постепенное, но настойчивое» восстановление родового владельческого состава последней четверти XVI столетия 6 . К схожим выводам на материалах Владимиро-Суздальского региона пришла В. Кивельсон. Она полагала, что, в отличие от Европы, российский дворянин ассоциировал себя не с дедовской или отцовской вотчиной, которую считал своим «домом», а со всем уездом (регионом), где находились его земли, с которых он вместе с други-

2 Карнович Е.П. Замечательные богатства частных лиц в России. СПб., 1874. С. 5; Рождественский C.B. Служилое землевладение в Московском государстве XVI века. СПб., 1897. C. 61-78, 211, 228-229; Рожков Н.A. Сельское хозяйство Московской Руси в XVI веке. М., 1899. С. 458-460; Веселовский С.Б. Феодальное землевладение в Северо-Восточной Руси. М.; Л., 1947. Т. 1. С. 50-55, 80-86, 165-202; Хитров Д.А. Хозяйственно-демографическое развитие Нечерноземного Центра России в XVII-XVIII вв. (на примере Дмитровского уезда): Дис. ... канд. ист. наук. М., 2003. С. 99-100; Черненко Д.А. Землевладение и хозяйственно-демографические процессы в Центральной России XVII-XVIII вв.: опыт региональной типологии. Вологда, 2008. С. 191; Черников С.В. Власть и собственность: особенности мобилизации земельных владений в Московском уезде в первой половине XVIII века // Cahiers du Monde russe. 2012. Vol. 53. № 1. Р. 150-151.

3 Евреинов Г.А. Прошлое и настоящее значение русского дворянства. СПб., 1898. С. 79.

4 Готье Ю.В. Замосковный край в XVII веке: опыт исследования по истории экономического быта Московской Руси. М., 1906. С. 415-422.

5 Романович-Славатинский А.В. Дворянство в России от начала XVIII века до отмены крепостного права. СПб., 1870. С. 166, 402.

${ }^{6}$ Воробьев В.М., Дегтярев А.Я. Русское феодальное землевладение от «Смутного времени» до кануна петровских реформ. Л., 1986. С. 125-128. 
ми служилыми людьми нес государеву службуㄱ. Как показало мое недавнее исследование, относительно высокая преемственность родового состава владельцев наблюдалась не только в Новгородско-Псковском, Владимиро-Суздальском, но и в Галичском, Костромском, Вологодском, Ярославском, Рязанском, Тульском регионах ${ }^{8}$.

Настоящая работа посвящена изучению изменений в родовом составе каширского дворянства во второй половине XVI — начале XVIII вв. Основными источниками для анализа послужили материалы I ревизии по Каширскому уезду, писцовая книга 1578/79 г., а также десятни 1556 г. и 1596-1599 гг. ${ }^{9}$

Для начала рассмотрим родовую структуру дворянской собственности в Каширском уезде по I ревизии. Так как выявление родственных связей среди всех владельцев не представляется возможным, в статье используется весьма распространенный в литературе компромиссный подход: однофамильцы рассматриваются как представители одного рода. В период I ревизии населенными имениями в уезде владели представители 327 дворянских фамилий. В общей сложности им принадлежало 1335 вотчин и 46752 души крепостных ${ }^{10}$.

В следующей таблице приведены сведения о распределении собственности по четырем группам фамилий в Каширском уезде и Европейской России в целом ${ }^{11}$. В первую группу включены роды, представители которых в XVII в., до начала правления Петра I, служили в думных чинах. Ко второй группе отнесены фамилии, чьи представители достигли московских чинов (стряпчих, дворян московских, стольников) до конца 1660-х гг, а к третьей группе - в 1670-1690-х гг. Деление «московских» фамилий на две группы обусловлено тем, что в последний период произошло резкое увеличение численности Государева двора, а родовой состав столичного дворянства сильно изменился. Остальные фамилии включены в IV группу. Представители

${ }^{7}$ Kivelson V. Autocracy in the Provinces: the Muscovite Gentry and Political Culture in the Seventeenth Century. Stanford, 1996. P. 58-100.

8 Черников С.В. К вопросу о «неукорененности» московского служилого класса: изменения в фамильном составе в уездах Европейской России в XVII - начале XVIII вв. // Cahiers du Monde russe. 2020. Vol. 61. № 1-2. Р. 7-62.

9 РГАДА. Ф. 248. Д. 1161. Л. 527 об.-587; Писцовые книги Московского государства / Под ред. Н.В. Калачова. Ч. 1. Отд. 2. СПб., 1877. С. 1299-1537; Каширская десятня 1556 г. // Heraldica: Исторический сборник. СПб., 1900. Т. 1. С. 28-44; Описание документов и бумаг, хранящихся в Московском архиве Министерства юстиции. Кн. 8. М., 1891. С. 144-165; Лихачев Н.П. Десятня новиков, поверстанных в 1596 году // Известия Русского генеалогического общества. СПб., 1909. Вып. 3. С. 154-156. См. также: Бенцианов М.М. Каширская десятня 1556 года: к вопросу о становлении служилого «города» в русском государстве // Studia Slavica et Balcanica Petropolitana. 2011. № 1. С. 201-214.

10 Здесь и далее численность крепостных указывается в душах мужского пола.

${ }^{11}$ Общероссийские данные заимствованы из: Черников С.В. К вопросу о «неукорененности» московского служилого класса... Р. 15. 
подавляющего большинства родов из этой группы служили только с «городом» и не имели даже низшего, жилецкого, московского чина.

Таблица 1.

Фамильный состав дворян-владельцев населенных имений по I ревизии

\begin{tabular}{|c|c|c|c|c|}
\hline \multirow{2}{*}{$\begin{array}{c}\text { Группа } \\
\text { фамилий }\end{array}$} & \multicolumn{2}{|c|}{ Каширский уезд } & \multicolumn{2}{|c|}{ Европейская Россия } \\
\hline & $\begin{array}{l}\text { число фамилий } \\
\text { (доля, \%) }\end{array}$ & $\begin{array}{c}\text { крестьян, тыс. душ } \\
\text { (доля, \%) }\end{array}$ & $\begin{array}{c}\text { доля фамилий } \\
\text { (\%) }\end{array}$ & $\begin{array}{c}\text { доля душ } \\
\text { (\%) }\end{array}$ \\
\hline I & $59(18)$ & $20(43)$ & 3 & 43 \\
\hline II & $134(41)$ & $19(40)$ & 15 & 32 \\
\hline III & $69(21)$ & $6(12)$ & 15 & 11 \\
\hline IV & $65(20)$ & $2(5)$ & 67 & 14 \\
\hline Всего & $327(100)$ & $47(100)$ & 100 & 100 \\
\hline
\end{tabular}

Каширский уезд располагался в центре Европейской России и, как видим, в сравнении с общей массой российских дворян каширское дворянство являлось более «родословным». В московских чинах служили представители 80\% каширских фамилий. Для сравнения, аналогичный показатель по всему дворянству составлял лишь 33\%. На долю фамилий из I-III групп в Каширском уезде приходилось 95\% крестьян, а в целом по стране - 86\%.

В начале XVIII в. среди дворян Каширского уезда наблюдался весьма высокий уровень имущественного неравенства: по моим расчетам, коэффициент Джини составлял $0,71^{12}$.

Таблица 2.

Родовая структура собственности в Каширском уезде по I ревизии

\begin{tabular}{|c|c|c|c|c|}
\hline \multirow{2}{*}{$\begin{array}{c}\text { Крепостных крестьян } \\
\text { (душ) }\end{array}$} & \multicolumn{2}{|c|}{ дворянских родов } & \multicolumn{2}{c|}{ у них крестьян, тыс. душ } \\
\cline { 2 - 5 } & абс. & доля (\%) & абс. & доля (\%) \\
\hline $1-20$ & 114 & 35 & 1 & 2 \\
\hline $21-100$ & 117 & 36 & 6 & 12 \\
\hline $101-250$ & 58 & 18 & 10 & 21 \\
\hline $251-500$ & 19 & 6 & 7 & 15 \\
\hline $501-1000$ & 11 & 3 & 9 & 18 \\
\hline более 1000 & 8 & 2 & 15 & 31 \\
\hline всего & 327 & 100 & 47 & 100 \\
\hline
\end{tabular}

${ }^{12}$ Коэффициент Джини изменяется от нуля, при абсолютно равном распределении имущества, до единицы, при концентрации всей собственности в одних руках. 
Как видим из табл. 2, численность крепостных у 71\% дворянских фамилий не превышала 100 душ, а суммарно этим родам принадлежало лишь 14\% крестьян. С другой стороны, в руках представителей восьми фамилий (2\%) концентрировалась почти треть собственности (31\%). Это Нарышкины (5135 душ), Головкины (2245), Павловы (1550), Лихаревы (1207), Хотяинцовы (1203), Ильины (1143), Писаревы (1141) и Бибиковы (1088). Самым крупным вотчинником Каширского уезда в этот период являлся двоюродный брат Петра I, сын боярина Л.К. Нарышкина Александр Львович. В Соломенской волости, где располагались одноименные металлургические заводы, ему принадлежало 4584 души крестьян ${ }^{13}$. Значительными имениями обладали канцлер гр. Гаврила Иванович Головкин (Липецкая и Яковлевская волости, 2177 душ), вице-канцлер бар. Петр Павлович Шафиров (Жерновская волость, 825 душ) и сын ближнего стольника И.Р. Стрешнева Василий Иванович (с. Мокрое с деревнями в Растовском стане, 656 душ). Среди землевладельцев уезда мы также видим ближнего кравчего К.А. Нарышкина, стряпчего с ключом П.Б. Сумарокова, генерала от инфантерии А.И. Головина, капитана флота и будущего шаутбенахта И.А. Сенявина, генерал-поручика И.И. Бутурлина, действительного тайного советника кн. Г.Ф. Долгорукова, генерал-майоров П.И. Ягужинского, М.А. Матюшкина, кн. А.И. и Г.С. Волконских, генерал-аудитора И.В. Кикина, лейб-гвардии майора В.Д. Корчмина и ряд других влиятельных лиц.

Однако, несмотря на наличие имений, принадлежавших царским приближенным, и большое число новых родов, появившихся в XVII начале XVIII в., владельческий облик уезда во многом определяли те дворянские фамилии, которые были связаны с каширской землей еще до Смутного времени. В следующей таблице показано, сколько родов, из числа владевших имениями по I ревизии, встречается в материалах по Каширскому уезду второй половины XVI в., и какая доля собственности принадлежала этим фамилиям к началу XVIII столетия. Сразу заметим, что помимо представителей каширского служилого «города», состав которого отразился в десятнях, на территории уезда поместьями и вотчинами владели «иногородние» и московские дворяне, поэтому табличные показатели, относящиеся к писцовой книге, выше, чем аналогичные по десятням ${ }^{14}$.

${ }^{13}$ Юркин И.Н. Каширские заводы // Большая российская энциклопедия (URL: https:// bigenc.ru/domestic_history/text/2054600).

${ }^{14}$ Каширская десятня 1596 г. не имеет окончания. 
Таблица 3.

Сравнение родового состава дворян Каширского уезда по I ревизии с данными второй половины XVI в.

\begin{tabular}{|c|c|c|c|}
\hline & \multirow{2}{*}{$\begin{array}{c}\text { Дворянских } \\
\text { родов } \\
\text { (доля, \%) }\end{array}$} & \multicolumn{2}{|c|}{ За ними по I ревизии } \\
\hline & & $\begin{array}{l}\text { владений } \\
\text { (доля, \%) }\end{array}$ & $\begin{array}{r}\text { крестьян, } \\
\text { тыс. душ } \\
\text { (доля, \%) }\end{array}$ \\
\hline по I ревизии в уезде & 327 & 1335 & 47 \\
\hline найдено в десятне 1556 г. & $83(25)$ & $668(50)$ & $20(42)$ \\
\hline найдено в десятнях 1596-1599 гг. & $67(20)$ & $695(52)$ & $20(42)$ \\
\hline найдено в писцовой книге 1578/79 г. & $110(34)$ & $880(66)$ & $29(63)$ \\
\hline всего найдено в десятнях и писцовой книге & $123(38)$ & $910(68)$ & $30(65)$ \\
\hline
\end{tabular}

Как видим, в начале XVIII в. к числу «старых» каширских родов, связанных с уездом службой или земельными отношениями со второй половины XVI в., относились 123 фамилии (38\%). Владельческие позиции этих родов были весьма прочными: по I ревизии им принадлежало примерно две трети вотчин (68\%) и помещичьих крестьян (65\%). Отмечу, что к началу XVIII в. представители 103 из 123 «старых» каширских фамилий (84\%) уже служили в московских чинах ${ }^{15}$. Следовательно, пожалование представителей верхушки служилого «города» столичными чинами не вело к разрыву связей новоиспеченных жильцов или дворян московских со своим «родным» регионом.

Относительно высокая устойчивость родового состава дворян Каширского уезда объяснялась тем, что, в отличие от районов к западу от Москвы, он избежал разорения во время Смуты. Также важно, что в 1560-1570-х гг. Каширский, как и ряд других южных пограничных уездов, не входил в состав «государева удела» и, вследствие этого, в меньшей степени, нежели опричные, пострадал от переселений землевладельцев. По подсчетам А.П. Павлова, за период опричнины в земском Каширском уезде фамильный состав дворянства изменился менее чем на $30 \%{ }^{16}$.

15 Данные о фамильном составе московского дворянства, включая жильцов, в начале XVIII в. см.: Захаров A.B. База данных «Боярские списки XVIII века» (URL: http://zaharov.csu. ru/bspisok.pl).

16 Зимин А.А. Опричнина. М., 2001. С. 170-171, 193-194; Павлов А.П. Земельные переселения в годы опричнины: к вопросу о практической реализации указа об опричнине 1665 г. // История СССР. 1990. № 5. С. 98; Корзинин А.Л. Государев двор в доопричный период (1550-1565 гг.). Дис. ... д-ра ист. наук. В 2 т. СПб., 2016. С. 358; Корзинин А.Л. Земщина // Большая российская энциклопедия (URL: https://bigenc.ru/domestic_history/text/2877947). 
Выделим роды, которые ко времени I ревизии были наиболее прочно связаны с Каширским уездом. Обратим внимание на число вотчин, принадлежавших представителям фамилий. Очевидно, что значительное число имений, приходившихся на один род - это следствие устойчивого роста дворянских семейств, длительной, на протяжении нескольких поколений, практики наследования и дробления имений между родственниками, а также приобретения новых поместий и вотчин, включая «прииск» и освоение «порозжих» земель. Из числа «старых» самые устойчивые связи с уездом к началу XVIII в. имели 27 фамилий: Писаревы (47 вотчин), Хотяинцовы (45), Лихаревы (41), Павловы (40), Ильины (33), Сонины (27), Иевские, Скорняковы-Писаревы (по 25), Грековы (22), Хрущовы (21), Бакеевы, Бибиковы (по 19), Каверины (18), кн. Мещерские, Сонцовы, Фустовы (по 17), Колтовские (14), Рудневы (13), Дуровы, Темирязевы, Уваровы (по 12), Барыковы, Кропотовы, Тепловы, Фофановы, Хвощинские (по 11) и Хмыровы (10). Представители 24 из этих 27 фамилий (89\%) служили в составе каширской «городовой» корпорации во второй половине XVI столетия. Среди новых фамилий, появившихся в Каширском уезде в XVII в., десять и более владений по I ревизии было лишь у Григоровых (21 вотчина) и кн. Волконских (17).

Заметим, что относительно высокая устойчивость родового состава дворянства в целом по уезду, как и прочность владельческих позиций «старых» фамилий, сочетались с традиционной для России активной мобилизацией собственности. Сохранение поместий и вотчин в руках представителей одного рода на протяжении 140-150 лет было редким явлением. Для примера рассмотрим размещение имений у некоторых из перечисленных фамилий. Так, согласно писцовой книге 1578/79 г., за представителями рода Писаревых числились жеребьи в 20 населенных пунктах (2 села, 6 селец, 11 деревень, 1 починок). Ко времени проведения І ревизии Писаревы, включая ветви Скорняковых и Иванчиных, сохранили имения в восьми из них (40\%): селе Злобино, сельцах Наумовском и Белугино, деревнях Беляевой, Новоселках, Верхнее Корыстово, Руднево и Семенково. В общей сложности, Писаревым в начале XVIII в. принадлежало 76 вотчин в 48 населенных пунктах: 9 селах, 3 сельцах и 36 деревнях (см. карту в приложении $\left.{ }^{17}\right)$. Не менее значительные перемены произошли с собственностью Хотяинцовых. Во второй половине XVI в. они владели жеребьями в 24 населенных пунктах

${ }^{17}$ Для локализации населенных пунктов использовались планы Генерального межевания Тульской губернии (http://www.etomesto.ru/map-tula_pgm/) и Каширского уезда (Государственный архив Тульской области. Ф. 291. Оп. 7a/40. Д. 5б). Благодарю Д.А. Хитрова за возможность воспользоваться копией этой карты. 
(3 села, 2 сельца, 19 деревень). К началу XVIII в. имения за представителями рода сохранились лишь в пяти из них (21\%): селах Малаховском и Нечаево Манагарово тож, деревнях Бровкиной, Овечкиной и Санинской. Всего в это время Хотяинцовым принадлежало 45 вотчин в 23 населенных пунктах: 5 селах, 1 сельце и 17 деревнях. Схожие изменения в географии землевладения мы видим и у Лихаревых. По писцовой книге за ними числились жеребьи в 19 населенных пунктах (6 сел, 1 сельцо, 10 деревень, 1 починок, 1 слободка). К І ревизии представители этой фамилии сохранили вотчины только в пяти из них (26\%): селах Грабченки и Ягодное, сельце Лунево, деревнях Чеусовой и Конюшне. В общей сложности, по I ревизии Лихаревы владели 41 вотчиной в 28 населенных пунктах Каширского уезда: 10 селах, 2 сельцах и 16 деревнях. О причинах приобретения или утраты каждого конкретного имения мы можем лишь догадываться, но нельзя исключить, что целью мобилизации многих из перечисленных владений являлась концентрация семейной и родовой собственности в группе близлежащих селений (на что, на примере Владимиро-Суздальского региона, обращала внимание В. Кивельсон ${ }^{18}$ ). Как можно заметить на карте, ко времени I ревизии большинство вотчин Писаревых и Лихаревых были сосредоточены в центральной части Каширского уезда (в Растовском стане), а у Хотяинцовых - в западной (в Мстиславском, Беспуцком и Тешиловском станах).

Подведем итоги. Как показал анализ, открытость Каширского уезда для московских чинов, рост вотчин представителей правящей элиты и активная мобилизация земельной собственности не помешали укреплению позиций «коренных» каширских фамилий. Городовые дворяне, дослужившиеся до столичных чинов, могли приобретать поместья и вотчины в других уездах страны, но, тем не менее, сохраняли прочные связи со своим «родным» регионом. Даже к началу XVIII в. две трети вотчин и крепостных крестьян в Каширском уезде принадлежали фамилиям, владевшим здесь собственностью еще во второй половине XVI столетия.

${ }^{18}$ Kivelson V. Autocracy in the Provinces ... P. 92-97. 


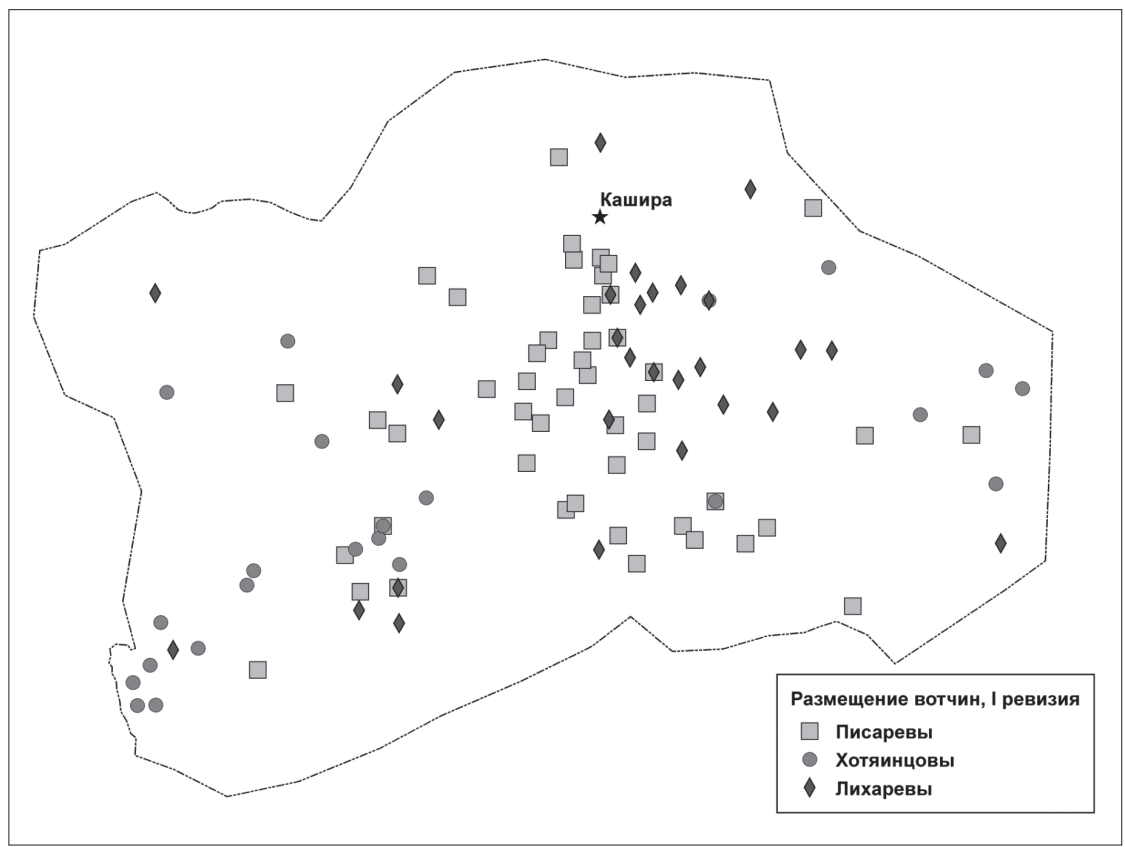

\section{Литература}

Бенцианов М.М. Каширская десятня 1556 года: к вопросу о становлении служилого «города» в русском государстве // Studia Slavica et Balcanica Petropolitana. 2011. № 1. С. 201-214.

Веселовский С.Б. Феодальное землевладение в Северо-Восточной Руси. М.; Л., 1947. T. 1.

Воробьев В.М., Дегтярев А.Я. Русское феодальное землевладение от «Смутного времени» до кануна петровских реформ. Л., 1986.

Готье Ю.В. Замосковный край в XVII веке: опыт исследования по истории экономического быта Московской Руси. М., 1906.

Евреинов Г.А. Прошлое и настоящее значение русского дворянства. СПб., 1898.

Захаров А.В. База данных «Боярские списки XVIII века» (URL: http://zaharov.csu.ru/ bspisok.pl).

Зимин А.А. Опричнина. М., 2001.

Карнович Е.П. Замечательные богатства частных лиц в России. СПб., 1874.

Каширская десятня 1556 г.//Heraldica: Исторический сборник. СПб., 1900. Т. 1. C. $28-44$.

Корзинин А.Л. Государев двор в доопричный период (1550-1565 гг.): Дис. ... д-ра ист. наук. В 2 т. СПб., 2016. 
Корзинин А.Л. Земщина // Большая российская энциклопедия (URL: https://bigenc. ru/domestic_history/text/2877947).

Лихачев Н.П. Десятня новиков, поверстанных в 1596 году // Известия Русского генеалогического общества. СПб., 1909. Вып. 3.

Описание документов и бумаг, хранящихся в Московском архиве Министерства юстиции. М., 1891. Кн. 8.

Павлов А.П. Земельные переселения в годы опричнины: к вопросу о практической реализации указа об опричнине 1665 г. // История СССР. 1990. № 5.

Писцовые книги Московского государства/Под ред. Н.В. Калачова. СПб., 1877. Ч. 1. Отд. 2. С. 1299-1537.

Рождественский C.B. Служилое землевладение в Московском государстве XVI века. СПб., 1897.

Рожков Н.А. Сельское хозяйство Московской Руси в XVI веке. М., 1899.

Романович-Славатинский А.В. Дворянство в России от начала XVIII века до отмены крепостного права. СПб., 1870.

Хитров Д.А. Хозяйственно-демографическое развитие Нечерноземного Центра России в XVII-XVIII вв. (на примере Дмитровского уезда): Дис. ... канд. ист. наук. М., 2003.

Черненко Д.А. Землевладение и хозяйственно-демографические процессы в Центральной России XVII-XVIII вв.: опыт региональной типологии. Вологда, 2008.

Черников C.B. Власть и собственность: особенности мобилизации земельных владений в Московском уезде в первой половине XVIII века//Cahiers du Monde russe. 2012. Vol. 53. № 1.

Черников C.B. К вопросу о «неукорененности» московского служилого класса: изменения в фамильном составе в уездах Европейской России в XVII - начале XVIII вв. // Cahiers du Monde russe. 2020. Vol. 61. № 1-2. Р. 7-62.

Юркин И.Н. Каширские заводы // Большая российская энциклопедия (URL: https:// bigenc.ru/domestic_history/text/2054600).

Kivelson $V$. Autocracy in the Provinces: the Muscovite Gentry and Political Culture in the Seventeenth Century. Stanford, 1996. 


\title{
И.Н. Шамина
}

\section{СОЦИАЛЬНЫЙ ПОРТРЕТ МОНАШЕСТВУЮЩИХ КОЛОМЕНСКОЙ ЕПАРХИИ В КОНЦЕ XVII — НАЧАЛЕ XVIII В.}

\begin{abstract}
Аннотация В статье на основе переписных книг монастырей Коломенской епархии 1701-1702 гг. проведено изучение социального состава монашествующих 12 обителей, входивших в состав епархии на рубеже XVII и XVIII вв. Рассмотрены вопросы о времени и месте пострига монахов, проанализированы данные о социальном статусе их семей и месте проживания до поступления в монастырь, занятиях и др.

Ключевые слова: Коломенская епархия, монастырские переписные книги, социальный состав монашествующих.

Summary Based on the census books of the monasteries of the Kolomna diocese of 1701-1702, the article examines the social composition of the monks of 12 monasteries that were part of the diocese at the turn of the XVII and XVIII centuries. Questions about the time and place of the monks' vows are considered, data on the social status of their families and the place of residence before entering the monastery, classes, etc. are analyzed.

Keywords: Kolomna diocese, monastic census books, social composition of the monks.
\end{abstract}

Православные монастыри на протяжении всей истории Русского государства играли существенную роль. Они являлись не только крупными вотчинниками, но и центрами культуры, велико было их социальное значение. И.К. Смолич установил, что к 1724 г. в Российском государстве насчитывалось 14534 монаха и 10673 монахини ${ }^{1}$. Несмотря на то что в структуре общества XVII-XVIII в. это была весьма существенная по численности группа населения, вопрос о том, представители каких сословий чаще всего и в связи с чем стремились уйти в монастыри, до сих пор относится к числу малоизученных.

1 Смолич И.К. Русское монашество, 988-1917. Жизнь и учение старцев. М., 1999. С. 563. 
О социальном и географическом происхождении монахов XVII столетия в историографии имеются лишь отдельные упоминания, касающиеся прежде всего уникальных в этом отношении обителей. Так, о московском Андреевском, «что во Пленницех», монастыре, основанном Ф.М. Ртищевым, известно, что там, наряду с русскими, селились монахи из украинских, белорусских, литовских и других православных монастырей ${ }^{2}$ О происхождении пострижеников Воскресенского Новоиерусалимского монастыря со ссылкой на патриаршего келейника Ивана Шушерина упомянула В.С. Румянцева: «В Воскресенском монастыре... в то время пребываху даже многие иноземцы греки и поляки, черкасы и белорусцы, и новокрещенные немцы и жиды» ${ }^{3}$, а в Иверский на Валдае монастырь в 1655 г. были переведены более 70 монахов из упраздненного белорусского Кутеинского оршанского монастыря 4 и др. Анализ отдельных сторон социального происхождения насельников вологодских монастырей XVII-XVIII вв. был предпринят составителями издания «Переписные книги вологодских монастырей XVI-XVIII вв.» ${ }^{5}$.

Несколько более изучен вопрос о социальном составе монашествующих XVIII столетия. Так, некоторые обобщающие наблюдения о ситуации, сложившейся в это время, сделала Е.Б. Емченко. По ее мнению, в XVIII в. социальный состав монашествующих мужчин и женщин различался, что во многом объяснялось государственной политикой по отношению к монашеству. В мужских монастырях было традиционно много выходцев из духовного сословия, в то время как в женских, располагавшихся, как правило, в городах или вблизи них, преобладали представительницы дворянского, купеческого и мещанского сословий ${ }^{6}$.

Социальный и гендерный состав монашествующих на примере Урала и Перми проанализировала Е.В. Кустова. Используя в первую очередь данные ведомостей 1724 г., она выяснила, что «особенностью Приуралья было фактическое отсутствие среди братии представителей дворянства

2 Румянцева В.С., Даниленко В., прот. Андреевский монастырь в Пленницах // Православная энциклопедия. М., 2001. Т. 2. С. 350.

3 Румянцева В.C. Монастыри и монашество в XVII веке // Монашество и монастыри в России. XI-XX века: Исторические очерки. М., 2002. С. 176.

4 Жервэ Н.Н. Валдайский Святоозерский в честь Иверской иконы Божией Матери мужской монастырь // Православная энциклопедия. М., 2003. Т. 6. С. 615.

5 Башнин Н.В., Черкасова М.С., Шамина И.Н. Описи вологодских монастырей как источник по аграрной и демографической истории // Переписные книги вологодских монастырей XVI-XVIII вв.: исследование и тексты / Изд. подгот. О.Н. Адаменко, Н.В. Башнин, М.С. Черкасова при участии А.П. Анишиной, Н.А. Бараевой, Е.А. Виноградовой, А.Н. Красикова, С.Н. Смольникова, И.Н. Шаминой. Вологда, 2011. С. 439-444.

${ }^{6}$ Емченко Е.Б. Женские монастыри в России // Монашество и монастыри в России. XI-XX века: Исторические очерки. М., 2002. С. 265-266. 
и боярства», «лутчие люди» «предпочитали принимать постриг в достаточно обеспеченных городских монастырях, благотворителями которых обычно являлись». Исследовательница пришла к выводу о в целом демократичном социальном составе монастырей изучаемого ею региона, включавшем все группы населения ${ }^{7}$. Особенности монашества Среднего Урала в синодальный период рассмотрела М.Ю. Нечаева. Она установила, что в 1722-1724 гг. больше половины монастырских насельников региона принадлежали к крестьянству, 18\% были горожанам, 7\% - выходцами из приходского духовенства, 4\% - представителями служилых сословий. В то же время в Вятской епархии 78\% монахов составляли жители городов, а в далматовских обителях Зауралья преобладали иноки из служилых людей ${ }^{8}$.

В целом же вопрос о социальном происхождении монашествующих в конце XVII - начале XVIII в. остается малоизученным. Важным источником, позволяющим осветить эту проблему, являются монастырские переписные книги. Несмотря на активное их изучение и публикацию в последние годы ${ }^{9}$, переписные книги как источник по социальному происхождению монахов

7 Kустова Е.В. Монастыри и монашество в социокультурной истории Приуралья в середине XVI - первой четверти XVIII в. Дис. ... д-ра ист. наук. Киров, 2017. Т. 2.

${ }_{8}$ Нечаева М.Ю. Монашество Среднего Урала синодального периода: принципы формирования и социальный состав. Екатеринбург, 2019. С. 30, 31.

9 См. например: Отписная книга Введенского Корнильево-Комельского монастыря переписи В.Г. Данилова-Домнина, составленная при передаче монастыря игумену Рафаилу и келарю Александру 2 декабря 1657 г. / Публ. Ю.С. Васильева // Городок на Московской дороге: Историко-краеведческий сборник. Вологда, 1994. С. 130-169; Дмитриева 3.В. Вытные и описные книги Кирилло-Белозерского монастыря XVI-XVII вв. СПб., 2003; Описи Соловецкого монастыря XVI в.: Комментированное издание / Сост. З.В. Дмитриева, Е.В. Крушельницкая, М.И. Мильчик, отв. ред М.И. Мильчик. СПб., 2003; Опись строений и имущества Кирилло-Белозерского монастыря 1601 года: Комментированное издание // Сост. 3.В. Дмитриева, М.А. Шаромазов. СПб., 1998; Опись строений и имущества Кирилло-Новоезерского монастыря 1657 г. / Публ. Т.В. Сазоновой // Белозерье. Краеведческий альманах. Вып. 2. Вологда, 1998. С. 130-165; Соколова Н.В. Описание церковно-монастырских владений в процессе секуляризации начала XVIII в.: Опыт реконструкции (на материалах Нижегородского уезда)// Северо-Запад в аграрной истории России: Межвузовский тематический сборник научных трудов. Калининград, 2008; Шамина И.Н. Преподобный Иннокентий Комельский и основанный им монастырь // Вестник церковной истории. 2009. № 1/2(13/14). С. 26-99; Шамина И.Н. Опись имущества вологодского Павлова Обнорского монастыря 1701-1702 годов // Вестник церковной истории. 2010. № 1/2(17/18). С. 17-107; Переписные книги вологодских монастырей XVI-XVIII вв...; Шамина И.Н. Документы по истории Григориева Пельшемского монастыря XVII - начала XVIII в. // Вестник церковной истории. 2011. № 3/4(23/24). С. 30-63; Башнин Н.В. Опись имущества и строений Дионисиева Глушицкого монастыря 1701 г. и переписные книги вотчины Дионисиева Глушицкого монастыря 1702 г. // Вестник церковной истории. 2013. № 3/4(31/32). С. 138-177; Шамина И.Н. Переписные книги коломенских Спасо-Преображенского, Голутвина, Бобренева и Брусенского монастырей 1701 г. // Вестник церковной истории. 2017. № 3/4(47/48). С. 96-226; Шамина И.Н. Переписная книга вологодского Спасо-Нуромского монастыря и его вотчины 1701-1702 гг. // Вестник церковной истории. 2020. № 1/2(57/58). С. 5-37; и др. 
российских монастырей остаются недооцененными. Между тем в них содержится подчас уникальная информация по интересующей нас теме.

В настоящей статье предпринята попытка охарактеризовать состав монашествующих Коломенской епархии на рубеже XVII и XVIII вв. по переписным монастырским книгам 1701-1702 гг. Описание монастырей Российского государства в 1701-1703 гг. ${ }^{10}$ проводилось по инициативе правительства Петра I в связи с передачей дел воссозданному в 1701 г. Монастырскому приказу. Вместе с монастырями описывались также архиерейские дома и приходские церкви. Перепись начала XVIII в. являлась одним из этапов практической реализации церковной реформы, направленной на частичную секуляризацию церковно-монастырского землевладения и хозяйства. Дошедшие до наших дней переписные книги 1701-1703 гг. хранятся преимущественно в фонде Монастырского приказа (РГАДА, ф. 237).

Историки неоднократно обращались к материалам этого описания. В частности, Е.Н. Швейковская изучала переписные книги Вологодского архиерейского дома и Спасо-Прилуцкого монастыря. Она отметила, что в ходе переписи начала XVIII в. «учету подлежали вся церковная утварь, одежда, книги, казна, а также акты, на основании которых монастырь или архиепископский дом владел своими землями и деревнями. Основной упор при переписи делался на выяснение всех статей дохода в церковной вотчине» ${ }^{11}$.

Коломенская епархия была учреждена в середине XIV в. В ее состав входили земли центральных и южных уездов страны. К середине XVII в. это, как писал Павел Алеппский, была «беднейшая из всех архиерейских кафедр в стране Московской» ${ }^{12}$. К концу XVII в. ее земли располагались в ряде центральных и южных уездов государства - Коломенском, Каширском, Тульском, Орловском, Крапивенском и др.

Составление переписных книг монастырей Коломенской епархии, как и большинства других регионов Российского государства, проходило в 1701-1702 гг. Сохранившиеся описания вошли в книгу 58 (РГАДА, ф. 237, оп. 1, ч. 1). В это время в составе епархии находились 12 обителей (9 мужских и 3 женских), однако их переписные книги составляли разные переписчики. Коломенские Спасо-Преображенский, Голутвин, Бобренев, Бру-

${ }^{10}$ И.А. Булыгин датирует описание 1701-1705 гг. (Бульгин И.А. Монастырские крестьяне России в первой четверти XVIII в. М., 1977. С. 35).

${ }^{11}$ Бакланова [Швейковская] E.Н. Крестьянский двор и община на Русском Севере. Конец XVII - начало XVIII в. М., 1976. С. 52.

${ }^{12}$ Павел Алеппский. Путешествие антиохийского патриарха Макария в Россию в половине XVII века, описанное его сыном, архидиаконом Павлом Алеппским / Пер. Г.А. Муркос. M., 2005. C. 226-227. 
сенский, тульские Иоанно-Предтеченский и Успенский монастыри, а также каширские Соколову, Саввину (Березину) и Николаевскую на Гнилуше в Коломенском уезде пустыни наряду с Коломенским архиерейским домом описывал стольник Иван Васильевич Кикин (1660-1723 гг.); орловские Введенский и Успенский монастыри, а также Троицкий монастырь в Крапивне - стольник Михаил Толубеев.

Следует заметить, что переписные книги российских монастырей 17011703 гг. по содержанию несколько отличаются друг от друга. Видимо, единого строгого формуляра не существовало, и объем информации по тому или иному пункту описания устанавливал сам переписчик. Это относится, в частности, и к разделу о монахах. Так, стольник В.И. Кошелев, составлявший переписные книги вологодских монастырей, перечисляя монахов указывал их имена, род занятий и место жительства до пострига, место принятия иноческого сана и должность в монастыре ${ }^{13}$. Многие переписчики, как, например, служки Троице-Сергиева монастыря, описывавшие приписные к Троице Белопесоцкий и Алатырский монастыри, перечислили имена монахов, упустив другие сведения о них ${ }^{14}$. Стольник же В.Р. Воейков, направленный в Углич и Угличский уезд, зафиксировал лишь имена настоятелей и назвал число остальных насельников ${ }^{15}$.

Описания же части монастырей Коломенской епархии (расположенных в Коломне, Туле, а также Коломенском и Каширском уездах), составленные И.В. Кикиным, в этом смысле наиболее подробны. В частности, в каждом случае стольник привел не только имена монахов, но также время и место их пострига, сведения о семье и месте проживания, занятиях или социальном статусе до поступления в монастырь. Из описаний можно узнать о переходе монахов из других монастырей, о женщинах есть указания на то, были ли они до прихода в монастырь замужем или постриглись незамужними.

В то же время переписные книги других монастырей Коломенской епархии - орловских и крапивенского, - составленные Михаилом Толубеевым, более краткие. Информация о монахах, как и в отмеченных выше приписных обителях Троице-Сергиева монастыря, включает лишь их имена.

\footnotetext{
${ }^{13}$ См., например, переписные книги Спасо-Каменного и сямженского Спасо-Евфимиева монастыря (Переписные книги вологодских монастырей... С. 154-155, 251), Павлова Обнорского (Шамина И.Н. Опись имущества вологодского Павлова Обнорского монастыря... С. 85-88) и др.

${ }^{14}$ РГАДА. Ф. 237. Оп. 1. Ч. 1. Кн. 40. Л. 430-430 об.; Алатырский Троицкий мужской монастырь. Документы 1612-1703 годов / Сост. В.Д. Кочетков, А.А. Чибис. Ульяновск, 2015. C. $328-329$.

${ }^{15}$ Углич: материалы для истории города XVII и XVIII столетий. М., 1887. С. 176 и др.
} 
Следовательно, в центре внимания настоящей статьи будут находиться в первую очередь монастыри Коломны, Тулы, а также Коломенского и Каширского уездов.

Переписные книги монастырей Коломенской епархии 1701-1702 гг. позволяют в первую очередь установить численность пострижеников. Наиболее населенным в эти годы был орловский женский Введенский монастырь, в нем перечислена 41 монахиня. К числу крупных можно отнести также тульские Успенский женский (40 монахинь) и Иоанно-Предтеченский мужской (36 монахов) монастыри. Чуть меньше монахов жило в коломенских Голутвине (28) и Брусенском женском (26) монастырях, а также в Успенском монастыре Орловского уезда (20). Численность монашествующих в остальных обителях составляла от 15 человек в Троицком крапивенском и 12 в коломенском Спасо-Преображенском до 8 человек в коломенском Бобреневе монастырях. В Николаевской пустыни на реке Гнилуше на момент описания проживали 7 пострижеников, в каширской Саввине пустыни указан лишь один строитель, а каширская Соколова пустынь к началу XVIII в. и вовсе осталась без насельников: «В тои-де пустыне строителей и монахов нет прошлаго 1701-го году с марта месяца» ${ }^{16}$.

В целом в начале XVIII в. монастырях Коломенской епархии жили 234 постриженика. Среди них 107 человек (около 46\%) составляли женщины. Как видим, численность монахинь и монахов была примерно одинаковой, в то время как женские монастыри оказались более населенными, чем мужские. К подобному выводу пришла и Е.Б. Емченко, касаясь более позднего периода. Она показала, что женские монастыри, «будучи более многочисленными, чем мужские... были крайне бедными и получали дотацию от государства» ${ }^{17}$. В переписных книгах монастырей Коломенской епархии должности, выполняемые монахами в обители, не указаны. Отмечены только настоятели, казначеи, иеромонахи и иеродиаконы, названы имена рядовых монахов. В женских монастырях постриженицы делятся на монахинь и схимонахинь. В ряде случаев лиц, занимавших некоторые монастырские должности, можно установить по отдельным упоминаниям или по скрепам. Так, например, в описании коломенских Спасо-Преображенского и Голутвина монастыря упоминаются конюшенные и житенные старцы.

Из содержания переписных книг следует, что подавляющее большинство монахов (88\%) приняли постриг в том монастыре, где находились на момент составления описания.

${ }^{16}$ РГАДА. Ф. 237. ОП. 1. Ч. 1. Кн. 58. Л. 435 об.

${ }^{17}$ Емченко Е.Б. Женские монастыри в России. С. 258-259. 
Таблица 1.

Место пострига монахов Коломенской епархии

\begin{tabular}{|c|c|c|c|}
\hline Монастыри & Всего монахов & $\begin{array}{c}\text { Постриглись в том же } \\
\text { монастыре }\end{array}$ & $\begin{array}{c}\text { Постриглись в других } \\
\text { монастырях }\end{array}$ \\
\hline Успенский & $40(100 \%)$ & $37(92,5 \%)$ & $3(7,5 \%)$ \\
\hline Иоанно-Предтеченский & $36(100 \%)$ & $34(94 \%)$ & $2(6 \%)$ \\
\hline Богоявленский Голутвин & $28(100 \%)$ & $22(79 \%)$ & $6(21 \%)$ \\
\hline Брусенский & $26(100 \%)$ & $25(96 \%)$ & $2(4 \%)$ \\
\hline Спасо-Преображенский & $12(100 \%)$ & $10(83 \%)$ & $2(25 \%)$ \\
\hline Бобренев & $8(100 \%)$ & $6(75 \%)$ & $2(29 \%)$ \\
\hline Николаевская пустынь & $7(100 \%)$ & $5(71 \%)$ & $1(100 \%)$ \\
\hline Саввина пустынь & $1(100 \%)$ & - & $19 \%)$ \\
\hline Всего по монастырям & $158(100 \%)$ & $139(88 \%)$ & \\
\hline епархии & & & \\
\hline
\end{tabular}

Число монахов, перешедших из других обителей, независимо от размера монастыря, - не более двух человек. Исключение составляет лишь Голутвин монастырь, где таких пострижеников оказалось в три раза больше. В большинстве случаев перешедшими из других обителей отмечены настоятели.

B XVI в. в соответствии с монастырскими уставами настоятелей избирали сами монахи, затем их кандидатуру утверждал епархиальный архиерей. Однако в XVII в. настоятели стали назначаться архиереем. Об этом прямо говорится в переписной книге Саввиной пустыни Каширского уезда: строитель Паисий «пострижен в Троицком Белопесоцком монастыре, а в тои-де Савиной пустыни по архиерейскому указу живет он третей год» ${ }^{18}$.

Игумен тульского Иоанно-Предтеченского монастыря Корнилий начал свой монашеский путь в 1661 г. в коломенском Голутвине монастыре, после чего был назначен игуменом в Троицкий монастырь в Кромах (по крайней мере до середины XVII в. Кромы входили в состав Коломенской епархии ${ }^{19}$ ) и спустя два года, в начале 1670-х гг, возглавил Предтеченский монастырь ${ }^{20}$. Однако, видимо, управлял он этим монастырем с перерывом. Некоторое время, до 1701 г., игуменом Предтеченского монастыря был Сильвестр - будущий настоятель коломенского Бобренева монастыря: «А он, Силивестр... пострижен на Туле в Предтечеве монастыре тому десять лет и в том монастыре был игуменом. А в Бобренев монастырь переведен ис того Предтечева

${ }^{18}$ РГАДА. Ф. 237. Оп. 1. Ч. 1. Кн. 58. Л. 425.

${ }^{19}$ Печников М.В., Пидгайко В.Г. Коломенская епархия // Православная энциклопедия. М., 2014. T. 36. C. $390-398$.

${ }^{20}$ РГАДА. Ф. 237. Оп. 1. Ч. 1. Кн. 58. Л. 537. 
монастыря в нынешнем 1701-м году в феврале месеце» ${ }^{21}$. Получается, что после него Корнилий вступил в должность настоятеля повторно. В справочнике П.М. Строева игумен Сильвестр не упоминается.

Игумен Голутвина монастыря Иов принял постриг в коломенском Спасо-Преображенском монастыре, был настоятелем в каширском Троицком Белопесоцком монастыре. В архиве последнего в начале XVIII в. хранилась составленная им роспись: «А по той росписи довелось взять Белопесоцкого монастыря вотчин на крестьянех казенных доимочных денег дватцать семь рублев с полтиною» ${ }^{22}$. В 1700 г. Троицкий Белопесоцкий монастырь был приписан к Троице-Сергиеву монастырю. Возможно, это событие и послужило причиной того, что игумена Иова перевели в Голутвин.

Перемещение настоятелей из одного монастыря в другой во второй половине XVII - начале XVIII в. в целом по стране было достаточно распространенным явлением. На примере же рассматриваемых монастырей мы видим, что перевод настоятелей в эти годы совершался лишь в рамках конкретной епархии.

Иную картину наблюдаем при анализе перемещений монахов. Так, монах коломенского Спасо-Преображенского монастыря Авраамий принял иноческий сан в московском Покровском монастыре, «что на убогих доме», и спустя примерно 17 лет перешел в коломенский Спасо-Преображенский монастырь. Монах Пафнутий постригся в Бундурове монастыре ${ }^{23}$, жил в каширской Саввиной пустыни и в Спасо-Преображенский монастырь перешел незадолго до начала его описания.

Монах Матфей пришел в Голутвин монастырь из Болдыревой пустыни Луховского уезда, монах Аввакум - из Липновской пустыни Курского уезда. Последний, судя по всему, в начале 1670-х гг. бывал в Голутвине монастыре, поскольку, как следует из переписной книги, в 1671/72 г. «по указу великого государя из Голутвина монастыря ис козначейства отдан Белоградцкому митрополиту, а у нево был у приказных дел» ${ }^{24}$. С 1699 г. он вновь поселился в Голутвине монастыре. Подавляющее большинство насельниц женских монастырей также приняли постриг в стенах своей обители. Исключение составляют лишь схимонахиня Брусенского монастыря Ефросиния, о которой сказано, что она «пострижена лет 3 дватцеть, а в Брусенском монастыре живет четвертой год», и трое монахинь

${ }^{21}$ Шамина И.Н. Переписные книги коломенских монастырей... С. 206.

22 РГАДА. Ф. 237. ОП. 1. Ч. 1. Кн. 40. Л. 435.

${ }^{23}$ Возможно, имеется в виду Благовещенский Бунырев монастырь, основанный около 1623 г. в 6 км от Алексина и в 52 км от Тулы на берегах рек Вашана и Ока. В 1764 г. упразднен.

${ }^{24}$ Шамина И.Н. Переписные книги коломенских монастырей... С. 52. 
тульской Успенской обители, пришедшие из московского Зачатьевского монастыря.

Наиболее известной личностью, отмеченной в переписной книге Голутвина монастыря как пришедший извне, оказался бывший строитель московского Андреевского монастыря, «что во Пленницех», Авраамий. Старец Авраамий известен как автор «Тетрадей», адресованных Петру I. Он жил в Андреевском монастыре еще при его основателе Ф.М. Ртищеве. «Тетради» старца Авраамия - это, по сути, челобитная о «государственном нестроении», виновником которого он объявил царя. В 1696 г. Авраамий попытался передать свое сочинение Петру I, а в 1697 г. в Преображенском приказе началось следствие. В результате Авраамий был сослан в Голутвин монастырь «под начал». Уже находясь в Голутвине, в 1701 г. Авраамий отправил Петру I новое письмо, в котором просил забрать его к Москве. После этого следствие возобновилось ${ }^{25}$. По мнению В.С. Румянцевой и протоиерея Б. Даниленко, старец Авраамий попал в опалу и был сослан в Коломну за участие в тайном кружке молодых подьячих, действовавшем в Андреевском монастыре в первой половине $1690-$ х гг. ${ }^{26}$

Прямых указаний на причины смены монастыря другими монахами, кроме монаха Авраамия, в переписных книгах нет. В одном случае, правда, можно предположить, чем могло быть вызвано такое перемещение. Так, о монахе Спасо-Преображенского монастыря Коломны Пафнутии сказано, что он прибыл из каширской Саввиной пустыни и живет в коломенском монастыре «третей год». Так же, «третей год» по указу архиепископа Саввиной пустынью управлял строитель Паисий, назначенный туда по архиерейскому указу ${ }^{27}$. Возможно, по архиерейскому указу, по причине старости или болезни, оттуда был переведен в Спасо-Преображенский монастырь и Пафнутий, а на смену ему назначен Паисий.

Таким образом, перемещения монахов из монастыря в монастырь были редкими, однако не ограничивались пределами одной епархии. Монахи могли переводиться «под начал» в другие монастыри в качестве наказания или по решению архиерея. Возможно, причиной перехода служили и личные мотивы.

Еще один ряд данных, содержащихся в переписных книгах 17011702 гг. - место жительства монашествующих до их пострига. Этот вопрос

${ }^{25}$ Панченко А.М. Авраамий // Словарь книжников и книжности Древней Руси. Вып. 3 (XVII в.). Ч. 1 / Отв. ред. Д.С. Лихачев. СПб., 1992. С. 34-36.

${ }^{26}$ Румянцева В.С., Даниленко Б., прот. Андреевский монастырь в Пленницах // Православная энциклопедия. Т. 2. С. 350.

${ }^{27}$ РГАДА. Ф. 237. Оп. 1. Ч. 1. Кн. 58. Л. 425. 
затрагивала, в частности, Е.В. Кустова, отметив в пермских монастырях высокий процент выходцев из других земель. По мнению исследовательницы, это могло быть связано «с большой активностью сибирского пути и широкой крестьянской колонизацией региона» ${ }^{28}$. Далее в таблицах приводится информация о том, откуда прибыли постриженики монастырей Тулы и Коломны. Расстояние в 400 км использовано в таблице как условная граница относительно близких и дальних к тому или иному монастырю территорий, поскольку в XVII в. путь в 400 км преодолевался достаточно часто и на это уходило примерно 10 дней ${ }^{29}$. Очевидно, что из более дальних мест люди перемещались значительно реже.

Таблица 2.

Место жительства до пострига монахов тульских Иоанно-Предтеченского и Успенского монастырей

\begin{tabular}{|c|c|c|c|c|c|c|}
\hline \multirow[t]{2}{*}{ Регион } & \multicolumn{2}{|c|}{$\begin{array}{c}\text { Иоанно-Предтеченский } \\
\text { монастырь }\end{array}$} & \multicolumn{2}{|c|}{$\begin{array}{c}\text { Успенский женский } \\
\text { монастырь }\end{array}$} & \multicolumn{2}{|c|}{ Всего по Туле } \\
\hline & всего & $\%$ & всего & $\%$ & всего & $\%$ \\
\hline Тула & 9 & 25 & 5 & 12,5 & 14 & 18,4 \\
\hline Тульский уезд & 3 & 8,5 & 3 & 7,5 & 6 & 7,9 \\
\hline $\begin{array}{l}\text { Ближайшие к Тульскому } \\
\text { уезду районы }\end{array}$ & 10 & 28 & 10 & 25 & 20 & 26,3 \\
\hline $\begin{array}{l}\text { Российские города } \\
\text { и уезды, находящиеся } \\
\text { на расстоянии до } 400 \text { км } \\
\text { от Тулы }\end{array}$ & 3 & 8,5 & 2 & 5 & 6 & 7,9 \\
\hline $\begin{array}{l}\text { Российские города } \\
\text { и уезды, находящиеся } \\
\text { на расстоянии свыше } \\
400 \text { км от Тулы }\end{array}$ & 5 & 13,8 & 2 & 5 & 6 & 7,9 \\
\hline $\begin{array}{l}\text { Литовские, польские, } \\
\text { малороссийские города } \\
\text { и уезды }\end{array}$ & 4 & 11 & 1 & 2,5 & 5 & 6,6 \\
\hline Крым & & & 1 & 2,5 & 1 & 1,3 \\
\hline Неизвестно & 2 & 5 & 16 & 40 & 18 & 23,7 \\
\hline Всего монахов & 36 & 100 & 40 & 100 & 76 & 100 \\
\hline
\end{tabular}

В тульском Иоанно-Предтеченском монастыре, как видим из таблицы, большинство монахов происходили из Тулы и ближайших к ней городов

${ }^{28}$ Кустова Е.В. Монастыри и монашество... Т. 2. С. 15.

${ }^{29}$ См.: Башнин H.B. К вопросу о транспортных путях и средствах передвижения в XVII в. (по материалам приходо-расходных книг Вологодского архиерейского дома // Вестник церковной истории. 2018. № 3/4(51/52). С. 303. 
и уездов (Венев, Кашира, Крапивна, Дедилов, Богородицк и др.). Интересно, что здесь жили и выходцы из дальних уездов. В частности, игумен Корнилий был уроженцем Смоленска, но пришел в Тулу из Коломны, где принял постриг в Голутвине монастыре. Казначей Иосиф пришел из Вологды. Он был сыном посадского человека Мефодия Богданова. Оттуда же, из Вологды, пришел в Тулу монах Сафоний, «Николаевскаго Озерскаго монастыря слушкин сын». Монах Иосиф пришел из Ржевы Володимировой, монах Иов - из Смоленского уезда.

Большой интерес представляет группа монахов (5 человек), указавших местом своего рождения Литву или Малороссию. Так, монах Никон сказал, что пришел из «малороссийского Смелого города». Предположительно, это местечко Смела, располагавшееся неподалеку от Киева, на почтовой дороге в Черкасы ${ }^{30}$. Монах Боголеп пришел в Предтеченский монастырь из Вильны, Матфей - сын шляхтича Хриштофа Разнотовского - из «литовского города Лиды» (город в западной части современной Белоруссии, в составе Гродненской области); монах Мисаил — из деревни Гришино вблизи польского населенного пункта Мигновичи (современная Смоленская область).

В переписной книге тульского Успенского женского монастыря местожительство до пострига можно примерно установить лишь для 24 насельниц. Большинство из них, как и в тульском Предтеченском монастыре, прибыли из ближайших к Туле уездов. Среди других городов указаны Москва, Коломна, Ярославль, Чернский и Костромской уезды. Для схимонахини Софии место ее жительства до пострига обозначено как «Черкасские города», монахиня Марфа ранее жила в Крыму, затем попала в плен и позднее оказалась в тульском Успенском монастыре (см. табл. 3).

Большинство пострижеников коломенского Голутвина монастыря пришли из регионов, расположенных на расстоянии до 400 км от монастыря (Москва, Венев, Тверь, Кромский, Костромской, Нижнеломовский уезды и др.). Около трети составляли жители Коломны и Коломенского уезда. В 5 случаях из 28 установить место жительства монахов до поступления в монастырь не удалось. Еще одно из мест жительства можно предположительно установить из сообщения о месте пострига. Так, упоминавшийся выше монах Аввакум принял монашеский сан в Липновской пустыни Курского уезда ${ }^{31}$. Возможно, там, в Курском уезде, и жила его семья. Местом мирского служения монаха Савватия указано село Чиркино Коломенского

\footnotetext{
${ }^{30}$ См.: Похилевич Л.И. Сказания о населенных местностях Киевской губернии, или Статистические исторические и церковные заметки о всех деревнях, селах, местечках и городах, в пределах губернии находящихся. Киев, 1864. С. 643.

${ }^{31}$ Шамина И.Н. Переписные книги коломенских монастырей... С. 155-156.
} 


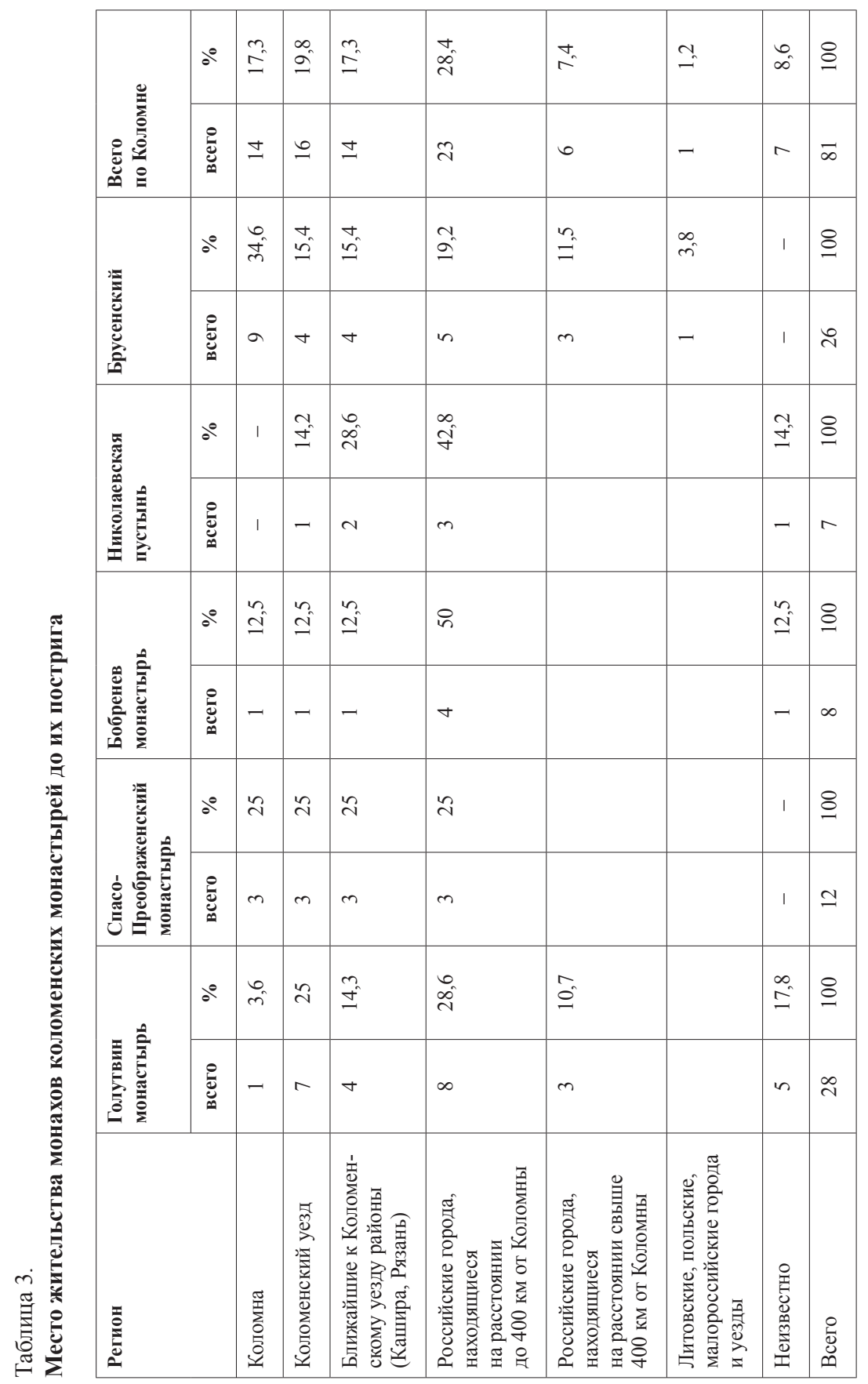


уезда, однако принял постриг он в Тверском Отроче монастыре, где был монастырским слугой его отец, и лишь спустя несколько лет перешел в Голутвин ${ }^{32}$.

В Спасо-Преображенском монастыре одинаковое число монахов поступило из четырех групп территорий. В Бобреневе монастыре большинство монахов (половина от их общего числа) происходили из регионов, находящихся на расстоянии до 400 км от монастыря. В качестве предыдущих их мест жительства указаны Тула, Орел, Орловский и Веневский уезды. О монахе Никите, чье место жительства до пострига в переписной книге не указано, можно предположительно установить из краткой записи о его отце: «Васильев сын курченин». В Николаевскую пустынь на реке Гнилуше желающие принять постриг приходили из Каширского, Алексинского, Суздальского уездов, а также из Каширы и города Михайлова (Рязанский уезд).

В женский Брусенский монастырь, в отличие от мужских обителей города, постриглись в первую очередь жительницы Коломны. Значительная доля принадлежит также выходцам из других российских регионов - Каширы, Москвы, Коломенского уезда, Углича, Нижнего Новгорода, Суздаля, Костромы и др.

В целом же получается, что наибольшее число пострижеников коломенских монастырей происходили из других российских городов, в то время как из Коломны и Коломенского уезда, несмотря на их очевидную близость, монахов поступало меньше.

Переписные книги могут дать ответ и на вопрос, кем были родители пострижеников; часто названы их имена. В ряде случаев, если речь идет о мужских монастырях, также известно, чем занимались до пострига сами монахи. К сожалению, такая информация есть не по каждому человеку, но все же источник позволяет представить социальное происхождение монахов Коломенской епархии в целом. Поскольку данные по мужским и женским монастырям несколько различаются, эти категории будут рассмотрены отдельно.

В тульском Иоанно-Предтеченском монастыре только о четверых монахах известно, кем они были до пострига. Так, иеромонах Авраамий и монах Арсений служили один в Пятницкой церкви села Коптева Тульского уезда, другой — в Никитской церкви Тулы. Монах Митрофан был крестьянином, а монах Антоний «служил по жилецкому списку». Гораздо подробнее информация о родителях монахов. Такие сведения есть о большинстве из них. 10 человек происходили из семей священнослужителей, шестеро

\footnotetext{
${ }^{32}$ Там же. С. 154-155.
} 
были выходцами из крестьян, трое - из семей посадских людей, двое из семей монастырских слуг. В качестве родителей монахов указаны также «торговый человек», солдаты рейтарского строя, городовой тульский дворянин Фома Терентьев Козлов, казак, сын боярский Андрей Брежнев, городовой сын боярский Стефан Кропотов, засечный сторож и др. В одном случае происхождение монаха осталось неизвестным: «Симонов сын, а чей прозванием и какова чину, того сказал не упомнит». Известно лишь, что он прибыл в Тулу из Вильны ${ }^{33}$. Не смог назвать имени своего отца и монах Сафоний, прибывший в Тулу из Вологды. Он был сыном слуги Николаевского Озерского монастыря, однако «как-де отца ево звали, того не помнит, остался в малых летех» ${ }^{34}$. Точно так же, еще ребенком, был взят в монастырь монах Иев: «Из Смоленского уезду взят с малых лет, а с коих мест, того сказать не упомнит» ${ }^{35}$.

Род занятий до поступления в монастырь среди голутвинских пострижеников по переписной книге можно установить для 26 человек. Почти половина из них (12) в миру были священнослужителями, 7 человек служили в домах различных владельцев (у Анны Яковлевны Колтовской, «коломнятина» Никиты Порвоснева у московского истопника И. Спиридонова, в вотчине Белопесоцкого монастыря и др.). Трое монахов до пострига были крестьянами. Указаны также бывшие «приказу Дохтурова пятисотной» и кузнец Оружейной палаты. Монах Сергий до пострига жил в Москве и «кормился черной работой».

Большинство монахов Голутвина монастыря наследовали род занятий своих родителей — становились священнослужителями, работниками в домах помещиков или при монастырях. К выводу о наследственной закрепляемости статуса духовенства, на основе анализа ведомостей устюжских церквей 1720-х гг. пришла и М.С. Черкасова ${ }^{36}$. Однако известны исключения. Так, например, иеромонах Иоасаф был сыном подьячего Московского Судного приказа. Вначале он тоже стал чиновником - подьячим в Коломенской приказной избе, но затем был «ис подьячих посвящен в попы» ${ }^{37}$. Иеромонах Иона - сын посадского человека из Балахны - стал священником в церкви свт. Николая Чудотворца в селе Щира Кромского уезда.

${ }^{33}$ РГАДА. Ф. 237. ОП. 1. Ч. 1. Кн. 58. Л. 541.

${ }^{34}$ Там же. Л. 540 об.

${ }^{35}$ Там же. Л. 539.

36 Черкасова М.С. Демография духовенства Устюжской епархии по данным первой ревизии 1720-1724 гг. // Церковь. Богословие. История: Материалы VII Всероссийской научно-богословской конференции, посвященной 100-летию мученической кончины святых Царственных страстотерпцев и их верных спутников. Екатеринбург, 2019. С. 314-320.

${ }^{37}$ Шамина И.Н. Переписные книги коломенских монастырей... С. 154. 
Монах Ефрем, будучи сыном жителя Тулы, служил священником в селе Шкиня Коломенского уезда и др.

В Спасо-Преображенском монастыре шесть человек до пострига были священнослужителями, двое - крестьянами, один - жителем посада Коломны. Из семей священнослужителей происходила половина пострижеников. 5 из них сами являлись в миру священнослужителями. Один из бывших священников - иеромонах Родион - вышел из семьи коломенского посадского человека. Для двоих монахов Бобренева монастыря установить род занятий в миру по переписной книге не удалось. Пятеро из остальных пострижеников в миру были священнослужителями, один «служил во дворе столника князь Алексея княж Михайлова сына Каркодинова». Монахи - бывшие священнослужители за исключением игумена Сильвестра были детьми священников. Игумен же происходил из семьи «служиваго кормового человека Иоакимова сына Михайлова».

Служили до пострига священниками и трое монахов Николаевской пустыни на Гнилуше, один — «сказал церковнаго дьячка сын» (это единственный случай в этой обители, когда известно об отце постриженика). Монах Ефимий был солдатом, монах Павел «послуживцем Дмитрия Иванова сына Полуехтова». Один из монахов до пострига был крестьянином.

В приведенной ниже сводной таблице в первую очередь учитывается информация о роде деятельности самих монахов. Если таковая отсутствует, принимается во внимание социальное положение его семьи (см. табл. 4).

Таким образом, большинство монахов до пострига были священниками и/или происходили из семей священнослужителей. Служба в церкви являлась наследственной. У родителей-священнослужителей дети, как правило, также становились священниками или диаконами. Существенную долю составляли крестьяне, а также слуги дворян. Достаточно часто в монастыре оказывались представители служилого сословия. Остальные категории населения были представлены в монастырях в меньшей степени. Интересно, что в городских по большей части монастырях оказалось незначительное число жителей посада.

В переписных книгах женских Брусенского и тульского Успенского монастырей информация о занятиях пострижениц в миру является исключением. Как правило, известны только имена отцов и мужей. Если женщина до пострига была замужем, указывались имена и отца, и мужа. Если женщина поступала в монастырь девицей, очевидно, указывался только отец. Так, у 9 монахинь (22,5\%) Успенского монастыря указаны только имена отцов. Для некоторых из них есть уточнение: «пострижена в монастырь девицею». В Брусенском монастыре в 17 случаях из 26 (65\%) известны все эти данные. 


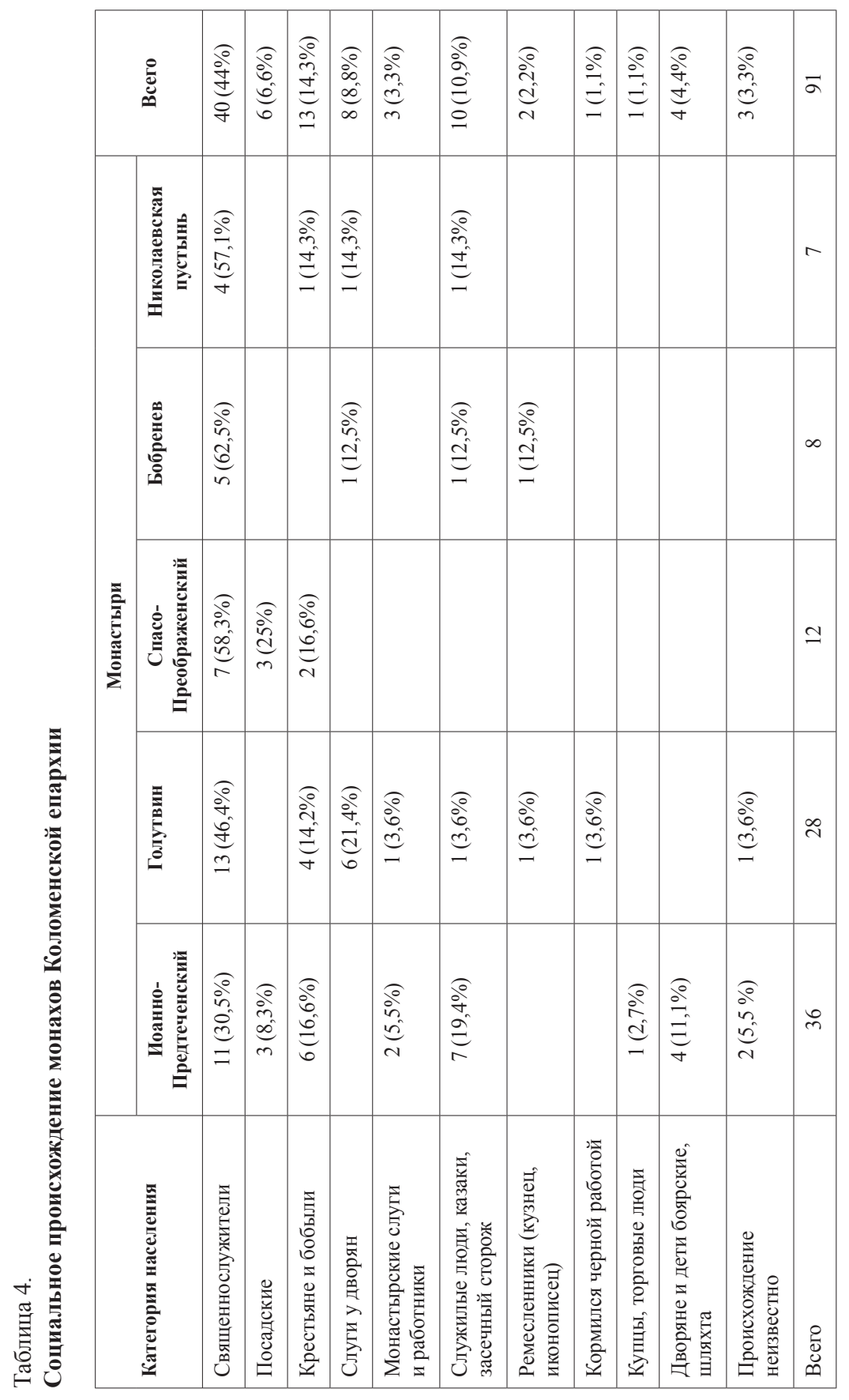


В остальных - только имя отца (мужа) и место их жительства. В Успенском монастыре эти характеристики есть для 9 монахинь (30\% из 30 постриженных замужних). В 5 случаях (16\% из 30) указано, кем были отцы, но неизвестен род деятельности супругов. В почти трети $(31,8 \%)$ случаев в двух монастырях в целом род деятельности родителей или супругов установить не удалось: в переписных книгах сказаны лишь их имена и есть косвенное указание на место, где они жили («углеченин», «коширенин», «туленин»). В приведенной ниже таблице приоритетными считаются данные о занятиях мужей. Если таковых не было, то берутся в расчет сведения о родителях.

Таблица 5.

Социальное происхождение монахинь в монастырях Коломенской епархии

\begin{tabular}{|l|c|c|c|}
\hline & Брусенский монастырь & Успенский монастырь & Всего \\
\hline Посадские & $1(3,8 \%)$ & $3(7,5 \%)$ & $4(6,1 \%)$ \\
\hline чиновники & $3(11,5 \%)$ & & $3(4,5 \%)$ \\
\hline священники & $9(34,6 \%)$ & $3(7,5 \%)$ & $12(18,2 \%)$ \\
\hline крестьяне & $3(11,5 \%)$ & $6(15 \%)$ & $9(13,6 \%)$ \\
\hline $\begin{array}{l}\text { Монастырские } \\
\text { слуги }\end{array}$ & $1(3,8 \%)$ & & $1(1,5 \%)$ \\
\hline $\begin{array}{l}\text { Служилые } \\
\text { люди (пушкарь, } \\
\text { засечный сторож) }\end{array}$ & $2(7,7 \%)$ & $9(22,5 \%)$ & $3(4,5 \%)$ \\
\hline Дворяне, шляхта & $1(3,8 \%)$ & $2(5 \%)$ & $2(3,1 \%)$ \\
\hline $\begin{array}{l}\text { Полонянка, } \\
\text { послуживица }\end{array}$ & $6(23,1 \%)$ & $15(37,5 \%)$ & $21(31,8 \%)$ \\
\hline Неизвестно & 26 & 40 & 66 \\
\hline Всего & & & $2(5 \%)$ \\
\hline
\end{tabular}

Видим, что, как и в мужских монастырях, большинство монахинь также происходили из семей священнослужителей. Так, например, в Брусенском монастыре семь монахинь из 17 вышли из семей, где священнослужителями были отец и муж. Еще в двух случаях служил в церкви лишь один из них. Так, монахиня Евдокия была дочерью священника коломенской соборной церкви, а вышла замуж за подьячего приказа Холопьего суда ${ }^{38}$.

Однако велика доля и тех, чьими мужьями или отцами были служилые люди. В источниках называются рейтары, стрельцы, пушкари, казаки и др. Особенно много женщин из таких семей оказалось в тульском Успенском монастыре.

\footnotetext{
${ }^{38}$ Там же. С. 221.
} 
Трое женщин из обоих монастырей принадлежали к привилегированному сословию. Так, схимонахиня Брусенского монастыря Таисия была дочерью шляхтича «Луцкого города» Якова Берташевича. Монахиня Успенского монастыря Агрипена, родившись в крестьянской семье в Тульском уезде, вышла замуж за своего господина — «Заупского стану того ж помещика Герасимовская жена Трифонова ${ }^{39}$. Монахиня того же монастыря Ираида приходилась дочерью князю Федору Засекину, а замуж вышла за некоего Никиту Палицына. Схимонахиня София, попавшая в Тулу из «Черкасских городов», сообщила, что «отца своего не помнит». Не указаны и родственники крымской полонянки монахини Марфы. Но о последней сказано, что она была «послуживицей Авакума Иевлева».

Возраст монахов в переписных книгах не указан, но можно установить, как давно они приняли иноческий сан и живут в данном монастыре. В некоторых случаях дата пострига написана, в других ее можно установить, исходя из записей: «в монастыре тому три года», «пострижен в том монастыре нынешняго году», «пострижен тому другой год» и т. д. В приведенной ниже таблице время, прошедшее после пострига, условно разделено на несколько периодов: от 0 до 4 лет, от 5 до 10 лет, от 11 до 15 лет, более 15 лет.

Таблица 6.

Срок нахождения монахов в монастыре

\begin{tabular}{|l|c|c|c|c|c|c|}
\hline \multicolumn{1}{|c|}{ Монастырь } & $0-4$ года & $5-10$ лет & $11-15$ лет & $\begin{array}{c}\text { Более } 15 \\
\text { лет }\end{array}$ & $\begin{array}{c}\text { Время } \\
\text { пострига } \\
\text { неизвестно }\end{array}$ & Всего \\
\hline Успенский & $15(37,5 \%)$ & $1(27,5 \%)$ & $7(17,5 \%)$ & $5(12,5 \%)$ & - & 40 \\
\hline $\begin{array}{l}\text { Иоанно- } \\
\text { Предтеченский }\end{array}$ & $7(19,4 \%)$ & $9(25 \%)$ & $7(19,4 \%)$ & $13(36,1 \%)$ & & 36 \\
\hline Голутвин & $3(10,7 \%)$ & $10(35,7 \%)$ & $7(25 \%)$ & $7(25 \%)$ & $1(3,5 \%)$ & 28 \\
\hline Брусенский & $11(42,3 \%)$ & $9(34,6 \%)$ & $2(7,7 \%)$ & $4(15,4 \%)$ & - & 26 \\
\hline $\begin{array}{l}\text { Ппасо- } \\
\text { Преображенский }\end{array}$ & $1(8,3 \%)$ & $3(25 \%)$ & $3(25 \%)$ & $5(41,7 \%)$ & & 12 \\
\hline Бобренев & $2(25 \%)$ & $3(37,5 \%)$ & $3(37,5 \%)$ & - & - & 8 \\
\hline $\begin{array}{l}\text { Николаевская } \\
\text { пустынь }\end{array}$ & $1(14,3 \%)$ & $5(71,4 \%)$ & $1(14,3 \%)$ & - & - & 7 \\
\hline
\end{tabular}

Видим, что основной состав монахов тульского Иоанно-Предтеченского монастыря сформировался к началу 1690-х гг., но и в последующие годы

${ }^{39}$ РГАДА. Ф. 237. Оп. 1. Ч. 1. Л. 596. 
число монахов относительно равномерно увеличивалось. В Голутвине монастыре больше всего постригов пришлось на 1690-е гг., в Спасо-Преображенском - на 1680-е и ранее. Наибольший «стаж» монашества в последнем - почти 50 лет - имели Макарий и Авраамий. Оба были пострижены в 1653/54 г. и, очевидно, на момент составления переписной книги находились в довольно преклонных годах. В Николаевской Гнилушской пустыни основной состав монашествующих так же, как в Голутвине, сформировался в 1690-х гг. Тогда приняли постриг 5 человек. В 1695 г. в обитель пришел новый настоятель - строитель Тихон, ранее возглавлявший Соколову пустынь в Каширском уезде. Возможно, с этим связано появление в обители большого числа новых насельников. Женские Брусенский и Успенский монастыри также наиболее активно начали заселяться в 1690-е гг. Почти половина монахинь Брусенского монастыря пришла сюда после 1695 г. В Успенском монастыре основная масса насельниц постриглась в последние 10 лет (26 человек, 65\%).

Исследование показало, что социальный портрет монахов Коломенской епархии отличался от той картины, которую, например, можно видеть по материалам монастырей Вологодской епархии, где основная масса пострижеников происходила из крестьянской среды. Так, в Павлове Обнорском монастыре доля крестьян среди монахов составляла 70\% (42 человека из 60$)^{40}$, в Спасо-Нуромском — 92\% (11 из 12 человек) ${ }^{41}$. По подсчетам О.Н. Адаменко, в вологодском Спасо-Каменном монастыре «абсолютное большинство приказных монахов происходило из крестьянских семей близлежащих светских вотчин и своей монастырской вотчины» ${ }^{42}$. Е. В. Кустова, изучив монастыри Приуралья, также пришла к выводу об абсолютном преобладании среди монашествующих региона представителей податных сословий - крестьян и посадских. Причем, по ее мнению, преобладание выходцев из крестьянства в монашестве являлось общей тенденцией того времени ${ }^{43}$.

Если большинство монастырей Русского Севера и Приуралья являлись сельскими, то в Коломенской епархии насчитывалось всего 3 обители, расположенных за пределами городов, две из которых практически запустели. По крайней мере до второй половины XVII в. в состав епархии входил

${ }^{40}$ Шамина И.Н. Опись имущества вологодского Павлова Обнорского монастыря.... C. $85-88$.

${ }^{41}$ Шамина И.Н. Переписная книга вологодского Спасо-Нуромского монастыря... С. 22.

${ }^{42}$ Адаменко О.Н. Монашество Вологодского Заозерья в XVII - начале XVIII в. (по переписным книгам Спасо-Каменного и Сямженского Евфимиева монастырей) // Историческое краеведение и архивы. Вологда, 2012. Вып. 19. С. 134-140.

${ }^{43}$ Кустова Е.В. Монастыри и монашество... Т. 2. С. 10. 
также сельский по месту расположения Николаевский Венев монастырь (на момент переписи - патриарший). В нем доля крестьян была несколько выше (около 47\% ${ }^{44}$, однако все же уступала аналогичным показателям по северным монастырям.

В изучаемом регионе почти половину пострижеников монастырей составляли священно- и церковнослужители. Большая часть приходилась также на представителей служилого сословия. Доля же крестьян в среднем не превышала 15\%. В значительной мере эта картина определялась близостью территории Коломенской епархии к южным границам государства. Вероятно, на состав монашествующих повлияли и местные культурные традиции. В любом случае, проведенное исследование показало, что социальное происхождение монахов в разных регионах отличалось, а причины этих различий требуют дальнейшего изучения.

\section{Литература}

Адаменко О.Н. Монашество Вологодского Заозерья в XVII - начале XVIII в. (по переписным книгам Спасо-Каменного и Сямженского Евфимиева монастырей) // Историческое краеведение и архивы. Вологда, 2012. Вып. 19. С. 134-140.

Алатырский Троицкий мужской монастырь. Документы 1612-1703 годов/ Сост. В.Д. Кочетков, А.А. Чибис. Ульяновск, 2015.

Бакланова [Швейковская] Е.Н. Крестьянский двор и община на Русском Севере. Конец XVII - начало XVIII в. М., 1976.

Башнин Н.В. К вопросу о транспортных путях и средствах передвижения в XVII в. (по материалам приходо-расходных книг Вологодского архиерейского дома // Вестник церковной истории. 2018. № 3/4(51/52). С. 303-330.

Башнин Н.В. Опись имущества и строений Дионисиева Глушицкого монастыря 1701 г. и переписные книги вотчины Дионисиева Глушицкого монастыря 1702 г. // Вестник церковной истории. 2013. № 3/4(31/32). С. 138-177.

Башнин Н.В., Черкасова М.С., Шамина И.Н. Описи вологодских монастырей как источник по аграрной и демографической истории // Переписные книги вологодских монастырей XVI-XVIII вв.: исследование и тексты / Изд. подгот. О.Н. Адаменко, Н.В. Башнин, М.С. Черкасова при участии А.П. Анишиной, Н.А. Бараевой, Е.А. Виноградовой, А.Н. Красикова, С.Н. Смольникова, И.Н. Шаминой. Вологда, 2011.

Бульгин И.А. Монастырские крестьяне России в первой четверти XVIII в. М., 1977. Дмитриева 3.B. Вытные и описные книги Кирилло-Белозерского монастыря XVIXVII вв. СПб., 2003.

${ }^{44}$ РГАДА. Ф. 237. ОП. 1. Ч. 1. Кн. 217. 
Емченко Е.Б. Женские монастыри в России // Монашество и монастыри в России. XI-XX века: Исторические очерки. М., 2002. С. 245-284.

Жервэ Н.Н. Валдайский Святоозерский в честь Иверской иконы Божией Матери мужской монастырь // Православная энциклопедия. М., 2003. Т. 6. С. 615.

Kyстова E.B. Монастыри и монашество в социокультурной истории Приуралья в середине XVI - первой четверти XVIII в. Дис. ... д-ра ист. наук. В 2 т. Киров, 2017.

Нечаева М.Ю. Монашество Среднего Урала синодального периода: принципы формирования и социальный состав. Екатеринбург, 2019.

Описи Соловецкого монастыря XVI в.: Комментированное издание / Сост. 3.В. Дмитриева, Е.В. Крушельницкая, М.И. Мильчик; отв. ред М.И. Мильчик. СПб., 2003.

Опись строений и имущества Кирилло-Белозерского монастыря 1601 года: Комментированное издание / Сост. 3.В. Дмитриева, М.А. Шаромазов. СПб., 1998.

Опись строений и имущества Кирилло-Новоезерского монастыря 1657 г. / Публ. Т.В. Сазоновой // Белозерье. Краеведческий альманах. Вып. 2. Вологда, 1998. C. $130-165$.

Отписная книга Введенского Корнильево-Комельского монастыря переписи В.Г. Данилова-Домнина, составленная при передаче монастыря игумену Рафаилу и келарю Александру 2 декабря 1657 г. / Публ. Ю.С. Васильева // Городок на Московской дороге: Историко-краеведческий сборник. Вологда, 1994. С. 130-169.

Павел Алеппский. Путешествие антиохийского патриарха Макария в Россию в половине XVII века, описанное его сыном, архидиаконом Павлом Алеппским / Пер. Г.А. Муркос. М., 2005.

Панченко А.М. Авраамий // Словарь книжников и книжности Древней Руси. Вып. 3 (XVII в.). Ч. 1 / Отв. ред. Д.С. Лихачев. СПб., 1992. С. 34-36.

Печников М.В., Пидгайко В.Г. Коломенская епархия // Православная энциклопедия. М., 2014. Т. 36. С. 390-398.

Похилевич Л.И. Сказания о населенных местностях Киевской губернии или Статистические исторические и церковные заметки о всех деревнях, селах, местечках и городах, в пределах губернии находящихся. Киев, 1864.

Румянцеева В.С. Монастыри и монашество в XVII веке// Монашество и монастыри в России. XI-XX века: Исторические очерки. М., 2002. С. 163-185.

Румянцева В.С., Даниленко Б., прот. Андреевский монастырь в Пленницах // Православная энциклопедия. М., 2001. Т. 2. С. 350.

Смолич И.К. Русское монашество, 988-1917. Жизнь и учение старцев. М., 1999.

Соколова Н.В. Описание церковно-монастырских владений в процессе секуляризации начала XVIII в.: Опыт реконструкции (на материалах Нижегородского уезда) // Северо-Запад в аграрной истории России: Межвузовский тематический сборник научных трудов. Калининград, 2008.

Углич: материалы для истории города XVII и XVIII столетий. М., 1887. 
Черкасова М.С. Демография духовенства Устюжской епархии по данным первой ревизии 1720-1724 гг. // Церковь. Богословие. История: Материалы VII Всероссийской научно-богословской конференции, посвященной 100-летию мученической кончины святых Царственных страстотерпцев и их верных спутников. Екатеринбург, 2019. С. 314-320.

Шамина И.Н. Документы по истории Григориева Пельшемского монастыря XVII начала XVIII в. // Вестник церковной истории. 2011. № 3/4(23/24). С. 30-63.

Шамина И.Н. Опись имущества вологодского Павлова Обнорского монастыря 1701-1702 годов // Вестник церковной истории. 2010. № 1/2(17/18). С. 17-107.

Шамина И.Н. Переписная книга вологодского Спасо-Нуромского монастыря и его вотчины 1701-1702 гг. // Вестник церковной истории. 2020. № 1/2(57/58). C. 5-37.

Шамина И.Н. Переписные книги коломенских Спасо-Преображенского, Голутвина, Бобренева и Брусенского монастырей 1701 г. // Вестник церковной истории. 2017. № 3/4(47/48). С. 96-226.

Шамина И.Н. Преподобный Иннокентий Комельский и основанный им монастырь // Вестник церковной истории. 2009. № 1/2(13/14). С. 26-99. 
М.Р. Яфарова

\title{
БОРЬБА И. САМОЙЛОВИЧА И Ю. ХМЕЛЬНИЦКОГО ЗА НАСЕЛЕНИЕ НА УКРАИНЕ ЗИМОЙ І678-І679 ГГ. ${ }^{1}$
}

\begin{abstract}
Аннотация В статье рассматриваются военные действия между гетманами Ю. Хмельницким и И. Самойловичем зимой 1678-1679 гг. На основе анализа документов Разрядного и Посольского приказов показано, что характер противостояния на Украине после завершения Чигиринского похода 1678 г. изменился. Обе стороны стремились к переводу населения на свою сторону Днепра и созданию буферной зоны, на территории контролируемой противником.

Ключевые слова: Чигиринский поход 1678 г., Ю. Хмельницкий, И. Самойлович.

Summary The article deals with the military actions between hetmans Y. Khmelnitsky and I. Samoylovich in the winter of 1678-1679. Based on the analysis of the documents of the Discharge and Embassy Orders, it is shown that the nature of the confrontation in Ukraine after the end of the Chigirinsky campaign in 1678 changed. Both sides sought to transfer the population to their side of the Dnieper and create a buffer zone in the territory controlled by the enemy. Keywords: Chigirinsky campaign of 1678, Y. Khmelnitsky, I. Samoylovich.
\end{abstract}

Чигиринский поход 1678 г. завершил ключевой этап первого русско-турецкого противостояния. В ходе масштабной и кровопролитной летней кампании этого года выяснилось, что ни одна из сторон не способна нанести решительного поражения другой: османы вынуждены были отказаться от своих масштабных завоевательных планов на Украине, но и русские не сумели удержать гетманскую столицу Правобережья, Чигирин. Осада и падение Канева, крупного центра Правобережья, придерживавшегося

1 Исследование выполнено при финансовой поддержке РФФИ в рамках научного проекта № 19-09-00496, «Московское государство, Османская империя и Крымское ханство в XVII в.». 
ориентации на Россию, который был взят войсками Кара-Мустафы накануне отступления с Украины, в начале сентября 1678 г., стала поворотным моментом в восстановлении османского протектората над Правобережьем: выяснилось, что русская сторона не способна защитить население этих территорий без его перевоза на левый берег Днепра. Это не могло устроить правобережную старшину, которая начала признавать власть Ю. Хмельницкого и искать соглашения с османами.

После ухода армии Кара Мустафы-паши была распущена и российская армия, понесшая тяжелые потери и измотанная длительной и кровавой кампанией. Ключевую роль в событиях зимы и весны 1678-1679 гг. предстояло, таким образом, сыграть казацким правителям - правобережному и левобережному гетманам, Юрию Хмельницкому и Ивану Самойловичу. При этом Ю. Хмельницкому помогали татары (собственно турецкие войска в событиях 1679 г. вообще не участвовали), а И. Самойлович действовал при помощи русских войск. В этой связи было важно, как поведет себя украинское население в новых условиях, и какие действия будут предприняты соперничавшими гетманами для укрепления своей власти. При этом военные действия зимой-весной 1678-1679 г. на короткий срок были перенесены на правый берег Днепра, что стало фактически единственным случаем совместного участия русско-украинских войск на Правобережье в 1679-1681 гг.

В историографии данный вопрос специально не исследовался, события зимы 1678-1679 гг. лишь кратко упоминались в исследованиях Н.И. Костомарова $^{2}$, И.Д. Беляева ${ }^{3}$, В.Н. Зарубы ${ }^{4}$ В то же время в Белгородских столбцах Разрядного приказа в РГАДА сохранилась переписка московского правительства с белгородским воеводой кн. И.Б. Милославским и с гетманом И. Самойловичем, а также отписки командующего русскими войсками на Украине Григория Косагова о военных действиях зимой 1679 г. Важные сведения содержатся и в полученных царским правительством «расспросных речах» различных посланников и ратных людей, участвовавших в отражении набега. Эти данные позволяют уточнить хронологию событий, происходивших на территории Украины зимой-весной 1679 г., и обрисовать меры, предпринятые гетманом И. Самойловичем для борьбы с Ю. Хмельницким.

\footnotetext{
${ }^{2}$ Костомаров Н.И. Руина // Костомаров Н.И. Исторические монографии и исследования. СПб., 1881. Т. 15.

3 Беляев И.Д. Поход боярина Петра Васильевича Большого Шереметева в Малороссию в 1679 году // Русский архив. 1915. Т. 5. С. 13-31.

4 Заруба В.М. Українське козацьке військо в російсько-турецьких війнах останньої чверті XVII століття. Дніпропетровськ, 2003.
} 
К началу ноября 1678 г. в Москве стало известно, что, хотя османская армия и покинула Украину, значительные татарские силы должны были появиться на Правобережье, действуя совместно с зависимым от них Ю. Хмельницким. Связано это было не столько с участившимися татарскими набегами, сколько с распространившимися слухами о скором совместном походе Ю. Хмельницкого и крымской орды. Так, в начале декабря И. Самойлович сообщал в Москву, что 16 ноября небольшой татарский отряд перешел Днепр и совершил нападение на городок Санжары для «взятья языков». Примечательно, что на этот раз татары пришли непосредственно из Крыма: «А присылали их два салтана крымские, которые ис Крыму с ордами... вышед, имеют злой свой замысл... под городы ваши государские украинные и малоросийские для помешки христианского мира и для корысти своей ударить». Поступали сведения о том, что «сам хан сюды ж войною готовился и ис Крыму вышел», впоследствии не подтвердившиеся. Татарское войско в полной готовности, по данным И. Самойловича, стояло «на сей стороне Перекопи на урочищи Каланчаке» ${ }^{5}$. Вести о готовившемся походе приходили и с Крымского полуострова от Б. Шереметева: в декабре «калга Тохтамыш-Гирей и нурадын Саха Гирей-салтан пошли ис Крыму с крымскими ратими... в поход за Днепр, а перешед Днепр, сходитца им, калге и нурадыну, с салтаном з белогороцкою ордою и итить им войною... на Борабаши» ${ }^{6}$. Речь в полученных сообщениях шла уже не о хаотичных татарских набегах, а о крупномасштабном походе многочисленной татарской конницы. Под угрозой могли оказаться территории Левобережной Украины и даже юга России.

Сведения о совместном выступлении Ю. Хмельницкого и крымской орды оказались верны. 27 декабря Ю. Хмельницкий разослал универсалы левобережным и малороссийским жителям с требованием покориться ему во избежание разорений․

Московское правительство, естественно, было весьма обеспокоено: русская армия к этому времени была распущена. 18 января было получено письмо из Курска от князя И.Б. Милославского, «что воинские люди татаровя болшим собранием стоят в степи на реках на Самаре и... хотят приходить на... украинные городы войною вскоре». В этой связи в этот же день из Москвы были направлены указные статьи белгородскому воеводе на случай татарского вторжения зимой-весной 1679 г. Во-первых, несмотря на то, что в этом году служилые люди уже призывались на долгую и тяжелую служ-

5 РГАДА. Ф. 210. Оп. 12. Д. 1205. Л. 715.

6 Там же. Ф. 123. 1679. Д. 12. Л. 24-25.

${ }^{7}$ Костомаров Н.И. Указ. соч. С. 591-592. 
бу, в Курске следовало осуществить сбор войск: «велено по тем вестям... Белогородцкого полку всех городов с ратными людми с конными и с пешими збиратца наспех». На Украине совместно с казаками гетмана И. Самойловича предполагалось участие генерала-майора Г. Косагова, при этом, в том случае, если «буде по вестям понадобитца, что из Сум генералу маеору Григорью Косагову итти к гетману и он бы, боярин и воевода (И.Б. Милославский. - М.Я.), из Сум Григорью Косагову велел итти к гетману по ево гетманову писму... а сами они боярин и воеводы шли в это время в Сумы». Кроме того, харьковскому полковнику Григорию Донцу следовало «собрався полку ево с казаками, над воинскими людми промышлять за чертою в полевых городех, чтоб воинских людей к украинным городом для войны не пропустить» ${ }^{8}$. Как видно, в Москве считали угрозу весьма серьезной и даже предполагали развертывание значительных сил на Украине.

10 января состоялся первый набег совместных сил Ю. Хмельницкого и крымцев: отряды наказного гетмана Ю. Хмельницкого И.П. Яненко и двух мурз белгородской орды перешли Днепр возле местечка Стайки и дошли почти до Нежина - под Козелец и Носовку 9 . По словам Самовидца, «орди немаліе з Яненком війшли... под Козелец и там великую шкоду у людей учинили коло Дніпра, аж по Носовку, многіе села повибирали» ${ }^{10}$. Этот набег был отбит.

Однако основной поход начался в 20-х числах января 1679 г. К Черкассам двинулось войско во главе с Ю. Хмельницким и четырьмя крымскими «салтанами», «с которими множество татар» ${ }^{11}$. По словам жовнинского сотника, «конечно орды силные с Юраском Хмелницким около Еремеевки Чигирин Дубровы и Жовнина стоят. И генваря, де, 21-го и 22-го дня Юраска Хмелницкой к Веремеевки приступали, и промысл, де, чинят беспрестанно» ${ }^{12}$. Таким образом, первым городком, которым они овладели, стала Веремиевка. В ней не было казацких отрядов, население было не в силах обороняться и сдалось ${ }^{13}$. Затем последовали Горошин, Городище, Жовнин. Ю. Хмельницкому под страхом смерти сдались около трех тысяч человек, которых он приказал поселить в Жаботине ${ }^{14}$. Из-под Жовнина и Горошина

8 РГАДА. Ф. 210. Оп. 12. Д. 793. Л. 113-114.

9 Костомаров Н.И. Указ. соч. С. 592; Заруба В.М. Указ. соч. С. 323-324.

10 Літопис Самовидця. Київ, 1971. С. 131-132.

${ }^{11}$ Там же. С. 132.

${ }^{12}$ РГАДА. Ф. 210. ОП. 12. Д. 793. Л. 205.

${ }_{13}^{13}$ Костомаров Н.И. Указ. соч. С. 592.

${ }^{14}$ Там же. С. 592-593. 
он также направил универсалы, в которых требовал от жителей Левобережной Украины сдаваться и переселяться на правый берег Днепра ${ }^{15}$.

В это же время Яненко опустошил городки Пески, Яблонев, Золотоношу и направился к Лубнам, где с казацкими отрядами укрепились лубенский полковник М. Ильяшенко и полковник компанейского полка И. Новицкий. 14 февраля они сообщали гадяцкому полковнику, что «Яненко с салтанами стоят под Яблоновым, и яблоновских было жителей прелстил и многих орде отдал, а остаточные, де, жители заперлись в малом городке и с теми неприятелскими людми бились и салтаны с ордою, отступя от Яблонова, пошли к Ирклееве долине и к Крапивной» ${ }^{16}$. Следует подчеркнуть, что в условиях, когда основную военную силу Ю. Хмельницкого составляли татары, часть покорившегося ему населения теряла свободу и становилась их пленниками. Неудивительно, что даже в захваченных городках Хмельницкий сталкивался с сопротивлением части жителей.

В отписке И. Самойловича от 26 февраля 1679 г. первоначальный успех войск Ю. Хмельницкого объяснялся следующим образом: «неприятели бусурманы калга и нурадын салтаны со всеми силами и с Хмелниченком, уведав о росположении... ратных людей и войска запорожского полков, которые... росположены на знатных местех, не дожидаясь на себя приходе, пошли за Днепр ${ }^{17}$. Именно знание дислокации русско-украинских войск, по мнению гетмана, позволило казацко-татарским отрядам разорить поднепровские городки.

Одновременно к Днепру двигались и русско-украинские войска. Из отписки царю Г. Косагова следует, что генерал-майор «из Лебедина с... ратными людми пошол в малоросийские городы февраля в 3 день немедленно. И Войска Запорожского с полковниками з Гадицким и с Комонным Павловским сшолся в Веприке февраля в 4-м числе и, случась с ними, из Веприка пошол... с... ратными людми к Кременчюку, чтоб, пришедчи к Кременчюку, Чигирин Дуброву и Еремеевку, и Жовнин, которые здались крестопреступнику ростриге Юраску Хмелницкому привести под твою великого государя самодержавную высокую руку, и для промыслу над неприятелскими людьми» ${ }^{18}$.

Полтавский полковник П. Левенец первым подошел к Днепру: «Февраля в 10-м числе пришол он, Прокопей, с полком своим в Чигирин Дуброву

${ }^{15}$ Акты исторические, собранные и изданные Археографической комиссиею. СПб., 1842.

Т. 5. № 123. Стб. 156.

${ }^{16}$ РГАДА. Ф. 210. Оп. 12. Д. 793. Л. 7.

17 Там же. Ф. 229. Оп. 2. Д. 50. Л. 3.

${ }^{18}$ Там же. Ф. 210. Оп. 12. Д. 793. 
и в Жовнин. И от Жовнина посылал подъезды к Еремеевке, где стоит вор-рострига Юраска Хмельниченко» ${ }^{19}$. Кроме того, ему удалось взять в плен двух татар, которые в расспросе сообщили о действиях Ю. Хмельницкого. На Левобережье действовали весьма крупные татарские силы во главе с высшими крымскими сановниками: «Юраска, де, Хмелницкой стоит в Еремеевке с казаками, да при нем же черемисов сотня, да прежние орды пятьсот человек, да вновь пришло с Батыршею-мурзою две тысячи человек... А салтаны, де, калга и нурадын, и с ними орды пятнатцат тысяч, да Яненко с казаками пошли в войну, а в которые места, того те взятые языки сказали не ведают». Это же время Правобережный гетман был занят грабежом и угоном людей: «И сена и хлебные запасы возят за Днепр в Черкасы. . . И еремеевских и жовнинских жителей Юраско выгнал за Днепр, а которые итить не похотели, от них ушли и заперлися в Чигирин Дуброве» ${ }^{20}$. П. Левенцу удалось разбить Ю. Хмельницкого под Жовнино и оттеснить его к Лукомлю. Узнав, что части русско-украинских войск уже стоят близ Миргорода и Ирклеева, Ю. Хмельницкий с татарами, по словам И. Самойловича, «хотели уходить за Днепр». Однако «Хмелниченко з Батырчею мурзою послали было 3 двемя тысечами татар назад тою ж дорогою, которою было пришли на сю сторону Днепра, для того, чтоб сей стороны Днепра из городков всех жителей на ту сторону Днепра перевесть». Этим планам не суждено было осуществиться: «и Хмелниченко, видя то, посылал... татар в подъезд, и тех татар полтавской полковник с полком своим разгромил» ${ }^{21}$. Ю. Хмельницкий отступил с татарами за Днепр 22 . Отряд Яненко был разбит казаками лубенского полка, его уцелевшие войска, перейдя на правый берег Днепра, бежали в Корсунь ${ }^{23}$.

Однако на этом военные действия в Поднепровье не закончились. Крымские отряды, участвовавшие в походе с Ю. Хмельницким, перейдя на правый берег, разошлись. Калга с утомленными лошадьми вернулся в Крым. Другая часть татар, около 7 тыс. чел., во главе с нуреддином, 16-17 февраля снова перешла на левую сторону Днепра и ударила по городкам миргородского полка. Об этом становится известно из расспросных речей мурзы Адиля Темирбекова: «калга, де, салтан, поворотя от Яблонова к Черкасом отпустил Хмелниченко в Немиров з Батыршею мурзою, да с ним орды триста человек, а сам перебрав орды пошол на Великий Ингул в Крым, а нурадын салтан с татарскими пятью тысячи с лутчими

\footnotetext{
19 Там же. Л. 4.

${ }^{20}$ Там же. Л. 5-6.

${ }^{21}$ Там же. Ф. 229. Оп. 2. Д. 50. Л. 4.

${ }^{22}$ Костомаров Н.И. Указ. соч. С. 593.

23 заруба В.М. Указ. соч. С. 324.
} 
людми и на добрых лошедях перешли была на сю сторону Днепра меж городков Кременчюка и Чигирин Дубровы и били под Голтву и Остапьев». На сей раз это был обычный крымский набег, целью которого был грабеж и поимка ясыря. Войскам Г. Косагова и С. Самойловича удалось разбить крымцев под Кременчугом и освободить пленных. Из письма Г. Косагова кн. И.Б. Милославскому от 24 февраля 1679 г. следует, что «февраля ж, де, в 17 день прошла орда многая с нурадын салтаном, да калги салтана с сыном от Черкас меж Кременчюки и Власовки миргородцкого полку к Голтве и к Остапью. И он, де, генерал-маеор с полками и полковники... за тою ордою пошли того ж числа, взяв с собою пехоту с тысячю человек, и шесть пушак. И дошли, де, салтанов с ордою под местечком Манжебечкою за час до вечера, и был с ними бой болшой». Г. Косагову удалось обратить крымцев в бегство: «кумпанию тех неприятелских людей гнали и побивали на полтретьи версты, и многих мурз и знатных татар побили, и знамя калги салтана аги первого взяли, и знаменщика убили, и неволников у тех татар отбили болши двухсот человек, и на свой шлях их неприятелских людей итти не пустили. И те, де, салтаны, видя над войсками своими победу и много уроны, пошли в поле к Днепру и переправились Днепр меж Кереберды и Переволочкой ${ }^{24}$. Более того, они преследовали нуреддина с ордой до р. Малого Ингула, и «орда, не дав бою, побежали, и полон секли и лошеди и животину метали», однако погодные условия вынудили русско-украинский отряд вернуться назад ${ }^{25}$. За эту победу всем участникам боя было сказано царское милостивое слово и дано государево жалованье ${ }^{26} .21$ февраля войска под командованием Г. Косагова вернулись в Кременчуг ${ }^{27}$.

В целом эта зимняя кампания показала, что Ю. Хмельницкий не стремился закрепиться на Левобережье, но в то же время его цели не ограничивались грабежом и запугиванием левобережных жителей. Ему было необходимо привлечь на обезлюдевший правый берег Днепра достаточное количество населения, при этом, как правило, реализовать это он мог лишь с помощью силы. Люди были нужны и татарам, союзникам Ю. Хмельницкого, в качестве полоняников. Несмотря на то, что эти события разворачивались после завершения тяжелой и кровопролитной летней кампании 1678 г., московскому правительству и гетману И. Самойловичу удалось достаточно

${ }^{24}$ РГАДА. Ф. 210. Оп. 12. Д. 793. Л. 53.

${ }^{25}$ Там же. Л. 53-54. По словам Самовидца, в то время «сніги великіе випали, же не можна было конем куди хотіти ехати» (См.: Літопис Самовидця. С. 132).

${ }^{26}$ РГАДА. Ф. 229. Оп. 2. Д. 50. Л. 5; Беляев И.Д. Указ. соч. С. 19.

${ }^{27}$ РГАДА. Ф. 210. ОП. 12. Д. 793. 
быстро собрать силы и отразить вторжение. Важную роль в этом сыграло и сопротивление местных жителей.

Сложившаяся ситуация вынуждала гетмана И. Самойловича предпринять соответствующие меры, а именно - лишить Ю. Хмельницкого возможности набирать войска и рабочую силу с подвластных ему территорий путем переселения их жителей на левый берег Днепра. Подобные меры предлагал и бывший правобережный гетман П. Дорошенко, по мнению которого, следовало свезти всех жителей из Жаботина и Медведовки на Левобережье ${ }^{28}$. По словам самого гетмана И. Самойловича, необходимо было «чинить промысл» «над Черкасы и над иными заднепрскими городками, чтоб ис тех городков для воровства на сю сторону лазутчиков и за Днепром с сеей стороны людем и неприятелем пристанищи не было» ${ }^{29}$. Об этом также писал в Москву Г. Косагов: ему указал «словесно гетман Ыван Самойлович с Ываном Мазепою Корсунь, Черкасы, Канев, Мошны, Дрябовицы, Оловятины, Жаботин и иные малые городки и местечка и селы разорить нынешним зимним путем, смотря по тамошнему делу, чтоб ис тех городов для воровства на сю сорону Днепра лазутчиков и заднепрские стороны людем и неприятелем пристанища не было» ${ }^{30}$. Таким образом, вполне определенно была поставлена задача создания буферной зоны вдоль правого берега Днепра.

В этой связи в феврале 1679 г. был организован ответный поход на Правобережье, «чтоб те городки Черкасы, Корсунь, Мошны и иные разорить нынешним последним зимнем путем, а как, де, реки роспалятца, тогда трудно будет над ними промысл чинить» ${ }^{31}$. Его возглавил Семен Самойлович, сын гетмана И. Самойловича, в распоряжении которого были казацкие сотни нежинского, киевского, переяславского, прилуцкого, лубенского полков и компанейский полк И. Новицкого ${ }^{32}$, общая численность которых составляла около 8 тыс. чел.

23 февраля С. Самойлович выдвинулся из Переславля на Ржищев. 2425 февраля казацкими войсками Ржищев был взят приступом, а также захвачено в плен несколько десятков татар и казаков, а его жителей расселили в Переяславском полку ${ }^{33}$. Затем войско под командованием С. Самойловича двинулось к Корсуни, где укрепился с небольшими казацким и татарским

\footnotetext{
${ }^{28}$ Ходырева Г.В. Взаимоотношения России и гетманов Украины с Турцией в 1666-1681 гг. Дис. ... канд. ист. наук. М., 2001. С. 170.

${ }^{29}$ РГАДА. Ф. 210.ОП. 12. Д. 793. Л. 109.

${ }^{30}$ Там же. Л. 56.

${ }^{31}$ Там же. Л. 207.

32 Там же. Л. 206.

${ }^{33}$ Костомаров Н.И. Указ. соч. С. 599-600, Заруба В.М. Указ. соч. С. 325-326.
} 
отрядами Яненко, по дороге заняв Канев, который сдался добровольно: «по взятии Ржищева, как к Корсуню пошли с войском, и на дороге каневские жители в свободе своей, учиня покорный привет... и з животами своими собрався, приклонились ис под бусурманской обороны... и под обыклую отеческую христианскую монарха нашею защиту пришли в Переясловль» ${ }^{34}$.

Подойдя к Корсуни, С. Самойлович «изменника Яненку застал было с татары. Которых часть татар, наперед против наших из городка выбежав, и по тоею дорогою к Лысенке скоро убежали. А враг Яненченко с своими надежными с немногими татары на побег не успел, остался было с людми корсунскими, городок выжег и дав огненного бою против наших ис пушак». Однако наступление темного времени суток сыграло сподвижнику Ю. Хмельницкого на руку, ему удалось сбежать из осажденной казацкими войсками Корсуни из-за невозможности полностью оцепить город: «И так с полночи оный враг Яненко, как хитрая лисица, сам из городка выкрадчись тайным местом мимо сторожу компанейскую ушол в Немиров, за которым наши хотя и гнали, взяв ведомость из городка нескоро, но уже много часов прошло, тем он, бедник, свой живот унес». После побега Яненко в Немиров, «назавтрее на розсветаньи городок корсунский... при склонности людской взяли. А осталых татар там на площади посекли, а иных живых поймали, а людей в целости выпроводили. А яненковы ратные збруи и четыре пушки и литавры, забрав, город сожгли» ${ }^{35}$.

После взятия Корсуни войска С. Самойловича пошли вниз по р. Рось «к Деревенковцу, Драбовцу, Староборью, где татары стояли». Однако на этот раз местные жители самостоятельно захватили небольшие татарские отряды и привезли С. Самойловичу: «всех татар сколко десятков было тамошние жители, повязав, к нему в обоз привезли, а сами те жители все на сю сторону Днепра сошли», и после этого, «чтоб там неприятели пристанища не имели, огнем выжгли и за Днепр отступили» ${ }^{36}$.

Одновременно на правом берегу Днепра действовали войска под командованием генерала-майора Г. Косагова. Согласно расспросным речам казака Фомы Орловского, они «пошли ис Кременчюка для промыслу над заднепрьскими городами марта в 1-й день и пришли за Днепр под Жаботин марта в 4-м числе ${ }^{37}$. Помимо ратных людей, с Г. Косаговым находились казаки «с сумским и с охтырским з гадецким и с комонным и с миргородцким полковниками». О действиях русско-украинских войск над Жаботиным

\footnotetext{
${ }^{34}$ РГАДА. Ф. 210. Оп. 12. Д. 793. Л. 212.

${ }^{35}$ Там же. Л. 212-214.

${ }^{36}$ Там же. Л. 213-214.

37 Там же. Л. 121.
} 
сообщает в своей отписке Г. Косагов к царю от 8 марта 1679 г. По его словам, «з жаботинцы под городом был бой. И на том бою многих жаботинских жителей побили». Впрочем, возможно, что для Г. Косагова было важным отчитаться о серьезном сражении, при этом, по его же словам, потери русских были совсем небольшие: «ратных людей ранено два человека, убит один человек». Чуть позже, «как пришла под город пехота с пушками и учали чинить над ними промысл военной ис пушек, и жаботинские жители и еремеевские, и жовнинские переведенцы, видя... ратных людей всех полков крепкое наступление и промысл, того ж числа в ночь прислали ко мне... и к гадицкому полковнику попов и отамана, и мещан и... в винах своих били челом, и под великого государя самодержавную руку поддалися, и залогу яненкову выдали. И я... и гадицкой полковник жаботинских жителей, и еремеивских, и жовнинских переведенцев всех до одного человека переправили и выгнали со всеми их пожитками на сю сторону Днепра семей с тысячю и болши, и город Жаботин и замок и подворки и села хутори выпалили без остатку» ${ }^{38}$.

5 марта войска под командованием Г. Косагова подступили к Черкассам и «город зажгли, а жители, де, того города все вышли на сю сторону Днепра до приходу» ${ }^{39}$ русско-украинских войск. Кроме того, Г. Косагов также подтверждал, что сын гетмана И. Самойловича «был под Корсунем и Ржищевым и все заднепрские городы привел под твою великого государя высокодержавную руку и жителей тамошних всех переслал на сю сторону Днепра» ${ }^{40}$.

По сути, военные действия закончились 5 марта, именно в этот день С. Самойлович двинулся назад в Переяславль, войска Г. Косагова были распущены по домам 6 марта ${ }^{41}$. Ю. Хмельницкий и его сподвижник Яненко осели в Немирове, причем они по-прежнему опирались не на собственные силы, а на татар: «а орды при них сказывают с пятсот человек»42.

Итог военным действиям зимы-весны 1679 г. подвел сам И. Самойловича, «все жители ржищевские, каневские, корсунские, староборские, мошенские, урабовские, белозерские, тагановские, черкаские на сю сторону согнаны и от неприятеля отстранены, а города и села, и местечки, и деревни их, где они прежде жили в той стороне без остатку выжжены» ${ }^{43}$. Как видно,

\footnotetext{
38 Там же. Л. 234.

39 Там же. Л. 121.

40 Там же. Л. 234.

${ }^{41}$ Там же. Л. 208.

42 Там же. Л. 122.

${ }^{43}$ Цит. по: Костомаров Н.И. Указ. соч. С. 603-604.
} 
речь шла об обширной территории на правом берегу Днепра между Киевом и Чигирином, относившейся к 11 правобережным полкам. Н.Г. Крикун уточняет, к каким именно - к черкасскому, каневскому, белоцерковскому, корсуньскому, брацлавскому, уманьскому, кальницкому, подольскому, паволочскому, торговицкому и чигиринскому полкам ${ }^{44}$.

Итак, зимой 1678-1679 гг. Ю. Хмельницкий, заручившись поддержкой крымских татар, предпринял попытку перевести в свои правобережные владения часть населения левого берега Днепра. Для отражения этого набега были задействованы не только казачьи отряды И. Самойловича, но и силы Белгородского разряда, прежде всего слободских полков, под командованием генерал-майора Григория Косагова. В ответ русско-украинские силы опустошили широкую полосу земель на Правобережье, стремясь создать вдоль границы широкую полосу разоренных земель. Важно, что левобережный гетман оставил неоднократно предпринимавшиеся им ранее попытки укрепить свою власть на Правобережье, предпочтя вывести население и сжечь населенные пункты вдоль правого берега Днепра. Таким образом, можно заключить, что в ходе зимней кампании 1678-1679 г. обе стороны стремились создать буферную зону вдоль Днепра - Ю. Хмельницкий на левом, а И. Самойлович на правом берегу. Действия русскоукраинских войск и сопротивление населения действовавшим от имени Хмельницкого татарам привели к тому, что успех сопутствовал планам левобережного гетмана.

\section{Литература}

Акты исторические, собранные и изданные Археографической комиссиею. СПб., 1842. Т. 5.

Беляев И.Д. Поход боярина Петра Васильевича Большого Шереметева в Малороссию в 1679 году // Русский архив. 1915. Т. 5. С. 13-31.

Заруба В.М. Українське козацьке військо в російсько-турецьких війнах останньої чверті XVII століття. Дніпропетровськ, 2003.

Костомаров Н.И. Руина // Костомаров Н.И. Исторические монографии и исследования. СПб., 1881. Т. 15.

Крикун М.Г. Між війною і радою. Козацтво правобережної України в другій половині XVII — на початку XVIII століття. Київ, 2006.

Літопис Самовидця. Київ, 1971.

Ходырева Г.В. Взаимоотношения России и гетманов Украины с Турцией в 16661681 гг. Дис. ... канд. ист. наук. М., 2001.

${ }^{44}$ Крикун М.Г. Між війною і радою. Козацтво правобережної України в другій половині XVII - на початку XVIII століття. Київ, 2006. С. 394-395. 


\section{СвЕДЕНИЯ ОБ АВТОРАХ}

Гневашев Дмитрий Евгеньевич, главный специалист Государственного архива Российской Федерации

Gnevashev Dmitrii Evgen'evich, chief specialist, State Archives of the Russian Federation

Горский Антон Анатольевич, доктор исторических наук, главный научный сотрудник Института российской истории РАН

Gorskiy Anton Anatol'evich, Grand $\mathrm{PhD}$ (History), chief researcher, The Institute of Russian History of the Russian Academy of Sciences

Грацианская Любовь Игоревна, кандидат исторических наук, доцент Российского государственного гуманитарного университета

Gratsianskaya Lyubov Igorevna, $\mathrm{PhD}$ (History), associate professor, Russian State University for the Humanities

Дмитриева Зоя Васильевна, доктор исторических наук, ведущий научный сотрудник Санкт-Петербургского института истории РАН

Dmitrieva Zoya Vasil'evna, Grand PhD (History), leading researcher, The St. Petersburg Institute of History of the Russian Academy of Sciences

Иванова Галина Анатольевна, заместитель начальника Отдела научно-справочного аппарата Российского государственного архива древних актов

Ivanova Galina Anatol'evna, Deputy Head of Division Finding Aids, Russian State Archives of Ancient Documents

Ковальчук Алексей Викторович, кандидат исторических наук, старший научный сотрудник Института российской истории РАН

Koval'chuk Alexey Viktorovich, $\mathrm{PhD}$ (History), senior researcher, The Institute of Russian History of the Russian Academy of Sciences

Козлова Наталия Вадимовна, доктор исторических наук, профессор исторического факультета Московского государственного университета им. М.В. Ломоносова

Kozlova Natalia Vadimovna, Grand $\mathrm{PhD}$ (History), professor, Faculty of history, Lomonosov Moscow State University

Комиссаренко Аркадий Иванович, доктор исторических наук, профессор Российского государственного гуманитарного университета

Komissarenko Arkadii Ivanovich, Grand PhD (History), professor, Russian State University for the Humanities

Комочев Никита Алексеевич, кандидат исторических наук, научный сотрудник Института славяноведения РАН; доцент Историко-архивного института Российского государственного гуманитарного университета

Komochev Nikita Alexeevich, PhD (History), researcher, The Institute of Slavic Studies of the Russian Academy of Sciences; associate professor, The Institute for History and Archives, Russian State University for the Humanities 
Лифшиц Александр Львович, кандидат филологических наук, доцент Национального исследовательского университета «Высшая школа экономики»

Lifshits Alexandr L'vovich, PhD (Russian Philology), associate professor, National Research University «Higher School of Economics»

Лукин Павел Владимирович, доктор исторических наук, главный научный сотрудник Института российской истории РАН

Lukin Pavel Vladimirovich, Grand PhD (History), chief researcher, The Institute of Russian History of the Russian Academy of Sciences

Медведева Татьяна Валерьевна, кандидат исторических наук, старший научный сотрудник Института славяноведения РАН, ученый секретарь Археографической комиссии РАН

Medvedeva Tatiana Valer'evna, $\mathrm{PhD}$ (History), senior researcher, The Institute of Slavic Studies of the Russian Academy of Sciences; academic secretary of the Archaeographical commission of the Russian Academy of Sciences

Мельников Андрей Васильевич, кандидат исторических наук, заведующий Отделом археографии Института славяноведения РАН; старший научный сотрудник Архива PAH

Mel'nikov Andrey Vasil'evich, PhD (History), Head of Department of archaeography, The Institute of Slavic Studies of the Russian Academy of Sciences; senior researcher, Archive of the Russian Academy of Sciences

Мироненко Мария Павловна, кандидат исторических наук, старший научный сотрудник Института славяноведения РАН

Mironenko Maria Pavlovna, PhD (History), senior researcher, The Institute of Slavic Studies of the Russian Academy of Sciences

Новохатко Ольга Владимировна, доктор исторических наук, главный научный сотрудник Института российской истории РАН

Novokhatko Ol'ga Vladimirovna, Grand $\mathrm{PhD}$ (History), chief researcher, The Institute of Russian History of the Russian Academy of Sciences

Петров Константин Васильевич, кандидат исторических наук, доцент, старший научный сотрудник ФКУ «Информационный историко-научный центр — военная историческая библиотека Генерального штаба Вооруженных сил России», доцент кафедры управления и профессионального образования Ленинградского областного института развития образования

Petrov Konstantin Vasil'evich, PhD (History), senior researcher of the Information historical and scientific center - military historical library of the General Staff of the Armed Forces of the Russian Federation, associate professor of the Department of Management and Professional Education of the Leningrad Regional Institute for the Development of Education

Пугач Иван Васильевич, кандидат исторических наук, доцент Вологодского государственного университета

Pugach Ivan Vasil'evich, PhD (History), associate professor, Vologda State University

Румянцева Марина Федоровна, кандидат исторических наук, доцент Школы исторических наук Факультета гуманитарных наук Национального исследовательского университета «Высшая школа экономики»

Rumyantseva Marina Fedorovna, PhD (History), associate professor of School of History, the Faculty of Humanities, National Research University «Higher School of Economics» 
Свердлов Михаил Борисович, доктор исторических наук, главный научный сотрудник Санкт-Петербургского института истории РАН, профессор Российского государственного педагогического университета им. А. И. Герцена

Sverdlov Mikhail Borisovich, Grand PhD (History), chief researcher, The St. Petersburg Institute of History of the Russian Academy of Sciences; professor, The Herzen State Pedagogical University of Russia

Сиренов Алексей Владимирович, доктор исторических наук, член-корреспондент РАН, директор Санкт-Петербургского института истории РАН

Sirenov Alexey Vladimirovich, Grand $\mathrm{PhD}$ (History), correspondent member of the Russian Academy of Sciences, director, The St. Petersburg Institute of History of the Russian Academy of Sciences

Смилянская Елена Борисовна, доктор исторических наук, профессор Факультета гуманитарных наук Национального исследовательского университета «Высшая школа экономики»

Smilyanskaya Elena Borisovna, Grand $\mathrm{PhD}$ (History), professor, the Faculty of Humanities, National Research University «Higher School of Economics»

Соколова Наталья Викторовна, кандидат исторических наук, старший научный сотрудник Института славяноведения РАН

Sokolova Natalia Viktorovna, PhD (History), senior researcher, The Institute of Slavic Studies of the Russian Academy of Sciences

Флоря Борис Николаевич, доктор исторических наук, член-корреспондент РАН, заведующий Отделом истории Средних веков Института славяноведения РАН

Florya Boris Nikolayevich, Grand $\mathrm{PhD}$ (History), correspondent member of the Russian Academy of Sciences, Head of Department of History of the Middle Ages, The Institute of Slavic studies of the Russian Academy of Sciences

Хитров Дмитрий Алексеевич, кандидат исторических наук, доцент исторического факультета Московского государственного университета имени М. В. Ломоносова

Khitrov Dmitrii Alekseevich, PhD (History), associate professor, Lomonosov Moscow State University, the Faculty of history

Черкасова Марина Сергеевна, доктор исторических наук, профессор Вологодского государственного университета

Cherkasova Marina Sergeevna, Grand $\mathrm{PhD}$ (History), professor, Vologda State University

Черненко Дмитрий Анатольевич, кандидат исторических наук, доцент кафедры истории России XIX - начала XX в. Московского государственного университета им. М.В. Ломоносова

Chernenko Dmitrii Anatol'evich, PhD (History), associate professor, Lomonosov Moscow State University

Черников Сергей Васильевич, кандидат исторических наук, доцент Липецкого государственного технического университета

Chernikov Sergey Vasil'evich, PhD (History), associate professor, Lipetsk State Technical University

Шамина Ирина Николаевна, кандидат исторических наук, научный сотрудник Института российской истории РАН

Shamina Irina Nikolaevna, PhD (History), researcher, The Institute of Russian History of Russian Academy of Sciences

Яфарова Мадина Рашидовна, кандидат исторических наук, научный сотрудник Института российской истории РАН

Yafarova Madina Rashidovna, $\mathrm{PhD}$ (History), researcher, The Institute of Russian History of Russian Academy of Sciences 


\section{СПИСОК СОКРАЩЕНИЙ}

ААЭ — - - —Акты, собранные в библиотеках и архивах Российской империи Археографическою экспсдициею Императорской Академии наук»

АИ — - «Акты исторические, собранные и изданные Археографическою комиссиею»

АРАН - Архив Российской академии наук

АФЗиХ — «Акты феодального землевладения и хозяйства»

ВГИАХМЗ - Вологодский государственный историко-архитектурный и художественный музей-заповедник

ГА РФ — - Государственный архив Российской Федерации

ГАВО - Государственный архив Вологодской области

ГВНП — - «рамоты Великого Новгорода и Пскова»

ИРИ РАН - Институт российской истории Российской академии наук

ИСл РАН - Институт славяноведения Российской академии наук

МАМЮ - Московский архив Министерства юстиции

МГУ — Московский государственный университет им. М.В. Ломоносова

НБ МГУ - Научная библиотека Московского государственного университета им. М.В. Ломоносова

ОДиДС — «Описание документов и дел, хранящихся в архиве Святейшего Правительствующего Синода»

ОПИ ГИМ - Отдел письменных источников Государственного исторического музея

ОР БАН — Рукописный отдел Библиотеки Академии наук

ОР РГБ — Отдел рукописей Российской государственной библиотеки

ОР РНБ — Отдел рукописей Российской национальной библиотеки

ПВЛ — - «Повесть временных лет»

ПРиОК - «Приходо-расходные денежные книги Вологодского архиерейского дома святой Софии и окладные книги церквей Вологодской епархии. XVII начало XVIII в.»

ПС3-I — «Полное собрание законов Российской Империи. Собрание первое. $1649-1825$ гг.»

ПСРЛ — - «Полное собрание русских летописей»

РГАДА — Российский государственный архив древних актов

РГБ — Российская государственная библиотека

РГВИА — Российский государственный военно-исторический архив

РГГУ — Российский государственный гуманитарный университет

РГИА — Российский государственный исторический архив

РФФИ — - Российский фонд фундаментальных исследований

СлРЯ — - «Словарь русского языка XI-XVII вв.»

СПб ФА РАН - Санкт-Петербургский филиал Архива Российской академии наук

СПбГУ - Санкт-Петербургский государственный университет

СПбИИ РАН - Санкт-Петербургский институт истории Российской академии наук

СРНГ — - « - «ловарь русских народных говоров»

ТОДРЛ - «Труды Отдела древнерусской литературы» Института русской литературы (Пушкинского Дома) Российской академии наук

ЦГА Москвы - Центральный государственный архив города Москвы

ЧОИДР - «Чтения в Обществе истории и древностей российских при Московском университете» 


\section{СОДЕРЖАНИЕ}

К юбилею Елены Николаевны Швейковской . . . . . . . . . . . . . . . . 3

Список печатных трудов Е.Н. Швейковской (cocm. А.В. Мельников) . . . . . . . . 5

Д.Е. Гневашев

Вологодское поместье Малюты Скуратова $\ldots \ldots \ldots \ldots \ldots \ldots \ldots \ldots \ldots$

А.А. Горский

«Волхвы» и «жрецы» в древнерусской книжности . . . . . . . . . . . 52

Л.И. Грацианская

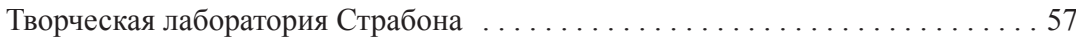

3.В. Диитриева

Цены на зерно по вкладной книге

Кирилло-Белозерского монастыря (1570-1610-е гг.) . . . . . . . . . . . . . . . . 68

Г.А. Иванова

Подьячие, возглавлявшие писцовые комиссии XVII в. . . . . . . . . . . . 81

А.В. Ковальчук

Комиссия о коммерции и дискуссия о крестьянской

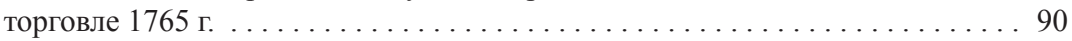

Н.В. Козлова

Венценосные особы в роли душеприказчиков и гарантов

наследственных прав знати в петровское время. . . . . . . . . . . . 106

А.И. Комиссаренко

«Учинили нападение и оружейную и из луков стрельбу»

(социальные движения в Вятском крае в первой половине XVIII в.) . . . . . 121

Н.А. Комочев

О первом научном труде Е.Н. Швейковской . . . . . . . . . . . . . . . 129

А.Л. Лифиии

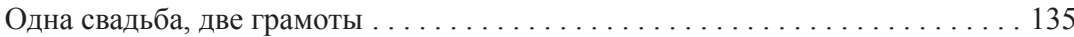

П.В. Лукин

Забожничье. Новая попытка интерпретации понятия . . . . . . . . . . . . . . . 145

T.В. Медведева

Люди Нового времени в трудах Н.В. Голицына . . . . . . . . . . . . . 160

А.В. Мельников

Переписка С.Ф. Платонова и М.М. Богословского . . . . . . . . . . . . . . . 174

М.П. Мироненко

Судьба русского археолога на переломе эпох $\ldots \ldots \ldots \ldots \ldots \ldots \ldots \ldots$ 
О.В. Новохатко

Россия середины XVII в.: еще раз об абсолютизме . . . . . . . . . . . . . . . . 194

К.В. Петров

Социальная (сословная) мобильность дворян и детей боярских

в России второй половины XVI-XVII вв. . . . . . . . . . . . . . . . 219

И.В. Пугач

Вологодский гарнизон в XVII в. . . . . . . . . . . . . . . . . . . . . . . . . 249

М.Ф. Румянцева

Источники (по) истории крестьянства:

источниковедческие наблюдения … . . . . . . . . . . . . . . . . 269

М.Б. Свердлов

Человек и закон на Руси первой трети ХІІ в. . . . . . . . . . . . . . . 282

А.В. Сиренов

Камень Прокопия Устюжского в начале XIX в.

Е.Б. Смилянская

Простолюдины Санкт-Петербурга в записках

британской «посольши» Джейн Каткарт (1768-1770 гг.) . . . . . . . . . . . . . . 308

Н.В. Соколова

«...А другую крошку взять в мир» (о функциях крестьянской

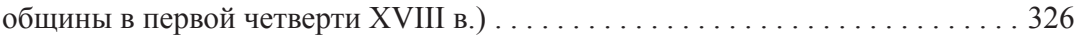

Б.Н. Флоря

Строительство Смоленского кремля и отношения власти

и общества в России на рубеже XVI-XVII вв. . . . . . . . . . . . . . . . . . . . . 343

Д.А. Хитров

Вологодский уезд и административная реформа

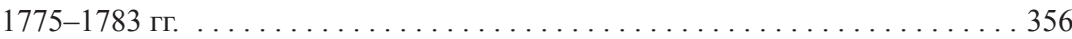

М.С. Черкасова

Спасо-Прилуцкий монастырь и торговые люди в конце XVI в.

Д.А. Черненко

Земли городов Вологодской губернии в конце XVIII в.:

размеры, типология, владельческая принадлежность . . . . . . . . . . . . . 383

С.В. Черников

Фамильный состав каширского дворянства в период I ревизии

(в сравнении с десятнями и писцовой книгой второй половины XVI в.) . . . 397

И.Н. Шамина

Социальный портрет монашествующих

Коломенской епархии в конце XVII — начале XVIII в. . . . . . . . . . . . . . 407

М.Р. Яфарова

Борьба И. Самойловича и Ю. Хмельницкого за население

на Украине зимой $1678-1679$ гг. . . . . . . . . . . . . . . . . . . . . . . . . 429

Сведения об авторах ........................... 440

Список сокращений ........................... 443 


\section{CONTENTS}

For the Anniversary of Elena Nikolaevna Shveykovskaya. . . . . . . . . . . 3

List of printed works of E.N. Shveykovskaya (compiled by Andrey Mel'nikov) . . . . . 5

Dmitrii Gnevashev

Malyuta Skuratov's estate in Vologda district . . . . . . . . . . . 23

Anton Gorskiy

«Volkhvy» and «Zhretsy» in old Russian bookishness . . . . . . . . . . . 52

Lyubov Gratsianskaya

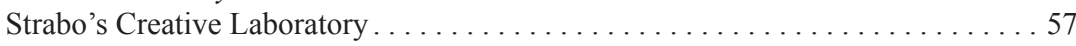

Zoya Dmitrieva

Grain Prices in the Contribution book of Kirillo-Belozersky monastery

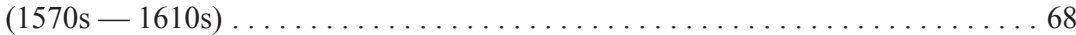

Galina Ivanova

Clerks at the Head of the Scribal commissions in the 17 th century Russia. . . . . 81

Alexey Koval'chuk

Commission on Commerce and a discussion on peasant trade in $1765 \ldots \ldots$. . . 90

Natalia Kozlova

Crowned persons in the role of executors and guarantors

of the hereditary rights of the nobility in Peter's time. . . . . . . . . . 106

Arkadii Komissarenko

«They attacked and shot from guns and bows»:

Social movement in Vyatka region in the first half of 18 th century . . . . . . 121

Nikita Komochev

About the first scientific work of E.N. Shveykovskaya . . . . . . . . . . . . . 129

Alexandr Lifshits

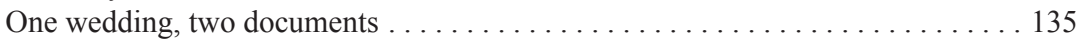

Pavel Lukin

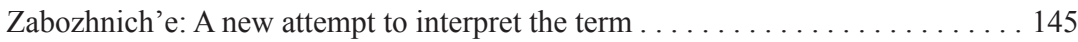

Tatiana Medvedeva

The people of the Modern Era in the works of N.V. Golitsyn . . . . . . . . 160

Andrey Mel'nikov

Correspondence of S.F. Platonov and M.M. Bogoslovsky . . . . . . . . . . . . 174

Maria Mironenko

The fate of the Russian archaeologist at the era-breaking time 
Olga Novokhatko

Russia in the middle of the 17 th century: once again about absolutism

Konstantin Petrov

Social mobility of nobles in Russia in the second half of the 16th -

17 th centuries

Ivan Pugach

Vologda garrison in the 17 th century

Marina Rumyantseva

Sources on the history of peasantry: Source observations . . . . . . . . . 269

Mikhail Sverdlov

A Man and a Law at the first third of the 12th century

Alexey Sirenov

The Stone of Prokopius Ustyuzhsky at the beginning of the 19th century

\section{Elena Smilyanskaya}

«Common people» of St. Petersburg in the Memoranda

of the British ambassadrice Jane Cathcart (1768-1770)

\section{Natalia Sokolova}

«...And to take the other kroshka to the mir»: (On the functions

of obschina in the first quarter of the 18 th century)

Boris Florya

Construction of the Smolensk Kremlin and relations between government

and society in Russia at the turn of the 16 th -17 th centuries

Dmitrii Khitrov

Vologda uezd and the administrative reform of $1775-1783$

Marina Cherkasova

Spaso-Prilutsky monastery and merchants at the end

of the 16 th century

\section{Dmitrii Chernenko}

Lands of the cities of the Vologda province at the end of the 18th century:

size, typology, ownership

Sergey Chernikov

Family structure of the Kashirian nobility in the early 18th century

(in comparison with lists of service men and scribal books of the second half

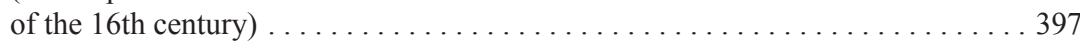

Irina Shamina

Social portrait of the monastics of the Kolomna diocese in the late

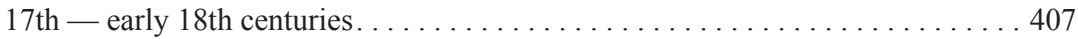

Madina Yafarova

The struggle between I. Samoilovich and Y. Khmelnitsky for the population

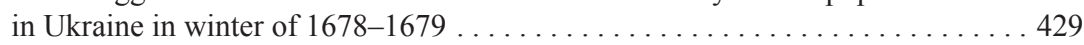

Notes on contributors . . . . . . . . . . . . . . . . . . . . . . 440

Abbreviations ................................. 443 
Научное издание

\title{
Традиционные и новаторские пути изучения социальной истории России XII-XX веков
}

Сборник статей в честь

Елены Николаевны Швейковской

\author{
Редактор А.В. Мельников \\ Корректор А.В. Мельников
}

Верстка и оригинал-макет Т.Ю. Захарова

\author{
Утверждено к печати Ученым советом Института славяноведения РАН \\ (Протокол № 4 заседания Ученого совета \\ ФГБУН Института славяноведения РАН от 27.04.2021) \\ и Ученым советом Института российской истории РАН \\ (Протокол № 5 заседания Ученого совета \\ ФГБУН Института российской истории РАН от 13.05.2021)
}

Налоговая льгота -

Общероссийский классификатор продукции

OK-005-93, том 2

953000 — книги, брошюры

Ассоциация «Издательство Новый Хронограф»

Контактный телефон + 7 (916) 651-30-94

по вопросам реализации +7 (903) 669-69-09

E-mail: nkhronograf@mail.ru

Информация об издательстве: http://www.novhron.info

Подписано к печати 10.12.2021

Формат 60×90/16. Бумага офсетная.

Печать офсетная. Объем 28,0 усл.-печ. л.

Тираж 300. Заказ №

Отпечатано в АО «Первая Образцовая типография»

Филиал «Чеховский Печатный Двор»

142300, Московская область, г. Чехов, ул. Полиграфистов, д. 1

Сайт: www.chpd.ru, E-mail: sales@chpd.ru

Тел.: 8 (499) 270-73-59

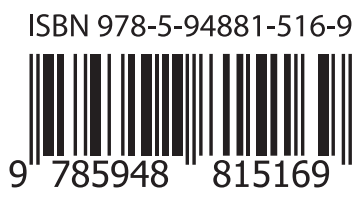

